\title{
Evaluation of the National Weatherization Assistance Program during Program Years 2009-2011 (American Reinvestment and Recovery Act Period)
}

December 29, 2011

Prepared by

Bruce Tonn

Erin Rose

Richard Schmoyer

Joel Eisenberg Mark Ternes

Martin Schweitzer

Timothy Hendrick

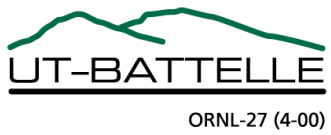




\section{DOCUMENT AVAILABILITY}

Reports produced after January 1, 1996, are generally available free via the U.S. Department of Energy (DOE) Information Bridge.

Web site http://www.osti.gov/bridge

Reports produced before January 1, 1996, may be purchased by members of the public from the following source.

National Technical Information Service

5285 Port Royal Road

Springfield, VA 22161

Telephone 703-605-6000 (1-800-553-6847)

TDD 703-487-4639

Fax 703-605-6900

E-mail info@ntis.gov

Web site http://www.ntis.gov/support/ordernowabout.htm

Reports are available to DOE employees, DOE contractors, Energy Technology Data Exchange (ETDE) representatives, and International Nuclear Information System (INIS) representatives from the following source.

Office of Scientific and Technical Information

P.O. Box 62

Oak Ridge, TN 37831

Telephone 865-576-8401

Fax 865-576-5728

E-mail reports@osti.gov

Web site http://www.osti.gov/contact.html

This report was prepared as an account of work sponsored by an agency of the United States Government. Neither the United States Government nor any agency thereof, nor any of their employees, makes any warranty, express or implied, or assumes any legal liability or responsibility for the accuracy, completeness, or usefulness of any information, apparatus, product, or process disclosed, or represents that its use would not infringe privately owned rights. Reference herein to any specific commercial product, process, or service by trade name, trademark, manufacturer, or otherwise, does not necessarily constitute or imply its endorsement, recommendation, or favoring by the United States Government or any agency thereof. The views and opinions of authors expressed herein do not necessarily state or reflect those of the United States Government or any agency thereof. 


\title{
NATIONAL EVALUATION OF THE WEATHERIZATION ASSISTANCE PROGRAM DURING THE ARRA PERIOD: PROGRAM YEARS 2009-2011
}

\author{
Bruce Tonn \\ Erin Rose \\ Richard Schmoyer \\ Joel F. Eisenberg \\ Mark Ternes \\ Martin Schweitzer \\ Tim Hendrick
}

Date Published: December 29, 2011

Prepared by

OAK RIDGE NATIONAL LABORATORY

Oak Ridge, Tennessee 37831-6283

managed by

UT-BATTELLE, LLC

for the

U.S. DEPARTMENT OF ENERGY

under contract number DE-AC05-00OR22725 
THIS PAGE LEFT INTENTIONALLY BLANK 


\section{CONTENTS}

Page

LIST OF FIGURES ............................................................................................................... viii

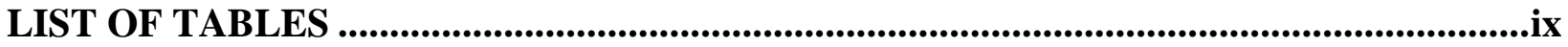

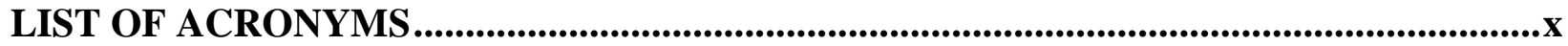

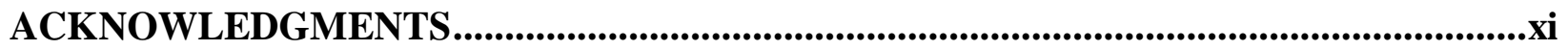

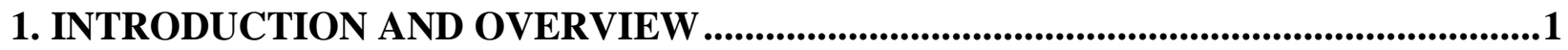

1.1 PURPOSES AND RESEARCH QUESTIONS ............................................................................. 2

1.1.1 Network Planning Committee.....................................................................................................2

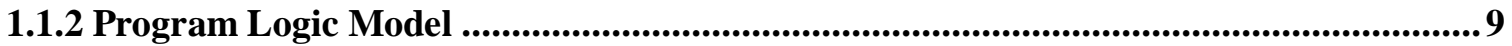

1.1.3 Program Evaluation Design Matrix....................................................................................... 12

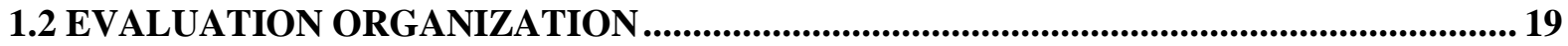

1.3 COMPARISON OF WAP RETROSPECTIVE AND ARRA PERIOD EVALUATIONS ... 19

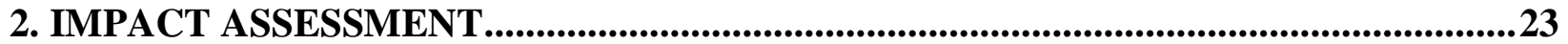

2.1 PROGRAM CHARACTERIZATION STUDY ............................................................ 24

2.1.1 Data and Sampling Frames ......................................................................................................... 24

2.1.2 Low-Income Weatherization Market Analysis.................................................................27

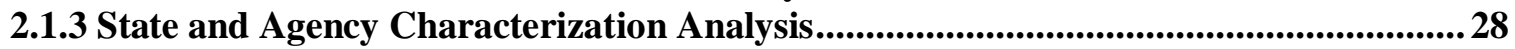

2.1.4 Detailed Characterization of Program and Analysis of Implementation .....................28

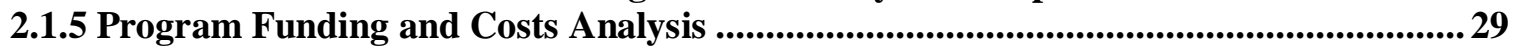

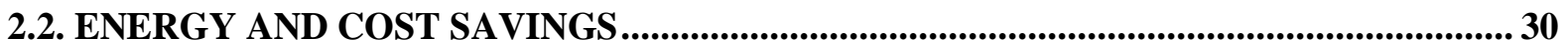

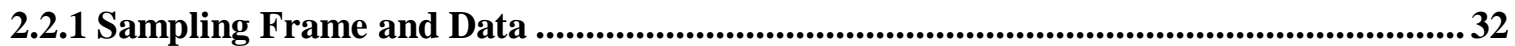

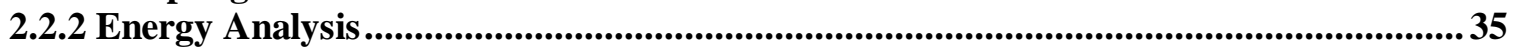

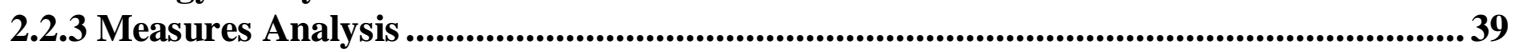

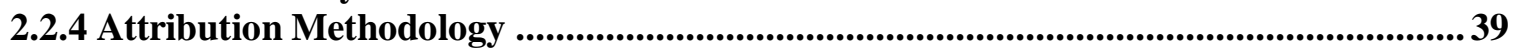

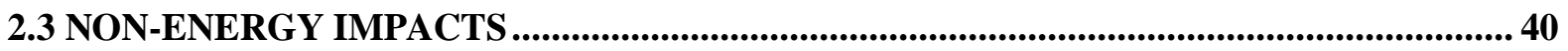

2.3.1 Monetized Data Collection and Analysis .............................................................................. 49

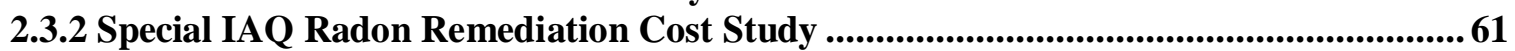

2.3.3 Non-Monetized Data Collection and Analysis ..........................................................................63

2.3.4 Social Network Study .............................................................................................................66 66

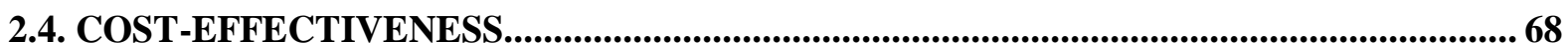

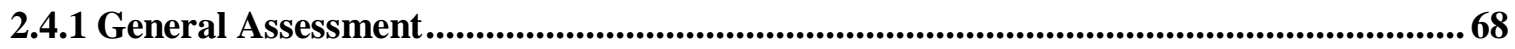

2.4.2 In-Depth Cost Assessment of Weatherization Measures...................................................70

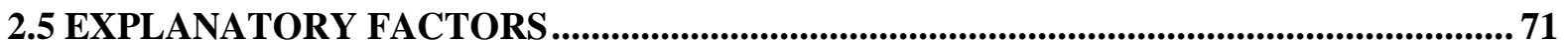




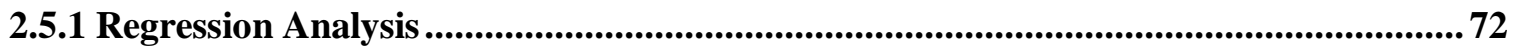

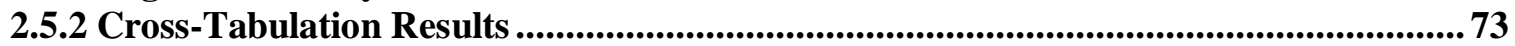

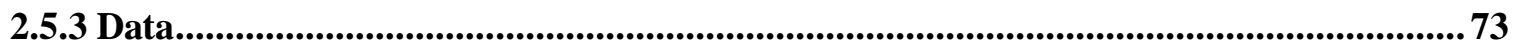

3. PROCESS ASSESSMENT .......................................................................................................74

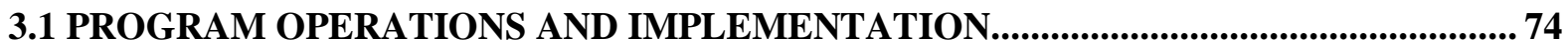

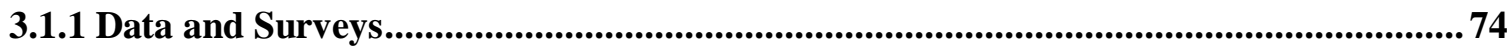

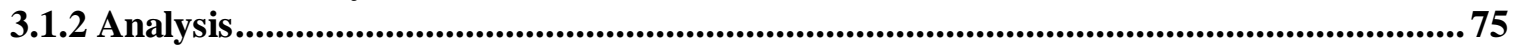

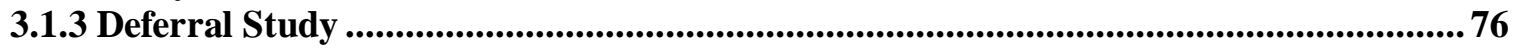

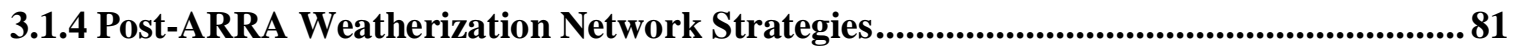

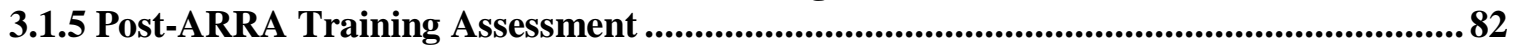

4. SPECIAL STUDIES.................................................................................................................83

4.1 UNDERPERFORMING WEATHERIZED UNITS................................................... 83

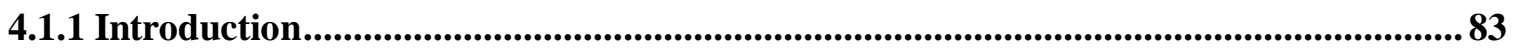

4.1.2 Potential Causes of Underperformance and Over-performance ....................................83

4.1.3 Evaluation Approach: Single Family and Mobile Homes ..........................................8 84

4.1.4 Evaluation Approach: Large Multifamily Buildings ......................................................... 85

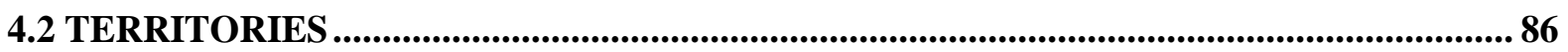

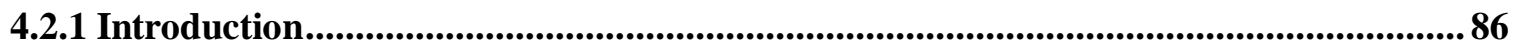

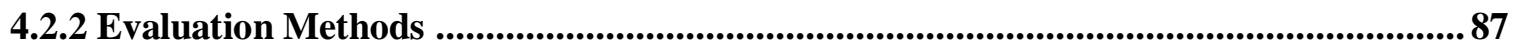

4.2.3 Puerto Rico Case Study ................................................................................................................ 88

4.3 WEATHERIZATION INNOVATION PILOT PROGRAM.................................................. 90

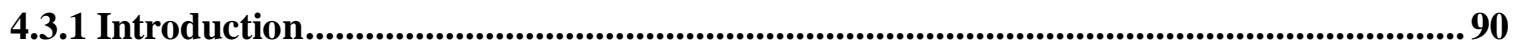

4.3.2. WIPP Programmatic Questions - For all grantees/approaches ...................................92

4.3.3. WIPP Project Activities and Evaluation Questions and Approaches ............................ 92

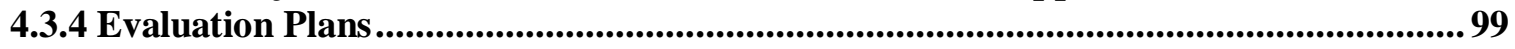

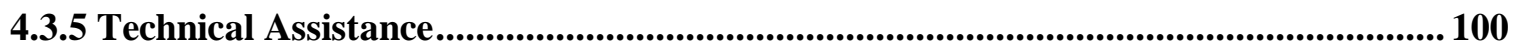

4.4 SUSTAINABLE ENERGY RESOURCES FOR CONSUMERS..................................... 101

4.4.1. Comprehensive Evaluation Approach ..........................................................................102

4.4.2 Technologies Selected for High-Rigor Approach ..................................................... 105

4.4.3 SERC Randomized Controlled Trials (RCTs) ................................................................... 105

4.5 PERSISTENCE OF ENERGY SAVINGS................................................................. 107

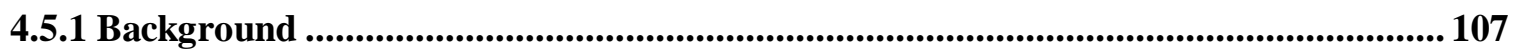

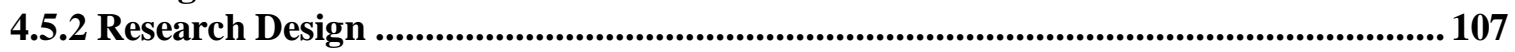

4.5.3 Tasking Statement .......................................................................................................................... 108

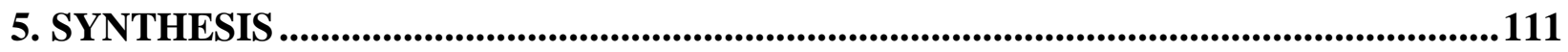

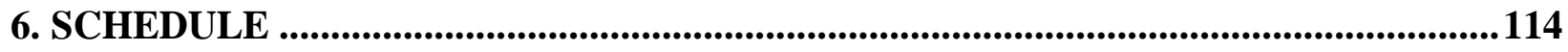


APPENDIX A. NATIONAL WEATHERIZATION NETWORK COMMITTEE .............118

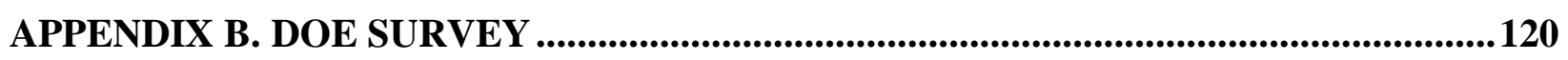

APPENDIX C: S1: ALL STATES PROGRAM INFORMATION SURVEY .....................121

APPENDIX D -- S2: ALL AGENCIES PROGRAM INFORMATION SURVEY ............. 174

APPENDIX E. S3: SUBSET OF AGENCIES DETAILED PROGRAM INFORMATION

SURVEY.

APPENDIX F. DF2: HOUSING UNIT INFORMATION SURVEY ................................255

APPENDIX G. DF3: BUILDING INFORMATION SURVEY ..........................................278

APPENDIX H. DF4: ELECTRIC \& NATURAL GAS BILLING INFORMATION FROM

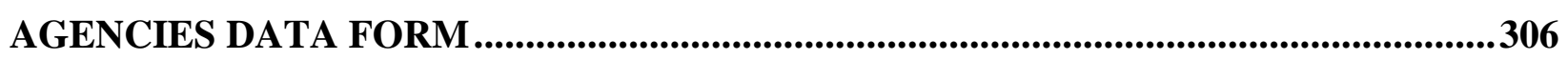

APPENDIX I: DF5A - NATIONAL WEATHERIZATION ASSISTANCE PROGRAM EVALUATION HOUSEHOLD ELECTRICITY USAGE FORM......................................313

APPENDIX J. DF5B: NATIONAL WEATHERIZATION ASSISTANCE PROGRAM EVALUATION HOUSEHOLD NATURAL GAS USAGE FORM....................................319

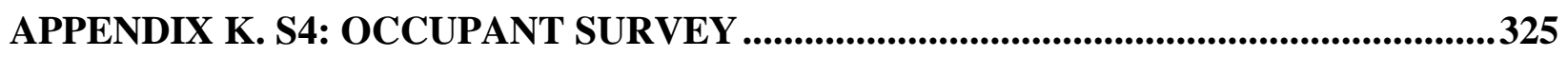

APPENDIX L - DF9 OCCUPANT SURVEY INFORMATION DATA FORM .................385

APPENDIX M: WEATHERIZATION STAFF SURVEY .........................................................411

APPENDIX N: DF11 - WEATHERIZATION STAFF SURVEY DATA FORM ...............418

APPENDIX O. SAMPLE SIZE JUSTIFICATION .........................................................420

O.1 POPULATIONS SAMPLED ..................................................................................................... 420

0.2 AGENCY SAMPLING ..................................................................................................... 421

0.2.1 Agency sampling for energy benefits (billing data analysis) ...........................................421

0.2.2 Agency sampling for program characterization and process assessment....................423

0.2.3 Agency staff subsampling ..................................................................................................423

O.3 WEATHERIZATION INNOVATION PILOT PROGRAM SAMPLING ......................... 424

O.4 SUSTAINABLE ENERGY RESOURCES FOR CONSUMERS SAMPLING ................... 429

O.5 DEFERRAL STUDY SAMPLING ............................................................................................ 429 


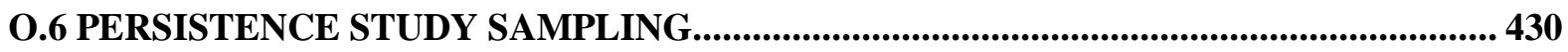

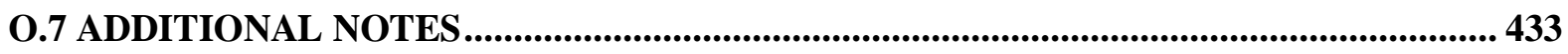

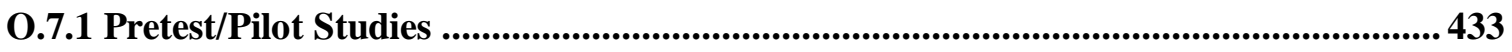

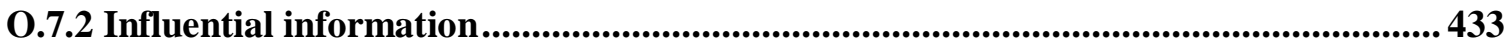

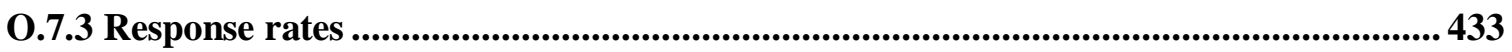

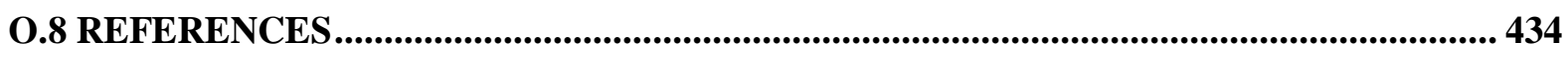

APPENDIX P. BUILDING TYPE DEFINITIONS .....................................................437

APPENDIX Q. UNIT/BUILDING LEVEL ENERGY ANALYSIS .................................439

Q.1 SINGLE-FAMILY HOUSES AND MOBILE HOMES ................................................. 439

Q.2 LARGE MULTIFAMILY BUILDINGS .......................................................................... 440

Q.2.1 Buildings with central building heating systems ..................................................... 440

Q.2.2 Buildings with apartment-level heating systems ...................................................442

Q.3 SMALL MULTIFAMILY BUILDINGS ...................................................................... 443

APPENDIX R. ORNL AGGREGATE MODEL ........................................................445

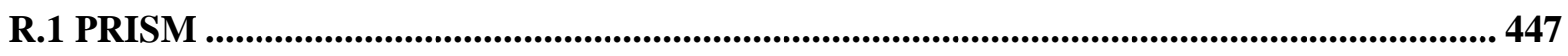

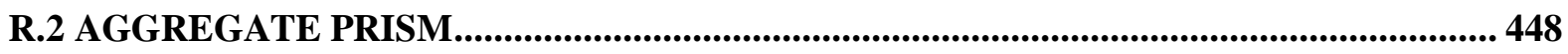

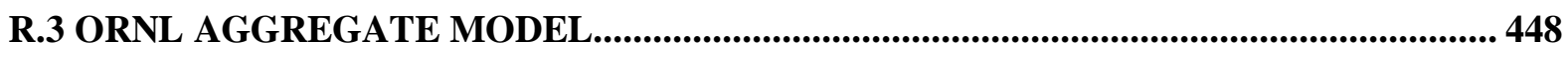

APPENDIX S. ASSESSMENT OF A POTENTIAL SPLIT-WINTER RCT

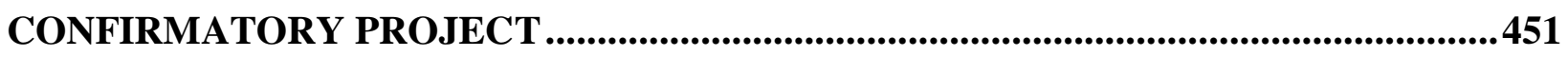

APPENDIX T. S6: ALL STATES POST-ARRA SURVEY .........................................459

APPENDIX U: S7: ALL AGENCIES POST-ARRA SURVEY ....................................465

APPENDIX V. S8: WEATHERIZATION TRAINING CENTERS POST-ARRA SURVEY472 
THIS PAGE LEFT INTENTIONALLY BLANK 


\section{LIST OF FIGURES}

Figure

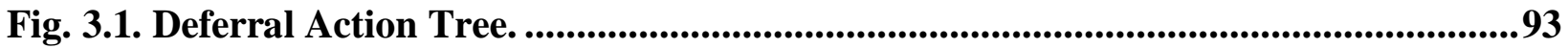

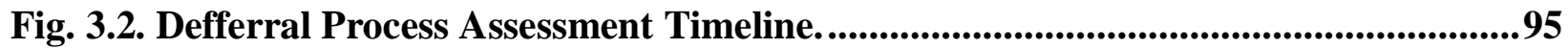

Fig. 6.1. WAP--ARRA Period Evaluation schedule........................................................132 


\section{LIST OF TABLES}

Table

Table 1.1. Logic model for the Weatherization Assistance Program ...................................10

Table 1.2. Evaluation design matrix for the Weatherization Assistance Program ...............28

Table 1.3. Design matrix questions addressing each logic model outcome ............................32

Table 1.4. Comparison of WAP Retrospective and WAP-ARRA Peirod Evaluations..........34

Table 2.1. Data fields for this study from RECS, CPS, AHS databases...............................39

Table 2.2. Total annual Program energy savings.......................................................50

Table 2.3. Non-engery impacts and the household-level data and metrics required to

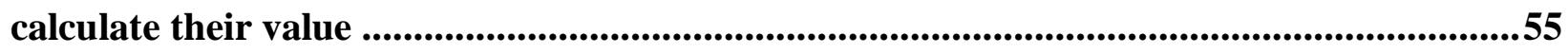

Table 2.4. Impacts, metrics, and factors required to determine need for new data .............63

Table 3.1. Deferral Protocol for All States and Territories .............................................90

Table 3.2. Deferral Observation Assessment Criteria .................................................91

Table 3.3. Unit or Agency Attributes...........................................................................92

Table 4.1. WAP funding allocations, key measures, and evaluation methods for U.S.

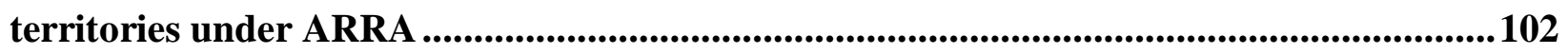

Table 4.2. WIPP Funded Projects ............................................................................................ 103

Table 4.3. Evaluation Methods Applied to Categories of WIPP Activities ........................... 111

Table 4.4. Schedule of Evaluation Activities ..................................................................112

Table 4.5. Schedule of Categories and Tasks ............................................................................ 114

Table 4.6. Technology Categories ......................................................................... 115 


\section{LIST OF ACRONYMS}

\begin{tabular}{|c|c|}
\hline AFUE & Annual Fuel Utilization Efficiency \\
\hline AHS & American Housing Survey \\
\hline ANOVA & Analysis of variance \\
\hline ASHRAE & American Society of Heating, Refrigerating, and Air Conditioning Engineers \\
\hline Btu & British thermal unit \\
\hline CATI & Computer assisted telephone interviewing \\
\hline CDA & Conditional demand analysis \\
\hline $\mathrm{cfm}$ & Cubic feet per minute \\
\hline CFR & Code of Federal Regulations \\
\hline $\mathrm{CH} 4$ & Methane \\
\hline $\mathrm{CO}$ & Carbon monoxide \\
\hline $\mathrm{CO}_{2}$ & Carbon dioxide \\
\hline CPS & Current Population Survey \\
\hline $\mathrm{CV}$ & Coefficient of variance \\
\hline DOE & Department of Energy \\
\hline EERE & Energy Efficiency and Renewable Energy \\
\hline GPRA & Government Performance and Results Act \\
\hline IMT & Inverse Modeling Toolkit \\
\hline $\mathrm{kWh}$ & Kilowatt hours \\
\hline LIHEAP & Low-Income Home Energy Assistance Program \\
\hline NAC & Normalized annual consumption \\
\hline NASCSP & National Association For State Community Services Programs \\
\hline NCAF & National Community Action Foundation \\
\hline NEI & Non-energy impact \\
\hline NOx & Nitrogen oxides \\
\hline $\mathrm{O}_{2}$ & Oxygen \\
\hline OMB & Office of Management and Budget \\
\hline ORNL & Oak Ridge National Laboratory \\
\hline PBA & Planning, Budget, and Analysis \\
\hline PM & Particulate matter \\
\hline PRA & Paperwork Reduction Act \\
\hline \multicolumn{2}{|c|}{ PRISM Princeton Scorekeeping Method } \\
\hline PVE & Petroleum Violation Escrow \\
\hline PY & Program year \\
\hline $\mathrm{R}^{2}$ & Coefficient of determination \\
\hline RECS & Residential Energy Consumption Survey \\
\hline SAE & Statistically Adjusted Engineering \\
\hline SIR & Savings-to-investment ratio \\
\hline SOx & Sulfur oxides \\
\hline SSI & Supplemental Security Income \\
\hline TANF & Temporary Assistance for Needy Families \\
\hline
\end{tabular}




\section{ACKNOWLEDGMENTS}

We wish to thank the National Weatherization Network committee for their input to this plan to evaluate WAP during the ARRA period. We also wish to thank Bob Adams, Jennifer Somers, Tyler Huebner, Brian Levy, Frank Norcross, and Jon Muckey of DOE for their inputs as well. Comments on drafts of this report provided by Inga Treitler were very much appreciated. We also appreciate the editorial touch provided by Em Turner Chitty. Lastly, we thank Tracy Clem for her hard work on this report as well. 
THIS PAGE LEFT INTENTIONALLY BLANK 


\section{INTRODUCTION AND OVERVIEW}

The U.S. Department of Energy's (DOE's) Weatherization Assistance Program (WAP) was created by Congress in 1976 under Title IV of the Energy Conservation and Production Act. The purpose and scope of the Program as currently stated in the Code of Federal Regulations (CFR) 10CFR 440.1 is "to increase the energy efficiency of dwellings owned or occupied by low-income persons, reduce their total residential expenditures, and improve their health and safety, especially low-income persons who are particularly vulnerable such as the elderly, persons with disabilities, families with children, high residential energy users, and households with high energy burden" (Code of Federal Regulations, 2005).

DOE sponsored the first comprehensive evaluation of the Program in the early 1990's to provide policy makers and Program implementers with the up-to-date and reliable information they needed for effective decision-making and cost-effective operations. Oak Ridge National Laboratory (ORNL) managed the five-part study, which was based primarily on data from Program Year (PY) 1989 and supplemented by data from 1991-92 (Brown, Berry, and Kinney, 1994). ORNL has also conducted four meta-evaluations ${ }^{1}$ of the Program's energy savings using studies conducted by individual states between the years 1990-1996 (Berry, 1997), 1996-1998 (Schweitzer and Berry, 1999), 1993-2002 (Berry and Schweitzer, 2003), and 1993-2005 (Schweitzer, 2005).

In April 2009, DOE directed ORNL and its team of independent energy program evaluators to initiate a second, now retrospective, evaluation of the Program for PYs 2007 and 2008 (Ternes et al. 2007). The Program changed significantly during the almost two-decade period between these evaluations. In response to findings and recommendations resulting from the 1989 National Evaluation, the Weatherization Plus strategic planning process, and other federal, state, and local initiatives, the Program incorporated new funding sources, management principles, audit procedures, and energyefficiency measures. In particular, the use of computerized audits was increased, cooling and baseload measures were added, and weatherization approaches that were tailored to the unique construction characteristics of mobile homes were developed; in addition, the weatherization of large multifamily buildings was expanded and became more sophisticated, while greater flexibility to improve "energyrelated" health and safety was provided. Finally, the Program's ability to leverage influence with utilities, other state programs, and owners of large multifamily buildings increased considerably. The retrospective evaluation is expected to be completed by Fall 2012.

This report describes the third major evaluation of the Program, encompassing program years 2009 to 2011. In this report, this period of time is referred to as the ARRA Period. This is a special period of time for the Program because the American Recovery and Reinvestment Act (ARRA) of 2009 has allocated $\$ 5$ billion of funding for the Program. In normal program years, WAP's annual appropriation is in the range of \$200-250 million, supporting the weatherization of approximately 100,000 homes. With the addition of ARRA funding during these program years, the expectation is that weatherization activity will exceed 300,000 homes per year. In addition to saving energy and reducing low-income energy bills, expanded WAP funding is expected to stimulate the economy by providing new jobs in the weatherization field and allowing low-income households to spend more money on goods and services by spending less on energy.

During the ARRA period, the Weatherization Assistance Program is a much different program than it was as recently as PY 2008 and also likely different than it will be in the future. Among the key

\footnotetext{
${ }^{1}$ The term "meta-evaluations" refers to the analysis of analyses; these are a more rigorous alternative to the narrative discussion of research studies. Meta-evaluations involve the statistical analysis of a collection of analysis results from individual studies for the purpose of integrating the findings.
} 
differences are the following: First, a greatly expanded weatherization workforce has been recruited, trained, organized, and sent into the field. In order to support this expansion, the percentage of spending allowed for training and technical assistance has been raised from 10 percent to 20 percent.

Second, all states and U.S. territories have received unprecedented increases in their weatherization funding and some grantees have grappled with budgets that were several times larger than anything they had previously managed. Some states, faced with this massive program expansion, have used WAP funds for weatherization, while others have implemented other approaches, including innovations in Program delivery and management.

Third, substantial amounts of funding have been set aside to support innovations in Program funding and design. The first of these, for the Sustainable Energy Resources for Consumers (SERC) grants, sets aside up to $2 \%$ of funds to encourage innovative projects by Weatherization subgrantees (i.e., local weatherization agencies) to further weatherization efforts that are outside the scope of existing Program regulations and restrictions. The second, the Weatherization Innovation Pilot Program (WIPP), sets aside $\$ 30$ million to encourage the formation of partnerships with both traditional and non-traditional weatherization providers so that non-federal resources can be leveraged to pursue the Program's purposes.

Lastly, to accommodate the expansion of the weatherization program, several major changes in Program administration were made. Eligibility requirements were eased: The household income threshold increased from $150 \%$ to $200 \%$ of the Poverty Income Guidelines. Also, the average cost ceiling (the average amount of money that can be spent by grantees to weatherize homes) was increased from $\$ 2,500$ to $\$ 6,500$. Additionally, for the first time, the wages for weatherization workers were adjusted to conform to Davis-Bacon Act prevailing wage requirements. All of these factors affect energy and cost savings and have an impact on Program delivery; they may also have relevance to future Program design and are included as topics in this evaluation.

\subsection{PURPOSES AND RESEARCH QUESTIONS}

ORNL reconvened a National Weatherization Network Committee to provide comments and input for the evaluation of the WAP during the ARRA period (Section 1.1.1). The formalized planning process used for the retrospective evaluation, based on the concept of a program logic model and evaluation design matrix as developed by the W. K. Kellogg Foundation (2001), was again undertaken (see Sections 1.1.2 and 1.1.3, respectively). This section concludes with an overview of the WAP-ARRA period evaluation.

\subsubsection{Network Planning Committee}

One of the evaluation's most important goals is to meet the needs of the weatherization community, since that community, also referred to as the weatherization network, will be a primary beneficiary and user of the evaluation's findings. In addition, the network of state offices and over one thousand local agencies will be relied upon to collect and provide significant amounts of the data needed for the evaluation. Therefore, ORNL felt that it was important to involve the weatherization community early in the planning process in order to establish open communications with them, get them actively engaged in the evaluation, strengthen their voice in the planning process, clearly identify their expectations of the evaluation, and increase their participation in the evaluation's implementation.

ORNL convened a National Weatherization Network Committee to provide input for the retrospective evaluation in 2009 and reconvened a reconstituted Network Committee in January 2010 in Washington, DC to provide input for the WAP-ARRA period evaluation. 
After receiving recommendations from DOE headquarters and regional program staff, ORNL selected 36 people from the National Association for State Community Services Programs (NASCSP) and the National Community Action Foundation (NCAF) to serve on the committee. The committee members are identified in Appendix A. The committee members include state weatherization officials, local weatherization officials, DOE staff, ORNL staff, and independent evaluators.

The committee was tasked by ORNL to identify the information that they would find most useful from the national evaluation; to identify data available at national, regional, state, and local levels that would be pertinent to the evaluation; and to provide insight into how the evaluation and specifically the data collection could be best conducted. This information was solicited to assist ORNL in developing the evaluation's research questions, identifying the various studies that would need to be performed under the evaluation, and formulating details of the implementation.

At the January 2010 meeting, a moderator led the committee through several discussions to identify numerous research questions. These research questions may be broken into five main groups relating to the following areas: (1) energy savings and cost-effectiveness; (2) process issues; (3) nonenergy-related benefits; (4) indications for post-ARRA research; and (5) broad research questions.

1) Energy Savings and Cost-effectiveness: It is important to measure energy savings attributable to WAP during the ARRA period, but it is equally important to study changes "on the ground" resulting from the ARRA and those of its provisions related to weatherization assistance. Therefore, evaluation questions related to energy savings include these:

How much in household energy savings is attributable to WAP during the ARRA period?

$>$ How cost-effective are these savings?

$>$ Were changes in the prices of weatherization measures possibly attributable to the uniqueness of the ARRA-period impact cost-effectiveness?

$>$ Did the ARRA-period change in the formula for distribution of WAP funds to grantees (i.e., states and territories) affect energy savings and cost-effectiveness?

$>$ Did the expansion of existing weatherization crews and the establishment of new ones have an impact on energy savings and cost-effectiveness?

$>$ How much energy was saved in the studied initiatives to weatherize public housing units, and were those savings cost-effective?

$>$ How did the change in the assistance eligibility standard impact energy savings?

$>$ How did the increase in average expenditures on weatherization measures from $\$ 2,500$ to $\$ 6,500$ impact measure selection and energy savings?

$>$ What are the energy savings attributable to the SERC and WIPP projects?

2) Process Issues: ARRA funding for the WAP has had a significant impact on Program operation and management. Process issues abound. These issues have been grouped into four categories: (a) management and oversight; (b) prevailing wages (Davis-Bacon Act), (c) the national weatherization network, and (d) labor force and training issues.

(a) Management and Oversight: The expansion of WAP has led to many management challenges and opportunities. Scrutiny of the Program has also increased substantially. Here are suggested evaluation questions that address Program management and oversight during the ARRA period:

At the state level, what programmatic changes and innovative approaches were implemented to disburse weatherization funds, and how effective were those approaches (e.g., changes in reporting requirements, changes in subgrantee participation, changes in training and technical assistance procedures, changes in audit approaches)? 
$>$ What programmatic changes and innovative approaches at the local level were implemented to deliver weatherization services, and how effective were those innovations (e.g., changes in intake procedures, changes in the mix of buildings weatherized, etc.)?

$>$ What were the results of experiments allowing some weatherization funds to be used in public housing?

$>$ What types of projects were funded under SERC and WIPP?

$>$ How did hot-climate states manage substantial increases in weatherization funding?

$>$ How did U.S. territories deal with Program initiation?

$>$ Did walk-away policies (i.e., deferrals of weatherization efforts on unsuitable properties) and the frequency of such deferrals change due to this increase in the amount of available funds for weatherization measures?

$>$ How satisfied were clients with the weatherization services provided during the ARRA period?

$>$ Have the demographic characteristics of clients receiving weatherization and those on weatherization waiting lists changed during the ARRA period?

$>$ Has DOE managed WAP effectively during the ARRA period (i.e. in terms of clarity and timeliness of guidance);

$>$ What have been the actual monetary administrative costs associated with increased oversight during the ARRA period for states and local weatherization agencies (e.g., from DOE IG, GAO)?

$>$ Has ARRA funding both allowed states and agencies to afford new technologies and pushed them to use new information to increase operational and reporting efficiencies? If so, what new technologies are being implemented?

$>$ Has ARRA funding allowed the purchase of new field technologies? If so, what new field technologies are being implemented?

$>$ To what extent have the weatherization costs used in savings-to-investment ratio (SIR) calculations differed from actual, possibly highly fluctuating measure costs endured during ARRA?

$>$ To what extent have other large DOE programs competed with WAP for labor during the ARRA period (e.g. SEP, EECGB)?

$>$ Were there any material, equipment or other supply-chain bottlenecks that hampered or prevented weatherization production during the ARRA period?

$>$ What new state regulations were enacted with respect to weatherization during ARRA, and to what extent did these regulations have unintended consequences?

(b) Prevailing Wages (Davis-Bacon Act): "Davis-Bacon" is the common name applied to a 1931 Act that requires all federal construction projects to pay prevailing wages to their workers. As part of the ARRA legislation, Congress stipulated that projects funded with ARRA money must follow Davis-Bacon rules. The U.S. Department of Labor (DoL) has the responsibility for identifying "prevailing wages" in the construction industry. These wages are identified for a set of construction industry jobs and are estimated for each county in the United States. Prior to ARRA, weatherization activities have not been subject to the requirements of Davis-Bacon. However, under ARRA, it was realized that weatherization-related jobs did not overlap with construction-industry jobs. Therefore, DoL needed to establish prevailing wages for weatherization-related jobs in every county in the country and DOE needed to develop new guidance related to Davis-Bacon. Predictably, much confusion and many delays resulted. An entire set of evaluation questions is devoted to process issues surrounding Davis-Bacon:

Did Davis-Bacon, on balance, lead to positive job creation?

$>$ Did the application of Davis-Bacon lead to changes in weatherization wages?

$>$ What were the actual monetary administrative costs for complying with Davis-Bacon?

$>$ Did paperwork requirements lead some experienced weatherization contractors to leave the lowincome weatherization field? 
$>$ Has Davis-Bacon led local weatherization agencies to change their mix of in-house vs. contractor labor and crews?

$>$ How did multi-county weatherization agencies deal with county-specific Davis-Bacon wage-rate requirements?

$>$ How has Davis-Bacon affected weatherization costs associated with multifamily buildings of four stories and higher?

$>$ Have changes in weatherization costs associated with Davis-Bacon altered residents' choices of measures installed in homes?

$>$ Overall, how did Davis-Bacon implementation impact the Program's cost-effectiveness?

(c) National Weatherization Network: The unprecedented flow of federal funds into low-income home weatherization efforts has changed the national weatherization network in several ways: firstly, the size of the labor force has necessarily increased; secondly, these funding increases have naturally drawn new stakeholders into the network. The new funding has also affected long-standing leveraging relationships, in which states and agencies are able to leverage DOE funding in order to attract non-DOE funding both positively and negatively; thus, it has increased the visibility of low-income weatherization. The following evaluation questions are designed to document and evaluate changes in the national weatherization network during the ARRA period.

Has the composition of the national weatherization network changed during the ARRA period?

$>$ What types of newcomers have joined the network during ARRA?

$>$ Has the influx of ARRA funding negatively affected existing leveraging relationships?

$>$ Are new leveraging relationships forming?

D Has the public's perception of low-income weatherization changed during the ARRA period?

$>$ Has ARRA brought low-income weatherization more attention from state and local elected officials and administrators? If so, has the attention been generally positive or negative?

$>$ How has the media portrayed low-income weatherization during the ARRA period?

$>$ To what extent have inexperienced and unqualified entities entered the weatherization network and attempted to reap benefits from the increases in WAP funding?

$>$ How have private companies tried to change state and local weatherization procedures to benefit themselves (e.g., by selling more insulation or energy-efficient lights)?

$>$ How have relationships between state and local weatherization agencies changed during ARRA?

$>$ How did local non-profit weatherization agencies deal with Program expansion (i.e., what models did they use and which were more successful than others)?

$>$ Did expanding local weatherization agencies result in any economies of scale;

$>$ Did ARRA change the way local agencies procured weatherization services under contract (e.g., changes in using requests for proposals [RFPs] vs. bids)?

$>$ How did the weatherization community (including federal, state, and local stakeholders) interact with federal agencies during the ARRA period?

(d) Labor Force and Training Issues: As mentioned above, the weatherization labor force necessarily increased to meet the increase in the weatherization production rate. The following evaluation questions address how the weatherization community handled this challenge:

What approaches did local agencies and/or contractors use to recruit qualified, reliable, and trustworthy weatherization crew members, and how effective were these recruitment approaches?

$>$ What approaches did states and local agencies use to train the expanded weatherization workforce and how effective were these approaches?

$>$ Did staff turnover and retention rates change during the ARRA period?

$>$ How did states manage the creation and training of staff associated with new subgrantees?

$>$ How did states and agencies manage increasing workloads and performance expectations? 
How well did new weatherization staff perform?

$>$ How have certification programs changed during the ARRA period?

$>$ What are the strengths and weaknesses of national weatherization certification practices?

$>$ How have certification requirements changed weatherization staff hiring and retention practices?

3) Non-Energy-Related Benefits: The national evaluation currently being implemented will assess nonenergy benefits associated with WAP for houses under the $\$ 2,500$ average expenditure level per house. It is also important to assess non-energy benefits at the higher $\$ 6,500$ level. Additionally, the greatly increased scale of the ARRA weatherization effort should also increase the scale of the non-energy benefits, especially with respect to employment and other economic issues. The following are potential evaluation questions related to non-energy benefits:

$>$ Did utilities experience fewer problems with arrears and shut-offs associated with weatherized homes because the Program participants' utility bills were more manageable as a result of the increase in measure expenditures and the number of homes weatherized?

$>$ In households whose homes were weatherized at the higher level, how much more affordable were their energy bills?

$>$ What other non-energy benefits to households increased at the higher level of expenditures (e.g., home value increases, improvements in health)?

$>$ Are low-income households whose homes have been weatherized less vulnerable to the impacts of climate change, and if so, to what extent?

$>$ Nationally, how many new weatherization-related businesses were created during the ARRA period?

$>$ Nationally, how many new jobs were created and existing jobs retained during this period?

$>$ Did the increased scale of WAP assistance affect local unemployment rates directly? Indirectly?

$>$ To what extent have people who received weatherization training under ARRA been able to transfer their new skills to other sectors of the green economy in particular and the larger economy in general?

$>$ Has WAP during ARRA affected the market for non-low-income weatherization?

$>$ Has WAP during ARRA affected the market for building related energy-efficiency products; and

$>$ What amount of greenhouse gas emissions was avoided during this period?

4) Indications for Post-ARRA Research Questions: This section poses additional policy-related and research questions whose answers could benefit the low-income weatherization community in the period after ARRA. The questions fall into four groups: (a) fundamental Program management and regulation questions; (b) post-ARRA challenges; (c) technical research questions; and (d) broader research questions. This evaluation of WAP during the ARRA period will not be able to pursue all of the questions listed below due to time and budget constraints. In addition, answers to some questions will not be available until the results from the retrospective and the WAP-ARRA period evaluations can be synthesized. Lastly, many of the questions are not evaluative questions per se; rather, they represent important research and analytical questions that should be pursued through other projects. However, these questions are included in this report to ensure that important points made during the Network Committee meeting are documented.

(a) Program Management and Regulation Questions: Numerous policy decisions shape the implementation of the Program ranging from what measures are allowed to be installed in homes to who is eligible for the Program. Some of these provisions were changed during ARRA. Moving forward, several policy-related questions such as these could be considered:

$>$ Should WAP endeavor to go "deeper" into home-weatherization efforts? 
$>$ What are the benefits of having greater Program flexibility diversity in state and local weatherization agency administration of WAP?

$>$ What are the benefits and costs of various income eligibility thresholds (e.g., 150\%, 200\% or more of poverty level)?

$>$ Is it possible for homeowners' participation in a weatherization program to help forestall home foreclosure?

$>$ Should the policy on re-weatherization be reconsidered in light of Program changes and new technology developments?

$>$ What are the benefits and costs of various average per-house weatherization investment levels (e.g., \$2500, \$6500)?

$>$ How should certification efforts move forward after the ARRA period?

$>$ What are the benefits and costs of using e-learning programs in weatherization training?

$>$ Should the fundamental funding mechanism of WAP (block grants) be reconsidered;

$>$ How might anticipated retirements in the next five or so years impact the leadership of the national weatherization community?

$>$ Could WAP formally incorporate water conservation into its Program? Should it?

(b) Post-ARRA Challenges: An important issue for the weatherization community is what will happen after ARRA. States and subgrantees are gearing up to weatherize up to twice as many homes per year as they have in recent years. The capacity of the national weatherization network is expected to expand greatly. Will efforts to retain this capacity be made? If so, what might those efforts be at the federal, state, and local levels? Post-ARRA evaluation questions include the following:

$>$ What are states and agencies planning to do, if anything, to maintain their expanded capacities for weatherization after ARRA?

$>$ What options are there at the federal, state, and local levels for marshalling additional resources to maintain the expanded weatherization capacity?

$>$ How many weatherization jobs created during ARRA may be lost after ARRA?

$>$ What might the costs to states and local weatherization agencies associated with workforce reductions (e.g., workers compensation) be?

$>$ How can leveraging relationships that were damaged or lost during ARRA because abundant ARRA money took the place of the leveraging partners' involvement during the Program be rebuilt?

$>$ What leveraging opportunities, such as opportunities to tap into voluntary carbon-reduction markets, might expand after ARRA?

$>$ Will quality issues identified, rightly or wrongly, by the media during ARRA have lasting impacts on weatherization funding?

$>$ What level of emission reductions (for carbon and other pollutants) is necessary for the weatherization program to attract other funding?

$>$ Will the training capacity that has been created by states, agencies, community colleges, etc., be sustainable after the expiration of ARRA?

$>$ Will expenses for new equipment, software, etc. purchased during ARRA be sustainable after ARRA?

$>$ What strategies can be used to retain young weatherization staffers hired during ARRA?

(c) Technical Research Questions: The availability of data from two national evaluations of the Program brings up many interesting research questions whose answers could have an impact on future Program design. These questions include the following: 
What lessons about the delivery of weatherization services can be learned through insights gained from the retrospective and WAP-ARRA evaluations (e.g., through comparing energy savings, cost-effectiveness, weatherization staff training and retention etc.)?

$>$ How long do energy savings attributable to weatherization last?

$>$ What are the benefits and costs of using computer audits vs. priority lists?

$>$ Are there any differences in energy savings and cost-effectiveness between homes weatherized using only DOE WAP funds vs. a combination of DOE WAP and LIHEAP funds;

$>$ What are the benefits and costs of various new information technologies that allow real-time reporting of audits and weatherization activities from the field?

$>$ Can energy savings attributable to weatherization be estimated or "normalized" without taking human behavior into account?

$>$ What opportunities exist to use random control trial methodologies to evaluate aspects of the lowincome weatherization program;

$>$ What are the impacts of weatherization on "whole-service" utility bills;

$>$ Have any areas in the United States been "saturated" with WAP-funded low-income weatherization (i.e., are there any areas where most eligible homes have been weatherized with WAP-funded assistance)?

$>$ Should weatherization decisions take into account local or regional peculiarities of utility rate structures and other whole billing provisions?

$>$ Has the consolidation of the natural gas and electric utility industries impacted low-income weatherization and/or evaluation? 
5) Broad Research Questions: Lastly, numerous questions can be asked about the Program in the larger national context. Suggested questions include the following:

$>$ Can weatherization programs be used to increase the market penetration of new energy efficiency and renewable technologies in the residential sector, whether or not they meet current costeffectiveness standards (i.e., the currently defined SIR)?

$>$ What are the prospects for building a low-income weatherization portfolio within the voluntary carbon markets?

$>$ How has the proliferation of historic preservation programs and historic districts affected the implementation of low-income weatherization?

$>$ What might be the impact of the potential Home Score program on low-income weatherization?

$>$ How can states and other governmental entities build their own evaluations upon the retrospective and ARRA period evaluations?

$>$ Has the expanded weatherization effort under ARRA transformed markets for any energy efficient products?

$>$ What other weatherization programs serving the low-income community exist in the United States?

$>$ Are the terms "weatherization," "green jobs," and "clean energy" confused in the minds of the public?

\subsubsection{Program Logic Model}

A program logic model is a tool used to provide complete analysis of a program's inputs, activities, outputs (products), and outcomes. In following the W. K. Kellogg Foundation's formalized evaluation planning process, development of a program logic model is an integral first step before a set of program evaluation questions within the framework of a design matrix can be formulated. The program logic model shown in Table 1.1 shows how the WAP is intended to work by systematically identifying first, the resources available to operate the Program; second, the activities the Program is intended to perform; and third, the results the Program is intended to accomplish. The program logic model for the WAP shown in Table 1.1 comprises four sections:

1. Resources/Inputs - The first column identifies the resources ("inputs") of various kinds - human, financial, organizational, and community - available to operate the Program. The first input identified is the Federal legislation authorizing the Program and stipulating the Program's mission and overall objectives. Financial inputs include direct DOE funding of the Program, funding from other Federal sources such as the Low-Income Home Energy Assistance Program (LIHEAP), Petroleum Violation Escrow (PVE) funds, and other leveraged sources, such as state public benefits funds or utility programs. The organizations involved with the Program include Department of Energy (DOE) program staff; state grantees and local agency subgrantees that directly implement the Program, along with their related national organizations; a network of support groups such as DOE's national laboratories, state and regional training centers, and various support contractors; and other organizations, such as utilities and national and state energy organizations.

2. Activities - The processes, techniques, tools, events, technologies, and actions that the Program conducts using the resources/inputs are considered its "activities" and are listed in the second column. The Program's primary activities are performed by three groups: DOE, the state grantees, and the local agency subgrantees. DOE's activities focus on administering and running the Program; these activities involve developing policy, guidance, and regulations; making and monitoring grants; providing training; maintaining technical capabilities and tools; performing periodic evaluations; and coordinating with other organizations. The states' activities are also administrative in nature, as they involve making and monitoring contracts with the local agencies, establishing goals and implementation procedures for the agencies, providing training, and establishing partnerships to 
leverage resources. Local agencies implement the Program at a basic level, identifying clients and performing all the tasks needed to select and install weatherization measures. The local agencies also perform some administrative functions, such as providing client education, referring clients to other programs and services, and teaching crews the correct procedures needed to perform these tasks.

3. Outputs - The Program's outputs are the direct products and services delivered as a result of its activities. DOE's activities result in guidance and regulations being published and audits being developed, improved, and approved. Through the activities of DOE, the states, and local agencies, a known number of homes are weatherized, priority households weatherized, weatherization staff trained, and clients referred to other programs or services. Other important services resulting from the Program include the installation of cost-effective measures in the weatherized homes, the mitigation of health and safety deficiencies in these homes, and the education of clients on energy usage. Through the combined efforts of all organizations, partnerships with the Program are established. 
Table 1.1. Logic model for the Weatherization Assistance Program

\begin{tabular}{|c|c|c|c|c|c|}
\hline \multirow{2}{*}{$\begin{array}{l}\text { Resources/ } \\
\text { Inputs }\end{array}$} & \multirow[t]{2}{*}{ Roles/Activities } & \multirow[t]{2}{*}{ Outputs } & \multicolumn{3}{|c|}{ Outcomes } \\
\hline & & & Short-Term & Medium-Term & Long-Term \\
\hline $\begin{array}{l}\text { Federal authorizing } \\
\text { legislation } \\
\text { Direct funding } \\
\text { from DOE, } \\
\text { LIHEAP, PVE, } \\
\text { and leveraged } \\
\text { sources } \\
\text { DOE Program staff } \\
\text { State grant } \\
\text { administration } \\
\text { agencies and } \\
\text { related national } \\
\text { organizations } \\
\text { Local service } \\
\text { network of } 900 \\
\text { agencies and } \\
\text { related national } \\
\text { organizations } \\
\text { Support network in } \\
\text { national } \\
\text { laboratories, } \\
\text { training centers, } \\
\text { and support } \\
\text { contractors with } \\
\text { special technical } \\
\text { skills } \\
\text { Utilities and } \\
\text { national and state } \\
\text { energy } \\
\text { organizations }\end{array}$ & $\begin{array}{l}\text { DOE } \\
\text { - Establish and explain national policy direction } \\
\text { - Formulate annual budgets and grant guidance, and make grants } \\
\text { - Formulate Program rules and regulations } \\
\text { - Initiate and coordinate strategic planning with network } \\
\text { - Approve and monitor state plans and their implementation } \\
\text { - Create, coordinate, and conduct technical training and assistance to state and } \\
\text { local agencies } \\
\text { - Develop and maintain core capabilities of the Program including audit tools } \\
\text { and standards, evaluations, and assessments } \\
\text { - Coordinate Program relations with other Federal agencies, programs, and } \\
\text { institutions } \\
\text { States } \\
\text { - Set eligibility requirements and priorities for participants } \\
\text { - Contract with local agencies and allocate funding } \\
\text { - Establish production goals (number of units weatherized) and schedule } \\
\text { - Specify diagnostic, audit, and inspection procedures and allowable measures } \\
\text { for local agencies } \\
\text { - Determine extent of allowable repair, health, and safety work } \\
\text { - Provide training and assistance to local agencies } \\
\text { - Establish leveraging programs and expand resources and partnerships } \\
\text { - Monitor local agency work } \\
\text { Local Agencies } \\
\text { - Solicit and process applications and select low-income residents to receive } \\
\text { weatherization services } \\
\text { - Train crew members } \\
\text { - Perform home energy diagnostics, audits, and inspections } \\
\text { - Determine most cost-effective weatherization measures and other work needed } \\
\text { for each home } \\
\text { - Purchase, store, and maintain equipment, materials, and supplies } \\
\text { - Install measures and perform other specified work } \\
\text { - Perform quality assurance work } \\
\text { - Meet with clients to review improvements and provide educational materials } \\
\text { - Support advocacy and leveraging } \\
\text { - Link clients to other programs and services } \\
\text { - Track and report client status, expenditures, and funding }\end{array}$ & 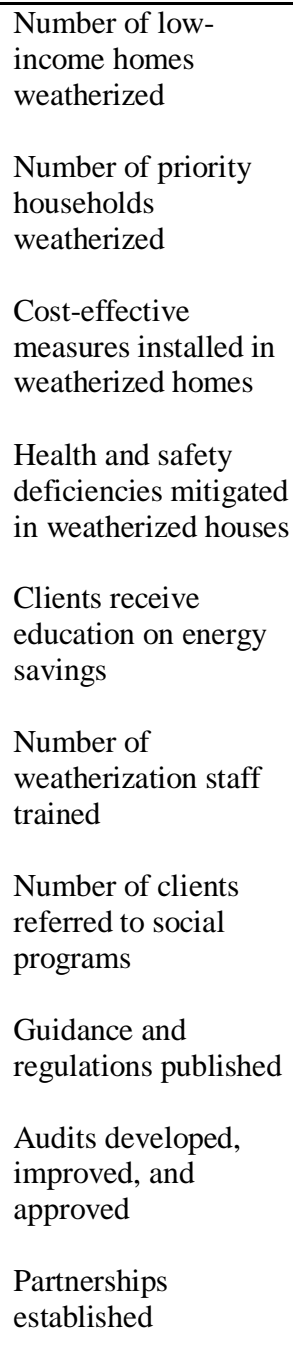 & $\begin{array}{l}\text { Weatherized } \\
\text { homes, } \\
\text { particularly those } \\
\text { of priority } \\
\text { populations, have } \\
\text { increased energy } \\
\text { efficiency } \\
\text { Health and safety } \\
\text { of those living in } \\
\text { weatherized } \\
\text { homes improved } \\
\text { Indoor comfort of } \\
\text { those living in } \\
\text { weatherized } \\
\text { homes improved } \\
\text { Clients have } \\
\text { increased } \\
\text { knowledge of } \\
\text { energy savings } \\
\text { strategies }\end{array}$ & 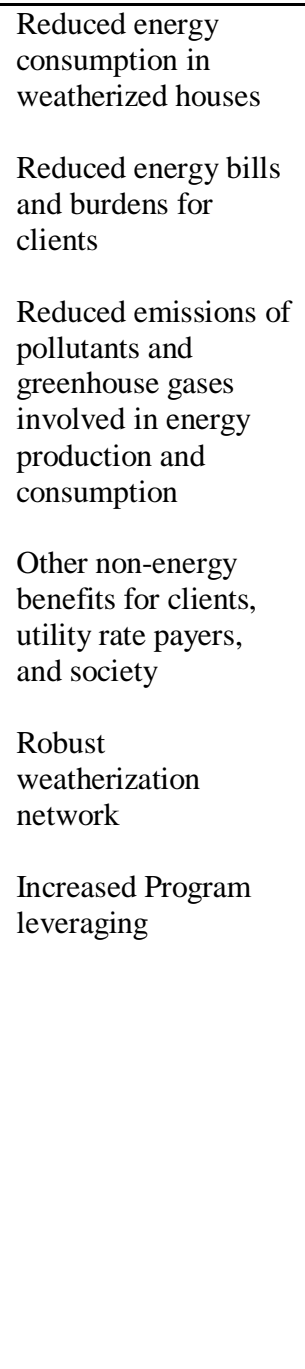 & $\begin{array}{l}\text { Reduced gap } \\
\text { between low- } \\
\text { income energy } \\
\text { needs and actual } \\
\text { consumption of } \\
\text { energy services } \\
\text { Reduced impact of } \\
\text { energy price } \\
\text { inflation and } \\
\text { market disruptions } \\
\text { on low-income } \\
\text { communities } \\
\text { Improved health } \\
\text { and safety for } \\
\text { communities } \\
\text { Improved local } \\
\text { housing stock } \\
\text { Workforce } \\
\text { enhancement in } \\
\text { local communities } \\
\text { Creation of } \\
\text { sustainable } \\
\text { weatherization } \\
\text { services market } \\
\text { Increased non- } \\
\text { energy purchases } \\
\text { in low-income } \\
\text { communities } \\
\text { Transform market } \\
\text { for weatherization } \\
\text { products }\end{array}$ \\
\hline
\end{tabular}




\section{Outcomes}

4a and 4b. Short- and Medium-Term Outcomes - Program outcomes are those short-term (1-3 months) and medium-term (1-year) changes that occur as a result of the Program's activities that impact the Program's participants, participating households, and the Program itself. The immediate results of the Program are that the energy efficiency of the weatherized homes is increased; that the health, safety, and comfort of those living in the weatherized houses are improved; and that clients know more about energysaving strategies. In the medium term, energy consumption in the weatherized houses is reduced, leading to reduced energy bills and energy burdens for the clients as well as non-energy benefits realized by the clients, utility ratepayers, and society as a whole (especially benefits related to reductions in pollution and greenhouse gas emissions from reduced energy use). In addition, a more robust weatherization network community should result and the ability of the program to leverage additional resources should increase.

4c. Long-Term Outcomes - The fundamental, long-term (3-7 years) changes in organizations, communities, or systems that result from the program's activities are its "long-term" outcomes. By reducing low-income clients' energy use and energy burdens, the gap between the energy needs of the low-income community and the available resources to meet this need should be reduced; in addition, the low-income community should be less susceptible to rising energy prices and market fluctuations; and finally, clients should have more funds available to make non-energy purchases within their communities. Non-energy benefits realized by the community as a result of the program include improved health and safety, better housing stock, greater job creation, and a more skilled work force. Finally, the program would be expected to encourage market transformation for weatherization products.

\subsubsection{Program Evaluation Design Matrix}

The evaluation design matrix shown in Table 1.2 identifies the general questions the program evaluation will address. These questions were developed by examining the program's logic model (see Table 1.1 and Section 1.1.2) and incorporating the input received from the Network Planning Committee (see Section 1.1.1). The evaluation questions are organized into three categories in the design matrix:

1. Context: Relationships and Capacity-The context questions explore how the program functioned within the economic, social, and political environment of the weatherization community; these questions also address issues regarding the program's relationships and capacity. In terms of the program's logic model, the context questions focus on how the program's resources and inputs led to its activities. The evaluation questions dealing with the program's context focus primarily on characterizing the low-income weatherization market, the weatherization network/community and how it operates, and the partnership and leveraging opportunities available to the program and how well the program is taking advantage of these opportunities. Context questions also deal with whether the program has the capacity and structure to fulfill the mission and objectives established for it by law, and put into context the role the program plays in the larger low-income energy assistance effort.

2. Implementation: Quality and Quantity-Implementation questions assess the extent to which the activities listed in the program's logic model were executed as planned, and whether the outputs listed in the program's logic model were achieved. Implementation questions deal with the characterization of the clients and households served by the program, the services the program delivered to these clients and households and how well these services were provided, and the costs associated with delivering the program. An important implementation question based on the input received from the Network Planning Committee is to fully determine the best approaches to implementing audits, client education, training, and technical monitoring. A final implementation question deals with whether the states and local agencies are fulfilling their obligations under federal regulations and the state plans they have submitted. 
3. Outcomes: Effectiveness, Magnitude, and Satisfaction-Outcome questions focus on the extent to which progress was made toward the desired changes in the program participants, participating households, and the low-income community and systems. In terms of the logic model, these questions examine how well the program's outputs led to its desired outcomes. The Outcomes questions focus on the energy savings achieved under the Program, the non-energy impacts that are being realized, the Program's cost-effectiveness, how well individual measures work, and process variables that affect these outcomes. These outcome questions include Items 1-4 raised by the Network Planning Committee (see Section 1.1.1). Several final outcomes questions bring all the results of the evaluation together, asking whether the Program is meeting the legislative missions and objectives identified previously in the context questions, to what extent the program is meeting the needs of the lowincome weatherization community, and how the program and the weatherization network can be improved.

Table 1.3 compares the program outcomes identified in the logic model (Table 1.1) to the program evaluation questions listed in the design matrix (Table 1.2) to make sure that the evaluation is addressing and measuring all the outcomes associated with the program. As shown by Table 1.3, all the program outcomes are being addressed by the questions posed in the design matrix with the exception of the market transformation activity anticipated for the program, which is beyond the scope of this evaluation.

The evaluation as planned takes and evaluates a snapshot of the program's performance as it was implemented in PYs 2009-2011. The evaluation does not focus most directly on the long-term outcomes, instead focusing on the short- and medium-term outcomes listed in the logic model (Table 1.1). However, longer-term outcomes are also being addressed, in some cases by assuming that short- and medium-term results will have larger impacts as they are sustained over time. The snapshot-type evaluation being planned does not allow long-term market transformation activity to be evaluated. Although this outcome could be addressed by looking back in time at how the Program helped transform the weatherization market, such an effort is not being planned at this time.

In the final synthesis (see Section 5), the evaluation should recommend how a longer-term, more continuous evaluation of the Program could be implemented by DOE so that the longer-term outcomes of the program could be more fully addressed. One process that should be explored is to identify other government programs that are evaluating community and public-welfare issues (e.g., the Health Department, the Census Bureau) and determine how the program's long-term outcomes might be evaluated from these existing sources. 
Table 1.2. Evaluation design matrix for the Weatherization Assistance Program

\begin{tabular}{|c|c|c|c|c|}
\hline $\begin{array}{c}\text { Evaluation focus } \\
\text { area }\end{array}$ & Question & Audience & Information use & Study \\
\hline \multirow[t]{10}{*}{$\begin{array}{l}\text { Context: } \\
\text { Relationships and } \\
\text { Capacity }\end{array}$} & $\begin{array}{l}\text { 1. What are the mission and associated } \\
\text { objectives of the Program as established } \\
\text { by law? }\end{array}$ & $\begin{array}{l}\text { DOE - WAP } \\
\text { Weatherization network }\end{array}$ & Establish mission context & $\begin{array}{c}\text { Process } \\
\text { Assessment }\end{array}$ \\
\hline & $\begin{array}{l}\text { 2. Does the Program have the capacity } \\
\text { and structure (e.g., funding, staffing) to } \\
\text { meet its objectives? }\end{array}$ & $\begin{array}{l}\text { DOE - EERE } \\
\text { DOE - WAP } \\
\text { Weatherization network }\end{array}$ & Program administration & Synthesis \\
\hline & $\begin{array}{l}\text { 3. What are the characteristics of the } \\
\text { national low-income weatherization } \\
\text { market? }\end{array}$ & $\begin{array}{l}\text { DOE - WAP } \\
\text { Weatherization network }\end{array}$ & $\begin{array}{l}\text { Strategic planning; Program } \\
\text { design and marketing }\end{array}$ & $\begin{array}{c}\text { Impact } \\
\text { Assessment }\end{array}$ \\
\hline & $\begin{array}{l}\text { 4. Which segments of this market are } \\
\text { being served by the Program and other } \\
\text { parties? }\end{array}$ & $\begin{array}{l}\text { DOE - WAP } \\
\text { Weatherization network }\end{array}$ & $\begin{array}{l}\text { Strategic planning; Program } \\
\text { design and marketing }\end{array}$ & $\begin{array}{c}\text { Impact } \\
\text { Assessment }\end{array}$ \\
\hline & $\begin{array}{l}\text { 5. What organizations are involved in } \\
\text { national low-income weatherization (e.g., } \\
\text { agencies, states, utilities, private sector } \\
\text { firms)? }\end{array}$ & $\begin{array}{l}\text { White House } \\
\text { Congress } \\
\text { DOE - Secretarial } \\
\text { DOE - EERE } \\
\text { DOE - WAP } \\
\text { Weatherization network } \\
\end{array}$ & $\begin{array}{l}\text { Establish Program context; } \\
\text { Program support and } \\
\text { marketing }\end{array}$ & $\begin{array}{c}\text { Process } \\
\text { Assessment }\end{array}$ \\
\hline & $\begin{array}{l}\text { 6. What are the characteristics of the } \\
\text { weatherization network? }\end{array}$ & $\begin{array}{l}\text { DOE - WAP } \\
\text { Weatherization network }\end{array}$ & $\begin{array}{l}\text { Strategic planning; Program } \\
\text { design and marketing }\end{array}$ & $\begin{array}{c}\text { Impact } \\
\text { Assessment }\end{array}$ \\
\hline & $\begin{array}{l}\text { 7. How does the weatherization network } \\
\text { work? }\end{array}$ & $\begin{array}{l}\text { DOE - WAP } \\
\text { Weatherization network }\end{array}$ & $\begin{array}{l}\text { Organization and participation } \\
\text { decisions }\end{array}$ & $\begin{array}{c}\text { Process } \\
\text { Assessment }\end{array}$ \\
\hline & $\begin{array}{l}\text { 8. What are the core leveraging and } \\
\text { partnership opportunities for the } \\
\text { Program? }\end{array}$ & $\begin{array}{l}\text { DOE - WAP } \\
\text { Weatherization network }\end{array}$ & Program design and marketing & Synthesis \\
\hline & $\begin{array}{l}\text { 9. Is the Program exploiting its leveraging } \\
\text { and partnership opportunities? }\end{array}$ & $\begin{array}{l}\text { DOE - WAP } \\
\text { Weatherization network }\end{array}$ & Program design and marketing & $\begin{array}{c}\text { Process } \\
\text { Assessment }\end{array}$ \\
\hline & $\begin{array}{l}\text { 10. Are the Program's regulations } \\
\text { enhancing and/or inhibiting leveraging } \\
\text { and partnership opportunities? }\end{array}$ & $\begin{array}{l}\text { Congress } \\
\text { DOE - Secretarial } \\
\text { DOE - EERE } \\
\text { DOE - WAP } \\
\text { Weatherization network }\end{array}$ & Program design & $\begin{array}{c}\text { Process } \\
\text { Assessment }\end{array}$ \\
\hline
\end{tabular}


Table 1.2. Evaluation design matrix for the Weatherization Assistance Program

\begin{tabular}{|c|c|c|c|c|}
\hline $\begin{array}{c}\text { Evaluation focus } \\
\text { area }\end{array}$ & Question & Audience & Information use & Study \\
\hline \multirow{7}{*}{$\begin{array}{l}\text { Implementation - } \\
\text { Quality and } \\
\text { Quantity }\end{array}$} & $\begin{array}{l}\text { 1. What are the characteristics of those } \\
\text { receiving Program services? }\end{array}$ & $\begin{array}{l}\text { DOE - WAP } \\
\text { Weatherization network }\end{array}$ & $\begin{array}{l}\text { Program design, planning, and } \\
\text { implementation }\end{array}$ & $\begin{array}{c}\text { Impact } \\
\text { Assessment }\end{array}$ \\
\hline & $\begin{array}{l}\text { 2. What Program services are being } \\
\text { delivered to low-income households? }\end{array}$ & $\begin{array}{l}\text { DOE - WAP } \\
\text { Weatherization network }\end{array}$ & $\begin{array}{l}\text { Program design, planning, and } \\
\text { implementation }\end{array}$ & $\begin{array}{c}\text { Impact } \\
\text { Assessment }\end{array}$ \\
\hline & $\begin{array}{l}\text { 3. How well is the Program delivering its } \\
\text { services, including from the client } \\
\text { perspective? }\end{array}$ & $\begin{array}{l}\text { DOE - WAP } \\
\text { Weatherization network }\end{array}$ & $\begin{array}{l}\text { Program design, planning, and } \\
\text { implementation }\end{array}$ & $\begin{array}{l}\text { Process } \\
\text { Assessment }\end{array}$ \\
\hline & $\begin{array}{l}\text { 4. What are the costs associated with the } \\
\text { Program services? }\end{array}$ & $\begin{array}{l}\text { DOE - WAP } \\
\text { Weatherization network }\end{array}$ & $\begin{array}{l}\text { Program design, planning, and } \\
\text { implementation }\end{array}$ & $\begin{array}{c}\text { Impact } \\
\text { Assessment }\end{array}$ \\
\hline & $\begin{array}{l}\text { 5. What are the best approaches to } \\
\text { implementing audits and measure } \\
\text { selection tools, client education, training, } \\
\text { and monitoring? }\end{array}$ & Weatherization network & $\begin{array}{l}\text { State- and agency-level } \\
\text { Program design, planning, and } \\
\text { implementation }\end{array}$ & $\begin{array}{c}\text { Process } \\
\text { Assessment }\end{array}$ \\
\hline & $\begin{array}{l}\text { 6. Are the Program's characterization and } \\
\text { process results valid and reliable? }\end{array}$ & Evaluation community & $\begin{array}{l}\text { Generalize results to other } \\
\text { contexts }\end{array}$ & $\begin{array}{c}\text { Peer } \\
\text { Review }\end{array}$ \\
\hline & $\begin{array}{l}\text { 7. Are the states and local agencies } \\
\text { fulfilling their obligations under federal } \\
\text { regulations and state plans? }\end{array}$ & $\begin{array}{l}\text { DOE - WAP } \\
\text { Weatherization network }\end{array}$ & $\begin{array}{l}\text { Program design, planning, and } \\
\text { implementation }\end{array}$ & Synthesis \\
\hline \multirow[t]{3}{*}{$\begin{array}{l}\text { Outcomes - } \\
\text { Effectiveness, } \\
\text { Magnitude, and } \\
\text { Satisfaction }\end{array}$} & $\begin{array}{l}\text { 1. What are the Programs average energy } \\
\text { benefits (heating, cooling, and baseload) } \\
\text { nationally and by climate region, housing } \\
\text { type, and fuel type? }\end{array}$ & $\begin{array}{l}\text { OMB } \\
\text { DOE - Secretarial } \\
\text { DOE - EERE } \\
\text { DOE - WAP } \\
\text { Weatherization network } \\
\text { Utilities } \\
\text { Commissioners } \\
\end{array}$ & $\begin{array}{l}\text { Budget justification; Program } \\
\text { marketing; utility business } \\
\text { planning; rule making }\end{array}$ & $\begin{array}{c}\text { Impact } \\
\text { Assessment }\end{array}$ \\
\hline & $\begin{array}{l}\text { 2. How much energy is saved in aggregate } \\
\text { by the Program? }\end{array}$ & $\begin{array}{l}\text { DOE - EERE (PBA) } \\
\text { DOE - EERE }\end{array}$ & $\begin{array}{l}\text { Energy savings and GPRA } \\
\text { metrics }\end{array}$ & $\begin{array}{c}\text { Impact } \\
\text { Assessment }\end{array}$ \\
\hline & $\begin{array}{l}\text { What are the Program's non-energy } \\
\text { impacts? }\end{array}$ & $\begin{array}{l}\text { DOE - WAP } \\
\text { Weatherization network } \\
\text { Utilities } \\
\text { Commissioners }\end{array}$ & $\begin{array}{l}\text { Program marketing; utility } \\
\text { business planning; rule } \\
\text { making }\end{array}$ & $\begin{array}{c}\text { Impact } \\
\text { Assessment }\end{array}$ \\
\hline
\end{tabular}


Table 1.2. Evaluation design matrix for the Weatherization Assistance Program

\begin{tabular}{|c|c|c|c|c|}
\hline \multirow{9}{*}{$\begin{array}{l}\text { Evaluation focus } \\
\text { area }\end{array}$} & Question & Audience & Information use & Study \\
\hline & $\begin{array}{l}\text { 4. How do clients feel about the } \\
\text { Program's impact on their comfort, health } \\
\text { and safety, and energy costs? }\end{array}$ & $\begin{array}{l}\text { DOE - WAP } \\
\text { Weatherization network }\end{array}$ & $\begin{array}{l}\text { Program design, planning, and } \\
\text { implementation }\end{array}$ & $\begin{array}{c}\text { Impact } \\
\text { Assessment }\end{array}$ \\
\hline & 5. Is the Program cost-effective? & $\begin{array}{l}\text { White House } \\
\text { Congress } \\
\text { OMB } \\
\text { DOE - Secretarial } \\
\text { DOE - EERE } \\
\text { DOE - WAP } \\
\text { Weatherization network }\end{array}$ & $\begin{array}{l}\text { Cost-benefit analysis; future } \\
\text { funding decisions; Program } \\
\text { design, planning, and } \\
\text { implementation }\end{array}$ & $\begin{array}{c}\text { Impact } \\
\text { Assessment }\end{array}$ \\
\hline & $\begin{array}{l}\text { 6. What impact do alternative per } \\
\text { household investment levels (e.g., } \$ 2500 \\
\text { vs. } \$ 6500 \text { ) have on key Program metrics } \\
\text { (e.g., units weatherized, average savings } \\
\text { per house, house and Program SIRs)? }\end{array}$ & & $\begin{array}{l}\text { State and agency-level } \\
\text { Program design, planning, and } \\
\text { implementation }\end{array}$ & $\begin{array}{c}\text { Impact } \\
\text { Assessment }\end{array}$ \\
\hline & $\begin{array}{l}\text { 7. How well do the selected measures } \\
\text { result in energy savings }\end{array}$ & $\begin{array}{l}\text { DOE - WAP } \\
\text { Weatherization network }\end{array}$ & $\begin{array}{l}\text { Program design, planning, and } \\
\text { implementation }\end{array}$ & $\begin{array}{c}\text { Impact } \\
\text { Assessment }\end{array}$ \\
\hline & $\begin{array}{l}\text { 8. What factors and measures explain } \\
\text { variation in energy savings and cost- } \\
\text { effective results? }\end{array}$ & $\begin{array}{l}\text { DOE - WAP } \\
\text { Weatherization network }\end{array}$ & $\begin{array}{l}\text { Program design, planning, and } \\
\text { implementation }\end{array}$ & $\begin{array}{c}\text { Impact } \\
\text { Assessment }\end{array}$ \\
\hline & $\begin{array}{l}\text { 9. How are the hot Southern climate } \\
\text { region market and performance unique? }\end{array}$ & $\begin{array}{l}\text { DOE - WAP } \\
\text { Weatherization network }\end{array}$ & $\begin{array}{l}\text { Program design, planning, and } \\
\text { implementation }\end{array}$ & $\begin{array}{c}\text { Impact } \\
\text { Assessment } \\
\text { and } \\
\text { Special } \\
\text { Technical } \\
\text { Studies }\end{array}$ \\
\hline & $\begin{array}{l}\text { 10. Are the outcome estimates valid and } \\
\text { reliable? }\end{array}$ & Evaluation community & $\begin{array}{l}\text { Generalize results to other } \\
\text { contexts }\end{array}$ & Peer Review \\
\hline & $\begin{array}{l}\text { 11. Is the Program meeting its legislative } \\
\text { missions and objectives? }\end{array}$ & $\begin{array}{l}\text { DOE - WAP } \\
\text { Weatherization network }\end{array}$ & $\begin{array}{l}\text { Budget justification; Program } \\
\text { marketing }\end{array}$ & Synthesis \\
\hline
\end{tabular}


Table 1.2. Evaluation design matrix for the Weatherization Assistance Program

\begin{tabular}{|c|c|c|c|c|}
\hline \multirow{6}{*}{$\begin{array}{l}\text { Evaluation focus } \\
\text { area }\end{array}$} & Question & Audience & Information use & Study \\
\hline & $\begin{array}{l}\text { 12. How much have the emissions of } \\
\text { greenhouse gases been reduced? }\end{array}$ & $\begin{array}{l}\text { White House } \\
\text { Congress } \\
\text { OMB } \\
\text { DOE - Secretarial } \\
\text { DOE - EERE } \\
\text { DOE - WAP } \\
\text { Weatherization network }\end{array}$ & $\begin{array}{l}\text { Cost-benefit analysis; future } \\
\text { funding decisions; Program } \\
\text { design, planning, and } \\
\text { implementation }\end{array}$ & $\begin{array}{l}\text { Special } \\
\text { Studies }\end{array}$ \\
\hline & $\begin{array}{l}\text { 13. How well have expanded } \\
\text { weatherization activities in the U.S. } \\
\text { territories succeeded? }\end{array}$ & $\begin{array}{l}\text { DOE - WAP } \\
\text { Weatherization network }\end{array}$ & $\begin{array}{l}\text { Budget justification; strategic } \\
\text { planning }\end{array}$ & $\begin{array}{l}\text { Special } \\
\text { Studies }\end{array}$ \\
\hline & $\begin{array}{l}\text { 14. What are the impacts and process } \\
\text { outcomes of the SERC and WIPP } \\
\text { projects? }\end{array}$ & $\begin{array}{l}\text { White House } \\
\text { Congress } \\
\text { OMB } \\
\text { DOE - Secretarial } \\
\text { DOE - EERE } \\
\text { DOE - WAP } \\
\text { Weatherization network }\end{array}$ & $\begin{array}{l}\text { Cost-benefit analysis; future } \\
\text { funding decisions; Program } \\
\text { design, planning, and } \\
\text { implementation }\end{array}$ & $\begin{array}{l}\text { Special } \\
\text { Studies }\end{array}$ \\
\hline & $\begin{array}{l}15 . \text { To what extent is the Program } \\
\text { meeting the needs of the national low- } \\
\text { income weatherization market? }\end{array}$ & $\begin{array}{l}\text { DOE - WAP } \\
\text { Weatherization network }\end{array}$ & $\begin{array}{l}\text { Budget justification; strategic } \\
\text { planning }\end{array}$ & Synthesis \\
\hline & $\begin{array}{l}\text { 16. In what ways can the weatherization } \\
\text { network's performance be improved? }\end{array}$ & $\begin{array}{l}\text { DOE - WAP } \\
\text { Weatherization network }\end{array}$ & Program planning & Synthesis \\
\hline
\end{tabular}


Table 1.3. Design matrix questions addressing each logic model outcome

\begin{tabular}{|c|c|c|c|}
\hline \multirow[t]{2}{*}{$\begin{array}{l}\text { Outcomes listed in the logic model } \\
\text { (Table 1.1) }\end{array}$} & \multicolumn{3}{|c|}{$\begin{array}{l}\text { Number of questions in the evaluation design matrix } \\
\text { related to context, implementation, and outcomes } \\
\text { (Table 1.2) }\end{array}$} \\
\hline & Context & Implementation & Outcomes \\
\hline \multicolumn{4}{|c|}{ Short -Term Outcomes } \\
\hline 1. Increased energy efficiency in homes & 4 & & 1,2 \\
\hline 2. Improved health and safety in homes & & & 3,4 \\
\hline 3. Improved indoor comfort & & & 3,4 \\
\hline 4. Increased client knowledge of energy & & 5 & \\
\hline \multicolumn{4}{|c|}{ Medium -Term Outcomes } \\
\hline 1. Reduced energy use in homes & & 7 & $1,2,8$ \\
\hline $\begin{array}{l}\text { 2. Reduced bills and financial burden for } \\
\text { clients }\end{array}$ & & 7,14 & $1,2,4,8$ \\
\hline 3. Reduced emissions & & & $3,12,14$ \\
\hline 4. Other non-energy benefits & & & 3,4 \\
\hline 5. Robust weatherization network & $2,5,6,7$ & 13 & 13,16 \\
\hline 6. Increased Program leveraging & $8,9,10$ & & \\
\hline \multicolumn{4}{|c|}{ Long-Term Outcomes } \\
\hline 1. Reduced gap between energy need and use & & & $1,2,4,11,15$ \\
\hline $\begin{array}{l}\text { 2. Reduced impact of inflation/market } \\
\text { fluctuations }\end{array}$ & & & $1,2,4,15$ \\
\hline 3. Improved health and safety in community & & & 3,4 \\
\hline 4. Improved local housing stock & & & 3,4 \\
\hline 5. Workforce enhancements & & & 3,14 \\
\hline $\begin{array}{l}\text { 6. Creation of sustainable weatherization } \\
\text { service market }\end{array}$ & $2,4-11$ & & 14,15 \\
\hline 7. Increased non-energy purchases & & & 3 \\
\hline $\begin{array}{l}\text { 8. Transformed market for weatherization } \\
\text { products }\end{array}$ & \multicolumn{3}{|c|}{ Will not be addressed in this evaluation } \\
\hline
\end{tabular}




\subsection{EVALUATION ORGANIZATION}

Based on a review of the evaluation design matrix (see Section 1.1.3), the evaluation of the Program will include four studies, identified in Table 1.2, which will address each of the questions listed in the evaluation design matrix. These studies and the organization of the remaining elements of the report are outlined below:

- Impact Assessment - Section 2 describes the plan for evaluating the Program's impact in PYs 20092011. The weatherization network will be characterized, along with the nature and scope of the Program's implementation and weatherization processes. Energy and its subsequent costs savings will be quantified, along with non-energy impacts in order that the Program's cost-effectiveness can be determined. Explanatory factors pertinent to energy savings, energy costs savings, and costeffectiveness will be identified.

- Process Assessment - Section 3 describes a process assessment that will examine how well the weatherization network and Program operated in during the ARRA period in delivering weatherization services, and how well the Program is exploiting opportunities for leveraging and partnership. Case studies of weatherization programs in territories will be performed. The national weatherization network will be approached to assess plans post-ARRA.

- Special Studies-Section 4 describes special studies that will be performed. These studies include an analysis of underperforming weatherized units; energy savings analyses for selected U.S. territories; SERC; and WIPP. To explore the feasibility of employing random control trial methods to estimate energy impact savings, an encouragement design study will be conducted. Lastly, an in-depth study of greenhouse gas emission reductions and further potential reductions at the local level will also be conducted.

- Synthesis Study - Section 5 describes how results from the evaluation work performed under Sections 2-4 will be synthesized to address how well the program is meeting its overall goals, the extent to which the program is serving the weatherization needs of the low-income community; and how the program's and weatherization network's performance can be improved. Lessons learned from both the retrospective and ARRA period evaluations will be identified.

- Schedule-Section 6 outlines a schedule for the evaluation.

It should be noted that under the terms of the Paperwork Reduction Act, the Office of Management and Budget (OMB) must approve most of the sampling plans and survey instruments associated with this evaluation. Therefore, the sampling plans and survey instruments presented in this preliminary evaluation plan may be modified during the OMB review process. However, once approved by $\mathrm{OMB}$, they will not be subject to any substantive modifications.

\subsection{COMPARISON OF WAP RETROSPECTIVE AND ARRA PERIOD EVALUATIONS}

There are several important points to make regarding the similarities, differences, and overlaps between the retrospective evaluation of WAP as described in Ternes et al. (2007) and the WAP-ARRA evaluation described in the balance of this report. First, as Table 1.4 shows, the two evaluations generally encompass the same research tasks. For example, the central component of each evaluation is the collection of billing histories for homes heated with electricity and natural gas; these data provide the basis for the national estimate of energy savings attributable to the program as well as associated costeffectiveness analyses. Non-energy impacts are assessed by both evaluations. Additionally, both evaluations administer a core set of surveys and data forms (e.g., S1: All States Program Information Survey). All of these tasks focus on the Program Years (PYs) indicated in the Table 1.4. 
The third column of Table 1.4 shows that the retrospective evaluation overlaps with the ARRA period in five research areas. When the retrospective evaluation was conceived in 2005 and when the plan was written in 2006 and 2007, it was assumed that the Program would not undergo any major changes that could change the evaluation results. Thus, the retrospective evaluation was designed to estimate national energy savings and to constitute most of the process assessment for the immediately past Program Year (PY2008) while simultaneously implementing several research tasks during the Program Year in which the evaluation was to take place (i.e., PY 2009). When the retrospective evaluation began, though it was decided to look back to pre-ARRA Program Years 2007 and 2008, the ARRA period had already begun.

Thus, these five research tasks that are being funded by the retrospective evaluation are actually assessing weatherization activities that took place during the ARRA period: analysis of sub-metered data for homes heated with bulk fuels; a major indoor air-quality study; case studies of high-performing agencies and exemplary client-education programs; and the administration of two major surveys, S4 (Occupant Survey) and S5 (Weatherization Staff Survey).

Table 1.4 also indicates that a few of the tasks undertaken by the retrospective evaluation will not be duplicated by the WAP-ARRA period evaluation (and vice versa). For example, the retrospective evaluation will fund case studies of high-performing agencies and exemplary client-education programs, but the WAP-ARRA evaluation will not. Conversely, the WAP-ARRA period evaluation will fund case studies of underperforming weatherized units and one U.S. territory that received new, substantial ARRA funding (e.g., Puerto Rico), which, naturally, is not covered in the retrospective evaluation. 
Table 1.4 Comparison of WAP Retrospective and WAP-ARRA Period Evaluations

\begin{tabular}{|c|c|c|c|}
\hline & $\begin{array}{c}\text { Retrospective Evaluation } \\
\text { on Weatherization } \\
\text { Assistance Program }\end{array}$ & $\begin{array}{c}\text { Retrospective Evaluation } \\
\text { Research Taking Place } \\
\text { during (Overlapping with) } \\
\text { ARRA Period }\end{array}$ & $\begin{array}{l}\text { WAP-ARRA Period } \\
\text { Evaluation Research }\end{array}$ \\
\hline $\begin{array}{l}\text { Analysis of Billing Histories: } \\
\text { Homes heated with electricity } \\
\text { and natural gas }\end{array}$ & $\begin{array}{l}\text { Program Years } 2007 \text { and } \\
2008\end{array}$ & & $\begin{array}{l}\text { Program Years 2009, } \\
2010, \text { and } 2011\end{array}$ \\
\hline $\begin{array}{l}\text { Analysis of Submetered Data: } \\
\text { Homes heated with propane } \\
\text { and fuel oil }\end{array}$ & & $\begin{array}{l}\text { Winter 2010-2011 and } \\
\text { Winter 2011-2012 }\end{array}$ & \\
\hline $\begin{array}{l}\text { Analysis of Persistence of } \\
\text { Energy Savings in } \\
\text { Weatherized Homes }\end{array}$ & & & $\begin{array}{l}\text { Program Years in the } \\
1990 \text { s }\end{array}$ \\
\hline Cost-effectiveness Analyses & Program Year 2008 & & Program Year 2010 \\
\hline Non-Energy Impacts & Program Year 2008 & & Program Year 2010 \\
\hline Social Network Study & & & Program Year 2011 \\
\hline GHG Emissions Study & & & $\begin{array}{l}\text { Program Years 2007- } \\
2010\end{array}$ \\
\hline $\begin{array}{l}\text { S1: All States Program } \\
\text { Information Survey }\end{array}$ & Program Year 2008 & & Program Year 2010 \\
\hline $\begin{array}{l}\text { S2: All Agencies Program } \\
\text { Information Survey }\end{array}$ & Program Year 2008 & & Program Year 2010 \\
\hline $\begin{array}{l}\text { S3: Subset of Agencies } \\
\text { Detailed Program Information } \\
\text { Survey }\end{array}$ & Program Year 2008 & & Program Year 2010 \\
\hline S4: Occupant Survey & & CY's 2011 and 2012 & CY2012 \\
\hline $\begin{array}{l}\text { S5: Weatherization Staff } \\
\text { Survey }\end{array}$ & & CY 2011 & CY 2012 \\
\hline Program Characterization & Program Year 2008 & & Program Year 2010 \\
\hline Case Studies & & $\begin{array}{l}\text { Program Year } 2008-\text { Six } \\
\text { High Performing Agencies } \\
\text { and Six Exemplary Client } \\
\text { Ed Programs }\end{array}$ & $\begin{array}{l}\text { Program Year } 2010- \\
\text { One U.S. Territory }\end{array}$ \\
\hline Weatherization Deferral Study & & & Program Year 2010 \\
\hline Under-Performers Study & & & $\begin{array}{l}\text { Program Years 2007- } \\
2009\end{array}$ \\
\hline $\begin{array}{l}\text { DF2/3: Housing and Building } \\
\text { Information Data Forms }\end{array}$ & Program Year 2008 & & Program Year 2010 \\
\hline $\begin{array}{l}\text { DF4: Utility Information from } \\
\text { Agencies Data Form }\end{array}$ & $\begin{array}{l}\text { Program Years } 2007 \text { and } \\
2008\end{array}$ & & $\begin{array}{l}\text { Program Years 2009, } \\
2010,2011\end{array}$ \\
\hline $\begin{array}{l}\text { DF5: Utility Billing History } \\
\text { Data Forms }\end{array}$ & $\begin{array}{l}\text { Program Years } 2007 \text { and } \\
2008\end{array}$ & & $\begin{array}{l}\text { Program Years 2009, } \\
2010,2011\end{array}$ \\
\hline Indoor Air Quality & & $\begin{array}{l}\text { Winter 2010-2011, } \\
\text { Summer 2011, Winter } \\
\text { 2011-2012 }\end{array}$ & \\
\hline Field Process Study & & CY 2011 & \\
\hline Special Studies & & & $\begin{array}{l}\text { WIPP and SERC } \\
\text { Program Years 2010- } \\
2011 ; \\
\text { Encouragement Design } \\
\text { - Program Year 2011 }\end{array}$ \\
\hline Post ARRA Surveys $(\mathrm{S} 6,7,8)$ & & & CY 2011 \\
\hline
\end{tabular}




\section{IMPACT ASSESSMENT}

The impact assessment portion of the evaluation will address many of the questions identified in the evaluation design matrix (see Table 1.2), especially those dealing specifically with the following:

- Context-Questions 3, 4, and 6;

- Implementation - Questions 1, 2, and 4; and

- Outcomes-Questions 1-9.

The context, implementation, and outcomes questions listed above deal with characterizing the weatherization network, the market that the Program serves, and the households served by the Program; identifying the services delivered by the Program and their costs; determining the Program's energy and non-energy benefits and cost-effectiveness; and understanding factors that have an impact on savings, cost-effectiveness, and other key Program metrics, such as the number of units weatherized.

In addition, the impact assessment will address the following high-priority and consensus goals that were identified by the Network Planning Committee:

- Energy savings analysis - reports energy savings by various subgroups and includes measured savings from propane and fuel-oil heated houses in the evaluation;

- Baseload measures - includes savings for all end uses in the measured savings from the Program;

- Non-energy impacts - quantifies non-energy impacts produced by the Program;

- Cost-effectiveness - determines the impacts of alternative per-household investment levels on cost-effectiveness; and

The impact assessment will be performed by executing five integrated studies, focusing on the performance of the Program in Program years 2009-2011:

1. The Program Characterization study will characterize the low-income population eligible for and in need of the Program and, for PY 2010, characterize the segment of this population served by the Program; the housing units and clients served; the weatherization and other services performed by the Program; and the Program's expenditures and funding sources.

2. The Energy and Costs Savings study will establish the total and per-household energy and cost savings (heating, cooling, and baseload) being achieved nationally and by climate region under the Program in Program years 2009-2011, classified by the principal building types served and primary fuel types used.

3. Non-Energy Impacts study will ascertain the non-energy impacts attributable to the Program in PYs 2009-2011 (especially those benefits addressing health and safety) and the value of those impacts from the client, utility, and societal perspectives;

4. The Program Cost-effectiveness study will estimate the cost-effectiveness of the Program in PYs 2009-2011 on a national and climate-region basis and will seek to clarify the impact that alternative per-household investment levels can have on cost-effectiveness and other Program metrics; and

5. The Explanatory Factors study will identify how specific weatherization measures and process variables correlate, both positively and negatively, with energy savings and cost-effectiveness.

Each of these studies is described in detail below, including an outline of the data that need to be collected to perform the study and how these data will be analyzed. For each study, a final report including all the details of the study will be written; a final summary report for the impact assessment will also be written to draw all the findings from the studies together. 


\subsection{PROGRAM CHARACTERIZATION STUDY}

As mentioned in the introduction, the WAP during the ARRA period has been very different from the Program as it existed in the past. Not only are several key Program guidelines different (for example, the average allowable investment in homes was increased from $\$ 2500$ to $\$ 6500$ ), but the grantees and subgrantees faced numerous challenges with ramping up the weatherization production, complying with the Davis-Bacon Act, and handling other issues unique to ARRA. The impact assessment will collect key data on the Program's implementation and weatherization processes in order to describe the following:

- the low-income population eligible for the Program, in need of it, and actually being served by it;

- the weatherization network (community) and how it works; especially the organizations that administer the Program at the state and agency level (e.g., organization features and structure, staffing, operational processes, funding levels);

- the housing units that are served (including descriptors of their condition, state of repair, health and safety issues with respect to them, and the types of heating and cooling equipment installed), the clients served by the Program, and how they were selected for inclusion in it;

- the types of audit and diagnostic procedures used on the houses, the time when the diagnostics were performed relative to when measures were installed, and by whom the diagnostics were performed (e.g., auditor, crew, or inspector);

- the weatherization measures installed in the weatherized units (including repairs made, health and safety issues addressed, and client education provided), the installation methods employed, and by whom the measures were installed (contractor vs. in-house crew);

- other Program services performed on the weatherized houses and how they were delivered; and

- the Program's expenditures, expenditures per household, and funding sources.

The data to be collected and the analysis to be performed for the characterization study are presented below.

\subsubsection{Data and Sampling Frames}

The eligible low-income population will be characterized using data from the following three national databases:

- Residential Energy Consumption Survey (RECS) conducted by the U.S. Energy Information Administration

- Current Population Survey (CPS) from the U.S. Census

- American Housing Survey (AHS) from the U.S. Department of Housing and Urban Development.

A list of the data fields to be mined from these databases is provided in Table 2.1 below.

The entities that received WAP-ARRA period funding--all 50 states, the District of Columbia, and U.S. territories--will be asked to complete the S1 (All States Program Information Survey, see Appendix C) at the end of their PY 2010. As part of this survey, the following information on their PY 2010 and 2011 activities will be obtained from all states:

- general information on the characteristics of each state

- details on PY 2010 funding and expenditure

- characteristic data compiled at the state level on housing units weatherized in PY 2010

- characterization data on state staff experience and activity in PY 2010

- characterization data on training and monitoring performed at the state level in PY 2010. 
All of the approximately 1000 agencies $^{2}$ (i.e., subgrantees) that have been or are being employed to implement the Program will be surveyed at the end of PY 2010, using the S2 (All Agencies Program Information Survey, see Appendix D), to collect information on

- PY 2010 funding and expenditure details

- agency-level compiled characteristic data on housing units weatherized in PY 2010.

Although agencies supply similar information to their respective states, this information will be collected from the agencies, not from the states, in order to get the information directly from the original source and to make sure the data are accurate and consistent across all states and agencies.

The 400 agencies included in the billing data sample (see Section 2.2.1) will be surveyed in the S3 (Subset of Agencies Detailed Program Information Survey, see Appendix E) at the end of their PY 2010. The following information will be obtained:

- general characteristic information on each agency,

- data characterizing agency staff experience and activity in PY 2010,

- data characterizing how the agencies implemented client selection in PY 2010, and

- data characterizing house audits, client education, training, and monitoring performed at the agency level in PY 2010.

${ }^{2}$ The number of local weatherization agencies increased to over 1000 during the ARRA period, from just over 900 in the pre-ARRA period. 
Table 2.1. Data fields for this study from RECS, CPS, AHS databases

\begin{tabular}{|l|l|}
\hline Data field & Definitions of data field terms \\
\hline Low-income status & $\begin{array}{l}\text { Defined by ARRA eligibility maximums (i.e., 200\% of poverty level or 60\% of } \\
\text { state median income, whichever is higher) }\end{array}$ \\
\hline State & \\
\hline Census region & Ownership \\
\hline Housing type & \\
\hline Tenure & Presence/absence of wall insulation, storm windows, etc. \\
type & Presence of at least one child in household as defined by Program regulations \\
\hline House energy features & $\begin{array}{l}\text { Presence of at least one elderly person in the household as defined by Program } \\
\text { regulations }\end{array}$ \\
\hline Children & $\begin{array}{l}\text { Presence of at least one handicapped person in the household as defined by } \\
\text { Program regulations }\end{array}$ \\
\hline Elderly & \\
\hline Handicapped & Total household income \\
\hline Single parent & Fixed or not \\
\hline Ethnicity & Total, heating, cooling, and baseload that are nominal and weather-adjusted \\
\hline Income & CPI adjusted; high energy expenditures as defined by Program regulations \\
\hline Source of income & $\begin{array}{l}\text { Calculated from income and energy expenditures, with "high" energy burden as } \\
\text { defined by Program regulations }\end{array}$ \\
\hline Nature of income & $\begin{array}{l}\text { LIHEAP, Food Stamps, Temporary Assistance for Needy Families (TANF), } \\
\text { Section 8, Public Housing, Medicaid, Supplemental Security Income (SSI) }\end{array}$ \\
\hline Energy consumption & \\
\hline Energy expenditures & \\
\hline Energy burden & $\begin{array}{l}\text { Participation in public } \\
\text { assistance programs }\end{array}$
\end{tabular}

For each weatherized housing unit or building included in the billing data sample (see Section 2.2.1), using the DF2 (Housing Unit Information Data Form, see Appendix F) or the DF3 (Building Information Data Form, see Appendix G), the following data will be collected from the agencies:

- detailed housing unit/building and occupant characteristics,

- identification of the diagnostics performed,

- diagnostic data measured by the agencies,

- identification of the measures installed, and

- costs for measures installed and other work performed.

The billing data sample includes data only on those housing units or buildings that use natural gas or electricity as their primary heating fuel. In order to fully characterize all housing units and buildings served by the Program (not just those heated by natural gas or electricity), information will be collected from the same 400 agencies used in the billing data sample on $25 \%$ of the housing units and buildings from each agency whose primary heating fuel is NOT natural gas or electricity. These data will be collected using DF2 (Housing Unit Information Data Form, see Appendix F) or DF3 (Building Information Data Form, see Appendix G).

The data requested in DF2 and DF3, above, are typically maintained in the records of each agency, so no additional information will need to be collected by the agencies. Agencies that store these data electronically will likely be able to provide it on all the housing units and/or buildings they weatherize rather than the $33 \%$ sample required for units and buildings heated by natural gas or electricity 
(see Section 2.21.) or the $25 \%$ sample required for units and buildings heated by other fuels. These data will be collected just after the end of the agency's PY 2010.

\subsubsection{Low-Income Weatherization Market Analysis}

To get a broad picture of the low-income weatherization market, descriptive statistics on key attributes of the eligible population will be developed using data from RECS, CPS, and AHS. Households with incomes of $60 \%$ or less of their state's median income will be the focus of this analysis. The entire low-income population will be characterized, as well as the five subsets of the population allowed by DOE to receive priority service: households with elderly, children, or handicapped; and houses with high energy expenditures or high energy burdens. Other subsets of houses that may be studied separately if there are sufficient data in the databases include "low-efficiency" houses (e.g., houses with no attic insulation), houses of people on fixed incomes, and/or houses whose occupants receive a majority of their income from Social Security. The key attributes that will be studied include the following:

- housing characteristics (housing type, tenure),

- type of primary heating fuel,

- demographics (elderly, children, handicapped, single parent, and ethnicity),

- income,

- energy usage (total, heating, cooling, and/or baseload),

- energy burden,

- energy expenditures, and

- participation in other public-assistance programs.

These attributes will be presented nationally and by climate region in terms of means, medians, distributions, and other characteristics. They will also be cross-tabulated by other key attributes.

Comparisons will be made between the low-income population and the national population, and among the findings from this evaluation, the retrospective evaluation, and the 1989 National Evaluation in order to identify changes since 1989 .

A literature review will be conducted to explore the impact of energy expenditures on households eligible for the Program as well as on households with higher incomes that might also have difficulty paying their energy bills. This literature review will examine the issue of energy affordability across different income categories and will provide a description of the population in need of assistance in order to place the objectives of the Program in their appropriate context.

Using data collected from all states and agencies nationwide via the web-based survey, all the units weatherized by the Program in the program year will be characterized by the following key attributes:

- classification as DOE or non-DOE units,

- housing type,

- primary heating fuel,

- tenure,

- climate region,

- participation in other federal assistance programs,

- income,

- ethnicity,

- single-parent, and

- priority traits of occupants and houses for weatherization. 
These attributes will be presented nationally and by climate region in terms of means, medians, distributions, and cross-tabulations with other key attributes. The results will then be compared to the characterization of the eligible population to identify the segments of the eligible population and eligible housing stock being served by the Program. Results will be presented in relative percentages and proportions nationally and by climate regions.

\subsubsection{State and Agency Characterization Analysis}

Local and state agencies will be characterized by key attributes, including the following:

- agency type and size,

- funding (both DOE and non-DOE),

- how funding is allocated by function (e.g., intake, auditing, training, weatherization, quality assurance monitoring),

- number of units weatherized (total and by funding source, with tagging to avoid duplicated counts),

- number of units on a waiting list,

- number of units referred to other programs,

- number of units receiving on-site services from non-energy programs, and

- number of staff/employees by role, tenure, training, experience, and those needing certification.

The scope and scale of agency involvement with other energy, housing, and low-income programs will be characterized and described. The location and status of the state agencies administering the Program within their state government organizations will be described, and the relationship of the state agencies to other energy, housing, and low-income programs will be characterized and described. Descriptive statistics will be presented nationally and by climate region in terms of totals, means, medians, and distributions, as appropriate.

\subsubsection{Detailed Characterization of Program and Analysis of Implementation}

The approaches used to select clients, audit houses, provide client education, train crews and agencies, and monitor agencies will be thoroughly characterized as part of the in-depth analysis to be performed on audits and client education under the impact assessment portion of this evaluation. Results from these characterization analyses will be used and integrated with the other characterizations being described in this section.

The client-selection process will be characterized by the outreach and marketing methods that are used to get clients to apply for the Program (i.e., how a waiting list is developed) and the methods used to select clients for weatherization from among the qualified applicants (i.e., from clients on a waiting list). These characterizations will be organized nationally and by climate region.

Using the detailed data collected on the housing units that will be used in the energy analyses, the houses and occupants weatherized under the Program will be further characterized by key attributes, including:

- building characteristics (e.g., building type, tenure, floor area, age, number of stories, condition/state of repair, health and safety problems present),

- equipment characteristics (e.g., primary and supplemental heating fuels, central heating system, air conditioning type), and

- $\quad$ occupancy characteristics (e.g., number of occupants; number of children, elderly, and/or handicapped; income; energy burden). 
The key attributes will be characterized nationally and by climate region, primary heating fuel, and dwelling type. Distributions will be examined and reported as appropriate. Results will be integrated into the market analysis described in Section 2.1.2.

The frequency with which various weatherization measures are installed in houses under the Program will be reported and classified into eight major categories: air and duct leakage, insulation, window and doors, space heating equipment, cooling equipment, baseload, client education, and health and safety/repair. Subcategories will further refine these categories and will note different implementation approaches. For example,

- the insulation category will be broken down into attic, wall, and floor insulation, and wall insulation will be further divided into high-density and standard installation techniques;

- the baseload category will be broken down into specific water-heater measures, lighting, and refrigerators;

- the client education category will be divided by different client-education approaches; and

- health and safety/repairs will be classified as replacements of roofs, floors, doors, and windows; installation of smoke and $\mathrm{CO}$ detectors; electrical-system repairs; replacement of unsafe space heaters; replacement of broken air conditioners; and plumbing repairs.

These frequencies will be reported nationally and by climate region, and by primary heating fuel, dwelling type, and other subgroups. The frequency with which different measures are installed by contractors vs. crews will also be tabulated.

The frequency with which diagnostic techniques are used in weatherized houses will be reported for the various techniques (e.g., blower doors, infrared cameras). These frequencies will be reported nationally and by climate region, as well as by primary heating fuel, dwelling type, and other subgroups. For each technique, frequencies will also be tabulated on when the diagnostics were performed (e.g., during the audit, at time of measure installation, or during final inspection) and who performed the diagnostics (e.g., auditor, crew member, or inspector).

\subsubsection{Program Funding and Costs Analysis}

Using agency- and state-level data, financial resources used for weatherization at the local level (both DOE and leveraged, non-DOE) will be characterized, as well as how those resources are combined to weatherize individual units by unduplicated counts (i.e., units weatherized with funds from more than one funding source will not be double counted). These data will be presented nationally and by climate region. Performance requirements for non-DOE funding sources will be analyzed to determine how these compare and relate to requirements for the DOE program. A similar analysis has recently been performed for the Program by Economic Opportunity Studies (Power, 2003). This section will expand that study's analysis outside its formal evaluation budget form to meet the present needs of this evaluation.

Using house-level cost data collected for the energy savings analyses, the average installation costs (labor plus materials) per house will be determined nationally and by the following:

- climate region,

- building type,

- fuel type,

- tenure (ownership),

- type of installer (contractor or in-house crew),

- funding source, and

- possibly other categories. 
Distributions will be examined and reported as appropriate. Prices paid for materials and measures will be assessed against market rates. Average per-house labor and material costs will be examined in a similar manner, as will material costs for individual measures (labor costs per individual measure will only be studied if consistent, high-quality data can be obtained from agencies; however, the availability of such data is not anticipated).

\subsection{ENERGY AND COST SAVINGS}

A major task for the impact evaluation is to estimate energy savings attributable to WAP in homes heated by natural gas and electricity; this study implements a quasi-experimental approach. It is understood that, all things being equal, a random control trial (RCT) approach would be preferred over a quasi-experimental approach. However, there are compelling reasons, explained in this subsection, why a quasi-experimental design has been chosen instead.

The retrospective study, which was also designed quasi-experimentally, was based on the WAP evaluation conducted two decades ago (when the last national evaluation of the Program was conducted). The quasi-experimental design for the retrospective evaluation implemented probabilityproportional-to-size sampling (PPS) to subsample 400 subgrantees (out of 900 ) (discussed in more detail below). Sampling one-third of the units weatherized by these agencies in a targeted program year (e.g., PY 2008) yields a treatment sample size of approximately 10,000 units (out of approximately 100,000 WAP weatherized per year pre-ARRA). The approach calls for an equal number of units to be in the control group, to be drawn from homes weatherized during the following program year.

This choice of control group is reasonable because this group, like the treatment group, has selfselected to apply for weatherization services, and the two groups are likely to be similar in all variables correlated to energy use. (Historically, WAP has only served a small percentage of eligible homes [100,000 homes per year vs. a potential pool of approximately 35 million] and the observed homes going through the Program have had quite similar and constant characteristics for many years.

According to a recent GAO report, "program evaluation literature generally agrees that wellconducted randomized experiments are best suited for assessing effectiveness when multiple causal influences create uncertainty about what caused results." ${ }^{3}$ The GAO report goes on to note, however, that randomized experiments "are often difficult, and sometimes impossible, to carry out," and that "requiring evidence from randomized studies as sole proof of effectiveness will likely exclude many potentially effective and worthwhile practices." ${ }^{4}$ When randomized studies are impractical or impossible to carry out, quasi-experimental (QE) comparison group studies satisfactorily provide "rigorous alternatives to randomized experiments." For legal and practical considerations, we believe that a classical randomized control trial (RCT) approach cannot be implemented to evaluate WAP during the ARRA period.

Additionally, the WAP is administered by States (i.e., grantees) through subgrantees who must prioritize WAP applicants in order to select them. The primary barrier to randomization in a WAP evaluation is in fact legislative priority constraints on how the subgrantees should prioritize WAP applicants. From the U.S. Department of Energy, Weatherization Assistance Program for Low-Income Persons, Title 10, Part 440 (Direct Final Rule, Federal Register, June 22, 2006) ${ }^{5}$ :

\footnotetext{
3“"Program Evaluation: A Variety of Rigorous Methods Can Help Identify Effective Interventions," GAO-10-30, November 2009.

${ }^{4}$ Ibid.

${ }^{5}$ See http://www.waptac.org/sp.asp?id=1812\#minimum.
} 
Section 440.16 Minimum program requirements...(b) Priority is given to identifying and providing weatherization assistance to:

(1) Elderly persons;

(2) Persons with disabilities;

(3) Families with children;

(4) High residential energy users; and

(5) Households with a high energy burden.

Thus, Title 10, Part 440 essentially prohibits the purely random assignment of WAP applicants to control groups, meaning that the RCP approach is not possible.

In conjunction with Title 10, Part 440, there is also a practical and perceived moral obligation among subgrantees to provide services to all applicants — and particularly to high-priority applicants - as fairly and expediently as the Program will allow. This institutional resistance to random assignment to and the consequential delay of service to control groups would have to be overcome before an RCT could be correctly implemented. Changing existing practices would mean that the evaluation team would need to vigorously engage DOE WAP management and all the grantees and subgrantees to convince them all to change Program management processes to fit the needs of an RCT evaluation. This task is beyond the responsibilities of the evaluation team and would be virtually impossible to implement in time, given that we are already well into the ARRA period.

Despite the barriers to a classical RCT approach to WAP evaluation, we consider in Appendix S a hypothetical "split-winter" RCT that could be conducted in conjunction with the QE WAP evaluation study. By "split-winter," we mean that weatherization would be performed during one particular winter, and the total duration of the study would generally be less than in a full evaluation. Sample-size calculations for the split-winter RCT suggest that, even if the legislative and cultural barriers could be circumvented, this alternative RCT approach would still not be a good idea because of very large (and therefore expensive) sample-size requirements. This further supports the assumption that an RCT is not feasible in the WAP-ARRA context and that a carefully conducted QE study is a better approach.

The quasi-experimental approach that has been decided upon for this analysis includes these components:

- estimating variation in billing history data;

- estimating treatment and control group sample sizes;

- determining how many subgrantees (i.e., local weatherization agencies) need to be sampled;

- asking the subgrantees to provide lists of units weatherized during the program year under study;

- asking the sampled subgrantees to provide lists of units weatherized during the following program year to act as a control group;

- sampling units from these two lists to identify units for which billing histories will be collected; and

- contacting the appropriate natural gas and electricity utilities to collect the billing histories, one year pre- and one year post-weatherization.

Adopting the quasi-experimental design approach, the evaluation will focus on estimating the following two aspects of energy and cost savings:

- total annual energy savings achieved from all units weatherized by the Program in PYs 2009, 2010 and 2011 (all fuels combined — natural gas, fuel oil, propane, electricity, etc.-representing a combination of all space-heating, cooling, and baseload energy uses in the houses); and 
- average annual energy savings (calculated separately by electricity savings and energy savings for all non-electric primary space-heating fuels combined) achieved per household in PYs 2009, 2010 and 2011 nationally and by climate region, housing type, primary space-heating fuel type, and the five client groups that the Program is specifically instructed to focus on (i.e., the elderly, persons with disabilities, families with children, high residential energy users, and households with high energy burden).

The cost savings associated with the above energy savings will be calculated using regionallydependent fuel costs; the estimated energy and cost savings for PYs 2009, 2010 and 2011 will be compared to results from the retrospective evaluation, the 1990 National Evaluation, and the metaevaluations performed between 1990 and 2005. Although average energy and cost savings will be calculated in this study by region, housing type, and primary space-heating fuel type, a full analysis of factors affecting energy consumptions and savings will be performed (see Section 2.5).

Energy savings will be estimated based on a sample of housing units or buildings selected from each state in the nation. Billing data will be collected and analyzed on a majority of the housing units/buildings sampled. Energy savings estimated for individual housing units or buildings will be used to develop national estimates. Details are provided below.

\subsubsection{Sampling Frame and Data}

For the retrospective sampling approach, the following information were needed to design and implement the energy analysis sampling frames described in this section:

- DOE funding received by each agency from ARRA;

- identification of agencies that weatherize a significant number of the following types of units: large multifamily units, large multifamily buildings heated by fuel oil, single-family houses heated by fuel oil, single-family houses heated by propane, or mobile homes heated by propane; and

- identification of agencies whose housing units or buildings are served by natural gas and electric utilities that will be cooperative in providing billing data for the evaluation.

This information will be collected as part of S1 (All States Program Information Survey, see Appendix C) administered to all states and territories and S2 (All Agencies Program Information Survey, see Appendix D) administered to all agencies just after the end of PY 2010.

Billing Data Sample - For the retrospective evaluation, natural gas and electricity billing data were collected on a sample of the single-family houses, mobile homes, and both small and large multifamily housing units that were weatherized by 400 agencies in PYs 2007 and 2008. For each agency, all units whose primary heating fuel was natural gas or electricity were sampled if utility account data and other information can be easily provided electronically by the agency; otherwise 33 percent of such units will be sampled (total number of units is estimated to be approximately 10,000). Natural gas billing data were collected on those units whose primary heating fuel was natural gas. Electricity billing data were collected from all the sampled units. Billing data were collected for at least 12 months before and 12 months after each unit's weatherization date. Billing data on a comparable number of control houses were also collected.

The sample size of 400 agencies and 10,000 housing units was selected so that the nationwide total annual energy savings (and average energy savings per housing unit) attributable to the Program can be estimated to within $\sim 15 \%$ of its actual value at a $90 \%$ confidence level after non-response and attrition are taken into account (see Appendix $\mathrm{O}$ for a detailed justification for this sample size). Agencies (and 
thus their housing units) were sampled rather than sampling housing units directly from among all agencies nationwide because of the cost that would be involved in working cooperatively with $~ 900$ separate agencies. The 400 agencies were selected in two steps: the number of agencies to be selected from each state was determined first, and then agencies within each state were selected.

The selection of the 400 agencies was stratified by state because such stratification

- controls for differences in geography, climate, housing stock, fuel types, and other factors;

- controls for the fact that each state administers its program differently (i.e., savings for homes or agencies are likely to be similar to other homes or agencies in the same state rather than a different state);

- ensures that each state will have at least one agency included in the sample; and

- ensures that data provided by states that wish to contribute resources to extend the survey in their states can be easily incorporated into the analysis, and the benefit to the state from doing so can be clearly seen.

The number of individual agencies that were selected from each state were in proportion to the amount (or "size") of the weatherization activity that occurred in each state in PY 2008. For the retrospective evaluation, "size" was defined as the amount of DOE Program funding received by the state. If, for example, a state received 10 percent of the Program's available funding, then 30 agencies (10 percent of 400) would be selected from that state. The number of agencies counted in a state was rounded up to 2 even if its numerical proportion was 1.5 or less in order to ensure that an agency from each state was included in the sample, that standard deviations could be calculated for each state, and that the 14 hot-climate states were adequately represented. It should be stressed that neither the retrospective nor the WAP ARRA period evaluations are interested in comparing states, but that the method of stratification by states is being used to improve the sampling randomization and to minimize the sampling error.

Agencies were selected within a state using PPS sampling, with "size" again defined as the amount of DOE Program funding received by the agency from ARRA funds. PPS sampling is a standard statistical method that selected agencies that were representative of the entire state but which preferentially selects larger agencies (i.e., agencies that received more DOE Program funding) with a higher probability than smaller agencies. This sampling approach led to estimates of totals that are more accurate than estimates based on simple random sampling (i.e., equal probability sampling).

In general, 33 percent of the housing units and buildings whose primary heating fuel is natural gas or electricity and that were weatherized by each agency were randomly selected for inclusion in the retrospective evaluation sample. If an agency was able to provide in electronic form utility account information on all the natural gas and electrically heated units or buildings it weatherized in PYs 2007 and 2008, all such units and buildings weatherized by the agency were included in the billing data sample. At least seven housing units will be selected from each agency to ensure that three housing units remain for each agency after non-response and attrition are considered.

The agency sampling for this WAP ARRA period evaluation will differ from the agency sampling approach for the retrospective study for three reasons. First, there are 129 more agencies providing weatherization services during the ARRA period than during the retrospective period. The sampling approach needs to include some new agencies in the sub-sample.

Second, as explained in depth in Section 4.4, an important component of this evaluation is an assessment of the outcomes of the Sustainable Energy Resources for Consumers Program (SERC), initiated during the ARRA period. This program awarded grants to 92 local weatherization agencies to 
install renewable energy and advanced energy efficiency measures. For reasons explained in Section 4.4, it is necessary to collect billing histories for the SERC homes for all 92 agencies. Thus, all 92 agencies need to be part of the subsample. Of these 92 agencies, 35 were in the original sample of 400,50 were not, and 5 are new to the program. ${ }^{6}$

Third, experiences gained during the data collection phase of the retrospective evaluation suggest that some of the subsampled agencies cannot be persuaded to participate in this project. On the other hand, the identities of very willing agency participants are known. Thus, the revised methodology incorporates known respondents and drops known non-respondents from the set of sub-sample agencies. It should be noted that it is important to ensure that the WAP ARRA period sub-sample of agencies includes a substantial number of agency respondents for the retrospective evaluation in order to facilitate comparisons across a large number of variables between the two time periods.

Combining these factors together yields the following approach to developing the set of sub-sampled agencies:

- The 344 agencies that responded during the retrospective study will be included in the sub-sample (344 out of 847 equals $41 \%$ of the original set of retrospective agencies);

- Included in this set of 344 agencies are 35 agencies that received SERC grants;

- Fifty-six new agencies will be included in the sample (56 out of 129 new agencies equals $43 \%$ of the new agencies);

- All five of the new agencies that also received SERC grants will be included in the set of 56 new agencies;

- The other 50 agencies that received SERC grants but were not part of the retrospective subsample of agencies will also be included in the new set of sub-sampled agencies; and

- The sample size for the sub-sampled agencies for the WAP ARRA period evaluation will increase to 450 for this reason.

Just like the retrospective evaluation, for each house and building included in the billing data sample, the names of the electric and gas (if applicable) utilities, account numbers, weatherization period, and waiver (release) forms will be collected from the agencies, along with the other housing unit and building information described in Section 2.1.1 using the DF2 (Housing Unit Information Survey, see Appendix F) or the DF3 (Building Information Survey, see Appendix G).

The evaluation team will collect the actual electricity and natural gas billing data directly from the utilities (at least 12 months of bills before weatherization and 12 months of bills after weatherization), although agency assistance may be needed in the collection of these data. Natural gas billing data will be collected on those housing units and buildings whose primary heating fuel was natural gas. Electricity billing data will be collected on all housing units and buildings sampled (i.e., both those whose primary heating fuel was electricity and those whose primary heating fuel was natural gas). For multifamily buildings, natural gas and electricity bills will be collected for all master meters as well as for all meters serving the individual apartment units. Utilities will be asked to provide data for each address regardless of occupancy changes and to note when occupancy changes occurred, as these data will be used in the study of non-energy impacts (see Section 2.3.1). The following will be done in order to improve the response rate for the billing data requests:

- an appropriate person at each utility will be contacted to smooth out the process,

\footnotetext{
${ }^{6}$ As of this writing, the identities of the other two agencies are uncertain because of conflicting information in programmatic records.
} 
- the billing data requests will be planned so that data for multiple housing units and buildings are requested from a utility at one time,

- billing data will be requested at regular intervals to reduce the chance that the utilities will not be able to provide data that have already been archived and no longer readily accessible, but the number of such requests will be limited so that utilities have to provide data a limited number of times during the course of the evaluation, and

- assistance from utility regulatory commissions and similar organizations will be solicited as needed.

A control group for the billing data sample will be developed using housing units and buildings weatherized by the same agencies in the PY immediately following. So for example, the control group for homes weatherized in PY 2010 would be homes weatherized in PY 2011. Such a control group will have characteristics that are similar to the weatherized group because they are houses and buildings served by the same agencies; in addition, the client self-selection that led to clients' applying for weatherization assistance will be the same, and the selection process used by the agencies will be the same. The number of control housing units and buildings selected from each agency will be approximately the same as the number of weatherized units sampled from that agency. Controls will be selected from each agency throughout the PY so that pre- and post-weatherization periods for the control units will be similar to those for the weatherized units. Controls will be randomly selected within each agency after building type and primary heating fuel are considered, so that these general characteristics closely match those for the weatherized group.

\subsubsection{Energy Analysis}

For the energy analysis, energy savings for individual housing units and buildings, normalized to a typical-weather year, will be estimated using data and approaches that depend on the building type (see Appendix $\mathrm{P}$ for a detailed definition and description of the building types that will be used in the evaluation) and on whether billing data or sub-metered data were collected. Weather-normalized savings estimates for individual houses and buildings will then be used to estimate the total annual energy savings or average annual per-household energy savings for the Program. Energy-savings estimates will be converted to cost savings using known fuel costs.

Energy Analyses Using Billing Data-Billing data collected on housing units or buildings will be analyzed using three different methods:

- the Princeton Scorekeeping Method (PRISM) as outlined in more detail in Appendix R or suitable substitution;

- the ORNL Aggregate Method as outlined in Appendix R; and

- a third method based on a review of the state-of-the-art techniques such as Statistically Adjusted Engineering (SAE) models, Analysis of Covariance (ANOVA) models, Conditional Demand Analysis (CDA), and fixed-effect models (Hall, 2006; Hall 2004).

For houses or buildings using natural gas as the primary space-heating fuel, two analyses will be performed using each of the three methods: one analysis to determine the weather-normalized savings in the space-heating fuel and another analysis to determine the weather-normalized electricity savings.

PRISM, one of the analysis methods used in the retrospective evaluation, was also the primary method used in the 1989 National Evaluation. It has been recommended that methods other than PRISM be used to supplement and/or serve as an overall check on the PRISM analysis (especially in the hotclimate region, where attrition has been high in previous studies and statistically significant savings have been difficult to measure). Simple methods, such as using simple degree-day adjustments or summing up 
seasonal usage, have been suggested to reduce model failures when PRISM is used and to avoid the subsequent bias that can be introduced. The ORNL aggregate model was selected as a primary alternative method that will be used because, like PRISM, it identifies baseload consumption and allows uncertainties in estimated parameters and calculated values to be determined with a statistical basis. A second alternative method will be selected after a review of the most current methods.

Annual Program Energy Savings-The total annual energy savings achieved by the Program in PYs 2009, 2010 and 2011 will be estimated using the weather-normalized saving estimates for the individual houses and buildings sampled and a statistical approach based on how these houses and buildings were sampled. As outlined below, the total annual energy savings achieved by each state in PYs 2009, 2010 and 2011 will be estimated, and these state values will then be summed to calculate the total annual energy-savings estimate for the Program. State savings are being estimated as an intermediate value to estimating the Program savings because the selection of agencies (and hence housing units and buildings) was stratified by state. Also, the best estimator for savings achieved in housing units and by agencies within a state are savings measured in other housing units and by other agencies within that same state because of differences in how states implement the Program (e.g., what measures are installed, how measures are installed, etc.). The total energy-savings estimates for each state and the Program will be calculated on both a site and source basis.

For each state, the cells in Table 2.2 will be filled in and summed to calculate the total annual energy-savings estimate for the state as follows:

- The savings estimate for each cell involving natural gas or electricity use will be calculated using the weather-normalized savings estimates for the individual houses and buildings sampled in the state, along with appropriate weighting factors, which are based on how the agencies were sampled, the size of the agencies, the number of houses sampled, the number of houses weatherized in the state, etc. Weather-normalized savings estimates for the individual housing units and buildings will be those calculated using PRISM, the ORNL Aggregate Method, the third method chosen, or a combination of these, especially for cell entries based on normalized annual consumptions (NACs) that cannot be well determined, as, for example, analyzing the electricity use in homes where electricity is not the primary heating fuel or fuel use in homes in hot climates with little heating load).

- For cells involving fuel oil and propane, energy savings will be estimated based on the results of the fuel-oil and propane monitored samples from the retrospective evaluation.

- For the "other" cells, engineering estimates will be made based on savings measured for other cells in that state. It is anticipated that engineering estimates will only be required for cells that represent a small percentage of the units weatherized in a state because of the breadth of the proposed sampling plan.

Electricity savings on all sampled houses will be estimated (in part to address space cooling, especially in the hot-climate region) and to include savings from baseload energy uses in the total Program energy-savings estimate. The analysis approach presented above accomplishes this. Electricity consumptions and savings will be estimated in all sampled houses and buildings (not just those that are electrically heated). The analysis of natural gas and electricity billing data will include baseload uses as well as space heating and space cooling.

The average annual energy savings per household achieved by the Program will be estimated in a manner similar to that for the total annual energy savings described above, except that savings will be normalized by the number of units weatherized. Average energy savings will be calculated on both an absolute and percentage basis, and separately by electricity and all other primary space-heating fuels combined. Average annual per household energy savings will be calculated by climate region, housing 
type, primary space-heating fuel type, and various combinations of these categories, as well as by the five client groups that the Program is specifically encouraged to focus on (i.e., the elderly, persons with disabilities, families with children, high residential energy users, and households with high energy burden). Four climate regions consistent with those used in the retrospective evaluation and 1989 National Evaluation will be used: cold, moderate, hot-humid, and hot-dry.

Table 2.2. Total annual Program energy savings

\begin{tabular}{|c|c|c|c|c|c|}
\hline \multirow[t]{2}{*}{$\begin{array}{l}\text { Building type/ } \\
\text { Primary space-heating fuel }\end{array}$} & \multirow[t]{2}{*}{$\begin{array}{l}\text { Number of units } \\
\text { served by the } \\
\text { Program }\end{array}$} & \multirow[t]{2}{*}{$\begin{array}{c}\text { Non-electric } \\
\text { fuels } \\
\text { (Btu) }\end{array}$} & \multirow[t]{2}{*}{$\begin{array}{l}\text { Electricity } \\
\quad(\mathbf{k W h})\end{array}$} & \multicolumn{2}{|c|}{$\begin{array}{l}\text { Total } \\
\text { (Btu) }\end{array}$} \\
\hline & & & & Site & Source \\
\hline \multicolumn{6}{|l|}{ Single-family: } \\
\hline \multicolumn{6}{|l|}{ Natural gas } \\
\hline \multicolumn{6}{|l|}{ Electricity } \\
\hline \multicolumn{6}{|l|}{ Fuel oil } \\
\hline \multicolumn{6}{|l|}{ Propane } \\
\hline \multicolumn{6}{|l|}{ Other } \\
\hline \multicolumn{6}{|l|}{ Mobile home: } \\
\hline \multicolumn{6}{|l|}{ Natural gas } \\
\hline \multicolumn{6}{|l|}{ Electricity } \\
\hline \multicolumn{6}{|l|}{ Fuel oil } \\
\hline \multicolumn{6}{|l|}{ Propane } \\
\hline \multicolumn{6}{|l|}{ Other } \\
\hline \multicolumn{6}{|l|}{ Small multifamily: } \\
\hline \multicolumn{6}{|l|}{ Natural gas } \\
\hline \multicolumn{6}{|l|}{ Electricity } \\
\hline \multicolumn{6}{|l|}{ Fuel oil } \\
\hline \multicolumn{6}{|l|}{ Propane } \\
\hline \multicolumn{6}{|c|}{ Other } \\
\hline \multicolumn{6}{|l|}{ Large multifamily: } \\
\hline \multicolumn{6}{|l|}{ Natural gas } \\
\hline \multicolumn{6}{|l|}{ Electricity } \\
\hline \multicolumn{6}{|l|}{ Fuel oil } \\
\hline \multicolumn{6}{|l|}{ Other } \\
\hline Total & & & & & \\
\hline
\end{tabular}


The total annual energy savings and the average annual per household energy savings described above will be calculated two ways when PRISM results are used. First, results will be calculated using only those houses or buildings that have typical indicators of model reliability (coefficient of determination $\left(\mathrm{R}^{2}\right)$ and coefficient of variance $(\mathrm{CV})$ of the normalized annual consumption that pass standard PRISM criteria (or equivalent for the sub-metered models). This is consistent with past evaluations and is done to eliminate houses and buildings that have models with poor predictive ability from the analysis. Secondly, because of concerns that eliminating such houses and buildings may introduce bias into the results, additional results will be calculated using those houses that pass a more relaxed set of criteria and/or a minimum set of criteria (essentially all houses and buildings). In all cases, a "flatness index" available in PRISM will be used to pass additional houses and buildings that would otherwise fail the PRISM criteria. The flatness index identifies houses and buildings with neither a strong heating nor cooling signal (where $\mathrm{R}^{2}$ is very low) but with a normalized annual consumption that is well determined. This occurs, for example, in examining the space-heating fuel use in a house in a warm climate that has little heating load, the electricity use of a house in a cold climate that has little cooling load, and the electricity use of a house in any climate without an air conditioner. Also, in all cases, outliers will be identified, data quality will be carefully checked, and outliers possibly screened.

In calculating the total annual energy savings and the average annual per-household savings as described above, occupancy changes (and the subsequent large fluctuation in energy consumption that may result) will not cause a house or building to be removed from the analysis. The Program is intended to increase the energy efficiency of low-income housing, and occupancy changes occur naturally in such houses. This is consistent with the approach taken in the retrospective evaluation and 1989 National Evaluation but somewhat atypical of other weatherization evaluations. If desired and deemed necessary, separate analyses with and without occupancy changes will be performed. One concern in automatically dropping such housing units is that large sample attrition may result because low-income housing can have high turnover rates. Another concern is that bias could be introduced because housing units with occupancy changes may have different energy-related characteristics than housing units without occupancy changes and the characteristics and behaviors of movers could be different from that of people who do not move.

The total annual energy savings and the average annual per household savings calculated above will be calculated with and without adjustments for savings in a comparable set of control homes and buildings (i.e., both gross and net results will be presented). Inclusion of a control group (i.e., adjustment of savings for weatherized housing units by the savings for the control group) allows estimation of energy consumption changes that would have occurred in the absence of the Program and controls for factors such as occupant behavior and fuel prices that influence housing-unit energy consumption.

It is desirable to help states that want to determine the savings in their specific state using both data collected under this evaluation and supplemental data collected specifically for that state. The evaluation approach presented in this section easily allows for this since data are being collected in each state and savings are built up by state. Additional funding will be provided by the states or from some other sources to (1) determine what additional data need to be collected needed to perform a state-level analysis, (2) develop the necessary sampling plans and survey instruments, (3) collect the additional data, (4) analyze the additional data together with information already collected under this evaluation in the state, and (5) write a report for the state. The supplemental information collected for an individual state will be incorporated into the analysis performed for the national evaluation by using it, together with data collected in that state under the evaluation, to develop state values.

Cost Savings - The energy savings estimated above will be converted to cost savings using the best available fuel-cost data, which are based on the actual costs incurred by the weatherized homes used in the analysis discussed in this section. Average published fuel-cost data are unlikely to match the 
climate regions being used in the evaluation and are likely representative of all households rather than just low-income households. Therefore, fuel-cost data obtained for the homes in the energy analyses should be used to convert energy savings into cost savings. Special care will be taken in converting energy savings into cost savings if costs were especially volatile over the Program year.

Sensitivity Analysis-After all energy and cost savings are calculated, a sensitivity analysis will be conducted to see how out-year estimates of energy and costs savings might change in response to variation in key driving factors, such as changing demographics in the houses, loss of housing stock, volatility in fuel costs, new technology, and climate change. The results of this analysis will be used in the sensitivity analyses performed for non-energy impacts (see Section 2.3.1) and cost-effectiveness (see Section 2.4).

\subsubsection{Measures Analysis}

Lastly, an in-depth analysis of the measures installed will be conducted. This is a particularly important task for this WAP-ARRA period evaluation because during this time, the average investment in homes increased from $\$ 2500$ to $\$ 6500$. This task will answer the question: How did the packages of measures installed in homes change from PY 2008 to PY 2010?

Several analytical techniques will be applied. First, descriptive statistics that compare the absolute number of measures by type of measure installed in PY 2008 vs. PY 2010 will be produced. Second, percentages of each measure installed (out of all measures installed) will be calculated for both program years. Third, the average number of measures installed per home for both program years will be calculated. Fourth, the probabilities that any particular measure will be installed in a home will be calculated for both program years. Fifth, cluster analyses will be done to explore if there are regular groupings of installed measures and to assess whether the most common measure packages changed between program years. These statistics will be calculated nationally and also by climate region and house type (e.g., single family, mobile home). This information should provide a comprehensive picture of changes in measure installation from PY 2008 to PY 2010.

\subsubsection{Attribution Methodology}

While the Program is the major driving force behind the weatherization of low-income homes in the United States, the Program's resources are leveraged by several other parties and programs, including LIHEAP, PVE, public benefits funds, states, utilities, and non-profit organizations. It is important to properly attribute energy savings and energy cost savings to those parties that, along with DOE, contribute financial and in-kind resources to weatherize low-income homes.

This evaluation will develop a methodology to allow energy savings and energy cost savings to be attributed to the set of parties mentioned above based on well-known concepts found in the field of decision analysis. Generally, the methodology will be based on concepts used in multi-criteria decisionmaking, which includes such tools as decision matrices and evaluation criteria. More specifically, the methodology will categorize weatherization into a finite set of activities and functions (program management, outreach and marketing, client selection, audit and measure selection, measure installation, and training). The contributions of the parties to these activities and functions will be estimated using information collected from all the states as part of S1 (All States Program Information Survey, see Appendix C) and from the 400 agencies included in the billing data sample as part of S3 (Subset of Agencies Program Information Survey, see Appendix E). The influence of these activities and functions on energy savings and cost savings will be estimated by a panel of experts. Using the two sets of estimates and a decision-matrix approach, the accurate attribution of energy savings and cost savings appears to be fairly technically straightforward. If the panel of experts feels that the influences of the activities and functions on savings vary by known state characteristics (e.g., states with that have utility 
weatherization involvement vs. those that do not), then the analysis could be performed by categories of states to build up the appropriate national attribution values.

The challenges to implementing an attribution methodology are likely not to be so much technical as related to the process. For example, one important question relates to who should be involved in making the two sets of estimates described above (although an approach is outlined above). How should the estimates be generated if several parties are involved? How should disagreements among the parties about the estimates be resolved? Lastly, the scale of the attribution methodology needs to be carefully considered. It is assumed that the methodology will be developed within a national context. However, various parties may request that the methodology be applied on a state-by-state basis. This latter approach may require considerably more data collection and would certainly require much more effort to generate the two sets of estimates for every state. Therefore, the process parameters must be clearly established in order to achieve a meaningful, accurate, and efficient survey.

\subsection{NON-ENERGY IMPACTS}

As part of the impact assessment, the non-energy impacts (NEIs) attributable to the Program that affect the clients served, the ratepayers, the utilities, and society will be ascertained. Table 2.3 shows the primary non-energy impacts that have been identified to date and that will be quantified in this evaluation. Schweitzer and Tonn (2002) identified most of these non-energy impacts as being applicable to the Program and provide a detailed discussion of each. It is important to note that the project team will have the flexibility to consider new impacts, new metrics, and new values for existing metrics, as long as such investigation does not involve the collection of primary data not previously approved by OMB under the terms of the Paperwork Reduction Act (PRA).

In addition to the non-energy impacts identified in Table 2.3, the number of actions taken by weatherization providers to improve health and safety (e.g., fix broken flues, replace cracked heat exchangers) will be reported as part of this evaluation.

Table 2.3 also quantifies each of the primary non-energy impacts as a monetized or non-monetized value. Definitions of these terms for the purpose of this evaluation follow.

- Monetized value - For most of the Program-generated non-energy impacts, a monetary value (annual dollar value and lifetime net present dollar value) will be calculated nationally (and possibly by climate region) from different perspectives (client, utility/ratepayer, and society) using a computer model or some other mechanism for performing the necessary calculations. The major inputs for these calculations include household-level data gathered for this national evaluation, a large set of performance metrics describing key Program outputs, and a set of monetized metrics that converts performance measures into dollar values. The dollar value of each monetized impact is calculated by taking the number of relevant household-level activities reported, multiplying that number by the appropriate performance metric, and multiplying that product by the matching monetized metric. Both a point estimate and a confidence interval are expected to be calculated for each impact, in recognition of the uncertainty surrounding these estimates. The "monetized value" will represent the net economic value of the impact, as both costs and benefits associated with the impact will be included. However, monetized values will be calculated only where a specific identifiable expense is avoided or incurred, or where a clear monetary impact is obtained. Subjective approaches to calculating the dollar value of non-energy impacts (e.g., using willingness-to-pay or relative-valuation approaches) will not be used in this evaluation. 
- Non-monetized value - For a sizable minority of Program-generated non-energy impacts, all of which fall under the broad umbrella of "safety, health, and comfort," a non-monetary value will be calculated. Most of these non-monetary values will come from surveys of occupant perceptions, but some will come from the direct measurement of such key factors as indoor air temperature and humidity levels. In assessing the value of these non-monetized impacts, the performance metrics will be calculated directly from the relevant household-level data.

Table 2.3 shows the household-level data that will be used as a basis for calculating each nonenergy impact, as well as for calculating the performance metric and the monetized metric (where applicable) associated with each specific impact.

Under the impact assessment, data will be collected to update some of the performance and monetized metrics needed from earlier estimates before calculating values for the monetized non-energy impacts. In updating these metrics, both costs and benefits will be considered so that net economic values are developed. In addition, household-level data will be collected and analyzed to directly calculate values for the non-monetized impacts. The required data collection and analyses are described more fully below. 
Table 2.3. Non-energy impacts and the household-level data and metrics required to calculate their value

\begin{tabular}{|c|c|c|c|c|}
\hline $\begin{array}{c}\text { Impact } \\
\text { Categories and } \\
\text { Specific Impacts }\end{array}$ & $\begin{array}{c}\text { Type of } \\
\text { Value } \\
\text { Calculated }\end{array}$ & $\begin{array}{l}\text { Household- } \\
\text { Level } \\
\text { Data (used as } \\
\text { basis for } \\
\text { calculating the } \\
\text { value of } \\
\text { impacts) } \\
\end{array}$ & $\begin{array}{l}\text { Performance Metric (to } \\
\text { be multiplied by } \\
\text { household-level data for } \\
\text { monetized impacts and } \\
\text { calculated from } \\
\text { household-level data for } \\
\text { non-monetized impacts) }\end{array}$ & $\begin{array}{c}\text { Monetized Metric } \\
\text { (to be multiplied by } \\
\text { Performance Metric } \\
\text { unless the two are } \\
\text { identical) }\end{array}$ \\
\hline
\end{tabular}

\begin{tabular}{|c|c|c|c|c|}
\hline \multicolumn{5}{|c|}{ A. Payment-Related Impacts } \\
\hline $\begin{array}{l}\text { 1. Rate subsidy } \\
\text { payments } \\
\text { avoided by state } \\
\text { aid agencies } \\
\end{array}$ & Monetized & $\begin{array}{l}\text { Number of } \\
\text { households } \\
\text { weatherized }\end{array}$ & $\begin{array}{l}\text { Average reduction in } \\
\text { number of subsidized } \\
\text { units of energy sold per } \\
\text { weatherized household }\end{array}$ & $\begin{array}{l}\text { Cost to utility per } \\
\text { subsidized unit of energy } \\
\text { sold }\end{array}$ \\
\hline $\begin{array}{l}\text { 2. Lower rate of } \\
\text { bad debt write- } \\
\text { offs }\end{array}$ & Monetized & $\begin{array}{l}\text { Number of } \\
\text { households } \\
\text { weatherized }\end{array}$ & $\begin{array}{l}\text { Average reduction in } \\
\text { amount of bad debt } \\
\text { written off by utility per } \\
\text { weatherized household }\end{array}$ & $\begin{array}{l}\text { Same as Performance } \\
\text { Metric }\end{array}$ \\
\hline $\begin{array}{l}\text { 3. Reduced } \\
\text { carrying cost on } \\
\text { arrearages }\end{array}$ & Monetized & $\begin{array}{l}\text { Number of } \\
\text { households } \\
\text { weatherized }\end{array}$ & $\begin{array}{l}\text { Average dollar reduction } \\
\text { in arrearage per } \\
\text { weatherized household }\end{array}$ & $\begin{array}{l}\text { Interest due utility per } \\
\text { dollar of arrearage }\end{array}$ \\
\hline $\begin{array}{l}\text { 4. Fewer notices } \\
\text { and customer } \\
\text { calls }\end{array}$ & Monetized & $\begin{array}{l}\text { Number of } \\
\text { households } \\
\text { weatherized }\end{array}$ & $\begin{array}{l}\text { Average reduction in } \\
\text { number of notices sent } \\
\text { and calls made to } \\
\text { customers, per } \\
\text { weatherized household }\end{array}$ & $\begin{array}{l}\text { Average cost to utility per } \\
\text { notice sent and call made }\end{array}$ \\
\hline $\begin{array}{l}\text { 5. Fewer shut- } \\
\text { offs and } \\
\text { reconnections for } \\
\text { delinquency }\end{array}$ & Monetized & $\begin{array}{l}\text { Number of } \\
\text { households } \\
\text { weatherized }\end{array}$ & $\begin{array}{l}\text { Average reduction in } \\
\text { number of customer shut- } \\
\text { offs and reconnections } \\
\text { made by utility, per } \\
\text { weatherized household }\end{array}$ & $\begin{array}{l}\text { Average cost to utility per } \\
\text { shut-off and reconnection }\end{array}$ \\
\hline $\begin{array}{l}\text { 6. Reduced } \\
\text { collection costs } \\
\text { for delinquent } \\
\text { payments }\end{array}$ & Monetized & $\begin{array}{l}\text { Number of } \\
\text { households } \\
\text { weatherized }\end{array}$ & $\begin{array}{l}\text { Average reduction in } \\
\text { number of collections } \\
\text { made by utility per } \\
\text { weatherized household }\end{array}$ & $\begin{array}{l}\text { Average cost to utility per } \\
\text { collection }\end{array}$ \\
\hline \multicolumn{5}{|c|}{ B. Service Provision Impacts } \\
\hline $\begin{array}{l}\text { 1. Fewer } \\
\text { emergency gas } \\
\text { service calls }\end{array}$ & Monetized & $\begin{array}{l}\text { Number of } \\
\text { households } \\
\text { weatherized }\end{array}$ & $\begin{array}{l}\text { Average reduction in } \\
\text { number of emergency } \\
\text { service calls made per } \\
\text { weatherized household }\end{array}$ & $\begin{array}{l}\text { Average cost to utility per } \\
\text { service call }\end{array}$ \\
\hline $\begin{array}{l}\text { 2. Reduction in } \\
\text { transmission and } \\
\text { distribution } \\
\text { losses } \\
\end{array}$ & Monetized & $\begin{array}{l}\text { Electricity } \\
\text { savings (in kWh) } \\
\text { in weatherized } \\
\text { houses } \\
\end{array}$ & $\begin{array}{l}\text { Average amount of } \\
\text { electricity lost in } \\
\text { transmission and } \\
\text { distribution, per kWh sold }\end{array}$ & $\begin{array}{l}\text { Average cost to utility per } \\
\text { unit of lost electricity }\end{array}$ \\
\hline $\begin{array}{l}\text { 3. Insurance } \\
\text { savings }\end{array}$ & Monetized & $\begin{array}{l}\text { Number of } \\
\text { households } \\
\text { weatherized }\end{array}$ & $\begin{array}{l}\text { Average reduction in } \\
\text { utility's cost for insurance } \\
\text { to cover household fires } \\
\text { and explosions, per } \\
\text { weatherized household }\end{array}$ & $\begin{array}{l}\text { Same as Performance } \\
\text { Metric }\end{array}$ \\
\hline
\end{tabular}


Table 2.3. Non-energy impacts and the household-level data and metrics required to calculate their value

\begin{tabular}{|c|c|c|c|c|}
\hline $\begin{array}{c}\text { Impact } \\
\text { Categories and } \\
\text { Specific Impacts }\end{array}$ & $\begin{array}{c}\text { Type of } \\
\text { Value } \\
\text { Calculated }\end{array}$ & $\begin{array}{l}\text { Household- } \\
\text { Level } \\
\text { Data (used as } \\
\text { basis for } \\
\text { calculating the } \\
\text { value of } \\
\text { impacts) }\end{array}$ & $\begin{array}{c}\text { Performance Metric (to } \\
\text { be multiplied by } \\
\text { household-level data for } \\
\text { monetized impacts and } \\
\text { calculated from } \\
\text { household-level data for } \\
\text { non-monetized impacts) }\end{array}$ & $\begin{array}{c}\text { Monetized Metric } \\
\text { (to be multiplied by } \\
\text { Performance Metric } \\
\text { unless the two are } \\
\text { identical) }\end{array}$ \\
\hline $\begin{array}{l}\text { 4. Shifted fixed } \\
\text { costs to utilities }\end{array}$ & Monetized & $\begin{array}{l}\text { Number of } \\
\text { households } \\
\text { weatherized }\end{array}$ & $\begin{array}{l}\text { Average energy savings in } \\
\text { weatherized houses }\end{array}$ & $\begin{array}{l}\text { Change in fuel cost per unit } \\
\text { of energy savings to cover } \\
\text { fixed costs }\end{array}$ \\
\hline \multicolumn{5}{|c|}{ II. Impacts on Participating Households } \\
\hline \multicolumn{5}{|c|}{ A. Affordable Housing Impacts } \\
\hline $\begin{array}{l}\text { 1. Water and } \\
\text { sewer service } \\
\text { savings }\end{array}$ & Monetized & $\begin{array}{l}\text { Number of } \\
\text { water-saving } \\
\text { devices installed } \\
\text { in weatherized } \\
\text { houses }\end{array}$ & $\begin{array}{l}\text { Average water savings (in } \\
\text { gallons) per device } \\
\text { installed }\end{array}$ & $\begin{array}{l}\text { Cost of water and sewer } \\
\text { service per gallon of water }\end{array}$ \\
\hline $\begin{array}{l}\text { 2. Property value } \\
\text { impacts }\end{array}$ & Monetized & $\begin{array}{l}\text { Number of } \\
\text { households } \\
\text { weatherized }\end{array}$ & $\begin{array}{l}\text { Average cost of structural } \\
\text { repairs per weatherized } \\
\text { household }\end{array}$ & $\begin{array}{l}\text { Same as Performance } \\
\text { Metric }\end{array}$ \\
\hline $\begin{array}{l}\text { 3. Avoided shut- } \\
\text { offs and } \\
\text { reconnections }\end{array}$ & Monetized & $\begin{array}{l}\text { Number of } \\
\text { households } \\
\text { weatherized }\end{array}$ & $\begin{array}{l}\text { Average reduction in } \\
\text { number of shut-offs and } \\
\text { reconnections, per } \\
\text { weatherized household }\end{array}$ & $\begin{array}{l}\text { Average cost to customer } \\
\text { per shut-off (for "lost rent" } \\
\text { and restart fee) }\end{array}$ \\
\hline $\begin{array}{l}\text { 4. Reduced } \\
\text { mobility }\end{array}$ & Monetized & $\begin{array}{l}\text { Number of } \\
\text { households } \\
\text { weatherized }\end{array}$ & $\begin{array}{l}\text { Average reduction in } \\
\text { number of moves per } \\
\text { weatherized household }\end{array}$ & Average cost per move \\
\hline $\begin{array}{l}\text { 5. Reduced } \\
\text { transaction costs }\end{array}$ & Monetized & $\begin{array}{l}\text { Number of } \\
\text { households } \\
\text { weatherized }\end{array}$ & $\begin{array}{l}\text { Average number of hours } \\
\text { required to become } \\
\text { familiar with energy- } \\
\text { saving products per } \\
\text { household }\end{array}$ & $\begin{array}{l}\text { Average cost per hour of } \\
\text { time (use minimum wage } \\
\text { for this calculation) }\end{array}$ \\
\hline \multicolumn{5}{|c|}{ B. Safety, Health, and Comfort Impacts } \\
\hline \multirow[t]{2}{*}{ 1. Fewer fires } & Monetized & $\begin{array}{l}\text { Number of } \\
\text { households } \\
\text { weatherized }\end{array}$ & $\begin{array}{l}\text { Average reduction in } \\
\text { number of fires per } \\
\text { weatherized household }\end{array}$ & $\begin{array}{l}\text { Average monetary loss to } \\
\text { household (property, } \\
\text { injury, and death) per fire }\end{array}$ \\
\hline & $\begin{array}{l}\text { Non- } \\
\text { monetized }\end{array}$ & $\begin{array}{l}\text { Occupant } \\
\text { perceptions of } \\
\text { household fire } \\
\text { safety before and } \\
\text { after } \\
\text { weatherization }\end{array}$ & $\begin{array}{l}\text { Perceived changes in } \\
\text { safety of heating system } \\
\text { and electrical wiring in } \\
\text { weatherized houses }\end{array}$ & Not applicable \\
\hline $\begin{array}{l}\text { 2. Changes in } \\
\text { frequency of } \\
\text { health problems }\end{array}$ & $\begin{array}{l}\text { Non- } \\
\text { monetized }\end{array}$ & $\begin{array}{l}\text { Occupant } \\
\text { perceptions of } \\
\text { general health } \\
\text { and safety before } \\
\text { and after } \\
\text { weatherization }\end{array}$ & $\begin{array}{l}\text { Perceived change in } \\
\text { health problems in } \\
\text { weatherized houses }\end{array}$ & Not applicable \\
\hline
\end{tabular}


Table 2.3. Non-energy impacts and the household-level data and metrics required to calculate their value

\begin{tabular}{|c|c|c|c|c|}
\hline $\begin{array}{c}\text { Impact } \\
\text { Categories and } \\
\text { Specific Impacts }\end{array}$ & $\begin{array}{l}\text { Type of } \\
\text { Value } \\
\text { Calculated }\end{array}$ & $\begin{array}{l}\text { Household- } \\
\text { Level } \\
\text { Data (used as } \\
\text { basis for } \\
\text { calculating the } \\
\text { value of } \\
\text { impacts) } \\
\end{array}$ & $\begin{array}{l}\text { Performance Metric (to } \\
\text { be multiplied by } \\
\text { household-level data for } \\
\text { monetized impacts and } \\
\text { calculated from } \\
\text { household-level data for } \\
\text { non-monetized impacts) }\end{array}$ & $\begin{array}{c}\text { Monetized Metric } \\
\text { (to be multiplied by } \\
\text { Performance Metric } \\
\text { unless the two are } \\
\text { identical) }\end{array}$ \\
\hline & Monetized & $\begin{array}{l}\text { Number of } \\
\text { households } \\
\text { weatherized }\end{array}$ & $\begin{array}{l}\text { Average reduction in } \\
\text { number of workdays lost } \\
\text { due to health problems per } \\
\text { weatherized household }\end{array}$ & $\begin{array}{l}\text { Average cost to household } \\
\text { per lost work day }\end{array}$ \\
\hline & $\begin{array}{l}\text { Non- } \\
\text { monetized }\end{array}$ & $\begin{array}{l}\text { Occupant reports } \\
\text { on incidence of } \\
\text { symptoms or } \\
\text { occurrences of } \\
\text { specific health } \\
\text { problems before } \\
\text { and after } \\
\text { weatherization }\end{array}$ & $\begin{array}{l}\text { Change in incidence of } \\
\text { symptoms or occurrences } \\
\text { of specific health } \\
\text { problems in weatherized } \\
\text { houses }\end{array}$ & Not applicable \\
\hline \multirow[t]{2}{*}{$\begin{array}{l}\text { 3. Enhanced } \\
\text { prevention and } \\
\text { treatment of } \\
\text { health problems }\end{array}$} & $\begin{array}{l}\text { Non- } \\
\text { monetized }\end{array}$ & $\begin{array}{l}\text { Occupant reports } \\
\text { on number of } \\
\text { times food } \\
\text { purchases were } \\
\text { postponed or not } \\
\text { made in order to } \\
\text { pay utility bills } \\
\text { before and after } \\
\text { weatherization }\end{array}$ & $\begin{array}{l}\text { Reduction in number of } \\
\text { times food could not be } \\
\text { purchased due to size of } \\
\text { utility bill in weatherized } \\
\text { houses }\end{array}$ & Not applicable \\
\hline & $\begin{array}{l}\text { Non- } \\
\text { monetized }\end{array}$ & $\begin{array}{l}\text { Occupant reports } \\
\text { on access to } \\
\text { health care and } \\
\text { medication } \\
\text { before and after } \\
\text { weatherization }\end{array}$ & $\begin{array}{l}\text { Change in access to and } \\
\text { ability to pay for health } \\
\text { care and medication in } \\
\text { weatherized houses }\end{array}$ & Not applicable \\
\hline \multirow[t]{2}{*}{$\begin{array}{l}\text { 4. Changes in } \\
\text { indoor air quality }\end{array}$} & $\begin{array}{l}\text { Non- } \\
\text { monetized }\end{array}$ & $\begin{array}{l}\text { Measured CO } \\
\text { levels before and } \\
\text { after } \\
\text { weatherization } \\
\end{array}$ & $\begin{array}{l}\text { Measured change in } \mathrm{CO} \\
\text { levels in weatherized } \\
\text { houses }\end{array}$ & Not applicable \\
\hline & $\begin{array}{l}\text { Non- } \\
\text { monetized }\end{array}$ & $\begin{array}{l}\text { Measured levels } \\
\text { of indoor } \\
\text { airborne mold } \\
\text { spores relative to } \\
\text { outdoor levels } \\
\text { before and after } \\
\text { weatherization }\end{array}$ & $\begin{array}{l}\text { Measured change in level } \\
\text { of indoor airborne mold } \\
\text { spores relative to outdoor } \\
\text { levels in weatherized } \\
\text { houses }\end{array}$ & Not applicable \\
\hline
\end{tabular}


Table 2.3. Non-energy impacts and the household-level data and metrics required to calculate their value

\begin{tabular}{|c|c|c|c|c|}
\hline $\begin{array}{c}\text { Impact } \\
\text { Categories and } \\
\text { Specific Impacts }\end{array}$ & $\begin{array}{l}\text { Type of } \\
\text { Value } \\
\text { Calculated }\end{array}$ & $\begin{array}{l}\text { Household- } \\
\text { Level } \\
\text { Data (used as } \\
\text { basis for } \\
\text { calculating the } \\
\text { value of } \\
\text { impacts) } \\
\end{array}$ & $\begin{array}{l}\text { Performance Metric (to } \\
\text { be multiplied by } \\
\text { household-level data for } \\
\text { monetized impacts and } \\
\text { calculated from } \\
\text { household-level data for } \\
\text { non-monetized impacts) }\end{array}$ & $\begin{array}{c}\text { Monetized Metric } \\
\text { (to be multiplied by } \\
\text { Performance Metric } \\
\text { unless the two are } \\
\text { identical) }\end{array}$ \\
\hline & $\begin{array}{l}\text { Non- } \\
\text { monetized }\end{array}$ & $\begin{array}{l}\text { Measured levels } \\
\text { of indoor } \\
\text { airborne pollen } \\
\text { relative to } \\
\text { outdoor levels } \\
\text { before and after } \\
\text { weatherization } \\
\end{array}$ & $\begin{array}{l}\text { Measured change in level } \\
\text { of indoor airborne pollen } \\
\text { relative to outdoor levels } \\
\text { in weatherized houses }\end{array}$ & Not applicable \\
\hline & $\begin{array}{l}\text { Non- } \\
\text { monetized }\end{array}$ & $\begin{array}{l}\text { Occupant } \\
\text { perceptions of } \\
\text { odors that could } \\
\text { indicate a } \\
\text { problem with } \\
\text { indoor air quality }\end{array}$ & $\begin{array}{l}\text { Perceived change in } \\
\text { frequency of odors within } \\
\text { weatherized houses }\end{array}$ & Not applicable \\
\hline $\begin{array}{l}\text { 5. Changes in } \\
\text { household } \\
\text { moisture levels }\end{array}$ & $\begin{array}{l}\text { Non- } \\
\text { monetized }\end{array}$ & $\begin{array}{l}\text { Measured levels } \\
\text { of indoor } \\
\text { humidity before } \\
\text { and after } \\
\text { weatherization }\end{array}$ & $\begin{array}{l}\text { Measured change in } \\
\text { humidity levels in } \\
\text { weatherized houses }\end{array}$ & Not applicable \\
\hline \multirow[t]{2}{*}{$\begin{array}{l}\text { 6. Decreased } \\
\text { incidence of } \\
\text { hypothermia and } \\
\text { hyperthermia }\end{array}$} & Monetized & $\begin{array}{l}\text { Number of } \\
\text { households } \\
\text { weatherized }\end{array}$ & $\begin{array}{l}\text { Average reduction in } \\
\text { number of times } \\
\text { emergency medical care is } \\
\text { sought due to heat stress } \\
\text { or overexposure to cold } \\
\text { per weatherized } \\
\text { household }\end{array}$ & $\begin{array}{l}\text { Average cost of emergency } \\
\text { medical care at hospital, } \\
\text { emergency room, or urgent } \\
\text { care facility }\end{array}$ \\
\hline & $\begin{array}{l}\text { Non- } \\
\text { monetized }\end{array}$ & $\begin{array}{l}\text { Occupant reports } \\
\text { on incidence of } \\
\text { students' } \\
\text { disrupted study } \\
\text { due to excessive } \\
\text { heat or cold } \\
\text { before and after } \\
\text { weatherization }\end{array}$ & $\begin{array}{l}\text { Change in incidence of } \\
\text { students' disrupted study } \\
\text { in weatherized houses }\end{array}$ & Not applicable \\
\hline $\begin{array}{l}\text { 7. Improved food } \\
\text { safety }\end{array}$ & $\begin{array}{l}\text { Non- } \\
\text { monetized }\end{array}$ & $\begin{array}{l}\text { Measured } \\
\text { temperature in } \\
\text { refrigerator } \\
\text { before and after } \\
\text { weatherization }\end{array}$ & $\begin{array}{l}\text { Measured change in } \\
\text { refrigerator temperature in } \\
\text { weatherized houses }\end{array}$ & Not applicable \\
\hline
\end{tabular}


Table 2.3. Non-energy impacts and the household-level data and metrics required to calculate their value

\begin{tabular}{|c|c|c|c|c|}
\hline $\begin{array}{c}\text { Impact } \\
\text { Categories and } \\
\text { Specific Impacts } \\
\end{array}$ & $\begin{array}{c}\text { Type of } \\
\text { Value } \\
\text { Calculated } \\
\end{array}$ & $\begin{array}{l}\text { Household- } \\
\text { Level } \\
\text { Data (used as } \\
\text { basis for } \\
\text { calculating the } \\
\text { value of } \\
\text { impacts) } \\
\end{array}$ & $\begin{array}{c}\text { Performance Metric (to } \\
\text { be multiplied by } \\
\text { household-level data for } \\
\text { monetized impacts and } \\
\text { calculated from } \\
\text { household-level data for } \\
\text { non-monetized impacts) }\end{array}$ & $\begin{array}{c}\text { Monetized Metric } \\
\text { (to be multiplied by } \\
\text { Performance Metric } \\
\text { unless the two are } \\
\text { identical) } \\
\end{array}$ \\
\hline & $\begin{array}{l}\text { Non- } \\
\text { monetized }\end{array}$ & $\begin{array}{l}\text { Occupant reports } \\
\text { on number of } \\
\text { incidents of } \\
\text { gastrointestinal } \\
\text { problems and } \\
\text { food poisoning } \\
\text { before and after } \\
\text { weatherization }\end{array}$ & $\begin{array}{l}\text { Change in incidence of } \\
\text { gastrointestinal problems } \\
\text { and food poisoning in } \\
\text { weatherized houses }\end{array}$ & Not applicable \\
\hline \multirow[t]{4}{*}{$\begin{array}{l}\text { 8. Improved } \\
\text { household safety } \\
\text { and security }\end{array}$} & Monetized & $\begin{array}{l}\text { Number of } \\
\text { households } \\
\text { weatherized }\end{array}$ & $\begin{array}{l}\text { Average reduction in } \\
\text { number of times } \\
\text { emergency medical care is } \\
\text { sought for injuries from } \\
\text { tripping and falling in the } \\
\text { home }\end{array}$ & $\begin{array}{l}\text { Average cost of emergency } \\
\text { medical care at hospital, } \\
\text { emergency room, or } \\
\text { urgent-care facility }\end{array}$ \\
\hline & Monetized & $\begin{array}{l}\text { Number of } \\
\text { households } \\
\text { weatherized }\end{array}$ & $\begin{array}{l}\text { Average reduction in } \\
\text { number of times } \\
\text { emergency medical care is } \\
\text { sought for burns from } \\
\text { scalding from domestic } \\
\text { hot water }\end{array}$ & $\begin{array}{l}\text { Average cost of emergency } \\
\text { medical care at hospital, } \\
\text { emergency room, or } \\
\text { urgent-care facility }\end{array}$ \\
\hline & $\begin{array}{l}\text { Non- } \\
\text { monetized }\end{array}$ & $\begin{array}{l}\text { Occupant } \\
\text { perceptions of } \\
\text { security of home } \\
\text { from criminal } \\
\text { intrusion before } \\
\text { and after } \\
\text { weatherization } \\
\end{array}$ & $\begin{array}{l}\text { Perceived change in } \\
\text { security from criminal } \\
\text { intrusion in weatherized } \\
\text { houses }\end{array}$ & Not applicable \\
\hline & Monetized & $\begin{array}{l}\text { Number of } \\
\text { households } \\
\text { weatherized }\end{array}$ & $\begin{array}{l}\text { Average reduction in } \\
\text { number of break-ins per } \\
\text { weatherized household }\end{array}$ & $\begin{array}{l}\text { Average value of items } \\
\text { stolen in break-in }\end{array}$ \\
\hline \multirow[t]{2}{*}{$\begin{array}{l}\text { 9. Change in } \\
\text { presence of } \\
\text { environmental } \\
\text { hazards }\end{array}$} & $\begin{array}{l}\text { Non- } \\
\text { monetized }\end{array}$ & $\begin{array}{l}\text { Measured levels } \\
\text { of asbestos and } \\
\text { radon in houses } \\
\text { before and after } \\
\text { weatherization } \\
\end{array}$ & $\begin{array}{l}\text { Measured change in levels } \\
\text { of asbestos and radon in } \\
\text { weatherized houses }\end{array}$ & Not applicable \\
\hline & $\begin{array}{l}\text { Non- } \\
\text { monetized }\end{array}$ & $\begin{array}{l}\text { Reports on } \\
\text { incidence of } \\
\text { poisoning from } \\
\text { household } \\
\text { chemicals before } \\
\text { and after } \\
\text { weatherization }\end{array}$ & $\begin{array}{l}\text { Change in number of } \\
\text { poisonings from } \\
\text { household chemicals in } \\
\text { weatherized houses }\end{array}$ & Not applicable \\
\hline
\end{tabular}


Table 2.3. Non-energy impacts and the household-level data and metrics required to calculate their value

\begin{tabular}{|c|c|c|c|c|}
\hline $\begin{array}{c}\text { Impact } \\
\text { Categories and } \\
\text { Specific Impacts }\end{array}$ & $\begin{array}{c}\text { Type of } \\
\text { Value } \\
\text { Calculated }\end{array}$ & $\begin{array}{l}\text { Household- } \\
\text { Level } \\
\text { Data (used as } \\
\text { basis for } \\
\text { calculating the } \\
\text { value of } \\
\text { impacts) }\end{array}$ & $\begin{array}{l}\text { Performance Metric (to } \\
\text { be multiplied by } \\
\text { household-level data for } \\
\text { monetized impacts and } \\
\text { calculated from } \\
\text { household-level data for } \\
\text { non-monetized impacts) }\end{array}$ & $\begin{array}{l}\text { Monetized Metric } \\
\text { (to be multiplied by } \\
\text { Performance Metric } \\
\text { unless the two are } \\
\text { identical) }\end{array}$ \\
\hline & $\begin{array}{l}\text { Non- } \\
\text { monetized }\end{array}$ & $\begin{array}{l}\text { Occupant reports } \\
\text { on level of } \\
\text { household } \\
\text { infestation with } \\
\text { vermin before } \\
\text { and after } \\
\text { weatherization }\end{array}$ & $\begin{array}{l}\text { Change in level of vermin } \\
\text { infestation in weatherized } \\
\text { houses }\end{array}$ & Not applicable \\
\hline \multirow[t]{2}{*}{$\begin{array}{l}\text { 10. Improved } \\
\text { comfort }\end{array}$} & $\begin{array}{l}\text { Non- } \\
\text { monetized }\end{array}$ & $\begin{array}{l}\text { Occupant } \\
\text { perceptions of } \\
\text { indoor comfort } \\
\text { (temperature and } \\
\text { draftiness) before } \\
\text { and after } \\
\text { weatherization }\end{array}$ & $\begin{array}{l}\text { Perceived improvement in } \\
\text { indoor comfort } \\
\text { (temperature and } \\
\text { draftiness) in weatherized } \\
\text { houses }\end{array}$ & Not applicable \\
\hline & $\begin{array}{l}\text { Non- } \\
\text { monetized }\end{array}$ & $\begin{array}{l}\text { Measured indoor } \\
\text { air temperature } \\
\text { before and after } \\
\text { weatherization } \\
\end{array}$ & $\begin{array}{l}\text { Measured change in } \\
\text { indoor air temperature in } \\
\text { weatherized houses }\end{array}$ & Not Applicable \\
\hline $\begin{array}{l}\text { 11. Improved } \\
\text { appearance }\end{array}$ & $\begin{array}{l}\text { Non- } \\
\text { monetized }\end{array}$ & $\begin{array}{l}\text { Occupant } \\
\text { perceptions of } \\
\text { appearance of } \\
\text { dwelling before } \\
\text { and after } \\
\text { weatherization }\end{array}$ & $\begin{array}{l}\text { Perceived improvement in } \\
\text { appearance of weatherized } \\
\text { dwellings }\end{array}$ & Not Applicable \\
\hline $\begin{array}{l}\text { 12. Reduced } \\
\text { noise inside } \\
\text { dwelling }\end{array}$ & $\begin{array}{l}\text { Non- } \\
\text { monetized }\end{array}$ & $\begin{array}{l}\text { Occupant } \\
\text { perceptions of } \\
\text { noise level } \\
\text { within dwelling } \\
\text { before and after } \\
\text { weatherization }\end{array}$ & $\begin{array}{l}\text { Perceived reduction in } \\
\text { noise within weatherized } \\
\text { dwellings }\end{array}$ & Not applicable \\
\hline \multicolumn{5}{|c|}{ III. Societal Impacts } \\
\hline \multicolumn{5}{|c|}{ A. Environmental Impacts } \\
\hline $\begin{array}{l}\text { 1. Air emissions: } \\
\mathrm{CO} 2\end{array}$ & Monetized & $\begin{array}{l}\text { Units of energy } \\
\text { saved in } \\
\text { weatherized } \\
\text { houses }\end{array}$ & $\begin{array}{l}\text { Pounds of } \mathrm{CO} 2 \text { emitted } \\
\text { per unit of energy saved }\end{array}$ & $\begin{array}{l}\text { Value of } \mathrm{CO} 2 \text { emission } \\
\text { reduction in dollars per } \\
\text { pound }\end{array}$ \\
\hline $\begin{array}{l}\text { 2. Air emissions: } \\
\text { SOx }\end{array}$ & Monetized & $\begin{array}{l}\text { Units of energy } \\
\text { saved in } \\
\text { weatherized } \\
\text { houses }\end{array}$ & $\begin{array}{l}\text { Pounds of SOx emitted } \\
\text { per unit of energy saved }\end{array}$ & $\begin{array}{l}\text { Value of SOx emission } \\
\text { reduction in dollars per } \\
\text { pound }\end{array}$ \\
\hline
\end{tabular}


Table 2.3. Non-energy impacts and the household-level data and metrics required to calculate their value

\begin{tabular}{|c|c|c|c|c|}
\hline $\begin{array}{c}\text { Impact } \\
\text { Categories and } \\
\text { Specific Impacts }\end{array}$ & $\begin{array}{c}\text { Type of } \\
\text { Value } \\
\text { Calculated }\end{array}$ & $\begin{array}{l}\text { Household- } \\
\text { Level } \\
\text { Data (used as } \\
\text { basis for } \\
\text { calculating the } \\
\text { value of } \\
\text { impacts) }\end{array}$ & $\begin{array}{l}\text { Performance Metric (to } \\
\text { be multiplied by } \\
\text { household-level data for } \\
\text { monetized impacts and } \\
\text { calculated from } \\
\text { household-level data for } \\
\text { non-monetized impacts) }\end{array}$ & $\begin{array}{c}\text { Monetized Metric } \\
\text { (to be multiplied by } \\
\text { Performance Metric } \\
\text { unless the two are } \\
\text { identical) }\end{array}$ \\
\hline $\begin{array}{l}\text { 3. Air emissions: } \\
\text { NOx }\end{array}$ & Monetized & $\begin{array}{l}\text { Units of energy } \\
\text { saved in } \\
\text { weatherized } \\
\text { houses }\end{array}$ & $\begin{array}{l}\text { Pounds of NOx emitted } \\
\text { per unit of energy saved }\end{array}$ & $\begin{array}{l}\text { Value of NOx emission } \\
\text { reduction in dollars per } \\
\text { pound }\end{array}$ \\
\hline $\begin{array}{l}\text { 4. Air emissions: } \\
\mathrm{CO}\end{array}$ & Monetized & $\begin{array}{l}\text { Units of energy } \\
\text { saved in } \\
\text { weatherized } \\
\text { houses }\end{array}$ & $\begin{array}{l}\text { Pounds of CO emitted per } \\
\text { unit of energy saved }\end{array}$ & $\begin{array}{l}\text { Value of CO emission } \\
\text { reduction in dollars per } \\
\text { pound }\end{array}$ \\
\hline $\begin{array}{l}\text { 5. Air emissions: } \\
\text { CH4 }\end{array}$ & Monetized & $\begin{array}{l}\text { Units of energy } \\
\text { saved in } \\
\text { weatherized } \\
\text { houses }\end{array}$ & $\begin{array}{l}\text { Pounds of } \mathrm{CH} 4 \text { emitted } \\
\text { per unit of energy saved }\end{array}$ & $\begin{array}{l}\text { Value of CH4 emission } \\
\text { reduction in dollars per } \\
\text { pound }\end{array}$ \\
\hline $\begin{array}{l}\text { 6. Air emissions: } \\
\text { PM }\end{array}$ & Monetized & $\begin{array}{l}\text { Units of energy } \\
\text { saved in } \\
\text { weatherized } \\
\text { houses }\end{array}$ & $\begin{array}{l}\text { Pounds of PM emitted per } \\
\text { unit of energy saved }\end{array}$ & $\begin{array}{l}\text { Value of PM emission } \\
\text { reduction in dollars per } \\
\text { pound }\end{array}$ \\
\hline $\begin{array}{l}\text { 7. Air emissions: } \\
\text { heavy metals }\end{array}$ & Monetized & $\begin{array}{l}\text { Units of energy } \\
\text { saved in } \\
\text { weatherized } \\
\text { houses }\end{array}$ & $\begin{array}{l}\text { Pounds of heavy metals } \\
\text { emitted per unit of energy } \\
\text { saved }\end{array}$ & $\begin{array}{l}\text { Value of heavy metal } \\
\text { emission reduction in } \\
\text { dollars per pound }\end{array}$ \\
\hline $\begin{array}{l}\text { 8. Fish } \\
\text { impingement }\end{array}$ & Monetized & $\begin{array}{l}\text { Units of } \\
\text { electricity saved } \\
\text { in weatherized } \\
\text { houses }\end{array}$ & $\begin{array}{l}\text { Number of fish impinged } \\
\text { at power plants per unit of } \\
\text { electricity saved }\end{array}$ & $\begin{array}{l}\text { Dollar value per impinged } \\
\text { fish }\end{array}$ \\
\hline $\begin{array}{l}\text { 9. Wastewater } \\
\text { and sewage in } \\
\text { electricity } \\
\text { production }\end{array}$ & Monetized & $\begin{array}{l}\text { Units of } \\
\text { electricity saved } \\
\text { in weatherized } \\
\text { houses }\end{array}$ & $\begin{array}{l}\text { Amount of wastewater } \\
\text { and sewage (in gallons) } \\
\text { produced per unit of } \\
\text { electricity saved }\end{array}$ & $\begin{array}{l}\text { Cost per gallon of treating } \\
\text { wastewater and sewage }\end{array}$ \\
\hline \multicolumn{5}{|l|}{ B. Social Impacts } \\
\hline $\begin{array}{l}\text { 1.Jobs for } \\
\text { unemployed } \\
\text { workers }\end{array}$ & Monetized & $\begin{array}{l}\text { Dollars spent to } \\
\text { weatherize client } \\
\text { homes }\end{array}$ & $\begin{array}{l}\text { Average number of } \\
\text { unemployed workers } \\
\text { given jobs per dollar spent } \\
\text { on weatherization }\end{array}$ & $\begin{array}{l}\text { Average cost of } \\
\text { unemployment benefits } \\
\text { paid per unemployed } \\
\text { worker }\end{array}$ \\
\hline \multicolumn{5}{|c|}{ C. Economic Impacts } \\
\hline $\begin{array}{l}\text { 1. Direct and } \\
\text { indirect } \\
\text { employment }\end{array}$ & Monetized & $\begin{array}{l}\text { Dollars spent to } \\
\text { weatherize client } \\
\text { homes }\end{array}$ & $\begin{array}{l}\text { Average number of direct } \\
\text { and indirect jobs created } \\
\text { per dollar spent on } \\
\text { weatherization }\end{array}$ & $\begin{array}{l}\text { Taxes paid (local, state, } \\
\text { and federal) and dollars } \\
\text { spent locally, per job } \\
\text { created }\end{array}$ \\
\hline 2. Lost rental & Monetized & $\begin{array}{l}\text { Number of rental } \\
\text { households } \\
\text { weatherized }\end{array}$ & $\begin{array}{l}\text { Average amount of unpaid } \\
\text { rent per weatherized rental } \\
\text { household before and after } \\
\text { weatherization }\end{array}$ & $\begin{array}{l}\text { Same as Performance } \\
\text { Metric }\end{array}$ \\
\hline
\end{tabular}


Table 2.3. Non-energy impacts and the household-level data and metrics required to calculate their value

\begin{tabular}{|c|c|c|c|c|}
\hline $\begin{array}{c}\text { Impact } \\
\text { Categories and } \\
\text { Specific Impacts }\end{array}$ & $\begin{array}{c}\text { Type of } \\
\text { Value } \\
\text { Calculated }\end{array}$ & $\begin{array}{l}\text { Household- } \\
\text { Level } \\
\text { Data (used as } \\
\text { basis for } \\
\text { calculating the } \\
\text { value of } \\
\text { impacts) }\end{array}$ & $\begin{array}{l}\text { Performance Metric (to } \\
\text { be multiplied by } \\
\text { household-level data for } \\
\text { monetized impacts and } \\
\text { calculated from } \\
\text { household-level data for } \\
\text { non-monetized impacts) }\end{array}$ & $\begin{array}{l}\text { Monetized Metric } \\
\text { (to be multiplied by } \\
\text { Performance Metric } \\
\text { unless the two are } \\
\text { identical) }\end{array}$ \\
\hline $\begin{array}{l}\text { 3. National } \\
\text { security }\end{array}$ & Monetized & $\begin{array}{l}\text { Units of source } \\
\text { energy saved in } \\
\text { weatherized } \\
\text { houses }\end{array}$ & $\begin{array}{l}\text { Average proportion of } \\
\text { source energy used for } \\
\text { residential purposes that is } \\
\text { normally imported }\end{array}$ & $\begin{array}{l}\text { "Premium" paid in higher } \\
\text { prices and disturbance to } \\
\text { economy per unit of } \\
\text { imported energy }\end{array}$ \\
\hline
\end{tabular}

Care will be taken to avoid double-counting any non-energy impact and to make sure that measured impacts are truly attributable to the Program (e.g., by use of control groups). In addition, the non-energy impacts addressed in this evaluation will not include the impact of market transformation, which can be thought of as additional energy savings that "spill over" from direct program effects. The possible differences between non-energy impacts achieved in urban and in rural areas are also not subjects of this evaluation.

\subsubsection{Monetized Data Collection and Analysis}

To calculate the monetary values of selected non-energy impacts, coefficients for the performance metrics and monetized metrics will be acquired either from previous research on non-energy impacts or from new primary and secondary data gathered for this evaluation The default values for the performance and monetized metric coefficients will be those used in ORNL's 2002 review of non-energy impacts of the Weatherization Program (Schweitzer and Tonn 2002). The default values will be replaced with new, updated values that reflect current conditions for the Program under the following circumstances:

- coefficients from newer studies or computerized models are judged to be superior,

- existing coefficients do not adequately represent program impacts nationwide or the net economic value of the impact, or

- the impact was quantified with a new household level variable.

To the extent possible, coefficients that disaggregate non-energy impacts by geographic and/or climate region should be used, and the coefficients used for this study, whether existing or newly developed, will be of this type. It is likely (and acceptable) that region-specific coefficients (such as the cost of water service) will be used for some non-energy impacts and not for others. In addition, the types of housing units to which the available data apply (e.g., single-family dwellings, mobile homes, multifamily units) will be tracked and, where appropriate (and data allowing), separate coefficients for the different housing types will be developed.

Table 2.4 identifies the monetized non-energy impacts for which new performance and/or monetized metrics will be developed in this evaluation. Table 2.4 also shows the factors to be considered in determining what new data are needed. The determination about what new data to acquire is guided by how much uncertainty surrounds current metrics, the potential magnitude of a metric's salience, and how closely the metric is tied to primary Program purposes. It is possible that after existing performance and monetized metric coefficients are examined, it will be concluded that other new coefficients are also 
needed. As noted earlier, it is acceptable for new impacts, new metrics, and new values for existing metrics to be added as long as no data are collected that have not been previously approved by OMB.

For each monetized non-energy impact, the data to be collected to update its performance and/or monetized metric are described below, as well as the methods that will be used to collect and analyze those data: 
Table 2.4. Impacts, metrics, and factors required to determine need for new data

\begin{tabular}{|l|c|c|c|c|c|}
\hline $\begin{array}{c}\text { Impact } \\
\text { Categories and } \\
\text { Specific } \\
\text { Impacts }\end{array}$ & $\begin{array}{c}\text { Performance } \\
\text { Metric and } \\
\text { Uncertainty } \\
(\mathrm{L}, \mathrm{M}, \mathrm{H})\end{array}$ & $\begin{array}{c}\text { Monetized Metric } \\
\text { and Uncertainty } \\
(\mathrm{L}, \mathrm{M}, \mathrm{H})\end{array}$ & $\begin{array}{c}\text { Potential } \\
\text { Magnitude of } \\
\text { Monetized } \\
\text { Value } \\
(\mathrm{L}, \mathrm{M}, \mathrm{H})\end{array}$ & $\begin{array}{c}\text { Metric is } \\
\text { Closely } \\
\text { Tied to } \\
\text { Program } \\
\text { Purposes } \\
\text { (Y, N) }\end{array}$ & $\begin{array}{c}\text { New Data to } \\
\text { Collect for } \\
\text { This Study }\end{array}$ \\
\end{tabular}

A. Payment-Related Impacts

\begin{tabular}{|c|c|c|c|c|c|}
\hline $\begin{array}{l}\text { 1. Rate } \\
\text { subsidies } \\
\text { avoided }\end{array}$ & $\begin{array}{l}\text { Average reduction in } \\
\text { number of } \\
\text { subsidized units of } \\
\text { energy sold per } \\
\text { weatherized } \\
\text { household (L) } \\
\end{array}$ & $\begin{array}{l}\text { Cost to utility per } \\
\text { subsidized unit of } \\
\text { energy sold (L) }\end{array}$ & $\mathrm{L}$ & $\mathrm{N}$ & None \\
\hline $\begin{array}{l}\text { 2. Lower bad } \\
\text { debt write-off }\end{array}$ & $\begin{array}{l}\text { Average reduction in } \\
\text { amount of bad debt } \\
\text { written off by utility } \\
\text { per weatherized } \\
\text { household (L) } \\
\end{array}$ & $\begin{array}{l}\text { Same as } \\
\text { Performance } \\
\text { Metric (L) }\end{array}$ & $\mathrm{M}$ & $\mathrm{N}$ & None \\
\hline $\begin{array}{l}\text { 3. Reduced } \\
\text { carrying cost on } \\
\text { arrearages }\end{array}$ & $\begin{array}{l}\text { Average dollar } \\
\text { reduction in } \\
\text { arrearage per } \\
\text { weatherized } \\
\text { household }(\mathrm{L}) \\
\end{array}$ & $\begin{array}{l}\text { Interest due utility } \\
\text { per dollar of } \\
\text { arrearage (L) }\end{array}$ & $\mathrm{L}$ & $\mathrm{N}$ & None \\
\hline $\begin{array}{l}\text { 4. Fewer notices } \\
\text { and customer } \\
\text { calls }\end{array}$ & $\begin{array}{l}\text { Average reduction in } \\
\text { number of notices } \\
\text { sent and calls made } \\
\text { to customers, per } \\
\text { weatherized } \\
\text { household (L) } \\
\end{array}$ & $\begin{array}{l}\text { Average cost to } \\
\text { utility per notice } \\
\text { sent and call made } \\
\text { (L) }\end{array}$ & $\mathrm{L}$ & $\mathrm{N}$ & None \\
\hline $\begin{array}{l}\text { 5. Fewer shut- } \\
\text { offs and } \\
\text { reconnections } \\
\text { for delinquency }\end{array}$ & $\begin{array}{l}\text { Average reduction in } \\
\text { number of customer } \\
\text { shut-offs and } \\
\text { reconnections made } \\
\text { by utility, per } \\
\text { weatherized } \\
\text { household (L) } \\
\end{array}$ & $\begin{array}{l}\text { Average cost to } \\
\text { utility per shut-off } \\
\text { and reconnection } \\
\text { (L) }\end{array}$ & $\mathrm{L}$ & $\mathrm{N}$ & None \\
\hline $\begin{array}{l}\text { 6. Reduced } \\
\text { collection costs } \\
\text { for delinquent } \\
\text { payments }\end{array}$ & $\begin{array}{l}\text { Average reduction in } \\
\text { number of } \\
\text { collections made by } \\
\text { utility per } \\
\text { weatherized } \\
\text { household }(\mathrm{H}) \\
\end{array}$ & $\begin{array}{l}\text { Average cost to } \\
\text { utility per } \\
\text { collection (M) }\end{array}$ & $\mathrm{L}$ & $\mathrm{N}$ & None \\
\hline \multicolumn{6}{|c|}{ B. Service Provision Impacts } \\
\hline $\begin{array}{l}\text { 1. Fewer } \\
\text { emergency gas } \\
\text { service calls }\end{array}$ & $\begin{array}{l}\text { Average reduction in } \\
\text { number of } \\
\text { emergency service } \\
\text { calls made per } \\
\text { weatherized } \\
\text { household (L) }\end{array}$ & $\begin{array}{l}\text { Average cost to } \\
\text { utility per service } \\
\text { call (L) }\end{array}$ & $\mathrm{M}$ & $\mathrm{N}$ & None \\
\hline
\end{tabular}


Table 2.4. Impacts, metrics, and factors required to determine need for new data

\begin{tabular}{|c|c|c|c|c|c|}
\hline $\begin{array}{c}\text { Impact } \\
\text { Categories and } \\
\text { Specific } \\
\text { Impacts }\end{array}$ & $\begin{array}{c}\text { Performance } \\
\text { Metric and } \\
\text { Uncertainty } \\
(\mathbf{L}, \mathbf{M}, \mathbf{H})\end{array}$ & $\begin{array}{l}\text { Monetized Metric } \\
\text { and Uncertainty } \\
\quad(\mathrm{L}, \mathrm{M}, \mathrm{H})\end{array}$ & $\begin{array}{c}\text { Potential } \\
\text { Magnitude of } \\
\text { Monetized } \\
\text { Value } \\
(\mathbf{L}, \mathbf{M}, \mathbf{H})\end{array}$ & $\begin{array}{c}\text { Metric is } \\
\text { Closely } \\
\text { Tied to } \\
\text { Program } \\
\text { Purposes } \\
(\mathbf{Y}, \mathbf{N})\end{array}$ & $\begin{array}{l}\text { New Data to } \\
\text { Collect for } \\
\text { This Study }\end{array}$ \\
\hline $\begin{array}{l}\text { 2. Trans- } \\
\text { mission and } \\
\text { distribution loss } \\
\text { reduction }\end{array}$ & $\begin{array}{l}\text { Average amount of } \\
\text { electricity lost in } \\
\text { transmission and } \\
\text { distribution, per } \\
\mathrm{kWh} \text { sold (L) }\end{array}$ & $\begin{array}{l}\text { Average cost to } \\
\text { utility per unit of } \\
\text { electricity lost (L) }\end{array}$ & $\mathrm{L}$ & $\mathrm{N}$ & None \\
\hline $\begin{array}{l}\text { 3. Insurance } \\
\text { savings }\end{array}$ & $\begin{array}{l}\text { Average reduction in } \\
\text { utility's cost for } \\
\text { insurance to cover } \\
\text { household fires and } \\
\text { explosions, per } \\
\text { weatherized } \\
\text { household (M) } \\
\end{array}$ & $\begin{array}{l}\text { Same as } \\
\text { Performance } \\
\text { Metric (M) }\end{array}$ & $\mathrm{L}$ & $\mathrm{N}$ & None \\
\hline $\begin{array}{l}\text { 4. Shifted utility } \\
\text { fixed costs }\end{array}$ & $\begin{array}{l}\text { Average energy } \\
\text { savings in } \\
\text { weatherized houses } \\
\text { (L) }\end{array}$ & $\begin{array}{l}\text { Change in fuel cost } \\
\text { per unit of energy } \\
\text { savings to cover } \\
\text { fixed costs }(M)\end{array}$ & $\mathrm{L}$ & $\mathrm{N}$ & $\begin{array}{l}\text { Monetized } \\
\text { Metric }\end{array}$ \\
\hline \multicolumn{6}{|c|}{ II. Impacts to Participating Households } \\
\hline \multicolumn{6}{|c|}{ A. Affordable Housing Impacts } \\
\hline $\begin{array}{l}\text { 1. Water and } \\
\text { sewer savings }\end{array}$ & $\begin{array}{l}\text { Average water } \\
\text { savings (in gallons) } \\
\text { per device installed } \\
\text { (M) }\end{array}$ & $\begin{array}{l}\text { Cost of water and } \\
\text { sewer service per } \\
\text { gallon of water }(\mathrm{H})\end{array}$ & $\mathrm{M}$ & $\mathrm{N}$ & $\begin{array}{l}\text { Performance } \\
\text { and Monetary } \\
\text { Metrics }\end{array}$ \\
\hline $\begin{array}{l}\text { 2. Property } \\
\text { value impacts }\end{array}$ & $\begin{array}{l}\text { Average cost of } \\
\text { structural repairs per } \\
\text { weatherized } \\
\text { household (L) }\end{array}$ & $\begin{array}{l}\text { Same as } \\
\text { Performance } \\
\text { Metric (L) }\end{array}$ & $\mathrm{M}$ & $\mathrm{N}$ & $\begin{array}{l}\text { Performance } \\
\text { Metric (data } \\
\text { collected in } \\
\text { samples) }\end{array}$ \\
\hline $\begin{array}{l}\text { 3. Avoided } \\
\text { shut-offs and } \\
\text { reconnections }\end{array}$ & $\begin{array}{l}\text { Average reduction in } \\
\text { number of shut-offs } \\
\text { and reconnections, } \\
\text { per weatherized } \\
\text { household (L) }\end{array}$ & $\begin{array}{l}\text { Average cost to } \\
\text { customer per shut- } \\
\text { off (for "lost rent" } \\
\text { and restart fee) (L) }\end{array}$ & $\mathrm{L}$ & $\mathrm{Y}$ & \\
\hline $\begin{array}{l}\text { 4. Reduced } \\
\text { mobility }\end{array}$ & $\begin{array}{l}\text { Average reduction } \\
\text { in number of } \\
\text { moves per } \\
\text { weatherized } \\
\text { household }(\mathrm{H})\end{array}$ & $\begin{array}{l}\text { Average cost per } \\
\text { move }(\mathrm{M})\end{array}$ & $\mathrm{M}$ & $\mathrm{N}$ & $\begin{array}{l}\text { Performance } \\
\text { and Monetary } \\
\text { Metrics }\end{array}$ \\
\hline $\begin{array}{l}\text {. Reduced } \\
\text { transaction } \\
\text { costs }\end{array}$ & $\begin{array}{l}\text { Average number } \\
\text { of hours required } \\
\text { to become familiar } \\
\text { with energy- } \\
\text { saving products } \\
\text { per household (L) }\end{array}$ & $\begin{array}{l}\text { Average cost per } \\
\text { hour of time (use } \\
\text { minimum wage } \\
\text { for this } \\
\text { calculation) (M) }\end{array}$ & $\mathrm{L}$ & $\mathrm{N}$ & \\
\hline
\end{tabular}


Table 2.4. Impacts, metrics, and factors required to determine need for new data

\begin{tabular}{|c|c|c|c|c|c|}
\hline $\begin{array}{c}\text { Impact } \\
\text { Categories and } \\
\text { Specific } \\
\text { Impacts }\end{array}$ & $\begin{array}{c}\text { Performance } \\
\text { Metric and } \\
\text { Uncertainty } \\
(\mathrm{L}, \mathrm{M}, \mathrm{H})\end{array}$ & $\begin{array}{c}\text { Monetized Metric } \\
\text { and Uncertainty } \\
(\mathrm{L}, \mathrm{M}, \mathrm{H})\end{array}$ & $\begin{array}{c}\text { Potential } \\
\text { Magnitude of } \\
\text { Monetized } \\
\text { Value } \\
(\mathbf{L}, \mathbf{M}, \mathbf{H})\end{array}$ & $\begin{array}{c}\text { Metric is } \\
\text { Closely } \\
\text { Tied to } \\
\text { Program } \\
\text { Purposes } \\
\text { (Y, N) }\end{array}$ & $\begin{array}{l}\text { New Data to } \\
\text { Collect for } \\
\text { This Study }\end{array}$ \\
\hline \multirow[t]{2}{*}{ 1. Fewer fires } & $\begin{array}{l}\text { Average reduction } \\
\text { in number of fires } \\
\text { per weatherized } \\
\text { household }(\mathrm{M})\end{array}$ & $\begin{array}{l}\text { Average } \\
\text { monetary loss to } \\
\text { household } \\
\text { (property, injury, } \\
\text { and death) per } \\
\text { fire (M) }\end{array}$ & $\mathrm{M}$ & $\mathrm{Y}$ & $\begin{array}{l}\text { Performance } \\
\text { and Monetary } \\
\text { Metrics }\end{array}$ \\
\hline & $\begin{array}{l}\text { Perceived changes } \\
\text { in safety of } \\
\text { heating system and } \\
\text { electrical wiring in } \\
\text { weatherized } \\
\text { houses }(\mathrm{H})\end{array}$ & Not applicable & $\begin{array}{l}\text { Not } \\
\text { applicable }\end{array}$ & $\mathrm{Y}$ & $\begin{array}{l}\text { Household- } \\
\text { level Data }\end{array}$ \\
\hline \multirow[t]{3}{*}{$\begin{array}{l}\text { 2. Changes in } \\
\text { frequency of } \\
\text { health } \\
\text { problems }\end{array}$} & $\begin{array}{l}\text { Perceived change } \\
\text { in health problems } \\
\text { in weatherized } \\
\text { houses }(\mathrm{H})\end{array}$ & Not applicable & $\begin{array}{l}\text { Not } \\
\text { applicable }\end{array}$ & $\mathrm{Y}$ & $\begin{array}{l}\text { Household- } \\
\text { level Data }\end{array}$ \\
\hline & $\begin{array}{l}\text { Average reduction } \\
\text { in number of } \\
\text { workdays lost due } \\
\text { to health problems } \\
\text { per weatherized } \\
\text { household }(\mathrm{H})\end{array}$ & $\begin{array}{l}\text { Average cost to } \\
\text { household per } \\
\text { lost work day (L) }\end{array}$ & $\mathrm{M}$ & $\mathrm{Y}$ & $\begin{array}{l}\text { Performance } \\
\text { Metric }\end{array}$ \\
\hline & $\begin{array}{l}\text { Change in } \\
\text { incidence of } \\
\text { symptoms or } \\
\text { occurrences of } \\
\text { specific health } \\
\text { problems in } \\
\text { weatherized } \\
\text { houses }(\mathrm{H})\end{array}$ & Not applicable & $\begin{array}{l}\text { Not } \\
\text { applicable }\end{array}$ & $\mathrm{Y}$ & $\begin{array}{l}\text { Household- } \\
\text { level Data }\end{array}$ \\
\hline \multirow[t]{2}{*}{$\begin{array}{l}\text { 3. Enhanced } \\
\text { prevention and } \\
\text { treatment of } \\
\text { health } \\
\text { problems }\end{array}$} & $\begin{array}{l}\text { Reduction in } \\
\text { number of times } \\
\text { food could not be } \\
\text { purchased due to } \\
\text { size of utility bill } \\
\text { in weatherized } \\
\text { houses }(\mathrm{H}) \\
\end{array}$ & Not applicable & $\begin{array}{l}\text { Not } \\
\text { applicable }\end{array}$ & $\mathrm{Y}$ & $\begin{array}{l}\text { Household- } \\
\text { level Data }\end{array}$ \\
\hline & $\begin{array}{l}\text { Change in access } \\
\text { to health care and } \\
\text { medication in } \\
\text { weatherized } \\
\text { houses }\end{array}$ & Not applicable & $\begin{array}{l}\text { Not } \\
\text { applicable }\end{array}$ & $\mathrm{Y}$ & $\begin{array}{l}\text { Household- } \\
\text { level Data }\end{array}$ \\
\hline
\end{tabular}


Table 2.4. Impacts, metrics, and factors required to determine need for new data

\begin{tabular}{|c|c|c|c|c|c|}
\hline $\begin{array}{c}\text { Impact } \\
\text { Categories and } \\
\text { Specific } \\
\text { Impacts }\end{array}$ & $\begin{array}{c}\text { Performance } \\
\text { Metric and } \\
\text { Uncertainty } \\
(\mathrm{L}, \mathrm{M}, \mathrm{H})\end{array}$ & $\begin{array}{c}\text { Monetized Metric } \\
\text { and Uncertainty } \\
(\mathrm{L}, \mathrm{M}, \mathrm{H})\end{array}$ & $\begin{array}{c}\text { Potential } \\
\text { Magnitude of } \\
\text { Monetized } \\
\text { Value } \\
(\mathbf{L}, \mathbf{M}, \mathbf{H})\end{array}$ & $\begin{array}{c}\text { Metric is } \\
\text { Closely } \\
\text { Tied to } \\
\text { Program } \\
\text { Purposes } \\
\text { (Y, N) }\end{array}$ & $\begin{array}{l}\text { New Data to } \\
\text { Collect for } \\
\text { This Study }\end{array}$ \\
\hline \multirow[t]{4}{*}{$\begin{array}{l}\text { 4. Changes in } \\
\text { indoor air } \\
\text { quality }\end{array}$} & $\begin{array}{l}\text { Measured change } \\
\text { in CO levels in } \\
\text { weatherized } \\
\text { houses }(\mathrm{H})\end{array}$ & Not applicable & $\begin{array}{l}\text { Not } \\
\text { applicable }\end{array}$ & $\mathrm{Y}$ & $\begin{array}{l}\text { Household- } \\
\text { level Data }\end{array}$ \\
\hline & $\begin{array}{l}\text { Measured change } \\
\text { in level of indoor } \\
\text { airborne mold } \\
\text { spores relative to } \\
\text { outdoor levels in } \\
\text { weatherized } \\
\text { houses }(\mathrm{H})\end{array}$ & Not applicable & $\begin{array}{l}\text { Not } \\
\text { applicable }\end{array}$ & $\mathrm{Y}$ & $\begin{array}{l}\text { Household- } \\
\text { level Data }\end{array}$ \\
\hline & $\begin{array}{l}\text { Measured change } \\
\text { in level of indoor } \\
\text { airborne pollen } \\
\text { relative to outdoor } \\
\text { levels in } \\
\text { weatherized } \\
\text { houses }(\mathrm{H}) \\
\end{array}$ & Not applicable & $\begin{array}{l}\text { Not } \\
\text { applicable }\end{array}$ & $\mathrm{Y}$ & $\begin{array}{l}\text { Household- } \\
\text { level Data }\end{array}$ \\
\hline & $\begin{array}{l}\text { Perceived change } \\
\text { in frequency of } \\
\text { odors within } \\
\text { weatherized } \\
\text { houses }(\mathrm{H})\end{array}$ & Not applicable & $\begin{array}{l}\text { Not } \\
\text { applicable }\end{array}$ & $\mathrm{Y}$ & $\begin{array}{l}\text { Household- } \\
\text { level Data }\end{array}$ \\
\hline $\begin{array}{l}\text { 5. Changes in } \\
\text { household } \\
\text { moisture } \\
\text { levels }\end{array}$ & $\begin{array}{l}\text { Measured change } \\
\text { in humidity levels } \\
\text { in weatherized } \\
\text { houses }(\mathrm{H})\end{array}$ & Not applicable & $\begin{array}{l}\text { Not } \\
\text { applicable }\end{array}$ & $\mathrm{Y}$ & $\begin{array}{l}\text { Household- } \\
\text { level Data }\end{array}$ \\
\hline \multirow[t]{2}{*}{$\begin{array}{l}\text { 6. Decreased } \\
\text { incidence of } \\
\text { hypothermia } \\
\text { and } \\
\text { hyperthermia }\end{array}$} & $\begin{array}{l}\text { Average reduction } \\
\text { in number of times } \\
\text { emergency } \\
\text { medical care is } \\
\text { sought due to heat } \\
\text { stress or over } \\
\text { exposure to cold } \\
\text { per weatherized } \\
\text { household }(\mathrm{H})\end{array}$ & $\begin{array}{l}\text { Average cost of } \\
\text { emergency } \\
\text { medical care at } \\
\text { hospital, } \\
\text { emergency room, } \\
\text { or urgent care } \\
\text { facility (L) }\end{array}$ & $\mathrm{M}$ & $Y$ & $\begin{array}{l}\text { Performance } \\
\text { and Monetary } \\
\text { Metrics }\end{array}$ \\
\hline & $\begin{array}{l}\text { Change in } \\
\text { incidence of } \\
\text { students' disrupted } \\
\text { study in } \\
\text { weatherized } \\
\text { houses }(\mathrm{H})\end{array}$ & Not applicable & $\begin{array}{l}\text { Not } \\
\text { applicable }\end{array}$ & $\mathrm{Y}$ & $\begin{array}{l}\text { Household- } \\
\text { level Data }\end{array}$ \\
\hline
\end{tabular}


Table 2.4. Impacts, metrics, and factors required to determine need for new data

\begin{tabular}{|c|c|c|c|c|c|}
\hline $\begin{array}{c}\text { Impact } \\
\text { Categories and } \\
\text { Specific } \\
\text { Impacts }\end{array}$ & $\begin{array}{l}\text { Performance } \\
\text { Metric and } \\
\text { Uncertainty } \\
(\mathbf{L}, \mathbf{M}, \mathbf{H})\end{array}$ & $\begin{array}{l}\text { Monetized Metric } \\
\text { and Uncertainty } \\
(\mathrm{L}, \mathrm{M}, \mathrm{H})\end{array}$ & $\begin{array}{c}\text { Potential } \\
\text { Magnitude of } \\
\text { Monetized } \\
\text { Value } \\
(\mathbf{L}, \mathbf{M}, \mathbf{H})\end{array}$ & $\begin{array}{l}\text { Metric is } \\
\text { Closely } \\
\text { Tied to } \\
\text { Program } \\
\text { Purposes } \\
(Y, N)\end{array}$ & $\begin{array}{l}\text { New Data to } \\
\text { Collect for } \\
\text { This Study }\end{array}$ \\
\hline \multirow[t]{2}{*}{$\begin{array}{l}\text { 7. Improved } \\
\text { food safety }\end{array}$} & $\begin{array}{l}\text { Measured change } \\
\text { in refrigerator } \\
\text { temperature in } \\
\text { weatherized } \\
\text { houses }(\mathrm{H})\end{array}$ & Not applicable & $\begin{array}{l}\text { Not } \\
\text { applicable }\end{array}$ & $\mathrm{Y}$ & $\begin{array}{l}\text { Household- } \\
\text { level Data }\end{array}$ \\
\hline & $\begin{array}{l}\text { Change in } \\
\text { incidence of } \\
\text { gastrointestinal } \\
\text { problems and food } \\
\text { poisoning in } \\
\text { weatherized } \\
\text { houses }(\mathrm{H})\end{array}$ & Not applicable & $\begin{array}{l}\text { Not } \\
\text { applicable }\end{array}$ & $\mathrm{Y}$ & $\begin{array}{l}\text { Household- } \\
\text { level Data }\end{array}$ \\
\hline \multirow[t]{4}{*}{$\begin{array}{l}\text { 8. Improved } \\
\text { household } \\
\text { safety and } \\
\text { security }\end{array}$} & $\begin{array}{l}\text { Average reduction } \\
\text { in number of times } \\
\text { emergency } \\
\text { medical care is } \\
\text { sought for injuries } \\
\text { from tripping and } \\
\text { falling in the home } \\
\text { (H) }\end{array}$ & $\begin{array}{l}\text { Average cost of } \\
\text { emergency } \\
\text { medical care at } \\
\text { hospital, } \\
\text { emergency room, } \\
\text { or urgent care } \\
\text { facility (L) }\end{array}$ & $\mathrm{M}$ & $\mathrm{Y}$ & $\begin{array}{l}\text { Performance } \\
\text { and monetary } \\
\text { Metrics }\end{array}$ \\
\hline & $\begin{array}{l}\text { Average reduction } \\
\text { in number of times } \\
\text { emergency } \\
\text { medical care is } \\
\text { sought for burns } \\
\text { from scalding } \\
\text { from domestic hot } \\
\text { water }(\mathrm{H})\end{array}$ & $\begin{array}{l}\text { Average cost of } \\
\text { emergency } \\
\text { medical care at } \\
\text { hospital, } \\
\text { emergency room, } \\
\text { or urgent care } \\
\text { facility (L) }\end{array}$ & $\mathrm{M}$ & $\mathrm{Y}$ & $\begin{array}{l}\text { Performance } \\
\text { and Monetary } \\
\text { Metrics }\end{array}$ \\
\hline & $\begin{array}{l}\text { Perceived change } \\
\text { in security from } \\
\text { criminal intrusion } \\
\text { in weatherized } \\
\text { houses }(\mathrm{H})\end{array}$ & Not applicable & $\begin{array}{l}\text { Not } \\
\text { applicable }\end{array}$ & $\bar{Y}$ & $\begin{array}{l}\text { Household- } \\
\text { level Data }\end{array}$ \\
\hline & $\begin{array}{l}\text { Average reduction } \\
\text { in number of } \\
\text { break-ins per } \\
\text { weatherized } \\
\text { household }(\mathrm{H})\end{array}$ & $\begin{array}{l}\text { Average value of } \\
\text { items stolen in } \\
\text { break-in }(H)\end{array}$ & M & $\mathrm{Y}$ & $\begin{array}{l}\text { Performance } \\
\text { and Monetary } \\
\text { Metrics }\end{array}$ \\
\hline $\begin{array}{l}\text { 9. Change in } \\
\text { presence of } \\
\text { environmental } \\
\text { hazards }\end{array}$ & $\begin{array}{l}\text { Measured change } \\
\text { in levels of } \\
\text { asbestos and radon } \\
\text { in weatherized } \\
\text { houses }(\mathrm{H})\end{array}$ & Not applicable & $\begin{array}{l}\text { Not } \\
\text { applicable }\end{array}$ & $\bar{Y}$ & $\begin{array}{l}\text { Household- } \\
\text { level Data }\end{array}$ \\
\hline
\end{tabular}


Table 2.4. Impacts, metrics, and factors required to determine need for new data

\begin{tabular}{|c|c|c|c|c|c|}
\hline $\begin{array}{c}\text { Impact } \\
\text { Categories and } \\
\text { Specific } \\
\text { Impacts }\end{array}$ & $\begin{array}{c}\text { Performance } \\
\text { Metric and } \\
\text { Uncertainty } \\
(\mathrm{L}, \mathrm{M}, \mathrm{H})\end{array}$ & $\begin{array}{c}\text { Monetized Metric } \\
\text { and Uncertainty } \\
(\mathrm{L}, \mathrm{M}, \mathrm{H})\end{array}$ & $\begin{array}{c}\text { Potential } \\
\text { Magnitude of } \\
\text { Monetized } \\
\text { Value } \\
(\mathbf{L}, \mathbf{M}, \mathbf{H})\end{array}$ & $\begin{array}{c}\text { Metric is } \\
\text { Closely } \\
\text { Tied to } \\
\text { Program } \\
\text { Purposes } \\
\text { (Y, N) }\end{array}$ & $\begin{array}{l}\text { New Data to } \\
\text { Collect for } \\
\text { This Study }\end{array}$ \\
\hline & $\begin{array}{l}\text { Change in number } \\
\text { of poisonings from } \\
\text { household } \\
\text { chemicals in } \\
\text { weatherized } \\
\text { houses }(\mathrm{H})\end{array}$ & Not applicable & $\begin{array}{l}\text { Not } \\
\text { applicable }\end{array}$ & $\mathrm{Y}$ & $\begin{array}{l}\text { Household- } \\
\text { level Data }\end{array}$ \\
\hline & $\begin{array}{l}\text { Change in level of } \\
\text { vermin infestation } \\
\text { in weatherized } \\
\text { houses }(\mathrm{H})\end{array}$ & Not applicable & $\begin{array}{l}\text { Not } \\
\text { applicable }\end{array}$ & $\mathrm{Y}$ & $\begin{array}{l}\text { Household- } \\
\text { level Data }\end{array}$ \\
\hline $\begin{array}{l}\text { 10. Improved } \\
\text { comfort }\end{array}$ & $\begin{array}{l}\text { Perceived } \\
\text { improvement in } \\
\text { indoor comfort } \\
\text { (temperature and } \\
\text { draftiness) in } \\
\text { weatherized } \\
\text { houses }(\mathrm{H}) \\
\end{array}$ & Not applicable & $\begin{array}{l}\text { Not } \\
\text { applicable }\end{array}$ & $\mathrm{Y}$ & $\begin{array}{l}\text { Household- } \\
\text { level Data }\end{array}$ \\
\hline & $\begin{array}{l}\text { Measured change } \\
\text { in indoor air } \\
\text { temperature in } \\
\text { weatherized } \\
\text { houses }(\mathrm{H})\end{array}$ & Not Applicable & $\begin{array}{l}\text { Not } \\
\text { applicable }\end{array}$ & $\mathrm{Y}$ & $\begin{array}{l}\text { Household- } \\
\text { level Data }\end{array}$ \\
\hline $\begin{array}{l}\text { 11. Improved } \\
\text { appearance }\end{array}$ & $\begin{array}{l}\text { Perceived } \\
\text { improvement in } \\
\text { appearance of } \\
\text { weatherized } \\
\text { dwellings }(\mathrm{H}) \\
\end{array}$ & Not Applicable & $\begin{array}{l}\text { Not } \\
\text { applicable }\end{array}$ & $\mathrm{N}$ & $\begin{array}{l}\text { Household- } \\
\text { level Data }\end{array}$ \\
\hline $\begin{array}{l}\text { 12. Reduced } \\
\text { noise inside } \\
\text { dwelling }\end{array}$ & $\begin{array}{l}\text { Perceived } \\
\text { reduction in noise } \\
\text { within weatherized } \\
\text { dwellings }(H)\end{array}$ & Not applicable & $\begin{array}{l}\text { Not } \\
\text { applicable }\end{array}$ & $\mathrm{Y}$ & $\begin{array}{l}\text { Household- } \\
\text { level Data }\end{array}$ \\
\hline \multicolumn{6}{|c|}{ III. Societal Impacts } \\
\hline \multicolumn{6}{|c|}{ A. Environmental Impacts } \\
\hline $\begin{array}{l}\text { 1. Air } \\
\text { emissions: } \\
\mathrm{CO} 2\end{array}$ & $\begin{array}{l}\text { Pounds of } \mathrm{CO} 2 \\
\text { emitted per unit of } \\
\text { energy saved (M) }\end{array}$ & $\begin{array}{l}\text { Value of CO2 } \\
\text { emission } \\
\text { reduction in } \\
\text { dollars per pound } \\
\text { (H) }\end{array}$ & $\mathrm{H}$ & $\mathrm{N}$ & $\begin{array}{l}\text { Performance } \\
\text { and Monetary } \\
\text { Metrics }\end{array}$ \\
\hline
\end{tabular}


Table 2.4. Impacts, metrics, and factors required to determine need for new data

\begin{tabular}{|c|c|c|c|c|c|}
\hline $\begin{array}{c}\text { Impact } \\
\text { Categories and } \\
\text { Specific } \\
\text { Impacts }\end{array}$ & $\begin{array}{c}\text { Performance } \\
\text { Metric and } \\
\text { Uncertainty } \\
(\mathrm{L}, \mathrm{M}, \mathbf{H})\end{array}$ & $\begin{array}{c}\text { Monetized Metric } \\
\text { and Uncertainty } \\
(\mathrm{L}, \mathrm{M}, \mathrm{H})\end{array}$ & $\begin{array}{c}\text { Potential } \\
\text { Magnitude of } \\
\text { Monetized } \\
\text { Value } \\
(\mathbf{L}, \mathbf{M}, \mathbf{H})\end{array}$ & $\begin{array}{c}\text { Metric is } \\
\text { Closely } \\
\text { Tied to } \\
\text { Program } \\
\text { Purposes } \\
(\mathbf{Y}, \mathbf{N})\end{array}$ & $\begin{array}{l}\text { New Data to } \\
\text { Collect for } \\
\text { This Study }\end{array}$ \\
\hline $\begin{array}{l}\text { 2. Air } \\
\text { emissions: } \\
\text { SOx }\end{array}$ & $\begin{array}{l}\text { Pounds of SOx } \\
\text { emitted per unit of } \\
\text { energy saved }(\mathrm{M})\end{array}$ & $\begin{array}{l}\text { Value of SOx } \\
\text { emission } \\
\text { reduction in } \\
\text { dollars per pound } \\
\text { (H) }\end{array}$ & $\mathrm{M}$ & $\mathrm{N}$ & $\begin{array}{l}\text { Performance } \\
\text { and Monetary } \\
\text { Metrics }\end{array}$ \\
\hline $\begin{array}{l}\text { 3. Air } \\
\text { emissions: } \\
\text { NOx }\end{array}$ & $\begin{array}{l}\text { Pounds of NOx } \\
\text { emitted per unit of } \\
\text { energy saved }(\mathrm{M})\end{array}$ & $\begin{array}{l}\text { Value of NOx } \\
\text { emission } \\
\text { reduction in } \\
\text { dollars per pound } \\
(\mathrm{H})\end{array}$ & $\mathrm{H}$ & $\mathrm{N}$ & $\begin{array}{l}\text { Performance } \\
\text { and Monetary } \\
\text { Metrics }\end{array}$ \\
\hline $\begin{array}{l}\text { 4. Air } \\
\text { emissions: } \mathrm{CO}\end{array}$ & $\begin{array}{l}\text { Pounds of } \mathrm{CO} \\
\text { emitted per unit of } \\
\text { energy saved }(\mathrm{M})\end{array}$ & $\begin{array}{l}\text { Value of } \mathrm{CO} \\
\text { emission } \\
\text { reduction in } \\
\text { dollars per pound } \\
(\mathrm{H})\end{array}$ & $\mathrm{M}$ & $\mathrm{N}$ & $\begin{array}{l}\text { Performance } \\
\text { and Monetary } \\
\text { Metrics }\end{array}$ \\
\hline $\begin{array}{l}\text { 5. Air } \\
\text { emissions: } \\
\text { CH4 }\end{array}$ & $\begin{array}{l}\text { Pounds of } \mathrm{CH} 4 \\
\text { emitted per unit of } \\
\text { energy saved }(\mathrm{M})\end{array}$ & $\begin{array}{l}\text { Value of } \mathrm{CH} 4 \\
\text { emission } \\
\text { reduction in } \\
\text { dollars per pound } \\
(\mathrm{H})\end{array}$ & $\mathrm{M}$ & $\mathrm{N}$ & $\begin{array}{l}\text { Performance } \\
\text { and Monetary } \\
\text { Metrics }\end{array}$ \\
\hline $\begin{array}{l}\text { 6. Air } \\
\text { emissions: PM }\end{array}$ & $\begin{array}{l}\text { Pounds of PM } \\
\text { emitted per unit of } \\
\text { energy saved }(M)\end{array}$ & $\begin{array}{l}\text { Value of PM } \\
\text { emission } \\
\text { reduction in } \\
\text { dollars per pound } \\
(\mathrm{H})\end{array}$ & $\mathrm{M}$ & $\mathrm{N}$ & $\begin{array}{l}\text { Performance } \\
\text { and Monetary } \\
\text { Metrics }\end{array}$ \\
\hline $\begin{array}{l}\text { 7. Air } \\
\text { emissions: } \\
\text { heavy metals }\end{array}$ & $\begin{array}{l}\text { Pounds of heavy } \\
\text { metals emitted per } \\
\text { unit of energy } \\
\text { saved (M) }\end{array}$ & $\begin{array}{l}\text { Value of heavy } \\
\text { metal emission } \\
\text { reduction in } \\
\text { dollars per pound } \\
(\mathrm{H})\end{array}$ & $\mathrm{H}$ & $\mathrm{N}$ & $\begin{array}{l}\text { Performance } \\
\text { and Monetary } \\
\text { Metrics }\end{array}$ \\
\hline $\begin{array}{l}\text { 8. Fish } \\
\text { impingement }\end{array}$ & $\begin{array}{l}\text { Number of fish } \\
\text { impinged at power } \\
\text { plants per unit of } \\
\text { electricity saved } \\
\text { (L) }\end{array}$ & $\begin{array}{l}\text { Dollar value per } \\
\text { impinged fish (L) }\end{array}$ & $\mathrm{L}$ & $\mathrm{N}$ & \\
\hline $\begin{array}{l}\text { 9. Wastewater } \\
\text { and sewage in } \\
\text { electricity } \\
\text { production }\end{array}$ & $\begin{array}{l}\text { Amount of } \\
\text { wastewater and } \\
\text { sewage (in } \\
\text { gallons) produced } \\
\text { per unit of } \\
\text { electricity saved } \\
\text { (M) }\end{array}$ & $\begin{array}{l}\text { Cost per gallon of } \\
\text { treating } \\
\text { wastewater and } \\
\text { sewage }(\mathrm{M})\end{array}$ & $\mathrm{M}$ & $\mathrm{N}$ & $\begin{array}{l}\text { Performance } \\
\text { and Monetary } \\
\text { Metrics }\end{array}$ \\
\hline
\end{tabular}


Table 2.4. Impacts, metrics, and factors required to determine need for new data

\begin{tabular}{|c|c|c|c|c|c|}
\hline $\begin{array}{c}\text { Impact } \\
\text { Categories and } \\
\text { Specific } \\
\text { Impacts }\end{array}$ & $\begin{array}{c}\text { Performance } \\
\text { Metric and } \\
\text { Uncertainty } \\
(\mathrm{L}, \mathrm{M}, \mathrm{H})\end{array}$ & $\begin{array}{c}\text { Monetized Metric } \\
\text { and Uncertainty } \\
(\mathrm{L}, \mathrm{M}, \mathrm{H})\end{array}$ & $\begin{array}{c}\text { Potential } \\
\text { Magnitude of } \\
\text { Monetized } \\
\text { Value } \\
(\mathbf{L}, \mathbf{M}, \mathbf{H})\end{array}$ & $\begin{array}{l}\text { Metric is } \\
\text { Closely } \\
\text { Tied to } \\
\text { Program } \\
\text { Purposes } \\
(Y, N) \\
\end{array}$ & $\begin{array}{l}\text { New Data to } \\
\text { Collect for } \\
\text { This Study }\end{array}$ \\
\hline \multicolumn{6}{|c|}{ B. Social Impacts } \\
\hline $\begin{array}{l}\text { 1. Avoided } \\
\text { unemployment } \\
\text { impact }\end{array}$ & $\begin{array}{l}\text { Average number } \\
\text { of unemployed } \\
\text { workers given jobs } \\
\text { per dollar spent on } \\
\text { weatherization (L) }\end{array}$ & $\begin{array}{l}\text { Average cost of } \\
\text { unemployment } \\
\text { benefits paid per } \\
\text { unemployed } \\
\text { worker (L) }\end{array}$ & $\bar{M}$ & $\mathrm{~N}$ & \\
\hline \multicolumn{6}{|c|}{ C. Economic Impacts } \\
\hline $\begin{array}{l}\text { 1. Direct and } \\
\text { indirect } \\
\text { employment }\end{array}$ & $\begin{array}{l}\text { Average number } \\
\text { of direct and } \\
\text { indirect jobs } \\
\text { created per dollar } \\
\text { spent on } \\
\text { weatherization } \\
\text { (M) }\end{array}$ & $\begin{array}{l}\text { Taxes paid (local, } \\
\text { state, and federal) } \\
\text { and dollars spent } \\
\text { locally, per job } \\
\text { created (L) }\end{array}$ & $\mathrm{H}$ & $\mathrm{N}$ & $\begin{array}{l}\text { Performance } \\
\text { Metric }\end{array}$ \\
\hline 2. Lost rental & $\begin{array}{l}\text { Average amount } \\
\text { of unpaid rent per } \\
\text { weatherized rental } \\
\text { household before } \\
\text { and after } \\
\text { weatherization (L) }\end{array}$ & $\begin{array}{l}\text { Same as } \\
\text { Performance } \\
\text { Metric (L) }\end{array}$ & $\mathrm{L}$ & $\mathrm{N}$ & \\
\hline $\begin{array}{l}\text { 3. National } \\
\text { security }\end{array}$ & $\begin{array}{l}\text { Average } \\
\text { proportion of } \\
\text { source energy used } \\
\text { for residential } \\
\text { purposes that is } \\
\text { imported (L) }\end{array}$ & $\begin{array}{l}\text { "Premium" paid } \\
\text { in higher prices } \\
\text { and disturbance } \\
\text { to economy per } \\
\text { unit of imported } \\
\text { energy }(\mathrm{H})\end{array}$ & $\mathrm{H}$ & $\bar{Y}$ & $\begin{array}{l}\text { Performance } \\
\text { and Monetary } \\
\text { Metrics }\end{array}$ \\
\hline
\end{tabular}

- Shifted utility fixed costs-Monetized Metric: Change in fuel cost per unit of energy savings to cover fixed costs. Information from the literature will be collected on how fuel cost prices increase as a result of reduced consumption to cover utilities' fixed costs.

- Water and sewer savings-Performance Metric: Average water savings (in gallons) per device installed; Monetized Metric: Cost of water and sewer service per gallon of water. For the performance metric, information will be collected from the literature on the amount of water saved through the installation of low-flow showerheads and faucet aerators. From those secondary sources, average water savings per device will be calculated. For the monetary metric, primary data on the cost of water and sewer service (i.e., costs per unit of consumption) will be collected from a nationwide sample of 30 to 50 water utilities serving the houses used in the energy study by examining published information on their websites. From this, average costs will be calculated for the entire nation and, if possible, for individual geographic and/or climate regions. The rates of the utilities chosen will be representative of climate regions and housing types. 
- Property value impacts-Performance Metric: Average cost of structural repairs per weatherized household. Information on the dollar value of the structural repairs performed for each unit weatherized in PY 2010 will be collected as part of the Program characterization study (see Section 2.1). The average cost of structural repairs per weatherized household will be calculated by summing the value of repairs performed on all units and dividing by the number of dwellings weatherized. An alternative Performance Metric for evaluating property value impacts might be to collect information from realtors or appraisers to determine the increase in property value based on the amount of structural repairs performed.

- Reduced mobility-Performance Metric: Average reduction in number of moves per weatherized household; Monetized Metric: Average cost per move. If the billing data gathered for the billing data sample indicate when the occupants of a dwelling move, the average number of moves per household will be calculated for the treatment group in the year following weatherization; that number will then be compared to the average number of moves during that same period for the control group (using an appropriate statistical procedure). If the billing data do not identify when occupants moved, program participants and a control group of non-participants will be surveyed via telephone regarding the number of times they changed residences in the year after the weatherization. As before, the mean number of moves for the treatment and control groups will be compared. Only the post-weatherization period will be studied because it is expected that prospective participants will move much less frequently than non-participants during the pre-weatherization period because of the process of applying for and awaiting the weatherization. The average cost of moving for a typical low-income family will be gathered from secondary sources.

- Fewer fires-Performance Metric: Average reduction in number of fires per weatherized household; Monetized Metric: Average monetary loss to household per fire. Data on weatherization-induced changes in the number of fires will be gathered using the Occupant Survey, which is being conducted by the retrospective evaluation during WAP-ARRA PYs 2011 and 2012 (Ternes et al. 2007). Additional data on the reduction in fires will be taken from reliable secondary sources. (It is important to augment survey findings through the use of national statistics when examining relatively rare events such as fires.) The average monetary loss per fire will also be gathered from secondary sources. The most difficult aspect of quantifying monetary loss is, of course, assigning an acceptable value to the loss of a human life.

- Changes in frequency of health problems-Performance Metric: Average reduction in number of workdays lost per weatherized household due to health problems. Occupants of the same weatherized and control units mentioned above will be surveyed over the phone using a portion of the Occupant Survey to determine the number of days they were absent from work during the pre- and post-weatherization periods due to health problems. Net change in number of lost workdays from the pre- to the post-weatherization period will be determined by comparing change for the treatment and control groups using an appropriate statistical procedure.

- Decreased incidence of hypothermia and hyperthermia-Performance Metric: Average reduction in number of times emergency medical care is sought due to heat stress or overexposure to cold per weatherized household; Monetized Metric: Average cost of emergency medical care at hospital, emergency room, or urgent care facility. A portion of the Occupant Survey will be used to determine the number of times a household member sought emergency medical care due to heat stress or overexposure to cold during the pre- and post-weatherization periods. Changes between the two periods will be compared for the treatment and control groups using an appropriate statistical procedure. The average cost of emergency medical care at a hospital, emergency room, or urgent-care facility will be gathered from secondary sources. 
- Improved household safety and security-Performance Metric: Average reduction in number of times emergency medical care is sought for injuries from tripping and falling in the home; Monetized Metric: Average cost of emergency medical care at hospital, emergency room, or urgent care facility. Once again, the Occupant Survey will be administered to the same weatherized and control units described above. During the pre-weatherization period and again in the postweatherization period, the subjects will be asked to report the number of times a household member has sought emergency medical care for injuries from tripping and falling in the home. Net change from the pre- to post-weatherization period will be determined by comparing change for the treatment and control groups using an appropriate statistical procedure. Additional data on the frequency of serious trip and fall injuries will be taken from reliable secondary sources. The average cost of emergency medical care at a hospital, emergency room, or urgent care facility will also be gathered from secondary sources.

- Improved household safety and security-Performance Metric: Average reduction in number of times emergency medical care is sought for burns from scalding from domestic hot water in weatherized houses; Monetized Metric: Average cost of emergency medical care at hospital, emergency room, or urgent care facility. The Occupant Survey will be administered to the same weatherized and control units described above. The subjects will be asked to report the number of times a household member sought emergency medical care as a result of burns from scalding water from a faucet or showerhead in their home during the pre- and post-weatherization periods. Changes between the two periods will be compared for the treatment and control groups using the same general approach described above. As noted previously, the average cost of emergency medical care at a hospital, emergency room, or urgent care facility will be gathered from secondary sources.

- Improved household safety and security-Performance Metric: Average reduction in number of break-ins per weatherized household: Monetized Metric: Average value of items stolen per break-in. Houses that are weatherized often get new windows and doors that have better security features such as locks and bolts than did the unweatherized original fixtures. This can result in better security and household safety. For both the performance and monetary metric, the necessary data will be collected through the previously described Occupant Survey. In both the pre- and postweatherization periods, the subjects will be asked to report the number of break-ins to their residence during the previous year and the value of the items stolen during those incidents. An appropriate statistical procedure will be used to compare changes from the pre- to post-weatherization period for the treatment and control groups.

- ALL air emissions-Performance Metrics: Pounds of substances (CO2, SOx, NOx, CO, CH4, PM, heavy metals) emitted per unit of energy saved; Monetized Metrics: Value of substances emitted in dollars per pound. Necessary data pertaining to these metrics can be collected from secondary sources. Specifically, a literature review will be conducted regarding the amount of each relevant substance typically emitted per unit of energy saved. This review will focus on emissions for those households that are "on the margin," meaning that their fuel consumption is most likely to be cut when energy use is reduced. Getting region-specific numbers for these factors should be relatively straightforward, and emissions reductions will be able to be calculated from the energy savings findings (see Section 2.2). To determine the monetary value of the emissions reductions, information on the values established by the market through emissions trading for each substance will be gathered. It should be noted that getting good, up-to-date information on the monetary metrics is even more important than gathering data on the performance metrics because the former is surrounded by greater uncertainty. 
- Wastewater and sewage-Performance Metric: Amount of wastewater and sewage produced per unit of electricity; Monetized Metric: Cost per gallon of treating wastewater and sewage. Necessary data pertaining to these metrics will be gathered through a literature review.

- Direct and indirect employment-Performance Metric: Average number of direct and indirect jobs created per dollar spent on weatherization. Secondary sources on economic multipliers will be used to calculate the average number of direct and indirect jobs created per dollar spent on weatherization in the geographic areas under study. Input/output models utilizing the best available data should be useful for this purpose. To the extent possible, the analysis will attempt to identify the net impact, which is the effect the Weatherization Program had on employment minus the employment effect that might have resulted from the same magnitude of expenditure on likely alternative projects.

- National security-Performance Metric: Average proportion of source energy used for residential purposes that is imported; Monetized Metric: "Premium" paid in higher prices and disturbance to economy per unit of imported energy. Data on energy imports will be derived from the most up-to-date secondary sources. The value of the imported energy "premium" will be taken from a study currently being performed by ORNL researchers.

Once the full data-collection effort is complete and new coefficients have been developed, an analysis will be performed to calculate values for all monetized non-energy impacts. In the final report for this study, each coefficient used to calculate the total monetized value of non-energy impacts will be described, and the reason it was selected will be explained. Impacts will be reported separately for each major category shown in Tables 2.3 and 2.4 (Utility/Ratepayer Impacts, Impacts to Participating Households, and Societal Impacts) and the total impact for all categories combined will also be given.

After all monetized impacts have been calculated, a quick sensitivity analysis will be conducted to see how out-year estimates of non-energy impacts might change in response to variation in key driving factors and assumptions made in the calculations, such as changing demographics in the houses, loss of housing stock, energy prices, discount rates, new technology, and climate change. This analysis will use the results of a prior sensitivity analysis of how energy savings may change in response to variance in the same driving factors (see Section 2.2.2). The results of this analysis will be used in the sensitivity analyses performed for cost-effectiveness (see Section 2.4).

Additional analyses will be performed to explore the effects of specific agency actions on various monetized health- and safety-related impacts. This can be done by (1) performing regression analysis to search for relationships between various impacts and agency actions (e.g., installation of smoke alarms, security measures) that have the potential to affect health and safety; and (2) doing a literature review on the relationships between selected agency actions and health effects.

\subsubsection{Special IAQ Radon Remediation Cost Study}

One of the tasks of the retrospective evaluation is to study the potential impacts of weatherization on indoor air quality. To accomplish this goal, a large-scale field study of approximately 550 homes (the IAQ study) is being implemented nationally. Homes for the study were selected based on a two-stage sampling strategy that first selected geographic areas of the country, and then sampled single-family households scheduled for weatherization by local agencies within each geographic region. The geographic sampling was based on areas defined by the U.S. Census Bureau, known as super-PUMAs (Public Use Microdata Areas), which are areas with a population of at least 400,000. The 532 superPUMAs in the U.S. were stratified regionally and by radon level by the Census Bureau, and a national sample of 80 super-PUMAs was drawn with probability proportional to the Census 2000 population of 
single-family, weatherization-eligible households and weatherization funding in PY 2008. High-radon areas were explicitly over-sampled in order to ensure that our sample contained enough homes to statistically explore relationships between the installation of various weatherization measures and changes in radon in the home. ${ }^{7}$ Local weatherization agencies serving sampled super-PUMAs were then contacted to obtain lists of homes soon to be weatherized. Homes were randomly chosen from these lists and contacted to be part of the study. The goal was to enroll six to eight homes in this IAQ study from each sampled super-PUMA, with two to three of these homes randomly assigned to a control group of homes that will not be weatherized until the study is completed.

This study is measuring pre- and post-weatherization levels of the following indoor air pollutants: carbon monoxide $(\mathrm{CO})$, radon, formaldehyde, and indoor humidity.

$\mathrm{CO}$ is produced by incomplete combustion from fossil-fueled heating systems, appliances, and other combustion sources and can be a serious problem in homes. Home-energy audits under WAP commonly assess $\mathrm{CO}$ production by combustion appliances in post-weatherization inspections to ensure that the installation of weatherization measures, especially those related to furnace work, have not caused CO problems.

Naturally occurring radon gas can accumulate in confined spaces in homes and, being radioactive, is often responsible for the majority of a person's exposure to background radiation. Radon and formaldehyde issues are not formally addressed by energy audits at the present time. Radon problems can be mitigated by weatherization measures that air-seal unheated basements and crawlspaces from the living areas; conversely, it can be exacerbated by overall home weatherization "tightening." At least one prior study found no relationship between weatherization and radon risks, although that study was conducted over two decades ago and involved a relatively small sample of homes.

Formaldehyde was included in this study to represent the larger class of VOCs that could be present in homes. Additionally, home-energy auditors regularly make note of moisture and mold issues in homes, and ventilation measures are often implemented to deal with these issues.

As mentioned above, the retrospective study's design called for over-sampling in high radon areas. This is because the impacts of weatherization on radon in the home are a point of emphasis of this study. The retrospective study will conduct analyses to identify any relationships between weatherization and changes in radon levels in homes from pre- to post weatherization. This study will also assess the relationships between various weatherization measures and changes in radon levels.

The WAP-ARRA period study will take this radon work one step further. The project team will remediate all homes that test for radon levels over the recommended federal threshold of $4 \mathrm{pC} / \mathrm{L}$ postweatherization and in a second test post-weatherization. Low-cost weatherization measures will be implemented first, and if after re-testing the threshold is still exceeded, standard remediation actions will be taken. Accurate cost information will be collected for all remediation work performed. This information will be useful in estimating the costs of radon remediation performed in the low-income weatherization context and providing insights as to whether there are any correlations between radon levels post-weatherization and the cost of radon remediation.

\footnotetext{
${ }^{7}$ We used county-level estimates results from both Lawrence Berkeley National Laboratory's radon research and the Environmental Protection Agency to define four radon-level strata based on the estimated proportion of homes at the county level with radon levels exceeding $4 \mathrm{pCi} / \mathrm{l}$ : see $\mathrm{http}: / /$ eetd.lbl.gov/iep/high-radon/hr.html and http://www.epa.gov/radon/zonemap.html. County level data were then aggregated to the super-PUMA level using Census 2000 population counts.
} 


\subsubsection{Non-Monetized Data Collection and Analysis}

Performance metrics to determine the value of all non-monetized impacts will be calculated directly from the relevant household-level data shown in Table 2.3. The appropriate performance metric for each non-monetized non-energy impact is identified in Table 2.4. The methods that will be used to collect and analyze the relevant data for each non-monetized impact are described below. As with the monetized non-energy impacts, to the extent possible, results will be developed that are specific to geographic region, climate region, and/or housing type.

For most of the non-monetized impacts described below, information will be obtained using a portion of the S4 Occupant Survey. The survey will be administered immediately after each house is audited and again a year after weatherization, and an incentive will be provided to improve the response rate.

The other main data-collection approach used for the study of non-monetized health, safety, and comfort impacts is the direct measurement of key indoor air quality factors. These data will be collected by means of the Indoor Air Quality study, part of the retrospective evaluation being conducted in PYs 2010, 2011 and 2012.

Non-monetized impacts include the following:

- Fewer fires-Performance Metric: Perceived changes in safety of heating system and electrical wiring in weatherized houses. Using the Occupant Survey described above, program participants and a control group of non-participants will be asked for their perceptions of the safety of their dwelling's heating system and electrical wiring before and after the period in which weatherization work is performed. Net change in perceptions from the pre- to post-weatherization period will be determined by comparing change for the treatment and control groups using an appropriate statistical procedure.

- Changes in frequency of health problems-Performance Metric: Perceived change in health problems in weatherized houses. Program participants and a control group of non-participants will be surveyed using the Occupant Survey regarding the perceived condition of their (and their family's) health in the pre- and post-weatherization periods. An appropriate statistical procedure will be used to compare the change from the pre- to post-weatherization period for the weatherized and control groups.

- Changes in frequency of health problems-Performance Metric: Change in incidence of symptoms or occurrences of specific health problems in weatherized houses. Through the Occupant Survey, program participants and non-participants will be asked to report the frequency with which they experience certain health problems or the principal symptoms of those problems during the pre-weatherization period and again during the post-weatherization period. Subjects will be asked specifically about occurrences of asthma and other respiratory problems, as well as colds and flu. They will also be asked to report symptoms of these and other conditions possibly resulting from exposure to allergens, mold, and CO. Such symptoms include wheezing, shortness of breath, coughing, congestion, headaches, and nausea.

- Enhanced prevention and treatment of health problems-Performance Metric: Reduction in number of times food could not be purchased due to size of utility bill in weatherized houses. The Occupant Survey will ask weatherization clients and a control group about the frequency with which they have foregone the purchase of food in order to pay utility bills and the frequency with which they have not paid utility bills in order to purchase food. The same questions will be asked 
during the pre- and post-weatherization periods, and any changes from the former to the latter will be calculated. The net change from the pre- to post-weatherization period will be determined by comparing change for the treatment and control groups using an appropriate statistical procedure.

- Enhanced prevention and treatment of health problems-Performance Metric: Change in access to health care and medication in weatherized houses. The Occupant Survey will ask residents of weatherized and non-weatherized households questions similar to those described above for food purchases about the trade-offs they have made between paying utility bills and purchasing prescription medicines. Changes from the pre- to post-weatherization period will be compared for the weatherized and control groups. In addition, the weatherized and non-weatherized groups will be compared in terms of how their number of visits to emergency rooms, primary physicians, or other primary health-care providers changed from the pre- to post-weatherization period. The frequency with which respondents report not having a primary-care physician or other primary health-care provider will also be examined.

- Changes in indoor air quality-Performance Metric: Measured change in CO levels in weatherized houses. As part of the retrospective evaluation's Indoor Air Quality task, mentioned above, equipment will be installed in weatherized housing and control units to measure carbon monoxide (CO) levels during both the pre- and post-weatherization periods. The non-weatherized houses will be measured at the same time as the weatherized units to control for any possible changes in outdoor temperature or other climatic conditions. Net change in CO levels from the pre- to the post-weatherization period will be determined by comparing change for the treatment and control groups using an appropriate statistical procedure. In addition, descriptive statistics showing the frequency with which dangerously high levels of $\mathrm{CO}$ were found during the pre-weatherization period will be generated and an appropriate statistical test will be used to calculate the frequency with which those high concentrations were reduced to safe levels in weatherized units.

- Changes in indoor air quality-Performance Metric: Perceived change in frequency of odors within weatherized houses. The Occupant Survey will ask a sample of weatherization participants and non-participants for their perceptions of how often there are odors inside their home that could indicate a problem with indoor air quality. The occupants will be asked to describe the situation separately for the winter and the summer, and the survey will be administered both before and after weatherization. Net change from the pre- to post-weatherization period will be determined by comparing changes for the treatment and control groups using an appropriate statistical procedure.

- Changes in household moisture levels-Performance Metric: Measured change in humidity levels in weatherized houses. Relative humidity will be measured in the same housing units for which the concentrations of $\mathrm{CO}$, indoor mold spores, and pollen will be examined, during both the pre- and post-weatherization periods. The non-weatherized units will be measured at the same time as the weatherized units, and careful attention will be paid to the season in which the measurements are taken. Net change in humidity levels from the pre- to post-weatherization period will be determined by comparing changes for the treatment and control groups using an appropriate statistical procedure.

- Decreased incidence of hypothermia and hyperthermia-Performance Metric: Change in incidence of students' disrupted study in weatherized houses. The Occupant Survey will ask how frequently household residents find it hard to study at home because of excessive heat or cold. The net change in frequency of study disruption from the pre- to post-weatherization period will be determined by comparing change for the treatment and control groups using an appropriate statistical procedure. 
- Improved food safety-Performance Metric: Measured change in refrigerator temperature in weatherized houses. In the same housing units for which $\mathrm{CO}$, indoor mold spores, pollen, and relative humidity are examined, the change in the internal temperature of refrigerators will also be measured. Temperatures will be taken inside the household refrigerator both before and after weatherization, and the net change in refrigerator temperature from the pre- to post-weatherization period will be calculated from both the treatment and control group data using an appropriate statistical procedure. In addition, descriptive statistics will be generated showing the frequency with which unsafe temperatures were found inside refrigerators during the pre-weatherization period, and an appropriate statistical test will be used to calculate the frequency with which those high temperatures were reduced to safe levels in weatherized units.

- Improved food safety-Performance Metric: Change in incidence of gastrointestinal problems and food poisoning in weatherized houses. The Occupant Survey will ask people in weatherized and non-weatherized households whether they have experienced serious gastrointestinal problems in the previous month or have suffered from food poisoning during the past six months. The same questions will be asked both before and after weatherization, and the changes will be compared for the weatherized and control groups.

- Improved household safety and security-Performance Metric: Perceived change in security from criminal intrusion in weatherized houses. Using the Occupant Survey, program participants and a control group of non-participants will be asked for their perceptions of how secure their home is from intrusion by criminals both before and after weatherization. The change over time will be compared for the weatherized and control groups using an appropriate statistical procedure.

- Change in presence of environmental hazards-Performance Metric: Measured change in levels of radon in weatherized houses. In the same dwellings for which $\mathrm{CO}$ and other factors will be measured, the levels of radon will be measured during both the pre- and post-weatherization periods; net change will be calculated as described previously. In addition, descriptive statistics will be generated showing the frequency with which unsafe levels of asbestos and radon were found during the pre- weatherization period, and an appropriate statistical test will be used to calculate the frequency with which those high concentrations were reduced to safe levels in weatherized units.

- Change in presence of environmental hazards-Performance Metric: Change in number of poisonings from household chemicals in weatherized houses. Through the Occupant Survey, subjects in both weatherized and non-weatherized dwellings will be asked to report whether the members of their household had been poisoned by household chemicals during the past year and, if so, to identify the substance with which they had been poisoned. Net change from the pre- to postweatherization period will be determined by comparing change for the treatment and control groups using an appropriate statistical procedure. Additional data on the frequency of poisoning from household chemicals will be taken from reliable secondary sources.

- Change in presence of environmental hazards-Performance Metric: Change in level of vermin infestation in weatherized houses. The Occupant Survey will solicit information from both weatherization participants and non-participants on the extent to which their dwelling is infested with rats, cockroaches, and other vermin. This question will be asked both before and after weatherization. The net change in this factor from the pre- to post-weatherization period will be determined by comparing change for the treatment and control groups.

- Improved comfort-Performance Metric: Perceived improvement in indoor comfort in weatherized houses. A sample of Program participants and a control group of non-participants will 
be asked about their perceptions of the indoor comfort of their dwelling unit during the pre- and postweatherization period via the Occupant Survey. "Comfort" will include both indoor temperature and draftiness, as in the 1989 Weatherization Program national evaluation, as well as the floor area or number of rooms that can be conditioned. Responses will be solicited during both the heating and cooling seasons. Net change from the pre- to post-weatherization period will be determined using an appropriate statistical procedure.

- Improved comfort-Performance Metric: Measured change in indoor air temperature in weatherized houses. Equipment will be installed in the previously mentioned homes in the previously mentioned Indoor Air Quality study to measure indoor winter and, if possible, summer air temperatures during both the pre- and post-weatherization periods. The non-weatherized houses will be measured at the same time as the weatherized units to control for any possible changes in outdoor temperature or other climatic conditions, and careful attention will be paid to the season in which the measurements are taken. Net change from the pre- to post-weatherization period will be determined by comparing change from the treatment and control groups using an appropriate statistical procedure.

- Improved appearance-Performance Metric: Perceived improvement in appearance of weatherized dwellings. Using the Occupant Survey, a sample of Program participants and a control group of non-participants will be asked for their perceptions of the appearance of their dwellings both before and after weatherization. Changes from the pre- to post-weatherization period will be compared for the treatment and control groups.

- Reduced noise inside dwelling-Performance Metric: Perceived reduction in noise within weatherized dwellings. The Occupant Survey will ask a sample of weatherization participants and non-participants for their perceptions of the noise level within their dwellings both before and after weatherization. Once again, net change from the pre- to post-weatherization period will be determined by comparing change for the treatment and control groups using an appropriate statistical procedure.

As described above, the magnitude of each non-monetized impact will be calculated separately. In addition, the effects of specific agency actions on various non-monetized health- and safety-related impacts will be explored. This can be done by (1) performing regression analysis to search for relationships between various impacts and agency actions (e.g., plumbing repairs, improved ventilation) that have the potential to affect health and safety; and (2) doing a literature review on the relationships between selected agency actions and health effects.

\subsubsection{Social Network Study}

The non-energy benefits research described above addresses many additional ways that the Program can generate benefits to clients and society. This section addresses yet another potential benefit of the Program: the potential for two groups, clients and the weatherization staff, to influence energy savings beyond their homes and their day jobs. Every individual and every household has a network of social contacts that may be visualized as a map of nodes (individuals/households) and lines (connections). The analysis of social networks (Social Network Analysis or SNA) will be employed to explore linkages between individual households, weatherization staff, and agencies as nodes within a multi-level and multi-relational social system that could influence energy savings beyond the Program. 
Taking advantage of the natural tendency to build social networks to create a system of information flow in which information about weatherization can be shared, SNA will allow evaluators to visually capture the structural attributes of the network and relational data in order to provide both statistical and visual analysis.

The clients will be studied to determine whether and how they communicate with neighbors, acquaintances, friends, and family about the results of their home audits, the measures installed, any changes in their energy bills, and any other energy and non-energy benefits.

In the case of weatherization staff, technicians have social networks of their own. This study will serve to identify and map ways in which the WAP program encourages secondary impacts on home energy savings through social networks. The timeframe for this project extends from March 2010 through September 2011 to allow time for culturally sensitive implementation plans for each agency, hiring and training of research staff, sampling, interviewing, and analysis.

The communities in our pilot, though economically marginal, are likely to be sophisticated in social media usage. Any network analysis must start with a population's access to modes of communication from letter writing to modern social media such as online forums, listservs, instant messaging, Twitter, and Facebook.

This project will leverage the results from a task being undertaken by the retrospective evaluation to conduct case studies on approximately six high performing local agencies. The retrospective evaluation's case studies will describe local agency operations, philosophies, and approaches, and how the local agencies reach out to surrounding communities to promote weatherization and other social services. In addition, these case studies will describe how the agencies act as nods of communication about energy efficiency within the community.

The SNA employed in this evaluation will add to the retrospective study's results, enhancing the description of the network by adding clients and weatherization staff as nodes in the community network.

Upon identification of the high performance agencies and communities to be assessed, census tracking, and other forms of structural data will be collected for the WAP-ARRA evaluation to reveal community demographics with regards to socio-economic status of the community as a whole, individual income levels within particular neighborhoods, racial or ethnic make-up, median age, disability rates, number of single parent homes, unemployment, population density, and education statistics. This information will provide potential factors relating to the high performance rate of the agency, as well as cultural implications related to social networking systems. Quantitative and qualitative data will be evaluated for a rich ethnographic understanding of the community as a whole. This reading of the community will help understand how information within the community is shared (possibly feeding a viral spread of interest in weatherization), and what the core values are in place that might support or hinder adoption of new energy practices.

To conduct the client-based SNA, a list of weatherized homes will be supplied from the agencies. A visual spatial map will be created using this list. This visual aid will assist with identifying high utilization clusters within the community and will assist with identifying initial client (i.e., household) nodes for this analysis. Upon selection of the preliminary household nodes to initiate the study of social networking around the household, in-person interviews will be conducted with the clients to collect information to build frameworks of their social networks. Snowball sampling methods will be used to contact people within the clients' social networks via telephone or in person. Researchers will talk with members of the client's network to learn more about their interest in weatherization. By soliciting broad information, rather than targeted "source of influence," the respondent may volunteer unanticipated 
information beyond the scope of initial researcher knowledge. Researchers will attempt to determine the impact the clients' weatherization activities had on the behavior of other individuals, measured by the number of applications for Program services, household energy-use behavior, and influence on investment in energy-efficiency measures. Individuals one step away from the initial client nodes will be asked for a list of other nodes in their own social networks and a second round of snowball interviews will be conducted. The goal is to conduct approximately 100 interviews per agency.

To gather information about the household nodes and to create a social network map, local recipients of the program will be recruited and hired through the local agencies. This technique, known as participatory research, will allow information to be collected starting with the initial client as a node. Efforts will be made to recruit researchers who are well versed in the culture of the area, have good interpersonal skills, and are familiar with the WAP application process and with energy conservation. These researchers will be trained by research professionals before collecting data within their local areas, and once trained, will make contact with the initial client nodes, paying special attention to whether or not the household either may have served as a catalyst for energy change within the community or its own social network, or conversely, whether the household was influenced by another household that could better be identified as a catalyst. SNA of the household nodes will present a visual analysis at the conclusion of the study and will offer insight into program utilization process; this analysis will further provide data for a secondary impact analysis of the Program's influence on home energy conservation.

To conduct the SNA of the weatherization staff, local workers employed by the high-performing agencies within the retrospective study's Case Study Analysis will be interviewed to gain insight regarding the impact these local workers have on the rate of homes weatherized within their own social or professional networks or communities. Weatherization staff will be interviewed to initiate a second snowball sampling with follow-up telephone surveys. Additionally, the weatherization staff survey will be modified for this study to include questions related to communication of the program within social networks.

This approach (use of participatory techniques within client populations and partnering with community agencies) is reflective of OMB's Open Government Directive, which emphasizes the need to incorporate transparency, participation, and collaboration with multi-disciplinary approaches into the design, implementation and analysis of federal programs and projects. The participatory research technique also offers the benefit of empowering clients and workers and work experience that may extend those individuals' employment opportunities.

\subsection{COST-EFFECTIVENESS}

\subsubsection{General Assessment}

The impact assessment will determine the cost-effectiveness of the Program as implemented in PYs 2009, 2010 and 2011 on a national basis and by climate region, housing type, primary space-heating fuel type, and the five client groups that the Program is specifically instructed to focus on (the elderly, persons with disabilities, families with children, high residential energy users, and households with high energy burden). The cost-effectiveness of the Program in PYs 2009, 2010 and 2011 will then be compared to results from the retrospective evaluation (PYs 2007 and 2008) and the 1989 National Evaluation and from the meta-evaluations performed between 1990 and 2005. It should be noted that, although cost-effectiveness will be calculated by climate region, housing type, and type of primary spaceheating fuel, a full analysis of factors affecting cost-effectiveness will be performed as described in Section 2.5. 
The cost-effectiveness of the Program will be calculated using appropriate methods for coordinated programs (Brown and Hill, 1994; Hill and Brown, 1994). Specifically, cost-effectiveness for WAP-ARRA will be calculated using the total costs spent on the house from all funding sources as collected and analyzed in Section 2.1, the energy cost savings calculated in Section 2.2, and the monetary values of the non-energy impacts (which may include both benefits and costs) estimated in Section 2.3. Cost-effectiveness will be determined using savings-to-investment ratio (SIR), the same indicator as used in the retrospective and the 1989 National Evaluation. Standard formulas for this indicator will be used. Cost-effectiveness will be examined from three perspectives:

- Installation perspective - “savings" are limited to energy savings (all heating, cooling, and baseload energy savings combined), and "investments" (i.e., costs) are limited to installation expenditures (on-site labor and materials),

- Program perspective - "savings" are limited to energy savings as above, but "investments" are expanded to include management and overhead costs along with installation expenditures, and

- Societal perspective - “savings" include both energy savings and monetary values for nonenergy impacts (which may include both benefits and costs and, therefore, are net economic values), and "investments" include installation, management, and overhead expenditures.

To calculate the SIR, it is necessary to include information about the average lifetime of measures, such as refrigerators or windows, that are implemented. This information will be determined by weighting the individual lifetimes of each measure (as determined from secondary sources) by the frequency of its installation and relative energy savings. The monetary values of the non-energy impacts used in the calculations will be the net present value of the impact and, thus, will already have taken into account the lifetime of the impact and how the impact varies over time. Real discount rates and fuel escalation rates as recommended by the Department of Commerce will be used in the calculations.

A sensitivity analysis will be performed to determine the impact of key assumptions used in the calculation of SIR. These key assumptions include energy savings, fuel costs, measure lifetime, real discount rate, fuel escalation rate, and the monetary value of non-energy impacts. The risk analysis modeling approach to be used allows the uncertainty in model inputs to be defined by probability distributions, so that distributions of likely SIR outcomes can be developed. Results from the sensitivity analysis performed specifically for energy savings (see Section 2.2.2) and non-energy impacts (see Section 2.3.1) will be used in this analysis.

As part of the cost-effectiveness analysis, the impact that alternative per-household investment levels can have on Program cost-effectiveness and other key Program metrics, such as the number of units weatherized and average energy savings, should be examined (i.e., it should be examined whether there are investment levels that optimize the SIR at an agency or state level and, if so, how this subsequently impacts the number of units weatherized by the agency or state and the average energy savings per weatherized unit). The analysis method to determine this impact has not yet been determined. However, in addition to a review of the relevant research, insight into the impact of household investment levels might be obtained by two possible methods:

- Calculating SIRs for different expenditure categories of weatherization jobs (e.g., those costing between $\$ 1,500$ and $\$ 2,000$, between $\$ 2,000$ and $\$ 2,500$, up to $\$ 6500$ etc.) and then comparing the means of each category using appropriate statistical methods. Information on the houses used in the billing data sample would be sufficient to perform such an analysis 
- Using an audit program such as the Weatherization Assistant (Gettings, 2006). A significantly large number (perhaps 100 units) of real or typical houses could be modeled for a real or example agency to identify all the measures with an SIR greater than 1.0 for each house and then to estimate the cost and SIR for each of these individual measures. The cost-effectiveness and average investment level for this agency can be calculated for a fixed budget that is sufficient to install all the measures with an SIR greater than 1.0 in, perhaps, the first 50 houses, as well as to perform all administrative functions associated with these 50 houses (e.g., intake, auditing, and post-weatherization inspections). The cost-effectiveness and average investment level for the agency would then be recalculated as the SIR cutoff, which is used to determine which measures are installed in each house, is raised (or the average investment level per house is decreased), such that fewer measures are installed in these first 50 houses but measures with high SIRs are installed in additional houses until the same fixed budget is expended. If desired, houses used in the billing data sample could be modeled, and the model predictions could be calibrated to actual energy data. The analysis could be repeated using different costs to perform the administrative functions to gain insight into how the optimal SIR cutoff and average investment level changes as these fixed costs change.

\subsubsection{In-Depth Cost Assessment of Weatherization Measures}

It is possible that ARRA funding for weatherization and other energy-related programs (e.g., State Energy Program, Energy Efficient Community Block Grant Program) had an impact on the cost and availability of weatherization measures. This study will assess the changes in the costs of weatherization measures, as well as bottlenecks in their availability, during the ARRA period and related impacts on cost-effectiveness. This study will also compare the costs used in SIR calculations to those actually encountered in the field.

One way to perform this assessment is by using linear regression analysis to find the Total Installed Measures Costs (TIMC). The general form of the equation to be estimated is as follows:

$\mathrm{TIMC}_{\mathrm{i}}=\mathrm{f}\left(\mathrm{b}_{1} * \mathrm{M}_{1}+\mathrm{b}_{2} * \mathrm{M}_{2}+\mathrm{b}_{3} * \mathrm{M}_{3}+\mathrm{b}_{4} * \mathrm{M}_{4}+\ldots . \mathrm{b}_{\mathrm{n}} * \mathrm{M}_{\mathrm{n}}\right)$

where $\mathrm{TIMC}_{\mathrm{i}}$ stands for Total Installed Measures Costs for home, and $\mathrm{M}_{\mathrm{i}}$ is a "dummy" variable indicating whether or not that measure was installed in any given home ${ }_{\mathrm{i}}$. Up to $\mathrm{n}$ different measures could be installed in a home. The beta coefficients represent estimates of each measure's cost.

Information about the Total Installed Measure Costs and the measures installed in each home will be available through the DF2 (Housing Unit Information Data Form), which local agencies will complete for each home (single-family detached, single-family attached, and mobile home) included in the national sample of weatherized homes heated with electricity or natural gas. The database is expected to include approximately 10,000 records, which is a database large enough to estimate regression models that are stratified by climate region at the very least and maybe also by housing type (e.g., single-family detached vs. mobile home by climate region).

Models will be estimated for PY2008 and PY2010. Beta coefficients for each measure will be compared between the models to estimate possible measure price changes. It is possible that the PY 2008 coefficients will also be adjusted for inflation.

Controls to make sure that the beta coefficients are valid as accurate estimates of measure prices will be done in three manners. First, specific coefficients for specific measures will be compared to prices for analogous measures compiled by the Producer Price Index (PPI) (http://www.bls.gov/ppi/) and possibly the Consumer Price Index (CPI) (http://www.bls.gov/cpi/). The PPI tracks prices related to air 
conditioners, furnaces, lights, and insulation, and the CPI tracks prices related to such consumer goods as lights and energy. Second, the estimated regression models will be run on the data agency-by-agency to estimate total measure costs by sampled agencies. These results will be compared to total reported measure costs by agency. Third, a small number of questions about the cost of weatherization measures will be included in S3 (Subset of Agencies Detailed Program Information Survey, see Appendix E) to collect subjective estimations of changes in measure costs from PY 2008 to PY 2010.

A similar approach will be used to explore possible changes in labor costs. Regression models will be run with Total Labor Costs per home as the dependent variable and "dummy" variables for measure installation. The beta coefficients will represent the costs for installing each measure. Beta coefficients will be compared between PY 2008 and PY 2010 (the former may be adjusted for inflation). As a check on the validity of these beta coefficients, the database Occupational Employment Statistics (http://www.bls.gov/oes/), which has data on contractor wages, will be consulted.

Validated measure costs will be compared to measure costs used in SIR calculations during PY 2010, as appropriate by climate region and house type. NEAT will be used as the source of the SIR calculations. Bottlenecks in measure availability will be explored through the addition of several questions to S3 (Subset of Agencies Detailed Program Information Survey, see Appendix E).

\subsection{EXPLANATORY FACTORS}

Although average energy and cost savings will be calculated in the impact assessment by climate region, housing type, and primary space-heating fuel type (see Sections 2.2 and 2.4), a full analysis of factors that explain variations in energy savings and cost-effectiveness will also be performed. The impact assessment will assess how the energy savings achieved by the Program and the cost-effectiveness of the Program are affected by the various organizational features and operational processes of the Program, the households the Program serves, the measures installed, and the environment in which the Program operates. Some specific factors that will be examined include the following:

- household pre-weatherization energy consumption,

- installation of particular weatherization measures,

- key house characteristics (e.g., type, size),

- key occupant characteristics (e.g., age, disability),

- fuel prices,

- climate zone,

- training methods for weatherization crews,

- type of audit used,

- client education approach used,

- monitoring procedure employed,

- total investment levels,

- funding sources,

- low and high material expenditures (as opposed to total expenditures, which include labor costs),

- weatherization using only DOE funds vs. funds from multiple sources,

- air-leakage reduction,

- duct-leakage reduction, and

- increased furnace steady-state efficiency.

A broad range of potential explanatory variables will be examined using regression analysis. In addition, average savings associated with and without a single factor will be compared using all houses, and mean savings for explanatory factors will be compared between high-saving and low-saving houses. 
Those factors that explain the most variation and are controllable by state and local weatherization agencies will be given the most attention, because results in those areas can suggest potentially valuable changes in program implementation. Special emphasis will be placed in these analyses on identifying variables that explain why the performance in the hot-climate region is unique. Details on these analyses are provided below in Section 2.5.1.

\subsubsection{Regression Analysis}

The primary analytical approach that will be used to study explanatory factors will be regression analysis. The regression analysis will explore the relationships between household energy savings and cost-effectiveness and a broad variety of factors; this form of analysis has the potential to explain variations in those two performance measures, including many of those identified above. By examining the possible influence of pre-weatherization energy use, it will be possible to identify whether any of the observed relationship is due to the regression-to-the-mean phenomenon (in which extreme measurements are subsequently followed by measurements closer to the norm).

Hypotheses will be developed concerning a priori expectations of the influences of each independent (explanatory) variable on the dependent variables (savings and cost-effectiveness). Energy savings will be measured first in absolute terms, secondly as a percentage of pre-weatherization wholehouse energy use, and thirdly as a percentage of the pre-weatherization energy used for space heating. Cost-effectiveness will be defined as energy savings divided by the cost required to achieve those savings. The results of the regression analyses will be examined, and significant beta coefficients of the proper sign will provide support for the hypotheses. Insignificant variables will be dropped from the regression models.

Separate regression analyses will be run for houses heated by natural gas, electrically-heated houses, and houses heated by non-metered fuels (fuel oil and propane). Within those categories, the factors influencing energy savings and those influencing cost-effectiveness will be examined separately. For all dwellings other than those heated with electricity, further analyses will be performed to focus on factors affecting savings of the primary heating fuel only, baseload electricity only, and both fuels (heating and baseload electricity) combined.

Houses Heated by Natural Gas - As part of the regression analysis, a large multiple regression model that includes all potential explanatory variables will be run . It is likely that this will be a "stepwise" regression, in which independent factors are added to the model in the order of their explanatory significance. In addition, a series of simple regressions will probably be conducted using one independent variable at a time, and a factor analysis will likely be done to examine what sets of explanatory variables are associated with each other.

The above analyses will be run first using energy savings as the dependent variable and then again using cost-effectiveness as the dependent variable. Actually, the analysis of energy savings will consist of three different analyses, one for each of the above-mentioned definitions of savings (absolute household savings, household savings as a percentage of pre-weatherization whole-house energy use, and household savings as a percentage of the pre-weatherization energy used for space-heating). Further complexity will be added by the fact that energy savings will be first defined as savings of the primary heating fuel only, then as baseload electricity savings, and finally as savings of both fuels (heating and baseload electricity) combined.

Once the above analyses are run for all weatherized households, they will be run again for relevant subsets of households. These subsets will include, but are not limited to, different geographic and/or climate regions, agency sizes, and housing types. 
Finally, regression analyses will be run using average household savings and cost-effectiveness per weatherization agency as the dependent variable. The same independent variables and analytical procedures listed above will be used. The theory behind undertaking this analysis is that using agency averages is likely to reduce the variability of results.

Electrically-Heated Houses - The regression analyses conducted for electrically-heated homes will be the same as those described above for gas-heated homes, except that they will be run only for the primary heating fuel because the dwellings involved use electricity both for heating and baseload purposes.

\subsubsection{Cross-Tabulation Results}

Average savings associated with a single factor (e.g., savings in houses that received wall insulation compared to houses that did not) will be compared for all houses and by subgroups of houses depending on primary heating fuel. Mean values for key explanatory factors (e.g., floor area, preweatherization energy use, installation of attic insulation) for high-saving and low-saving houses and for high-saving and low-saving agencies will also be calculated and compared.

\subsubsection{Data}

This analysis of explanatory factors will use pre-weatherization energy consumptions and energy savings as described in Section 2.2, and cost-effectiveness calculated for individual houses as described in Section 2.4. This analysis will also draw upon data relating to house, occupant, and program characteristics as described in Section 2.1. Information on some potential explanatory factors will be gathered for all weatherized houses, while data on other factors will be collected from a subset of houses if they are not available for all dwellings served by the program. Average data for a number of factors will be calculated for all weatherization agencies, and some additional information will be collected from a selected group of agencies. 


\section{PROCESS ASSESSMENT}

The process assessment portion of the evaluation will address many of the questions that were identified in the evaluation design matrix (see Table 1.2), but which the impact assessment did not address:

- Context-Questions 1, 5, 7 and 9-11; and

- Implementation-Questions 3 and 5.

The above questions relate to identifying the missions and associated objectives of the Program and the organizations that the Program works with; understanding how the weatherization network works and the role of the Program in serving the low-income weatherization market; investigating the leveraging and partnership opportunities for the Program; and determining how well the Program is delivering services as well as how essential elements of the Program can be improved.

\subsection{PROGRAM OPERATIONS AND IMPLEMENTATION}

This assessment will aim to understand the context in which the Program operates by

- identifying the legislatively mandated goals (missions and associated objectives) of the Program and determining the Program's ability to meet these goals;

- identifying how states implement the Program relative to the logic model developed for the Program (see Section 1.1.2);

- determining how well DOE manages and administers the Program;

- determining how well the Program and the weatherization network are delivering services to the low-income weatherization market;

- identifying the leveraging and partnership opportunities the Program is exploiting (i.e., identifying the degree to which states and agencies coordinate the implementation of the Program with other federal, state, utility, and similar programs) and determining whether the Program's regulations are enhancing or inhibiting leveraging and partnership opportunities (or doing both); and

- determining the role the Program plays in the larger low-income energy-assistance effort.

\subsubsection{Data and Surveys}

Information on process improvement will be collected from all states as part of S1 (All States Program Information Survey, see Appendix C) and from the 400 agencies involved in the billing data energy-savings portion of the impact assessment (see Section 2.2.1) as part of S3 (Subset of Agencies Detailed Program Information Survey, see Appendix E). Both surveys will also ascertain states and agencies views of how DOE manages and administers the Program and will collect detailed input on how the states and agencies implement house audits, client education, training, and monitoring, as previously described in Section 2.1.1. The state survey will also collect information that defines state "implementation models." These surveys will be implemented after each state and agency completes PYs 2010 and 2011. 
DOE will be surveyed using the DOE Survey (see Appendix B) to collect information on staffing, costs, and their enforcement of state and local agency data collection, storage, and data mining capabilities. This survey will be given when PYs 2010 and 2011 are complete for all states.

Open-ended interviews will be held with DOE and a subset of states and agencies via telephone or by means of one or more group meetings to solicit needed process information for this study. The sampling plan and survey instruments associated with this data collection will need to be developed; however, the survey instrument should include the following information:

- major strengths/positive traits at each implementation level (DOE, state, and agency),

- major weaknesses/negative traits at each level,

- major barriers to effective operation posed by each level and outside partners,

- adequacy of current resources,

- suggested reallocation of current resources,

- suggested allocation of additional resources,

- coordination,

- communications, and

- Program administration.

The Occupant Survey that is being implemented as part of the retrospective evaluation contains a customer satisfaction section, so this survey will collect information such as the timeliness of the work performed (e.g., audit, measure installation, inspection), whether agency staff reported at scheduled times, the condition in which workers left the house following their work (e.g., cleanliness, debris removal), and the courtesy of the agency personnel.

\subsubsection{Analysis}

The mission and objectives of the Program and DOE's management structure and responsibilities will be described. This will include a summary of:

- the Program's legal authority and its regulatory framework;

- the goals, objectives, and key performance measures as viewed by Congress, the Department, and the Administration; and

- Federal, state, and local responsibilities as described by both regulation and network participants.

In addition, particular attention will be paid to leveraging activities allowed under the Programs rules and regulations.

An analysis of the management structure, responsibilities, and resources for each of the Program's management levels (i.e., headquarters, regions, state, and local agencies) will be performed. This analysis will focus on operations at each management level, the allocation of human and funding resources to various functions, and whether each management level perceives the resources it has to perform its functions both within and between management levels. A secondary focus of this analysis will be the perceived barriers to effective operations imposed by each management level on other management levels and barriers at each management level to effective operations with outside partners.

Organizational activities relating to how well Program services were delivered will be identified, and a measurable indicator for each activity will be developed (e.g., whether an audit was performed on time, whether measures were installed when scheduled, etc.). Information collected from all agencies or a 
subset of agencies on all houses or a subset of houses weatherized will be used to determine the average values for these indicators.

Approximately five typical models of how states administer and implement the Program will be developed based on information collected from the state survey and from reviewing state weatherization plans submitted to DOE. How well these models work, and how well they fit the theory and logic of the Program, will be discussed using the logic model developed for the Program (see Section 1.1.2) as a guide. Lessons learned from the various approaches, model dependencies, and key issues and administrative concerns affecting model effectiveness are expected to be identified.

Occupants' perceptions on how well Program services were delivered will be compared to the perceptions provided by the agency staff and crews and the comparisons analyzed.

The role of the Program in the overall low-income energy assistance effort will be assessed by drawing together information from the impact assessment on the Program characteristics (see Section 2.1) with information collected and analyzed in this study. Program characteristics that will be used include information on the national low-income population, the segment of the market currently being served by the Program, and the characterization of the local and state agencies and the scope of their programs.

\subsubsection{Deferral Study}

The Process Assessment for the WAP-ARRA Evaluation includes an exploratory study of federal, state, and local weatherization agencies' policies, procedures, incidence rates, and final weatherization service status regarding deferrals, (i.e., situations where agencies decide to postpone weatherization till a later date or ultimately where weatherization services are not provided). Reasons for deferral of weatherization treatment are generally categorized into two areas:

- Health and Safety - conditions in the home may pose health and/or safety risks to weatherization workers; and

- Cost-effectiveness - home may be in such disrepair that weatherization measures might not result in cost effective energy savings.

Regional and state field guides or manuals provide guidance for policy and acceptable reasons for deferment. OSHA standards for Health and Safety for weatherization auditors, contractors, and crew members must be adhered to and are referred to within the Health and Safety section of the OSHA field manual.

This exploratory research study will utilize information from the state, agency, weatherization staff/occupant surveys, the retrospective case-study process evaluation, and data collected from a sample of 10 states and 10 local agencies that describes the processes experienced by 200 occupants engaged in the deferral process. Appendix O, Section 5, contains an in-depth discussion of the sampling plan for this study.

The exploratory design involves documenting the accessibility and use of field manuals (which may have deferral guidelines, reported deferral frequency rates, and agency protocols and standards. The first task to be undertaken is to identify each state's deferral protocols for PY2010. Table 3.1 presents the structure for preliminary data collection in order to shape the exploratory design of the process assessment; this structure will be updated throughout the data-collection process. 
Table 3.1 Deferral Protocol for All States and Territories

\begin{tabular}{|l|l|}
\cline { 2 - 2 } \multicolumn{1}{l|}{} & State or Territory \\
\hline Regional Guide & \\
\hline State Guide & \\
\hline Agency Guide & \\
\hline Standard Forms & \\
\hline Appeal Procedure & \\
\hline Appeal Forms & \\
\hline Grievance Forms & \\
\hline Referral Plan & \\
\hline $\begin{array}{l}\text { Referral } \\
\text { Documentation }\end{array}$ & \\
\hline $\begin{array}{l}\text { Tracking System } \\
\text { for Deferral } \\
\text { Incidence }\end{array}$ & \\
\hline
\end{tabular}

The conditions under which deferrals may be granted vary from state and state, and potentially, from agency to agency. The reasons that people abandon a housing unit will initially be categorized by the evaluators based on the list of deferral conditions posted by the Weatherization Assistance Program Technical Assistance Center (WAPTAC) and on additional conditions found in regional protocols. Additional conditions suggested by weatherization staff or surveyed occupants, or from state or agency survey instruments, may be added.

The retrospective evaluation's versions of S1 (All States Program Information Survey) and S2 (All Agencies Program Information Survey) will be modified to include requests for data designed specifically to capture tracking of deferral rates and to confirm sources for deferral policies and procedures nationally.

The weatherization staff survey, also being conducted as part of the retrospective evaluation, will be administered nationally to 271 auditors between Spring 2011 and Summer 2011. Specific questions about deferral policy, procedure, and frequency of specific conditions or reasons for deferring services have been included in a revised version of this staff survey. Responses collected from the survey will be compared to state deferral-protocol standards, while incidence rates reported (if they were in fact tracked) for PY2010.

Before beginning to collect data for the records analysis, evaluators will observe at least four deferrals in process. The four agencies selected for observation will be based on the criteria in Table 3.2. Evaluators will be instructed to note the following:

- cause of deferral,

- assessment of impact of accessibility to standard deferral plans,

- utilization of standard forms,

- auditor knowledge of community resources (e.g., other social services available to the household) targeting the specific cause(s) for the deferral,

- innovative techniques for preventing potential deferrals,

- range of subjective or ethnocentric responses to home conditions (i.e., auditors and/or clients judgments about conditions in the homes) or client behavior, and 
- other characteristics of the homes and weatherization personnel. A case-study process evaluation will be conducted to record the overall assessment of the observed deferral occurrences; this process evaluation will entail interviews with clients and weatherization staff, review of available documentation, and analysis of collected data.

\section{Table 3.2. Deferral Observation Assessment Criteria}

\begin{tabular}{|l|l|}
\hline Formal Deferral Plan; Low Incidence & No State Formal Deferral Plan; Low Incidence \\
\hline Formal State Deferral Plan; High Incidence & No State Formal Deferral Plan; High Incidence \\
\hline
\end{tabular}

Assessment of the deferral process will follow a sequence of events during PY 2010, beginning with the home audit through to the final deferral decision. Figure 3.1 illustrates the potential actions within deferral processes and is subject to change according to differing processes among states, agencies, or households.

Data for analysis will be collected after the deferral decision is made. A sample of 10 states and 10 local weatherization agencies will be selected based on the varying levels of historical commitment to successfully resolving deferral situations and adoption of individual vs. regional deferral protocols. The technical aspects of this study are flexible due to these variables. Each state and agency is presumed to organize its deferral documentation differently, since there is no nationally accepted streamlined approach to tracking and monitoring in place. The sample of agencies and their corresponding state grantees will be stratified to allow for comparison between states that have written deferral policies and procedures codified in state field guides and states that rely only on regional field manuals. It is presumed that states with state field guides and protocols are also states with historical commitment to WAP; if so, a second comparison can be made between those states with established weatherization programs and states that have historically low levels of Program participation. The study will compare quality assurance, frequency rates, and documentation of deferrals between those sub-sampled states and agencies that have standard deferral plans and those that do not; additionally, the study will consider how unit or agency attributes correlate with adopted deferral plans (Table 3.3). 


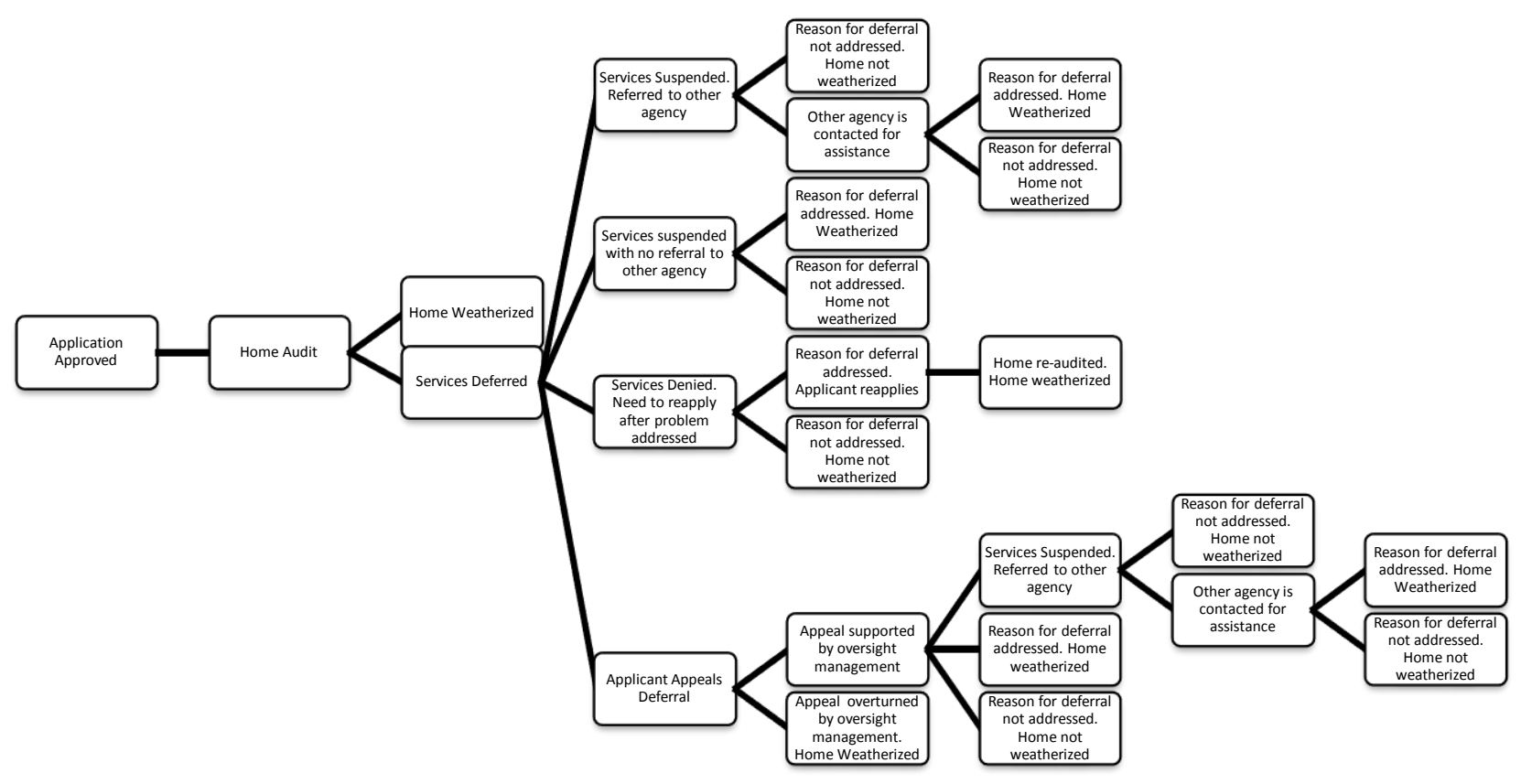

Table 3.3 Unit or Agency Attributes

\begin{tabular}{|l|c|c|c|c|c|}
\hline & $\begin{array}{c}\text { Urban } \\
\text { vs } \\
\text { Rural }\end{array}$ & $\begin{array}{c}\text { Hot } \\
\text { vs. } \\
\text { Cold }\end{array}$ & $\begin{array}{c}\text { Single Family vs. } \\
\text { Multifamily vs. Mobile } \\
\text { Home }\end{array}$ & $\begin{array}{c}\text { Age of } \\
\text { Housing } \\
\text { Unit }\end{array}$ & $\begin{array}{c}\text { Wx Agency } \\
\text { Experience }\end{array}$ \\
\hline Formal Plan & & & & & \\
\hline No Formal Plan & & & & & \\
\hline
\end{tabular}

Evaluators will retrieve documents detailing deferral forms or deferral notes from individual applicant files or from agency data files organized either electronically or in paper form. Oversight and tracking processes, if observed, will also be documented. To reduce the burden on local weatherization agencies, methods of data collection may include site visits to the sampled agencies by evaluators, as well as the methods used to implement the staff survey.

Evaluators will follow the deferral process in real time for a sample of 203 households. This process assessment will involve phone interviews with occupants and weatherization staff, as well as records collection. The 203 households will not be randomly selected due to the unpredictable nature of deferrals and the value of collecting data in real time. The purpose of the household survey is to document the occupant's account of the deferral and his or her perception of the overall process. The evaluators will administer the survey as a pre-tested telephone questionnaire, which may require a one-time call or an initial call with additional follow-up if treatment has been deferred for a certain amount of time, or if an appeal is in process. 
The following information will be collected from the sample of 10 local weatherization agencies and the 200 sampled households:

- Standard or informal deferral policy or protocol

- Documentation of deferral process

- Reasons for suspended and deferred treatment

- Incidence of suspended and deferred treatment

- Efforts to communicate with applicant

- Appeal process for deferred applicant

- Incidence of appeals

- Incidence of weatherization post-deferral

- Tracking mechanisms imposed by local agency or state office.

This study seeks to explore the ways in which agencies and states differ in their deferral strategies, and the limitations these differences place on the representativeness of results for the nation as a whole. The following attribute data will be collected and factored into the analysis of results across local, state, and federal systems:

- Variations in determination of health and safety standards

- Determination of what measures are deemed to be cost-ineffective

- Accessibility of state or regional field manuals and whether or not these field guides are consulted at the local agency level

- Whether there is a lack of a streamlined documentation and tracking strategy to effectively capture the incidence of walk-aways on both agency-to-agency and state-tostate levels

- Objectivity of the determinations made by auditors, contractors and crew members

- Cultural influence on home conditions

- Cultural or language barriers between auditor or crew members and occupants

- Prevalence of health and safety barriers specific to geographic areas

- Other attribute and relational data discovered though process assessment.

Because there is no current tracking system in place, the data that will be collected to provide insight into the frequency of deferrals will be reported as an estimation of the incidence of deferrals. Incidence estimates within the 10 states sampled will help determine the need for policy and for standardized procedures aimed at minimizing deferral rates within the states. The data collection and analysis aim to

- Calculate estimates of incidence rates of interrupted or suspended weatherization as a result of health and safety issues or cost-effectiveness concerns

- Provide estimates of the rate of final deferrals of treatment, in which the applicant is advised to reapply after addressing extensive concerns observed in the home

- Assess policy and protocols for deferral of treatment as defined in regional, state, and local field manuals or guides

- Compare deferral protocols and OSHA standards

- Assess the impact of standard deferral forms on incidence and documentation

- Review quality assurance issues regarding the deferral or suspended work phase to ensure fair treatment of applicants

- Assess the potential benefit of streamlining the deferral process and documentation on a national level to ensure the health and safety of weatherization auditors, contractors and crew members

- Assess policy and procedure with regard to documentation, tracking, and monitoring of individual deferral occurrences and collective incidents on state and national levels 
- Identify effective model strategies for tracking deferrals for future studies aimed at seeking more accurate incidence records of deferrals on a national level

- Determine the incidence of referrals made to alternate resource(s) for assistance, with reasons(s) for deferred services

- Provide discussion of needed resources from government, private, and non-profit sectors to better address the underlying causes for home deferrals discovered through the data collection and analysis

- Ascertain whether reasons for deferrals are acceptable and are subject to appropriate management oversight

- Determine how "user-friendly" the appeal process is for deferred applicants

- Determine the impact of Program mandated limitations on weatherization funds allowable for health and safety conditions of the home

This study has two primary objectives. The first is to determine deferral incidence rates and to explore impacts on the Program The second is to identify both strengths and weaknesses in the deferral process at the local agency level, in the monitoring system established by the state grantees of WAP, and in oversight of the grantees by DOE Project Officers assigned to each state. It is hoped that existing and effective tracking mechanisms with the potential to serve as a model for state monitoring of local agencies or subgrantees will be identified. The timeline for tasks associated with the Deferral Process Evaluation is shown in Figure 1.2.

\section{Figure 3.2 Deferral Process Assessment Timeline}

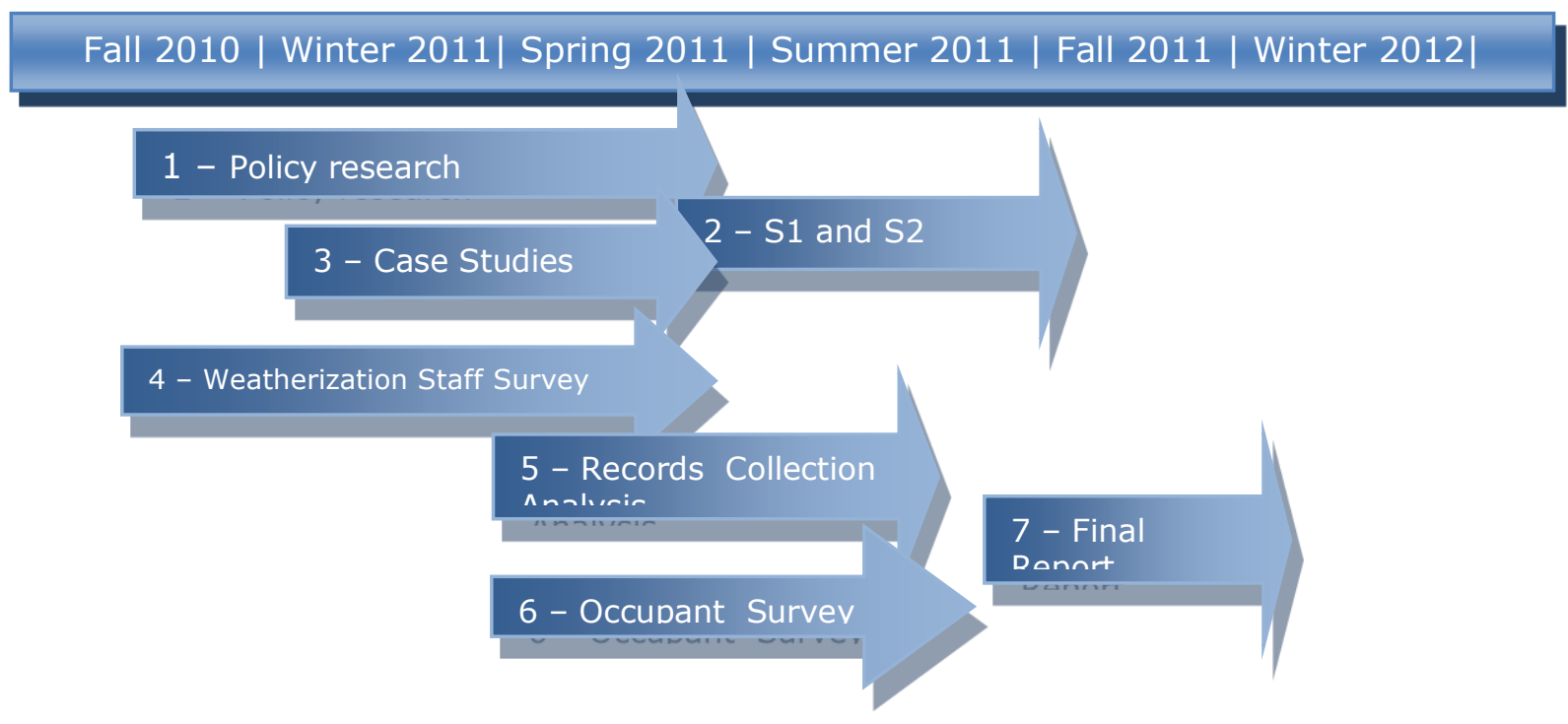

\subsubsection{Post-ARRA Weatherization Network Strategies}

As mentioned above, ARRA funding required the national weatherization network to expand greatly in a short period of time, essentially doubling the annual number of homes weatherized during PY's 2009, 2010, and 2011. This increase in production required associated increases in training and manpower. As this document is being written, the activity of the national weatherization network is peaking and then is expected to plateau. States and agencies are already considering what to do when the WAP-ARRA period ends in March 2012.

The purpose of this task is to collect information for DOE and the national weatherization network on strategies being developed by grantees and subgrantees post-ARRA. It is envisioned that strategic decisions about in-house staffing will need to be made; equally, the existing leveraging 
relationships, future implementation of innovative financing programs (e.g., revolving loan funds, participation in carbon markets), and ongoing maintenance of the weatherization training infrastructure (see 3.1.5) will have to be considered, among many topics. Suggestions about how the transition could be softened will also be collected. The following activities will be undertaken:

- Winter 2011 - ORNL will arrange for a national conference call with its National Weatherization Network Committee (see Appendix A) to discuss the types of information ORNL should attempt to collect to inform the Network and DOE about post-ARRA strategies. ORNL will use these inputs to develop new questions to be included in these two surveys: S1 (All States Program Information Survey) and S2 (All Agencies Program Information Survey). ORNL will take the opportunity during this call to also update the Network Committee on the progress that has been made on the retrospective evaluation and on the planning for the WAP-ARRA period evaluation.

- Winter/Spring 2011 - ORNL staff will meet with members of the national weatherization network in various forums to discuss evolving strategies. It is expected that ORNL will arrange for time to meet with network members at the NASCSP Mid-Winter Training Conference in early March 2011, and at a similar NCAF event. ORNL will also arrange conference calls with DOE/OWIP program officers to discuss what they may be seeing during their visits and discussions with grantees.

- Summer 2011 - The revised versions of S1 and S2 will be administered to all grantees and subgrantees.

- Fall 2011 - The survey results and inputs from various discussions will be summarized into a stand-alone report.

\subsubsection{Post-ARRA Training Assessment}

This task specifically focuses on strategies and plans that address the national weatherization training infrastructure. This infrastructure significantly expanded during the ARRA period (for example, the number of DOE-supported training centers increased from single to double digits). There is some evidence that spillover into related but separate endeavors may be occurring; for example, it has been reported anecdotally that the training centers may be serving purposes beyond training people to do lowincome weatherization. Some of those who have received DOE-supported training may be equipping themselves to work in the non-low-income retrofit sector as well. Some high-school students are receiving training as part of after-school career development programs. The training centers may be able to play a role in supporting other federal home-retrofit initiatives, such as Home Score.

With these thoughts in mind, training issues will be integrated in the four tasks listed under 3.1.4. That is, training infrastructure issues will be addressed with the National Weatherization Network Committee, in meetings at NASCSP and NCF, and in revisions of S1 and S2. Information from grantees and subgrantees will be collected to anticipate training needs beyond the ARRA period. Use of the DOEsupported training centers by individuals not directly involved in low-income weatherization is being tracked by the Weatherization Staff survey which is being used in the retrospective evaluation. Results from this survey, along with discussions with appropriate national stakeholders, will be used to project those national weatherization training needs beyond low-income weatherization that could be met by the DOE-supported training infrastructure. A summary report on post-ARRA training strategies will also be prepared during Fall 2011. 


\section{SPECIAL STUDIES}

\subsection{UNDERPERFORMING WEATHERIZED UNITS}

\subsubsection{Introduction}

In spite of the marked decreases in energy consumption and utility cost savings that low-income home weatherization has notably achieved, some weatherized units produce less-than-expected changes in levels of energy consumption after weatherization. Dubbed "underperformers," these cases occur across all building types (single-family, multifamily, and mobile homes) and regions. DOE, weatherization agencies, and ORNL evaluators have all identified the need for an investigation into multifamily units and the potential causes for their underperformance. Homes weatherized in PY 2009 and large multifamily buildings weatherized in PYs 2007, 2008, and 2009 will be included in this study.

\subsubsection{Potential Causes of Underperformance and Over-performance}

There are several possible causes for underperformance in weatherized units; these include

- Take-back or Rebound Effect - After weatherization, some households spend their energy cost savings on measures to increase the comfort of their homes (for example, buying new climatecontrol technology), thereby increasing their energy consumption to pre-weatherization levels.

- Change in Household Demographics - After weatherization, the size and/or composition of the household may change. For example, grandparents may take in grandchildren. Household members previously employed may become unemployed and, as a result, spend more time in the home. This could lead to increases in energy use during the day.

- More energy-consuming equipment may be bought or used after weatherization - It is possible that some households purchase or use more energy-consuming equipment (e.g. deep freezers, new televisions or computers, clothes dryers, etc.) after their home has been weatherized, thereby affecting the predicted energy performance of the home.

- Simple Regression to Mean - There is no reason to believe that every year's energy consumption by a household should be the same. There may be natural variations in energy use that would only become apparent through analysis of billing histories several years before and after weatherization. This hypothesis suggests, for example, that households might actually show savings two or more years after weatherization.

- Inaccurate Audit Tool - The variations in home designs, internal and external conditions, household energy consumption patterns, and household compositions are considerable. No computerized audit tool or priority list can be expected to accurately model energy savings associated with potential weatherization measures for every conceivable home situation encountered in the field. It is possible that some audits recommended less-than-optimal sets of measures to install in some homes.

- Poorly Done Audit - It could be that some auditors need additional training or that they tend to recommend measures that occupants want but that do not contribute much to the energy efficiency of the homes.

- Substandard Installation of Measures - Some weatherization measures may not be installed properly; recommended insulation levels may not be met; furnaces may not be properly tuned up; and some recommended measures are simply not installed. Such issues could reduce observed energy savings in homes.

- Failure of Measures - It is possible that some properly installed measures could fail during the one-year post-weatherization period during which bills are collected. In these cases, households may be forced to use old, inefficient technologies and/or revert to previous, energy-inefficient behaviors. 
- Poor Operation of Measures - In the large multifamily building context, it could be that those responsible for energy management may not be operating new technologies as prescribed. For example, building supervisors may be neglecting to use inputs from new temperature sensors located in select apartments.

- Lack of Education - Anyone, from multi-family building owners and managers to residents in single-family units, may lack effective and comprehensive energy education.

- No significant Weatherization Measures Installed - If no major weatherization measures are installed in a house/unit, then expected energy savings will be small. A unit with a small level of expected savings could appear as multifamily when compared to all weatherized units.

It is useful to consider whether some of the causes of underperformance could, if reversed, lead to over-performance. There are several possible causes for over-performance in weatherized units, which include:

- Reverse take-back effect - Households extend their energy cost savings by changing behaviors within the home to reduce energy consumption (e.g. changing the thermostat settings).

- Less energy-consuming equipment - Some households may discard energy-consuming equipment after weatherization.

- Simple regression to the mean - "Over-performing" households could actually show less savings two or more years after weatherization.

- Reverse change in household demographics - If one or more residents moves out of a house or unit after weatherization, higher energy performance in the unit as compared to estimated savings could result.

- Inaccurate audit tool - The audit of a unit may have underestimated the potential energy savings after weatherization.

- High occupant education - Multifamily building owners and staff and residents of weatherized homes/units may have received a higher-than-expected level of client education.

The evaluation approaches discussed below are designed to test these types of hypotheses.

\subsubsection{Evaluation Approach: Single Family and Mobile Homes}

The evaluation methods discussed in this section are designed to assess major potential causes for underperformance among the three major types of weatherized units - single-family, multifamily, and mobile homes.

The first task is to define underperforming (and over-performing) homes. "Underperforming" homes are defined to be in the bottom $10 \%$ when audit-estimated energy savings are compared to measured energy savings post-weatherization as set out in Equation (1). "Over-performing" homes are defined to be in the top $10 \%$.

Equation (1):

Level of performance $=$ (weather-adjusted audit-estimated energy savings minus weatheradjusted measured energy savings)/

(weather-adjusted audit-estimated energy savings)

Distributions of the level of performance will be estimated for all of the approximately 450 subsampled agencies. The top and bottom $10 \%$ of homes will be identified, and a list of agencies with eight or more multifamily and four or more over-performing homes will be compiled. Twenty agencies will be randomly selected from this list to be part of this study. For each selected agency, the approximately four multifamily homes (total of 73) and two over-performing homes (total of 42), (a total of 115 homes) will 
be randomly selected for inclusion in this study. The study will start with a larger sample and pre-screen to ensure that home inspections are warranted (i.e., that major demographic changes in the home are not the sole cause for under- or over-performance.

The project team will already have a good deal of information about these homes. In addition to the billing histories (only homes heated with natural gas or electricity will be included in this part of the study), the project team will have housing unit, installed weatherization measure information, and auditestimated savings from the DF2 Housing Unit Information Dataform and additional information from the DF4b form. From S2 and S3, the project team will have retrieved information on how the agencies conduct their audits, the extent to which the agencies use contractors, and how client education is delivered. Each classification will be crossed-referenced against building and weatherization characteristics, identifying numbers of multifamily units of each building type and particular technologies present in multifamily units. Data on client-education measures will also be compared to unit performance classifications and building types to ascertain the effect that client education can exert on level of performance.

Each underperforming and over-performing home will be thoroughly inspected, and the inspectors will review audit procedures and recommended measures. In the cases of priority lists, the lists will be evaluated to determine the level of appropriateness for the multifamily unit. In instances of computer audit, the auditing process will be evaluated to determine whether the audit software made mistakes (such as overestimates), whether calculated savings estimates were unreliable, or whether auditors misused software. In addition to inspecting the auditing process, evaluators will inspect for incorrect installation of measures. Thoroughness of installation will be compared against the recommended list of measures to be installed, thus allowing evaluators to determine whether any measures were forgotten during installation.

Occupant surveys will also be administered to collect further data on those living in the weatherized units that have been identified as either poorly performing or over-performing. The occupant surveys will also show whether residents are correctly utilizing the newly installed measures. The survey data will expose any behavioral change resulting from the weatherization process, and if any change is noted, may provide insights into under- and over-performing units. Changes in household demographics and composition will be noted.

Lastly, this study will develop regression models to help explain variations in energy savings among weatherized homes. The regression models will contain variables such as installed measures and demographics. The 120 homes included in this study will be run through the appropriate regression models to ascertain their predicted savings and whether the models also predicted the homes to be underand over-performers. The project team will address the significant variables in the models during its investigations to generate more detailed support or non-support for the inclusion of the variables in the models. Conversely, the project team may find in the field causal factors that might have been included in the models but were not.

\subsubsection{Evaluation Approach: Large Multifamily Buildings}

The complexities of large multifamily units require a different evaluation approach. This project will work with two organizations in the New York City region that routinely perform large multifamily building audits: Community Environmental Center (CEC) and the Association for Energy Affordability, Inc. (AEA). Each organization will identify five large multifamily buildings and two "over-performing" buildings, based on their audit results and post-weatherization energy-savings analyses, to be included in this study. The study will also include five multifamily and two over-performing buildings in the greater Chicago-Milwaukee region. 
Each of the twenty-one buildings in the study will be treated as a case study. The project team will interview building owners and managers about the weatherization process and the operation of newly installed measures (including boilers and energy-management systems). The project team will collect information to ascertain whether the occupancy of the building changed from pre-weatherization to postweatherization. Each building will be inspected to determine the quality of the weatherization measures' installation and will compare what was actually done in each building to the audit recommendations.

The case studies will aim to answer the following questions:

- How effective is the whole-building approach?

- What effect does poor implementation of installed measures have on the whole-building approach?

- How well is energy monitoring being implemented, and what effect does it have on the whole-building approach?

- Do any buildings utilize off-site energy management tools, and if so, how effective are they?

- How and to what level are building staff trained to use newly installed measures, and how effective is this training?

- Is building age a factor in performance?

- Are occupants correctly utilizing the newly installed measures?

- Are occupants educated in how to use the measures correctly?

\subsection{TERRITORIES}

\subsubsection{Introduction}

In March 2009, a Final Rule was published in the Federal Register amending DOE's definition of "state" to include the Commonwealth of Puerto Rico, Guam, the US Virgin Islands, the Commonwealth of the Northern Marianas Islands, and American Samoa. The new definition is consistent with modifications made to Section 411(c) of the Energy Independence and Security Act (EISA) of 2007. The final rule extended all federal regulations and guidances of the Weatherization Assistance Program (WAP) to these US territories under both regular and ARRA program years.

The proposed evaluation approach discussed in this document allows for a comparative analysis of the results achieved in the tropical and semi-tropical climates typical of the U.S. territories and the results from other US climate zones.

Table 4.1 shows the current WAP funding allocation for each US territory during the ARRA program years, along with the number of projected housing units to be weatherized, assuming a maximum cost allocation of $\$ 6500$ as per WAP-ARRA guidance. Although households in hot-weather climates typically use much less energy than the average US household, residents of island states can pay up to double in electricity per $\mathrm{kWh}$, resulting in a near comparable home energy cost burden.

Hot-climate weatherization projects tend to focus on base-load electric measures from household appliances and efficient cooling systems, both of which tend to be less costly than heating system replacements or installations. For example, approximately $24 \%$ of home energy use in Puerto Rico is attributed to air conditioning; heating system expenditures are not allowable in some territories' WAP program plans (www.energystar.gov, 2009). As a result, the per-unit cost of retrofits in the tropical and sub-tropical marine climate zones of these US territories could be lower than in the rest of the United States, allowing an increased number of local housing units to be weatherized. However, it is also possible that a greater number of housing units in the territories will be fitted with renewable energy technologies due to the ample availability of renewable energy in the forms of solar, wind, and 
geothermal resources. Currently, two of the five US territories have placed solar hot-water heaters on their priority lists for weatherization (Table 4.1). The use of this technology could increase the cost per unit, creating the potential for those dwellings to reach the maximum allowable cost and resulting in the final number of homes weatherized being similar to initial projections.

\subsubsection{Evaluation Methods}

The evaluation methods for this study are designed to determine average energy and cost savings associated with weatherization and calculate program efficiency. Variations in technology priorities and the use of weatherization measures that are appropriate for these tropical and sub-tropical territories in light of possible increases in the frequency of extreme weather events due to climate change will also be assessed.

Prior to the implementation of evaluation tasks, members of the evaluation team will complete an on-site field visit to Puerto Rico. Puerto Rico was singled out for this because it is by far the most populous territory and its funding allocation under ARRA is more than 10 times that of all the other U.S. territories combined. This site visit is expected to allow evaluators the opportunity to accomplish the following goals:

- Introduce the evaluation team

- Observe the Program in process

- Collaborate with weatherization network members regarding selected aspects of the evaluation approach, methods and tasks

- Disseminate information regarding the proposed evaluation tasks impacting network members.

- Report anticipated burden of the evaluation on network members

- Allow network members the opportunity to ask questions in person regarding the evaluation process

- Complete a preliminary assessment of cultural factors which may enhance or challenge the evaluation process

- Complete a preliminary assessment of variations in priorities regarding weatherization technologies and measures for tropical marine climates.

All territories will receive the All State Program Information Survey (S1) for the WAP process evaluation and program characterization at the same time as other U.S. states participating in the National evaluation. The evaluation will collect additional information from representatives of both the Pacific and Caribbean island territories at various stages in PY 2010, 2011 and 2012 (Table 4.1). Guam has been selected to represent the Pacific islands and Puerto Rico has been selected to represent the Caribbean islands. Both are located in tropical climate zones. It is presumed that the geographic and cultural differences between the two regions may present varying logistical issues and possible variations in energy efficiency practices and results so both regions will be studied with equal amounts of rigor regarding energy and cost savings.

For both Puerto Rico and Guam, a sample of housing units will be selected for home energy savings analysis. For those households, monthly billing data will be collected and analyzed for the purpose of calculating energy and cost savings. As shown in Table 4.1, the Subset of Agencies Detailed Program Information Survey (S3), Housing Unit Information Surveys (DF2), and Building Information Surveys for Multifamily housing (DF3) (if applicable) will also be administered in those two territories. 


\subsubsection{Puerto Rico Case Study}

A case study will be conducted for Puerto Rico only. Puerto Rico was selected for this based on the level of awarded funding, number of homes projected for weatherization services, eligible population size, and geographic location. In addition to the energy savings analysis, the S4: Occupant Survey will be administered to 258 occupants. The Case Study aims to answer the following questions:

- What are the measures taken by Puerto Rico and their one sub-grantee to manage over $\$ 65 \mathrm{M}$ in ARRA funding for the WAP?

- What challenges are the client, sub-grantee, grantee, and DOE project officer facing with the new eligibility and ARRA ramp up?

- What are the overall strengths and deficits of the Puerto Rico WAP?

- How well does the Puerto Rico State Plan for WAP under ARRA harmonize with the practical application of services and with expectations from DOE?

- What is the demand for services?

- How efficient and client friendly are the application and implementation processes from the agency and client perspectives?

- What is the inspection protocol for homes weatherized and does it assure quality

- What unique or innovative measures or technologies are installed addressing marine climate characteristics and how are these measures/technologies influenced and accepted by the client population?

- What client education techniques are being employed to ensure long-term impact on energy efficiency?

- Is the weatherization network taking advantage of available renewable or sustainable resources inherent to island characteristics?

- Are measures taken to create a cultural norm around home energy efficiency?

- What measures are being implemented to address the expected post-ARRA decrease in funding and resources?

- Does installation of solar water heaters in weatherized homes influence others in the household's social network or other moderate and high income families not eligible for the WAP services to invest in solar water heaters or other renewable resource technologies, especially those eligible for a federal tax credit or other economic incentives? 
*S1, S3, DF2, DF3, and DF4 are surveys and data forms contained in the appendices.

\begin{tabular}{|c|c|c|c|}
\hline \multicolumn{4}{|c|}{$\begin{array}{l}\text { Table 4.1. WAP funding allocations, key measures, and evaluation methods for U.S. } \\
\text { territories under ARRA }\end{array}$} \\
\hline $\begin{array}{l}\text { US } \\
\text { Territory }\end{array}$ & $\begin{array}{l}\text { Funding } \\
\text { Allocation } \\
\text { under } \\
\text { ARRA }\end{array}$ & $\begin{array}{l}\text { Primary } \\
\text { installations/measures }\end{array}$ & $\begin{array}{l}\text { Evaluation Methods and } \\
\text { Time Frames for Task } \\
\text { Completion }\end{array}$ \\
\hline $\begin{array}{l}\text { American } \\
\text { Samoa }\end{array}$ & $\$ 896,449$ & $\begin{array}{l}\text { CFLs, solar water heaters, } \\
\text { refrigerator replacement, } \\
\text { window air conditioners, and } \\
\text { low-flow faucets and } \\
\text { showerheads }\end{array}$ & $\begin{array}{l}\text { - Preliminary review of State Plan } \\
\text { (Fall 2010) } \\
\text { - Survey: S1 (Spring 2011)* }\end{array}$ \\
\hline Puerto Rico & $\$ 65,262,581$ & $\begin{array}{l}\text { Reflective films, air leakage } \\
\text { in air conditioned areas, solar } \\
\text { hot water heaters, Energy } \\
\text { Star water heaters and air } \\
\text { conditioners, refrigerator } \\
\text { replacement, CFLs, shower } \\
\text { head replacements, smart } \\
\text { power strips, and mitigation } \\
\text { of energy related health and } \\
\text { safety concerns }\end{array}$ & $\begin{array}{l}\text { - Preliminary review of State Plan } \\
\text { (Fall 2010) } \\
\text { - Surveys: } \\
\text { S1, S2, S3, DF2, DF3, DF4 (if } \\
\text { applicable) (Spring 2011) } \\
\text { - Billing Data Collection } \\
\text { (Summer 2011, 2012, and 2013) } \\
\text { - } 1 \text { Week of QA Inspections } \\
\text { (PY 2011) } \\
\text { - Case Study (Spring/Summer 2011) }\end{array}$ \\
\hline $\begin{array}{l}\text { Northern } \\
\text { Mariana } \\
\text { Islands }\end{array}$ & $\$ 997,686$ & $\begin{array}{l}\text { Baseload efficiency } \\
\text { appliances, and cooling } \\
\text { systems. (Details will need to } \\
\text { be requested) }\end{array}$ & $\begin{array}{l}\text { - Preliminary review of State Plan } \\
\text { (Fall 2010) } \\
\text { - Survey: S1 (Spring 2011) }\end{array}$ \\
\hline Guam & $\$ 1,431,132$ & $\begin{array}{l}\text { Weather-stripping and } \\
\text { sealing of air leaks, CFLs, } \\
\text { replacement of refrigerators } \\
\text { and air conditioners with } \\
\text { energy efficient appliances, } \\
\text { shower head and faucet } \\
\text { aerator replacement, } \\
\text { installation of smoke and } \\
\text { carbon monoxide detectors }\end{array}$ & $\begin{array}{l}\text { - Preliminary review of State Plan } \\
\text { (Fall 2010) } \\
\text { - Surveys: } \\
\text { S1, S2, S3, DF2, DF3, DF4 (if } \\
\text { applicable) (Spring 2011) } \\
\text { - Billing Data Collection } \\
\quad \text { (Summer 2011, 2012, and 2013) } \\
\text { - } 1 \text { Week of QA Inspections } \\
\text { (PY 2011) }\end{array}$ \\
\hline $\begin{array}{l}\text { US Virgin } \\
\text { Islands }\end{array}$ & $\$ 1,827,182$ & $\begin{array}{l}\text { CFLs, refrigerator } \\
\text { replacement, timers on water } \\
\text { heaters, low-flow } \\
\text { showerheads and aerators }\end{array}$ & $\begin{array}{l}\text { - Preliminary review of State Plan } \\
\text { (Fall 2010) } \\
\text { - Survey: S1 (Spring 2011) }\end{array}$ \\
\hline
\end{tabular}




\subsection{WEATHERIZATION INNOVATION PILOT PROGRAM}

\subsubsection{Introduction}

This piece addresses the evaluation of OWIP's Weatherization Innovation Pilot Program (WIPP). Recently, OWIP announced awards to sixteen grantees of approximately $\$ 30 \mathrm{M}$, with another $\$ 90 \mathrm{M}$ of leveraged funding pledged by grantee partners. Table 4.2 summarizes the sixteen projects and funding levels.

Most of the sixteen projects contain multiple activities. Each separate activity could be the focus of specific evaluation activities. The next section identifies nine important project activities that are contained in the sixteen projects, proposes meta-evaluation questions (i.e., questions framed within the broader policy context), lists specific evaluation questions to be explored via a comprehensive evaluation, and the provides the evaluation activities that would be conducted to answer the evaluation questions. The following section summarizes the evaluation activities across the ten project activities. 
Table 4.2. WIPP Funded Projects

\begin{tabular}{|c|c|c|c|c|c|c|}
\hline & Organization & State & $\begin{array}{l}\text { Type (Non-Profit, } \\
\text { State, Private, } \\
\text { Utility, etc) }\end{array}$ & Program Structure & $\begin{array}{l}\text { DOE Funds } \\
\text { Requested }\end{array}$ & $\begin{array}{l}\text { Leveraged } \\
\text { Funds }\end{array}$ \\
\hline \multirow{7}{*}{ 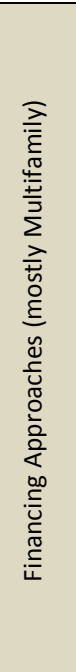 } & $\begin{array}{l}\text { DEPARTMENT OF } \\
\text { COMMERCE (Washington } \\
\text { State) }\end{array}$ & WA & $\begin{array}{l}\text { State / WAP } \\
\text { Agency }\end{array}$ & $\begin{array}{l}\text { Multifamily owner loans through } \\
\text { CDFI's }\end{array}$ & $\$ 3,000,000$ & $\$ 9,386,008$ \\
\hline & $\begin{array}{l}\text { LEAP: Local Energy Alliance } \\
\text { Program }\end{array}$ & $\mathrm{VA}(1)$ & Non-Profit & Multifamily ESCO approach & $\$ 1,898,938$ & $\$ 5,950,000$ \\
\hline & $\begin{array}{l}\text { UTAH DEPARTMENT OF } \\
\text { COMMUNITY AND } \\
\text { ECONOMIC DEVELOPMENT }\end{array}$ & UT & $\begin{array}{l}\text { State / WAP } \\
\text { Agency }\end{array}$ & $\begin{array}{l}\text { Revolving Loan Fund and } \\
\text { Performance Contracting to home } \\
\text { owners }\end{array}$ & $\$ 850,000$ & $\$ 2,550,000$ \\
\hline & $\begin{array}{l}\text { COMMUNITY } \\
\text { ENVIRONMENTAL CENTER } \\
\text { INC }\end{array}$ & NY & $\begin{array}{l}\text { Non-Profit, WAP } \\
\text { Subgrantee }\end{array}$ & $\begin{array}{l}\text { Low-rise multifamily approach with } \\
\text { on-bill financing }\end{array}$ & $\$ 3,000,000$ & $\$ 9,000,000$ \\
\hline & $\begin{array}{l}\text { STEWARDS OF AFFORDABLE } \\
\text { HOUSING }\end{array}$ & DC & Non-Profit & Multifamily ESCO approach & $\$ 2,590,523$ & $\$ 8,750,000$ \\
\hline & ENERGY PIONEER SOLUTIONS & NE & Private Company & $\begin{array}{l}\text { Private company offering } 50 \% \text { loans } \\
\text { to customers, with on-bill } \\
\text { repayment }\end{array}$ & $\$ 812,418$ & $\$ 2,959,150$ \\
\hline & DANVILLE, CITY OF & $\mathrm{VA}(2)$ & City & $\begin{array}{l}\text { City-wide collaboration with housing } \\
\text { agencies for rental multifamily; } \\
\text { smart meters; PACE or RLF }\end{array}$ & $\$ 1,015,746$ & $\$ 1,290,000$ \\
\hline \multirow{2}{*}{ 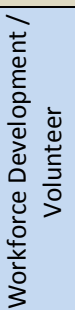 } & YouthBuild USA, Inc. & $\begin{array}{l}\text { CT, NY, } \\
M N, M D \\
\text { WV, VA }\end{array}$ & Non-Profit & $\begin{array}{l}\text { Geographically diverse pilots for } \\
\text { workforce development and } \\
\text { volunteer models }\end{array}$ & $\$ 1,374,020$ & $\$ 4,020,593$ \\
\hline & $\begin{array}{l}\text { HABITAT FOR HUMANITY } \\
\text { INTERNATIONAL (HFHI) }\end{array}$ & $\begin{array}{c}\text { AL, CA, DC, } \\
\text { FL, IA, IL, } \\
\text { ME, MI, } \\
\text { MN, MS, } \\
\text { NC, PA, TN, } \\
\text { TX }\end{array}$ & Non-Profit & $\begin{array}{l}\text { Geographically diverse pilots for } \\
\text { workforce development and } \\
\text { volunteer models }\end{array}$ & $\$ 3,000,000$ & $\$ 9,010,000$ \\
\hline \multirow{3}{*}{ 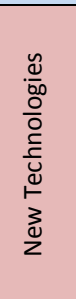 } & EFFICIENCY VERMONT & VT & Non-Profit & $\begin{array}{l}\text { In-home metering and behavioral } \\
\text { interventions }\end{array}$ & $\$ 719,380$ & $\$ 1,200,000$ \\
\hline & $\begin{array}{l}\text { Commission on Economic } \\
\text { Opportunity }\end{array}$ & PA & $\begin{array}{l}\text { Non-Profit, WAP } \\
\text { Subgrantee }\end{array}$ & In-home metering & $\$ 2,449,607$ & $\$ 9,291,200$ \\
\hline & $\begin{array}{l}\text { UNIVERSITY OF NORTH } \\
\text { CAROLINA CHARLOTTE }\end{array}$ & NC & $\begin{array}{l}\text { College / } \\
\text { University }\end{array}$ & $\begin{array}{l}\text { Non-traditional provider with new } \\
\text { technologies: ductless heat pump, } \\
\text { whole house fan, in-home meter } \\
\text { (Google/TED) }\end{array}$ & $\$ 2,005,945$ & $\$ 6,214,400$ \\
\hline \multirow{2}{*}{ 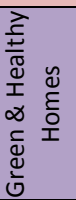 } & $\begin{array}{l}\text { The United Illuminating } \\
\text { Company }\end{array}$ & $\mathrm{CT}$ & Private, Utility & $\begin{array}{l}\text { Green and Healthy Homes Initiative } \\
\text { led by Private utility }\end{array}$ & $\$ 3,000,000$ & $\$ 11,047,475$ \\
\hline & $\begin{array}{l}\text { Coalition to End Childhood } \\
\text { Lead Poisoning }\end{array}$ & MD & Non-Profit & $\begin{array}{l}\text { Green and Healthy Homes } \\
\text { Inititiative, led by non-traditional } \\
\text { provider }\end{array}$ & $\$ 1,287,598$ & $\$ 3,862,793$ \\
\hline \multirow{2}{*}{$\frac{\grave{d}}{\frac{1}{ \pm}}$} & P W C & $\mathrm{OH}$ & $\begin{array}{l}\text { Non-Profit, WAP } \\
\text { Subgrantee }\end{array}$ & $\begin{array}{l}\text { Standard weatherization with } \\
\text { volunteer element and freezers, } \\
\text { solar PV technologies. }\end{array}$ & $\$ 1,500,000$ & $\$ 4,529,536$ \\
\hline & $\begin{array}{l}\text { New Hampshire Community } \\
\text { Loan Fund, Inc. }\end{array}$ & $\mathrm{NH}$ & $\begin{array}{l}\text { State / WAP } \\
\text { Agency }\end{array}$ & $\begin{array}{l}\text { Manufactured/mobile housing } \\
\text { approach in targeted communities, } \\
\text { leverage RGGI grant }\end{array}$ & $\$ 600,000$ & $\$ 2,500,000$ \\
\hline & & & & & $\$ 29,104,175$ & $\$ 91,561,155$ \\
\hline
\end{tabular}




\subsubsection{WIPP Programmatic Questions - For all grantees/approaches}

Meta-Policy Questions

1. Evidence to answer public policy question: should we be using DOE dollars for multifamily buildings? Discuss effectiveness of single-family vs multifamily innovative approaches.

\section{Statement of Project Objectives (SOPO) Questions}

1. How does the project compare to formula WAP program in terms of: job quality, monitoring and quality assurance, cost effectiveness, energy savings per unit, low-income household benefits and non-energy benefits?

2. Did the leveraged resources perform as proposed?

3. What are the primary lessons learned in terms of project scalability and replicability?

\subsubsection{WIPP Project Activities and Evaluation Questions and Approaches}

\section{Questions Associated with Finance Projects (Danville [VA2], UT, WA)}

\section{Loans and Loan Funds}

Meta-Policy Questions - What is the current use of revolving loan funds for non-low income residential energy efficiency programs? How much money is out there in private sector financial markets that could be diverted to revolving weatherization loan funds? What is preventing money from flowing into revolving low-income weatherization loan funds? How much DOE money is needed to seed lowincome weatherization loan funds?

\section{Detailed Evaluation Questions -}

a) What is an optimal size for a revolving loan fund?

b) How many weatherization jobs annually can be supported by what size of loan fund?

c) Do loan funds shrink or grow over time?

d) What happens when a loan recipient defaults?

e) How is loan worthiness judged?

f) How is the amount of the loan judged?

g) How are loan terms determined?

h) Do loan recipients fully understand the terms of the loans?

i) How much extra financial burden is placed on landlords because of the loan payments?

j) What are the benefits to renters in properties where the landlord has taken out a loan to pay for weatherization measures, and how certain are those benefits?

k) How are landlords involved and what are the benefits and risks (if any) to them?

1) What are the options when the client moves, is unable or unwilling to pay bills, or household size changes?

m) Should the funds be only focused on the multi-family sector or also include the single-family sector?

n) What is the average loan amount and repayment schedule?

o) What marketing approaches work best to attract clients to the loan program?

Evaluation Approaches - Conduct literature review of current status of use of revolving loan funds in the residential energy efficiency arena. Conduct case study process evaluation that includes interviews with key participants, examination of primary documents, and associated analyses. Survey loan program participants to ascertain their viewpoints on the program. Conduct detailed economic analyses of program operations to assess soundness of financial decisions. This will include billing analysis to ascertain energy savings and bill reduction in order to determine benefits and cash flows for all participants. 


\section{Carbon Offsets and RECS (LEAP [VA1], WA, CEO, PA)}

Meta-Policy Questions - What investments are voluntary carbon markets currently making in non-low income energy efficiency projects? How much money is out there in the carbon offset markets that could be diverted to low-income weatherization investments? What is preventing money flowing from the carbon offset world into low-income weatherization? What investments must DOE make to catalyze this leveraging potential?

\section{Detailed Evaluation Questions}

a. How much money was attracted from the carbon markets for the project(s)?

b. What were the constraints and barriers to getting this money?

c. Who ultimately received the money from the carbon markets?

d. Who owns the carbon offsets?

Evaluation Approaches - Conduct literature review of current status of carbon offset market investments in energy efficiency projects. Conduct case-study process evaluation that includes interviews with key participants, examination of primary documents, and associated analyses. Conduct detailed economic analyses of program operations to assess financial feasibility and sustainability.

\section{ESCOs (SAFH [DC], LEAP [VA1])}

Meta-Policy Questions - What is the current involvement of ESCOs in the non-low income residential marketplace? How much money is out there in the ESCO world that could be diverted to lowincome weatherization? What has been preventing this money from flowing into (multifamily) low income weatherization? What investments are needed from DOE to get ESCOs to enter this market?

Detailed Evaluation Questions -

a) How successful was the project in engaging ESCOs? What were the primary constraints and barriers?

b) What appear to be the financial thresholds that must be crossed in order to get ESCOs engaged?

c) What are the main barriers to ESCO engagement in (multi-family) low-income weatherization?

d) How do building owners view working with ESCOs? How do ESCOs view working with lowincome building owners?

e) What are the most effective financial approaches to incentivize multi-family owners to invest in building retrofits?

f) What are the primary HUD barriers to engaging in multifamily retrofit work?

g) How are energy performance contracts best structured?

Evaluation Approaches - Conduct literature review of current status of ESCO involvement in the residential sector. Conduct case study process evaluation that includes interviews with key participants, examination of primary documents, and associated analyses. Survey ESCO program participants to ascertain their viewpoints on the program. Conduct detailed economic analyses of program operations to assess financial soundness and sustainability. This will include billing analysis to ascertain energy savings and bill reduction in order to determine benefits and cash flows for all participants.

\section{Utility Bill Repayments (EPS [NE])}

Meta-Policy Questions - What is the current status of utility bill re-payment programs outside of the low-income residential sector? How much money is out there in the utility world that could be diverted to weatherization/utility bill re-payment programs for low-income households? What is 
preventing the spread of these programs? How much money might DOE need to invest to increase the number of these programs?

\section{Detailed Evaluation Questions -}

a) How are weatherization investment levels in homes optimally set?

b) How are monthly re-payment schedules optimally set for the client base?

c) How is client eligibility best determined to assure program sustainability?

d) How much does the program add to utility bills on average?

e) What happens when the client moves or is unable to pay bills?

f) How does the program adapt in the case of sharp utility prices changes during the re-payment period?

g) How does the program adapt in the case of fluctuating weather patterns year to year?

h) Do clients express clear understanding of the program?

i) What are the primary costs, benefits, and risks for clients?

j) What are the primary motivations for utility company involvement, and what are their primary concerns?

Evaluation Approaches - Conduct literature review of current status of non-low-income utility bill re-payment programs. Conduct case study process evaluation that includes interviews with key participants, examination of primary documents, and associated analyses. Survey utility bill re-payment program participants to ascertain their viewpoints on the program. Conduct detailed economic analyses of program operations to assess financial soundness and sustainability. This will include billing analysis to ascertain energy savings and bill reduction in order to determine benefits and cash flows for all participants.

Questions Associated with Alternative Weatherization Workforce and Workforce Building Projects (Habitat [national], YouthBuild [national], UNC ([NC])

Meta-Policy Questions - What are the costs and benefits of conducting weatherization work with non-professionals? What is the national capacity of the alternative weatherization workforce? What resources might DOE provide to train this workforce? Is the program replicable within other affiliates of the non-profit (i.e. can it become a new line of business)? Is the program replicable to other organizations, or is success specific to the nature of the implementing organization (i.e. Youthbuild, Habitat)? If so, does it require further DOE investment? Can DOE establish a standard that outside organizations, without DOE funds, would weatherize to and assure quality? 
Detailed Evaluation Questions

a) What are best practices among the $\mathrm{XX}$ affiliates in terms of training and providing weatherization services?

b) What are the experiences of the youth and/or volunteers?

c) Does client satisfaction vary between $\mathrm{XX}$ and WAP clients?

d) Are there specific workforce issues with respect to XX-selected workers, and how are they best addressed?

e) What is the success rate of placing Habitat graduates into weatherization and home retrofit jobs?

Evaluation Approaches - Conduct case study process evaluation that includes interviews with key participants, examination of primary documents, and associated analyses. Collect billing histories for homes weatherized by non-professionals and compare energy savings to a control group of homes weatherized during the ARRA period and pre-ARRA. Inspect a sample of homes. Administer portions of the Weatherization Staff survey and attempt to track non-professional weatherization workers. Implement customer satisfaction portion of Occupant Survey. Have agencies provide detailed information about measures installed in each weatherized home.

\section{Questions Associated with In-Home Metering Projects [CEO (PA), VEIC [VT], UNC [NC])}

Meta-Policy Questions - How much energy is saved beyond the installation of weatherization measures in homes that have in-home energy meters/monitors? Should this measure be on Appendix A? If so, at what standard, and with what provisions? If not, why not? Do low-income clients see benefits equal to, greater, or less than other studies have shown for pilots/programs in the U.S.?

Detailed Evaluation Questions -

a) What types of meters were installed, and where?

b) Do any homes refuse to have meters installed and if so, why?

c) What are the most common client misunderstandings about the meters and the information being conveyed by them?

d) Are homes with meters installed different in some way from the larger population of weatherized homes?

e) Were there any technical issues associated with meter installation?

f) How do energy savings vary by a) presence of a simple and end-use in-home energy displays b) intervention strategy to groups of clients, c) type of meter, d) placement of meter within the home.

\section{VEIC/CEO specific questions:}

a) General questions

b) Meter questions

a. Did the leveraged resources perform as proposed?

a. What types of meters were installed, and where?

b. Do any homes refuse to have meters installed and if so, why?

c. Were there any technical or customer issues associated with meter installation?

d. Are homes with meters installed different in some way from the larger population of weatherized homes?

e. How do energy savings vary by: (a) presence of simple and end-use, in-home energy displays? (b) intervention strategy to groups of clients? (c) type of meter?

f. Given the project's mix of low-income rural, suburban, and urban settings, and this project's implementation by different types of utilities, what-given 
any lessons learned - are the limits and the potential for project scalability and replicability?

\section{UNC-specific questions:}

1. New technology project questions:

a. What are the costs and energy savings associated with ductless heat pumps and whole house fans?

b. What types of meters were installed, and where?

c. Do any homes refuse to have meters installed and if so, why?

d. What are the most common client misunderstandings about the meters and the information being conveyed by them?

e. Are homes with meters installed different in some way from the larger population of weatherized homes?

f. Were there any technical issues associated with meter installation?

g. How do energy savings vary by a) presence of a simple and end-use in-home energy displays b) intervention strategy to groups of clients, c) type of meter, d) placement of meter within the home.

Evaluation Approaches - Collect billing histories for homes weatherized with meters and compare energy savings to a control group of weatherized homes. Inspect a sample of meter installations. Implement energy knowledge/behavior and meter portions of Occupant Survey. Have agencies provide detailed information about measures installed in each weatherized home.

\section{Questions Associated with Client Outreach, Education and Follow-up Projects (CEC [NY], NHCLF (NH), LEAP (VA1), PWC (OH), CEO (PA)]}

Meta-Policy Questions - How much more energy is saved beyond the installation of weatherization measures in homes that have had extensive client education? Should DOE mandate client education and additional contact with clients for a lengthy period of time post-weatherization? What type of client education works, and how can DOE ensure that a further rollout would continue to work? How do projects incentivize and empower building owners to engage in client education?

Detailed Evaluation Questions -

a) What client education methods were used?

b) How does the client outreach and education strategy affect energy savings?

c) How do demographic characteristics affect energy savings (with breakdown by outreach strategy, as appropriate)?

\section{CEC further revised their plan as follows:}

a) Community-based Outreach:

a. What aspects of outreach can be streamlined through community-based outreach?

b. Are there measurable benefits to the use of peer-led enrollment strategies?

c. What particular outreach methods are most effective in low-income communities?

d. Can program outreach efforts be effectively combined with environmental awareness campaigns

e. How should strategies differ between rental properties and resident-owned properties? 


\section{NHCLF further revised their plan as follows:}

a) Client education questions

a. Are there characteristics of Resident-Owned Communities of manufactured homes that make them particularly fruitful places for public investments in weatherization? We will focus on the importance of two characteristics:

i. shared ownership and community networks as a tool to mobilize homeowners to apply

ii. relative density of eligible homes of similar construction as a means to achieve economies of scale in the application process and in the actual weatherization work.

The key measure of success will be energy saved per dollar of public subsidy: a function of efficiency in the sign-up phase, economies of scale in the weatherization work, and improvements in building performance per dollar invested in each home.

a. Can neighborhood-based recruitment efforts increase the number of eligible residents seeking LIHEAP and weatherization services? If so, by what percentage?

b. If a resident-owned community is organized and its residents well informed about the weatherization program, will CAP agencies respond to invitations to receive applications in those communities (possibly even within the eligible homes) and will that level of service increase participation and cost-effectiveness?

c. What are the economies of scale in working on four or more homes sequentially in a single neighborhood? Labor, transportation, materials? Are the manufactured homes themselves sufficiently similar to permit savings in bulk purchase of materials?

d. Does the neighborhood structure of most ROCs help make weatherization a community norm? NHCLF assumes that recruitment efforts will induce many-but not all-eligible homeowners to apply for weatherization. NHCLF also assumes that the resulting weatherization projects will be highly visible and benefits widely discussed within the community. We will try to determine if the first wave of weatherization generates a second wave of applications for weatherization services or private investments by homeowners who don't qualify for the federal program.

Evaluation Approaches - Conduct case study process evaluation that includes interviews with key participants, examination of primary documents, and associated analyses. Collect billing histories for homes weatherized by programs administering additional client education and re-contacts and compare energy savings to a control group of weatherized homes. Observe a sample of client education situations. Implement energy knowledge and consuming behavior portions of Occupant Survey. Have agencies provide detailed information about measures installed in each weatherized home.

\section{Questions Associated with Consolidated, Coordinated, One-Stop Whole-House Projects [United Illuminated (CT), Coalition to End Childhood Lead Poisoning (MD), PWC (OH), WA]}

This category of activities pertains to projects whose representatives are able to offer multiple public program services to households during one point-of-contact. Within this category are two distinct types of projects. The projects being conducted by The United Illuminating Company and the Coalition to End Childhood Lead Poisoning are primarily concerned with one-stop shopping of programs that address 
healthy homes. The PWC and Washington State projects act primarily to bring multiple funding sources together to facilitate weatherization.

Meta-Policy Questions - Is it possible for local organizations to consolidate disparate federal and state programs into a coordinated program from the clients 'point-of-view'? What are the benefits to the clients? What are the benefits to DOE and WAP?

\section{Detailed Evaluation Questions}

a) Did the comprehensive approach to weatherization (and healthy homes) work? What worked and what did not work?

b) Does program consolidation lead to better outcomes in terms of client health and other nonenergy benefits?

c) Are clients satisfied with the One-Stop program?

Evaluation Approaches - Conduct case study process evaluation that includes interviews with key participants, examination of primary documents, and associated analyses. Collect billing histories for homes weatherized by One-Stop programs and compare energy savings to a control group of weatherized homes. Observe One-Stop program delivery. Implement customer satisfaction and health portions of Occupant Survey. Have agencies provide detailed information about measures installed in each weatherized home.

\section{Other (CEC [NY], UT)}

\section{CEC added the following questions to their evaluation plan:}

a) Alternate cost-effectiveness rationale:

a. How can meaningful measures of societal and community benefits be included in cost-effectiveness determination?

b. How do building owners feel about pursuing non-direct weatherization benefits?

c. Are local residents/organizations willing to support strategies that benefit entire communities?

d. What is the benefit to overall WAP-delivery of using these rationales?

e. How can the 'return on investment' needs of owners be balanced with societal benefits in WAP work scope determination?

f. What renewable generation strategies become feasible with alternate costeffectiveness determination?

g. What societal and building-owner benefits do renewable energy generation strategies deliver?

b) Post-construction monitoring and technical support:

a. How does the actual performance of energy efficiency measures compare to preconstruction projections?

b. What are common causes of unmet savings potential?

c. What level of post-construction investment is necessary to remedy problematic retrofits?

d. Do building operators of multifamily buildings or homeowners have the requisite skills to maintain modern building systems?

e. What energy monitoring and management systems are most effective in supporting post-retrofit support?

f. How do client and tenant education strategies affect energy savings? 
Utah added the following questions to their evaluation plan:

f. What are best practices regarding performance-based contracting?

g. What issues interfere with achieving expected levels of post-retrofit energy savings?

\subsubsection{Evaluation Plans}

Table 4.3 maps the eight types of evaluation methods listed in the evaluation approaches presented above to the nine types of activities that the WIPP grants are supporting, as organized above. The second column in the table indicates which states/projects fall into the ten types of activity categories. This evaluation plan can be considered a comprehensive approach to evaluating the most important aspects of WIPP. It will incorporate four literature reviews, eight case studies and four detailed economic analyses. Billing histories will be collected for a sample of homes weatherized associated with all activity areas (for approximately 4000 units), as would the associated data from the grantees about measures installed in the homes. Approximately 1000 of those receiving benefits from WIPP activities will be surveyed. Approximately 225 members of the alternative workforce will also be surveyed. A sample of approximately 50 homes of weatherized by the alternative workforce will be inspected for quality assurance purposes.

Table 4.3 Evaluation Methods Applied to Categories of WIPP Activities

\begin{tabular}{|c|c|c|c|c|c|c|c|c|c|}
\hline & & $\begin{array}{c}\text { Lit. } \\
\text { Review }\end{array}$ & $\begin{array}{l}\text { Case } \\
\text { Study }\end{array}$ & $\begin{array}{l}\text { Econ } \\
\text { Anal. }\end{array}$ & $\begin{array}{l}\text { Home } \\
\text { Inspect }\end{array}$ & $\begin{array}{l}\text { Occupant } \\
\text { Survey }\end{array}$ & $\begin{array}{c}\text { Wx } \\
\text { Staff } \\
\text { Survey }\end{array}$ & $\begin{array}{l}\text { Bills } \\
\text { Anal. }\end{array}$ & $\begin{array}{l}\text { Grantee } \\
\text { Surveys }\end{array}$ \\
\hline Loan Funds & WA, UT, VA2* & $\bullet$ & $\bullet$ & $\bullet$ & & $\bullet$ & & $\bullet$ & $\bullet$ \\
\hline Carbon Offsets & $\mathrm{WA}, \mathrm{PA}, \mathrm{VA} 1 * *$ & $\bullet$ & $\bullet$ & $\bullet$ & & & & $\bullet$ & $\bullet$ \\
\hline ESCOs & $\mathrm{VA} 1 * *, \mathrm{DC}$ & $\bullet$ & $\bullet$ & $\bullet$ & & $\bullet$ & & $\bullet$ & $\bullet$ \\
\hline Utility Bills & $\mathrm{NE}$ & $\bullet$ & $\bullet$ & $\bullet$ & & $\bullet$ & & $\bullet$ & $\bullet$ \\
\hline Alt. Workforce & $\mathrm{YB}^{* * *}, \mathrm{HFHI}, \mathrm{NC}$ & & $\bullet$ & & $\bullet$ & & $\bullet$ & $\bullet$ & $\bullet$ \\
\hline In-home Meters & VT, PA, NC & & & & & $\bullet$ & & $\bullet$ & $\bullet$ \\
\hline Client Ed & $\begin{array}{l}\text { NY, NH, VA1**, } \\
\text { OH, PA }\end{array}$ & & $\bullet$ & & & $\bullet$ & & $\S$ & $\S$ \\
\hline One-Stop Shop & $\mathrm{CT}, \mathrm{MD}, \mathrm{OH}, \mathrm{WA}$ & & $\bullet$ & & & $\bullet$ & & $\bullet$ & $\bullet$ \\
\hline
\end{tabular}

* City of Danville, ** Local Energy Alliance Program, *** YouthBuild

$\S$ Bills and other data will be collected as part of the in-home meters project analyses.

Table 4.4 outlines the schedule for the evaluation activities. The first evaluation activity to be undertaken will be the four literature reviews, which will be conducted during the $2^{\text {nd }}$ quarter of 2011 . Case studies will be initiated during the third quarter and will be completed early in the fourth quarter of 2011. Initial economic assessments that will focus on financial decision rules will also be conducted during this time period. Independent reports will be prepared to document the literature reviews, case studies, and initial economic assessments.

Units weatherized by the various projects through June 30, 2011 will be eligible for inclusion in the billing analysis study. This date was chosen to piggyback upon the larger WAP-ARRA period evaluation. Starting in July 2012, the larger project will ask utility companies nationwide for billing histories. Billing histories needed for the WIPP evaluation will be rolled into this much larger task and will yield tremendous cost efficiencies.

Given this timeframe, approximately 68 on-site inspections of homes weatherized by alternative workforces will be conducted during the third quarter 2011. Collection of detailed weatherization information from the grantees will also begin at this time and continue until all required information is 
collected or until data collection ends on September 30, 2012. Billing history analyses will be conducted as the various project-based and activity-based data sets are completed. The goal of this project is to complete the energy savings analyses during the fourth quarter of 2012.

Occupant surveys, 267, and weatherization worker surveys, 243 , will be conducted during the $2^{\text {nd }}$ quarter 2012. These surveys are delayed somewhat in order to give occupants some time to experience program results (especially those participating in financial programs) and alternative weatherization workforce members some time to possibly change their employment situations. A final report will be completed by the end of CY 2012.

Table 4.4 Schedule of Evaluation Activities

\begin{tabular}{|c|c|c|c|c|c|c|c|c|}
\hline & $\begin{array}{c}1^{\text {st }} \text { Quarter } \\
2011\end{array}$ & $\begin{array}{c}2^{\text {nd }} \text { Quarter } \\
2011\end{array}$ & $\begin{array}{c}3^{\text {rd }} \text { Quarter } \\
2011\end{array}$ & $\begin{array}{c}4^{\text {th }} \text { Quarter } \\
2011\end{array}$ & $\begin{array}{c}1^{\text {st }} \text { Quarter } \\
2012\end{array}$ & $\begin{array}{c}2^{\text {nd }} \text { Quarter } \\
2012\end{array}$ & $\begin{array}{c}3^{\text {rd }} \text { Quarter } \\
2012\end{array}$ & $\begin{array}{c}4^{\text {th }} \text { Quarter } \\
2012\end{array}$ \\
\hline Lit Reviews & & XXXX & & & & & & \\
\hline Case Studies & & & $\mathrm{XX}$ & $\mathrm{XX}$ & & & & \\
\hline $\begin{array}{l}\text { Economic } \\
\text { Analyses }\end{array}$ & & & $\mathrm{XX}$ & $\mathrm{XX}$ & & & XX & $\mathrm{XX}$ \\
\hline $\begin{array}{l}\text { Home } \\
\text { Inspections }\end{array}$ & & & XXXX & & & & & \\
\hline $\begin{array}{l}\text { Occupant } \\
\text { Surveys }\end{array}$ & & & & & & XXXX & & \\
\hline $\begin{array}{l}\text { Wx Staff } \\
\text { Surveys }\end{array}$ & & & & & & XXXX & & \\
\hline $\begin{array}{l}\text { Grantee } \\
\text { Surveys }\end{array}$ & & & & $\mathrm{XX}$ & $\mathrm{XX}$ & $\mathrm{XX}$ & $\mathrm{XX}$ & \\
\hline $\begin{array}{l}\text { Billing } \\
\text { Analyses }\end{array}$ & & & & $\mathrm{XX}$ & $\mathrm{XX}$ & $\mathrm{XX}$ & $\mathrm{XX}$ & \\
\hline Final Report & & & & & & & & XXXX \\
\hline
\end{tabular}

Finally, it should be noted that the timely administration of the surveys and the collection of the weatherization information and billing data are contingent upon OMB approval. ORNL plans to submit to OMB an Information Collection Request (ICR) for the entire WAP ARRA period evaluation in early 2011. This request will include the already approved data forms (DF2/3 that collect weatherization measure information; DF4A/B, which collects utility account information; DF5, which collects billing histories from utilities) needed by this project and two surveys that are currently under OMB review (S4 [Occupant Survey] and S5 [Weatherization Staff Survey]). ORNL will be primarily asking to increase burden numbers and for approval of any new methodologies.

\subsubsection{Technical Assistance}

ORNL will provide technical assistance to grantees on an as-needed basis. ORNL will assist grantees implement appropriate data collection procedures. ORNL will also assist grantees implement program administration procedures in cases where evaluation plans require random control trial designs. Projects that might be appropriate for RCT designs include those involving in-home metering and installation of non-standard measures (e.g., solar PV technologies). 


\subsection{SUSTAINABLE ENERGY RESOURCES FOR CONSUMERS}

This segment describes the evaluation approach designed to assess OWIP's Sustainable Energy Resources for Consumers (SERC) Grant authorized under the Energy Independence and Security Act of 2007 (EISA) Pub. L. 110-140, Section 411(b). In June 2010, OWIP requested funding proposals for projects focused on efficient, and renewable technologies, as well as innovative or evidence-based interventions aimed at reducing home energy consumption. The SERC grant gives 92 high-performing local weatherization agencies in 27 states the opportunity to employ alternative measures in the residential sector that may have otherwise been deemed lower priority as a result of low cost efficiency, or that may have been considered not allowable under current WAP standards due to the inherent risks involved with innovation. In selecting grantees, priority was given based on the following criteria outlined in EISA Section 411(b)(2):

“(2) PRIORITY.- In selecting grant recipients under this subsection, the Secretary shall give priority to-

(A) the expected effectiveness and benefits of the proposed project to low- and moderate-income energy consumers;

(B) the potential for replication of successful results;

(C) the impact on the health and safety and energy costs of consumers served; and

(D) the extent of partnerships with other public and private entities that contribute to the

resources and implementation of the program, including financial partnerships."

This section of the evaluation describes approved technology measures and outreach approaches, their attributes, and a selective evaluation methodology based on available funding allocated for analysis. Evaluation of OWIP's SERC Program should deliver answers to the following broad areas and more specific questions:

Area 1: Quantitative Evaluation of Impacts

- How do the projected energy savings compare to resulting savings upon application of the measures?

- What is the SIR for the measures rigorously evaluated?

- How can the weatherization community assist with raising the SIR of a measure to $\geq 1$, and under what conditions?

- How does modification of occupant energy consumption behavior factor into home energy savings with sustainable energy technologies?

- Which technologies deserve inclusion on the approved installation measures list for WAP based on either SIR or cost-effectiveness?

- How do these technologies impact energy security (defined as household access to home energy and measured by total number of utility interruptions pre-and post installation) across socio-economic status of the populations served?

Area 2: Process Evaluation

- Were the approved agencies able to allot the proposed number of innovative or renewable technology units to willing households?

- What were the barriers to meeting project goals?

- What are the issues associated with implementing innovative strategies or measures for reducing home energy consumption?

- Did the technologies operate as expected? Were there any installation problems?

- How well did SERC projects harmonize with standard weatherization process and treatments offered under WAP? 
- How much, if any, follow-up with occupants is necessary to promote maximum savings as a result of the new technology, measure, or outreach?

- Should WAP transition into the sustainable energy resources arena for home weatherization retrofits after the expiration of ARRA?

\subsubsection{Comprehensive Evaluation Approach}

The evaluation of SERC projects involves the assignment and application of a selected methodology with an associated level of rigor for each broad category of technology or outreach. The more innovative technologies or those projects infused with substantial amounts of funding will be placed in a highly rigorous category for statistical analysis based on energy billing data. Data collection for approximately 4000 homes will be used for determining home energy savings and SIR results. Although the selected technologies for this grant are not expected to meet the SIR of 1.0, SIR calculations will initiate discussion on future potential for cost-effectiveness and under what conditions, such as comparisons of the cost of replacement upon failure of technology vs. early replacement, or buy-downs created with secondary funding sources.

Those measures selected for moderate levels of rigor will be subjected to methodologies making use of a technique called "deemed savings analysis." For example, "deemed savings" for a household with newly installed LED lights would be determined by surveying agencies to get the total number of installed lights and then calculating energy savings based on their associated energy output as reported in the literature. Outreach activities and innovative technologies requiring process assessment will be evaluated through the use of structured interviews or field observations to get insight into the overall impact of the measure. TABLE 4.5 describes each category of evaluation by rigor and the associated tasks involved. TABLE 4.6 exhibits the approved technology, measure, or outreach by level of evaluation rigor.

The evaluation will focus on 10 categories of SERC technologies (15 technologies to be evaluated with high rigor, 29 measures to be evaluated with a moderate level of rigor, and two categories of technologies or interventions appropriate for process analysis). Process analysis questions pertaining to the other 44 (15 high rigor and 29 moderate rigor) technologies will require the use of structured interview tools. 
Table 4.5 Evaluation Categories and Tasks

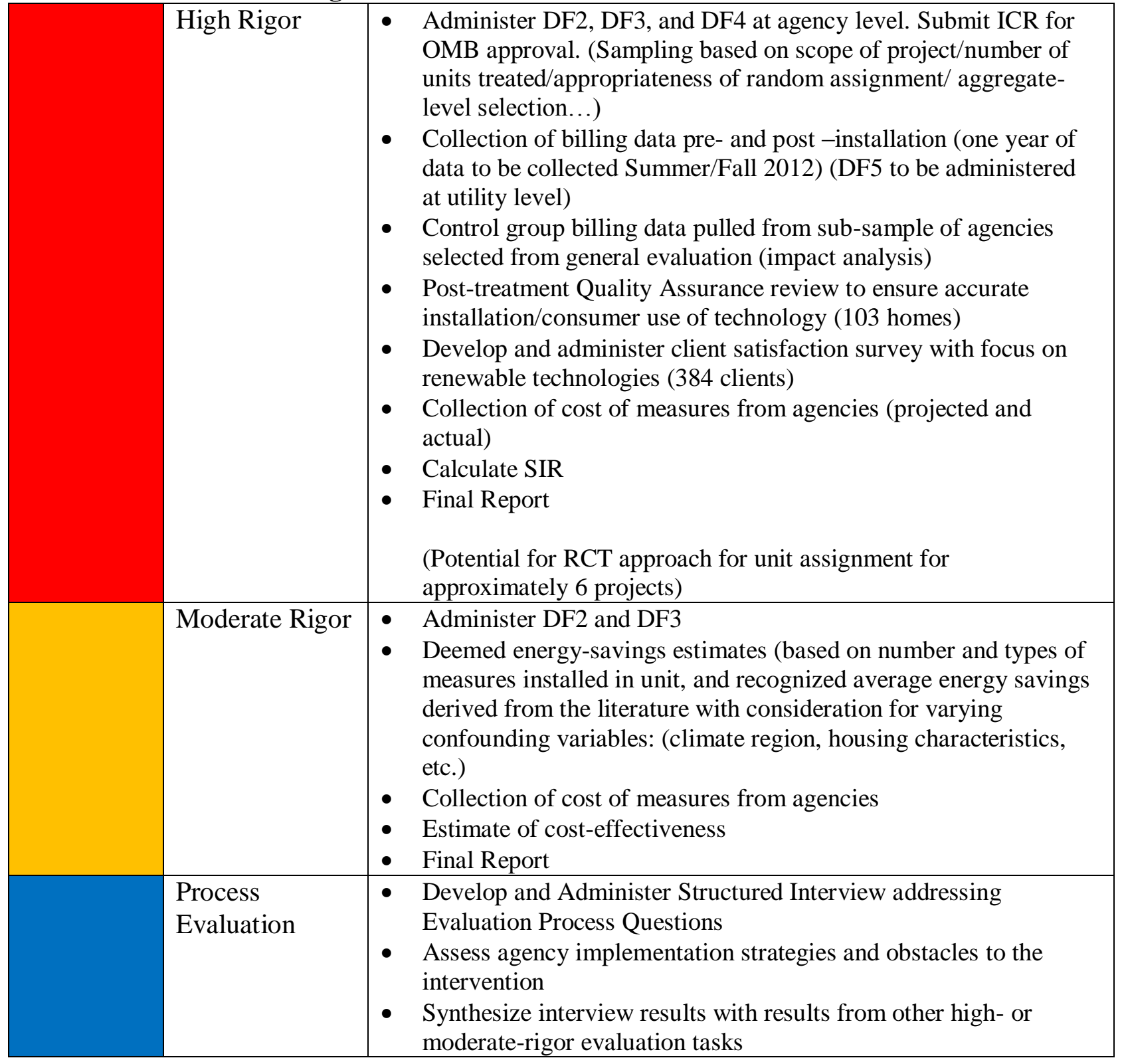


Table 4.6 Technology Categories

\begin{tabular}{|l|l|}
\hline \multicolumn{1}{|c|}{ Technology Category } & $\begin{array}{l}\text { Rigor } \\
\text { Level }\end{array}$ \\
\hline 1.0 RENEWABLE ENERGY & \\
\hline 1.1 Solar PV \\
\hline 1.2 PV: shingles \\
\hline 1.3 Wind: small-scale residential & \\
\hline 2.0 HOT WATER SYSTEMS & \\
\hline 2.1 Solar HW \\
\hline 2.2 Tankless/On-demand HW \\
\hline 2.3 Condensing HW \\
\hline 2.4 Heat Pump/Hybrid HW & \\
\hline 2.5 Combination HW and Boiler & \\
\hline 2.6 Other HW (specify) & \\
\hline 3.0 HVAC SYSTEMS & \\
\hline 3.1 Heat Pumps: Geothermal & \\
\hline 3.2 Heat Pumps: Air & \\
\hline $\begin{array}{l}\text { 3.3 Heat Pumps: mini split-system } \\
\text { ductless }\end{array}$ \\
\hline $\begin{array}{l}\text { 3.4 Replacement of improperly sized } \\
\text { HVAC equipment }\end{array}$ & \\
\hline 3.5 Solar thermal (home heat) & \\
\hline 3.6 Wood Pellet Stoves & \\
\hline 3.7 Ultra Cooling Systems & \\
\hline 3.8 Central AC units & \\
\hline 3.9 Window AC units installed & \\
\hline 3.10 Micro-combined heat and power & \\
\hline 3.11 High-efficiency furnaces & \\
\hline 3.12 Heat recovery ventilators & \\
\hline 3.14 Evaporative Cooling System & \\
\hline 4.0 ROOFING: \\
\hline 4.0 Cool roof technology installed & \\
\hline
\end{tabular}

\begin{tabular}{|c|c|}
\hline Technology Category & $\begin{array}{l}\text { Rigor } \\
\text { Level }\end{array}$ \\
\hline \multicolumn{2}{|l|}{ 5.0 APPLIANCES } \\
\hline \multicolumn{2}{|l|}{ 5.1 Energy Star Clothes Washer } \\
\hline \multicolumn{2}{|l|}{ 5.2 Energy-Efficient Clothes Dryer } \\
\hline \multicolumn{2}{|l|}{ 5.3 Energy-Efficient Refrigerator } \\
\hline \multicolumn{2}{|l|}{ 5.4 Appliance Energy Meters } \\
\hline \multicolumn{2}{|l|}{ 6.0 INSULATION } \\
\hline \multicolumn{2}{|l|}{6.1 Insulation: Aerogel/super } \\
\hline \multicolumn{2}{|l|}{$\begin{array}{l}6.2 \text { Insulation: foam injection } \\
\text { technology }\end{array}$} \\
\hline \multicolumn{2}{|l|}{6.3 Insulation: Masonry Foam } \\
\hline \multicolumn{2}{|l|}{6.4 Insulation: Radiant barrier attic } \\
\hline \multicolumn{2}{|l|}{6.5 Insulation: Spray Foam } \\
\hline \multicolumn{2}{|l|}{$\begin{array}{l}6.6 \text { Insulation: Reflective attic } \\
\text { insulation }\end{array}$} \\
\hline \multicolumn{2}{|l|}{ 7.0 WHOLE-HOUSE RETROFIT } \\
\hline \multicolumn{2}{|l|}{ 7.1 Centralized building controls } \\
\hline \multicolumn{2}{|l|}{ 7.2 Deep energy retrofits } \\
\hline \multicolumn{2}{|l|}{$\begin{array}{l}7.3 \text { High-performance space } \\
\text { conditioning retrofits }\end{array}$} \\
\hline \multicolumn{2}{|l|}{$\begin{array}{l}7.4 \text { High-performance building } \\
\text { envelope retrofits }\end{array}$} \\
\hline \multicolumn{2}{|l|}{ 7.5 Cold Energy Retrofits } \\
\hline \multicolumn{2}{|l|}{ 7.6 Warm Energy Retrofits } \\
\hline \multicolumn{2}{|l|}{ 8.0 OUTREACH } \\
\hline \multicolumn{2}{|l|}{ 8.1 Home Energy Saver Workshops } \\
\hline \multicolumn{2}{|l|}{$\begin{array}{l}8.2 \text { Households touched by behavioral } \\
\text { change message }\end{array}$} \\
\hline \multicolumn{2}{|l|}{ 9.0 EQUIPMENT } \\
\hline \multicolumn{2}{|l|}{$\begin{array}{l}9.1 \text { Monitoring: In-home energy } \\
\text { monitors }\end{array}$} \\
\hline \multicolumn{2}{|l|}{ 10.0 OTHER } \\
\hline \multicolumn{2}{|l|}{ 10.1 Units with Window upgrades } \\
\hline \multicolumn{2}{|l|}{ 10.2 Outdoor solar security lighting } \\
\hline \multicolumn{2}{|l|}{ 10.3 Ceiling Fans } \\
\hline 10.4 LED Lights & \\
\hline
\end{tabular}




\subsubsection{Technologies Selected for High-Rigor Approach}

The proposed strategy for a highly rigorous evaluation of SERC projects involves analysis of 15 selected innovative or highly funded technologies. TABLE 4.6 displays the identified technologies selected for this evaluation strategy. The technologies were selected based on the following factors:

- Number of local agencies, number of projected installations, and estimated budget associated with the technology

- Potential for future inclusion in WAP

- Potential for Randomized Controlled Trials (RCTs)

Each of these technologies will be approached with statistical rigor requiring the selection of a random sample of households across projects. For example, approximately 550 geothermal heat pumps are slated to be installed by 12 agencies from eight states across the country. A random sample of households will be selected for evaluation from the eight states. Households selected to represent the impact of the measure will be stratified for conditions such as climate region, high energy usage, and housing characteristics. The evaluation will compare the national results of the impact analysis of the installed technology with a control sample offering baseline weatherization results, and with the impact analysis of the 14 other technologies selected to undergo highly rigorous evaluation.

Analysis of home energy billing data pre- and post- retrofit will be compared to a control group of weatherized homes selected from the WAP-ARRA Evaluation sample. Pre-tested survey instruments will be administered to agencies and occupants, and post-treatment quality assurance inspections will be completed. The Occupant Survey will be administered to a sample of households with installed renewable energy technologies, or in-home monitoring devises.

\subsubsection{SERC Randomized Controlled Trials (RCTs)}

Projects will be reviewed to identify likely candidates for randomized controlled trials (RCTs) or randomized trials between like technologies. For example, Colorado received approval for the installation of in-home energy monitoring devices as part of a 1600-household project. Project planners already intend to split the sample into 800 treatment homes, which will receive the monitoring device and 800 control homes, which will not receive the device. If an RCT method is adopted, households will be randomly assigned to either the treatment or control group, and the project's findings will be strengthened by the power of the statistical method used. As another example, two agencies in Arizona have been approved to install two different hot-water technologies, solar and heat pump, for a total of 470 units; this offers the potential for a randomized trial between the two interventions. In the randomized trial cases, household recipients of standard weatherization treatment would be sampled from the WAP-ARRA Evaluation to serve as a baseline comparison group. Randomized trials serve as an alternative to RCTs in projects or program areas with assignment challenges and still offer significant results. Evaluators would review these types of methodologies and then communicate with the grantees to determine any challenges regarding randomly assigning homes to either treatment or control groups. If the conditions prove ideal, then an RCT will be coordinated and implemented with follow-up training and technical assistance (T\&TA) from the evaluation team for the duration of the study. RCT and randomized trial projects will be evaluated with statistical rigor. Approximately six projects will be selected for RCT experimental design. Upon identification of potential RCT projects by the evaluation team and DOE, implementation plans will be designed with the help of project leaders at the sub-grantee level.

Analysis of the SERC projects offers OWIP the ability to better inform WAP stakeholders of their options-clearly presented by strengths and deficits-for each of the evaluated SERC interventions, with successes and challenges associated during the stages of eligibility, implementation, and analysis of energy and cost savings. Detailed evaluation designs will be developed pending further information 
received on project descriptions, implementation plans, and communication with the awarded local weatherization agencies. 


\subsection{PERSISTENCE OF ENERGY SAVINGS}

Almost two decades ago, Ed Vine wrote: "The persistence of energy and demand savings is an important issue to many stakeholders: building owners, architects and engineers, utility program managers and evaluators, regulators, utility shareholders, resource planners, forecasters, and researchers."

\subsubsection{Background}

The U.S. Department of Energy, as well as states and utilities, has funded the weatherization of low-income homes for over three decades. As stated by Ed Vine in 1992 (see footnote above), it is important for many reasons and from many viewpoints to understand how energy savings persist in weatherized homes. With increasing concerns about global climate change, it is even more important to estimate persistence because of the carbon emissions benefits from weatherizing homes. Many are exploring how carbon credits can be generated from weatherizing low-income homes, and potential purchasers of carbon credits need to know what amount of carbon emissions will be reduced for what period of time.

Unfortunately, no credible persistence studies have been conducted in recent years and only a few have ever been conducted. Those studies that were conducted date back to the late 1980s and early $1990 \mathrm{~s}^{9}$ and only explored persistence two to three years after weatherization. Thus, the weatherization and voluntary carbon market communities have little information about how to estimate persistence of energy savings in weatherized low-income homes.

\subsubsection{Research Design}

Proposed herein is a pilot project to retrospectively estimate persistence of energy savings in approximately 114 weatherized single-family and low-income mobile homes. The project team will work with the State of Wisconsin (where several local weatherization agencies have been identified that have comprehensive historical weatherization records) and possibly one or two additional states to identify several hundred homes that were weatherized around 1995 by three to four different local agencies. From this sample, the goal will be to identify 114 homes that have good weatherization records and whose occupants will allow home inspections and will consent to participating in a short survey (see below).

Homes that were weatherized by the same agencies in Program Years 2007, 2008, and 2009 will be used as a control group for this study. Specifically, treatment and control homes will be matched by age. In other words, a fifteen year old home weatherized in 1995 of a general type and size would be matched with a twenty-eight year old home weatherized in 2008 of the same general type and size, making sure that the latter had not been weatherized previously. This matching technique allows researchers to track changes in air leakage rates over time. A blower door test done pre-weatherization on the 2008 home would represent the tightness not only of that home but what the tightness of the 1995 home might have been in 2008 had it not been weatherized in 1995. Since new blower tests will be performed for all homes weatherized in the 1995 period, one can then estimate the persistence of 1995 weatherization measures on air leakage rates by taking the difference between the blower door test results for the 2008 weatherized homes and the 2008 blower door test results for the 1995 weatherized homes. An added bonus would be if blower door test results were also available pre- and post-weatherization for the homes weatherized during the 1995 period.

\footnotetext{
${ }^{8}$ Vine, E. 1992. Persistence of Energy Savings: What Do We Know and How Can It Be Ensured? Energy, Vol. 17, No. 11, 1073-1084.

${ }^{9}$ E.g., Brandis, P., and Haeri, H. 1992. The Persistence of Energy Savings Over Time: Two and Three Years After Participation in a Retrofit Program. Policy Studies Review, Vol. 20, No. 1, 68-75.
} 
An essential part of this proposed project is home inspection. As detailed in Task 4, each treatment home will receive an on-site inspection to generate information about weatherization measures installed in the home years in the past. The inspections will reveal the condition of the measures and whether they have been replaced or discarded. Any changes in house structure and integrity will also be noted.

The last component of this research design is a short interview. The current occupants of the homes included in the study will be asked about their knowledge of the weatherization measures installed in their homes, the occupant history of the homes (to the extent possible), and any changes in house structure, integrity, occupancy, etc. that could be useful in understanding variations in energy use in the home over time.

\subsubsection{Tasking Statement}

The proposed project will be composed of the following nine tasks:

Task 1. Agencies for Retrospective Study - The first task is to identify three or four local weatherization agencies in Wisconsin to participate in this study. The focus of this pilot study will be in cold-weather regions, under the assumption that weatherization activities save more energy, and therefore reduce carbon emissions more, in cold regions. Future projects should balance this information by focusing on homes in hot climates. The study will focus only on single-family and mobile homes that heat with fossil fuels or electricity produced by fossil fuels. Any local agencies selected to participate in this project will be required to have excellent records of past weatherization activities the 1995 time period. Information needed will include home addresses, audit reports, and installed weatherization measures. The records need not be in electronic form, although that would be preferable.

Task 2. Collect Weatherization Records-Project members will visit the participating local agencies to collect weatherization records. The goal will be to collect records for approximately 400 homes that were weatherized in the 1995 period.

Task 3. Sample Development - This task entails matching homes weatherized in the 2007, 2008, and 2009 period to homes weatherized in the 1995 period. As mentioned above, each home in the former list needs to be matched with a home in the latter list that was build in exactly the same year and is essentially the same type and size. The goal is to end up with a matched sample of approximately 125 homes.

Task 4. Conduct Inspections - Households will be paid an incentive to encourage them to participate in this study. The incentive will encourage households, firstly, to allow their homes to be thoroughly inspected. With the audit reports and list of installed weatherization measures in hand, inspectors will visit the treatment homes to document the following:

$>$ Measure degradation - Weather stripping and other air-sealing measures will be examined. Infrared technology may be used to measure any settling of insulation in the walls. Measurements of the depth of insulation in ceilings will be taken. The condition of insulation around water heaters and ducts will also be noted. It is understood that past records may not include infrared measurements, for example, but using expert judgment, some conclusions can be made about measure degradation in these cases; 
$>$ Measure replacement - It will be determined whether various installed measures were replaced and if so, whether they were replaced with measures that had better, worse or the same energy-savings characteristics. Examples of measures that could be replaced include furnaces, windows, doors, and refrigerators;

$>$ Measure retention - It will be determined whether various installed measures were retained in the home. Examples of these types of measures include CFLs and low-flow shower heads;

$>$ Change in the condition or size of the home - Inspectors will determine to the extent possible whether the size of the home has changed (e.g., whether there have been any additions). Also, the inspectors will note any possible changes in the condition of the home (e.g., broken windows, holes in the roof) that could significantly impact energy savings; and

$>$ Any other changes in the home that may impact energy-savings persistence estimates will be noted. Such changes could include the addition of window air conditioners, portable heaters, and wood furnaces.

It is proposed that blower door tests be conducted on treatment homes. If available, these results can be compared to blower test results from 1995, allowing for the possibility that tests conducted in 1995 were less accurate that those conducted today. Blower door test results from pre-weatherization and immediately post-weatherization for recently weatherized homes can be used as benchmarks. Additionally, it is proposed that the efficiency of furnaces be measured, along with the emissions of $\mathrm{CO}$ in flu gases. Indoor temperatures and water-heater temperatures may also be recorded.

Task 5. Conduct Household Interviews - These will be conducted on-site by the inspectors. They will inquire about the occupancy history of the home and any major structural or other changes in the home that may have significantly changed energy consumption over the past decade and a half years.

Task 6. Collect Utility Bills - The project will attempt collect twelve years of billing histories for all homes enrolled in the study (i.e., both treatment and control). It is anticipated that these data will be available in various formats, from readily available electronic data bases to paper files residing in filing cabinets in the basements of utility buildings.

Task 7. Energy Savings Data Analysis - PRISM and one or two other methods will be used to weather adjust and analyze the billing histories. Energy use for each group of homes will plotted over time (pre-and post-weatherization). Comparisons will be made between weatherized and control homes and the persistence of gross and net energy savings will be estimated.

Task 8. Implications for Voluntary Carbon Markets - An exercise will be conducted to estimate carbon emissions reductions that could be associated with each group of weatherized homes. Costs associated with weatherizing the homes will be compared to typical prices for carbon credits found in representative voluntary carbon markets. The cost-effectiveness of home weatherization as a potential vehicle for voluntary carbon markets will be assessed. 
Task 9. Develop a Forward-Looking Data-Collection Protocol on Persistence- The data collection procedures described above probably only represent a first try at the types of data one might actually wish to do in persistence studies. For example, thoroughly documenting the condition and structural characteristics of homes at the time of weatherization and every three or four years afterward, through complete inspection reports and photographic documentation, would be much preferable to relying only on anecdotal evidence or the memories of occupants. Also, more extensive testing and data collection at the time of weatherization could serve as benchmarks (blower door tests, even infrared analyses of insulation in walls immediately after weatherization) for future studies; those would then be supplemented by repeated testing and data collection repeated every three or four years in the same homes. The output of this task will be a comprehensive and detailed data collection protocol to be implemented on any homes chosen to be enrolled in persistence studies.

Task 10. Draft and Final Reports - A draft report will be prepared and peer-reviewed. The final report will be revised accordingly. 


\section{SYNTHESIS}

After the impact assessment, process assessment, and special technical studies have been performed, results from these studies will be drawn together via a synthesis study to address remaining questions identified in the evaluation design matrix (see Table 1.2):

- Context-Questions 2 and 8,

- Implementation-Question 7, and

- Outcomes-Questions 11 and 15-16.

Specifically, the synthesis study will determine:

- whether the Program has the capacity and structure (e.g., funding, staffing) to meet its legislative missions and objectives,

- how well the Program is meeting its legislative missions and objectives,

- whether the states and local agencies are fulfilling their obligations under federal regulations and state plans,

- the extent to which the Program is serving the weatherization needs of the low-income community and meeting the needs of the national low-income weatherization market, and

- how the weatherization network's performance can be improved to guide the Program into the next decade.

The Program objectives as set by legislation will be identified in the impact assessment (see Section 3.1). One or more measurable indicators will be developed under the synthesis study for each identified objective and an expected value for each indicator will be established based on the legislative intent. Evaluation data and results from the previous studies will be used to determine an actual value for each indicator, and the actual value of each indicator will be compared to the expected value to determine whether the legislative intent is being met. The key Program objectives that will be examined include:

- the number of clients served by the Program,

- the extent to which the Program focused on low-income persons who are particularly vulnerable as defined by DOE (i.e., households with elderly or disabled persons, those with children, and those with high residential energy use and high energy burden), and

- the spending of Program financial resources according to federal regulations (e.g., adherence to spending limits for training, overhead, and weatherization measures ; following rules concerning materials purchased and measures installed with Program funds).

Using results from the impact and process assessments, a determination will be made as to whether states and agencies are fulfilling their obligations under Federal regulations and state plans (e.g., units weatherized, average household expenditures, expenditures for training and overhead).

The extent to which the weatherization needs of low-income households are being met by the Program will be assessed by examining (from the previous studies) the households being served by the Program compared to the larger low-income population, the breadth of activity performed nationally 
under the Program and differences in this activity by climate region, and the energy impacts of this activity and the quality of the jobs performed.

The results and findings from the previous three study areas (i.e., impact assessment, process assessment, and special technical studies) will be brought together and examined to develop recommendations on how the Program and the weatherization network's performance can be improved. In addition to synthesizing and distilling findings about Program outcomes and processes concerning PYs 2009, 2010 and 2011, this study will develop insights useful for guiding the Program into the next decade. Future trends of many variables relevant to the Program will be assessed, including demographics, energy prices and availability, housing stock, residential energy technologies, possibly new energy and environmental legislation, restructuring of the electric utility industry, and workforce. Recommendations will address the full breadth of the Program and the network's operation, including the delivery of the Program, communications within the network, coordination with other programs, and reporting of this coordination to DOE. Recommendations should also be developed on how a longer-term, more continuous evaluation of the Program could be implemented by DOE so that the longer-term outcomes of the Program and the long-term persistence of energy savings could be more fully addressed (see Section 1.1.3). The standardized data collection needed to support such an effort should also be addressed. Two groups will be consulted to help develop the recommendations:

- Network Committee - The Network Committee will be re-convened to consider the evaluation's findings and trends into the future. The Committee will identify those trends that could most impact the Program in the next decade and will also make recommendations to the Program with respect to guiding the program into the next decade.

- Expert Panel-An Expert Panel will be formed to solicit the opinions of about a dozen policy and public administration experts (most are expected to be academics). Through an iterative process, the Expert Panel members will provide (1) their opinions and insights about the evaluation's findings and their reactions to the opinions and insights of others, (2) their responses to policy-oriented and program administration questions and their reaction to the responses of others, and (3) their recommendations and their reaction to the recommendations proposed by others. It is expected that a well-run expert-panel process will find areas of consensus and disagreement amongst the panel members. This expert panel process will be run virtually (i.e., without convening the participants in one physical place), both to minimize expenses and also to maximize the time allowed to the panelists to provide answers, consider the inputs of the other panelists, and provide their reactions to the opinions of the panel.

The results of the discussions of the Network Committee and the Expert Panel will be compiled into a separate report and delivered to DOE for its use. 


\section{SCHEDULE}

A schedule for the evaluation is shown in Figure 6.1. It should be noted that the intent of the evaluation is to measure and evaluate PY 2009-2011 activities; PY 2009 starts in April 2009 and PY 2011 ends in June 2012.

The timely implementation of the data-collection aspects of this preliminary evaluation plan depends upon receiving approval of the national evaluation from OMB in a timely manner. DOE and the ORNL evaluation team are in the process of obtaining OMB's approval. 
Figure 6.1. WAP-ARRA Period Evaluation schedule

\begin{tabular}{|c|c|c|c|c|c|c|c|c|c|c|c|c|c|c|c|c|}
\hline Task Name & \multicolumn{4}{|c|}{$\begin{array}{c}\text { Calendar Year } \\
2011\end{array}$} & \multicolumn{4}{|c|}{$\begin{array}{c}\text { Calendar Year } \\
2012\end{array}$} & \multicolumn{4}{|c|}{$\begin{array}{c}\text { Calendar Year } \\
2013\end{array}$} & \multicolumn{4}{|c|}{$\begin{array}{c}\text { Calendar Year } \\
2014\end{array}$} \\
\hline & $\begin{array}{l}\mathrm{Q} \\
1\end{array}$ & $\begin{array}{l}\mathrm{Q} \\
2\end{array}$ & $\begin{array}{l}\text { Q } \\
3\end{array}$ & $\begin{array}{l}\mathrm{Q} \\
4\end{array}$ & $\begin{array}{l}\mathrm{Q} \\
1\end{array}$ & $\begin{array}{l}\mathrm{Q} \\
2\end{array}$ & $\begin{array}{l}\mathrm{Q} \\
3\end{array}$ & $\begin{array}{l}\mathrm{Q} \\
4\end{array}$ & $\begin{array}{l}\mathrm{Q} \\
1\end{array}$ & $\begin{array}{l}\mathrm{Q} \\
2\end{array}$ & $\begin{array}{l}\mathrm{Q} \\
3\end{array}$ & $\begin{array}{l}\mathrm{Q} \\
4\end{array}$ & $\begin{array}{l}\mathrm{Q} \\
1\end{array}$ & $\begin{array}{l}Q \\
2\end{array}$ & $\begin{array}{l}\mathrm{Q} \\
3\end{array}$ & $\begin{array}{l}\mathrm{Q} \\
4\end{array}$ \\
\hline $\begin{array}{l}\text { National } \\
\text { Energy } \\
\text { Savings } \\
\text { Analyses } \\
\end{array}$ & & & & & & & & & & & & & & & & \\
\hline $\begin{array}{l}\text { States Survey } \\
\text { (S1) }\end{array}$ & & & & & & & & & & & & & & & & \\
\hline $\begin{array}{l}\text { Agency } \\
\text { Surveys }\end{array}$ & & & & & & & & & & & & & & & & \\
\hline WIPP Study & & & & & & & & & & & & & & & & \\
\hline SERC Study & & & & & & & & & & & & & & & & \\
\hline $\begin{array}{l}\text { Under- } \\
\text { Performers } \\
\text { Study }\end{array}$ & & & & & & & & & & & & & & & & \\
\hline $\begin{array}{l}\text { GHG } \\
\text { Emissions } \\
\text { Study }\end{array}$ & & & & & & & & & & & & & & & & \\
\hline Deferral Study & & & & & & & & & & & & & & & & \\
\hline $\begin{array}{l}\text { Social } \\
\text { Network } \\
\text { Study }\end{array}$ & & & & & & & & & & & & & & & & \\
\hline $\begin{array}{l}\text { Weatherizatio } \\
\text { n Staff Survey } \\
\text { Follow-ups }\end{array}$ & & & & & & & & & & & & & & & & \\
\hline $\begin{array}{l}\text { Persistence } \\
\text { Study }\end{array}$ & & & & & & & & & & & & & & & & \\
\hline
\end{tabular}




\section{REFERENCES}

APPRISE Incorporated. “Ohio REACH Baseline Survey Instrument.”

APPRISE Incorporated. “NEADA 2009 National Energy Assistance Survey.” November 2009

Center for Studying Health System Change (HSC). "Community Tracking Study Household Survey Instrument." February 2005

Centers for Disease Control and Prevention (CDC). "2010 Behavioral Risk Factor Surveillance System Questionnaire.” 18 November 2009

Centers for Disease Control and Prevention (CDC). "National Asthma Survey." 18 April 2003

Centers for Disease Control and Prevention (CDC). "National Health Interview Survey." 3 March 2010

Code of Federal Regulations, National Archives and Records Administration, Office of the Federal Register, Title 10, Part 440, Section 1, Revised January 1, 2005 (see www.gpoaccess.gov/cfr).

Berry, Linda, "State-Level Evaluations of the Weatherization Assistance Program in 1990-1996: A Metaevaluation that Estimates National Savings," ORNL/CON-435, Oak Ridge National Laboratory, January 1997.

Berry, Linda and Martin Schweitzer, "Metaevaluation of National Weatherization Assistance Program Based on State Studies, 1993-2002," ORNL/CON-488, Oak Ridge National Laboratory, February 2003.

Brown, Marilyn A., Linda G. Berry, and Laurence F. Kinney, "Weatherization Works: Final Report of the National Weatherization Evaluation," ORNL/CON-395, Oak Ridge National Laboratory, September 1994.

Brown, Marilyn A., Linda G. Berry, Richard A. Balzer, and Ellen Faby, "National Impacts of the Weatherization Assistance Program in Single-Family and Small Multifamily Dwellings," ORNL/CON326, May 1993.

Brown, Marilyn A. and Lawrence J. Hill, "Low-Income DSM Programs: The Cost-Effectiveness of Coordinated Partnerships,” ORNL/CON-375, Oak Ridge National Laboratory, May 1994.

DOE, "Weatherization Program Notice 05-1," November 12, 2004 (see www.waptac.org).

Fels, M., K. Kissock, M. Marean, and C. Reynolds, "PRISM Advanced Version 1.0 User's Guide," Princeton University, Center for Energy and Environmental Studies, Princeton, NJ, 1995.

Gettings, Michael, "The Weatherization Assistant Users Manual for Administrative Features (Version 8)," ORNL/TM-2005/236, Oak Ridge National Laboratory, January 2006 (see "Energy Audits" under www.waptac.org).

Hall, Nick et al., "California Energy Efficiency Evaluation Protocols: Technical, Methodological, and Reporting Requirements for Evaluation Professionals," State of California Public Utilities Commission, April 2006. 
Hall, Nick et al., "The California Evaluation Framework," Southern California Edison Company, Project K2033910, June 2004.

Hill, Lawrence J. and Marilyn A. Brown, "Standard Practice: Estimating the Cost-Effectiveness of Coordinated DSM Programs,” ORNL/CON-390, Oak Ridge National Laboratory, December 1994.

W. K. Kellogg Foundation, "Logic Model Development Guide: Using Logic Models to Bring Together Planning, Evaluation, \& Action,” December 2001 (see www.wkkf.org).

Kissock, J. Kelly, Jeff S. Haberl, and David E. Claridge, "Development of a Toolkit for Calculating Linear, Change-Point Linear, and Multiple-Linear Inverse Building Energy Analysis Models," RP-1050, American Society for Heating, Refrigerating, and Air Conditioning Engineers, 2004.

Levins, William P. and Mark P. Ternes, "Impacts of the Weatherization Assistance Program in Fuel-Oil Heated Houses," ORNL/CON-327, Oak Ridge National Laboratory, October 1994.

National Center for Healthy Housing. "WATTS and Well-being Study Health Survey Questionnaire." 7 November 2009

Oak Ridge National Laboratory. “WAP Evaluation Occupant Survey.” 2006

Power, Meg, "Weatherization PLUS Other Efficiency and Housing Investments Delivered by Local Weatherizers in PY 2000," Economic Opportunity Studies, June 13, 2003

(www.opportunitystudies.org/repository/File/weatherization/utility-wap-combined-programs.pdf).

Schweitzer, Martin, "Estimating the National Effects of the U.S. Department of Energy's Weatherization Assistance Program with State-Level Data: A Metaevaluation Using Studies from 1993 to 2005," ORNL/CON-493, Oak Ridge National Laboratory, September 2005.

Schweitzer, Martin and Linda Berry, "Metaevaluation of National Weatherization Assistance Program Based on State Studies, 1996-1998," ORNL/CON-467, Oak Ridge National Laboratory, May 1999.

Schweitzer, M. and B. Tonn, "Nonenergy Benefits from the Weatherization Assistance Program: a Summary of Findings from the Recent Literature," ORNL/CON-484, Oak Ridge National Laboratory, April 2002.

Ternes, M., Schweitzer, M., Tonn, B., Schmoyer, R., and Eisenberg, J. 2007. "National Evaluation of the Department of Energy's Weatherization Assistance Program (WAP): Program Year 2006 Experimental Plan," ORNL/CON-498, Oak Ridge National Laboratory, Oak Ridge, TN, February.

USAID. “Household Food Insecurity Assessment Scale.”August 2007

US Department of Energy (DOE). "Residential Energy Consumption Survey.” 2009 


\section{APPENDIX A. NATIONAL WEATHERIZATION NETWORK COMMITTEE}

\begin{tabular}{|c|c|}
\hline Adams, Robert & DOE/OWIP/WAP \\
\hline Beachy, Bill & Virginia-Community Housing Partners Corporation \\
\hline Bennett, Randy & State of IL, Dept. Commerce \& Econ. Opp. \\
\hline Bensch, Ingo & Apprise \\
\hline Berger, Jackie & Apprise \\
\hline Bethke, Jack & Community Action of Minneapolis \\
\hline Bowmar, Kip & Community Action Kentucky \\
\hline Brady, Eugene & Pennsylvania-Commission on Economic Opportunity \\
\hline Carroll, David & Apprise \\
\hline Choate, JoAnn & Maine State Housing Authority \\
\hline Costello, Pat & NYS Division of Housing \& Community Rene \\
\hline Crisp, Jim & Michigan Community Action Agency Assoc. \\
\hline Cutchen, Kelly & SMS \\
\hline Diggs, Jean & DOE/OWIP/WAP \\
\hline Doyle, Dawn & Texas Department of Housing and Community Affairs \\
\hline Eisenberg, Joel & Oak Ridge National Laboratory \\
\hline Foote, Katherine & $\mathrm{DOE} / \mathrm{GO}$ \\
\hline Gerardot, Ed & Indiana Community Action Association \\
\hline Hamilton, John & Illinois - CEDA \\
\hline Harmelink, Suzanne & WI Energy Conservation Corporation \\
\hline Hepinstall, Dave & New York -Association for Energy Affordability \\
\hline Jacobson, Elliott & Massachusetts-Action, Inc \\
\hline Peterson, Mike & $\mathrm{DOE} / \mathrm{GO}$ \\
\hline Pitts, Keith & Ohio-Corporation for Ohio Appalachian Develop. \\
\hline Power, Meg & NCAF \\
\hline Quenemoen, Kane & Montana DPHHS \\
\hline Ravesloot, Holly & DOE/OWIP/WAP \\
\hline Sabree-Sylla,Clarice & NJ Department of Community Affairs \\
\hline Schweitzer, Martin & Oak Ridge National Laboratory \\
\hline Scott, Bob & NASCSP \\
\hline Simonson, Cynthia & SMS \\
\hline Smith, Carrie & Arizona - FSL \\
\hline Sunday, Nick & State of Ohio-Office of Community Service \\
\hline Tonn, Bruce & Oak Ridge National Laboratory \\
\hline Van der Meer, Bill & SMS \\
\hline Zamora, Christina & Idaho-CAPAI \\
\hline
\end{tabular}




\section{APPENDIX B. DOE SURVEY}

Pending DOE approval, the Project Team will interview key OWIP managers concerning the challenges to expanding and then ramping down WAP during the ARRA period. The interviews will be open-ended. 
OMB Control Number: XXXX-XXXX

\section{APPENDIX C: S1: ALL STATES PROGRAM INFORMATION SURVEY}

This data is being collected to conduct a process evaluation of the Weatherization Assistance Program at the state level. The data you supply will be used to characterize program activities during Program Year 2010.

Public reporting burden for this collection of information is estimated to average sixteen hours per response, including the time for reviewing instructions, searching existing data sources, gathering and maintaining the data needed, and completing and reviewing the collection of information. Send comments regarding this burden estimate or any other aspect of this collection of information, including suggestions for reducing this burden, to Office of the Chief Information Officer, Records Management Division, IM-11, Paperwork Reduction Project (XXXX-XXXX), U.S. Department of Energy, 1000 Independence Ave SW, Washington, DC, 20585-1290; and to the Office of Management and Budget (OMB), OIRA, Paperwork Reduction Project (XXXX-XXXX), Washington, DC 20503.

All of the information obtained from this survey will be protected and will remain confidential. The data will be analyzed in such a way that the information provided cannot be associated back to your state, your agencies, or the housing units and clients that your state served. Again, please note that the questions refer to PY 2010 unless otherwise noted.

\section{PROGRAM CHARACTERIZATION}

1. Please identify your state:

2. It is important to collect information about the weatherization of homes beyond the standard single family homes that are heated with natural gas or electricity. Please review the following information for accuracy about each of the local agencies (subgrantees) that you fund to provide weatherization services in your state. Please add any additional grantees and funding amount in the extra space at the bottom of the table:

\begin{tabular}{|l|c|c|c|}
\hline Local Agency (Subgrantee) Name & $\begin{array}{c}\text { Active } \\
\text { Subgrantee } \\
\text { (Y/N) }\end{array}$ & $\begin{array}{c}\text { Amount of DOE } \\
\text { Funds Received } \\
\text { by Agency in } \\
\text { Program Year } \\
\text { 2010 }\end{array}$ & $\begin{array}{c}\text { Correct Amount } \\
\text { (Y/N) } \\
\text { If NO, Please } \\
\text { Insert Correct } \\
\text { Amount }\end{array}$ \\
\hline & & & \\
\hline & & & \\
\hline & & & \\
\hline & & & \\
\hline & & & \\
\hline
\end{tabular}




\begin{tabular}{|l|c|c|c|}
\hline Local Agency (Subgrantee) Name & $\begin{array}{c}\text { Active } \\
\text { Subgrantee } \\
\text { (Y/N) }\end{array}$ & $\begin{array}{c}\text { Amount of DOE } \\
\text { Funds Received } \\
\text { by Agency in } \\
\text { Program Year } \\
\text { 2010 }\end{array}$ & $\begin{array}{c}\text { Correct Amount } \\
\text { (Y/N) } \\
\text { If NO, Please } \\
\text { Insert Correct } \\
\text { Amount }\end{array}$ \\
\hline & & & \\
\hline & & & \\
\hline & & & \\
\hline & & & \\
\hline & & & \\
\hline & & & \\
\hline & & & \\
\hline & & & \\
\hline & & & \\
\hline & & & \\
\hline & & & \\
\hline & & & \\
\hline & & & \\
\hline
\end{tabular}

3. During Program Year 2010, was the director of your State's Weatherization Program (Check best answer):

a civil servant political appointee elected official

4.During Program Year 2010, did the director of your State's Weatherization Program report to a (Check best answer): civil servant, political appointee elected official

5. For how many years had the current director of your State's Weatherization Program served in that capacity prior to PY 2010?

6. Did your State's Weatherization Program set annual performance goals for PY 2010 ? Yes No (go to Question 7)

6a. What agency, office, or department was responsible for reviewing the annual performance goals and achievement of goals of your State's Weatherization Program? 
7. Please list other important housing and/or energy-related programs for low-income residents that were administered by the same office that is in charge of your state's Weatherization Assistance Program.

8. What weatherization program data did your state require its weatherization agencies to provide in PY2010? (Check all that apply)

Number of homes weatherized

Number of homes weatherized for high priority categories

DOE weatherization funds expended

Non-DOE weatherization funds expended

Descriptive statistics on demographics of households weatherized

Descriptive statistics on weatherization measures installed in households weatherized

Descriptive statistics on energy use/savings of households weatherized

Copy of audits performed on the households weatherized

Results of certain diagnostic tests

Number of homes deferred for weatherization

Other

9. Does your state maintain an electronic state weatherization program data base?

a. Yes

b. No (Go to Q13)

10. If what does this database contain these weatherization related-elements? (check all that apply)

a. number of homes weatherized

b. number of homes weatherized by type

c. costs of measures installed

d. billing records for weatherized homes

e. audit records

f. measures installed by unit

g. other

11. Does your database also contains these types of information: (check all that apply)

a. LIHEAP records

b. household demographics

c. other

12. Who has access to this database? (check all that apply)

a. state weatherization office staff

b. other state employees

c. local weatherization agency staff

d. other

13. Please indicate the number of staff that supported your State's Weatherization Program and their work effort in Program Year 2010. In considering the number of staff, please include 
everyone who worked full- or part-time or who worked with the weatherization program as well as other state programs. Also include any non-agency staff supporting the state program that work under contract to the state.

\begin{tabular}{|l|l|l|}
\hline \multicolumn{1}{|c|}{ Type of Administrative Function } & $\begin{array}{c}\text { Number of } \\
\text { Staff (\# } \\
\text { persons) }\end{array}$ & $\begin{array}{c}\text { Total Staff Work } \\
\text { Effort (\# of FTE) }\end{array}$ \\
\hline Management/administration & & \\
\hline Agency monitoring & & \\
\hline Training and Technical Assistance & & \\
\hline Other (specify) & & \\
\hline TOTAL & & \\
\hline
\end{tabular}

14. For the in-house staff working on your state's weatherization program in each of the following functional areas in Program Year 2010, please indicate their collective level of experience with the weatherization program:

\begin{tabular}{|l|l|l|l|l|l|}
\hline & $\begin{array}{c}\text { Very } \\
\text { High }\end{array}$ & High & Medium & Low & Very Low \\
\hline Management/administration & & & & & \\
\hline Field monitoring/auditing & & & & & \\
\hline $\begin{array}{l}\text { Training and Technical } \\
\text { Assistance }\end{array}$ & & & & & \\
\hline Other (specify) & & & & & \\
\hline
\end{tabular}

15. For the in-house staff working in your state's weatherization program in each of the functional areas listed below, please indicate the amount of turnover in staff from the beginning of PY 2009 to the end of PY 2010. (Please check appropriate box representing the level of turnover for each functional area.)

\begin{tabular}{|l|c|c|c|}
\hline & $\begin{array}{c}\text { No Turnover } \\
\text { (all staff in this functional } \\
\text { area at the beginning of } \\
\text { PY 2009 were in the same } \\
\text { functional area by the end } \\
\text { of PY 2010) }\end{array}$ & $\begin{array}{c}\text { Some turnover } \\
\text { (1-15\% of the staff in this } \\
\text { functional area at the } \\
\text { beginning of PY 2009 did } \\
\text { not remain in the same } \\
\text { functional area by the end } \\
\text { of PY 2010) }\end{array}$ & $\begin{array}{c}\text { Substantial } \\
\text { turnover } \\
\text { (more than 15\% of the } \\
\text { staff in this functional } \\
\text { area at the beginning of } \\
\text { PY 2009 remained in the } \\
\text { same functional area at } \\
\text { the end of PY 2010) }\end{array}$ \\
\hline $\begin{array}{l}\text { Management/ } \\
\text { administration }\end{array}$ & $\square$ & $\square$ & $\square$ \\
\hline $\begin{array}{l}\text { Field monitoring/ } \\
\text { Auditing }\end{array}$ & $\square$ & $\square$ & $\square$ \\
\hline $\begin{array}{l}\text { Training and Technical } \\
\text { Assistance }\end{array}$ & $\square$ & $\square$ & $\square$ \\
\hline Other (specify) & $\square$ & $\square$ & $\square$ \\
\hline
\end{tabular}


16. The Federal Regulations governing the Weatherization Assistance Program define children as "dependents not exceeding 19 years or a lesser age set forth in the State plan." What age did your state use in your state's definition of children in PY 2010?

17. Did your state use a high energy burden category to prioritize the provision of weatherization services in PY 2010?

Yes

No (go to Question 18)

17a. How was 'high energy burden' defined?

18. Did your state use a high energy expenditure category to prioritize the provision of weatherization services in PY 2010? Yes

No (go to Question 19)

18a. How was 'high energy expenditure' defined?

19. What were the income guidelines for households to be eligible for your state's weatherization program in PY 2010? (Check all that apply) $150 \%$ of Federal Poverty Guidelines $200 \%$ of Federal Poverty Guidelines More than $200 \%$ of Federal Poverty Guidelines $60 \%$ of state median income Other: 


\section{LEVERAGING RELATIONSHIPS}

1. Please list weatherization funding received during PY 2010 by completing the table below.

Column A lists potential sources of weatherization funding. As a reference, Column B lists the amount of PY 2008 funding reported by your state in the retrospective evaluation S1 survey. If the PY 2008 funding amount is incorrect, please list the correct amount in Column B. In Column C, please indicate whether your state administered each funding source in PY 2010. In Column D, enter the total funding amount administered in PY 2010 from each source received. Please allocate the total funding amount listed in Column D to the sub-categories listed in Columns E through I.

\begin{tabular}{|c|c|c|c|c|c|c|c|c|c|}
\hline \multirow[b]{3}{*}{ Funding Source } & \multirow[b]{3}{*}{$\begin{array}{c}\text { Funds } \\
\text { administered } \\
\text { from this } \\
\text { source in PY } \\
2008\end{array}$} & \multicolumn{2}{|c|}{$\mathbf{C}$} & \multirow[b]{3}{*}{$\begin{array}{l}\text { Total funds } \\
\text { administered } \\
\text { from this } \\
\text { source in PY } \\
2010\end{array}$} & $\mathbf{E}$ & $\mathbf{F}$ & G & $\mathbf{H}$ & I \\
\hline & & \multirow{2}{*}{\multicolumn{2}{|c|}{$\begin{array}{l}\text { Did state } \\
\text { administer } \\
\text { weatherization } \\
\text { funds from } \\
\text { this source in } \\
\text { PY } 2010\end{array}$}} & & \multicolumn{2}{|c|}{$\begin{array}{l}\text { Funds retained and spent by } \\
\text { state }\end{array}$} & \multicolumn{3}{|c|}{ Funds passed on to subgrantees } \\
\hline & & & & & $\begin{array}{c}\text { Grantee } \\
\text { administration } \\
\text { and } \\
\text { leveraging }\end{array}$ & $\begin{array}{l}\text { Grantee } \\
\text { training and } \\
\text { technical } \\
\text { assistance } \\
\text { (T\&TA) }\end{array}$ & $\begin{array}{l}\text { Subgrantee } \\
\text { funding for } \\
\text { program } \\
\text { operations }^{2}\end{array}$ & $\begin{array}{c}\text { Subgrantee } \\
\text { administration } \\
\text { and leveraging }\end{array}$ & $\begin{array}{c}\text { Subgrantee } \\
\text { training and } \\
\text { technical } \\
\text { assistance } \\
\text { (T\&TA) }\end{array}$ \\
\hline $\mathrm{DOE}^{1}$ & $\begin{array}{l}\text { Pre- } \\
\text { populated }\end{array}$ & $\begin{array}{l}\text { Yes } \\
\text { No }\end{array}$ & $\begin{array}{l}\square \\
\square\end{array}$ & $\leftarrow$ Selecting & "no" will & gray out all & columns to the & right in & online survey \\
\hline LIHEAP & $\begin{array}{l}\text { Pre- } \\
\text { populated }\end{array}$ & $\begin{array}{l}\text { Yes } \\
\text { No }\end{array}$ & $\begin{array}{l}\square \\
\square\end{array}$ & $\leftarrow$ Selecting & "yes" will & drive skip & patterns in & Q1b-13 & \\
\hline $\begin{array}{l}\text { Petroleum } \\
\text { Violation Escrow } \\
\text { (PVE) }\end{array}$ & $\begin{array}{l}\text { Pre- } \\
\text { populated }\end{array}$ & & $\begin{array}{l}\square \\
\square\end{array}$ & & & & & & \\
\hline $\begin{array}{l}\text { Other Federal } \\
\text { Programs }\end{array}$ & $\begin{array}{l}\text { Pre- } \\
\text { populated }\end{array}$ & $\begin{array}{l}\text { Yes } \\
\text { No }\end{array}$ & $\begin{array}{l}\square \\
\square\end{array}$ & & & & & & \\
\hline $\begin{array}{l}\text { State Public } \\
\text { Benefit Funds }\end{array}$ & $\begin{array}{l}\text { Pre- } \\
\text { populated }\end{array}$ & $\begin{array}{l}\text { Yes } \\
\text { No }\end{array}$ & $\begin{array}{l}\square \\
\square\end{array}$ & & & & & & \\
\hline $\begin{array}{l}\text { Other State } \\
\text { Programs }\end{array}$ & $\begin{array}{l}\text { Pre- } \\
\text { populated }\end{array}$ & $\begin{array}{l}\text { Yes } \\
\text { No }\end{array}$ & $\begin{array}{l}\square \\
\square\end{array}$ & & & & & & \\
\hline Utilities & $\begin{array}{l}\text { Pre- } \\
\text { populated }\end{array}$ & $\begin{array}{l}\text { Yes } \\
\text { No }\end{array}$ & $\begin{array}{l}\square \\
\square\end{array}$ & & & & & & \\
\hline Program Income & $\begin{array}{l}\text { Pre- } \\
\text { populated }\end{array}$ & $\begin{array}{l}\text { Yes } \\
\text { No }\end{array}$ & $\begin{array}{l}\square \\
\square\end{array}$ & & & & & & \\
\hline In-Kind & $\begin{array}{l}\text { Pre- } \\
\text { populated }\end{array}$ & $\begin{array}{l}\text { Yes } \\
\text { No }\end{array}$ & $\begin{array}{l}\square \\
\square \\
\end{array}$ & & & & & & \\
\hline Non-Profits & $\begin{array}{l}\text { Pre- } \\
\text { populated }\end{array}$ & $\begin{array}{l}\text { Yes } \\
\text { No }\end{array}$ & $\begin{array}{l}\square \\
\square\end{array}$ & & & & & & \\
\hline $\begin{array}{l}\text { Third Party } \\
\text { (e.g., Foundations, } \\
\text { Lenders) }\end{array}$ & $\begin{array}{l}\text { Pre- } \\
\text { populated }\end{array}$ & & $\begin{array}{l}\square \\
\square\end{array}$ & & & & & & \\
\hline $\begin{array}{l}\text { All other } \\
\text { (Please specify) }\end{array}$ & $\begin{array}{l}\text { Pre- } \\
\text { populated }\end{array}$ & $\begin{array}{l}\text { Yes } \\
\text { No }\end{array}$ & $\begin{array}{l}\square \\
\square\end{array}$ & & & & & & \\
\hline$\overline{\text { TOTAL }}$ & $\begin{array}{l}\text { Pre- } \\
\text { populated }\end{array}$ & & & & & & & & \\
\hline
\end{tabular}


1a. Of the Program Year 2010 funds retained by your state's weatherization program for management functions, how much was used for each function listed below?

\begin{tabular}{|l|l|}
\hline \multicolumn{1}{|c|}{ Type of Management Function } & Total \\
\hline Administration* & \\
\hline Agency monitoring & \\
\hline Other (specify) & \\
\hline TOTAL & \\
\hline
\end{tabular}

* Includes planning, finance and accounting, clerical support, outreach, and evaluation.

[1b will be activated by 'yes' responses in the associated funding categories of Question 1 and skipped for any 'no' responses in those categories].

1b. In the categories below, please specify the name of each funder and the total amount of weatherization funding provided in PY 2010.

\begin{tabular}{|c|c|c|}
\hline & $\begin{array}{c}\text { Funding entity } \\
\text { (please enter names) }\end{array}$ & $\begin{array}{c}\text { Total weatherization funding } \\
\text { administered in PY 2010 } \\
\text { (please enter amounts) }\end{array}$ \\
\hline Utilities & & \\
\hline Utility 1 & & \\
\hline Utility 2 & & \\
\hline Utility 3 & & \\
\hline All other utilities & & \\
\hline In-kind contributions & & \\
\hline In-kind 1 & & \\
\hline In-kind 2 & & \\
\hline In-kind 3 & & \\
\hline All other in-kind & & \\
\hline Nonprofits & & \\
\hline Nonprofit 1 & & \\
\hline Nonprofit 2 & & \\
\hline Nonprofit 3 & & \\
\hline All other nonprofits & & \\
\hline Other & & \\
\hline Other 1 & & \\
\hline Other 2 & & \\
\hline Other 3 & & \\
\hline All others & & \\
\hline
\end{tabular}


[Q2 will be activated by 'yes' responses in the LIHEAP category of Question 1 and deactivated (skipped) for 'no' responses in that category.]

2a. When did you first receive weatherization funds from LIHEAP?

2b. If known, number of years that state worked to achieve this leveraging relationship (leave blank if unknown):

2c. Please describe the change in the leveraging relationship between your state's low-income weatherization program and LIHEAP during the ARRA period.

Extremely positive

Positive

No change

Negative

Extremely negative

2d. How do you expect leveraged funding from this source to change from PY 2010 to the postARRA period in PY 2012? increase decrease stay the same

2e. If leveraged funding from LIHEAP decreased from PY 2008, was the change attributable to increased ARRA funding?

Yes

No

Not applicable

2f. Did you require local agencies to follow DOE rules when spending weatherization funds from LIHEAP in PY 2010?

Yes

No

[2g will appear if respondent answered ' $\mathrm{no}$ ' in 2f]

$2 \mathrm{~g}$. What were the major differences in the rules governing the expenditure of LIHEAP funds in comparison to the rules governing the expenditure of DOE funds?

[Q3 will be activated by 'yes' responses in the PVE category of Question 1 and deactivated (skipped) for 'no' responses in that category.]

3a. When did state first receive weatherization funds from Petroleum Violation Escrow (PVE)?

3b. If known, number of years that state worked to achieve this leveraging relationship (leave blank if unknown): 
3c. Please describe the change in leveraging relationships between your state's low-income weatherization program and PVE during the ARRA period.

Extremely positive

Positive

No change

Negative

Extremely Negative

3d. How do you expect leveraged funding from this source to change from PY 2010 to the postARRA period in PY 2012? increase decrease stay the same

3e. If leveraged funding from PVE decreased from PY 2008, was the change attributable to increased ARRA funding? Yes

No

Not applicable

3f. Did you require local agencies to follow DOE rules when spending weatherization funds from PVE in PY 2010?

Yes

No

[ $3 \mathrm{~g}$ will appear if respondent answered ' $\mathrm{no}$ ' in $3 \mathrm{f}$ ]

$3 \mathrm{~g}$. What were the major differences in the rules governing the expenditure of PVE funds in comparison to the rules governing the expenditure of DOE funds?

[Q4 will be activated by 'yes' responses in the Other Federal Programs category of Question 1 and deactivated (skipped) for ' $n o$ ' responses in that category.]

4a. When did state first receive weatherization funds from Other Federal Programs?

4b. If known, number of years that state worked to achieve this leveraging relationship (leave blank if unknown):

4c. Please describe the change in leveraging relationships between your state's low-income weatherization program and Other Federal Programs during the ARRA period.

Extremely positive

Positive

No change

Negative

Extremely Negative 
4d. How do you expect leveraged funding from this source to change from PY 2010 to the postARRA period in PY 2012? increase decrease stay the same

4e. If leveraged funding from Other Federal Programs decreased from PY 2008, was the change attributable to increased ARRA funding?

Yes

No

Not applicable

4f. Did you require local agencies to follow DOE rules when spending weatherization funds from Other Federal Programs in PY 2010?

Yes

No

[ $4 \mathrm{~g}$ will appear if respondent answered ' $\mathrm{no}$ ' in $4 \mathrm{f}$ ]

$4 \mathrm{~g}$. What were the major differences in the rules governing the expenditure of Other Federal Programs funds in comparison to the rules governing the expenditure of DOE funds?

[Q5 will be activated by 'yes' responses in the State Public Benefit Funds category of Question 1 and deactivated (skipped) for 'no' responses in that category.]

5a. When did state first receive weatherization funds from State Public Benefit Funds?

5b. If known, number of years that state worked to achieve this leveraging relationship (leave blank if unknown):

5c. Please describe the change in leveraging relationships between your state's low-income weatherization program and State Public Benefit Funds during the ARRA period.

Extremely positive

Positive

No change

Negative

Extremely Negative

5d. How do you expect leveraged funding from this source to change from PY 2010 to the postARRA period in PY 2012? increase decrease stay the same 
5e. If leveraged funding from State Public Benefit Funds decreased from PY 2008, was the change attributable to increased ARRA funding?

Yes

No

Not applicable

5f. Did you require local agencies to follow DOE rules when spending weatherization funds from State Public Benefit Funds in PY 2010?

Yes

No

[5g will appear if respondent answered ' $n o$ ' in 5f]

$5 \mathrm{~g}$. What were the major differences in the rules governing the expenditure of State Public Benefit Funds in comparison to the rules governing the expenditure of DOE funds?

[Q6 will be activated by 'yes' responses in the Other State Programs category of Question 1 and deactivated (skipped) for 'no' responses in that category.]

6a. When did state first receive weatherization funds from Other State Programs?

6b. If known, number of years that state worked to achieve this leveraging relationship (leave blank if unknown):

6c. Please describe the change in leveraging relationships between your state's low-income weatherization program and Other State Programs during the ARRA period. Extremely positive Positive No change Negative Extremely Negative

6d. How do you expect leveraged funding from this source to change from PY 2010 to the postARRA period in PY 2012? increase decrease stay the same

6e. If leveraged funding from Other State Programs decreased from PY 2008, was the change attributable to increased ARRA funding? Yes No Not applicable

6f. Did you require local agencies to follow DOE rules when spending weatherization funds from Other State Programs in PY 2010? 
Yes

No

[6g will appear if respondent answered ' $\mathrm{no}$ ' in 6f]

$6 \mathrm{~g}$. What were the major differences in the rules governing the expenditure of Other State Programs funds in comparison to the rules governing the expenditure of DOE funds?

[Q7 will be activated by 'yes' responses in the Utilities category of Question 1 and deactivated (skipped) for 'no' responses in that category.]

7a. When did state first receive weatherization funds from Utilities?

7b. If known, number of years that state worked to achieve this leveraging relationship (leave blank if unknown):

7c. Please describe the change in leveraging relationships between your state's low-income weatherization program and Utilities during the ARRA period.

Extremely positive

Positive

No change

Negative

Extremely Negative

7d. How do you expect leveraged funding from this source to change from PY 2010 to the postARRA period in PY 2012? increase decrease stay the same

7e. If leveraged funding from Utilities decreased from PY 2008, was the change attributable to increased ARRA funding?

Yes

No

Not applicable

7f. Did you require local agencies to follow DOE rules when spending weatherization funds from Utilities in PY 2010?

Yes

No

[7g will appear if respondent answered ' $\mathrm{no}$ ' in 7f]

$7 \mathrm{~g}$. What were the major differences in the rules governing the expenditure of Utilities

funds in comparison to the rules governing the expenditure of DOE funds? 
[Q8 will be activated by 'yes' responses in the Program Income category of Question 1 and deactivated (skipped) for 'no' responses in that category.]

8a. When did state first receive weatherization funds from Program Income?

8b. If known, number of years that state worked to achieve this leveraging relationship (leave blank if unknown):

8c. Please describe the change in leveraging relationships between your state's low-income weatherization program and Program Income during the ARRA period.

Extremely positive

Positive

No change

Negative

Extremely Negative

8d. How do you expect leveraged funding from this source to change from PY 2010 to the postARRA period in PY 2012? increase decrease stay the same

8e. If leveraged funding from Program Income decreased from PY 2008, was the change attributable to increased ARRA funding?

Yes

No

Not applicable

8f. Did you require local agencies to follow DOE rules when spending weatherization funds from Program Income in PY 2010?

Yes

No

[8g will appear if respondent answered ' $\mathrm{no}$ ' in 8f]

$8 \mathrm{~g}$. What were the major differences in the rules governing the expenditure of Program Income funds in comparison to the rules governing the expenditure of DOE funds?

[Q9 will be activated by 'yes' responses in the In-Kind Contributions category of Question 1 and deactivated (skipped) for ' $n$ o' responses in that category.]

9a. When did state first receive weatherization funds from In-Kind Contributions?

9b. If known, number of years that state worked to achieve this leveraging relationship (leave blank if unknown): 
9c. Please describe the change in leveraging relationships between your state's low-income weatherization program and In-Kind Contributions during the ARRA period.

Extremely positive

Positive

No change

Negative

Extremely Negative

9d. How do you expect leveraged funding from this source to change from PY 2010 to the postARRA period in PY 2012? increase decrease stay the same

9e. If leveraged funding from In-Kind Contributions decreased from PY 2008, was the change attributable to increased ARRA funding?

Yes

No

Not applicable

9f. Did you require local agencies to follow DOE rules when spending weatherization funds from In-Kind Contributions in PY 2010?

Yes

No

[9g will appear if respondent answered ' $\mathrm{no}$ ' in 9f]

$9 \mathrm{~g}$. What were the major differences in the rules governing the expenditure of In-Kind Contributions in comparison to the rules governing the expenditure of DOE funds?

[Q10 will be activated by 'yes' responses in the Non-profits category of Question 1 and deactivated (skipped) for 'no' responses in that category.]

10a. When did state first receive weatherization funds from Non-profits?

10b. If known, number of years that state worked to achieve this leveraging relationship (leave blank if unknown):

10c. Please describe the change in leveraging relationships between your state's low-income weatherization program and Non-profits during the ARRA period.

Extremely positive

Positive

No change

Negative

Extremely Negative 
10d. How do you expect leveraged funding from this source to change from PY 2010 to the postARRA period in PY 2012? increase decrease stay the same

10e. If leveraged funding from Non-Profits decreased from PY 2008, was the change attributable to increased ARRA funding?

Yes

No

Not applicable

10f. Did you require local agencies to follow DOE rules when spending weatherization funds from Non-Profits in PY 2010?

Yes

No

[10g will appear if respondent answered ' $\mathrm{no}$ ' in 10f]

$10 \mathrm{~g}$. What were the major differences in the rules governing the expenditure of Non-

Profits funds in comparison to the rules governing the expenditure of DOE funds?

[Q11 will be activated by 'yes' responses in the Third Party category of Question 1 and deactivated (skipped) for 'no' responses in that category.]

11a. When did state first receive weatherization funds from Third Parties (foundations, lenders)?

11b. If known, number of years that state worked to achieve this leveraging relationship (leave blank if unknown):

11c. Please describe the change in leveraging relationships between your state's low-income weatherization program and Third Parties during the ARRA period.

Extremely positive

Positive

No change

Negative

Extremely Negative

11d. How do you expect leveraged funding from this source to change from PY 2010 to the postARRA period in PY 2012? increase decrease stay the same 
11e. If leveraged funding from Third Parties decreased from PY 2008, was the change attributable to increased ARRA funding?

Yes

No

Not applicable

11f. Did you require local agencies to follow DOE rules when spending weatherization funds from Third Parties in PY 2010?

Yes

No

[11g will appear if respondent answered ' $\mathrm{no}$ ' in 11f]

$11 \mathrm{~g}$. What were the major differences in the rules governing the expenditure of Third Party funds in comparison to the rules governing the expenditure of DOE funds?

[Q12 will be activated by 'yes' responses in All Other, Specify category of Question 1 and deactivated (skipped) for 'no' responses in that category.]

12a. When did state first receive weatherization funds from [insert text from 'All Other, Specify']?

12b. If known, number of years that state worked to achieve this leveraging relationship (leave blank if unknown):

12c. Please describe the change in leveraging relationships between your state's low-income weatherization program and [insert text from 'All Other, Specify'] during the ARRA period. Extremely positive

Positive

No change

Negative

Extremely Negative

12d. How do you expect leveraged funding from this source to change from PY 2010 to the postARRA period in PY 2012? increase decrease stay the same

12e. If leveraged funding from [insert text from 'All Other, Specify'] decreased from PY 2008, was the change attributable to increased ARRA funding?

Yes No

Not applicable 
12f. Did you require local agencies to follow DOE rules when spending weatherization funds from [insert text from 'All Other, Specify'] in PY 2010?

Yes

No

[12g will appear if respondent answered 'no' in 12f]

$12 \mathrm{~g}$. What were the major differences in the rules governing the expenditure of [insert text from 'All Other, Specify'] funds in comparison to the rules governing the expenditure of DOE funds?

13. You indicated your state did not administer leveraged funding from the sources listed below during PY 2010. For each funding source, please indicate your expectations for funding during the post-ARRA period beginning in PY 2012.

\begin{tabular}{|l|c|c|c|c|}
\hline & \multicolumn{4}{|c|}{ Expectations for funding in the post-ARRA period beginning in } \\
& & \multicolumn{3}{c|}{ PY 2012 } \\
\cline { 2 - 5 } & Funding will & $\begin{array}{c}\text { Funding will } \\
\text { increase } \\
\text { increase }\end{array}$ & \\
\hline $\begin{array}{l}\text { Fopunding Soutly } \\
\text { in Q1 }\end{array}$ & $\square$ & $\square$ & Uncertain \\
\hline $\begin{array}{l}\text { Populate from 'no' response } \\
\text { in Q1 }\end{array}$ & $\square$ & $\square$ & $\square$ & $\square$ \\
\hline $\begin{array}{l}\text { Populate from 'no' response } \\
\text { in Q1 }\end{array}$ & $\square$ & $\square$ & $\square$ & $\square$ \\
\hline $\begin{array}{l}\text { Populate from 'no' response } \\
\text { in Q1 }\end{array}$ & $\square$ & $\square$ & $\square$ & $\square$ \\
\hline
\end{tabular}

14. How important were leveraged funds for your State's Weatherization Program in PY 2010 compared to program years without additional ARRA funding? (Check best answer)

Very important

Important

Not very important

Not important at all

15. Did your state set aside funding to advocate for leveraged resources in PY 2010 ?

Yes

No (Go to Question 9)

16. What organizations advocated for leveraged resources in PY 2010? (Check all that apply)

Your state office

Your state's agencies

Non-profit organizations funded by your state

Other

17. How successful would you rate your state's efforts to acquire leveraged funds in PY 2010 ?

(Check best answer) 
Very successful

Successful

Not very successful

Not successful at all

State does not seek leveraged funds

18. What factors limited the success of your state's efforts to acquire leveraged funding in PY 2010 ?

19. Have you modified your state's weatherization program practices or regulations since PY 2008 to facilitate spending and reporting on leveraged resources?

Yes

No

20. Overall, how has the influx of ARRA funding impacted previously existing leveraging relationships?

a. Extremely positive impact

b. Positive impact

c. No Impact

d. Negative impact

e. Extremely negative impact

21. Can leveraging relationships damaged or lost during ARRA be re-built post-ARRA?

a. Yes, absolutely

b. Yes, probably

c. Uncertain

d. No, probably not

e. No, definitely not

22. Do you see state-level Renewable Portfolio Standards programs benefitting low-income weatherization? If so, how? If not, why not?

23. What aspects about your state's low-income weatherization program are most misunderstood by actual and potential leveraging partners?

24. How has your program worked to overcome these misunderstandings?

25. What information would your state's weatherization program like to have that could be used to overcome these misunderstandings?

26. What other information would your state's weatherization program like to have that could be used to 'sell' leveraging relationships?

27. Overall, what is your expectation for total state leveraged funding for low-income weatherization funding post ARRA in PY 2012 (post- ARRA) compared to PY 2008 (preARRA)?

a. Greatly increased 
b. Increased

c. Same level

d. Decreased

e. Greatly decreased

28. On balance, how beneficial do you think ARRA funding will prove to be over the longerterm on your state's ability to leverage DOE WAP-program funding for low-income weatherization?

a. Extremely beneficial

b. Beneficial

c. No long-term impact

d. Unbeneficial

e. Extremely unbeneficial

\section{PROGRAM OPERATIONS AND IMPLEMENTATION}

1. Using the following scale, how adequate was the Program Year 2010 funding received by your state from ALL funding sources for weatherizing the stock of eligible low-income dwelling units in your state in a timely fashion? (Check all that apply) Very Adequate Adequate Inadequate Very Inadequate

2. What was the quality of the management support that your state received from DOE and its contractors in Program Year 2010? (Check all that apply) very high quality high quality moderate quality low quality very low quality not applicable

3. What was the quality of the training that your state received from DOE and its contractors in Program Year 2010? (Check all that apply) very high quality high quality moderate quality low quality very low quality not applicable

4. What was the quality of the support and assistance on client education that your state received from DOE and its contractors in Program Year 2010? (Check all that apply) very high quality high quality moderate quality 
low quality

very low quality

not applicable

4a. If appropriate, why did you rate the quality very low or low?

5. What was the quality of the support and assistance on leveraging the Weatherization Assistance Program funding provided by DOE with other funding sources in Program Year 2010? (Check all that apply) very high quality high quality moderate quality low quality very low quality not applicable

5a. If appropriate, why did you rate the quality very low or low?

6. What was the quality of the technical support (e.g., measure selection and installation) that your state received from DOE and its contractors in Program Year 2010? (Check all that apply)

very high quality

high quality moderate quality low quality very low quality not applicable

6a. If appropriate, why did you rate the quality very low or low?

7. How flexible did you find the DOE program rules that governed the weatherization program in Program Year 2010? In other words, did the program rules allow your state to tailor your program to your needs (very flexible) or proscribe your program to only one way of operation (very inflexible)? (Check all that apply)

Very Flexible

Flexible

Inflexible

Very Inflexible 
7a. Using PY 2010 as the reference point, how should the program rules change? (One)

Become much more flexible

Become more flexible

Stay about the same

Become more inflexible

Become much more inflexible

7b. In what areas should the program rules become more flexible?

7c. In what areas should the program rules become less flexible?

8. Please describe any important political issues faced by your state's weatherization program in Program Year 2010.

9. At this point in time, does your state need the following (Check any needed items):

Additional administrative support and assistance from DOE

Improved training from DOE and its contractors

Additional assistance from DOE and its contractors with leveraging resources

Improved technical support from DOE and its contractors

Additional funding for the delivery of weatherization services

Improved data and information systems for the delivery of weatherization services

Additional assistance to develop and administer client education programs

\section{PROGRAM IMPLEMENTATION DURING THE ARRA PERIOD}

1. During the ARRA period, has your state added any new local weatherization agencies (i.e., sub-grantees) to its low-income weatherization program?

a. Yes

b. No (Skip to Question 4)

2. How many new local weatherization agencies were added?

3. Why were these agencies added? (check all that apply)

a. To meet increased production targets

b. To replace non-performing subgrantees

c. To build synergies between the state weatherization program and other community service programs in community action agencies that did not provide weatherization services

d. Other 
4. For many years, the national weatherization network and the state-level national weatherization networks had been relatively stable. During the ARRA period, beyond subgrantees, did the composition of your state-level weatherization network change?

a. Yes

b. No (Skip to Question 8)

5. How would you characterize the magnitude of this change?

a. Extreme

b. Great

c. Moderate

d. Small

6. Using the table below, please list the names and contributions of up to ten major new players.

\begin{tabular}{|l|l|}
\hline Name & $\begin{array}{l}\text { Description of Weatherization Related Contributions (e.g., } \\
\text { provides training, sells energy efficient products ) }\end{array}$ \\
\hline & \\
\hline & \\
\hline & \\
\hline & \\
\hline & \\
\hline & \\
\hline & \\
\hline & \\
\hline & \\
\hline
\end{tabular}

7. Please rate the quality of services and products provided by the new major players:

a. very high quality

b. high quality

c. fair quality

d. low quality

e. very low quality

8. Please provide your best estimate for how many new low-income weatherization-related businesses were created in your state during the ARRA period:

a. none

b. $1-10$

c. $11-20$

d. $21-30$

e. $30+$

f. don't know

9. How have private companies new to the weatherization network tried to change state and local weatherization procedures during the ARRA period? 
10. On balance, how beneficial have these new players been to your state's weatherization program?
a. Extremely beneficial
b. Beneficial
c. Neither beneficial nor unbeneficial
d. Unbeneficial
e. Extremely unbeneficial
Please Explain

11. During the ARRA period, did organizational responsibilities for your state's weatherization program (e.g., reporting lines, organizational home) change?
a. Yes
b. No (Skip to Question 13)

12. How did the organizational responsibilities change? Please Explain

13. How have relationships changed between your state weatherization office and local weatherization agencies during ARRA?
a. become much more congenial
b. become more congenial
c. no changes
d. become more strained
e. become much more strained

14. Which statement best describes how the existing local weatherization agencies (i.e., subgrantees) dealt with program expansion during the ARRA period?
a. promoted existing weatherization staff to management positions and hired new entry level workers
b. hired new weatherization managers and hired new entry level workers
c. promoted existing weatherization staff to management positions and hired contractors to ramp up production
d. hired contractors to ramp up production

15. Were there any material, equipment or other supply chain bottlenecks during the ARRA period that negatively impacted weatherization production in your state?
a. No
b. Yes
If yes, what was in short supply?

16. To what extent have large DOE/OWIP programs, WAP, State Energy Program, and Energy Efficiency Community Block Grant Program competed for labor during the ARRA period?
a. Not at all
b. a small extent
c. a moderate extent
d. a large extent
e. a very large extent 
17. During the ARRA period, how has state-level oversight of your state's weatherization assistance program changed?
a. Greatly increased
b. Increased
c. Stayed the same
d. Decreased
e. Greatly decreased

18. Has ARRA funding allowed your state program to purchase and implement new information technologies to improve program administration?
a. Yes
b. No
If yes, please describe these new information technologies.

19 During PY 2010, how much of a burden were your state program's administrative costs allocated to dealing with increased oversight during the ARRA period (e.g., from DOE IG, $\mathrm{GAO})$ ?
a. no burden
b. slight burden
c. moderate burden
d. substantial burden
e. extreme burden

20. Did your state change its audit approach during the ARRA-period from the approach used pre-ARRA (i.e., PY2008)?
a. Yes, went from priority list to computerized audit
b. Yes, went from computerized audit to priority list
c. Yes, changed from one computerized audit tool to another
d. No
e. Other

21. During the ARRA period, has your state passed any new laws and/or implemented any new regulations that have directly impacted your state's weatherization assistance program?
a. Yes
b. No (Skip to Question 25)

22. Please describe the new laws and/or regulations.

23. On balance, how beneficial have these new laws and/or regulations been to your state's weatherization program?
a. Extremely beneficial
b. Beneficial
c. Neither beneficial nor unbeneficial
d. Unbeneficial
e. Extremely unbeneficial
Please explain 
24. Would these laws and/or regulations have been passed without the increased attention on the program attributable to ARRA?
a. No, Wholly due to ARRA
b. No, Primarily due to ARRA
c. No, Somewhat due to ARRA
d. Yes, Would have been passed anyway without ARRA

25. Did your state change the way it provides technical assistance to its subgrantees during the ARRA period?
a. No
b. Yes
If yes, how?

26. Has your state implemented new certification requirements for weatherization workers during the ARRA period?

a. No (go to Q28)

b. Yes

27. What new certifications are required? (Check all that apply)

a. BPI Building Analyst

b. BPI Envelope

c. BPI Residential Building Envelope Accessible Areas Air Leakage Control Installer

d. Residential Building Envelope Whole House Air Leakage Control Crew Chief

e. BPI Manufactured Housing

f. BPI Heating

g. BPI Air Conditioning and Heat Pump

h. BPI Multifamily

i. HERS

j. LEED

k. Lead Safe Weatherization

1. Lead Certified Renovator

m. NAHB Green Building

n. Other

28. Which statement best describes changes in the level of employment in your state resulting from Davis-Bacon?

a. large number of jobs created

b. small number of jobs created

c. no change in the number of jobs

d. small number of jobs lost

e. large number of jobs lost

f. don't know 
29. Which statement best describes the impact of Davis-Bacon on wages paid to weatherization workers in your state?
a. large increase in wages (over $10 \%$ increase)
b. moderate increase in wages (between 5 and $10 \%$ increase)
c. small increase in wages (between 1 and $5 \%$ increase)
d. no increase in wages
e. small decrease in wages(between 1 and $5 \%$ decrease)
f. moderate decrease in wages(between 5 and $10 \%$ decrease)
g. large decrease in wages (over $10 \%$ decrease)

30. How much of a problem was there in your state in coordinating wages stipulated by DavisBacon for local weatherization agencies whose operations spanned multiple counties?
a. no problem
b. small problem
c. moderate problem
d. large problem
e. very large problem

31. In your state, on average, how much did Davis-Bacon rules increase the cost of weatherizing low-income multifamily buildings four stories and higher?
a. no increase
b. $1-10 \%$
c. $11-20 \%$
d. $21-30 \%$
e. $31+\%$
f. N/A

32. Overall, how did Davis-Bacon impact the costs of weatherization in your state?
a. greatly increased costs
b. increased costs
c. no change in costs
d. decreased costs
e. greatly decreased costs

33. Does your state allow the weatherization of large low-income multi-family buildings?
a. yes
b. no
If not, why not? 
34. What are the barriers to weatherizing large low-income multi-family buildings in your state? (check all that apply)
a. lack of trained auditors
b. lack of trained crew
c. too expensive
d. building owners are uncooperative
e. energy savings are not high enough
f. unclear guidance from DOE or other agencies on owner contributions
g. other

35. Does your state allow the weatherization of public housing, that is, housing owned by a public housing authority?
a. Yes
b. No
If not, why not?

36. Does your state allow the weatherization of HUD assisted housing?

a. Yes

b. No

If not, why not?

37. How many units of each type were weatherized in your state in PY 2010?

\begin{tabular}{|l|l|l|l|}
\hline Type of Housing & $\begin{array}{l}\text { Large Multi-family } \\
\text { (Not Public Housing or } \\
\text { HUD Assisted }\end{array}$ & $\begin{array}{l}\text { Public Housing Multi- } \\
\text { family }\end{array}$ & $\begin{array}{l}\text { HUD Assisted Multi- } \\
\text { family }\end{array}$ \\
\hline & & & \\
\hline
\end{tabular}

38. Are there any DOE rules that could be changed to make it easier to weatherize large lowincome multi-family buildings?

a. Yes. Describe:

b. No

39. Does your state's weatherization program have an agreement with your State Historic Preservation Office (SHPO)?
a. Yes
b. No

40. What percentage of units weatherized in PY 2010 fell under the SHPO agreement?
a. 0
b. $1-5$
c. $6-10$
d. $11-15$
e. $15+$ 
41. Has low-income weatherization had an impact in preventing home foreclosures in your state during the ARRA period?
a. no
b. little impact
c. moderate impact
d. great impact
e. very great impact
f. don't know

42. Does your state have a deferral policy?
a. Yes
b. No

43. Please estimate the number of units where weatherization was deferred during PY 2010 ?
a. $0 \%$
b. $1-5 \%$
c. $6-10 \%$
d. $10-20 \%$
e. $21-30 \%$
f. more than $30 \%$

44. Please estimate what percentage of units where weatherization was deferred during PY 2010 will eventually be weatherized?
a. $0 \%$
b. $1-25 \%$
c. $26-50 \%$
d. $51-75 \%$
e. $76-90 \%$
f. $91-100 \%$

45. Please describe your states deferral rates in PY2010 compared to PY2008:
a. very great increase
b. great increase
c. increase
d. no change
e. decrease
f. great decrease
g. very great decrease

46. How has the visibility of your state's weatherization program changed vis-à-vis state elected officials during the ARRA period?
a. greatly increased
b. increased
c. no change
d. decreased
e. greatly decreased 
47. How has the visibility of your state's weatherization program changed vis-à-vis the general public during the ARRA period?
a. greatly increased
b. increased
c. no change
d. decreased
e. greatly decreased

48. Please rate the quality of the media coverage your state's weatherization program has received during the ARRA period?
a. very high quality
b. high quality
c. moderate quality
d. low quality
e. very low quality
f. N/A no media coverage (skip to 52)
g. no opinion

49. Please describe the overall media coverage of your state's weatherization program during the ARRA period:
a. very positive
b. positive
c. neither positive or negative
d. negative
e. very negative

50. What topics did the media mainly focus on? (check all that apply)
a. Jobs created
b. Energy saved
c. Helping low income households
d. waste, fraud and abuse
e. Lack of energy savings
f. Organizational mis-steps
g. Other

51. Will weatherization issues identified rightly or wrongly by the media during ARRA have lasting impacts on leveraging weatherization funding for your state in the future?
a. could substantially reduce funding
b. could reduce funding
c. no impact
d. could increase funding
e. could substantially increase funding 
52. On balance, how beneficial has been the attention paid to your state's weatherization program during the ARRA period?
a. Extremely beneficial
b. Beneficial
c. Neither beneficial nor unbeneficial
d. Unbeneficial
e. Extremely unbeneficial

53. Please explain

\section{TRAINING}

1. For those staff working in your state's weatherization office who need to have knowledge about the following list of weatherization topics, how well trained were they in each area in PY 2010? Please use the following scale: 1 - not at all well trained; 2 - not well trained; 3 moderately well trained; 4 -well trained; 5 - very well trained; 6 - not applicable Circle best answer.

(1) Diagnostic procedures

(2) Insulation

-- single family dwellings

-- multifamily dwellings

-- mobile homes

(3) Space heating, ventilation, air conditioning

-- single family dwellings

-- multifamily dwellings

-- mobile homes

(4) Infiltration measures

-- single family dwellings

-- multifamily dwellings

-- mobile homes

(5) Doors and windows

-- single family dwellings

-- multifamily dwellings

-- mobile homes

(6) Hot water heating

-- single family dwellings

-- multifamily dwellings

-- mobile homes

(7) Baseloads (e.g., lighting, refrigerators)

-- single family dwellings

-- multifamily dwellings

-- mobile homes

$\begin{array}{llllll}1 & 2 & 3 & 4 & 5 & 6 \\ 1 & 2 & 3 & 4 & 5 & 6 \\ 1 & 2 & 3 & 4 & 5 & 6 \\ 1 & 2 & 3 & 4 & 5 & 6 \\ & & & & & \\ 1 & 2 & 3 & 4 & 5 & 6 \\ 1 & 2 & 3 & 4 & 5 & 6 \\ 1 & 2 & 3 & 4 & 5 & 6 \\ & & & & & \\ 1 & 2 & 3 & 4 & 5 & 6 \\ 1 & 2 & 3 & 4 & 5 & 6 \\ 1 & 2 & 3 & 4 & 5 & 6 \\ & & & & & \\ 1 & 2 & 3 & 4 & 5 & 6 \\ 1 & 2 & 3 & 4 & 5 & 6 \\ 1 & 2 & 3 & 4 & 5 & 6\end{array}$

$\begin{array}{llllll}1 & 2 & 3 & 4 & 5 & 6 \\ 1 & 2 & 3 & 4 & 5 & 6 \\ 1 & 2 & 3 & 4 & 5 & 6\end{array}$

$\begin{array}{llllll}1 & 2 & 3 & 4 & 5 & 6 \\ 1 & 2 & 3 & 4 & 5 & 6 \\ 1 & 2 & 3 & 4 & 5 & 6\end{array}$


1a. For those staff working in your state's weatherization office who need to have knowledge about the following list of administrative-related topics, how well trained were they in each area? Please use the following scale: 1 - not at all well trained; 2 - not well trained; 3 - moderately well trained; 4 -well trained; 5 - very well trained; 6 - not applicable Circle best answer.

(1) Management

(2) Client education

$\begin{array}{llllll}1 & 2 & 3 & 4 & 5 & 6 \\ 1 & 2 & 3 & 4 & 5 & 6 \\ 1 & 2 & 3 & 4 & 5 & 6 \\ 1 & 2 & 3 & 4 & 5 & 6 \\ 1 & 2 & 3 & 4 & 5 & 6 \\ 1 & 2 & 3 & 4 & 5 & 6 \\ 1 & 2 & 3 & 4 & 5 & 6 \\ 1 & 2 & 3 & 4 & 5 & 6 \\ 1 & 2 & 3 & 4 & 5 & 6\end{array}$

(4) Monitoring/quality control

(5) Financial topics

(6) Outreach and communications

(7) Other (please specify)

$$
\begin{aligned}
& \text {-- single family dwellings } \\
& \text {-- multifamily dwellings } \\
& \text {-- mobile homes }
\end{aligned}
$$

1b. For those staff working in your state's weatherization office who need to have knowledge about the following list of health and safety topics, how well trained were they in each area? Please use the following scale: 1 - not at all well trained; 2 - not well trained; 3 - moderately well trained; 4 -well trained; 5 - very well trained; 6 - not applicable Circle best answer.
(1) Fire safety
(2) Indoor air quality
(3) Measures to increase security of housing unit
(4) Measures to reduce common household hazards
(5) Mold and mildew
(6) Lead
(7) Asbestos
(8) Vermiculite
(9) General crew safety
(10) Other health and safety
(11) Other (please specify

$\begin{array}{llllll}1 & 2 & 3 & 4 & 5 & 6 \\ 1 & 2 & 3 & 4 & 5 & 6 \\ 1 & 2 & 3 & 4 & 5 & 6 \\ 1 & 2 & 3 & 4 & 5 & 6 \\ 1 & 2 & 3 & 4 & 5 & 6 \\ 1 & 2 & 3 & 4 & 5 & 6 \\ 1 & 2 & 3 & 4 & 5 & 6 \\ 1 & 2 & 3 & 4 & 5 & 6 \\ 1 & 2 & 3 & 4 & 5 & 6 \\ 1 & 2 & 3 & 4 & 5 & 6 \\ 1 & 2 & 3 & 4 & 5 & 6\end{array}$

1c. For categories receiving answers of (1)-not at all well trained, or (2)-not well trained to the above questions, what were the barriers for receiving this training:
a. Funding
b. Time
c. Not a priority
d. Not available
e. Other 
2. On which of the following weatherization subjects did staff working in your state's weatherization office receive training in Program Year 2010 from DOE, your state, or other entities? (Check all that apply)

(1) Diagnostic procedures

(2) Insulation

-- single family dwellings

-- multifamily dwellings

-- mobile homes

(3) Space heating, ventilation, air conditioning

-- single family dwellings

-- multifamily dwellings

-- mobile homes

(4) Infiltration measures

-- single family dwellings

-- multifamily dwellings

-- mobile homes

(5) Doors and windows

-- single family dwellings

-- multifamily dwellings

-- mobile homes

(6) Hot water heating

-- single family dwellings

-- multifamily dwellings

-- mobile homes

(7) Baseloads (e.g., lighting, refrigerators)

-- single family dwellings

-- multifamily dwellings

-- mobile homes

2a. On which administration-related topics did staff working in your state's weatherization office receive training in Program Year 2010 from DOE, your state, or other entities? (Check all that apply)

(1) Management

(2) Client education

(3) Auditing/estimating

-- single family dwellings

-- multifamily dwellings

-- mobile homes

(4) Monitoring/quality control

(5) Financial topics

(6) Outreach and communications

(7) Other (please specify) 
2b. On which health and safety topics did staff working in your state's weatherization office receive training in Program Year 2010 from DOE, your state, or other entities? (Check all that apply.)

Fire safety

Indoor air quality

Measures to increase security of housing unit

Measures to reduce common household hazards

Mold and mildew

Lead

Asbestos

Vermiculite

General crew safety

Other health and safety

Other (please specify 
3. For those staff working in your state's weatherization office who need to have knowledge about the following list of diagnostic topics, how well trained were they in each area in PY 2010? Please use the following scale: 1 - not at all well trained; 2 - not well trained; 3 moderately well trained; 4 -well trained; 5 - very well trained; 6 - not applicable Circle best answer.

\section{Pressure diagnostics:}

- Blower door (house air leakage rate)

- Zonal pressure measurements

- Room-to-room pressure measurements

- Duct pressure pan measurements

- Duct blower measurements (duct air leakage rate)

Space-heating system:

- Flue gas analysis (steady-state efficiency measurements) $1 \quad 2 \quad 3 \quad 3 \quad 4 \quad 56$

- Heat rise measurements

- CO measurements in flues

- Draft/spillage (normal operation)

Air-conditioning system:

- Refrigerant charge (e.g., superheat, subcooling)

HVAC components and cross-cutting diagnostics:

- Air handler flow rate

- Thermostat anticipator current

- Worst case draft/spillage (CAZ)

$\begin{array}{llllll}1 & 2 & 3 & 4 & 5 & 6 \\ 1 & 2 & 3 & 4 & 5 & 6 \\ 1 & 2 & 3 & 4 & 5 & 6 \\ 1 & 2 & 3 & 4 & 5 & 6 \\ 1 & 2 & 3 & 4 & 5 & 6\end{array}$

Hot-water (water-heating) system:

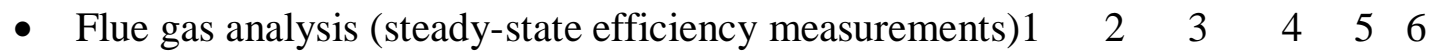

- CO measurements in flues

- Draft/spillage (normal operation)

- Water flow rates (showerheads and faucets)

Other CO measurements:

- $\mathrm{CO}$ measurements in equipment rooms

- Cooking stove

- CO measurements in living areas

Other diagnostics and inspections:

- Refrigerator energy use

- Exhaust fan air flow rate measurement

- Infrared scanning (camera)

- Radon testing

- Lead testing

- Mold and mildew testing

- Moisture context testing

- Other (please specify)

$\begin{array}{llllll}1 & 2 & 3 & 4 & 5 & 6\end{array}$

$\begin{array}{llllll}1 & 2 & 3 & 4 & 5 & 6\end{array}$

$\begin{array}{llllll}1 & 2 & 3 & 4 & 5 & 6\end{array}$

$\begin{array}{llllll}1 & 2 & 3 & 4 & 5 & 6\end{array}$

$\begin{array}{llllll}1 & 2 & 3 & 4 & 5 & 6\end{array}$

$\begin{array}{llllll}1 & 2 & 3 & 4 & 5 & 6\end{array}$

$\begin{array}{llllll}1 & 2 & 3 & 4 & 5 & 6\end{array}$

$\begin{array}{llllll}1 & 2 & 3 & 4 & 5 & 6\end{array}$

$\begin{array}{llllll}1 & 2 & 3 & 4 & 5 & 6\end{array}$

$\begin{array}{llllll}1 & 2 & 3 & 4 & 5 & 6\end{array}$

$\begin{array}{llllll}1 & 2 & 3 & 4 & 5 & 6\end{array}$

$\begin{array}{llllll}1 & 2 & 3 & 4 & 5 & 6\end{array}$

$\begin{array}{llllll}1 & 2 & 3 & 4 & 5 & 6\end{array}$

$\begin{array}{llllll}1 & 2 & 3 & 4 & 5 & 6\end{array}$

$\begin{array}{llllll}1 & 2 & 3 & 4 & 5 & 6\end{array}$

$\begin{array}{llllll}1 & 2 & 3 & 4 & 5 & 6\end{array}$

$\begin{array}{llllll}1 & 2 & 3 & 4 & 5 & 6\end{array}$

$\begin{array}{llllll}1 & 2 & 3 & 4 & 5 & 6\end{array}$

$\begin{array}{llllll}1 & 2 & 3 & 4 & 5 & 6\end{array}$

$\begin{array}{llllll}1 & 2 & 3 & 4 & 5 & 6\end{array}$

$\begin{array}{llllll}1 & 2 & 3 & 4 & 5 & 6\end{array}$ 
3a. For categories receiving answers of (1)-not at all well trained, or (2)-not well trained to the above question, what were the barriers for receiving this training:
a. Funding
b. Time
c. Not a priority
d. Not available
e. Other

4. On which of the following diagnostic procedures did staff working in your state's weatherization office receive training in Program Year 2010 from DOE, your state, or other entities? (Check all that apply.)

\section{Pressure diagnostics:}

- Blower door (house air leakage rate)

- Zonal pressure measurements

- Room-to-room pressure measurements (distribution balancing)

- Duct pressure pan measurements

- Duct blower measurements (duct air leakage rate)

Space-heating system:

- Flue gas analysis (steady-state efficiency measurements)

- Heat rise measurements

- CO measurements in flues

- Draft/spillage (normal operation)

Air-conditioning system:

- Refrigerant charge (e.g., superheat, subcooling)

HVAC components and cross-cutting diagnostics:

- Air handler flow rate

- Thermostat anticipator current

- Worst case draft/spillage (CAZ)

Hot-water (water-heating) system:

- Flue gas analysis (steady-state efficiency measurements)

- CO measurements in flues

- Draft/spillage (normal operation)

- Water flow rates (showerheads and faucets)

Other CO measurements:

- $\mathrm{CO}$ measurements in equipment rooms

- Cooking stove

- $\mathrm{CO}$ measurements in living areas

Other diagnostics and inspections:

- Refrigerator energy use

- Exhaust fan air flow rate measurement

- Infrared scanning (camera)

- Radon testing

- Lead testing

- Mold and mildew testing

- Moisture context testing 
- Other (please specify) 
5. For each broad subject listed in the left-most column of the following table, put a check mark in the appropriate cell(s) to indicate which training method(s) you believe were most effective for imparting key skills and information in that area to your state's in-house staff and any nonagency staff supporting the state program who work under contract to the state in PY 2010:

\begin{tabular}{|l|l|l|l|l|l|l|}
\hline \multicolumn{1}{|c|}{ Subject } & Conferences & $\begin{array}{c}\text { Primarily } \\
\text { Classroom } \\
\text { Training }\end{array}$ & $\begin{array}{c}\text { Primarily } \\
\text { Field } \\
\text { Training }\end{array}$ & $\begin{array}{c}\text { In-person } \\
\text { expert } \\
\text { visits }\end{array}$ & Web casts & Other (specify) \\
\hline Management & & & & & & \\
\hline $\begin{array}{l}\text { Weatherization skills } \\
\text { and methods }\end{array}$ & & & & & & \\
\hline $\begin{array}{l}\text { Auditing/Estimating/ } \\
\text { Measure selection }\end{array}$ & & & & & & \\
\hline $\begin{array}{l}\text { Monitoring and } \\
\text { quality control }\end{array}$ & & & & & & \\
\hline Financial topics & & & & & & \\
\hline $\begin{array}{l}\text { Outreach and } \\
\text { communications }\end{array}$ & & & & & & \\
\hline Health and safety & & & & & & \\
\hline $\begin{array}{l}\text { Diagnostic } \\
\text { procedures }\end{array}$ & & & & & & \\
\hline Client education & & & & & & \\
\hline Other (specify) & & & & & & \\
\hline
\end{tabular}


6. For each broad subject listed in the left-most column of the following table, please indicate the quality of training received in Program Year 2010 at the training venues listed in the column headings. Please leave cells blank were your in-house staff did not receive training during this period of time. Please use the following scale: 1-very low; 2 - low; 3-medium; 4- high; 5-very high

\begin{tabular}{|l|l|l|l|l|l|l|}
\hline & $\begin{array}{c}\text { National } \\
\text { Weatherization } \\
\text { Program } \\
\text { Conference }\end{array}$ & $\begin{array}{c}\text { Affordable } \\
\text { Comfort } \\
\text { Conference }\end{array}$ & $\begin{array}{c}\text { Regional } \\
\text { Weatherization } \\
\text { Conference }\end{array}$ & $\begin{array}{c}\text { State } \\
\text { Weatherization } \\
\text { Conference }\end{array}$ & $\begin{array}{c}\text { State/ } \\
\text { Tegional } \\
\text { Center }\end{array}$ & $\begin{array}{c}\text { Training } \\
\text { Provided by } \\
\text { Your Own } \\
\text { State }\end{array}$ \\
\hline Subject & & & & & & \\
\hline Management & & & & & & \\
\hline $\begin{array}{l}\text { Weatherization skills } \\
\text { and methods }\end{array}$ & & & & & & \\
\hline $\begin{array}{l}\text { Auditing/ } \\
\text { Estimating }\end{array}$ & & & & & & \\
\hline $\begin{array}{l}\text { Monitoring/ } \\
\text { quality control }\end{array}$ & & & & & & \\
\hline Financial topics & & & & & & \\
\hline $\begin{array}{l}\text { Outreach and } \\
\text { communications }\end{array}$ & & & & & & \\
\hline Health and safety & & & & & & \\
\hline $\begin{array}{l}\text { Diagnostic } \\
\text { procedures }\end{array}$ & & & & & & \\
\hline $\begin{array}{l}\text { Procedures for } \\
\text { selecting } \\
\text { weatherization } \\
\text { measures }\end{array}$ & & & & & & \\
\hline Client education & & & & & & \\
\hline \begin{tabular}{l} 
Other (specify) \\
\hline
\end{tabular} & & & & & & \\
\hline
\end{tabular}


7. On which of the following weatherization topics did your state provide training to your state's local weatherization agencies or their contractors in Program Year 2010? (Check all that apply)

(1) Diagnostic procedures

(2) Insulation

-- single family dwellings

-- multifamily dwellings

-- mobile homes

(3) Space heating, ventilation, air conditioning

-- single family dwellings

-- multifamily dwellings

-- mobile homes

(4) Infiltration measures

-- single family dwellings

-- multifamily dwellings

-- mobile homes

(5) Doors and windows

-- single family dwellings

-- multifamily dwellings

-- mobile homes

(6) Hot water heating

-- single family dwellings

-- multifamily dwellings

-- mobile homes

(7) Baseloads (e.g., lighting, refrigerators)

-- single family dwellings

-- multifamily dwellings

-- mobile homes

7a. On which of the following administrative-related topics did your state provide training to your state's local weatherization agencies or their contractors in Program Year 2010? (Check all that apply)

(1) Management

(2) Client education

(3) Auditing/estimating

-- single family dwellings

-- multifamily dwellings

-- mobile homes

(4) Monitoring/quality control

(5) Financial topics

(6) Outreach and communications

(7) Other (please specify) 
7b. On which of the following health and safety topics did your state provide training to your state's local weatherization agencies or their contractors in Program Year 2010? (Check all that apply)

Fire safety

Indoor air quality

Measures to increase security of housing unit

Measures to reduce common household hazards

Mold and mildew

Lead

Asbestos

Vermiculite

General crew safety

Other health and safety

Other (please specify) 
8. On which of the following diagnostic procedures did your state provide training to your state's local weatherization agencies or their contractors in Program Year 2010? (Check all that apply)

Pressure diagnostics:

- Blower door (house air leakage rate)

- Zonal pressure measurements

- Room-to-room pressure measurements (distribution balancing)

- Duct pressure pan measurements

- Duct blower measurements (duct air leakage rate)

Space-heating system:

- Flue gas analysis (steady-state efficiency measurements)

- Heat rise measurements

- CO measurements in flues

- Draft/spillage (normal operation)

Air-conditioning system:

- Refrigerant charge (e.g., superheat, subcooling)

HVAC components and cross-cutting diagnostics:

- Air handler flow rate

- Thermostat anticipator current

- Worst case draft/spillage (CAZ)

Hot-water (water-heating) system:

- Flue gas analysis (steady-state efficiency measurements)

- CO measurements in flues

- Draft/spillage (normal operation)

- Water flow rates (showerheads and faucets)

Other CO measurements:

- $\mathrm{CO}$ measurements in equipment rooms

- Cooking stove

- CO measurements in living areas

Other diagnostics and inspections:

- Refrigerator energy use

- Exhaust fan air flow rate measurement

- Infrared scanning (camera)

- Radon testing

- Lead testing

- Mold and mildew testing

- Moisture context testing

- Other (please specify) 
9. Which of the following types of personnel did your state use to provide training to your state's local weatherization agencies or their contractors in Program Year 2010? (Check all that apply)

- DOE staff

- DOE contractor

- State staff

- State contractor

- Staff from another state

- State training center staff

- Local agency staff from your state

- Agency staff from another state

- Manufacturer representative

- Utility staff

- Representative from trade organization

- Consultant

- Other (please specify)

10. What types of credentials or experience were required of the personnel your state used to provide training to your state's local weatherization agencies or their contractors in Program Year 2010? (Check all that apply)

- Technical certification

- Extensive weatherization field experience

- Construction experience

- Extensive management experience

- Extensive experience with financial matters

- Other (please specify)

10a. Using the scale below, please indicate how important each credential was for trainers to have in PY 2010?

1= Very Unimportant; 2=Unimportant; 3=Important; 4=Very Important

- Technical certification

- Extensive weatherization field experience

- Construction experience

- Extensive management experience

- Extensive experience with financial matters

- Other (please specify) 
11. How many of your state's weatherization office staff acted as instructors at the following training events that your state provided (e.g., funded, organized) to your state's local weatherization agencies or their contractors in Program Year 2010?

- State weatherization conference

- Other state conference

- State/regional training center class

- State-sponsored class taught at central location

- In-person expert visit (e.g., peer exchange, consultant)

- Instruction given to individual agency during an agency visit

- Web cast

- Other (please specify)

12. For each broad subject listed in the left-most column of the following table, put a check mark in the appropriate cell(s) to indicate which training method(s) you believe were most effective for imparting key skills and information in that area to your local weatherization agencies or their contractors in PY 2010:

\begin{tabular}{|l|l|l|l|l|l|l|l|l|}
\hline \multicolumn{1}{|c|}{ Subject } & $\begin{array}{c}\text { State } \\
\text { weatheriza } \\
\text { tion } \\
\text { conference }\end{array}$ & $\begin{array}{c}\text { Other state } \\
\text { conference }\end{array}$ & $\begin{array}{c}\text { State/ } \\
\text { regional } \\
\text { training } \\
\text { center } \\
\text { class }\end{array}$ & $\begin{array}{c}\text { State- } \\
\text { sponsored } \\
\text { class } \\
\text { taught at } \\
\text { central } \\
\text { location }\end{array}$ & $\begin{array}{c}\text { In- } \\
\text { person } \\
\text { expert } \\
\text { visit }\end{array}$ & $\begin{array}{c}\text { Instruction } \\
\text { given to } \\
\text { individual } \\
\text { agency }\end{array}$ & $\begin{array}{c}\text { Web } \\
\text { casts }\end{array}$ & $\begin{array}{c}\text { Other } \\
\text { (specify) }\end{array}$ \\
\hline Management & & & & & & & & \\
\hline $\begin{array}{l}\text { Weatherization skills } \\
\text { and methods }\end{array}$ & & & & & & & & \\
\hline $\begin{array}{l}\text { Auditing/Estimating/ } \\
\text { Measure selection }\end{array}$ & & & & & & & & \\
\hline $\begin{array}{l}\text { Monitoring and } \\
\text { quality control }\end{array}$ & & & & & & & & \\
\hline Financial topics & & & & & & & & \\
\hline $\begin{array}{l}\text { Outreach and } \\
\text { communications }\end{array}$ & & & & & & & & \\
\hline Health and safety & & & & & & & & \\
\hline Diagnostic procedures & & & & & & & & \\
\hline Client education & & & & & & & & \\
\hline Other (specify) & & & & & & & & \\
\hline
\end{tabular}


13. On average, how well trained were local weatherization crews (both agency and contractor) in your state in the following weatherization topics in PY 2010? Please use the following scale: 1- not at all well trained; 2 - not well trained; 3 - moderately well trained; 4 -well trained; 5 very well trained; 6 - not applicable Circle best answer.
(1) Diagnostic procedures
(2) Insulation
-- single family dwellings
-- multifamily dwellings
-- mobile homes

$\begin{array}{llllll}1 & 2 & 3 & 4 & 5 & 6 \\ 1 & 2 & 3 & 4 & 5 & 6 \\ 1 & 2 & 3 & 4 & 5 & 6 \\ 1 & 2 & 3 & 4 & 5 & 6\end{array}$

(3) Space heating, ventilation, air conditioning

-- single family dwellings

-- multifamily dwellings

-- mobile homes

(4) Infiltration measures

-- single family dwellings

-- multifamily dwellings

-- mobile homes

(5) Doors and windows

-- single family dwellings

-- multifamily dwellings

-- mobile homes

(6) Hot water heating

-- single family dwellings

-- multifamily dwellings

-- mobile homes

(7) Baseloads (e.g., lighting, refrigerators)

-- single family dwellings

-- multifamily dwellings

-- mobile homes

$\begin{array}{llllll}1 & 2 & 3 & 4 & 5 & 6 \\ 1 & 2 & 3 & 4 & 5 & 6 \\ 1 & 2 & 3 & 4 & 5 & 6\end{array}$

$\begin{array}{llllll}1 & 2 & 3 & 4 & 5 & 6 \\ 1 & 2 & 3 & 4 & 5 & 6 \\ 1 & 2 & 3 & 4 & 5 & 6\end{array}$

$\begin{array}{llllll}1 & 2 & 3 & 4 & 5 & 6 \\ 1 & 2 & 3 & 4 & 5 & 6 \\ 1 & 2 & 3 & 4 & 5 & 6\end{array}$

$\begin{array}{llllll}1 & 2 & 3 & 4 & 5 & 6 \\ 1 & 2 & 3 & 4 & 5 & 6 \\ 1 & 2 & 3 & 4 & 5 & 6\end{array}$

13a. On average, how well trained were local weatherization crews (both agency and contractor) in your state in the following administrative-related topics in PY 2010? Please use the following scale: 1 - not at all well trained; 2 - not well trained; 3 - moderately well trained; 4 -well trained; 5 - very well trained; 6 - not applicable Circle best answer.
(1) Management
(2) Client education

$\begin{array}{lll}1 & 2 & 3 \\ 1 & 2 & 3\end{array}$

$\begin{array}{lll}4 & 5 & 6 \\ 4 & 5 & 6\end{array}$
(3) Auditing/estimating
-- single family dwellings
-- multifamily dwellings
-- mobile homes
(4) Monitoring/quality control
(5) Financial topics
(6) Outreach and communications
(7) Other (please specify)

$\begin{array}{llllll}1 & 2 & 3 & 4 & 5 & 6 \\ 1 & 2 & 3 & 4 & 5 & 6 \\ 1 & 2 & 3 & 4 & 5 & 6 \\ 1 & 2 & 3 & 4 & 5 & 6 \\ 1 & 2 & 3 & 4 & 5 & 6 \\ 1 & 2 & 3 & 4 & 5 & 6 \\ 1 & 2 & 3 & 4 & 5 & 6\end{array}$


13b. On average, how well trained were local weatherization crews (both agency and contractor) in your state in the following health and safety topics in PY 2010? Please use the following scale: 1 - not at all well trained; 2 - not well trained; 3 - moderately well trained; 4 -well trained; 5 - very well trained; 6 - not applicable Circle best answer.

(1) Fire safety

(2) Indoor air quality

(3) Measures to increase security of housing unit

(4) Measures to reduce common household hazards

(5) Mold and mildew

(6) Lead

(7) Asbestos

(8) Vermiculite

(9) General crew safety

(10) Other health and safety

(11) Other (please specify

$\begin{array}{llllll}1 & 2 & 3 & 4 & 5 & 6 \\ 1 & 2 & 3 & 4 & 5 & 6 \\ 1 & 2 & 3 & 4 & 5 & 6 \\ 1 & 2 & 3 & 4 & 5 & 6 \\ 1 & 2 & 3 & 4 & 5 & 6 \\ 1 & 2 & 3 & 4 & 5 & 6 \\ 1 & 2 & 3 & 4 & 5 & 6 \\ 1 & 2 & 3 & 4 & 5 & 6 \\ 1 & 2 & 3 & 4 & 5 & 6 \\ 1 & 2 & 3 & 4 & 5 & 6 \\ 1 & 2 & 3 & 4 & 5 & 6\end{array}$

13c. For categories receiving answers of (1)-not at all well trained, or (2)-not well trained to the above question, what were the barriers for receiving this training:
a. Funding
b. Time
c. Not a priority
d. Not available
e. Other

14. Overall, how well trained were your state's weatherization crews in PY 2010? (Check best answer)

Very well trained

Well trained

Moderately well trained

Poorly trained

Very poorly trained

\section{MONITORING}

1. About how many state weatherization office staff went into the field to monitor local weatherization agencies in your state in Program Year 2010? \{Note: do not include people who do quality assurance at the local agency level for the local agencies.\}

- State staff

- State contractors

- Other (please specify) 
2. Which of the following types of post-weatherization quality control inspection did your state perform on weatherized dwelling units in Program Year 2010? (Check all that apply)

- Visual inspection of installed measures

- Verification of insulation depths/quantities

- Verification of operation of measures installed

- Assessment of quality of measures installed

- Identification of needed measures that were not installed

- Blower door test

- Heating system efficiency test (flue gas analysis)

- Draft/spillage tests of heating systems

- Carbon monoxide (CO) monitoring

- Infrared scanning

- Identification of unresolved health and safety issues

- Discussion with occupants

- Other (specify)

3. Please indicate which types of post-weatherization quality control inspection listed below were initiated since ARRA PY 2009. (Check all that apply)

- Visual inspection of installed measures

- Verification of insulation depths/quantities

- Verification of operation of measures installed

- Assessment of quality of measures installed

- Identification of needed measures that were not installed

- Blower door test

- Heating system efficiency test (flue gas analysis)

- Draft/spillage tests of heating systems

- Carbon monoxide (CO) monitoring

- Infrared scanning

- Identification of unresolved health and safety issues

- Discussion with occupants

- Other (specify) 
4. Please indicate the cost, the amount of training needed, the amount of time needed and the effectiveness of the following types of post-weatherization quality control inspection procedures relative to each other for PY 2010. Please use the following scale: 1 - very low; 2 - low; 3 - medium; 4 - high; 5 - very high.

\begin{tabular}{|l|l|l|l|l|}
\hline $\begin{array}{l}\text { Type of Post-Weatherization Quality } \\
\text { Control Inspection }\end{array}$ & Cost & $\begin{array}{c}\text { Training } \\
\text { Needed }\end{array}$ & $\begin{array}{c}\text { Time } \\
\text { Needed }\end{array}$ & Effectiveness \\
\hline Visual inspection of installed measures & & & & \\
\hline Verification of insulation depths/quantities & & & & \\
\hline $\begin{array}{l}\text { Verification of operation of measures } \\
\text { installed }\end{array}$ & & & & \\
\hline Assessment of quality of measures installed & & & & \\
\hline $\begin{array}{l}\text { Identification of needed measures that were } \\
\text { not installed }\end{array}$ & & & & \\
\hline Blower door test & & & & \\
\hline $\begin{array}{l}\text { Heating system efficiency test (flue gas } \\
\text { analysis) }\end{array}$ & & & & \\
\hline Draft/spillage tests of heating systems & & & & \\
\hline Carbon monoxide (CO) monitoring & & & & \\
\hline Infrared scanning & & & & \\
\hline $\begin{array}{l}\text { Identification of unresolved health and } \\
\text { safety issues }\end{array}$ & & & & \\
\hline Discussion with occupants & & & & \\
\hline Other (specify) & & & & \\
\hline
\end{tabular}

5. On average, how many hours were spent by state weatherization office staff on-site conducting post-weatherization quality control in a typical weatherized home in Program Year 2010?

6. What types of credentials or experience were required of your post-weatherization quality control inspectors in your state weatherization office in Program Year 2010? (Check all that apply)

- Technical certification

- Extensive experience performing pre-weatherization audits

- Extensive experience performing weatherization work

- Extensive experience supervising weatherization work

- Construction experience

- Other (please specify) 
7. Please indicate their level of experience of the post-weatherization quality control inspectors in your state weatherization office for each of the following areas in Program Year 2010.

\begin{tabular}{|l|l|l|l|l|l|}
\hline & $\begin{array}{c}\text { Very } \\
\text { High }\end{array}$ & High & Medium & Low & $\begin{array}{l}\text { Very } \\
\text { Low }\end{array}$ \\
\hline Performing pre-weatherization audits & & & & & \\
\hline Performing weatherization work & & & & & \\
\hline Supervising weatherization work & & & & & \\
\hline Working in construction & & & & & \\
\hline $\begin{array}{l}\text { Performing post-weatherization } \\
\text { inspections }\end{array}$ & & & & & \\
\hline Other (specify) & & & & & \\
\hline
\end{tabular}

8. On average, how frequently did state weatherization program office staff visit each local agency to conduct post-weatherization quality control inspections in Program Year 2010? (Check best answer)

Weekly
Monthly
Quarterly
Annually
Other (please specify)

9. On how many dwelling units did your state perform post-weatherization quality control inspections in Program Year 2010?

9a. Of those inspected, approximately how many were found to have a problem significant enough to require a return visit by local agency weatherization crews?

9b. Of those requiring a return visit, how many had work done that probably resulted in more energy savings?

9c. What were the three most common problems found in the dwelling units inspected by your state in Program Year 2010?

10. In those cases where a Program Year 2010 post-weatherization quality control inspection revealed a problem with the job performed, what single action was most commonly taken in response to that finding? (Check best answer)

- Made agency send crew back to correct problem

- Made agency send crew supervisor to correct problem

- Sent someone from state office to correct problem

- No action taken

- Other (please specify) 
11. What other actions were taken in Program Year 2010 in response to the discovery of a problem with the weatherization job performed? (Check all that apply)

- Made agency send original crew back to correct problem

- Made agency send different crew to correct problem

- Made agency send crew supervisor to correct problem

- Sent someone from state office to correct problem

- No action taken

- Other (please specify)

12. How often did the inspection reveal a misuse of the priority list?
a. Never
b. $1-5 \%$ of the time
c. $6-10 \%$ of the time
d. $11-20 \%$ of the time
e. More than $20 \%$ of the time
f. N/A

13. How often did the inspection reveal a misuse of the computer audit?
a. Never
b. $1-5 \%$ of the time
c. $6-10 \%$ of the time
d. $11-20 \%$ of the time
e. More than $20 \%$ of the time
f. N/A

14. Which of the following monitoring tasks did your state perform in Program Year 2010 to check on the administration of local weatherization efforts? (Check all that apply)

- Verification of number of dwelling units weatherized

- Verification of clients' income eligibility

- Verification of average expenditure per weatherized unit

- Verification of material expenditures

- Verification that installed measures had an SIR of 1.0 or greater

- Examination of vehicle costs

- Examination of other equipment costs

- Examination of training and technical assistance (T\&TA) costs

- Examination of administrative costs

- Examination of material inventory

- Interviews with agency staff

- Interviews with agency contractor staff

- Interviews with agency clients

- Other (please specify) 
15. Please indicate which types of monitoring tasks listed below were initiated since ARRA to PY 2009. (Check all that apply)

- Verification of number of dwelling units weatherized

- Verification of clients' income eligibility

- Verification of average expenditure per weatherized unit

- Verification of material expenditures

- Verification that installed measures had an SIR of 1.0 or greater

- Examination of vehicle costs

- Examination of other equipment costs

- Examination of training and technical assistance (T\&TA) costs

- Examination of administrative costs

- Examination of material inventory

- Interviews with agency staff

- Interviews with agency contractor staff

- Interviews with agency clients

- Other (please specify) 
16. Please indicate the cost, the amount of training needed, the amount of time needed and the effectiveness of the following types of monitoring tasks relative to each other for PY 2010. Please use the following scale: 1 - very low; 2 -- low; 3 - moderate; 4 -high; 5 - very high.

\begin{tabular}{|l|l|l|l|l|}
\hline Type of Monitoring Tasks & Cost & $\begin{array}{c}\text { Training } \\
\text { Needed }\end{array}$ & $\begin{array}{c}\text { Time } \\
\text { Needed }\end{array}$ & Effectiveness \\
\hline $\begin{array}{l}\text { Verification of number of dwelling units } \\
\text { weatherized }\end{array}$ & & & & \\
\hline Verification of clients' income eligibility & & & & \\
\hline $\begin{array}{l}\text { Verification of average expenditure per } \\
\text { weatherized unit }\end{array}$ & & & & \\
\hline Verification of material expenditures & & & & \\
\hline $\begin{array}{l}\text { Verification that installed measures had an } \\
\text { SIR of 1.0 or greater }\end{array}$ & & & & \\
\hline Examination of vehicle costs & & & & \\
\hline Examination of other equipment costs & & & & \\
\hline $\begin{array}{l}\text { Examination of training and technical } \\
\text { assistance (T\&TA) costs }\end{array}$ & & & & \\
\hline Examination of administrative costs & & & & \\
\hline Examination of material inventory & & & & \\
\hline Interviews with agency staff & & & & \\
\hline Interviews with agency contractor staff & & & & \\
\hline Interviews with agency clients & & & & \\
\hline Other (specify) & & & \\
\hline
\end{tabular}

17. On average, how many hours were spent by state weatherization office staff on-site at each local agency monitoring agency administrative activities in Program Year 2010?

18. What types of credentials or experience were required of those who monitored the administration of local weatherization efforts in your state in Program Year 2010? Check all that apply.

- Technical certification

- Extensive experience performing pre-weatherization audits

- Extensive experience performing weatherization work

- Extensive experience supervising weatherization work

- Construction experience

- Extensive management experience

- Extensive finance experience

- Extensive experience administering local weatherization programs

- Other (please specify) 
19. Please indicate their level of experience of the local agency monitors in your state weatherization office for each of the following areas in Program Year 2010.

\begin{tabular}{|l|l|l|l|l|l|}
\hline & $\begin{array}{c}\text { Very } \\
\text { High }\end{array}$ & High & Moderate & Low & $\begin{array}{l}\text { Very } \\
\text { Low }\end{array}$ \\
\hline Management & & & & & \\
\hline Finance & & & & & \\
\hline $\begin{array}{l}\text { Administration of local weatherization } \\
\text { programs }\end{array}$ & & & & & \\
\hline Other (specify) & & & & & \\
\hline
\end{tabular}

20. On average, how frequently did state weatherization program office staff visit each local agency to monitor administrative activities in Program Year 2010? (Check best answer)

Weekly
Monthly
Quarterly
Annually
Other (please specify)

21. For how many of the local weatherization agencies monitored in your state in Program Year 2010 was an administrative problem found that required corrective actions above and beyond acceptable findings and recommendations?

22. What were the three most common problems requiring corrective actions above and beyond acceptable findings and recommendations found in the local weatherization agencies monitored in your state in Program Year 2010?

23. In those cases where state monitoring of the administration of local weatherization efforts in Program Year 2010 revealed an administrative problem requiring corrective actions above and beyond acceptable findings and recommendations, what actions were taken in response? (Check all that apply)

- Sent written report to local agency

- Required corrective action

- Made presentation to local agency

- Sent someone from state office to help correct problem

- Sent state contractor to help correct problem

- No action taken

- Other (please specify) 
24 Did the observation of problems with the quality of weatherization work lead to changes in weatherization training for local agency staff?

Yes

No

24a. If Yes, what changes were made?

25. Does your state observe weatherization training sessions to help identify potential problem areas for monitoring in the field (e.g., with respect to installation of measures that trainees seem to have trouble understanding)?

Yes

No

25a. If Yes, briefly describe how your in-field monitoring activities were affected by your training session observations. 
OMB Control Number: XXXX-XXXX

\section{APPENDIX D -- S2: ALL AGENCIES PROGRAM INFORMATION SURVEY}

This data is being collected to conduct a process evaluation of the Weatherization Assistance Program at the local level. The data you supply will be used to characterize the program in Program Year 2010, unless otherwise noted.

Public reporting burden for this collection of information is estimated to average eight hours per response, including the time for reviewing instructions, searching existing data sources, gathering and maintaining the data needed, and completing and reviewing the collection of information. Send comments regarding this burden estimate or any other aspect of this collection of information, including suggestions for reducing this burden, to Office of the Chief Information Officer, Records Management Division, IM-11, Paperwork Reduction Project (XXXX-XXXX), U.S. Department of Energy, 1000 Independence Ave SW, Washington, DC, 20585-1290; and to the Office of Management and Budget (OMB), OIRA, Paperwork Reduction Project (XXXX-XXXX), Washington, DC 20503.

All of the information obtained from this survey will be protected and will remain confidential. The data will be analyzed in such a way that the information provided cannot be associated back to your state, your agencies, or the housing units and clients that your state served. Again, please note that the questions refer to PY 2010 unless otherwise noted.

\section{Part 1. General Information}

1. Please identify your state.

2. Please identify your local agency.

3. Which of the following best characterizes your agency? (Please check the one answer that best applies):

Local Non-Profit Organization

Local Government Agency

County Government Agency

Indian Tribe

Other entity not eligible for CSBG funding

Other (please specify)

4. For how many years had the current director of your local Weatherization Program served in that capacity prior to PY 2010? 
5. What agency, office, or department was responsible for reviewing the performance of your local Weatherization Program in PY 2010?

6. How many layers of management or supervision were there between your weatherization crews and the director of your local Weatherization Program in PY 2010? [If your weatherization crews reported directly to the Program director, the answer should be 0.]

7. Please indicate other energy-related, housing, and other programs that cooperated with your agency's weatherization program, by source of funding in PY 2010. Please check all that apply.

Type of Program

Federal

State

Utility

Other

Funding

Funding

Funding

Funding

Energy bill paying assistance

Housing re-habilitation

Home emergency repairs

Hardship funds (other than

for energy bill paying)

Fuel delivery in crisis

Fair housing

Health and safety

Energy education (other than

client education delivered by

weatherization program)

Home buying education

Rehabilitation loan

Mortgage loan

Emergency food

Emergency safety

Other (please specify)

Other (please specify)

Other (please specify)

Other (please specify)

Other (please specify)

Other (please specify) 


\section{Part 2. Leveraging}

\section{Please list weatherization funding received during PY 2010 by completing the table below.}

Column A lists potential sources of weatherization funding. As a reference, Column B lists the amount of PY 2008 funding reported by your agency in the retrospective evaluation S2 survey. If the PY 2008 funding amount is incorrect, please list the correct amount in Column B. In Column C, please indicate whether your agency received funding from each source in PY 2010. In Column D, enter the total funding amount received in PY 2010 from each source received. Please allocate the total funding amount listed in Column D to the sub-categories listed in Columns E through G.

\begin{tabular}{|c|c|c|c|c|c|c|c|}
\hline $\mathbf{A}$ & B & \multicolumn{2}{|c|}{$\mathbf{C}$} & D & $\mathbf{E}$ & $\mathbf{F}$ & $\mathbf{G}$ \\
\hline Funding source & $\begin{array}{l}\text { Funds } \\
\text { received from } \\
\text { this source in } \\
\text { PY } 2008\end{array}$ & \multicolumn{2}{|c|}{$\begin{array}{c}\text { Did agency } \\
\text { receive } \\
\text { weatherizati } \\
\text { on funds } \\
\text { from this } \\
\text { source in PY } \\
2010 ? \\
\end{array}$} & $\begin{array}{l}\text { Total funds } \\
\text { received from } \\
\text { this source in } \\
\text { PY } 2010\end{array}$ & $\begin{array}{c}\text { Funding for } \\
\text { program } \\
\text { operations }\end{array}$ & $\begin{array}{l}\text { Funding for } \\
\text { administration/ } \\
\text { program } \\
\text { management }\end{array}$ & $\begin{array}{c}\text { Funding for } \\
\text { training and } \\
\text { technical } \\
\text { assistance } \\
\text { (T\&TA) }\end{array}$ \\
\hline $\mathrm{DOE}^{1}$ & $\begin{array}{l}\text { Pre- } \\
\text { populated }\end{array}$ & $\begin{array}{l}\text { Yes } \\
\text { No }\end{array}$ & $\begin{array}{l}\square \\
\square\end{array}$ & $\leftarrow$ Selecting & no will gray & columns to & right \\
\hline LIHEAP & $\begin{array}{l}\text { Pre- } \\
\text { populated }\end{array}$ & $\begin{array}{l}\text { Yes } \\
\text { No }\end{array}$ & $\begin{array}{l}\square \\
\square\end{array}$ & $\leftarrow$ Selecting & yes will drive & skip patterns & in Q12-23 \\
\hline $\begin{array}{l}\text { Petroleum } \\
\text { Violation Escrow } \\
(\mathrm{PVE})\end{array}$ & $\begin{array}{l}\text { Pre- } \\
\text { populated }\end{array}$ & $\begin{array}{l}\text { Yes } \\
\text { No }\end{array}$ & $\begin{array}{l}\square \\
\square\end{array}$ & & & & \\
\hline $\begin{array}{l}\text { Other Federal } \\
\text { Programs }\end{array}$ & $\begin{array}{l}\text { Pre- } \\
\text { populated }\end{array}$ & $\begin{array}{l}\text { Yes } \\
\text { No }\end{array}$ & $\begin{array}{l}\square \\
\square\end{array}$ & & & & \\
\hline $\begin{array}{l}\text { State Public } \\
\text { Benefit Funds }\end{array}$ & $\begin{array}{l}\text { Pre- } \\
\text { populated }\end{array}$ & $\begin{array}{l}\text { Yes } \\
\text { No }\end{array}$ & $\begin{array}{l}\square \\
\square\end{array}$ & & & & \\
\hline $\begin{array}{l}\text { Other State } \\
\text { Programs }\end{array}$ & $\begin{array}{l}\text { Pre- } \\
\text { populated }\end{array}$ & $\begin{array}{l}\text { Yes } \\
\text { No }\end{array}$ & $\begin{array}{l}\square \\
\square\end{array}$ & & & & \\
\hline Utilities & $\begin{array}{l}\text { Pre- } \\
\text { populated }\end{array}$ & $\begin{array}{l}\text { Yes } \\
\text { No }\end{array}$ & $\begin{array}{l}\square \\
\square\end{array}$ & & & & \\
\hline Program Income & $\begin{array}{l}\text { Pre- } \\
\text { populated }\end{array}$ & $\begin{array}{l}\text { Yes } \\
\text { No }\end{array}$ & $\begin{array}{l}\square \\
\square\end{array}$ & & & & \\
\hline In-Kind & $\begin{array}{l}\text { Pre- } \\
\text { populated }\end{array}$ & $\begin{array}{l}\text { Yes } \\
\text { No }\end{array}$ & $\begin{array}{l}\square \\
\square\end{array}$ & & & & \\
\hline Non-Profits & $\begin{array}{l}\text { Pre- } \\
\text { populated }\end{array}$ & $\begin{array}{l}\text { Yes } \\
\text { No }\end{array}$ & $\begin{array}{l}\square \\
\square\end{array}$ & & & & \\
\hline $\begin{array}{l}\text { Third Party } \\
\text { (e.g., } \\
\text { Foundations, } \\
\text { Lenders) }\end{array}$ & $\begin{array}{l}\text { Pre- } \\
\text { populated }\end{array}$ & $\begin{array}{l}\text { Yes } \\
\text { No }\end{array}$ & $\begin{array}{l}\square \\
\square\end{array}$ & & & & \\
\hline $\begin{array}{l}\text { All other } \\
\text { (Please specify) }\end{array}$ & $\begin{array}{l}\text { Pre- } \\
\text { populated }\end{array}$ & $\begin{array}{l}\text { Yes } \\
\text { No }\end{array}$ & & & & & \\
\hline TOTAL & $\begin{array}{l}\text { Pre- } \\
\text { populated }\end{array}$ & & & & & & \\
\hline $\begin{array}{ll}\text { 3. } & \text { Include } \\
\text { 4. } & \text { List all } \mathrm{f} \\
& \text { on meas }\end{array}$ & $\begin{array}{l}\text { and ARRA } \\
\text { ing for weat } \\
\text { labor, heal }\end{array}$ & $\mathrm{ds}$ & & $\begin{array}{l}\text { rations tha } \\
\text { audits, liab }\end{array}$ & $\begin{array}{l}\text { assed on tc } \\
\text { surance, } v e\end{array}$ & $\begin{array}{l}\text { antees, includin } \\
\text { and equipment. }\end{array}$ & mounts spent \\
\hline
\end{tabular}


2. Of the Program Year 2010 funds retained by your Agency's Weatherization Program for Program Management (see Column F total in Question 1), how much was used for each function listed below?

\begin{tabular}{|l|l|}
\hline \multicolumn{1}{|c|}{ Type of Management Function } & Total \\
\hline Administration* & \\
\hline Agency monitoring & \\
\hline Other (specify) & \\
\hline TOTAL & \\
\hline
\end{tabular}

* Includes planning, finance and accounting, clerical support, outreach, and evaluation.

3. Did your agency classify its expenditures for client intake, audits, and post-weatherization inspections as program management costs or as allowable costs used in the calculation of average cost per unit in PY 2010? Please indicate your answer for each type of expenditure by checking the appropriate cell in the table below.

\begin{tabular}{|l|l|c|}
\hline \multicolumn{1}{|c|}{ Type of Expenditure } & $\begin{array}{c}\text { Classified as Program } \\
\text { Management Costs? }\end{array}$ & $\begin{array}{c}\text { Classified as Allowable Costs for } \\
\text { Purpose of Calculating Average } \\
\text { Cost per Unit? }\end{array}$ \\
\hline $\begin{array}{l}\text { Expenditures for Client } \\
\text { Intake }\end{array}$ & & \\
\hline Expenditures for Audits & & \\
\hline $\begin{array}{l}\text { Expenditures for Post- } \\
\text { Weatherization Quality } \\
\text { Control Inspections }\end{array}$ & & \\
\hline
\end{tabular}

4. Of the TOTAL amount spent by your agency in Program Year 2010 using funds from all sources (see Column D total in Question 1), please give your best estimate of how much was spent on Audits and Inspections. 
5. Please divide your agency's Program Year 2010 expenditures on program operations (see Column E total in Question 1) into in-house expenditures and contractor expenditures, as shown in the following table.

\begin{tabular}{|l|c|c|c|}
\hline \multicolumn{1}{|c|}{ Type of Expenditure } & $\begin{array}{c}\text { PY 2010 } \\
\text { In-house } \\
\text { Expenditur } \\
\text { es (in \$) }\end{array}$ & $\begin{array}{c}\text { PY 2010 } \\
\text { Contractor } \\
\text { Expenditures } \\
\text { (in \$) }\end{array}$ & $\begin{array}{c}\text { PY 2010 } \\
\text { Total } \\
\text { Expenditures } \\
\text { on program } \\
\text { operations } \\
\text { (in \$) }\end{array}$ \\
\hline $\begin{array}{l}\text { Expenditures for Health and Safety, Repairs, and } \\
\text { Other Non Cost-Effective Measures }\end{array}$ & & & \\
\hline $\begin{array}{l}\text { All Expenditures Defined as Allowable Costs for } \\
\text { Purpose of Calculating Average Cost per Unit }\end{array}$ & & & \\
\hline TOTAL FUNDS & & & \\
\hline
\end{tabular}

6. Of your agency's total Program Year 2010 expenditures on program operations (see Column E total in Question 1), please give your best estimate of how much was for labor, how much for materials, and how much for other expenses.

\begin{tabular}{|l|c|}
\hline \multicolumn{1}{|c|}{ Type of Expenditure } & $\begin{array}{c}\text { PY 2010 Expenditures on program } \\
\text { operations (in \$) }\end{array}$ \\
\hline Labor & \\
\hline Materials & \\
\hline $\begin{array}{l}\text { Other Expenses (e.g., costs for vehicles, } \\
\text { transportation, maintenance, and storage) }\end{array}$ & \\
\hline TOTAL FUNDS & \\
\hline
\end{tabular}


7. Please provide the following information about ALL low-income dwelling units weatherized by your agency in Program Year 2010.

\begin{tabular}{|c|c|c|c|c|}
\hline \multirow[b]{3}{*}{ Type of Unit Weatherized } & \multicolumn{4}{|c|}{ Number of Units Weatherized in PY 2010} \\
\hline & \multirow[b]{2}{*}{$\begin{array}{l}\text { DOE } \\
\text { Units }^{1}\end{array}$} & \multicolumn{2}{|c|}{ Non-DOE Units ${ }^{2}$} & \multirow[b]{2}{*}{$\begin{array}{l}\text { TOTAL } \\
\text { Units }\end{array}$} \\
\hline & & $\begin{array}{l}\text { Comprehensive } \\
\text { Weatherization }^{3}\end{array}$ & $\begin{array}{l}\text { Non-comprehensive } \\
\text { Weatherization }^{4}\end{array}$ & \\
\hline \multicolumn{5}{|l|}{$\begin{array}{l}\text { Single Family Attached and } \\
\text { Detached }\end{array}$} \\
\hline \multicolumn{5}{|l|}{$\begin{array}{l}\text { Small Multi-family (2-4 } \\
\text { units) }\end{array}$} \\
\hline \multicolumn{5}{|l|}{$\begin{array}{l}\text { Multifamily ( } 5 \text { or More } \\
\text { Units per Building) }\end{array}$} \\
\hline \multicolumn{5}{|l|}{ Mobile Home } \\
\hline \multicolumn{5}{|l|}{ Shelter } \\
\hline \multicolumn{5}{|l|}{ TOTAL UNITS } \\
\hline \multicolumn{5}{|c|}{$\begin{array}{l}{ }^{1} \text { These are dwelling units that your agency weatherized and reported to the State as "DOE Units" } \\
{ }^{2} \text { These are dwelling units that your agency weatherized but did not report as "DOE Units" } \\
{ }^{3} \text { Comprehensive weatherization units are those for which an audit or priority list was used that addressed a large } \\
\text { proportion of potential energy-saving measures. } \\
{ }^{4} \text { Non-comprehensive weatherization units are those for which a limited set of measures was considered (e.g., } \\
\text { baseload electric measures only; low cost/no cost measures only), reflecting the needs and priorities of the funding } \\
\text { entity. }\end{array}$} \\
\hline
\end{tabular}

8. Of all the DOE units weatherized by your agency in Program Year 2010, how many used each of the following as their main heating fuel (i.e., the fuel providing most of the heat for the dwelling unit) in the winter prior to weatherization?

- Natural gas

- Fuel oil

- Electricity

- Propane/LPG

- Kerosene or coal oil

- Wood

- Other (please specify)

9. Of all the DOE units weatherized by your agency in Program Year 2010, how many housed members of the following high-priority client populations (leave blank if do not know)?

- Children (according to your state's definition of that term)

- Elderly (age 60 and older)

- Disabled

- Native American

10. Did your state have official definitions of "high energy expenditure" or "high energy burden" in PY 2010?

Yes

No 
11. Of all the DOE units weatherized by your agency in Program Year 2010, how many met your state's definition of having "high energy expenditures" and "high energy burden" ? (leave blank if do not know or if state did not have that definition)

[Q12 will be activated by 'yes' responses in the associated funding categories of Question 1 and skipped for any 'no' responses in those categories].

12. In the categories below, please specify the name of each funder and the total amount of weatherization funding received in PY 2010.

\begin{tabular}{|c|c|c|}
\hline & $\begin{array}{c}\text { Funding entity } \\
\text { (please enter names) }\end{array}$ & $\begin{array}{c}\text { Total weatherization funding } \\
\text { administered in PY 2010 } \\
\text { (please enter amounts) }\end{array}$ \\
\hline Utilities & & \\
\hline Utility 1 & & \\
\hline Utility 2 & & \\
\hline Utility 3 & & \\
\hline All other utilities & & \\
\hline In-kind contributions & & \\
\hline In-kind 1 & & \\
\hline In-kind 2 & & \\
\hline In-kind 3 & & \\
\hline All other in-kind & & \\
\hline Nonprofits & & \\
\hline Nonprofit 1 & & \\
\hline Nonprofit 2 & & \\
\hline Nonprofit 3 & & \\
\hline All other nonprofits & & \\
\hline Other & & \\
\hline Other 1 & & \\
\hline Other 2 & & \\
\hline Other 3 & & \\
\hline All others & & \\
\hline
\end{tabular}


[Q13 will be activated by 'yes' responses in the LIHEAP category of Question 1 and deactivated (skipped) for 'no' responses in that category.]

13a. When did agency first receive weatherization funds from LIHEAP?

13b. Number of years that agency worked to achieve this leveraging relationship (leave blank if unknown):

13c. Please describe the change in the leveraging relationship between your agency's lowincome weatherization program and LIHEAP during the ARRA period.

Extremely positive

Positive

No change

Negative

Extremely negative

13d. How do you expect leveraged funding from this source to change from PY 2010 to the postARRA period in PY 2012? increase decrease stay the same

13e. If leveraged funding from LIHEAP decreased from PY 2008, was the change attributable to increased ARRA funding?

Yes

No

Not applicable

13f. Did you require local agencies to follow DOE rules when spending weatherization funds from LIHEAP in PY 2010?

Yes

No

[13g will appear if respondent answered ' $\mathrm{no}$ ' in 13f]

$13 \mathrm{~g}$. What were the major differences in the rules governing the expenditure of LIHEAP funds in comparison to the rules governing the expenditure of DOE funds?

13h. Did your agency experience any delays or other difficulties in spending funds from LIHEAP in PY 2010? Yes No

If yes, please provide a short description of the reasons for the delays or other difficulties: 
[Q14 will be activated by 'yes' responses in the PVE category of Question 1 and deactivated (skipped) for 'no' responses in that category.]

14a. When did agency first receive weatherization funds from Petroleum Violation Escrow (PVE)?

14b. Number of years that agency worked to achieve this leveraging relationship (leave blank if unknown):

14c. Please describe the change in leveraging relationships between your agency's low-income weatherization program and PVE during the ARRA period.

Extremely positive

Positive

No change

Negative

Extremely Negative

14d. How do you expect leveraged funding from this source to change from PY 2010 to the postARRA period in PY 2012? increase decrease stay the same

14e. If leveraged funding from PVE decreased from PY 2008, was the change attributable to increased ARRA funding?

Yes

No

Not applicable

14f. Did you require local agencies to follow DOE rules when spending weatherization funds from PVE in PY 2010?

Yes

No

[14g will appear if respondent answered 'no' in 14f]

$14 \mathrm{~g}$. What were the major differences in the rules governing the expenditure of PVE funds in comparison to the rules governing the expenditure of DOE funds?

14h. Did your agency experience any delays or other difficulties in spending funds from PVE in PY 2010? Yes No

If yes, please provide a short description of the reasons for the delays or other difficulties: 
[Q15 will be activated by 'yes' responses in the Other Federal Programs category of Question 1 and deactivated (skipped) for 'no' responses in that category.]

15a. When did agency first receive weatherization funds from Other Federal Programs?

15b. Number of years that agency worked to achieve this leveraging relationship (leave blank if unknown):

15c. Please describe the change in leveraging relationships between your agency's low-income weatherization program and Other Federal Programs during the ARRA period. Extremely positive Positive No change Negative Extremely Negative

15d. How do you expect leveraged funding from this source to change from PY 2010 to the postARRA period in PY 2012? increase decrease stay the same

15e. If leveraged funding from Other Federal Programs decreased from PY 2008, was the change attributable to increased ARRA funding? Yes No Not applicable

15f. Did you require local agencies to follow DOE rules when spending weatherization funds from Other Federal Programs in PY 2010? Yes No

[15g will appear if respondent answered ' $\mathrm{go}^{\prime}$ in $\left.15 \mathrm{f}\right]$ $15 \mathrm{~g}$. What were the major differences in the rules governing the expenditure of Other Federal Programs funds in comparison to the rules governing the expenditure of DOE funds?

15h. Did your agency experience any delays or other difficulties in spending funds from Other Federal Programs in PY 2010? Yes No

If yes, please provide a short description of the reasons for the delays or other difficulties: 
[Q16 will be activated by 'yes' responses in the State Public Benefit Funds category of Question 1 and deactivated (skipped) for 'no' responses in that category.]

16a. When did agency first receive weatherization funds from State Public Benefit Funds?

16b. Number of years that agency worked to achieve this leveraging relationship (leave blank if unknown):

16c. Please describe the change in leveraging relationships between your agency's low-income weatherization program and State Public Benefit Funds during the ARRA period.

Extremely positive

Positive

No change

Negative

Extremely Negative

16d. How do you expect leveraged funding from this source to change from PY 2010 to the post-

ARRA period in PY 2012? increase

decrease

stay the same

16e. If leveraged funding from State Public Benefit Funds decreased from PY 2008, was the change attributable to increased ARRA funding?

Yes

No

Not applicable

16f. Did you require local agencies to follow DOE rules when spending weatherization funds from State Public Benefit Funds in PY 2010?

Yes

No

[16g will appear if respondent answered ' $\mathrm{no}$ ' in 16f]

$16 \mathrm{~g}$. What were the major differences in the rules governing the expenditure of State

Public Benefit Funds in comparison to the rules governing the expenditure of DOE

funds?

16h. Did your agency experience any delays or other difficulties in spending funds from State Public Benefit Funds in PY 2010?

Yes

No 
If yes, please provide a short description of the reasons for the delays or other difficulties:

[Q17 will be activated by 'yes' responses in the Other State Programs category of Question 1 and deactivated (skipped) for ' $\mathrm{no}$ ' responses in that category.]

17a. When did agency first receive weatherization funds from Other State Programs?

17b. Number of years that agency worked to achieve this leveraging relationship (leave blank if unknown):

17c. Please describe the change in leveraging relationships between your agency's low-income weatherization program and Other State Programs during the ARRA period.

Extremely positive

Positive

No change

Negative

Extremely Negative

17d. How do you expect leveraged funding from this source to change from PY 2010 to the postARRA period in PY 2012? increase decrease stay the same

17e. If leveraged funding from Other State Programs decreased from PY 2008, was the change attributable to increased ARRA funding?

Yes

No

Not applicable

17f. Did you require local agencies to follow DOE rules when spending weatherization funds from Other State Programs in PY 2010?

Yes

No

[17g will appear if respondent answered ' $\mathrm{no}$ ' in 17f]

$17 \mathrm{~g}$. What were the major differences in the rules governing the expenditure of Other State Programs funds in comparison to the rules governing the expenditure of DOE funds?

17h. Did your agency experience any delays or other difficulties in spending funds from Other State Programs in PY 2010? Yes 
No

If yes, please provide a short description of the reasons for the delays or other difficulties:

[Q18 will be activated by 'yes' responses in the Utilities category of Question 1 and deactivated (skipped) for 'no' responses in that category.]

18a. When did agency first receive weatherization funds from Utilities?

18b. Number of years that agency worked to achieve this leveraging relationship (leave blank if unknown):

18c. Please describe the change in leveraging relationships between your agency's low-income weatherization program and Utilities during the ARRA period.

Extremely positive

Positive

No change

Negative

Extremely Negative

18d. How do you expect leveraged funding from this source to change from PY 2010 to the postARRA period in PY 2012? increase decrease stay the same

18e. If leveraged funding from Utilities decreased from PY 2008, was the change attributable to increased ARRA funding?

Yes

No

Not applicable

18f. Did you require local agencies to follow DOE rules when spending weatherization funds from Utilities in PY 2010?

Yes

No

[18g will appear if respondent answered 'no' in 18f]

$18 \mathrm{~g}$. What were the major differences in the rules governing the expenditure of Utilities funds in comparison to the rules governing the expenditure of DOE funds?

18h. Did your agency experience any delays or other difficulties in spending funds from Utilities in PY 2010? Yes 
No

If yes, please provide a short description of the reasons for the delays or other difficulties:

[Q19 will be activated by 'yes' responses in the Program Income category of Question 1 and deactivated (skipped) for 'no' responses in that category.]

19a. When did agency first receive weatherization funds from Program Income?

19b. Number of years that agency worked to achieve this leveraging relationship (leave blank if unknown):

19c. Please describe the change in leveraging relationships between your agency's low-income weatherization program and Program Income during the ARRA period.

Extremely positive

Positive

No change

Negative

Extremely Negative

19d. How do you expect leveraged funding from this source to change from PY 2010 to the postARRA period in PY 2012? increase decrease stay the same

19e. If leveraged funding from Program Income decreased from PY 20019, was the change attributable to increased ARRA funding?

Yes

No

Not applicable

19f. Did you require local agencies to follow DOE rules when spending weatherization funds from Program Income in PY 2010?

Yes

No

[19g will appear if respondent answered 'no' in 19f]

$19 \mathrm{~g}$. What were the major differences in the rules governing the expenditure of Program Income funds in comparison to the rules governing the expenditure of DOE funds?

19h. Did your agency experience any delays or other difficulties in spending funds from Program Income in PY 2010? Yes 
No

If yes, please provide a short description of the reasons for the delays or other difficulties:

[Q20 will be activated by 'yes' responses in the In-Kind Contributions category of Question 1 and deactivated (skipped) for 'no' responses in that category.]

20a. When did agency first receive weatherization funds from In-Kind Contributions?

20b. Number of years that agency worked to achieve this leveraging relationship (leave blank if unknown):

20c. Please describe the change in leveraging relationships between your agency's low-income weatherization program and In-Kind Contributions during the ARRA period.

Extremely positive

Positive

No change

Negative

Extremely Negative

20d. How do you expect leveraged funding from this source to change from PY 2010 to the postARRA period in PY 2012? increase decrease stay the same

20e. If leveraged funding from In-Kind Contributions decreased from PY 2008, was the change attributable to increased ARRA funding?

Yes

No

Not applicable

20f. Did you require local agencies to follow DOE rules when spending weatherization funds from In-Kind Contributions in PY 2010? Yes No

[20g will appear if respondent answered 'no' in 20f]

$20 \mathrm{~g}$. What were the major differences in the rules governing the expenditure of In-Kind Contributions in comparison to the rules governing the expenditure of DOE funds?

20h. Did your agency experience any delays or other difficulties in spending funds from In-Kind Contributions in PY 2010? 
If yes, please provide a short description of the reasons for the delays or other difficulties:

[Q21 will be activated by 'yes' responses in the Non-profits category of Question 1 and deactivated (skipped) for 'no' responses in that category.]

21a. When did agency first receive weatherization funds from Non-profits?

21b. Number of years that agency worked to achieve this leveraging relationship (leave blank if unknown):

21c. Please describe the change in leveraging relationships between your agency's low-income weatherization program and Non-profits during the ARRA period.

Extremely positive

Positive

No change

Negative

Extremely Negative

21d. How do you expect leveraged funding from this source to change from PY 2010 to the postARRA period in PY 2012? increase decrease stay the same

21e. If leveraged funding from Non-Profits decreased from PY 2008, was the change attributable to increased ARRA funding?

\begin{tabular}{l} 
Yes \\
No \\
\hline Not applicable
\end{tabular}

21f. Did you require local agencies to follow DOE rules when spending weatherization funds from Non-Profits in PY 2010? Yes No

[21g will appear if respondent answered ' $\mathrm{no}$ ' in 21f] $21 \mathrm{~g}$. What were the major differences in the rules governing the expenditure of NonProfits funds in comparison to the rules governing the expenditure of DOE funds?

$21 \mathrm{~h}$. Did your agency experience any delays or other difficulties in spending funds from Nonprofits in PY 2010? 
If yes, please provide a short description of the reasons for the delays or other difficulties:

[Q22 will be activated by 'yes' responses in the Third Party category of Question 1 and deactivated (skipped) for 'no' responses in that category.]

22a. When did agency first receive weatherization funds from Third Parties (foundations, lenders)?

22b. Number of years that agency worked to achieve this leveraging relationship (leave blank if unknown):

22c. Please describe the change in leveraging relationships between your agency's low-income weatherization program and Third Parties during the ARRA period.

Extremely positive

Positive

No change

Negative

Extremely Negative

22d. How do you expect leveraged funding from this source to change from PY 2010 to the postARRA period in PY 2012? increase decrease stay the same

22e. If leveraged funding from Third Parties decreased from PY 2008, was the change attributable to increased ARRA funding?

Yes

No

Not applicable

22f. Did you require local agencies to follow DOE rules when spending weatherization funds from Third Parties in PY 2010?

Yes

No

[22g will appear if respondent answered ' $\mathrm{no}$ ' in 22f]

$22 \mathrm{~g}$. What were the major differences in the rules governing the expenditure of Third Party funds in comparison to the rules governing the expenditure of DOE funds? 
22h. Did your agency experience any delays or other difficulties in spending funds from Third Parties in PY 2010?

Yes

No

If yes, please provide a short description of the reasons for the delays or other difficulties:

[Q23 will be activated by 'yes' responses in All Other, Specify category of Question 1 and deactivated (skipped) for 'no' responses in that category.]

23a. When did agency first receive weatherization funds from [insert text from 'All Other, Specify']?

23b. Number of years that agency worked to achieve this leveraging relationship (leave blank if unknown):

23c. Please describe the change in leveraging relationships between your agency's low-income weatherization program and [insert text from 'All Other, Specify'] during the ARRA period.

Extremely positive

Positive

No change

Negative

Extremely Negative

23d. How do you expect leveraged funding from this source to change from PY 2010 to the post-

ARRA period in PY 2012? increase decrease stay the same

23e. If leveraged funding from [insert text from 'All Other, Specify'] decreased from PY 2008, was the change attributable to increased ARRA funding?

Yes

No

Not applicable

23f. Did you require local agencies to follow DOE rules when spending weatherization funds from [insert text from 'All Other, Specify'] in PY 2010?

Yes

No

[23g will appear if respondent answered 'no' in 23f]

$23 \mathrm{~g}$. What were the major differences in the rules governing the expenditure of [insert text from 'All Other, Specify'] funds in comparison to the rules governing the expenditure of DOE funds? 
23h. Did your agency experience any delays or other difficulties in spending funds from [insert text from 'All Other, Specify'] in PY 2010?

Yes No

If yes, please provide a short description of the reasons for the delays or other difficulties:

24. How important were leveraged funds for your agency's Weatherization Program in PY 2010 compared to program years without additional ARRA funding? (Check best answer)

Very important

Important

Not very important

Not important at all

25. Did your agency set aside funding to advocate for leveraged resources in PY 2010?

Yes

No

26. How successful would you rate your agency's efforts to acquire leveraged funds in PY 2010?

(Check best answer)

Very successful

Successful

Not very successful

Not successful at all

State does not seek leveraged funds

27. What factors limited the success of your agency's efforts to acquire leveraged funding in PY 2010 ?

28. Did your agency encounter any of the following problems in spending non-DOE funds in general in PY 2010? (Check all that apply)

Our agency could not easily increase the number of homes weatherized during the year in order to better spend non-DOE funds

Our agency required the expenditure of DOE weatherization funds before non-

DOE funds were expended

We had insufficient staff to manage the receipt and expenditure of non-DOE funds We had inadequate accounting systems to manage the receipt and expenditure of non-DOE funds

Guidance received from DOE and/or our state made it difficult to expend non-

DOE funds in a timely manner

Other 
29. Have you modified your agency's weatherization program practices or regulations in the three years prior to PY 2010 to facilitate spending and reporting on leveraged resources? Yes No

30. How has the influx of ARRA funding impacted previously existing leveraging relationships?
a. Extremely positive impact
b. Positive impact
c. No Impact
d. Negative impact
e. Extremely negative impact

31. Can leveraging relationships damaged or lost during ARRA be re-built post-ARRA?
a. Yes, absolutely
b. Yes, probably
c. Uncertain
d. No, probably not
e. No, definitely not

32. What aspects about your agency's low-income weatherization program are most misunderstood by actual and potential leveraging partners?

33. How has your program worked to overcome these misunderstandings?

34. What information would your agency's weatherization program like to have that could be used to overcome these misunderstandings?

35. What other information would your agency's weatherization program like to have that could be used to 'sell' leveraging relationships?

36. What was the quality of the support and assistance on leveraging the Weatherization Assistance Program with other funding sources and related programs that your agency received from the state and its contractors in Program Year 2010? (Check best answer) very high quality
_ high quality moderate quality low quality very low quality not applicable

36a. If appropriate, why did you rate the quality very low or low?

37. Overall, what is your expectation for total agency leveraged for low-income weatherization funding post ARRA in PY 2012 compared to pre-ARRA PY 2008

a. Greatly increased

b. Increased 
c. Same level

d. Decreased

e. Greatly decreased

38. On balance, how beneficial do you think will ARRA funding prove to be over the longerterm on your agency's ability to leverage DOE WAP-program funding for low-income weatherization?
a. Extremely beneficial
b. Beneficial
c. No long-term impact
d. Unbeneficial
e. Extremely unbeneficial 


\section{PART 3. WAP ARRA Program Information}

1. For many years, the national weatherization network and the state-level national weatherization networks had been relatively stable. During the ARRA period, did the composition of your agency-level weatherization network change?

a. Yes

b. No (Skip to Question 5)

2. How would you characterize the magnitude of this change?

a. Extreme

b. Great

c. Moderate

d. Small

3. Using the table below, please list the names and contributions of the major new players.

\begin{tabular}{|l|l|}
\hline Name & $\begin{array}{l}\text { Description of Weatherization Related Contributions (e.g., } \\
\text { provides training, sells energy efficient products ) }\end{array}$ \\
\hline & \\
\hline & \\
\hline & \\
\hline & \\
\hline & \\
\hline & \\
\hline & \\
\hline & \\
\hline
\end{tabular}


4. On balance, how beneficial have these new players been to your agency's weatherization program?

a. Extremely beneficial

b. Beneficial

c. Neither beneficial nor unbeneficial

d. Unbeneficial

e. Extremely unbeneficial

Please Explain

5. During the ARRA period, did organizational responsibilities for your agency's weatherization program (e.g., reporting lines, organizational home) change?

a. Yes

b. No (Skip to Question 9)

6. How did the organizational responsibilities change? Please Explain

7. In your opinion, was this change a result of increased visibility of your agency's weatherization program created by the substantial funding increase?

a. Yes

b. No

8. On balance, how beneficial has this change been to your agency's weatherization program?

a. Extremely beneficial

b. Beneficial

c. Neither beneficial nor unbeneficial

d. Unbeneficial

e. Extremely unbeneficial

Please explain

9. During the ARRA period, how has state-level oversight of your agency's weatherization assistance program changed?

a. Greatly increased

b. Increased

c. Stayed the same

d. Decreased

e. Greatly decreased

10. During the ARRA period, has your state passed any new laws and/or implemented any new regulations that have directly impacted your agency's weatherization assistance program?

a. Yes

b. No (Skip to Question 14)

11. Please describe the new laws and/or regulations. 
12. On balance, how beneficial have these new laws and/or regulations been to your agency's weatherization program?
a. Extremely beneficial
b. Beneficial
c. Neither beneficial nor unbeneficial
d. Unbeneficial
e. Extremely unbeneficial
Please explain

13. Would these laws and/or regulations have been passed with or without the increased attention on the program attributable to ARRA?
a. Wholely due to ARRA
b. Primarily due to ARRA
c. Somewhat due to ARRA
d. Would have been passed anyway without ARRA

14. During the ARRA period, how has the visibility of your agency's weatherization program changed with respect to elected officials?
a. Greatly increased
b. Increased
c. Stayed the same
d. Decreased
e. Greatly decreased

15. On balance during the ARRA period, how has the public's support for your agency's weatherization assistance program changed?
a. Greatly increased
b. Increased
c. Stayed the same
d. Decreased
e. Greatly decreased
Please explain

16. How would you rate the public's understanding of your agency's low-income weatherization assistance program?
a. Excellent
b. Good
c. Fair
d. Poor

17. Please explain those aspects of the program that are most frequently misunderstood by the public. 
18. During the ARRA period, how has media attention on your agency's weatherization program changed?
a. Greatly increased
b. Increased
c. Stayed the same
d. Decreased
e. Greatly decreased

19. Please rate the quality of the media coverage your agency's weatherization program has received during the ARRA period?
a. very high quality
b. high quality
c. moderate quality
d. low quality
e. very low quality
f. N/A no media coverage (skip to 22)
g. no opinion

20. Please describe the overall media coverage of your agency's weatherization program during the ARRA period:
a. very positive
b. positive
c. neither positive or negative
d. negative
e. very negative

21. What topics did the media mainly focus on? (check all that apply)
a. Jobs created
b. Energy saved
c. Helping low income households
d. Waste, fraud and abuse
e. Lack of energy savings
f. Organizational mis-steps
g. Other

22. Will weatherization issues identified rightly or wrongly by the media during ARRA have lasting impacts on weatherization funding for your agency in the future?
a. could substantial reduce funding
b. could reduce funding
c. no impact
d. could increase funding
e. could substantially increase funding 
23. On balance, how beneficial has been the attention paid to your agency's weatherization program during the ARRA period?
a. Extremely beneficial
b. Beneficial
c. Neither beneficial nor unbeneficial
d. Unbeneficial
e. Extremely unbeneficial
Please explain

\section{PART 4. WAP PROGRAM IMPLEMENTATION DURING THE ARRA PERIOD}

1. How have relationships changed between your state weatherization office and your local weatherization agency during ARRA?
a. become much more congenial
b. become more congenial
c. no changes
d. become more strained
e. become much more strained

2. What was the quality of the administrative support and assistance that your agency received from the state and its contractors in Program Year 2010? (Check best answer)

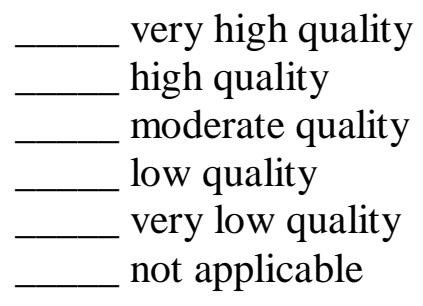

2a. If appropriate, why did you rate the quality very low or low?

3. What was the quality of the training that your agency received from the state and its contractors in Program Year 2010? (Check best answer) very high quality

\begin{tabular}{l}
\hline \\
high quality \\
moderate quality \\
low quality \\
\\
very low quality \\
not applicable
\end{tabular}

3a. If appropriate, why did you rate the quality very low or low? 
4. What was the quality of the support and assistance on client education that your agency received from the state and its contractors in Program Year 2010? (Check best answer) very high quality high quality moderate quality low quality very low quality not applicable

4a. If appropriate, why did you rate the quality very low or low?

5. What was the quality of the support and assistance on leveraging the Weatherization Assistance Program with other funding sources and related programs that your agency received from the state and its contractors in Program Year 2010? (Check best answer)

very high quality
high quality
moderate quality
low quality
very low quality
not applicable

5a. If appropriate, why did you rate the quality very low or low?

6. What was the quality of the technical support that your agency received from the state and its contractors in Program Year 2010? (Check best answer) very high quality high quality moderate quality low quality very low quality not applicable

6a. If appropriate, why did you rate the quality very low or low?

7. How flexible did you find the DOE program rules that governed the weatherization program in Program Year 2010? In other words, did the program rules allow your agency to tailor your program to your needs (very flexible) or proscribe your program to only one way of operation (very inflexible (Check best answer)

Very Flexible

Flexible

Inflexible

Very Inflexible 
7a. Using PY 2010 as the reference point, how should the program rules change?

Become much more flexible

Become more flexible

Stay about the same

Become more inflexible

Become much more inflexible

7b. In what areas should the program rules become more flexible?

7c. In what areas should the program rules become less flexible?

8. Please describe any important political issues faced by your agency's weatherization program in Program Year 2010.

9. Which statement best describes how your agency dealt with program expansion during the ARRA period?

a. promoted existing weatherization staff to management positions and hired new entry level workers

b. hired new weatherization managers and hired new entry level workers

c. promoted existing weatherization staff to management positions and hired contractors to ramp up production

d. simply hired contractors to ramp up production

10. Did expanding your agency's level of production result in any economies of scale benefits?

a. No

b. some benefits

c. moderate benefits

d. substantial benefits

11. How did your agency change its in-take procedures during the ARRA-period from the procedures used pre-ARRA (i.e., PY2008)? (Check Best Answer)
a. No change
b. Eligibility checks more stringent
c. Eligibility checks less stringent
d. Other

12. Were there any material, equipment or other supply chain bottlenecks during the ARRA period that negatively impacted weatherization production by your agency?
a. No
b. Yes
If yes, what was in short supply? 
13. To what extent have large DOE programs, WAP, State Energy Program, Energy Efficiency Community Block Grant Program, competed for labor during the ARRA period?
a. Not at all
b. a small extent
c. a moderate extent
d. a large extent
e. a very large extent

14. During the ARRA period, how has state-level oversight of your state's weatherization assistance program changed?
a. Greatly increased
b. Increased
c. Stayed the same
d. Decreased
e. Greatly decreased

15. How did your agency manage increasing workloads and performance expectations? Please Explain

16. Has ARRA funding allowed your agency to purchase and implement new information technologies to improve program administration?
a. Yes
b. No
If yes, please describe these new information technologies.

17. Has ARRA funding allowed your agency to purchase new field technologies (e.g., Infrared Thermal Imagers) to improve weatherization audits and measure installation?
a. Yes
b. No
If yes, please describe these purchases.

18. How timely has DOE's guidance been during the ARRA period?
a. very timely
b. timely
c. not very timely
d. not timely at all

19. How clear has DOE's guidance been during the ARRA period?
a. very clear
b. clear
c. not very clear
d. not clear at all 
20. During PY 2010, how much of a burden were your agency's administrative costs associated with increased oversight during the ARRA period (e.g., from DOE IG, GAO)?
a. no burden
b. slight burden
c. moderate burden
d. substantial burden
e. extreme burden

21. Did your agency change its audit approach during the ARRA-period from the approach used pre-ARRA (i.e., PY2008)?

a. Yes, went from priority list to computerized audit

b. Yes, went from computerized audit to priority list

c. Yes, changed from one computerized audit tool to another

d. No

22. To what extent have measure costs used in SIR calculations diverted from actual measure costs experienced during ARRA in PY 2010? (choose the best description)

a. on balance actual measure costs were much higher than SIR calculations

b. on balance actual measure costs were higher than SIR calculations

c. SIR calculations and actual measure costs were about the same

d. on balance SIR calculations and actual measure costs were about the same but the actual measure costs fluctuated a great deal up and down

e. on balance actual measure costs were lower than SIR calculations

f. on balance actual measure costs were much lower than SIR calculations

23. Did your agency change it quality assurance procedures during the ARRA-period (e.g., PY 2010) from the procedures used pre-ARRA (i.e., PY2008)?

a. Yes, procedures are much more stringent

b. Yes, procedures are more stringent

c. No

24. Did your agency change its approach to using in-house crews versus contractors during the ARRA-period (e.g., PY 2010) from the procedures used pre-ARRA (i.e., PY2008)?

a. Contractors are performing a much higher percentage of weatherization jobs

b. Contractors are performing a higher percentage of weatherization jobs

c. In-House crews are performing a higher percentage of weatherization jobs

d. In-house crews are performing a much higher percentage of weatherization jobs

e. No

24a. If there was a change, what prompted the change? (choose the best description)

a. Change was solely made to meet production targets

b. Change was solely made to deal with Davis-Bacon

c. Change was made to meet production targets and deal with Davis-Bacon

d. Other (Please explain) 
24b. How did your training requirements change with the change in approach?
a. All workers were required to be trained in weatherization work
b. Only in-house crews were required to be trained
c. Only contractors were required to be trained
d. No training was required.

25. Did your agency implement any innovative approaches to weatherization during the ARRAperiod?
a. No
b. Yes
If yes, please describe the innovative approaches

26. Did your agency implement any other major programmatic changes during the ARRAperiod?
a. No
b. Yes
If yes, please describe these programmatic changes

27. Does your agency have a deferral policy?
a. Yes
b. No

28. Please estimate the number of units where weatherization was deferred during PY 2010 ?
a. $0 \%$
b. $1-5 \%$
c. $6-10 \%$
d. $10-20 \%$
e. $21-30 \%$
f. more than $30 \%$

28a. What was the leading cause for deferral during PY 2010?

28b. Please estimate what percentage of units where weatherization was deferred during PY 2010 will eventually be weatherized?
a. $0 \%$
b. $1-25 \%$
c. $26-50 \%$
d. $51-75 \%$
e. $76-90 \%$
f. $91-100 \%$ 
28c. Please describe your agency's deferral rates in PY2010 compared to PY2008:
a. very great increase
b. great increase
c. increase
d. no change
e. decrease
f. great decrease
g. very great decrease

29. How much of a priority does your agency place on health and safety when weatherizing homes?
a. Very high priority
b. High priority
c. Medium priority
d. Low priority
e. Very low priority
f. No priority

30. What would be the ideal amount of money per home your agency would like to spend for addressing health and safety issues?

31. Of all the homes weatherized by your agency in Program Year 2010, how many did you refer to non-energy programs for additional services (e.g., nutrition; family counseling)?

32. What approaches did your local agency use to recruit new qualified, reliable and trustworthy weatherization crew members and how effective were these approaches:

33. What approaches did your local agency use to train the expanded weatherization workforce?

a. Utilized existing state program-basedtraining resources, i.e. State monitors or other staff providing training to the network

b. Sent weatherization workers to one of 26 newly funded weatherization training centers c.Sent weatherization workers to one of 12 legacy weatherization training centers (i.e. COAD, NRCERT, INCAA, BPC, PG\&E Stockton, NYSWDA, FSL, AEA, etc. YY)

d. Utilized private, consultant training providers (i.e. Saturn, BMI, EMC)

e. OTHER Please explain:

f. No additional training was provided

34. In your opinion, how effective were these approaches?
a. Highly effective
b. Very Effective
c. Somewhat effective
d. No effective

35. Has your agency implemented new certification requirements for weatherization workers during the ARRA period?

a. No (go to Q28)

b. Yes 
36. What new certifications are required? (Check all that apply)
a. BPI Building Analyst
b. BPI Envelope
c. BPI Residential Building Envelope Accessible Areas Air Leakage Control Installer
d. Residential Building Envelope Whole House Air Leakage Control Crew Chief
e. BPI Manufactured Housing
f. BPI Heating
g. BPI Air Conditioning and Heat Pump
h. BPI Multifamily
i. HERS
j. LEED
k. Lead Safe Weatherization
1. Lead Certified Renovator
m. NAHB Green Building
n. Other

37. Did staff turnover change during the ARRA period as compared to the pre-ARRA period?

a. Turnover greatly increased

b. Turnover increased

c. No, turnover did not change

d. Turnover decreased

e. Turnover greatly decreased

38. Which statement best describes changes in the level of employment in your agency's jurisdiction resulting from Davis-Bacon?

a. large number of jobs created

b. small number of jobs created

c. no change in the number of jobs

d. small number of jobs lost

e. large number of jobs lost

f. don't know

39. Which statement best describes the impact of Davis-Bacon on wages paid to weatherization workers by your agency?
a. large increase in wages
b. small increase in wages
c. no increase in wages
d. small decrease in wages
e. large decrease in wages

40. Did Davis-Bacon paperwork requirements lead some experienced weatherization contractors who worked for your agency to leave the low-income weatherization field?

a. No

b. Yes, a few 
c. Yes, many

41. How much of a problem was faced by your agency in coordinating wages stipulated by Davis-Bacon for weatherization workers whose operations spanned multiple counties?
a. no problem
b. small problem
c. moderate problem
d. large problem
e. very large problem
f. N/A because your agency works exclusively in one county

42. Have changes in weatherization costs associated with Davis-Bacon altered choices of measures installed in homes?

a. No

b. Yes

If yes, please explain

43. In your agency, on average, how much did Davis-Bacon rules increase the cost of weatherizing low-income multifamily buildings four stories and higher?
a. no increase
b. $1-10 \%$
c. $11-20 \%$
d. $21-30 \%$
e. $31+\%$
f. N/A

44. Overall, how did Davis-Bacon impact the costs of weatherization in your agency?
a. greatly increased costs
b. increased costs
c. no change in costs
d. decreased costs
e. greatly decreased costs

45. Does your state allow the weatherization of large low-income multi-family buildings?
a. yes
b. no (go to Q 40)

If not, why not?

46. Does your agency weatherize large low-income multi-family buildings?
a. No
b. Yes 
47. What are the barriers to weatherizing large low-income multi-family buildings? (check all that apply)
a. lack of trained auditors
b. lack of trained crew
c. too expensive
d. building owners are uncooperative
e. energy savings are not high enough
f. unclear guidance from DOE on owner contributions
g. other

48. Does your state allow the weatherization of public housing, that is, housing owned by a public housing authority?
a. Yes
b. No (go to Q. 43)
If not, why not?

49. Does your agency weatherize public housing?

a. No

b. Yes

50. What are the barriers to weatherizing public housing units?

51. Does your state allow the weatherization of HUD assisted housing?

a. Yes

b. No (go to Q46)

If not, why not?

52. Does your agency weatherize HUD assisted housing?
a. No
b. Yes

53. What are the barriers to weatherizing HUD assisted housing?

54. How many units of each type were weatherized in your state in PY 2010?

\begin{tabular}{|l|l|l|l|}
\hline Type of Housing & $\begin{array}{l}\text { Large Multi-family } \\
\text { (Not Public Housing or } \\
\text { HUD Assisted }\end{array}$ & $\begin{array}{l}\text { Public Housing Multi- } \\
\text { family }\end{array}$ & $\begin{array}{l}\text { HUD Assisted Multi- } \\
\text { family }\end{array}$ \\
\hline & & & \\
\hline
\end{tabular}

55. Are there any DOE rules that could be changed to make it easier to weatherize large lowincome multi-family buildings?
a. No
b. Yes
If yes, please explain 
56. Does your agency's weatherization program have an agreement with your State Historic Preservation Office (SHPO)?
a. Yes
b. No

57. What percentage of units weatherized by your agency in PY 2010 fell under the SHPO agreement?
a. 0
b. $1-5$
c. $6-10$
d. $11-15$
e. $15+$

58. In general, have the historic preservation guidelines changed the types of measures installed in these homes?
a. No
b. Yes
If yes, please explain

59. Has low-income weatherization had an impact in preventing home foreclosures during the ARRA period in your agency's jurisdiction?
a. no
b. little impact
c. moderate impact
d. great impact
e. very great impact
f. don't know

59a. Has low-income weatherization had an impact on preventing homelessness during the ARRA period in your agency's jurisdiction?
a. no
b. little impact
c. moderate impact
d. great impact
e. very great impact

60. How many homes were on your wait list for weatherization in PY 2010?

61. On average, how long was a home on the wait list before it was weatherized in PY 2010? 
62. In Program Year 2010, did your agency set targets and actively solicit participation by dwelling units of the types shown below? (Check all that apply)

\begin{tabular}{|l|l|l|}
\hline Type of dwelling unit & $\begin{array}{c}\text { Set targets for number } \\
\text { of dwelling units of this } \\
\text { type to weatherize }\end{array}$ & $\begin{array}{c}\text { Actively sought participation by } \\
\text { households residing in this type of } \\
\text { dwelling unit }\end{array}$ \\
\hline $\begin{array}{l}\text { Single Family Attached } \\
\text { and Detached }\end{array}$ & & \\
\hline $\begin{array}{l}\text { Small Multi-family (2-4 } \\
\text { units) }\end{array}$ & & \\
\hline $\begin{array}{l}\text { Multifamily (5 or More } \\
\text { Units per Building) }\end{array}$ & & \\
\hline Mobile Home & & \\
\hline Shelter & & \\
\hline
\end{tabular}

63. Which of the following approaches did your agency use in Program Year 2010 to market your weatherization services to low-income households? (Check all that apply)

- Targeted mailings to potential clients

- Targeted mailings to landlords of potential clients

- Visits to potential clients

- Visits to landlords of potential clients

- Advertising with other social service agencies

- Advertising in local newspapers or magazines

- Radio advertising

- Television advertising

- Posting information on website

- Other (please specify)

64. Who was responsible for leading the marketing/outreach efforts described above? (Check all that apply)

- Agency management

- In-house outreach coordinator

- Contractor outreach coordinator

- In-house communications staff

- Contractor communications staff

- Other in-house staff (please specify)

- Other contractor staff (please specify)

65. In general, how satisfied were you with the length of time between the client's request to have their home weatherized and when it was actually weatherized in PY 2010? (Check best answer)

Very satisfied

Satisfied

Not satisfied or dissatisfied

Dissatisfied

Very dissatisfied 
66. In general, how easy was it to schedule your visits to client homes to perform audits, weatherization, and inspections in PY 2010? (Check best answer)

Very easy

_ Easy

Not easy or difficult

Difficult

Very difficult

67. What percentage of households whose homes were weatherized by your agency in Program Year 2010 registered a complaint regarding the quality or nature of the weatherization job performed on their dwelling unit?

68. Of those households that filed complaints, what percentage of these required some additional work? 
OMB Control Number: XXXX-XXXX

\section{APPENDIX E. S3: SUBSET OF AGENCIES DETAILED PROGRAM INFORMATION SURVEY}

This data is being collected to conduct a detailed process evaluation of the Weatherization Assistance Program at the local level. The data you supply will be used to characterize local agency weatherization activities in Program Year 2010.

Public reporting burden for this collection of information is estimated to average sixteen hours per response, including the time for reviewing instructions, searching existing data sources, gathering and maintaining the data needed, and completing and reviewing the collection of information. Send comments regarding this burden estimate or any other aspect of this collection of information, including suggestions for reducing this burden, to Office of the Chief Information Officer, Records Management Division, IM-11, Paperwork Reduction Project (XXXX-XXXX), U.S. Department of Energy, 1000 Independence Ave SW, Washington, DC, 20585-1290; and to the Office of Management and Budget (OMB), OIRA, Paperwork Reduction Project (XXXX-XXXX), Washington, DC 20503.

All of the information obtained from this survey will be protected and will remain confidential. The data will be analyzed in such a way that the information provided cannot be associated back to your state, your agencies, or the housing units and clients that your state served. Again, please note that the questions refer to PY 2010 unless otherwise noted.

\section{PROGRAM CHARACTERIZATION}

1. Please identify your state.

2. Please identify your local agency.

3. Please indicate the number of staff that supported your agency's weatherization program and their work effort in Program Year 2010. In considering the number of staff, please include everyone who worked full- or part-time or who worked with the weatherization program as well as other agency programs.

\begin{tabular}{|l|c|c|}
\hline Type of Administrative Function & $\begin{array}{c}\text { Number of } \\
\text { Agency Staff } \\
\text { (\# persons) }\end{array}$ & $\begin{array}{c}\text { Agency Staff } \\
\text { Work Effort } \\
\text { (FTE) }\end{array}$ \\
\hline Management/administration & & \\
\hline
\end{tabular}




\begin{tabular}{|l|l|l|}
\hline Auditing/inspection & & \\
\hline Home weatherization & & \\
\hline Other (specify) & & \\
\hline
\end{tabular}

4. For the agency staff working on your agency's weatherization in each of the following functional areas in Program Year 2010, please indicate their level of experience with the weatherization program:

\begin{tabular}{|l|l|l|l|l|l|}
\hline & $\begin{array}{c}\text { Very } \\
\text { High }\end{array}$ & High & Average & Low & Very Low \\
\hline Management/administration & & & & & \\
\hline Auditing/inspection & & & & & \\
\hline Home weatherization & & & & & \\
\hline Other (specify) & & & & & \\
\hline
\end{tabular}

5. For the in-house staff working in your agency's weatherization program in each of the functional areas listed below, please indicate the amount of turnover in staff from the beginning of PY 2009 to the end of PY 2010. (Please check appropriate box representing the level of turnover for each functional area.)

\begin{tabular}{|l|c|c|c|}
\hline & $\begin{array}{c}\text { No Turnover } \\
\text { (all staff in this functional } \\
\text { area at the beginning of } \\
\text { PY 2009 were in the same } \\
\text { functional area by the end } \\
\text { of PY 2010) }\end{array}$ & $\begin{array}{c}\text { Some turnover } \\
\text { (1-15\% of the staff in this } \\
\text { functional area at the } \\
\text { beginning of PY 2009 did } \\
\text { not remain in the same } \\
\text { functional area by the end } \\
\text { of PY 2010) }\end{array}$ & $\begin{array}{c}\text { Substantial } \\
\text { turnover } \\
\text { (more than 15\% of the } \\
\text { staff in this functional } \\
\text { area at the beginning of } \\
\text { PY 2009 remained in the } \\
\text { same functional area at } \\
\text { the end of PY 2010) }\end{array}$ \\
\hline $\begin{array}{l}\text { Management/ } \\
\text { administration }\end{array}$ & $\square$ & $\square$ & $\square$ \\
\hline $\begin{array}{l}\text { Field monitoring/ } \\
\text { Auditing }\end{array}$ & $\square$ & $\square$ & $\square$ \\
\hline $\begin{array}{l}\text { Training and Technical } \\
\text { Assistance }\end{array}$ & $\square$ & $\square$ & $\square$ \\
\hline Other (specify) & $\square$ & $\square$ & $\square$ \\
\hline
\end{tabular}

6. For which of the following functional areas were there certification or licensing requirements in Program Year 2010 for the in-house or contractor staff serving your state's weatherization program? (Check all that apply)

\begin{tabular}{|l|c|c|}
\hline & $\begin{array}{c}\text { Certification or } \\
\text { Licensing } \\
\text { Requirement for } \\
\text { In-house Staff }\end{array}$ & $\begin{array}{c}\text { Certification or Licensing } \\
\text { Requirement for } \\
\text { Contractor Staff }\end{array}$ \\
\hline
\end{tabular}




\begin{tabular}{|l|l|l|}
\hline $\begin{array}{l}\text { Management/ } \\
\text { administration }\end{array}$ & & \\
\hline Auditing/inspection & & \\
\hline Home weatherization & & \\
\hline Other (specify) & & \\
\hline
\end{tabular}




\section{AUDIT}

1. What was the primary method that your agency used in Program Year 2010 to select weatherization measures for clients' dwelling units (excluding health, safety, and repair measures and general heat waste measures)? (Check best answer)

- Priority list used for all dwelling units

- Calculation procedure (e.g., spreadsheet, computerized audit) used for all dwelling units

- Priority list applied to dwelling units meeting specified guidelines and calculation procedure used for remaining units

- Other (specify)

2. Including PY 2010, for how many years had your agency used the weatherization measure selection method indicated above?

3. What types of credentials or experience were required of your staff or contractors who were engaged in measure selection in Program Year 2010? Check all that apply.

- Technical certification

- Extensive weatherization work experience

- Extensive weatherization supervision experience

- Construction experience

- Other (specify)

4. Please indicate the level of experience for the agency staff engaged in measure selection in Program Year 2010 in each of the following functional areas:

\begin{tabular}{|l|l|l|l|l|l|}
\hline & $\begin{array}{c}\text { Very } \\
\text { High }\end{array}$ & High & Average & Low & Very Low \\
\hline $\begin{array}{l}\text { Performing weatherization } \\
\text { work }\end{array}$ & & & & & \\
\hline $\begin{array}{l}\text { Supervising weatherization } \\
\text { work }\end{array}$ & & & & & \\
\hline Working in construction & & & & & \\
\hline $\begin{array}{l}\text { Performing pre- } \\
\text { weatherization audits }\end{array}$ & & & & & \\
\hline
\end{tabular}


5. On average, approximately how many hours did it take to select weatherization measures for a typical dwelling unit served by your agency in Program Year 2010, by the major components listed below?

- Preparation/scheduling

- Travel

- On-site auditing

- Post-audit analysis and write-up

- Other

- TOTAL of all components

6. If your agency used a priority list for at least some dwelling units in Program Year 2010, how difficult was it for your staff to use that priority list? (Check best answer)

Very Difficult

Difficult

Easy

Very Easy

7. If your agency used a priority list in Program Year 2010, how effective was that list?

(Check best answer)

Very Ineffective

Ineffective

Effective

Very Effective

8. If your agency used a calculation procedure for at least some dwelling units in Program Year 2010, what was the name of the procedure or procedures employed? Check all that apply.

- AK Warm

- EA-3

- EASY

- $\quad$ EA-QUIP

- HomeCheck

- Meadows 
- REES

- REM/Rate

- SMOC-ERS

- TIPS

- TREAT

- Weatherization Assistant (NEAT/MHEA)

- WXEOR

- Other (specify) 
9. If your agency used a calculation procedure in Program Year 2010, use the following scale to describe how difficult it was for your staff to use the applicable procedure(s). Circle best answer). 1=Very Difficult; 2=Difficult; 3= Easy; 4=Very Easy; 5 =N/A

- AK Warm

- EA-3

- EASY

- EA-QUIP

- HomeCheck

- Meadows

- REES

- $\mathrm{REM} /$ Rate

- SMOC-ERS

- TIPS

- TREAT

- Weatherization Assistant (NEAT/MHEA)

- WXEOR

- Other (specify)

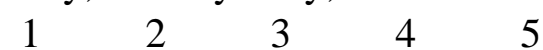

$\begin{array}{lllll}1 & 2 & 3 & 4 & 5\end{array}$

$\begin{array}{lllll}1 & 2 & 3 & 4 & 5\end{array}$

$\begin{array}{lllll}1 & 2 & 3 & 4 & 5\end{array}$

$\begin{array}{lllll}1 & 2 & 3 & 4 & 5\end{array}$

$\begin{array}{lllll}1 & 2 & 3 & 4 & 5\end{array}$

$\begin{array}{lllll}1 & 2 & 3 & 4 & 5\end{array}$

$\begin{array}{lllll}1 & 2 & 3 & 4 & 5\end{array}$

$\begin{array}{lllll}1 & 2 & 3 & 4 & 5\end{array}$

$\begin{array}{lllll}1 & 2 & 3 & 4 & 5\end{array}$

$\begin{array}{lllll}1 & 2 & 3 & 4 & 5\end{array}$

$\begin{array}{lllll}1 & 2 & 3 & 4 & 5\end{array}$

$\begin{array}{lllll}1 & 2 & 3 & 4 & 5\end{array}$

$\begin{array}{lllll}1 & 2 & 3 & 4 & 5\end{array}$

10. If your agency used a calculation procedure in Program Year 2010, use the following scale to describe how effective you found the applicable procedure(s). $1=$ Very Ineffective; 2=Ineffective; 3= Effective; 4=Very Effective; 5=N/A
a. AK Warm
12
b. EA-3

$\begin{array}{lllll}1 & 2 & 3 & 4 & 5\end{array}$
c. EASY

$\begin{array}{lllll}1 & 2 & 3 & 4 & 5\end{array}$
d. EA-QUIP

$\begin{array}{lllll}1 & 2 & 3 & 4 & 5\end{array}$
e. HomeCheck

$\begin{array}{lllll}1 & 2 & 3 & 4 & 5\end{array}$
f. Meadows

$\begin{array}{lllll}1 & 2 & 3 & 4 & 5\end{array}$




$\begin{array}{llllll}\text { g. REES } & 1 & 2 & 3 & 4 & 5 \\ \text { h. REM/Rate } & 1 & 2 & 3 & 4 & 5 \\ \text { i. SMOC-ERS } & 1 & 2 & 3 & 4 & 5 \\ \text { j. } \quad \text { TIPS } & 1 & 2 & 3 & 4 & 5 \\ \text { k. TREAT } & 1 & 2 & 3 & 4 & 5 \\ \text { l. Weatherization Assistant (NEAT/MHEA) } & 1 & 2 & 3 & 4 & 5 \\ \text { m. WXEOR } & 1 & 2 & 3 & 4 & 5 \\ \text { n. Other (specify) } & 1 & 2 & 3 & 4 & 5\end{array}$

11. If your agency used a calculation procedure for at least some dwelling units in Program Year 2010, did your state allow under DOE rules the installation of general heat waste measures (low-cost/no-cost weatherization activities) in those units without the need for an energy justification?

Yes

No (go to Question 13)

12. Please indicate which of the following general heat waste measures your agency was allowed to install in Program Year 2010. Check all that apply.

- Weatherstripping

- Caulking

- Insulation for plugging air leaks

- Low-flow shower heads

- Low-flow faucet aerators

- Air filters 
- Glass patching

\section{- Lighting}

- Hot water tank insulation (water heater wrap)

- Water pipe insulation

- Other (specify)

13. What was the primary justification used by your agency in Program Year 2010 for performing work specifically targeted at reducing air infiltration (i.e., air sealing work)? Check best answer.

- Work should be performed where the air leakage rate as measured by a blower door test is greater than a minimum number (e.g., minimum ventilation guideline) calculated for the dwelling unit in question

- Work should be performed to address occupant complaints

- All significant air leakage sites should be sealed

- Air sealing work should be performed on all dwelling units

- Other (specify)

14. What other justifications were used by your agency in Program Year 2010 for performing work specifically targeted at reducing air infiltration (i.e., air sealing work)? Check all that apply.

- Work should be performed where the air leakage rate as measured by a blower door test is greater than a minimum number (e.g., minimum ventilation guideline) calculated for the dwelling unit in question

- Work should be performed to address occupant complaints

- All significant air leakage sites should be sealed

- Air sealing work should be performed on all dwelling units

- Other (specify)

15. What was the primary method used by your agency in Program Year 2010 to identify air leakage sites to seal? Check only one. 
- Auditor identified air leakage sites visually and communicated relevant information

to crew

- Auditor identified air leakage sites using a blower door and/or pressure diagnostics and communicated relevant information to crew

- Crew identified air leakage sites visually

- Crew identified air leakage sites using a blower door and/or pressure diagnostics

- Other (specify)

16. What other methods were used by your agency in Program Year 2010 to identify air leakage sites to seal? Check all that apply.

- Auditor identified air leakage sites visually and communicated relevant information

to crew

- Auditor identified air leakage sites using a blower door and/or pressure diagnostics and communicated relevant information to crew

- Crew identified air leakage sites visually

- Crew identified air leakage sites using a blower door and/or pressure diagnostics

- Other (specify)

17. In Program Year 2010, at what point did your agency stop performing air sealing work on a given dwelling unit? Check all that apply.

- When all identified air leakage sites were sealed

- When all significant air leakage sites were sealed

- When the air leakage rate as measured by a blower door test dropped below a minimum number calculated for the dwelling unit in question

- When a blower door test indicated that the most recent infiltration reduction measure installed in the dwelling unit was not cost effective

- Other (specify) 
18. Did your agency do duct sealing work in Program Year 2010? Yes No (go to Question 22)

19. How did your agency determine when duct sealing work was needed for a particular dwelling unit in PY 2010? Check all that apply.

- All houses with ducts received duct sealing measures

- All houses with return air ducts get sealed

- Ducts were sealed in those cases where leakage sites were visible

- Ducts were sealed when a blower door test indicated the presence of leaks

- Ducts were sealed when duct diagnostics (blower door subtraction, duct blower, or pressure pan measurements) indicated that the leakage rate was greater than a minimum number calculated for the dwelling unit in question

20. What methods were used by your agency in Program Year 2010 to identify duct leakage sites to seal? Check all that apply.

- Auditor identified duct leakage sites visually and communicated relevant information to crew

- Auditor identified duct leakage sites using a blower door and communicated relevant information to crew

- Auditor identified duct leakage sites using duct diagnostics and communicated relevant information to crew

- Crew identified duct leakage sites visually

- Crew identified duct leakage sites using a blower door

- Crew identified duct leakage sites using duct diagnostics

- Other (specify)

21. In Program Year 2010, at what point did your agency stop performing duct sealing work on a given dwelling unit? Check all that apply.

- When all identified duct leakage sites were sealed

- When a blower door test indicated no more flow from the ducts 
- When the duct leakage rate as measured by duct diagnostics dropped below a minimum number calculated for the dwelling unit in question

- Other (specify)

22. How did you determine when a particular refrigerator should be replaced in PY 2010 ? Check all that apply.

- Not allowed to replace refrigerators

- Energy use of existing refrigerator was metered

- Energy use of existing refrigerator was assumed base on rated/nameplate value

- Non-energy criteria were used (e.g., age, color, physical appearance)

- Refrigerator was replaced if it was no longer running or could not maintain desired temperature

- Other (specify)

22a.How did you determine when a particular air conditioner should be replaced in PY 2010 ? Check all that apply.

- Not allowed to replace air conditioner

- Energy use of existing air conditioner was metered

- Energy use of existing air conditioner was assumed base on rated/nameplate value

- Non-energy criteria were used (e.g., age, physical appearance)

- Air conditioner was replaced if it was no longer running or could not maintain desired temperature

- Other (specify)

- Not applicable

23. Which of the following diagnostic procedures did your agency perform in Program Year 2010? Check all that apply.

Pressure diagnostics:

- Blower door (house air leakage rate) 
- Zonal pressure measurements

- Room-to-room pressure measurements (distribution balancing)

- Duct pressure pan measurements

- Duct blower measurements (duct air leakage rate)

Space-heating system:

- Flue gas analysis (steady-state efficiency measurements)

- Heat rise measurements

- CO measurements in flues

- Draft/spillage (normal operation)

Air-conditioning system:

- Refrigerant charge (e.g., superheat, subcooling)

HVAC components and cross-cutting diagnostics:

- Air handler flow rate

- Thermostat anticipator current

- Worst case draft/spillage (CAZ)

Hot-water (water-heating) system:

- Flue gas analysis (steady-state efficiency measurements)

- CO measurements in flues

- Draft/spillage (normal operation)

- Water flow rates (showerheads and faucets)

Other CO measurements:

- $\mathrm{CO}$ measurements in equipment rooms

- Cooking stove

- CO measurements in living areas

Other diagnostics and inspections:

- Refrigerator energy use

- Exhaust fan air flow rate measurement

- Infrared scanning (camera)

- Radon testing

- Lead testing

- Mold and mildew testing

- Moisture context testing

- Other (please specify) 
24. Which of the diagnostic procedures listed below were initiated by your agency in PY 2010 and the two years prior to PY 2010? If your agency did not use a particular procedure, leave that item blank.

\section{Pressure diagnostics:}

- Blower door (house air leakage rate)

- Zonal pressure measurements

- Room-to-room pressure measurements (distribution balancing)

- Duct pressure pan measurements

- Duct blower measurements (duct air leakage rate)

Space-heating system:

- Flue gas analysis (steady-state efficiency measurements)

- Heat rise measurements

- CO measurements in flues

- Draft/spillage (normal operation)

Air-conditioning system:

- Refrigerant charge (e.g., superheat, subcooling)

HVAC components and cross-cutting diagnostics:

- Air handler flow rate

- Thermostat anticipator current

- Worst case draft/spillage (CAZ)

Hot-water (water-heating) system:

- Flue gas analysis (steady-state efficiency measurements)

- CO measurements in flues

- Draft/spillage (normal operation)

- Water flow rates (showerheads and faucets)

Other CO measurements:

- CO measurements in equipment rooms

- Cooking stove

- $\mathrm{CO}$ measurements in living areas

Other diagnostics and inspections:

- Refrigerator energy use

- Exhaust fan air flow rate measurement

- Infrared scanning (camera)

- Radon testing

- Lead testing

- Mold and mildew testing

- Moisture context testing

- Other (please specify) 
25. What types of credentials or experience were required of your staff who performed diagnostic procedures in Program Year 2010? Check all that apply.

- Technical certification

- Extensive weatherization work experience

- Extensive weatherization supervision experience

- Construction experience

- Other (specify)

26. Approximately how many hours did your agency spend on performing diagnostic procedures for a typical dwelling unit served by your agency in Program Year 2010? 
27. Please indicate the cost, amount of training needed, amount of time needed and effectiveness of the following types of diagnostic procedures relative to each other for PY 2010. Please use the following scale: 1 - very low; 2 -- low; 3 - medium; 4 - high; 5 very high.

Pressure diagnostics:

$\begin{array}{llll}\text { Cost } & \text { Training } & \text { Time } & \text { Effectiveness } \\ & \text { Needed } & \text { Needed } & \end{array}$

Blower door (house air leakage rate)

Zonal pressure measurements

Room-to-room pressure measurements

(distribution balancing)

Duct pressure pan measurements

Duct blower measurements (duct air leakage rate)

Space-heating system:

Flue gas analysis (steady-state efficiency

measurements)

Heat rise measurements

CO measurements in flues

Draft/spillage (normal operation)

Air-conditioning system:

Refrigerant charge (e.g., superheat, subcooling)

HVAC components and cross-cutting diagnostics:

Air handler flow rate

Thermostat anticipator current

Worst case draft/spillage (CAZ)

Hot-water (water-heating) system:

Flue gas analysis (steady-state efficiency

measurements)

$\mathrm{CO}$ measurements in flues

Draft/spillage (normal operation)

Water flow rates (showerheads and faucets)

Other CO measurements:

$\mathrm{CO}$ measurements in equipment rooms

Cooking stove

$\mathrm{CO}$ measurements in living areas

Other diagnostics and inspections:

Refrigerator energy use

Exhaust fan air flow rate measurement

Infrared scanning (camera)

Radon testing

Lead testing

Mold and mildew testing

Moisture context testing

Other (please specify 


\section{CLIENT EDUCATION}

1. Which of the following client education approaches did your agency use in Program Year 2010? (Check all that apply)

- Provide literature at time of client intake

- Provide video, CD or DVD at time of client intake

- Provide in-person instruction at time of client intake

- Provide hardware kit at time of client intake

- Provide literature at time of audit

- Provide video, CD or DVD at time of audit

- Provide in-person instruction at time of audit

- Provide hardware kit at time of audit

- Provide literature at time of weatherization

- Provide video, CD or DVD at time of weatherization

- Provide in-person instruction at time of weatherization

- Provide hardware kit at time of weatherization

- Provide literature at separate client education visit

- Provide video, CD or DVD at separate client education visit

- Provide in-person instruction at separate client education visit

- Provide hardware kit at separate client education visit

- Provide literature at time of inspection

- Provide video, CD or DVD at time of inspection

- Provide in-person instruction at time of inspection

- Provide hardware kit at time of inspection 
- Group training class

- Other (please specify) 
2. Which of the following broad topics did your agency cover with clients in Program Year 2010 ? (Check all that apply)

- Thermostat management

- HV $\overline{\mathrm{AC}}$ system operation/maintenance

- Distribution system adjustment and zoning

- Cooling load reduction

- Windows

- Insulation

- Ventilation

- Mold

- Refrigerator

- Hot water use

- Water heating system operation/maintenance

- Lighting

- Laundry

- Kitchen appliance operation

- Other baseload electric use

- Energy Star

- Safety monitors (e.g., CO monitors, smoke alarm)

- Energy bills

- Other (please specify)

3. Which of the following people provided client education for your agency in Program Year 2010? Check all that apply.

a. In-house manager 
b. In-house education specialist

c. Contractor education specialist

d. Intake staff person

e. Auditor

f. In-house weatherization crew chief

g. Contractor weatherization crew chief

h. In-house weatherization crew member

i. Contractor weatherization crew member

j. Inspector

k. Other (please specify)

4. If in-person instruction was provided by your agency in Program Year 2010, who was your preferred target? (Check best answer) Applicant Other adult member of household Child living in household Adult not living in household Other (please specify

5. If in-person instruction was provided by your agency in Program Year 2010, was it typically provided to a single person or multiple persons? Check best answer. single person multiple persons

6. What types of credentials or experience were required of those who provided client education for your agency in Program Year 2010? Check all that apply.

- College degree

- Technical certification

- Extensive experience in performing weatherization work

- Extensive experience in supervising weatherization work

- Educational background 
- Other (please specify)

7. Which of the client education approaches listed below were initiated by your agency during the ARRA period? (Check all that apply)

- Provide literature at time of client intake

- Provide video, CD or DVD at time of client intake

- Provide in-person instruction at time of client intake

- Provide hardware kit at time of client intake

- Provide literature at time of audit

- Provide video, CD or DVD at time of audit

- Provide in-person instruction at time of audit

- Provide hardware kit at time of audit

- Provide literature at time of weatherization

- Provide video, CD or DVD at time of weatherization

- Provide in-person instruction at time of weatherization

- Provide hardware kit at time of weatherization

- Provide literature at separate client education visit

- Provide video, CD or DVD at separate client education visit

- Provide in-person instruction at separate client education visit

- Provide hardware kit at separate client education visit

- Provide literature at time of inspection

- Provide video, CD or DVD at time of inspection

- Provide in-person instruction at time of inspection

- Provide hardware kit at time of inspection 
- Group training class

- Other (please specify) 
8. Please indicate the cost, amount of training needed, amount of time needed and effectiveness of the following types of client education approaches relative to each other for PY 2010. Please use the following scale: 1 - very low; 2 -low; 3 - medium; 4 -high; 5 - very high.

\section{Cost}

Provide video, CD or DVD at time of client intake Provide in-person instruction at time of client intake

Provide hardware kit at time of client intake Provide literature at time of audit Provide video, CD or DVD at time of audit

Provide in-person instruction at time of audit

Provide hardware kit at time of audit Provide literature at time of weatherization Provide video, CD or DVD at time of weatherization Provide in-person instruction at time of weatherization

Provide hardware kit at time of weatherization

Provide literature at separate client education visit

Provide video, CD or DVD at separate client education visit Provide in-person instruction at separate client education visit Provide hardware kit at separate client education visit Provide literature at time of inspection Provide video, CD or DVD at time of inspection

Provide in-person instruction at time of inspection

Provide hardware kit at time of inspection

Group training class

Other (please specify)

$\begin{array}{ccc}\text { Training } & \text { Time } \\ \text { Needed } & \text { Eeeded }\end{array}$


9. On average, approximately how many minutes were spent in Program Year 2010 on client education in a typical dwelling?

\section{TRAINING}

1. On which of the following weatherization topics did agency staff working on your agency's weatherization efforts receive training in Program Year 2010? Check all that apply.

(1) Diagnostic procedures

(2) Insulation

-- single family dwellings

-- multifamily dwellings

-- mobile homes

(3) Space heating, ventilation, air conditioning

-- single family dwellings

-- multifamily dwellings

-- mobile homes

(4) Infiltration measures

-- single family dwellings

-- multifamily dwellings

-- mobile homes

(5) Doors and windows

-- single family dwellings

-- multifamily dwellings

-- mobile homes

(6) Hot water heating

-- single family dwellings

-- multifamily dwellings

-- mobile homes

(7) Baseloads (e.g., lighting, refrigerators)

-- single family dwellings

-- multifamily dwellings

-- mobile homes

1a. On which of the following administrative-related topics did agency staff working on your agency's weatherization efforts receive training in Program Year 2010? Check all that apply.

(1) Management

(2) Client education

(3) Auditing/estimating

-- single family dwellings

-- multifamily dwellings

-- mobile homes

(4) Monitoring/quality control

(5) Financial topics

(6) Outreach and communications

(7) Other (please specify) 
1b. On which of the following health and safety topics did agency staff working on your agency's weatherization efforts receive training in Program Year 2010? Check all that apply. Fire safety Indoor air quality

Measures to increase security of housing unit Measures to reduce common household hazards Mold and mildew Lead Asbestos

Vermiculite

General crew safety Other health and safety Other (please specify) 
2. On which of the following diagnostic procedures did agency staff working on your agency's weatherization efforts receive training in Program Year 2010? Check all that apply.

\section{Pressure diagnostics:}

- Blower door (house air leakage rate)

- Zonal pressure measurements

- Room-to-room pressure measurements (distribution balancing)

- Duct pressure pan measurements

- Duct blower measurements (duct air leakage rate) Space-heating system:

- Flue gas analysis (steady-state efficiency measurements)

- Heat rise measurements

- CO measurements in flues

- Draft/spillage (normal operation)

Air-conditioning system:

- Refrigerant charge (e.g., superheat, subcooling)

HVAC components and cross-cutting diagnostics:

- Air handler flow rate

- Thermostat anticipator current

- Worst case draft/spillage (CAZ)

Hot-water (water-heating) system:

- Flue gas analysis (steady-state efficiency measurements)

- CO measurements in flues

- Draft/spillage (normal operation)

- Water flow rates (showerheads and faucets)

Other CO measurements:

- CO measurements in equipment rooms

- Cooking stove

- $\mathrm{CO}$ measurements in living areas

Other diagnostics and inspections:

- Refrigerator energy use

- Exhaust fan air flow rate measurement

- Infrared scanning (camera)

- Radon testing

- Lead testing

- Mold and mildew testing

- Moisture context testing

- Other (please specify) 
3. How many of your agency's staff were trained at the following events in Program Year 2010 ?

National Weatherization Program Conference

Affordable Comfort Conference

Other national conference

Regional weatherization conference

Your state's weatherization conference

Some other relevant conference in your state

Weatherization conference given by another state

Some other relevant conference given by another state

Any state or regional training center class

Manufacturer's training school class

Utility training class

Training classes provided by your agency or those agencies you work for One-time state-sponsored class

Any other class not sponsored by your state (e.g., another state, trade organization) Visit to an agency you do not work for training

Instruction provided by your state to your individual agency or those agencies you

work for

In-person expert visit just to your agency (e.g., peer exchange, consultant)

Web cast

Other (please specify) 
4. Which of the following weatherization topics listed below were agency staff first trained on in PY 2010 and two years prior to PY 2010? (Check all that apply)

(1) Diagnostic procedures

(2) Insulation

-- single family dwellings

-- multifamily dwellings

-- mobile homes

(3) Space heating, ventilation, air conditioning

-- single family dwellings

-- multifamily dwellings

-- mobile homes

(4) Infiltration measures

-- single family dwellings

-- multifamily dwellings

-- mobile homes

(5) Doors and windows

-- single family dwellings

-- multifamily dwellings

-- mobile homes

(6) Hot water heating

-- single family dwellings

-- multifamily dwellings

-- mobile homes

(7) Baseloads (e.g., lighting, refrigerators)

-- single family dwellings

-- multifamily dwellings

-- mobile homes

4a. Which of the following administrative-related topics listed below were agency staff first trained on in PY 2010 and in the two years prior to PY 2010? If your agency did not receive training on a particular subject, leave that item blank.

(1) Management

(2) Client education

(3) Auditing/estimating

-- single family dwellings

-- multifamily dwellings

-- mobile homes

(4) Monitoring/quality control

(5) Financial topics

(6) Outreach and communications

(7) Other (please specify) 
4b. Which of the following health and safety topics listed below were agency staff first trained on in PY 2010 and in the two years prior to PY 2010? (Check all that apply)

Fire safety

Indoor air quality

Measures to increase security of housing unit

Measures to reduce common household hazards

Mold and mildew

Lead

Asbestos

Vermiculite

General crew safety

Other health and safety

Other (please specify)

5. On which of the following weatherization topics did your agency provide training to your own in-house staff in Program Year 2010? (Check all that apply)

(1) Diagnostic procedures

(2) Insulation

-- single family dwellings

-- multifamily dwellings

-- mobile homes

(3) Space heating, ventilation, air conditioning

-- single family dwellings

-- multifamily dwellings

-- mobile homes

(4) Infiltration measures

-- single family dwellings

-- multifamily dwellings

-- mobile homes

(5) Doors and windows

-- single family dwellings

-- multifamily dwellings

-- mobile homes

(6) Hot water heating

-- single family dwellings

-- multifamily dwellings

-- mobile homes

(7) Baseloads (e.g., lighting, refrigerators)

-- single family dwellings

-- multifamily dwellings

-- mobile homes 
5a. On which of the following administrative-related topics did your agency provide training to your own in-house staff in Program Year 2010? (Check all that apply)

(1) Management

(2) Client education

(3) Auditing/estimating -- single family dwellings

-- multifamily dwellings

-- mobile homes

(4) Monitoring/quality control

(5) Financial topics

(6) Outreach and communications

(7) Other (please specify)

5b. On which of the following health and safety topics did your agency provide training to your own in-house staff in Program Year 2010? (Check all that apply)

Fire safety

Indoor air quality

Measures to increase security of housing unit

Measures to reduce common household hazards

Mold and mildew

Lead

Asbestos

Vermiculite

General crew safety

Other health and safety

Other (please specify) 
6. On which of the following diagnostic procedures did your agency provide training to your staff in Program Year 2010? (Check all that apply)

Pressure diagnostics:

- Blower door (house air leakage rate)

- Zonal pressure measurements

- Room-to-room pressure measurements (distribution balancing)

- Duct pressure pan measurements

- Duct blower measurements (duct air leakage rate)

Space-heating system:

- Flue gas analysis (steady-state efficiency measurements)

- Heat rise measurements

- CO measurements in flues

- Draft/spillage (normal operation)

Air-conditioning system:

- Refrigerant charge (e.g., superheat, subcooling)

HVAC components and cross-cutting diagnostics:

- Air handler flow rate

- Thermostat anticipator current

- Worst case draft/spillage (CAZ)

Hot-water (water-heating) system:

- Flue gas analysis (steady-state efficiency measurements)

- CO measurements in flues

- Draft/spillage (normal operation)

- Water flow rates (showerheads and faucets)

Other CO measurements:

- $\mathrm{CO}$ measurements in equipment rooms

- Cooking stove

- CO measurements in living areas

Other diagnostics and inspections:

- Refrigerator energy use

- Exhaust fan air flow rate measurement

- Infrared scanning (camera)

- Radon testing

- Lead testing

- Mold and mildew testing

- Moisture context testing

- Other (please specify) 
7. For each broad subject listed in the left-most column of the following table, put a check mark in the appropriate cell(s) to indicate which training method(s) you believe were most effective for imparting key skills and information in that area to your agency's inhouse or contractor weatherization staff in PY 2010:

\begin{tabular}{|l|l|l|l|l|l|l|}
\hline & Conferences & $\begin{array}{c}\text { Primarily } \\
\text { Field } \\
\text { training }\end{array}$ & $\begin{array}{c}\text { Primarily } \\
\text { Classroom } \\
\text { training }\end{array}$ & $\begin{array}{c}\text { Agency } \\
\text { visits }\end{array}$ & $\begin{array}{c}\text { Web } \\
\text { casts }\end{array}$ & $\begin{array}{c}\text { Other } \\
\text { (specify) }\end{array}$ \\
\hline Subject & & & & & & \\
\hline Management & & & & & & \\
\hline $\begin{array}{l}\text { Weatherization skills and } \\
\text { methods }\end{array}$ & & & & & & \\
\hline $\begin{array}{l}\text { Auditing/ } \\
\text { Estimating }\end{array}$ & & & & & & \\
\hline $\begin{array}{l}\text { Monitoring/ } \\
\text { quality control }\end{array}$ & & & & & & \\
\hline Financial topics & & & & & & \\
\hline $\begin{array}{l}\text { Outreach and } \\
\text { communications }\end{array}$ & & & & & & \\
\hline Health and safety & & & & & & \\
\hline Diagnostic procedures & & & & & & \\
\hline $\begin{array}{l}\text { Procedures for selecting } \\
\text { weatherization measures }\end{array}$ & & & & & & \\
\hline Client education & & & & & \\
\hline Other (specify) & & & & & & \\
\hline
\end{tabular}


8. For each broad subject listed in the left-most column of the following table, please indicate the quality of training received in Program Year 2010 at the training venues listed in the column headings. Please leave cells blank were your agency did not receive training during this period of time. Please use the following scale: 1-very low; 2 - low; 3medium; 4- high; 5-very high

\begin{tabular}{|l|l|l|l|l|l|l|}
\hline & $\begin{array}{c}\text { National } \\
\text { Weatherization } \\
\text { Program } \\
\text { Conference }\end{array}$ & $\begin{array}{c}\text { Affordable } \\
\text { Comfort } \\
\text { Conference }\end{array}$ & $\begin{array}{c}\text { Regional } \\
\text { Weatherization } \\
\text { Conference }\end{array}$ & $\begin{array}{c}\text { State } \\
\text { Weatherization } \\
\text { Conference }\end{array}$ & $\begin{array}{c}\text { State/ } \\
\text { Regional } \\
\text { Training } \\
\text { Center }\end{array}$ & $\begin{array}{c}\text { Training } \\
\text { Provided by } \\
\text { Your Own } \\
\text { Agency }\end{array}$ \\
\hline Subject & & & & & & \\
\hline Management & & & & & & \\
\hline $\begin{array}{l}\text { Weatherization skills } \\
\text { and methods }\end{array}$ & & & & & & \\
\hline $\begin{array}{l}\text { Auditing/ } \\
\text { Estimating }\end{array}$ & & & & & & \\
\hline $\begin{array}{l}\text { Monitoring/ } \\
\text { quality control }\end{array}$ & & & & & & \\
\hline Financial topics & & & & & & \\
\hline $\begin{array}{l}\text { Outreach and } \\
\text { communications }\end{array}$ & & & & & & \\
\hline Health and safety & & & & & & \\
\hline $\begin{array}{l}\text { Diagnostic } \\
\text { procedures }\end{array}$ & & & & & & \\
\hline $\begin{array}{l}\text { Procedures for } \\
\text { selecting } \\
\text { weatherization } \\
\text { measures }\end{array}$ & & & & & & \\
\hline Client education & & & & & & \\
\hline Other (specify) & & & & & & \\
\hline
\end{tabular}


9. For those staff working in your agency who needed to have knowledge about the following list of weatherization topics in PY 2010, how well trained were they in each area in PY 2010? Please use the following scale: 1 - not at all well trained; 2 - not well trained; 3 moderately well trained; 4 -well trained; 5 - very well trained; 6 - not applicable Circle best answer.

(1) Diagnostic procedures

(2) Insulation

-- single family dwellings

-- multifamily dwellings

-- mobile homes

(3) Space heating, ventilation, air conditioning

-- single family dwellings

-- multifamily dwellings

-- mobile homes

(4) Infiltration measures

-- single family dwellings

-- multifamily dwellings

-- mobile homes

(5) Doors and windows

-- single family dwellings

-- multifamily dwellings

-- mobile homes

(6) Hot water heating

-- single family dwellings

-- multifamily dwellings

-- mobile homes

(7) Baseloads (e.g., lighting, refrigerators)

-- single family dwellings

-- multifamily dwellings

-- mobile homes

$\begin{array}{llllll}1 & 2 & 3 & 4 & 5 & 6 \\ 1 & 2 & 3 & 4 & 5 & 6 \\ 1 & 2 & 3 & 4 & 5 & 6 \\ 1 & 2 & 3 & 4 & 5 & 6\end{array}$

$\begin{array}{llllll}1 & 2 & 3 & 4 & 5 & 6 \\ 1 & 2 & 3 & 4 & 5 & 6 \\ 1 & 2 & 3 & 4 & 5 & 6\end{array}$

$\begin{array}{llllll}1 & 2 & 3 & 4 & 5 & 6 \\ 1 & 2 & 3 & 4 & 5 & 6 \\ 1 & 2 & 3 & 4 & 5 & 6\end{array}$

$\begin{array}{llllll}1 & 2 & 3 & 4 & 5 & 6 \\ 1 & 2 & 3 & 4 & 5 & 6 \\ 1 & 2 & 3 & 4 & 5 & 6\end{array}$

$\begin{array}{llllll}1 & 2 & 3 & 4 & 5 & 6 \\ 1 & 2 & 3 & 4 & 5 & 6 \\ 1 & 2 & 3 & 4 & 5 & 6\end{array}$

$\begin{array}{llllll}1 & 2 & 3 & 4 & 5 & 6 \\ 1 & 2 & 3 & 4 & 5 & 6 \\ 1 & 2 & 3 & 4 & 5 & 6\end{array}$

9a. For those staff working in your agency who needed to have knowledge about the following list of administrative-related topics, how well trained were they in each area in PY 2010? Please use the following scale: 1 - not at all well trained; 2 - not well trained; 3 moderately well trained; 4 -well trained; 5 - very well trained; 6 - not applicable Circle best answer.

(1) Management

(2) Client education

$\begin{array}{llllll}1 & 2 & 3 & 4 & 5 & 6 \\ 1 & 2 & 3 & 4 & 5 & 6\end{array}$

(3) Auditing/estimating

-- single family dwellings

-- multifamily dwellings

-- mobile homes

(4) Monitoring/quality control

(5) Financial topics

(6) Outreach and communications

$\begin{array}{llllll}1 & 2 & 3 & 4 & 5 & 6 \\ 1 & 2 & 3 & 4 & 5 & 6 \\ 1 & 2 & 3 & 4 & 5 & 6 \\ 1 & 2 & 3 & 4 & 5 & 6 \\ 1 & 2 & 3 & 4 & 5 & 6 \\ 1 & 2 & 3 & 4 & 5 & 6\end{array}$


$\begin{array}{lllllll}\text { (7) Other (please specify) } & 1 & 2 & 3 & 4 & 5 & 6\end{array}$

9b. For those staff working in your agency who needed to have knowledge about the following list of health and safety topics, how well trained were they in each area in PY 2010? Please use the following scale: 1 - not at all well trained; 2 - not well trained; 3 moderately well trained; 4 -well trained; 5 - very well trained; 6 - not applicable Circle best answer.

(1) Fire safety

(2) Indoor air quality

(3) Measures to increase security of housing unit

(4) Measures to reduce common household hazards

(5) Mold and mildew

(6) Lead

(7) Asbestos

(8) Vermiculite

(9) General crew safety

(10) Other health and safety

(11) Other (please specify

$\begin{array}{llllll}1 & 2 & 3 & 4 & 5 & 6 \\ 1 & 2 & 3 & 4 & 5 & 6 \\ 1 & 2 & 3 & 4 & 5 & 6 \\ 1 & 2 & 3 & 4 & 5 & 6 \\ 1 & 2 & 3 & 4 & 5 & 6 \\ 1 & 2 & 3 & 4 & 5 & 6 \\ 1 & 2 & 3 & 4 & 5 & 6 \\ 1 & 2 & 3 & 4 & 5 & 6 \\ 1 & 2 & 3 & 4 & 5 & 6 \\ 1 & 2 & 3 & 4 & 5 & 6 \\ 1 & 2 & 3 & 4 & 5 & 6\end{array}$

9c. For categories receiving answers of (1)-not at all well trained, or (2)-not well trained to the above questions, what were the barriers for receiving this training:
a. Funding
b. Time
c. Not a priority
d. Not available
e. Other 
10. For those staff working in your agency who needed to have knowledge about the following list of diagnostic topics, how well trained were they in each area in PY 2010?

Please use the following scale: 1 - not at all well trained; 2 - not well trained; 3 - moderately well trained; 4 -well trained; 5 - very well trained; 6 - not applicable Circle best answer.

\section{Pressure diagnostics:}

- Blower door (house air leakage rate)

- Zonal pressure measurements

- Room-to-room pressure measurements

- Duct pressure pan measurements

- Duct blower measurements (duct air leakage rate) Space-heating system:

- Flue gas analysis (steady-state efficiency measurements) $1 \quad 2 \quad \begin{array}{lllll}3 & 4 & 5 & 6\end{array}$

- Heat rise measurements

- CO measurements in flues

- Draft/spillage (normal operation)

Air-conditioning system:

- Refrigerant charge (e.g., superheat, subcooling)

HVAC components and cross-cutting diagnostics:

- Air handler flow rate

- Thermostat anticipator current

- Worst case draft/spillage (CAZ)

Hot-water (water-heating) system:

$\begin{array}{llllll}1 & 2 & 3 & 4 & 5 & 6 \\ 1 & 2 & 3 & 4 & 5 & 6 \\ 1 & 2 & 3 & 4 & 5 & 6 \\ 1 & 2 & 3 & 4 & 5 & 6 \\ 1 & 2 & 3 & 4 & 5 & 6\end{array}$

- Flue gas analysis (steady-state efficiency measurements)

- CO measurements in flues

- Draft/spillage (normal operation)

- Water flow rates (showerheads and faucets)

Other CO measurements:

- $\mathrm{CO}$ measurements in equipment rooms

- Cooking stove

- CO measurements in living areas

Other diagnostics and inspections:

- Refrigerator energy use

- Exhaust fan air flow rate measurement

- Infrared scanning (camera)

- Radon testing

- Lead testing

- Mold and mildew testing

- Moisture context testing

- Other (please specify)

$\begin{array}{llllll}1 & 2 & 3 & 4 & 5 & 6\end{array}$

$\begin{array}{llllll}1 & 2 & 3 & 4 & 5 & 6\end{array}$

$\begin{array}{llllll}1 & 2 & 3 & 4 & 5 & 6\end{array}$

$\begin{array}{llllll}1 & 2 & 3 & 4 & 5 & 6\end{array}$

$\begin{array}{llllll}1 & 2 & 3 & 4 & 5 & 6\end{array}$

$\begin{array}{llllll}1 & 2 & 3 & 4 & 5 & 6\end{array}$

$\begin{array}{llllll}1 & 2 & 3 & 4 & 5 & 6\end{array}$

$\begin{array}{llllll}1 & 2 & 3 & 4 & 5 & 6\end{array}$

$\begin{array}{llllll}1 & 2 & 3 & 4 & 5 & 6\end{array}$

$\begin{array}{llllll}1 & 2 & 3 & 4 & 5 & 6\end{array}$

$\begin{array}{llllll}1 & 2 & 3 & 4 & 5 & 6\end{array}$

$\begin{array}{llllll}1 & 2 & 3 & 4 & 5 & 6\end{array}$

$\begin{array}{llllll}1 & 2 & 3 & 4 & 5 & 6\end{array}$

$\begin{array}{llllll}1 & 2 & 3 & 4 & 5 & 6\end{array}$

$\begin{array}{llllll}1 & 2 & 3 & 4 & 5 & 6\end{array}$

10a. For categories receiving answers of (1)-not at all well trained, or (2)-not well trained to the above question, what were the barriers for receiving this training:

a. Funding

b. Time 
c. Not a priority

d. Not available

e. Other

11. Overall, how well trained were your agency's weatherization crews in PY 2010? (Check best answer)

Very well trained

Well trained

Neither well nor poorly trained

Poorly trained

Very poorly trained

12. What were the barriers that prevented your crews from receiving all the training they need? (Check all that apply)

Lack of training funds

Cannot take crews out of the field long enough for training

Training not available at the right times

Training not available at the right places

Available training is poor in quality

\section{INSPECTION}

1. Which of the following types of post-weatherization quality control inspection did your agency perform on your weatherized dwelling units in Program Year 2010? Check all that apply.

- Visual inspection of installed measures

- Verification of insulation depths/quantities

- Verification of operation of measures installed

- Assessment of quality of measures installed

- Identification of needed measures that were not installed

- Blower door test

- Heating system efficiency test (flue gas analysis)

- Draft/spillage tests of heating systems

- Carbon monoxide (CO) monitoring

- Infrared scanning 
- Identification of unresolved health and safety issues

- Discussion with occupants

- Other (specify)

2. Please indicate which types of post-weatherization quality control inspection listed below were initiated since ARRA PY 2009. Check all that apply.

- Visual inspection of installed measures

- Verification of insulation depths/quantities

- Verification of operation of measures installed

- Assessment of quality of measures installed

- Identification of needed measures that were not installed

- Blower door test

- Heating system efficiency test (flue gas analysis)

- Draft/spillage tests of heating systems

- Carbon monoxide (CO) monitoring

- Infrared scanning

- Identification of unresolved health and safety issues

- Discussion with occupants

- Other (specify)

3. Which of the following post-weatherization quality and control inspection topics listed below were agency staff trained on in PY 2010? Check all that apply.

- Visual inspection of installed measures

- Verification of insulation depths/quantities

- Verification of operation of measures installed 
- Assessment of quality of measures installed

- Identification of needed measures that were not installed

- Blower door test

- Other diagnostic tests

- Identification of unresolved health and safety issues

- Discussion with occupants

- Other (specify)

4. Please indicate the cost, amount of training needed, amount of time needed and effectiveness of the following types of post-weatherization quality control inspection procedures relative to each other for PY 2010. Please use the following scale: 1 - very low; 2 -low; 3 - medium; 4 - high; 5 - very high.

$\begin{array}{cccc}\text { Cost } & \text { Training } & \text { Time } & \text { Effectiveness } \\ & \text { Needed } & \text { Needed } & \end{array}$

Visual inspection of installed measures

Verification of insulation depths/quantities

Verification of operation of measures installed

Assessment of quality of measures installed

Identification of needed measures that were not

installed

Blower door test

Other diagnostic tests

Identification of unresolved health and safety

issues

Discussion with occupants

Other (please specify)

5. Approximately how many hours did it take to perform a typical post-weatherization quality control inspection in Program Year 2010, by the major components listed below?

- Scheduling

- Travel

- On-site work

- Post-inspection analysis and write-up 
- Other

- TOTAL of all components

6. Which of the following parties were involved in performing your agency's postweatherization quality control inspections in Program Year 2010? Check all that apply.

- In-house manager

- In-house inspection specialist

- Contractor inspection specialist

- In-house weatherization crew chief

- Contractor weatherization crew chief

- In-house weatherization crew member

- Contractor weatherization crew member

- Other (please specify)

6a. Which party was primarily responsible for post-weatherization quality control inspections? Check best answer.

- In-house manager

- In-house inspection specialist

- Contractor inspection specialist

- In-house weatherization crew chief

- Contractor weatherization crew chief

- In-house weatherization crew member

- Contractor weatherization crew member

- Other (please specify)

7. About how many agency weatherization office staff went into the field to monitor local weatherization agencies in your state in Program Year 2010? \{Note: do not include people who do quality assurance at the local agency level for the local agencies.\} 
- Agency staff

- Agency contractors

- Other (please specify)

8. What types of credentials or experience did your agency's post-weatherization quality control inspectors have in Program Year 2010? Check all that apply.

- Technical certification

- Extensive experience performing pre-weatherization audits

- Extensive experience performing weatherization work

- Extensive experience supervising weatherization work

- Construction experience

- Other (please specify)

9. Please indicate the level of experience for the agency staff engaged post-weatherization quality control inspections in Program Year 2010 in each of the following functional areas:

\begin{tabular}{|l|l|l|l|l|l|}
\hline & $\begin{array}{c}\text { Very } \\
\text { High }\end{array}$ & High & Average & Low & Very Low \\
\hline $\begin{array}{l}\text { Performing weatherization } \\
\text { work }\end{array}$ & & & & & \\
\hline $\begin{array}{l}\text { Supervising weatherization } \\
\text { work }\end{array}$ & & & & & \\
\hline Working in construction & & & & & \\
\hline $\begin{array}{l}\text { Performing pre- } \\
\text { weatherization audits }\end{array}$ & & & & & \\
\hline
\end{tabular}

10. For those dwelling units for which post-weatherization quality control inspections were performed by your agency in Program Year 2010, typically how many days after weatherization completion did the initial inspection take place?

11. In those cases where a Program Year 2010 post-weatherization quality control inspection revealed a problem with the job performed, what action was most commonly taken in response to that finding? Check one.

- Sent original crew or contractor back to correct problem

- Sent different crew or contractor to correct problem 
- Sent crew supervisor to correct problem

- Sent someone from state office to correct problem

- No action taken

- Other (please specify)

12. What other actions were taken in Program Year 2010 in response to the discovery of a problem with the weatherization job performed? Check all that apply.

- Sent original crew or contractor back to correct problem

- Sent different crew or contractor to correct problem

- Sent crew supervisor to correct problem

- Sent someone from state office to correct problem

- No action taken

- Other (please specify)

13. In Program Year 2010, how many of the dwelling units weatherized by your agency required some additional work as a result of the findings of your post-weatherization quality control inspections?

13a. Of those requiring some additional work, how many had work done that probably resulted in more energy savings?

14. What were the three most common problems found in the dwelling units inspected by your agency in Program Year 2010?
1)
2)
3)

15. In Program Year 2010, did your agency use findings from your post-weatherization quality control inspections to provide feedback to your in-house or contractor crews on workmanship or related issues?

16. To what extent does post-weatherization quality control inspection affect the quality of future weatherization work?
(1) No extent
(2) Little extent
(3) Moderate extent 
(4) Substantial extent

(5) Very substantial extent

17. Did the observation of problems with the quality of weatherization work lead to changes in weatherization training for your staff?

(1) Yes

(2) No

17a. If Yes, what changes were made?

18. Did your agency observe weatherization training sessions to help identify potential problem areas for inspecting in the field (e.g., with respect to installation of measures that trainees seem to have trouble understanding)?

(1) Yes

(2) No

18a. If Yes, briefly describe how your in-field inspection activities were affected by your training session observations. 
OMB Control Number: XXXX-XXXX

\section{APPENDIX F. DF2: HOUSING UNIT INFORMATION SURVEY}

Thank you for your prompt response to this data request which is part of the ARRAperiod evaluation of the Weatherization Assistance Program. Evaluation results will provide essential feedback to the weatherization community and inform policymakers about the program's effects on clients' energy consumption, cost savings, and nonenergy benefits.

This data form collects detailed information about homes weatherized by your agency in Program Year 2010. The information you supply will be used with billing history data to better understand energy savings attributable to the Weatherization Assistance Program under ARRA.

Please use this form (DF2) to provide information about any single family detached and attached houses, mobile homes, or individual units within multi-family buildings. The Building Information Survey (DF3) should be used to document information on small or large multifamily buildings in which the whole building and all units in the building were weatherized or are waitlisted. Refer to the definitions of each building type provided at the end of the survey because these definitions are slightly different than those commonly used within the Weatherization Assistance Program.

All of the information obtained from this survey will be protected and will remain confidential. The data will be analyzed in such a way that the information provided cannot be associated back to your state, your agencies, or the housing units and clients that your state served.

Thank you in advance for completing this survey.

Public reporting burden for this collection of information is estimated to average twenty hours per weatherization agency, including the time for reviewing instructions, searching existing data sources, gathering and maintaining the data needed, and completing and reviewing the collection of information. Send comments regarding this burden estimate or any other aspect of this collection of information, including suggestions for reducing this burden, to Office of the Chief Information Officer, Records Management Division, IM-11, Paperwork Reduction Project (__ _ U.S. Department of Energy, 1000 Independence Ave SW, Washington, DC, 20585-1290; and to the Office of Management and Budget (OMB), OIRA, Paperwork Reduction Project (__ _ W W W W 20503. 
Form completed by:

Date:

\section{IDENTIFICATION}

[Q1-5 will be pre-completed by the evaluation team]

1. Agency name:

2. State:

3. Agency job number:

4. Occupant name:

5a. Site address: 5b. City:

\section{WEATHERIZATION INFORMATION}

Weatherization dates (not audit or inspection dates):

6a. Started:

6b. Completed:

$$
\text { (month) } \overline{\text { (day) }}
$$

The start date is the first date that weatherization improvements were made to the home. The weatherization start date is not the date the audit or home assessment was conducted

UNLESS energy efficiency improvements were made at the time of the audit. Client education and low-cost measures such as light bulbs and showerheads ARE considered energy efficiency improvements, and if any of those are implemented at the time of the audit, then the start date is the audit date.

The end date is the last date that weatherization improvements were made to the home, including any rework required after agency or state-level post-weatherization inspections. The date of the post-inspection should NOT be used as the weatherization end date unless the post-inspection was conducted on the last day that improvements were made to the home and no rework was required.

7. Was this a "reweatherized" unit? (check only one)

$\square$ Yes

$\square$ No

$\square$ Don’t know

Check "yes" if the home was weatherized prior to PY 2010. 
8. Did this client file a complaint about the weatherization services you provided? (check only one) $\quad \square$ Yes

$\square$ No

$\square$ Don't know

\section{HOUSING UNIT}

9. Building type - see definitions at the end of the survey: (check only one)

$\square$ Single-family detached house

$\square$ Single-family attached house (e.g., side-by-side duplex, townhouse, row house)

$\checkmark$ Single-family - unknown whether attached or detached

$\square$ Mobile home

$\square$ Small multifamily building (2-4 units per building and not a SF attached house)

house)

$\square$ Large multifamily building ( 5 or more units per building and not a SF attached

$\square$ Shelter

$\square$ Don’t know

10. Number of stories above grade: (check only one)

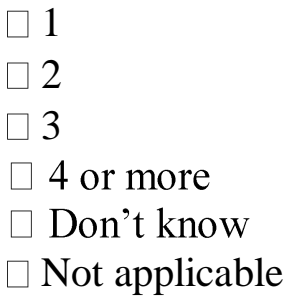

Please list the number of stories above ground-level. If there are half-stories, round up to the nearest whole number. For example, please check "2" for a 1.5-story split-level house.

11. If single-family attached, number of units attached (adjacent) to this unit: (check only one)
1
$\square 2$
$\square 3$
$\square 4$ or more
Don't know
$\square$ Not applicable

For single family attached homes, please list the number of separate housing units that share at least one wall with this housing unit. For example, check "2" if housing unit is a row house with homes on either side. Check "1" for a side-by-side duplex. 
12. If mobile home, number of rooms that have been added on: (check only one)

$$
\begin{aligned}
& \square \text { None } \\
& \square 1 \\
& \square 2 \\
& \square 3 \\
& \square 4 \text { or more } \\
& \square \text { Don't know } \\
& \square \text { Not applicable }
\end{aligned}
$$

13. If small or large multifamily building, number of units in the building: (check only one)

$$
\begin{aligned}
& \square 2 \\
& \square 3 \\
& \square 4 \\
& \square 5-9 \\
& \square 10-19 \\
& \square 20-29 \\
& \square 30-49 \\
& \square 50-99 \\
& \square 100 \text { or more } \\
& \square \text { Don't know } \\
& \square \text { Not applicable }
\end{aligned}
$$

14. Year house/building originally built: (check only one)
$\square 2000$ or later
$\square 1990$ to 1999
$\square 1980$ to 1989
$\square 1970$ to 1979
$\square 1960$ to 1969
$\square 1950$ to 1959
$\square 1940$ to 1949
$\square 1930$ to 1939
$\square 1920$ to 1929
$\square 1910$ to 1919
$\square 1900$ to 1909
$\square$ Before 1900
$\square$ Don’t know 
Conditioned floor area at the time of weatherization:

15a. Heated floor area: $\mathrm{ft}^{2}$

Don’t know

15b. Air conditioned floor area: $\mathrm{ft}^{2}$

Don’t know

Include the basement only if it is intentionally conditioned (heated and/or cooled).

If you only know the total square footage of the home, please select "don't know" rather than listing the total square footage.

16. Primary fuel used to heat the unit during the winter before weatherization: (check only one)
$\square$ Electricity
$\square$ Natural gas
$\square$ Propane/LPG
$\neg$ Fuel oil
Wood
Other (specify:
$\square$ Don’t know

17. Primary fuel used for water heating before weatherization: (check only one)

$\square$ Natural gas

$\square$ Propane/LPG

Electricity

Other (specify:

$\square$ Don't know

18. Type of primary space-heating system before weatherization: (check only one) electricity)

Central (ducted) warm-air furnace (forced-air or gravity, any fuel including

$\square$ Heat pump

Built-in electric units (e.g., electric baseboards, ceiling heat)

$\square$ Steam or hot water system (e.g., floor or baseboard radiators, convectors)

$\square$ Floor, wall, or pipeless (ductless) furnace (e.g., floor or wall furnace)

$\square$ Room/space heater (nonportable)

$\square$ Portable space heater

$\square$ Cooking stove

$\square$ None

$\square$ Don't know

Select "steam or hot water system" for homes heated with boilers. 
19. If small or large multifamily building, was the primary space-heating system shared with other housing units? (check only one)

$\square$ Yes

$\square$ No

$\square$ Don't know

$\square$ Not applicable

20. Supplemental fuel(s) used to heat the unit during the winter before weatherization: (check all that apply)

$\square$ Electricity

$\square$ Natural gas

$\square$ Propane/LPG

$\square$ Fuel oil

$\square$ Wood

$\square$ Other (specify:

$\square$ Don't know

21. Type of operable air conditioning system present before weatherization: (check all that apply)

$\square$ Central air conditioner/heat pump

$\square$ Window/wall units

$\square$ Evaporative cooling system ("swamp coolers")

$\square$ None

$\square$ Don't know

22. Number of window/wall air conditioning units: (check only one)
$\square$ None
$\square 1$
$\square 2$
$\square 3$
$\square 4$ or more
$\square$ Don't know

\section{AUDIT}

23. Primary method used to select weatherization measures for this house (excluding health, safety, and repair measures and general heat waste measures): (check only one)

$\square$ Priority list

$\square$ Calculation procedure (e.g., spreadsheet, computerized audit)

$\square$ Other (specify: )

24. If a calculation procedure was used, the name of the procedure(s): (check all that apply) $\square$ AK Warm 


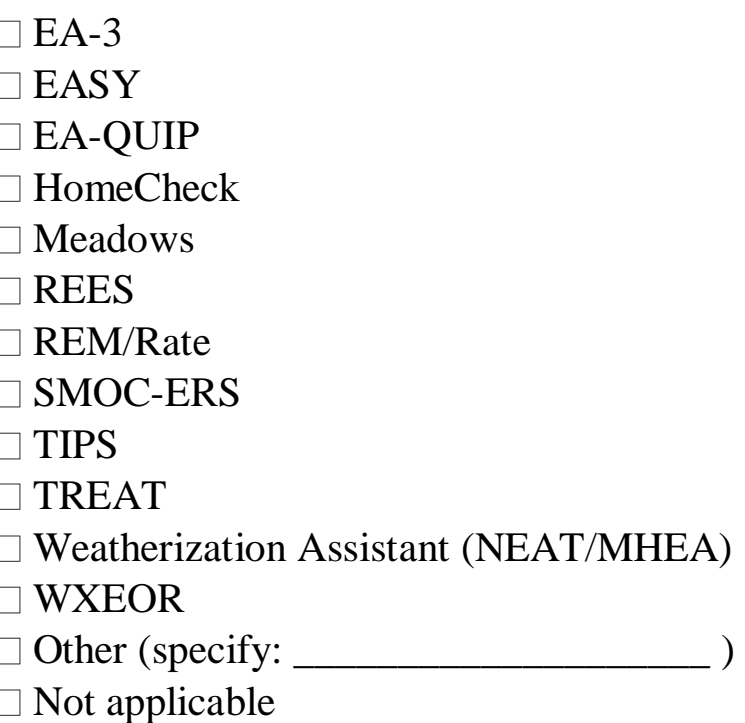

\section{DIAGNOSTICS AND INSPECTIONS}

If you know when a diagnostic/inspection procedure was performed, please check the appropriate box(es) in the first three response columns. If a diagnostic/inspection procedure was performed but you do not know when, please check the box in the "Performed?" column.

\begin{tabular}{|c|c|c|c|c|}
\hline \multirow[t]{2}{*}{ Diagnostic measurement or inspection } & \multicolumn{3}{|c|}{ Diagnostic/inspection performed during: } & \multirow[b]{2}{*}{ Performed? } \\
\hline & $\begin{array}{c}\text { Audit/house } \\
\text { assessment }\end{array}$ & $\begin{array}{c}\text { Measure } \\
\text { installation }\end{array}$ & $\begin{array}{c}\text { Post- } \\
\text { inspection }\end{array}$ & \\
\hline \multicolumn{5}{|l|}{ Pressure diagnostics: } \\
\hline 25a. House air leakage (blower door measurement) & $\square$ & $\square$ & $\square$ & $\square$ \\
\hline 25b. Zonal pressure & $\square$ & $\square$ & $\square$ & $\square$ \\
\hline $\begin{array}{l}\text { 25c. Room-to-room pressures (distribution system } \\
\text { balancing) }\end{array}$ & $\square$ & $\square$ & $\square$ & $\square$ \\
\hline 25d. Duct pressure pan measurements & $\square$ & $\square$ & $\square$ & $\square$ \\
\hline 25e. Duct blower measurement (duct air leakage rate) & $\square$ & $\square$ & $\square$ & $\square$ \\
\hline 25f. Blower door subtraction meas. (duct air leakage rate) & $\square$ & $\square$ & $\square$ & $\square$ \\
\hline \multicolumn{5}{|l|}{ Space-heating system: } \\
\hline $\begin{array}{l}\text { 26a. Flue gas analysis (steady-state efficiency } \\
\text { measurement) }\end{array}$ & $\square$ & $\square$ & $\square$ & $\square$ \\
\hline 26b. Heat rise & $\square$ & $\square$ & $\square$ & $\square$ \\
\hline 26c. CO level in flue & $\square$ & $\square$ & $\square$ & $\square$ \\
\hline
\end{tabular}




\begin{tabular}{|c|c|c|c|c|}
\hline \multirow[t]{2}{*}{ Diagnostic measurement or inspection } & \multicolumn{3}{|c|}{ Diagnostic/inspection performed during: } & \multirow[b]{2}{*}{ Performed? } \\
\hline & $\begin{array}{c}\text { Audit/house } \\
\text { assessment }\end{array}$ & $\begin{array}{c}\text { Measure } \\
\text { installation }\end{array}$ & $\begin{array}{c}\text { Post- } \\
\text { inspection }\end{array}$ & \\
\hline 26d. CO level of equipment room & $\square$ & $\square$ & $\square$ & $\square$ \\
\hline 26e. Draft/spillage (normal operation) & $\square$ & $\square$ & $\square$ & $\square$ \\
\hline 26f. Worst case draft/spillage (CAZ) & $\square$ & $\square$ & $\square$ & $\square$ \\
\hline 26g. Safety inspection & $\square$ & $\square$ & $\square$ & $\square$ \\
\hline \multicolumn{5}{|l|}{ Air-conditioning system: } \\
\hline 27a. Refrigerant charge (e.g., superheat or subcooling) & $\square$ & $\square$ & $\square$ & $\square$ \\
\hline 27b. Safety inspection & $\square$ & $\square$ & $\square$ & $\square$ \\
\hline \multicolumn{5}{|l|}{ HVAC components: } \\
\hline 28a. Air handler flow rate & $\square$ & $\square$ & $\square$ & $\square$ \\
\hline 28b. Thermostat anticipator current & $\square$ & $\square$ & $\square$ & $\square$ \\
\hline \multicolumn{5}{|l|}{ Hot-water (water-heating) system: } \\
\hline $\begin{array}{l}\text { 29a. Flue gas analysis (steady-state efficiency } \\
\text { measurement) }\end{array}$ & $\square$ & $\square$ & $\square$ & $\square$ \\
\hline 29b. CO level in flue & $\square$ & $\square$ & $\square$ & $\square$ \\
\hline 29c. CO level of equipment room & $\square$ & $\square$ & $\square$ & $\square$ \\
\hline 29d. Draft/spillage (normal operation) & $\square$ & $\square$ & $\square$ & $\square$ \\
\hline 29e. Worst case draft/spillage (CAZ) & $\square$ & $\square$ & $\square$ & $\square$ \\
\hline 29f. Hot water temperature & $\square$ & $\square$ & $\square$ & $\square$ \\
\hline 29g. Shower head flow rate & $\square$ & $\square$ & $\square$ & $\square$ \\
\hline 29h. Faucet flow rate & $\square$ & $\square$ & $\square$ & $\square$ \\
\hline 29i. Safety inspection & $\square$ & $\square$ & $\square$ & $\square$ \\
\hline \multicolumn{5}{|l|}{ Other CO measurements: } \\
\hline 30a. Cook stove & $\square$ & $\square$ & $\square$ & $\square$ \\
\hline 30b. Kitchen & $\square$ & $\square$ & $\square$ & $\square$ \\
\hline 30c. Main living area & $\square$ & $\square$ & $\square$ & $\square$ \\
\hline Other diagnostics and inspections: & & & & \\
\hline
\end{tabular}




\begin{tabular}{|c|c|c|c|c|}
\hline Diagnostic measurement or inspection & \multicolumn{3}{|c|}{ Diagnostic/inspection performed during: } & \\
\hline & $\begin{array}{c}\text { Audit/house } \\
\text { assessment }\end{array}$ & $\begin{array}{c}\text { Measure } \\
\text { installation }\end{array}$ & $\begin{array}{c}\text { Post- } \\
\text { inspection }\end{array}$ & Performed? \\
\hline 31a. Refrigerator energy use & $\square$ & $\square$ & $\square$ & $\square$ \\
\hline 31b. Exhaust fan air flow rate & $\square$ & $\square$ & $\square$ & $\square$ \\
\hline 31c. Infrared scanning (camera) & $\square$ & $\square$ & $\square$ & $\square$ \\
\hline 31d. Radon testing & $\square$ & $\square$ & $\square$ & $\square$ \\
\hline 31e. Other (specify: ___ ) & $\square$ & $\square$ & $\square$ & $\square$ \\
\hline 31f. Other (specify: ___ & $\square$ & $\square$ & $\square$ & $\square$ \\
\hline 31g. Other (specify: __ _ ) & $\square$ & $\square$ & $\square$ & $\square$ \\
\hline
\end{tabular}

Record the diagnostic measurements taken on THIS housing unit: (fill in all that were taken)

For diagnostics that were performed multiple times, please provide the measurements that are closest to the pre-weatherization and post-weatherization conditions of the home.

\begin{tabular}{|c|c|c|}
\hline Diagnostic measurement & $\begin{array}{c}\text { Pre- } \\
\text { weatherization }\end{array}$ & $\begin{array}{c}\text { Post } \\
\text { weatherization }\end{array}$ \\
\hline \multicolumn{3}{|l|}{ House air leakage (blower door measurement): } \\
\hline 32a. Air leakage rate & $\mathrm{cfm}$ & $\mathrm{cfm}$ \\
\hline 32b. House WRT outside pressure difference ${ }^{10}$ & $\mathrm{~Pa}$ & $\mathrm{~Pa}$ \\
\hline \multicolumn{3}{|l|}{ Duct leakage (pressure pan measurements): } \\
\hline 33a. Sum of pressure pan readings ${ }^{11}$ & $\mathrm{~Pa}$ & $\overline{\mathrm{Pa}}$ \\
\hline 33b. Number of registers included in sum ${ }^{12}$ & & \\
\hline 33c. House WRT outside pressure difference 13 & $\overline{\mathrm{Pa}}$ & $\overline{\mathrm{Pa}}$ \\
\hline Duct leakage (duct blower measurements) ${ }^{14}$ : & & \\
\hline
\end{tabular}

\footnotetext{
${ }^{10}$ Report the pressure differential at which the blower door test was performed. A typical value is 50 Pascals. Do not report baseline pressure (typically less than 5 Pascals).

${ }^{11}$ Total all of the individual measurements taken at registers in the home. The value for each register should be between 0 and 50 Pascals.

${ }^{12}$ Total the number of registers at which the test was performed.

${ }^{13}$ Report the pressure differential at which the test was performed (from blower door). A typical value is 50 Pascals.

${ }^{14}$ If total duct leakage (inside the home and to the outside) was measured with a Duct Blaster ${ }^{\mathrm{TM}}$ or
} 


\begin{tabular}{|l|r|r|}
\hline 34a. Total duct leakage rate & cfm & cfm \\
\hline 34b. Duct leakage to the outside & $\mathrm{cfm}$ & $\mathrm{Pa}$ \\
\hline 34c. Duct WRT outside pressure difference ${ }^{15}$ & $\mathrm{~Pa}$ & $\%$ \\
\hline Steady-state efficiency (flue gas analysis): & $\%$ & $\%$ \\
\hline 35a. Primary space-heating system & $\%$ & $\%$ \\
\hline 35b. Secondary space-heating system & $\%$ & \\
\hline 35c. Hot water heater & & \\
\hline
\end{tabular}

\section{MEASURES INSTALLED}

If you know whether in-house crew or a contractor installed a given measure, please check the appropriate box in the first two response columns. If a measure was installed but you do not know whether it was installed by in-house crew or a contractor, please check the box in the "Installed?" column.

\begin{tabular}{|c|c|c|c|}
\hline \multirow{2}{*}{ Measure } & \multicolumn{2}{|c|}{ Installed by } & \multirow[b]{2}{*}{ Installed? } \\
\hline & $\begin{array}{l}\text { In-house } \\
\text { crew }\end{array}$ & Contractor & \\
\hline \multicolumn{4}{|l|}{ Air sealing work: } \\
\hline $\begin{array}{l}\text { 36a. General house caulking and weatherstripping (e.g., doors, } \\
\text { windows) }\end{array}$ & $\square$ & $\square$ & $\square$ \\
\hline $\begin{array}{l}\text { 36b. Air sealing emphasizing bypasses (leaks identified by auditor } \\
\text { and/or crew without using a blower door) }\end{array}$ & $\square$ & $\square$ & $\square$ \\
\hline $\begin{array}{l}\text { 36c. Air sealing emphasizing bypasses (leaks identified by auditor } \\
\text { and/or crew with aid of a blower door) }\end{array}$ & $\square$ & $\square$ & $\square$ \\
\hline 36d. Air distribution system (duct) sealing or repair ${ }^{16}$ & $\square$ & $\square$ & $\square$ \\
\hline $\begin{array}{l}\text { 36e. Repairs to broken windows, doors, or other major holes in the } \\
\text { building shell }\end{array}$ & $\square$ & $\square$ & $\square$ \\
\hline 36f. Other non-window air sealing work (specify: __ & $\square$ & $\square$ & $\square$ \\
\hline 36g. Other non-window air sealing work (specify: & $\square$ & $\square$ & $\square$ \\
\hline \multicolumn{4}{|l|}{ Insulation: } \\
\hline 37a. Attic insulation & $\square$ & $\square$ & $\square$ \\
\hline
\end{tabular}

similar equipment, report results in 40a. If duct leakage to the outside was measured, report this result in 40b. Most agencies will report results in "a" or "b," but not both.

${ }^{15}$ Report the house-to-outside pressure differential (from blower door) at which the leakage-tooutside test was performed. A typical value is 25 Pascals.

${ }^{16}$ Check $42 \mathrm{~d}$ if duct sealing or duct repair was performed. Check $46 \mathrm{~d}$ if new ductwork was installed. Check 49c if new vents, grills or registers were installed. 


\begin{tabular}{|c|c|c|c|}
\hline \multirow[t]{2}{*}{ Measure } & \multicolumn{2}{|c|}{ Installed by } & \multirow[b]{2}{*}{ Installed? } \\
\hline & $\begin{array}{c}\text { In-house } \\
\text { crew }\end{array}$ & Contractor & \\
\hline \multicolumn{4}{|l|}{$\begin{array}{l}\text { If attic insulation was installed, please provide quantity: } \\
\begin{array}{l}37 \mathrm{~b} . \\
\text { or }\end{array} \\
\begin{array}{l}\text { 37c.__ } \\
\text { square feet }\end{array}\end{array}$} \\
\hline 37e. Wall insulation & $\square$ & $\square$ & $\square$ \\
\hline \multicolumn{4}{|l|}{$\begin{array}{l}\text { If wall insulation was installed, please provide quantity: } \\
\begin{array}{l}37 \mathrm{f} . \\
\text { or }\end{array} \\
37 \mathrm{~g} .\end{array}$} \\
\hline $37 \mathrm{~h}$. Floor insulation $^{17}$ & $\square$ & $\square$ & $\square$ \\
\hline 37i. Rim or band joist insulation (sill box) & $\square$ & $\square$ & $\square$ \\
\hline $37 \mathrm{j}$. Foundation wall insulation & $\square$ & $\square$ & $\square$ \\
\hline 37k. Duct insulation & $\square$ & $\square$ & $\square$ \\
\hline 371. White roof coat applied to mobile home & $\square$ & $\square$ & $\square$ \\
\hline 37m. Mobile home skirting & $\square$ & $\square$ & $\square$ \\
\hline 37n. Mobile home belly insulation & $\square$ & $\square$ & $\square$ \\
\hline 37o. Other insulation (specify: ___ & $\square$ & $\square$ & $\square$ \\
\hline 37p. Other insulation (specify: ___ & $\square$ & $\square$ & $\square$ \\
\hline \multicolumn{4}{|l|}{ Windows: } \\
\hline 38a. New window (justified because cost effective) & $\square$ & $\square$ & $\square$ \\
\hline 38b. New window (justified for reason other than cost effectiveness) & $\square$ & $\square$ & $\square$ \\
\hline \multicolumn{4}{|l|}{ 38c. If new windows were installed, please provide quantity: } \\
\hline $\begin{array}{l}\text { 38d. Window glass repair or replacement not included under air } \\
\text { sealing major holes in building shell }(42 \mathrm{e})\end{array}$ & $\square$ & $\square$ & $\square$ \\
\hline \multicolumn{4}{|l|}{ 38e. Repair of window sashes or frames } \\
\hline 38f. Window screen repair/replacement & $\square$ & $\square$ & $\square$ \\
\hline 38g. Window lock replacement & $\square$ & $\square$ & $\square$ \\
\hline 38h. Storm window installed & $\square$ & $\square$ & $\square$ \\
\hline 38i. Window shading (e.g., awning, film, sun screen) & $\square$ & $\square$ & $\square$ \\
\hline
\end{tabular}

\footnotetext{
${ }^{17}$ Exclude mobile home belly insulation, which should be listed under 43o.
} 


\begin{tabular}{|c|c|c|c|}
\hline \multirow[t]{2}{*}{ Measure } & \multicolumn{2}{|c|}{ Installed by } & \multirow[b]{2}{*}{ Installed? } \\
\hline & $\begin{array}{c}\text { In-house } \\
\text { crew }\end{array}$ & Contractor & \\
\hline 38j. Other window treatments (specify: & $\square$ & $\square$ & $\square$ \\
\hline 38k. Other window treatments (specify: & $\square$ & $\square$ & $\square$ \\
\hline \multicolumn{4}{|l|}{ Doors: } \\
\hline 39a. New door (justified because cost effective) & $\square$ & $\square$ & $\square$ \\
\hline 39b. New door (justified for reason other than cost effectiveness) & $\square$ & $\square$ & $\square$ \\
\hline 39c. Door lock (new or replacement) & $\square$ & $\square$ & $\square$ \\
\hline $\begin{array}{l}\text { 39d. Door or door framing repair not included under air sealing major } \\
\text { holes in building shell }(42 \mathrm{e})\end{array}$ & $\square$ & $\square$ & $\square$ \\
\hline 39e. Storm door installed & $\square$ & $\square$ & $\square$ \\
\hline 39f. Other door treatments (specify: & $\square$ & $\square$ & $\square$ \\
\hline 39g. Other door treatments (specify: ___ & $\square$ & $\square$ & $\square$ \\
\hline \multicolumn{4}{|l|}{ Central space heating systems (e.g., furnaces, boilers): ${ }^{18}$} \\
\hline 40a. New heating system (justified because cost effective) & $\square$ & $\square$ & $\square$ \\
\hline $\begin{array}{l}\text { 40b. New heating system (justified for reason other than cost } \\
\text { effectiveness) }\end{array}$ & $\square$ & $\square$ & $\square$ \\
\hline 40c. Space-heating system repair (e.g., controls, safety items, flues) & $\square$ & $\square$ & $\square$ \\
\hline \multicolumn{4}{|l|}{ 40d. New ductwork installed } \\
\hline 40e. Space-heating system tune-up & $\square$ & $\square$ & $\square$ \\
\hline 40f. Vent damper installed & $\square$ & $\square$ & $\square$ \\
\hline 40g. Intermittent ignition device installed & $\square$ & $\square$ & $\square$ \\
\hline 40h. Other heating system modification (specify: ___ ) $^{19}$ & $\square$ & $\square$ & $\square$ \\
\hline 40i. Other heating system modification (specify: ___ & $\square$ & $\square$ & $\square$ \\
\hline \multicolumn{4}{|l|}{ Air-conditioning systems: } \\
\hline 41a. New air conditioner (justified because cost effective) & $\square$ & $\square$ & $\square$ \\
\hline $\begin{array}{l}\text { 41b. New air conditioner (justified for reason other than cost } \\
\text { effectiveness) }\end{array}$ & $\square$ & $\square$ & $\square$ \\
\hline 41c. Air conditioner repair & $\square$ & $\square$ & $\square$ \\
\hline
\end{tabular}

\footnotetext{
${ }^{18}$ Include central heating systems installed through programs other than WAP, such as emergency heating system replacements funded by LIHEAP.

${ }^{19}$ Check $42 \mathrm{~d}$ if duct sealing or duct repair was performed. Check 46d if new ductwork was installed. Check 49c if new vents, grills or registers were installed.
} 


\begin{tabular}{|c|c|c|c|}
\hline \multirow[t]{2}{*}{ Measure } & \multicolumn{2}{|c|}{ Installed by } & \multirow[b]{2}{*}{ Installed? } \\
\hline & $\begin{array}{c}\text { In-house } \\
\text { crew }\end{array}$ & Contractor & \\
\hline 41d. Air conditioner recharge/tune-up & $\square$ & $\square$ & $\square$ \\
\hline 41e. Ceiling or whole-house fans & $\square$ & $\square$ & $\square$ \\
\hline 41f. Other air-conditioning system modification (specify: ___ & $\square$ & $\square$ & $\square$ \\
\hline 41g. Other air-conditioning system modification (specify: & $\square$ & $\square$ & $\square$ \\
\hline \multicolumn{4}{|l|}{ Ventilation: } \\
\hline 42a. New bathroom exhaust fan installed & $\square$ & $\square$ & $\square$ \\
\hline 42b. New kitchen exhaust fan installed & $\square$ & $\square$ & $\square$ \\
\hline \multicolumn{4}{|l|}{ 42c. Repair to kitchen or bathroom exhaust fan (including ductwork) } \\
\hline 42d. Whole-house ventilation system & $\square$ & $\square$ & $\square$ \\
\hline 42f. Other ventilation system improvements (specify: ___ & $\square$ & $\square$ & $\square$ \\
\hline 42g. Other ventilation system improvements (specify: ___ & $\square$ & $\square$ & $\square$ \\
\hline \multicolumn{4}{|l|}{ HVAC accessories: } \\
\hline 43a. New programmable (setback) thermostat & $\square$ & $\square$ & $\square$ \\
\hline 43b. New standard thermostat & $\square$ & $\square$ & $\square$ \\
\hline 43c. New duct vents, grills, or registers installed ${ }^{20}$ & $\square$ & $\square$ & $\square$ \\
\hline 43d. Standard air filter installed & $\square$ & $\square$ & $\square$ \\
\hline 43e. High efficiency particulate arresting (HEPA) air filter installed & $\square$ & $\square$ & $\square$ \\
\hline 43f. Other HVAC accessories (specify: __ & $\square$ & $\square$ & $\square$ \\
\hline 43g. Other HVAC accessories (specify: __ & $\square$ & $\square$ & $\square$ \\
\hline \multicolumn{4}{|l|}{ Water-heating system: } \\
\hline 44a. New water heater (justified because cost effective) & $\square$ & $\square$ & $\square$ \\
\hline $\begin{array}{l}\text { 44b. New water heater (justified for reason other than cost } \\
\text { effectiveness) }\end{array}$ & $\square$ & $\square$ & $\square$ \\
\hline 44c. Water-heating system repair & $\square$ & $\square$ & $\square$ \\
\hline 44d. Water-heater tank insulation wrap & $\square$ & $\square$ & $\square$ \\
\hline 44e. Pipe insulation & $\square$ & $\square$ & $\square$ \\
\hline
\end{tabular}

${ }^{20}$ Check $36 \mathrm{~d}$ if duct sealing OR duct repair was performed. Check $40 \mathrm{~d}$ if new ductwork was installed. 


\begin{tabular}{|c|c|c|c|}
\hline \multirow[t]{2}{*}{ Measure } & \multicolumn{2}{|c|}{ Installed by } & \multirow[b]{2}{*}{ Installed? } \\
\hline & $\begin{array}{c}\text { In-house } \\
\text { crew }\end{array}$ & Contractor & \\
\hline 44f. Installed low-flow showerhead & $\square$ & $\square$ & $\square$ \\
\hline 44g. Installed low-flow device on faucet (aerator) & $\square$ & $\square$ & $\square$ \\
\hline 44h. Water heater temperature reduction & $\square$ & $\square$ & $\square$ \\
\hline 44i. Other water heating system measure (specify: ___ & $\square$ & $\square$ & $\square$ \\
\hline $44 \mathrm{j}$. Other water heating system measure (specify: ___ & $\square$ & $\square$ & $\square$ \\
\hline \multicolumn{4}{|l|}{ Other baseloads: } \\
\hline 45a. Indoor lighting (energy efficient bulb or fixture) & $\square$ & $\square$ & $\square$ \\
\hline 45b. Outdoor lighting (energy efficient bulb or fixture) & $\square$ & $\square$ & $\square$ \\
\hline 45c. Lighting (indoor/outdoor location not recorded) & $\square$ & $\square$ & $\square$ \\
\hline 45d. Refrigerator (justified because cost effective) & $\square$ & $\square$ & $\square$ \\
\hline 45e. Refrigerator (justified for reason other than cost effectiveness) & $\square$ & $\square$ & $\square$ \\
\hline \multicolumn{4}{|l|}{$\begin{array}{l}45 \mathrm{f} \text {. If new refrigerator is installed, how many old refrigerators were } \\
\text { removed? }\end{array}$} \\
\hline \multicolumn{4}{|l|}{$\begin{array}{l}45 \mathrm{~g} . \text { If new refrigerator is installed, how many stand-alone freezers } \\
\text { were removed? }\end{array}$} \\
\hline 45h. Other baseload measure (specify: __ & $\square$ & $\square$ & $\square$ \\
\hline 45i. Other baseload measure (specify: __ & $\square$ & $\square$ & $\square$ \\
\hline \multicolumn{4}{|l|}{ Health and safety and repair: } \\
\hline 46a. Smoke alarm & $\square$ & $\square$ & $\square$ \\
\hline 46b. CO monitor & $\square$ & $\square$ & $\square$ \\
\hline 46c. Attic ventilation & $\square$ & $\square$ & $\square$ \\
\hline 46d. Roof repair & $\square$ & $\square$ & $\square$ \\
\hline 46e. Clothes dryer vent repair or replacement & $\square$ & $\square$ & $\square$ \\
\hline 46f. Ceiling repair & $\square$ & $\square$ & $\square$ \\
\hline 46g. Wall repair & $\square$ & $\square$ & $\square$ \\
\hline 46h. Floor repair & $\square$ & $\square$ & $\square$ \\
\hline 46i. Foundation repair & $\square$ & $\square$ & $\square$ \\
\hline 46j. Ground vapor barrier & $\square$ & $\square$ & $\square$ \\
\hline 46k. Gutter or downspout (installed or repaired) & $\square$ & $\square$ & $\square$ \\
\hline
\end{tabular}




\begin{tabular}{|c|c|c|c|}
\hline \multirow[t]{2}{*}{ Measure } & \multicolumn{2}{|c|}{ Installed by } & \multirow[b]{2}{*}{ Installed? } \\
\hline & $\begin{array}{c}\text { In-house } \\
\text { crew }\end{array}$ & Contractor & \\
\hline 461. Plumbing repair & $\square$ & $\square$ & $\square$ \\
\hline 46m. Sewer repair & $\square$ & $\square$ & $\square$ \\
\hline 46n. Electrical repair & $\square$ & $\square$ & $\square$ \\
\hline 46o. Stair repair & $\square$ & $\square$ & $\square$ \\
\hline 46p. Install/repair non-skid material on stairs & $\square$ & $\square$ & $\square$ \\
\hline 46q. Install/repair safety gate at stairs & $\boxminus$ & $\square$ & $\boxminus$ \\
\hline 46r. Install/repair grab bar in bathroom & $\boxminus$ & $\boxminus$ & $\boxminus$ \\
\hline 46s. Install/repair non-skid material in bathtub & $\boxminus$ & $\boxminus$ & $\boxminus$ \\
\hline 46t. Install/repair metal chimney liner & $\square$ & $\square$ & $\square$ \\
\hline 46u. Lead abatement & $\square$ & $\square$ & $\square$ \\
\hline 46v. Asbestos abatement & $\square$ & $\square$ & $\square$ \\
\hline 46w. Removal or safe storage of household poisons & $\square$ & $\square$ & $\square$ \\
\hline 46x. Other health and safety/repair items (specify: ___ & $\square$ & $\square$ & $\square$ \\
\hline 46y. Other health and safety/repair items (specify: ___ & $\square$ & $\square$ & $\square$ \\
\hline Client education: & & & \\
\hline $\begin{array}{l}\text { 47a. Did the occupants receive an in-home visit in which energy } \\
\text { education was provided? }\end{array}$ & & $\begin{array}{l}\text { Yes } \\
\text { No } \\
\text { Don't know }\end{array}$ & \\
\hline $\begin{array}{l}\text { 47b. Did the occupants participate in a classroom training in which } \\
\text { energy education was provided? }\end{array}$ & & $\begin{array}{l}\text { Yes } \\
\text { No } \\
\text { Don't know }\end{array}$ & \\
\hline
\end{tabular}

\section{SERC AND WIPP MEASURES INSTALLED}

48. Please indicate whether any additional measures were installed in this unit that were funded by the Sustainable Energy Resources for Consumers (SERC) Program and/or Weatherization Innovation Pilot Program (WIPP).

a. SERC funded measures were installed

b. WIPP funded measures were installed

c. Both SERC and WIPP funded measures were installed

d. The unit was not part of a SERC or WIPP grant (go to Q 61) 
If you know whether in-house crew or a contractor installed a given measure, please check the appropriate box in the first two response columns. If a measure was installed but you do not know whether it was installed by in-house crew or a contractor, please check the box in the "Installed?" column.

\begin{tabular}{|c|c|c|c|}
\hline \multirow[t]{2}{*}{ Measure } & \multicolumn{2}{|c|}{ Installed by } & \multirow[b]{2}{*}{ Installed? } \\
\hline & $\begin{array}{c}\text { In-house } \\
\text { crew }\end{array}$ & Contractor & \\
\hline \multicolumn{4}{|l|}{ RENEWABLE ENERGY } \\
\hline 49a. S1.1 Solar PV & $\square$ & $\square$ & $\square$ \\
\hline 49b. S1.2 PV: Shingles & $\square$ & $\square$ & $\square$ \\
\hline 49c. S1.3 Wind: Small-scale Residential & $\square$ & $\square$ & $\square$ \\
\hline \multicolumn{4}{|l|}{ 49d. S1.4 Passive Solar Panel } \\
\hline \multicolumn{4}{|l|}{ HOT WATER SYSTEMS } \\
\hline 50a. S2.1 Solar HW & $\square$ & $\square$ & $\square$ \\
\hline 50b. S2.2 Tankless/On-demand HW & $\square$ & $\square$ & $\square$ \\
\hline 50c. S2.3 Condensing HW & $\square$ & $\square$ & $\square$ \\
\hline 50d. S2.4 Heat Pump/Hybrid HW & $\square$ & $\square$ & $\square$ \\
\hline 50e. S2.5 Combination HW and Boiler & $\square$ & $\square$ & $\square$ \\
\hline 50f. S2.6 Other hot water & $\square$ & $\square$ & $\square$ \\
\hline \multicolumn{4}{|l|}{ HVAC SYSTEMS } \\
\hline 51a. S3.1 Heat Pumps: Geothermal/Ground-Source & $\square$ & $\square$ & $\square$ \\
\hline 51b. S3.2 Heat Pumps: Air & $\square$ & $\square$ & $\square$ \\
\hline 51c. S3.3 Heat Pumps: Mini Split System Ductless & $\square$ & $\square$ & $\square$ \\
\hline 51d. S3.4 Replacement of Improperly Sized HVAC Equipment & $\square$ & $\square$ & $\square$ \\
\hline 51e. S3.5 Solar Thermal (Home Heat) & $\square$ & $\square$ & $\square$ \\
\hline 51f. S3.6 Wood Pellet Stoves & $\square$ & $\square$ & $\square$ \\
\hline 51g. S3.7 Ultra Cooling Systems & $\square$ & $\square$ & $\square$ \\
\hline 51h. S3.8 Central AC Units & $\square$ & $\square$ & $\square$ \\
\hline 51i. S3.9 Window AC Units & $\square$ & $\square$ & $\square$ \\
\hline 51j. S3.10 Micro-combined Heat and Power & $\square$ & $\square$ & $\square$ \\
\hline 51k. S3.11 High-efficiency Furnaces & $\square$ & $\square$ & $\square$ \\
\hline 511. S3.12 Heat Recovery Ventilators & $\square$ & $\square$ & $\square$ \\
\hline 51m. S3.13 Biomass Thermal Units Installed & $\square$ & $\square$ & $\square$ \\
\hline 51n. S3.14 Evaporative Cooling System & $\square$ & $\square$ & $\square$ \\
\hline 510. S3.15 Vented Space Heating & $\square$ & $\square$ & $\square$ \\
\hline 51p. S3.16 Solar Powered Attic Ventilation & $\square$ & $\square$ & $\square$ \\
\hline 51q. S3.17 Energy Recovery Ventilator & $\square$ & $\square$ & $\square$ \\
\hline \multicolumn{4}{|l|}{ ROOFING: COOL ROOF } \\
\hline 52a. S4.1 Roofing: Cool Roof Technology Installed & $\square$ & $\square$ & $\square$ \\
\hline
\end{tabular}




\begin{tabular}{|c|c|c|c|}
\hline APPLIANCES & & & \\
\hline 53a. S5.1 Energy Star Clothes Washer & $\square$ & $\square$ & $\square$ \\
\hline 53b. S5.2 Energy-Efficient Clothes Dryer & $\square$ & $\square$ & $\square$ \\
\hline 53c. S5.3 Energy-Efficient Refrigerator & $\square$ & $\square$ & $\square$ \\
\hline 53d. S5.4 Appliance Energy Meters & $\square$ & $\square$ & $\square$ \\
\hline \multicolumn{4}{|l|}{ INSULATION } \\
\hline 54a. S6.1 Insulation: Aerogel/super & $\square$ & $\square$ & $\square$ \\
\hline 54b. S6.2 Insulation: Foam Injection Technology & $\square$ & $\square$ & $\square$ \\
\hline 54c. S6.3 Insulation: Masonry Foam & $\square$ & $\square$ & $\square$ \\
\hline 54d. S6.4 Insulation: Radiant Barrier Attic & $\square$ & $\square$ & $\square$ \\
\hline 54e. S6.5 Insulate: Spray Foam & $\square$ & $\square$ & $\square$ \\
\hline 54f. S6.6 Insulation: Reflective Attic Insulation & $\square$ & $\square$ & $\square$ \\
\hline \multicolumn{4}{|l|}{ WHOLE-HOUSE RETROFIT } \\
\hline 55a. S7.1 Centralized Building Controls & $\square$ & $\square$ & $\square$ \\
\hline 55b. S7.2 Deep Energy Retrofits & $\square$ & $\square$ & $\square$ \\
\hline 55c. S7.3 High-Performance Space Conditioning Retrofits & $\square$ & $\square$ & $\square$ \\
\hline 55d. S7.4 High-Performance Building Envelope Retrofits & $\square$ & $\square$ & $\square$ \\
\hline 55e. S7.5 Cold Energy Retrofits & $\square$ & $\square$ & $\square$ \\
\hline 55f. S7.6 Warm Energy Retrofits & $\square$ & $\square$ & $\square$ \\
\hline 55g. S7.7 Foundation Improvements & $\square$ & $\square$ & $\square$ \\
\hline \multicolumn{4}{|l|}{ OUTREACH } \\
\hline 56a. S8.1 Home Energy Saver Workshops & $\square$ & $\square$ & $\square$ \\
\hline 56b. S8.2 Households Touched by Behavioral Change Message & $\square$ & $\square$ & $\square$ \\
\hline \multicolumn{4}{|l|}{ EQUIPMENT } \\
\hline 57a. S9.1 Monitoring: In-Home Energy Monitors & $\square$ & $\square$ & $\square$ \\
\hline \multicolumn{4}{|l|}{ OTHER } \\
\hline 58a. S10.1 Units with Window Upgrades & $\square$ & $\square$ & $\square$ \\
\hline 58b. S10.2 Outdoor Solar Security Lighting & $\square$ & $\square$ & $\square$ \\
\hline 58c. S10.3 Ceiling Fans & $\square$ & $\square$ & $\square$ \\
\hline 58d. S10.4 LED Lights & $\square$ & $\square$ & $\square$ \\
\hline 58e. S10.5 Energy Star Doors & $\square$ & $\square$ & $\square$ \\
\hline
\end{tabular}

61. If a new space-heating system was installed, indicate the primary fuel used to heat the unit during the winter after weatherization: (check only one)

$\square$ Natural gas

$\square$ Propane/LPG

Kerosene (\#1 fuel oil)

$\square$ Fuel oil (\#2 fuel oil)

$\square$ Electricity

$\square$ Wood 
$\square$ Coal

Other (specify:

$\square$ Don't know

$\square$ Not applicable

62. If a new space-heating system was installed, indicate the type of primary space-heating system after weatherization: (check only one) electricity)

$\square$ Central (ducted) warm-air furnace (forced-air or gravity, any fuel including

$\square$ Heat pump

Built-in electric units (e.g., electric baseboards, ceiling heat)

$\square$ Steam or hot water system (e.g., floor or baseboard radiators, convectors)

$\checkmark$ Floor, wall, or pipeless (ductless) furnace (e.g., floor or wall furnace)

$\square$ Room/space heater (nonportable)

Portable space heater

$\square$ Cooking stove

$\square$ None

Other (specify:

Don't know

$\square$ Not applicable

Select "steam or hot water system" for homes heated with boilers.

63. If a new space-heating system was installed and justified for reasons other than cost effectiveness, identify the reason it was replaced: (check all that apply)

$\square$ Cost of repair/retrofit exceeded $50 \%$ of replacement cost

$\square$ Existing heating system was not running

$\square$ Existing heating system was old (e.g., at end of life, too old to be repaired/adjusted)

$\square$ To switch fuel

$\square$ To convert from a steam system to a hot water system

$\square$ Heat exchanger was cracked

$\square$ Boiler was leaking

$\square$ Safety switches/controls were not operational and could not be repaired

$\square$ To replace unvented space heater(s)

$\square$ Existing heating system was not safe to run for other reason (specify:

$\square$ Other (specify: 
64. Please identify any cost-effective energy-efficiency measures (not repair or health and safety measures) recommended by your energy audit procedures that you were unable to install in this housing unit because of insufficient funds: (check all that apply)

Air sealing

$\square$ Duct sealing

$\square$ Attic insulation

$\square$ Wall insulation

$\square$ Floor/foundation insulation

Duct insulation

$\square$ New window(s)

$\checkmark$ Storm windows(s)

Door(s)

$\square$ Storm door(s)

$\square$ New space-heating system

$\square$ Space-heating system tune-up

$\square$ New air conditioner(s)

$\checkmark$ Air conditioner tune-up(s)

$\square$ HVAC thermostat

$\square$ New water heater

$\square$ Water heater insulation wrap

$\square$ Water flow devices (e.g., showerheads, faucet aerators)

$\square$ Lighting

$\square$ Refrigerator

$\rightarrow$ Other:

$\square$ None

This question only applies in states where there is a per-home spending limit. If there is not a per-home spending limit in your state, check "none."

65. If energy efficiency measures were checked in the previous question, provide a rough estimate of the cost for installing all the measures checked: $\$$

66. Please identify any repair or health and safety measures recommended by your audit procedures that you were unable to install in this housing unit because of insufficient funds:

(check all that apply)

$\square$ New window(s)

$\square$ Window glazing(s)

$\checkmark$ Window screen(s)

Window $\operatorname{lock}(\mathrm{s})$

Window repair

$\square$ New door(s)

$\square$ Door lock(s)

$\square$ Door repair 
New space-heating system

Space-heating system repair

New air conditioner(s)

Air conditioner repair

$\checkmark$ Ceiling or whole-house fan(s)

$\square$ Exhaust fan(s) or ventilation system

$\square$ New water heater

$\square$ Water-heating system repair

Refrigerator

$\square$ Smoke alarm

CO monitor

Attic ventilation

$\square$ Roof, wall, floor, or foundation repair

Plumbing/sewer repair

Electrical repair

$\square$ Other:

$\square$ None

\section{This question only applies in states where there is a per-home spending limit. If there is} not a per-home spending limit in your state, check "none."

67. If repair or health and safety measures were checked in the previous question, provide a rough estimate of the cost for installing all the measures checked: $\$$

\section{COSTS}

68. Provide the total cost of weatherizing this housing unit. Include ALL sources of funding. Do NOT include program management costs (e.g., intake, audits, final inspections or program administration) or installation-related overhead costs (e.g., vehicles, equipment and training).

69. Divide the total costs spent on this housing unit (from Question 68) into the categories below.

\begin{tabular}{|l|l|}
\hline 69a. Material costs & \\
\hline 69b. Labor costs & \\
\hline 69c. Enter total job cost if above categories are not known & \\
\hline 69d. Total (should match Q68 total) & [Auto-tally] \\
\hline
\end{tabular}


70. Divide the labor costs (from Question 69b) into the categories below. If labor costs for inhouse crew are not tracked at the job level please leave 70a blank.

\begin{tabular}{|l|l|}
\hline 70a. In house crew labor & \\
\hline 70b. Contractor labor & \\
\hline 70c. Profit/overhead ${ }^{2}$ & \\
\hline 70d. Enter total labor costs if above categories are not known & [Auto-tally] \\
\hline 70e. Total (should match Q68b total) & $\begin{array}{l}{ }^{1} \text { Crew-based labor costs should be based on the crew's fully loaded hourly rate (rather than the crew's } \\
\text { take-home pay rate) which may include costs associated with medical and other insurance, workers } \\
\text { compensation, vacations, and other benefits. These labor costs should include the crew's time for } \\
\text { traveling to and from the job site. }\end{array}$ \\
\\
$\begin{array}{l}\text { 2If contractor profit and overhead are included in the contractor's material and labor costs, then leave } 70 \mathrm{~b} \\
\text { blank. }\end{array}$ \\
\hline
\end{tabular}

71. Provide estimates of non-monetary contributions to this weatherization job.

\begin{tabular}{|c|c|}
\hline 71a. Volunteer Hours ${ }^{1}$ & \\
\hline 71b. Apprentice Hours ${ }^{2}$ & \\
\hline 71c. Estimated Value of Material In-Kind Contribution & \\
\hline 71d. Estimated Value of Other In-Kind Contributions & \\
\hline
\end{tabular}

72. Divide the total costs spent on this housing unit (from Question 68) into the categories below.

\begin{tabular}{|l|l|}
\hline 72a. Cost effective energy-related measures (SIR > 1.0) & \\
\hline 72b. Health and safety and other non-cost effective measures & \\
\hline 72c. Incidental repairs & \\
\hline 72d. Enter total job cost if above categories are not known & \\
\hline 72e. Total (should match Q68 total) & [Auto-tally] \\
\hline
\end{tabular}

73. Divide the total costs spent on this housing unit (from Question 68) into these funding source categories below. 


\begin{tabular}{|l|l|}
\hline 73a. DOE-Normal Appropriation/Formula WAP funds ${ }^{1}$ & \\
\hline 73b. DOE SERC Funds & \\
\hline 73c. DOE WIPP Funds & \\
\hline 73d. Non-DOE (leveraged) funds & [Auto-tally] \\
\hline 73e. Total (should match Q68 total) & \\
\hline $\begin{array}{l}\text { I This line includes ARRA funds for standard weatherization } \\
\text { jobs. }\end{array}$ & \\
\hline
\end{tabular}

Energy Assistance Program (LI-EAP) funding should be considered Non-DOE funds if it is tracked separately.

74. Provide the amounts spent on the major measure categories below.

\begin{tabular}{|l|l|}
\hline 74a. HVAC measures & \\
\hline 74b. Water heating measures & \\
\hline 74c. Replacement windows and doors & \\
\hline $\begin{array}{l}\text { 74d. All other building shell measures (insulation, air sealing, } \\
\text { etc.) }\end{array}$ & \\
\hline
\end{tabular}




\section{Housing Type Definitions}

Single Family Detached - House that provides living space for one family or household, is contained within walls that go from the basement (or the ground floor, if there is no basement) to

the roof, and has no walls that are shared (or built in contact) with another household. A manufactured house assembled on site is a single family detached housing unit, not a mobile home.

Single Family Attached - House that provides living space for one household, is contained within walls that go from the basement (or the ground floor, if there is no basement) to the roof, has at

least one wall that is shared (or built in contact) with an adjacent household, and has an independent outside entrance. An attached house does not have any other households living above or below, and does not share basement or attic space with other housing units. Also, an attached house does not share a heating or cooling system with any other housing units. Examples include row houses, townhouses, condominiums and side-by-side duplexes that do not have shared attics, basements or HVAC equipment.

Small Multi-family (2-4 units) - Building with two to four housing units (i.e., building that is divided into living quarters for two, three, or four families or households) in which one household

lives above or beside another and does not meet the single family attached house definition. Includes houses originally intended for occupancy by one family (or for some other use) that have since been converted to separate dwellings for two to four families. Typical arrangements in these types of living quarters are separate apartments downstairs and upstairs or one apartment on each of three or four floors.

Large multifamily (5 or More Units per Building) - Building with five or more housing units (i.e., building that contains living quarters for five or more families or households) that does not meet the single family attached house definition.

Mobile Home - Home that is built on a movable chassis, is moved to the site, and may be placed on a permanent or temporary foundation. If rooms are added to the structure, it is considered a mobile home if the added floor area is less than the mobile home's original floor area; otherwise, it is a single family detached house. A manufactured house assembled on site is a single family detached house, not a mobile home.

Shelter - Structure whose principal purpose is to house individuals on a temporary basis who may or may not be related to one another and who are not living in nursing homes, prisons, or similar institutional care facilities. 
OMB Control Number: XXXX-XXXX

\section{APPENDIX G. DF3: BUILDING INFORMATION SURVEY}

\section{Thank you for your prompt response to this data request which is part of the ARRA- period evaluation of the Weatherization Assistance Program. Evaluation results will provide essential feedback to the weatherization community and inform policymakers about the program's effects on clients' energy consumption, cost savings, and non- energy benefits.}

This survey collects detailed information about multifamily buildings weatherized by your agency in Program Year 2010. The information you supply will be used with billing history data to better understand energy savings attributable to the Weatherization Assistance Program under ARRA.

Please use this form (DF3) to provide information about small or large multifamily buildings in which improvements were made to the building shell, common areas, central HVAC or domestic hot water systems. The Housing Unit Information Survey (DF2) should be used to document information on weatherized single family detached and attached houses, mobile homes, or individual units within multifamily buildings. Refer to the definitions of each building type provided at the end of the survey because these definitions are slightly different than those commonly used within the Weatherization Assistance Program.

All of the information obtained from this survey will be protected and will remain confidential. The data will be analyzed in such a way that the information provided cannot be associated back to your state, your agencies, or the housing units and clients that your state served.

Thank you in advance for completing this survey.

Public reporting burden for this collection of information is estimated to average twenty hours per weatherization agency, including the time for reviewing instructions, searching existing data sources, gathering and maintaining the data needed, and completing and reviewing the collection of information. Send comments regarding this burden estimate or any other aspect of this collection of information, including suggestions for reducing this burden, to Office of the Chief Information Officer, Records Management Division, IM-11, Paperwork Reduction Project (__ _ ) U.S. Department of Energy, 1000 Independence Ave SW, Washington, DC, 20585-1290; and to the Office of Management and Budget (OMB), OIRA, Paperwork Reduction Project (__), Washington, DC 20503. 
Form completed by:

Date:

\section{IDENTIFICATION}

[Q1-6 will be pre-completed by the evaluation team]

1. Agency name:

2. State:

3. Building ID number:

4. Building name:

5. Site address:

6. City: 


\section{WEATHERIZATION INFORMATION}

Weatherization dates (not audit or inspection dates):

7a. Started:

7b. Completed:

$$
\text { (month) } \overline{\text { (day) }}
$$

The start date is the first date that weatherization improvements were made to the building. The weatherization start date is not the date the audit or home assessment was conducted

UNLESS energy efficiency improvements were made at the time of the audit. Client education and low-cost measures such as light bulbs and showerheads ARE considered energy efficiency improvements, and if any of those are implemented at the time of the audit, then the start date is the audit date.

The end date is the last date that weatherization improvements were made to the building, including any rework required after agency or state-level post-weatherization inspections. The date of the post-inspection should NOT be used as the weatherization end date unless the post-inspection was conducted on the last day that improvements were made to the building and no rework was required.

8. Was this a "reweatherized" building? (check only one)

$\square$ Yes

$\square$ No

$\square$ Don’t know

Check "yes" if the building was previously weatherized in a prior program year.

9. Does the building meet your state's definition for being a high residential energy user? (check only one)

$\square$ Yes

$\square$ No

$\square$ No state definition in place

$\square$ Don’t know

10. Did the building owner or any occupants of housing units within the building file a complaint about the weatherization services you provided? (check only one)

$\square$ Yes

$\square$ No

$\square$ Don't know 


\section{BUILDING INFORMATION}

11a. Building type - see definitions at end of the survey: (check only one)

$\square$ Small multifamily building (2-4 units and not a single family attached house)

$\square$ Large multifamily building (5 or more units and not a single family attached house)

$\square$ Don't know

11b. If this is a large multi-family building, was HUD's list of pre-qualified buildings used to income qualify the building:
a. Yes
b. No
c. Don't know

11.c If this is a large multi-family building, please indicate which description best describes its ownership:
a. private owner
b. private owner but HUD assisted
c. Publically owned
d. Condominium owned by occupants
e. Other
f. Don't know

12. Number of housing units in the building:

13. Number of housing units in the building that met WAP eligibility requirements:

14. Number of stories above grade: (check only one)

$\square 1$
$\square 2$
$\square 3$
$\square 4$
$\square 5-9$
$\square 10-19$
$\square 20$ or more
$\square$ Don't know

Please list the number of stories above ground-level. If there are half-stories, round up to the nearest whole number.

15. Year building originally built: (check only one)
$\square 2000$ or later
1990 to 1999
1980 to 1989
$\square 1970$ to 1979 
$\square 1960$ to 1969

$\square 1950$ to 1959

$\square 1940$ to 1949

$\square 1930$ to 1939

$\square 1920$ to 1929

$\square 1910$ to 1919

$\square 1900$ to 1909

$\square$ Before 1900

$\square$ Don't know 
Conditioned floor area at the time of weatherization:

16a. Heated floor area: $\mathrm{ft}^{2}$

Don’t know

16b. Air conditioned floor area: $\mathrm{ft}^{2}$

Don’t know

Include the basement or common space only if it is intentionally conditioned (heated and/or cooled).

If you only know the total square footage of the building, please select "don't know" rather than listing the total square footage.

17. Primary fuel used to heat the building during the winter before weatherization: (check only one)
$\square$ Natural gas
$\square$ Propane/LPG
$\square$ Kerosene (\#1 fuel oil)
$\square$ Fuel oil \#2
$\square$ Fuel oil \#4
$\square$ Fuel oil \#6
$\square$ Electricity
$\square$ Steam (purchased from a central distribution system)
$\square$ Hot water (purchased from a central distribution system)
$\square$ Other (specify:
$\square$ Don't know

18. Primary fuel used for water heating before weatherization: (check only one)
Natural gas
Propane/LPG
Electricity
Other (specify:
Don't know 
19. Type of primary space-heating system before weatherization: (check only one) electricity)

Central (ducted) warm-air furnace (forced-air or gravity, any fuel including

$\square$ Heat pump

Built-in electric units (e.g., electric baseboards, ceiling heat)

$\square$ Steam or hot water system (e.g., floor or baseboard radiators, convectors)

$\square$ Floor, wall, or pipeless (ductless) furnace (e.g., floor or wall furnace)

$\square$ Room/space heater (nonportable)

$\square$ Portable space heater

$\square$ Cooking stove

None

$\square$ Don't know

Select "steam or hot water system" for buildings heated with boilers.

20. Was the primary space-heating system a central system? (check only one)

$\square$ Yes, a central system that supplied heat to all or most of the units in the building

$\square$ No, each unit had its own heating system

$\square$ Don't know

21. Supplemental fuel(s) used to heat the building during the winter before weatherization: (check all that apply)

Natural gas

$\square$ Propane/LPG

$\square$ Kerosene (\#1 fuel oil)

$\square$ Fuel oil \#2

$\square$ Fuel oil \#4

$\square$ Fuel oil \#6

$\square$ Electricity

$\square$ Steam (purchased from a central distribution system)

$\square$ Hot water (purchased from a central distribution system)

$\square$ Other (specify:

Don't know

22. Type of operable air conditioning system present before weatherization: (check all that apply)

$\square$ Central air conditioner/heat pump

$\square$ Window/wall units

$\square$ Evaporative cooling system ("swamp coolers")

$\checkmark$ None

$\square$ Don't know

23. Number of window/wall air conditioning units: (check only one) 


$\square$ None
$\square 1-4$
$\square 5-9$
$\square 10-19$
$\square 20-49$
$\square 50$ or more
$\square$ Don't know

\section{AUDIT}

24. Primary method used to select weatherization measures for this building (excluding health, safety, and repair measures and general heat waste measures): (check only one)

$\square$ Priority list

$\square$ Calculation procedure (e.g., spreadsheet, computerized audit)

$\square$ Other (specify:

25. If a calculation procedure was used, the name of the procedure(s): (check all that apply)

$\square$ AK Warm

$\square$ EA-3

$\square$ EASY

$\square$ EA-QUIP

$\square$ HomeCheck

$\square$ Meadows

$\square$ REES

$\square$ REM/Rate

$\square$ SMOC-ERS

$\square$ TIPS

$\square$ TREAT

$\square$ Weatherization Assistant (NEAT/MHEA)

$\square$ WXEOR

$\square$ Other (specify:

$\square$ Not applicable 


\section{DIAGNOSTICS AND INSPECTIONS}

If you know when a diagnostic/inspection procedure was performed, please check the appropriate box(es) in the first three response columns. If a diagnostic/inspection procedure was performed but you do not know when, please check the box in the "Performed?" column.

\section{If a diagnostic/inspection procedure was performed in ANY of the housing units in the} building please check the appropriate category.

\begin{tabular}{|c|c|c|c|c|}
\hline \multirow[t]{2}{*}{ Diagnostic measurement or inspection } & \multicolumn{4}{|c|}{ Diagnostic/inspection performed during: } \\
\hline & $\begin{array}{c}\text { Audit/house } \\
\text { assessment }\end{array}$ & $\begin{array}{c}\text { Measure } \\
\text { installation }\end{array}$ & $\begin{array}{c}\text { Post- } \\
\text { inspection }\end{array}$ & $\begin{array}{c}\text { Performed } \\
?\end{array}$ \\
\hline \multicolumn{5}{|l|}{ Pressure diagnostics: } \\
\hline $\begin{array}{l}\text { 26a. Unit-level blower door measurement (air leakage } \\
\text { rate for individual dwelling units) }\end{array}$ & $\square$ & $\square$ & $\square$ & $\square$ \\
\hline $\begin{array}{l}\text { 26b. Building-level blower door measurement (total air } \\
\text { leakage rate for the whole building) }\end{array}$ & $\square$ & $\square$ & $\square$ & $\square$ \\
\hline 26c. Zonal pressure & $\square$ & $\square$ & $\square$ & $\bar{\square}$ \\
\hline $\begin{array}{l}\text { 26d. Room-to-room pressures (distribution system } \\
\text { balancing) }\end{array}$ & $\square$ & $\square$ & $\square$ & $\square$ \\
\hline 26e. Duct pressure pan measurements & $\square$ & $\square$ & $\square$ & $\square$ \\
\hline 26f. Duct blower measurement (duct air leakage rate) & $\square$ & $\square$ & $\square$ & $\square$ \\
\hline 26g. Blower door subtraction meas. (duct air leakage rate) & $\square$ & $\square$ & $\square$ & $\square$ \\
\hline \multicolumn{5}{|l|}{ Space-heating system: } \\
\hline $\begin{array}{l}\text { 27a. Flue gas analysis (steady-state efficiency } \\
\text { measurement) }\end{array}$ & $\square$ & $\square$ & $\square$ & $\square$ \\
\hline 27b. Heat rise & $\square$ & $\square$ & $\square$ & $\square$ \\
\hline 27c. CO level in flue & $\square$ & $\square$ & $\square$ & $\bar{\square}$ \\
\hline 27d. CO level of equipment room & $\square$ & $\square$ & $\square$ & $\square$ \\
\hline \multicolumn{5}{|l|}{ Space-heating system (continued): } \\
\hline 27e. Draft/spillage (normal operation) & $\square$ & $\square$ & $\square$ & $\square$ \\
\hline 27f. Worst case draft/spillage (CAZ) & $\square$ & $\square$ & $\square$ & $\square$ \\
\hline 27g. Safety inspection & $\square$ & $\square$ & $\square$ & $\square$ \\
\hline \multicolumn{5}{|l|}{ Air-conditioning system: } \\
\hline 28a. Refrigerant charge (e.g., superheat or subcooling) & $\square$ & $\square$ & $\square$ & $\square$ \\
\hline
\end{tabular}




\begin{tabular}{|c|c|c|c|c|}
\hline \multirow[t]{2}{*}{ Diagnostic measurement or inspection } & \multicolumn{4}{|c|}{ Diagnostic/inspection performed during: } \\
\hline & $\begin{array}{c}\text { Audit/house } \\
\text { assessment }\end{array}$ & $\begin{array}{c}\text { Measure } \\
\text { installation }\end{array}$ & $\begin{array}{c}\text { Post- } \\
\text { inspection }\end{array}$ & $\begin{array}{c}\text { Performed } \\
?\end{array}$ \\
\hline 28b. Safety inspection & $\square$ & $\square$ & $\square$ & $\square$ \\
\hline \multicolumn{5}{|l|}{ HVAC components: } \\
\hline 29a. Air handler flow rate & $\square$ & $\square$ & $\square$ & $\square$ \\
\hline 29b. Thermostat anticipator current & $\square$ & $\square$ & $\square$ & $\square$ \\
\hline \multicolumn{5}{|l|}{ Hot-water (water-heating) system: } \\
\hline $\begin{array}{l}\text { 30a. Flue gas analysis (steady-state efficiency } \\
\text { measurement) }\end{array}$ & $\square$ & $\square$ & $\square$ & $\square$ \\
\hline 30b. CO level in flue & $\square$ & $\square$ & $\square$ & $\square$ \\
\hline 30c. CO level of equipment room & $\square$ & $\square$ & $\square$ & $\square$ \\
\hline 30d. Draft/spillage (normal operation) & $\square$ & $\square$ & $\square$ & $\square$ \\
\hline 30e. Worst case draft/spillage (CAZ) & $\square$ & $\square$ & $\square$ & $\square$ \\
\hline 30f. Hot water temperature & $\square$ & $\square$ & $\square$ & $\square$ \\
\hline 30g. Shower head flow rate & $\square$ & $\square$ & $\square$ & $\square$ \\
\hline 30h. Faucet flow rate & $\square$ & $\square$ & $\square$ & $\square$ \\
\hline 30i. Safety inspection & $\square$ & $\square$ & $\square$ & $\square$ \\
\hline \multicolumn{5}{|l|}{ Other CO measurements: } \\
\hline 31a. Cook stove & $\square$ & $\square$ & $\square$ & $\square$ \\
\hline 31b. Kitchen & $\square$ & $\square$ & $\square$ & $\square$ \\
\hline 31c. Main living area & $\square$ & $\square$ & $\square$ & $\square$ \\
\hline \multicolumn{5}{|l|}{ Other diagnostics and inspections: } \\
\hline 32a. Refrigerator energy use & $\square$ & $\square$ & $\square$ & $\square$ \\
\hline 32b. Exhaust fan air flow rate & $\square$ & $\square$ & $\square$ & $\square$ \\
\hline 32c. Infrared scanning (camera) & $\square$ & $\square$ & $\square$ & $\square$ \\
\hline 32d. Radon testing & $\square$ & $\square$ & $\square$ & $\square$ \\
\hline 32e. Other (specify: ___ ) & $\square$ & $\square$ & $\square$ & $\square$ \\
\hline 32f. Other (specify: __ & $\square$ & $\square$ & $\square$ & $\square$ \\
\hline
\end{tabular}




\begin{tabular}{|c|c|c|c|c|}
\hline Diagnostic measurement or inspection & \multicolumn{3}{|c|}{ Diagnostic/inspection performed during: } \\
\cline { 2 - 5 } & $\begin{array}{c}\text { Audit/house } \\
\text { assessment }\end{array}$ & $\begin{array}{c}\text { Measure } \\
\text { installation }\end{array}$ & $\begin{array}{c}\text { Post- } \\
\text { inspection }\end{array}$ & $\begin{array}{c}\text { Performed } \\
\boldsymbol{?}\end{array}$ \\
\hline 32g. Other (specify: & $\square$ & $\square$ & $\square$ & $\square$ \\
\hline
\end{tabular}


Record the diagnostic measurements taken on THIS building: (fill in all that were taken)

For diagnostics that were performed multiple times, please provide the measurements that are closest to the pre-weatherization and post-weatherization conditions of the building.

\begin{tabular}{|c|c|c|}
\hline Diagnostic measurement & $\begin{array}{c}\text { Pre- } \\
\text { weatherization }\end{array}$ & $\begin{array}{c}\text { Post } \\
\text { weatherization }\end{array}$ \\
\hline \multicolumn{3}{|l|}{ Building air leakage (blower door measurement): ${ }^{21}$} \\
\hline $\begin{array}{l}\text { 33a. Average air leakage rate per unit based on unit-level } \\
\text { testing }\end{array}$ & $\mathrm{cfm}$ & $\mathrm{cfm}$ \\
\hline $\begin{array}{l}\text { 33b. Total air leakage rate of the building based on whole } \\
\text { building test }\end{array}$ & $\mathrm{cfm}$ & $\mathrm{cfm}$ \\
\hline 33c. House WRT outside pressure difference ${ }^{22}$ & $\mathrm{~Pa}$ & $\mathrm{~Pa}$ \\
\hline \multicolumn{3}{|l|}{ Duct leakage (pressure pan measurements): ${ }^{23}$} \\
\hline 34a. Sum of pressure pan readings ${ }^{24}$ & $\mathrm{~Pa}$ & $\mathrm{~Pa}$ \\
\hline \multicolumn{3}{|l|}{ 34b. Number of registers included in sum $^{25}$} \\
\hline 34c. House WRT outside pressure difference ${ }^{26}$ & $\mathrm{~Pa}$ & $\mathrm{~Pa}$ \\
\hline \multicolumn{3}{|l|}{ Duct leakage (duct blower measurements) ${ }^{27}$ : } \\
\hline 35a. Total duct leakage rate & $\mathrm{cfm}$ & $\mathrm{cfm}$ \\
\hline 35b. Duct leakage to the outside & $\mathrm{cfm}$ & $\mathrm{cfm}$ \\
\hline 35c. Duct WRT outside pressure difference ${ }^{28}$ & $\mathrm{~Pa}$ & $\overline{\mathrm{Pa}}$ \\
\hline & & \\
\hline & & \\
\hline
\end{tabular}

${ }^{21}$ Most agencies will report results in "a" or "b," but not both.

${ }^{22}$ Report the pressure differential at which the blower door test was performed. A typical value is 50 Pascals.

Do not report baseline pressure (typically less than 5 Pascals).

${ }^{23}$ If building has more than one duct system, average the results across all systems that were tested.

${ }^{24}$ Total all of the individual measurements taken at registers in the building. The value for each register should be between 0 and 50 Pascals.

${ }^{25}$ Total the number of registers at which the test was performed.

${ }^{26}$ Report the pressure differential at which the test was performed (from blower door). A typical value is 50 Pascals.

${ }^{27}$ If building has more than one duct system, average the results across all systems that were tested. If total duct leakage (inside the building and to the outside) was measured with a Duct BlasterTM or similar equipment, report results in 35a. If duct leakage to the outside was measured, report this result in 35b. Most agencies will report results in "a" or "b," but not both.

${ }_{28}^{28}$ Report the house-to-outside pressure differential (from blower door) at which the leakage-to-outside test was performed. A typical value is 25 Pascals. 


\begin{tabular}{|c|r|r|}
\hline & & \\
\hline${\text { Steady-state efficiency (flue gas analysis): }{ }^{29}}$ & $\%$ & \\
\hline 36a. Primary space-heating system & $\%$ & $\%$ \\
\hline 36b. Secondary space-heating system & $\%$ & $\%$ \\
\hline 36c. Hot water heater & $\%$ & $\%$ \\
\hline
\end{tabular}

\section{MEASURES INSTALLED}

If you know whether in-house crew or a contractor installed a given measure, please check the appropriate box in the first two response columns. If a measure was installed but you do not know whether it was installed by in-house crew or a contractor, please check the box in the "Installed?" column.

If a measure was installed in ANY of the housing units in the building please check the appropriate category.

\begin{tabular}{|c|c|c|c|}
\hline \multirow[t]{2}{*}{ Measure } & \multicolumn{2}{|c|}{ Installed by } & \multirow[b]{2}{*}{ Installed? } \\
\hline & $\begin{array}{l}\text { In-house } \\
\text { crew }\end{array}$ & Contractor & \\
\hline Air sealing work: & & & \\
\hline $\begin{array}{l}\text { 37a. General house caulking and weatherstripping (e.g., doors, } \\
\text { windows) }\end{array}$ & $\square$ & $\square$ & $\square$ \\
\hline $\begin{array}{l}\text { 37b. House air sealing emphasizing bypasses (leaks identified by } \\
\text { auditor and/or crew without using a blower door) }\end{array}$ & $\square$ & $\square$ & $\square$ \\
\hline $\begin{array}{l}\text { 37c. House air sealing emphasizing bypasses (leaks identified by } \\
\text { auditor and/or crew with aid of a blower door) }\end{array}$ & $\square$ & $\square$ & $\square$ \\
\hline 37d. Air distribution system (duct) sealing and repair ${ }^{30}$ & $\square$ & $\square$ & $\square$ \\
\hline $\begin{array}{l}\text { 37e. Repairs to broken windows, doors, or other major holes in the } \\
\text { building shell }\end{array}$ & $\square$ & $\square$ & $\square$ \\
\hline 37f. Other air sealing work (specify: ___ & $\bar{\square}$ & $\square$ & $\square$ \\
\hline 37g. Other air sealing work (specify: ___ & $\bar{\square}$ & $\square$ & $\square$ \\
\hline
\end{tabular}

\footnotetext{
${ }^{29}$ If test was performed on multiple space- or water-heating systems, provide the average result across all systems that were tested.

${ }^{30}$ Check $37 \mathrm{~d}$ if duct sealing OR duct repair was performed. Check 41e if NEW ductwork was installed. Check $44 \mathrm{c}$ if new vents, grills or registers were installed.
} 


\begin{tabular}{|c|c|c|c|}
\hline \multirow[t]{2}{*}{ Measure } & \multicolumn{2}{|c|}{ Installed by } & \multirow[b]{2}{*}{ Installed? } \\
\hline & $\begin{array}{l}\text { In-house } \\
\text { crew }\end{array}$ & Contractor & \\
\hline \multicolumn{4}{|l|}{ Insulation: } \\
\hline 38a. Attic insulation & $\square$ & $\square$ & $\square$ \\
\hline \multicolumn{4}{|c|}{$\begin{array}{l}\text { If attic insulation was installed, please provide quantity: } \\
\begin{array}{l}38 \mathrm{~b} . \_ \text {square feet } \\
\text { or }\end{array} \\
38 \mathrm{c} \text { pounds } \\
\begin{array}{l}\text { 38d. What was the } \mathrm{R} \text { value of attic insulation prior to weatherization? } \\
\text { (Leave blank if unknown. Enter } 0 \text { if there was no existing insulation.) }\end{array}\end{array}$} \\
\hline 38e. Wall insulation & $\square$ & $\square$ & $\square$ \\
\hline \multicolumn{4}{|l|}{$\begin{array}{l}\text { If wall insulation was installed, please provide quantity: } \\
\begin{array}{ll}38 \mathrm{f} . & \text { square feet } \\
\text { or } & \\
37 \mathrm{~g} . & \text { pounds }\end{array}\end{array}$} \\
\hline 38h. Floor insulation & $\square$ & $\square$ & $\square$ \\
\hline 38i. Rim or band joist insulation (sill box) & $\square$ & $\square$ & $\square$ \\
\hline 38j. Foundation wall insulation & $\square$ & $\square$ & $\square$ \\
\hline 38k. Duct insulation & $\square$ & $\square$ & $\square$ \\
\hline 381. White roof coat & $\square$ & $\square$ & $\square$ \\
\hline 38m. Other insulation (specify: __ & $\square$ & $\square$ & $\square$ \\
\hline 38n. Other insulation (specify: ___ & $\square$ & $\square$ & $\square$ \\
\hline \multicolumn{4}{|l|}{ Windows: } \\
\hline 39a. New window (justified because cost effective) & $\square$ & $\square$ & $\square$ \\
\hline 39b. New window (justified for reason other than cost effectiveness) & $\square$ & $\square$ & $\square$ \\
\hline \multicolumn{4}{|l|}{ 39c. If new windows were installed, please provide quantity: } \\
\hline $\begin{array}{l}\text { 39d. Window glass repair or replacement not included under air } \\
\text { sealing major holes in building shell (37e) }\end{array}$ & $\square$ & $\square$ & $\square$ \\
\hline 39e. Repair of window sashes or frames & $\square$ & $\square$ & $\square$ \\
\hline 39f. Window screen repair/replacement & $\square$ & $\square$ & $\square$ \\
\hline 39g. Window lock replacement & $\square$ & $\square$ & $\square$ \\
\hline 39g. Other window repair (e.g., sashes, frames) & $\square$ & $\square$ & $\square$ \\
\hline 39h. Storm window & $\square$ & $\square$ & $\square$ \\
\hline 39i. Window shading (e.g., awning, film, sun screen) & $\square$ & $\square$ & $\square$ \\
\hline 39j. Other window treatments (specify: ___ & $\square$ & $\square$ & $\square$ \\
\hline
\end{tabular}




\begin{tabular}{|c|c|c|c|}
\hline \multirow[t]{2}{*}{ Measure } & \multicolumn{2}{|c|}{ Installed by } & \multirow[b]{2}{*}{ Installed? } \\
\hline & $\begin{array}{l}\text { In-house } \\
\text { crew }\end{array}$ & Contractor & \\
\hline 39k. Other window treatments (specify: ___ & $\square$ & $\square$ & $\square$ \\
\hline \multicolumn{4}{|l|}{ Doors: } \\
\hline 40a. New door (justified because cost effective) & $\square$ & $\square$ & $\square$ \\
\hline 40b. New door (justified for reason other than cost effectiveness) & $\square$ & $\square$ & $\square$ \\
\hline 40c. Door lock (new or replacement) & $\square$ & $\square$ & $\square$ \\
\hline $\begin{array}{l}\text { 40d. Door or door framing repair not included under air sealing major } \\
\text { holes in building shell (37e) }\end{array}$ & $\square$ & $\square$ & $\square$ \\
\hline 40e. Storm door installed & $\square$ & $\square$ & $\square$ \\
\hline 40f. Other door treatments (specify: ___ & $\square$ & $\square$ & $\square$ \\
\hline 40g. Other door treatments (specify: ___ & $\square$ & $\square$ & $\square$ \\
\hline \multicolumn{4}{|l|}{ Central space heating systems (e.g., furnaces, boilers): ${ }^{31}$} \\
\hline 41a. New heating system (justified because cost effective) & $\square$ & $\square$ & $\square$ \\
\hline $\begin{array}{l}\text { 41b. New heating system (justified for reason other than cost } \\
\text { effectiveness) }\end{array}$ & $\square$ & $\square$ & $\square$ \\
\hline 41c. Heating system repair (e.g., controls, safety items, flues) & $\square$ & $\square$ & $\square$ \\
\hline 41d. Space-heating system tune-up & $\square$ & $\square$ & $\square$ \\
\hline 41e. New ductwork installed & $\square$ & $\square$ & $\square$ \\
\hline 41f. Vent damper & $\square$ & $\square$ & $\square$ \\
\hline 41g. Intermittent ignition device & $\square$ & $\square$ & $\square$ \\
\hline 41h. Other space-heating system modification (specify: ___ $)^{32}$ & $\square$ & $\square$ & $\square$ \\
\hline 41i. Other space-heating system modification (specify: ___ & $\square$ & $\square$ & $\square$ \\
\hline \multicolumn{4}{|l|}{ Air-conditioning systems: } \\
\hline 42a. New air conditioner (justified because cost effective) & $\square$ & $\square$ & $\square$ \\
\hline $\begin{array}{l}\text { 42b. New air conditioner (justified for reason other than cost } \\
\text { effectiveness) }\end{array}$ & $\square$ & $\square$ & $\square$ \\
\hline 42c. Air conditioner repair & $\square$ & $\square$ & $\square$ \\
\hline
\end{tabular}

${ }^{31}$ Include central heating systems installed through programs other than WAP, such as emergency heating system replacements funded by LIHEAP.

${ }^{32}$ Check $37 \mathrm{~d}$ if duct sealing OR duct repair was performed. Check 41e if NEW ductwork was installed. Check $44 \mathrm{c}$ if new vents, grills or registers were installed. 


\begin{tabular}{|c|c|c|c|}
\hline \multirow[t]{2}{*}{ Measure } & \multicolumn{2}{|c|}{ Installed by } & \multirow[b]{2}{*}{ Installed? } \\
\hline & $\begin{array}{l}\text { In-house } \\
\text { crew }\end{array}$ & Contractor & \\
\hline 42d. Air conditioner recharge/tune-up & $\square$ & $\square$ & $\square$ \\
\hline 42e. Ceiling or whole-house fans & $\square$ & $\square$ & $\square$ \\
\hline 42f. Other air-conditioning system modification (specify:___ & $\square$ & $\square$ & $\square$ \\
\hline 42g. Other air-conditioning system modification (specify: ___ & $\square$ & $\square$ & $\square$ \\
\hline \multicolumn{4}{|l|}{ Ventilation: } \\
\hline 43a. New bathroom exhaust fan installed & $\square$ & $\square$ & $\square$ \\
\hline 43b. New kitchen exhaust fan installed & $\square$ & $\square$ & $\square$ \\
\hline 43c. Repair to kitchen or bathroom exhaust fan (including ductwork) & $\square$ & $\square$ & $\square$ \\
\hline 43d. Whole-house ventilation system & $\square$ & $\square$ & $\square$ \\
\hline 43e. Other ventilation system improvements (specify: ___ & $\square$ & $\square$ & $\square$ \\
\hline 43f. Other ventilation system improvements (specify:___ & $\square$ & $\square$ & $\square$ \\
\hline \multicolumn{4}{|l|}{ HVAC accessories: } \\
\hline 44a. New programmable (setback) thermostat & $\square$ & $\square$ & $\square$ \\
\hline 44b. New standard thermostat & $\square$ & $\square$ & $\square$ \\
\hline 44c. Duct vents, grills, or registers ${ }^{33}$ & $\square$ & $\square$ & $\square$ \\
\hline 44d. Standard air filter & $\square$ & $\square$ & $\square$ \\
\hline 44e. High efficiency particulate arresting (HEPA) air filter & $\square$ & $\square$ & $\square$ \\
\hline 44f. Other HVAC accessories (specify: ___ & $\square$ & $\square$ & $\square$ \\
\hline 44g. Other HVAC accessories (specify: ___ & $\square$ & $\square$ & $\square$ \\
\hline \multicolumn{4}{|l|}{ Water-heating system: } \\
\hline 45a. New water heater (justified because cost effective) & $\square$ & $\square$ & $\square$ \\
\hline $\begin{array}{l}\text { 45b. New water heater (justified for reason other than cost } \\
\text { effectiveness) }\end{array}$ & $\square$ & $\square$ & $\square$ \\
\hline 45c. Water-heating system repair & $\square$ & $\square$ & $\square$ \\
\hline 45d. Water-heater tank insulation wrap & $\square$ & $\square$ & $\square$ \\
\hline
\end{tabular}

${ }^{33}$ Check $37 \mathrm{~d}$ if duct sealing OR duct repair was performed. Check $41 \mathrm{e}$ if new ductwork was installed. Check $44 \mathrm{c}$ if new vents, grills or registers were installed. 


\begin{tabular}{|c|c|c|c|}
\hline \multirow{2}{*}{ Measure } & \multicolumn{2}{|c|}{ Installed by } & \multirow[b]{2}{*}{ Installed? } \\
\hline & $\begin{array}{l}\text { In-house } \\
\text { crew }\end{array}$ & Contractor & \\
\hline 45e. Pipe insulation & $\square$ & $\square$ & $\square$ \\
\hline 45f. Installed low-flow showerhead & $\square$ & $\square$ & $\square$ \\
\hline 45g. Installed low-flow device on faucet (aerator) & $\square$ & $\square$ & $\square$ \\
\hline $45 \mathrm{~h}$. Water heater temperature reduction & $\square$ & $\square$ & $\square$ \\
\hline 45i. Other water heating system measure (specify: ___ & $\square$ & $\square$ & $\square$ \\
\hline 45j. Other water heating system measure (specify: ___ & $\square$ & $\square$ & $\square$ \\
\hline \multicolumn{4}{|l|}{ Other baseloads: } \\
\hline 46a. Indoor lighting (energy efficient bulb or fixture) & $\square$ & $\square$ & $\square$ \\
\hline 46b. Outdoor lighting (energy efficient bulb or fixture) & $\square$ & $\square$ & $\square$ \\
\hline 46c. Lighting (indoor/outdoor location not recorded) & $\square$ & $\square$ & $\square$ \\
\hline 46d. Refrigerator (justified because cost effective) & $\square$ & $\square$ & $\square$ \\
\hline 46e. Refrigerator (justified for reason other than cost effectiveness) & $\square$ & $\square$ & $\square$ \\
\hline \multicolumn{4}{|l|}{$\begin{array}{l}\text { 46f. If new refrigerator is installed, how many old refrigerators were } \\
\text { removed? }\end{array}$} \\
\hline \multicolumn{4}{|l|}{$\begin{array}{l}46 \mathrm{~g} \text {. If new refrigerator is installed, how many old refrigerators were } \\
\text { removed? }\end{array}$} \\
\hline 46h. Other baseload measure (specify: ___ & $\square$ & $\square$ & $\square$ \\
\hline 46i. Other baseload measure (specify: ___ & $\square$ & $\square$ & $\square$ \\
\hline \multicolumn{4}{|l|}{ Health and safety and repair: } \\
\hline 47a. Smoke alarm & $\square$ & $\square$ & $\square$ \\
\hline 47b. CO monitor & $\square$ & $\square$ & $\square$ \\
\hline 47c. Attic ventilation & $\square$ & $\square$ & $\square$ \\
\hline 47d. Clothes dryer vent repair or replacement & $\square$ & $\square$ & $\square$ \\
\hline 47e. Roof repair & $\square$ & $\square$ & $\square$ \\
\hline 47f. Ceiling repair & $\square$ & $\square$ & $\square$ \\
\hline 47g. Wall repair & $\square$ & $\square$ & $\square$ \\
\hline 47h. Floor repair & $\square$ & $\square$ & $\square$ \\
\hline 47i. Foundation repair & $\square$ & $\square$ & $\square$ \\
\hline 47j. Ground vapor barrier & $\square$ & $\square$ & $\square$ \\
\hline
\end{tabular}




\begin{tabular}{|c|c|c|c|}
\hline \multirow[t]{2}{*}{ Measure } & \multicolumn{2}{|c|}{ Installed by } & \multirow[b]{2}{*}{ Installed? } \\
\hline & $\begin{array}{l}\text { In-house } \\
\text { crew }\end{array}$ & Contractor & \\
\hline 47k. Gutter or downspout (installed or repaired) & $\square$ & $\square$ & $\square$ \\
\hline 471. Plumbing repair & $\square$ & $\square$ & $\square$ \\
\hline 47m. Sewer repair & $\square$ & $\square$ & $\bar{\square}$ \\
\hline 47n. Electrical repair & $\square$ & $\square$ & $\square$ \\
\hline 47o. Stair repair & $\square$ & $\square$ & $\square$ \\
\hline 47p. Install/repair non-skid material on stairs & $\square$ & $\square$ & $\square$ \\
\hline 47q. Install/repair safety gate at stairs & $\square$ & $\square$ & $\square$ \\
\hline 47r. Install/repair grab bar in bathroom & $\square$ & $\square$ & $\square$ \\
\hline 47s. Install/repair non-skid material in bathtub & $\square$ & $\square$ & $\square$ \\
\hline 47t. Install/repair metal chimney liner & $\square$ & $\square$ & $\square$ \\
\hline 47u. Lead abatement & $\square$ & $\square$ & $\square$ \\
\hline $47 \mathrm{v}$. Asbestos abatement & $\square$ & $\square$ & $\square$ \\
\hline $47 \mathrm{w}$. Removal or safe storage of household poisons & $\square$ & $\square$ & $\square$ \\
\hline 47x. Other health \& safety or repair items (specify: ___ & $\square$ & $\square$ & $\square$ \\
\hline 47y. Other health \& safety or repair items (specify: ___ & $\square$ & $\square$ & $\square$ \\
\hline \multicolumn{4}{|l|}{ Client education: } \\
\hline $\begin{array}{l}\text { 48a. Did the occupants receive an in-home visit in which energy } \\
\text { education was provided? }\end{array}$ & \multicolumn{3}{|c|}{$\begin{array}{l}\text { Yes } \\
\square \text { No } \\
\square \text { Don't know }\end{array}$} \\
\hline $\begin{array}{l}\text { 48b. Did the occupants participate in a classroom training in which } \\
\text { energy education was provided? }\end{array}$ & \multicolumn{3}{|c|}{$\begin{array}{l}\square \text { Yes } \\
\square \text { No } \\
\square \text { Don't know }\end{array}$} \\
\hline
\end{tabular}




\section{SERC AND WIPP MEASURES INSTALLED}

49. Please indicate whether any additional measures were installed in this building that were funded by the Sustainable Energy Resources for Consumers (SERC) Program and/or Weatherization Innovation Pilot Program (WIPP).

SERC funded measures were installed

$\square$ WIPP funded measures were installed

$\square$ Both SERC and WIPP funded measures were installed

$\square$ The building was not part of a SERC or WIPP grant (skip to Q60)

If you know whether in-house crew or a contractor installed a given measure, please check the appropriate box in the first two response columns. If a measure was installed but you do not know whether it was installed by in-house crew or a contractor, please check the box in the "Installed?" column.

\begin{tabular}{|c|c|c|c|}
\hline \multirow[t]{2}{*}{ Measure } & \multicolumn{2}{|c|}{ Installed by } & \multirow[b]{2}{*}{ Installed? } \\
\hline & $\begin{array}{c}\text { In-house } \\
\text { crew }\end{array}$ & Contractor & \\
\hline \multicolumn{4}{|l|}{ RENEWABLE ENERGY } \\
\hline 50a. S1.1 Solar PV & $\square$ & $\square$ & $\square$ \\
\hline 50b. S1.2 PV: Shingles & $\square$ & $\square$ & $\square$ \\
\hline 50c. S1.3 Wind: Small-scale Residential & $\square$ & $\square$ & $\square$ \\
\hline \multicolumn{4}{|l|}{ 50d. S1.4 Passive Solar Panel } \\
\hline \multicolumn{4}{|l|}{ HOT WATER SYSTEMS } \\
\hline 51a. S2.1 Solar HW & $\square$ & $\square$ & $\square$ \\
\hline 51b. $\quad$ S2.2 Tankless/On-demand HW & $\square$ & $\square$ & $\square$ \\
\hline 51c. S2.3 Condensing HW & $\square$ & $\square$ & $\square$ \\
\hline 51d. S2.4 Heat Pump/Hybrid HW & $\square$ & $\square$ & $\square$ \\
\hline 51e. S2.5 Combination HW and Boiler & $\square$ & $\square$ & $\square$ \\
\hline 51f. S2.6 Other hot water & $\square$ & $\square$ & $\square$ \\
\hline \multicolumn{4}{|l|}{ HVAC SYSTEMS } \\
\hline 52a. S3.1 Heat Pumps: Geothermal/Ground-Source & $\square$ & $\square$ & $\square$ \\
\hline 52b. S3.2 Heat Pumps: Air & $\square$ & $\square$ & $\square$ \\
\hline 52c. S3.3 Heat Pumps: Mini Split System Ductless & $\square$ & $\square$ & $\square$ \\
\hline 52d. S3.4 Replacement of Improperly Sized HVAC Equipment & $\square$ & $\square$ & $\square$ \\
\hline 52e. S3.5 Solar Thermal (Home Heat) & $\square$ & $\square$ & $\square$ \\
\hline 52f. S3.6 Wood Pellet Stoves & $\square$ & $\square$ & $\square$ \\
\hline 52g. S3.7 Ultra Cooling Systems & $\square$ & $\square$ & $\square$ \\
\hline 52h. S3.8 Central AC Units & $\square$ & $\square$ & $\square$ \\
\hline 52i. S3.9 Window AC Units & $\square$ & $\square$ & $\square$ \\
\hline 52j. $\quad$ S3.10 Micro-combined Heat and Power & $\square$ & $\square$ & $\square$ \\
\hline 52k. S3.11 High-efficiency Furnaces & $\square$ & $\square$ & $\square$ \\
\hline 52l. S3.12 Heat Recovery Ventilators & $\square$ & $\square$ & $\square$ \\
\hline
\end{tabular}




\begin{tabular}{|c|c|c|c|}
\hline 52m. S3.13 Biomass Thermal Units Installed & $\square$ & $\square$ & $\square$ \\
\hline 52n. S3.14 Evaporative Cooling System & $\square$ & $\square$ & 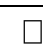 \\
\hline 520. S3.15 Vented Space Heating & $\square$ & $\square$ & $\square$ \\
\hline 52p. S3.16 Solar Powered Attic Ventilation & $\square$ & $\square$ & 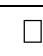 \\
\hline 52q. S3.17 Energy Recovery Ventilator & $\square$ & $\square$ & $\bar{\square}$ \\
\hline \multicolumn{4}{|l|}{ ROOFING: COOL ROOF } \\
\hline 53a. S4.1 Roofing: Cool Roof Technology Installed & $\square$ & $\square$ & $\square$ \\
\hline \multicolumn{4}{|l|}{ APPLIANCES } \\
\hline 54a. S5.1 Energy Star Clothes Washer & $\square$ & $\square$ & 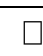 \\
\hline 54b. S5.2 Energy-Efficient Clothes Dryer & $\square$ & $\square$ & $\bar{\square}$ \\
\hline 54c. S5.3 Energy-Efficient Refrigerator & $\square$ & $\square$ & 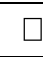 \\
\hline 54d. S5.4 Appliance Energy Meters & $\square$ & $\square$ & $\bar{\square}$ \\
\hline \multicolumn{4}{|l|}{ INSULATION } \\
\hline 55a. S6.1 Insulation: Aerogel/super & $\square$ & $\square$ & $\square$ \\
\hline 55b. S6.2 Insulation: Foam Injection Technology & $\square$ & $\square$ & $\square$ \\
\hline 55c. S6.3 Insulation: Masonry Foam & $\square$ & $\square$ & $\square$ \\
\hline 55d. S6.4 Insulation: Radiant Barrier Attic & $\square$ & $\square$ & $\square$ \\
\hline 55e. S6.5 Insulate: Spray Foam & $\square$ & $\square$ & $\bar{\square}$ \\
\hline 55f. S6.6 Insulation: Reflective Attic Insulation & $\square$ & $\square$ & 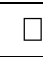 \\
\hline \multicolumn{4}{|l|}{ WHOLE-HOUSE RETROFIT } \\
\hline 56a. $\quad$ S7.1 Centralized Building Controls & $\square$ & $\square$ & $\square$ \\
\hline 56b. S7.2 Deep Energy Retrofits & $\square$ & $\square$ & $\square$ \\
\hline 56c. S7.3 High-Performance Space Conditioning Retrofits & $\square$ & $\square$ & $\square$ \\
\hline 56d. S7.4 High-Performance Building Envelope Retrofits & $\square$ & $\square$ & $\square$ \\
\hline 56e. S7.5 Cold Energy Retrofits & $\square$ & $\square$ & $\bar{\square}$ \\
\hline 56f. S7.6 Warm Energy Retrofits & $\square$ & $\square$ & 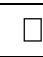 \\
\hline 56g. S7.7 Foundation Improvements & $\square$ & $\square$ & $\square$ \\
\hline \multicolumn{4}{|l|}{ OUTREACH } \\
\hline 57a. S8.1 Home Energy Saver Workshops & $\square$ & $\square$ & $\square$ \\
\hline 57b. S8.2 Households Touched by Behavioral Change Message & $\square$ & $\square$ & 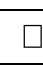 \\
\hline \multicolumn{4}{|l|}{ EQUIPMENT } \\
\hline 58a. S9.1 Monitoring: In-Home Energy Monitors & $\square$ & $\square$ & $\bar{\square}$ \\
\hline \multicolumn{4}{|l|}{ OTHER } \\
\hline 59a. S10.1 Units with Window Upgrades & $\square$ & $\square$ & $\square$ \\
\hline 59b. S10.2 Outdoor Solar Security Lighting & $\square$ & $\square$ & $\square$ \\
\hline 59c. S10.3 Ceiling Fans & $\square$ & $\square$ & $\square$ \\
\hline 59d. S10.4 LED Lights & $\square$ & $\square$ & $\square$ \\
\hline 59e. S10.5 Energy Star Doors & $\square$ & $\square$ & $\square$ \\
\hline
\end{tabular}


60. If a new space-heating system was installed, indicate the primary fuel used to heat the building during the winter after weatherization: (check only one)

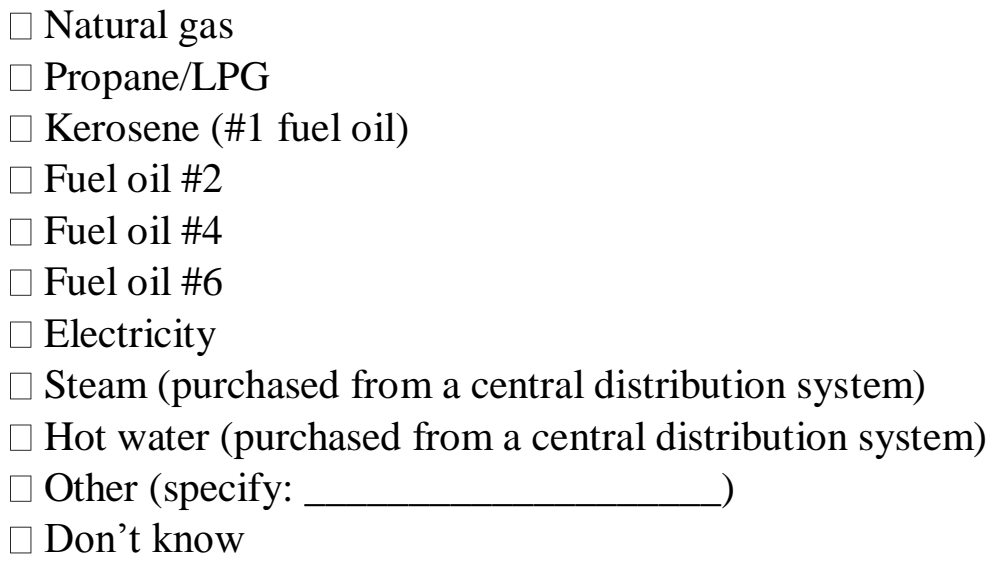

61. If a new space-heating system was installed, indicate the type of primary space-heating system after weatherization: (check only one) electricity)

$\square$ Central (ducted) warm-air furnace (forced-air or gravity, any fuel including

$\square$ Heat pump

Built-in electric units (e.g., electric baseboards, ceiling heat)

$\square$ Steam or hot water system (e.g., floor or baseboard radiators, convectors)

$\square$ Floor, wall, or pipeless (ductless) furnace (e.g., floor or wall furnace)

$\checkmark$ Room/space heater (nonportable)

$\square$ Portable space heater

$\square$ Cooking stove

$\square$ None

$\square$ Don't know

Not applicable

\section{Select "steam or hot water system" for buildings heated with boilers.}

62. If a new space-heating system was installed and justified for reasons other than cost effectiveness, identify the reason it was replaced: (check all that apply)

$\square$ Cost of repair/retrofit exceeded $50 \%$ of replacement cost

$\square$ Existing heating system was not running

Existing heating system was old (e.g., at end of life, too old to be repaired/adjusted)

$\square$ To switch fuel

To convert from a steam system to a hot water system

$\square$ Heat exchanger was cracked

$\checkmark$ Boiler was leaking

$\square$ Safety switches/controls were not operational and could not be repaired

$\square$ To replace unvented space heater(s) 
$\square$ Existing heating system was not safe to run for other reason (specify:

)

$\square$ Other (specify:

63. Please identify any cost-effective energy-efficiency measures (not repair or health and safety measures) recommended by your audit procedures that you were unable to install in this housing unit because of insufficient funds: (check all that apply)

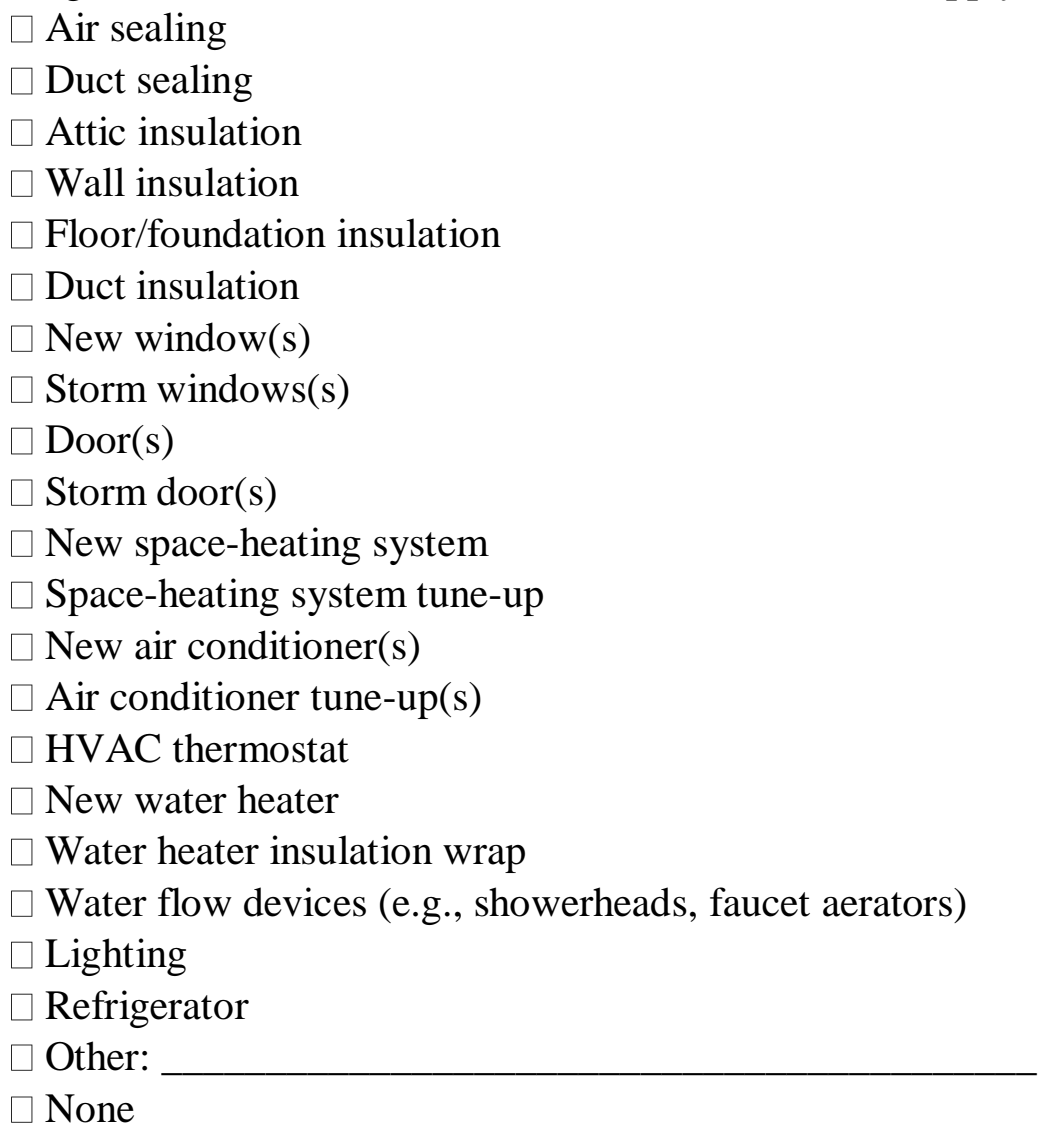

This question only applies in states where there is a per-building spending limit. If there is not a per-building spending limit in your state, check "none."

64. If energy efficiency measures were checked in the previous question, provide a rough estimate of the cost for installing all the measures checked: $\$$

65. Please identify any repair or health and safety measures recommended by your audit procedures that you were unable to install in this building because of insufficient funds: (check all that apply)

$\square$ New window(s)

$\checkmark$ Window glazing(s)

$\square$ Window screen(s)

$\square$ Window lock(s) 
$\square$ Window repair

New door(s)

$\square$ Door lock(s)

$\square$ Door repair

$\square$ New space-heating system

$\square$ Space-heating system repair

$\square$ New air conditioner(s)

$\checkmark$ Air conditioner repair

Ceiling or whole-house fan(s)

$\square$ Exhaust fan(s) or ventilation system

New water heater(s)

$\square$ Water-heating system repair

$\square$ Refrigerator(s)

$\square$ Smoke alarm(s)

$\checkmark \mathrm{CO}$ monitor(s)

$\square$ Attic ventilation

$\square$ Roof, wall, floor, or foundation repair

$\checkmark$ Plumbing/sewer repair

Electrical repair

$\square$ Other:

$\square$ None

This question only applies in states where there is a per-building spending limit. If there is not a per-building spending limit in your state, check "none."

66. If repair or health and safety measures were checked in the previous question, provide a rough estimate of the cost for installing all the measures checked: $\$$ 


\section{COSTS}

67. Provide the total cost of weatherizing this multifamily building. Include ALL sources of funding. Do NOT include program management costs (e.g., intake, audits, final inspections or program administration) or installation-related overhead costs (e.g., vehicles, equipment and training).

68. Divide the total costs spent on this building (from Question 67) into the categories below.

\begin{tabular}{|l|l|}
\hline 68a. Material costs & \\
\hline 68b. Labor costs & \\
\hline 68c. Enter total cost if above categories are not known & \\
\hline 68d. Total (should match Q67 total) & [Auto-tally] \\
\hline
\end{tabular}

69. Divide the labor costs (from Question 68b) into the categories below. If labor costs for inhouse crew are not tracked at the building level please leave 69a blank.

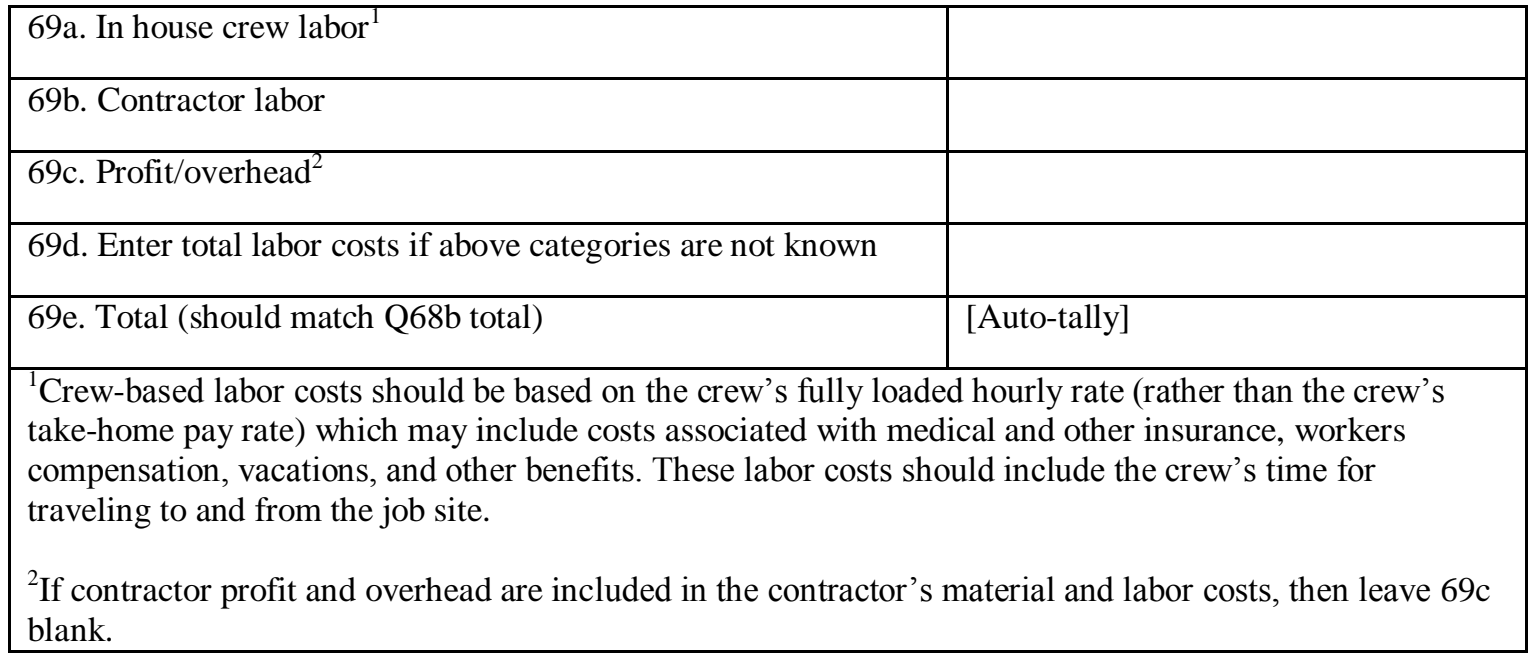


70. Provide estimates of non-monetary contributions to this weatherization job.

\begin{tabular}{|c|c|}
\hline 70a. Volunteer hours & \\
\hline 70b. Apprentice hours ${ }^{2}$ & \\
\hline 70c. Estimated value of material in-kind contributio & \\
\hline 70d. Estimated value of other in-kind contributions & \\
\hline
\end{tabular}

71. Divide the total costs spent on this building (from Question 67) into the categories below.

\begin{tabular}{|l|l|}
\hline 71a. Cost effective energy-related measures (SIR > 1.0) & \\
\hline 71b. Health and safety and other non-cost effective measures & \\
\hline 71c. Incidental repairs & \\
\hline 71d. Enter total job cost if above categories are not known & \\
\hline 70e. Total (should match Q67 total) & [Auto-tally] \\
\hline
\end{tabular}

72. Divide the total costs spent on this housing unit (from Question 67) into these funding source categories below.

\begin{tabular}{|l|l|}
\hline 72a. DOE normal appropriation/formula WAP funds ${ }^{1}$ & \\
\hline 72b. DOE SERC funds & \\
\hline 72c. DOE WIPP funds & \\
\hline 72d. Non-DOE (leveraged) funds & \\
\hline 72e. Total (should match Q67 total) & [Auto-tally] \\
\hline${ }^{1}$ This line includes ARRA funds for standard weatherization jobs. & \\
\hline
\end{tabular}

\section{Energy Assistance Program (LI-EAP) funding should be considered Non-DOE funds if it} is tracked separately. 
73. Provide the amounts spent on the major measure categories below.

\begin{tabular}{|l|l|}
\hline 73a. HVAC measures & \\
\hline 73b. Water heating measures & \\
\hline 73c. Replacement windows and doors & \\
\hline $\begin{array}{l}\text { 73d. All other building shell measures (insulation, air sealing, } \\
\text { etc.) }\end{array}$ & \\
\hline
\end{tabular}




\section{Housing Type Definitions}

Single Family Detached - House that provides living space for one family or household, is contained within walls that go from the basement (or the ground floor, if there is no basement) to

the roof, and has no walls that are shared (or built in contact) with another household. A manufactured house assembled on site is a single family detached housing unit, not a mobile home.

Single Family Attached - House that provides living space for one household, is contained within walls that go from the basement (or the ground floor, if there is no basement) to the roof, has at

least one wall that is shared (or built in contact) with an adjacent household, and has an independent outside entrance. An attached house does not have any other households living above or below, and does not share basement or attic space with other housing units. Also, an attached house does not share a heating or cooling system with any other housing units. Examples include row houses, townhouses, condominiums and side-by-side duplexes that do not have shared attics, basements or HVAC equipment.

Small Multifamily (2-4 units) - Building with two to four housing units (i.e., building that is divided into living quarters for two, three, or four families or households) in which one household

lives above or beside another and does not meet the single family attached house definition. Includes houses originally intended for occupancy by one family (or for some other use) that have since been converted to separate dwellings for two to four families. Typical arrangements in these types of living quarters are separate apartments downstairs and upstairs or one apartment on each of three or four floors.

Large multifamily (5 or More Units per Building) - Building with five or more housing units (i.e., building that contains living quarters for five or more families or households) that does not meet the single family attached house definition.

Mobile Home - Home that is built on a movable chassis, is moved to the site, and may be placed on a permanent or temporary foundation. If rooms are added to the structure, it is considered a mobile home if the added floor area is less than the mobile home's original floor area; otherwise, it is a single family detached house. A manufactured house assembled on site is a single family detached house, not a mobile home.

Shelter - Structure whose principal purpose is to house individuals on a temporary basis who may or may not be related to one another and who are not living in nursing homes, prisons, or similar institutional care facilities. 
OMB Control Number: XXXX-XXXX

\section{APPENDIX H. DF4: ELECTRIC \& NATURAL GAS BILLING INFORMATION FROM AGENCIES DATA FORM}

\begin{tabular}{l}
\hline Utility Information Survey Part A \\
\hline OMB control number XXXX-XXXX \\
\hline \multicolumn{1}{|c|}{ Introduction } \\
Thank you for your prompt response to this data request which is part of the ARRA- \\
period evaluation of the Weatherization Assistance Program. Evaluation results will \\
provide essential feedback to the weatherization community and inform policymakers \\
about the program's effects on clients' energy consumption, cost savings, and non- \\
energy benefits. \\
This data form collects detailed information about homes weatherized by your agency in \\
Program Years 2009 and 2010 . The data you supply will be used to characterize the program \\
and collect utility billing histories pre- and post-weatherization to better understand energy \\
savings attributable to the Weatherization Assistance Program during the ARRA period. \\
All of the information obtained from this survey and from utilities will be protected and will \\
remain confidential. The data will be analyzed in such a way that the information provided \\
cannot be associated back to your state, your agencies, or the housing units and clients that \\
your state served.
\end{tabular}

\section{Instructions}

Part A of the DF4 survey requests a list of the housing units and large multifamily buildings your agency weatherized in PY 2009* and PY 2010 $\%$.

The evaluation team will use the information provided in Part A to randomly select a sample of housing units and large multifamily buildings weatherized by your agency. After the sample is determined, you will be asked to complete Part B by providing detailed information about sampled units: housing type, primary heating fuel, occupant demographics and utility account information.

*For the purposes of this survey, Program Year 2009 is the WAP/ARRA funding year that includes the heating season spanning late 2009/early 2010.

$\dagger$ For the purposes of this survey, Program Year 2010 is the WAP/ARRA funding year that includes the heating season spanning late 2010/early 2011.

Public reporting burden for this collection of information is estimated to average 10 hours per response, including the time for reviewing instructions, searching existing data sources, gathering and maintaining the data needed, and completing and reviewing the collection of information. Send comments regarding this burden estimate or any other aspect of this collection of information, including suggestions for reducing this burden, to Office of the Chief Information Officer, Records Management Division, IM-11, Paperwork Reduction 
Project (__ ), U.S. Department of Energy, 1000 Independence Ave SW, Washington, DC, 20585-1290; and to the Office of Management and Budget (OMB), OIRA, Paperwork Reduction Project (__

\begin{tabular}{|l|l|}
\hline Utility Information Survey Part A & DF4a \\
\hline OMB control number & \\
\hline
\end{tabular}

To be completed by the evaluation team:

\begin{tabular}{|l|l|}
\hline Agency name & \\
\hline Agency ID & \\
\hline Contact name & \\
\hline
\end{tabular}

Section 1: List of weatherized housing units

Please list all housing units that were weatherized during PY2009 and PY2010 using funds from $\mathrm{DOE}^{34}$. Include all housing types. Do not include wait-listed or in-progress jobs.

\begin{tabular}{|c|c|c|c|}
\hline $\begin{array}{l}\text { Program } \\
\text { year }\end{array}$ & $\begin{array}{l}\text { Housing unit } \\
\text { unique ID } \\
\text { (e.g. job } \\
\text { number) }\end{array}$ & $\begin{array}{l}\text { Building type } \\
\text { SFA - Singe family attached } \\
\text { SFD - Single family detached } \\
\text { SFU - Single family unknown } \\
\text { attached/detached } \\
\text { MH - Mobile home } \\
\text { SH - Shelter } \\
\text { SMF - Small multifamily (2-4 } \\
\text { units) } \\
\text { LMF - Large multifamily (5+ } \\
\text { units)s }\end{array}$ & $\begin{array}{l}\text { Primary heating } \\
\text { fuel } \\
\text { EL - electricity } \\
\text { NG - natural } \\
\text { gas } \\
\text { LP - propane } \\
\text { FO - fuel oil } \\
\text { WO - wood } \\
\text { OT - other }\end{array}$ \\
\hline & & & \\
\hline & & & \\
\hline & & & \\
\hline & & & \\
\hline & & & \\
\hline & & & \\
\hline & & & \\
\hline & & & \\
\hline & & & \\
\hline & & & \\
\hline
\end{tabular}

\footnotetext{
${ }^{34}$ Include all units that meet the definition of a "DOE Unit:" A DOE unit is a dwelling on which a DOEapproved energy audit or priority list has been applied and weatherization work has been completed. As funds allow, the DOE measures installed on this unit have a Savings-to-Investment Ratio (SIR) of 1.0 or greater, but also may include any necessary energy-related health and safety measures. The use of DOE funds on this unit may include, but are not limited to auditing, testing, measure installation, inspection, or use of DOE equipment and/or vehicles, or if DOE provides the training and/or administrative funds. Therefore, a dwelling unit that meets both the definition of a DOE weatherized unit and has DOE funds used directly on it must be counted as a DOE unit.
} 


\begin{tabular}{|l|l|l|l|}
\hline & & & \\
\hline & & & \\
\hline & & & \\
\hline & & & \\
\hline & & & \\
\hline
\end{tabular}

\begin{tabular}{|l|l|}
\hline Utility Information Survey Part A & DF4a \\
\hline OMB control number XXXX-XXXX & \\
\hline
\end{tabular}

Section 2: List of large multifamily buildings

[Section 2 will only appear if the respondent selects "LMF" for at least one housing unit in Section 1.]

Please list all large multifamily buildings (5+ housing units) that were weatherized during PY2009 and PY2010 using DOE funds in which improvements were made to the building shell, common areas, central HVAC or domestic hot water systems. Do NOT include buildings where individual tenant units were weatherized but no improvements were made to the building shell, common areas, central HVAC or domestic hot water systems. Do not include wait-listed or in-progress jobs.

\begin{tabular}{|c|c|c|}
\hline $\begin{array}{l}\text { Program } \\
\text { year }\end{array}$ & $\begin{array}{l}\text { Building unique ID } \\
\text { (building-level } \\
\text { identification } \\
\text { number) }\end{array}$ & $\begin{array}{l}\text { Primary heating fuel } \\
\text { EL - electricity } \\
\text { NG - natural gas } \\
\text { LP - propane } \\
\text { FO - fuel oil } \\
\text { WO - wood } \\
\text { OT - other }\end{array}$ \\
\hline & & \\
\hline & & \\
\hline & & \\
\hline & & \\
\hline & & \\
\hline & & \\
\hline & & \\
\hline & & \\
\hline & & \\
\hline & & \\
\hline & & \\
\hline & & \\
\hline & & \\
\hline & & \\
\hline
\end{tabular}




\begin{tabular}{|l|l|}
\hline Utility Information Survey Part B & DF4b \\
\hline OMB control number XXXX-XXXX & \\
\hline \multicolumn{1}{|c|}{ Introduction } \\
Thank you for your prompt response to this data request which is part of the ARRA- \\
period evaluation of the Weatherization Assistance Program. Evaluation results will \\
provide essential feedback to the weatherization community and inform policymakers \\
about the program's effects on clients' energy consumption, cost savings, and non- \\
energy benefits. \\
This data form collects detailed information about homes weatherized by your agency in \\
Program Years 2009 and 2010 . The data you supply will be used to characterize the program \\
and collect utility billing histories pre- and post-weatherization to better understand energy \\
savings attributable to the Weatherization Assistance Program during the ARRA period. \\
All of the information obtained from this survey and from utilities will be protected and will \\
remain confidential. The data will be analyzed in such a way that the information provided \\
cannot be associated back to your state, your agencies, or the housing units and clients that \\
your state served.
\end{tabular}

\section{Instructions}

In Part B of the DF4 survey we request detailed information about a randomly-selected sample of housing units that your agency weatherized in PY 2009* and PY 2010†. Information requested in Part $B$ includes housing type, primary heating fuel, occupant demographics and utility account information.

*For the purposes of this survey, Program Year 2009 is the WAP/ARRA funding year that includes the heating season spanning late 2009/early 2010.

$\dagger$ For the purposes of this survey, Program Year 2010 is the WAP/ARRA funding year that includes the heating season spanning late 2010/early 2011.

Public reporting burden for this collection of information is estimated to average 20 hours per response, including the time for reviewing instructions, searching existing data sources, gathering and maintaining the data needed, and completing and reviewing the collection of information. Send comments regarding this burden estimate or any other aspect of this collection of information, including suggestions for reducing this burden, to Office of the Chief Information Officer, Records Management Division, IM-11, Paperwork Reduction Project (__ ) U.S. Department of Energy, 1000 Independence Ave SW, Washington, DC, 20585-1290; and to the Office of Management and Budget (OMB), OIRA, Paperwork Reduction Project (__ $)$, Washington, DC 20503. 


\begin{tabular}{|l|l|}
\hline Utility Information Survey Part B & DF4b \\
\hline OMB control number XXXX-XXXX & \\
\hline
\end{tabular}

To be completed by the evaluation team:

\begin{tabular}{|l|l|}
\hline Agency name & \\
\hline Agency ID & \\
\hline Contact name & \\
\hline
\end{tabular}

Section 1: Information about sampled housing units

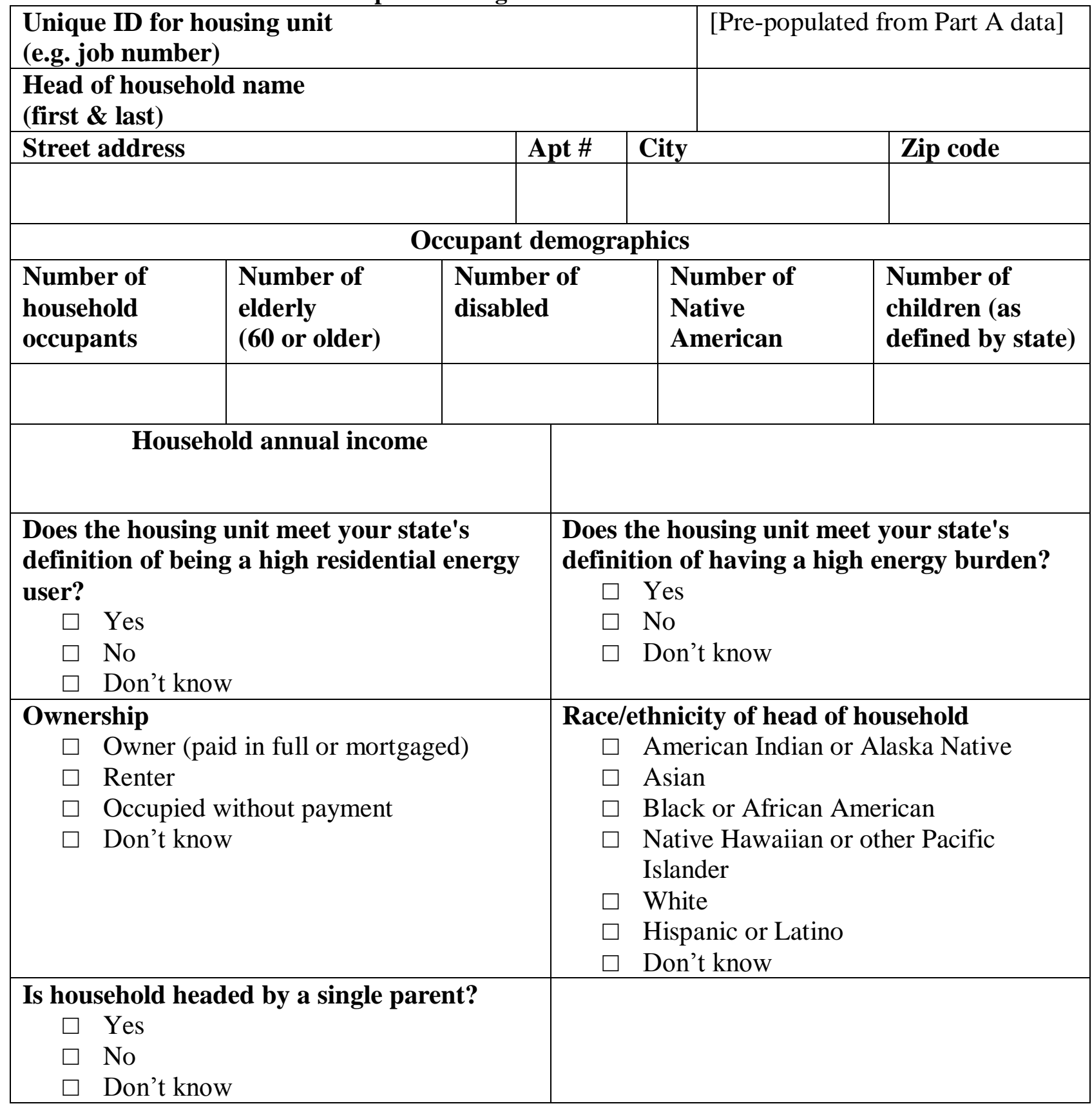




\section{Utility account information}

For units in large multifamily buildings, only list accounts that are paid by the tenant. Do not list utility accounts that serve multiple dwelling units, common areas, or the entire building. Building-level utility account information will be requested in Section 2.

\begin{tabular}{|l|l|l|}
\hline Housing type & [Pre-populated from Part A data] \\
\hline Primary heating fuel & [Pre-populated from Part A data] \\
\hline Electric utility name & $\begin{array}{l}\text { Natural gas utility } \\
\text { name }^{35}\end{array}$ & \\
\hline $\begin{array}{l}\text { Weatherization start } \\
\text { date }\end{array}$ & $\begin{array}{l}\text { Weatherization end } \\
\text { date }\end{array}$ & \\
\hline $\begin{array}{l}\text { Electric utility } \\
\text { account number }\end{array}$ & $\begin{array}{l}\text { Natural gas utility } \\
\text { account number }\end{array}$ & \\
\hline $\begin{array}{l}\text { I certify that the agency has a signed utility billing data release form } \\
\text { on file for this client. }\end{array}$ & $\square \quad \begin{array}{l}\text { Check to } \\
\text { certify }\end{array}$ \\
\hline
\end{tabular}

\footnotetext{
${ }^{35}$ If primary heating fuel is not natural gas provided by a utility, please leave this cell blank. Do NOT list propane or fuel oil providers.

${ }^{36}$ If primary heating fuel is not natural gas provided by a utility, please leave this cell blank. Do NOT list propane or fuel oil account numbers.
} 
Section 2: Information about sampled large multifamily buildings (5+ units)

[Agencies will see a series of screens, each one requesting the following information about a sampled large multifamily building.]

\begin{tabular}{|c|c|c|c|}
\hline \multirow{2}{*}{$\begin{array}{l}\text { Building unique ID } \\
\text { Number of housing units } \\
\text { in building }\end{array}$} & \multicolumn{3}{|c|}{ [Pre-populate from Section 1] } \\
\hline & & \begin{tabular}{|l|} 
Number of \\
weatherized housing \\
units
\end{tabular} & \\
\hline \multicolumn{2}{|l|}{ Street Address } & City & Zip code \\
\hline \multicolumn{3}{|c|}{$\begin{array}{l}\text { Does this building have one or more electric or natural gas utility meters that } \\
\text { provide service to multiple dwelling units or common areas in the building? } \\
\text { For example, answer "yes" if the building has a natural gas meter that provides heat } \\
\text { for the whole building or an electric meter that serves hallways and common areas. }\end{array}$} & $\begin{array}{ll}\square & \text { Yes } \\
\square & \text { No } \\
\square & \text { Don't } \\
& \text { know }\end{array}$ \\
\hline \multicolumn{3}{|c|}{ Utility account information for building-level meters } & $\begin{array}{l}\text { Check if this } \\
\text { meter serves } \\
\text { multiple buildings }\end{array}$ \\
\hline \multicolumn{3}{|l|}{ Electric account number 1} & $\square$ \\
\hline \multicolumn{3}{|l|}{ Electric account number 2} & $\square$ \\
\hline \multicolumn{3}{|l|}{ Electric account number 3} & $\square$ \\
\hline \multicolumn{3}{|l|}{ Electric account number 4} & $\square$ \\
\hline \multicolumn{3}{|l|}{ Electric account number 5} & $\square$ \\
\hline \multicolumn{3}{|c|}{ Natural gas account number 1} & $\square$ \\
\hline \multicolumn{3}{|c|}{ Natural gas account number 2} & $\square$ \\
\hline \multicolumn{3}{|c|}{ Natural gas account number 3} & $\square$ \\
\hline \multicolumn{3}{|c|}{ Natural gas account number 4} & $\square$ \\
\hline \multicolumn{3}{|c|}{ Natural gas account number 5} & $\square$ \\
\hline \multicolumn{3}{|c|}{$\begin{array}{l}\text { Do you have signed utility billing data release forms on file for any of these } \\
\text { master-metered accounts? }\end{array}$} & $\begin{array}{ll}\square & \text { Yes } \\
\square \quad \text { No } \\
\square \quad \text { Don’t } \\
\text { know }\end{array}$ \\
\hline
\end{tabular}


OMB Control Number: XXXX-XXXX

\section{APPENDIX I: DF5A - NATIONAL WEATHERIZATION ASSISTANCE PROGRAM EVALUATION HOUSEHOLD ELECTRICITY USAGE FORM}

This data is being collected to assist in the evaluation of energy savings attributable to the U.S. Department of Energy's Weatherization Assistance Program.

Public reporting burden for this collection of information is estimated to average twenty-four hours per response, including the time for reviewing instructions, searching existing data sources, gathering and maintaining the data needed, and completing and reviewing the collection of information. Send comments regarding this burden estimate or any other aspect of this collection of information, including suggestions for reducing this burden, to Office of the Chief Information Officer, Records Management Division, IM-11, Paperwork Reduction Project (XXXX-XXXX), U.S. Department of Energy, 1000 Independence Ave SW, Washington, DC, 20585-1290; and to the Office of Management and Budget (OMB), OIRA, Paperwork Reduction Project (XXXX-XXXX), Washington, DC 20503.

All of the information obtained from this data form will be protected and will remain confidential. The data will be analyzed in such a way that the information provided cannot be associated back to your utility or the housing units and buildings that your utility served.

\section{STEP 1 - Review List of Customer Accounts}

This form is accompanied by a list of households that have voluntarily participated in the Weatherization Assistance Program (WAP). These program participants have indicated that your company furnishes electric services to their household and have signed an Authorization Form that allows you to release data to ORNL for purposes of program evaluation. The list of customer accounts includes the following information:

\begin{tabular}{|c|c|c|}
\hline Field & Purpose & Notes \\
\hline Utility Company ID & Internal reference number & Developed by Evaluation Team \\
\hline WAP Project ID & Internal reference number & Developed by Evaluation Team \\
\hline Customer Account Number & $\begin{array}{l}\text { Identifies record to be } \\
\text { extracted }\end{array}$ & $\begin{array}{l}\text { Collected by local agency from } \\
\text { client at the time of service delivery }\end{array}$ \\
\hline Customer Last Name & $\begin{array}{l}\text { Last name of program } \\
\text { participant }\end{array}$ & \multirow{2}{*}{$\begin{array}{l}\text { Individual who signed the utility } \\
\text { data Authorization Form }\end{array}$} \\
\hline Customer First Name & $\begin{array}{l}\text { First name of program } \\
\text { participant }\end{array}$ & \\
\hline Service Address (Line 1) & Service address & \multirow{5}{*}{$\begin{array}{l}\text { Address at which the weatherization } \\
\text { services were delivered }\end{array}$} \\
\hline Service Address (Line 2) & $\begin{array}{l}\text { Supplemental address } \\
\text { information }\end{array}$ & \\
\hline City & City & \\
\hline State & State & \\
\hline ZIP & ZIP & \\
\hline
\end{tabular}


Please review this list of customers and confirm that the listed account numbers are consistent with your records.

\section{STEP 2 - Prepare a Data File with Customer Usage and Charge Information}

Please furnish an electronic data file with monthly electric usage and charge information for the period from XXXX through XXXX. The extract should furnish one record for each month for each customer. The required information includes:

\begin{tabular}{|c|c|c|}
\hline Field & Purpose & Notes \\
\hline Utility Company ID & Internal reference number & Developed by Evaluation Team \\
\hline WAP Project ID & Internal reference number & Developed by Evaluation Team \\
\hline $\begin{array}{l}\text { Customer Account } \\
\text { Number }\end{array}$ & $\begin{array}{l}\text { Identifies record to be } \\
\text { extracted }\end{array}$ & $\begin{array}{l}\text { Collected by local agency from } \\
\text { client at the time of service delivery }\end{array}$ \\
\hline Customer Last Name & $\begin{array}{l}\text { Last name of program } \\
\text { participant }\end{array}$ & \multirow{2}{*}{$\begin{array}{l}\text { Individual who signed the utility } \\
\text { data Authorization Form }\end{array}$} \\
\hline Customer First Name & $\begin{array}{l}\text { First name of program } \\
\text { participant }\end{array}$ & \\
\hline Service Address (Line 1) & Service address & \multirow{5}{*}{$\begin{array}{l}\text { Address at which the weatherization } \\
\text { services were delivered }\end{array}$} \\
\hline Service Address (Line 2) & $\begin{array}{l}\text { Supplemental address } \\
\text { information }\end{array}$ & \\
\hline City & City & \\
\hline State & State & \\
\hline ZIP & ZIP & \\
\hline Meter Read Date & Date of the read & MM/DD/YYYY or MM/DD/YY \\
\hline Days in Billing Period & $\begin{array}{l}\text { Allows computation of } \\
\text { start date }\end{array}$ & $\mathrm{XXX}$ \\
\hline Meter Reading Code & $\begin{array}{l}\text { Allows assessment of } \\
\text { data quality }\end{array}$ & $\begin{array}{l}\mathrm{A}=\text { Actual } \\
\mathrm{E}=\text { Estimated } \\
\mathrm{P}=\text { Phone } / \text { postcard customer read } \\
\mathrm{C}=\text { Corrected } \\
\mathrm{F}=\text { Final }\end{array}$ \\
\hline Usage Amount (kWh) & $\begin{array}{l}\text { Furnishes consumption } \\
\text { amount }\end{array}$ & Reported in $\mathrm{kWh}$ \\
\hline Usage Charge (\$\$.cc) & Furnishes charge amount & $\begin{array}{l}\text { Report usage charge only (exclude } \\
\text { service charge and charges for other } \\
\text { services) }\end{array}$ \\
\hline
\end{tabular}

We are interested in the monthly electricity consumption for each housing unit, even if a change of occupancy has occurred. We will review the monthly customer name field to identify a change of occupancy 


\section{STEP 3 - Return Data File via CD or FTP}

Your case manager will furnish instructions for delivery of the data file. The data can be delivered on a password protected CD or via a secure FTP site.

\section{HOUSEHOLD ELECTRIC USAGE FORM EXAMPLE}

\begin{tabular}{|c|c|c|c|c|c|c|c|c|c|c|c|c|c|c|}
\hline $\begin{array}{c}\text { Utility } \\
\text { Data } \\
\text { Request } \\
\text { ID } \\
\end{array}$ & $\begin{array}{c}\text { Project } \\
\text { Housing } \\
\text { Unit ID } \\
\end{array}$ & $\begin{array}{l}\text { Account } \\
\text { Number }\end{array}$ & $\begin{array}{c}\text { Last } \\
\text { Name } \\
\end{array}$ & $\begin{array}{c}\text { First } \\
\text { Name }\end{array}$ & $\begin{array}{c}\text { Service } \\
\text { Address } \\
\end{array}$ & $\begin{array}{c}\text { Service } \\
\text { Address } \\
\text { Line } 2 \\
\end{array}$ & City & State & $\begin{array}{c}\text { ZIP } \\
\text { Code }\end{array}$ & $\begin{array}{c}\text { Meter Read } \\
\text { Date } \\
(\mathrm{mm} / \mathrm{dd} / \mathrm{yy}) \\
\end{array}$ & $\begin{array}{c}\text { Days } \\
\text { in } \\
\text { Billing } \\
\text { Cycle } \\
\end{array}$ & $\begin{array}{c}\text { Meter- } \\
\text { Read } \\
\text { Code } \\
\text { A/E/P/C/F } \\
\end{array}$ & $\begin{array}{l}\text { Usage } \\
\text { (kWh) }\end{array}$ & $\begin{array}{l}\text { Charge } \\
(\$ \$ \$ . c c)\end{array}$ \\
\hline & & & & & & & & & & & & & & \\
\hline & & & & & & & & & & & & & & \\
\hline & & & & & & & & & & & & & & \\
\hline & & & & & & & & & & & & & & \\
\hline & & & & & & & & & & & & & & \\
\hline & & & & & & & & & & & & & & \\
\hline & & & & & & & & & & & & & & \\
\hline & & & & & & & & & & & & & & \\
\hline & & & & & & & & & & & & & & \\
\hline & & & & & & & & & & & & & & \\
\hline & & & & & & & & & & & & & & \\
\hline & & & & & & & & & & & & & & \\
\hline & & & & & & & & & & & & & & \\
\hline
\end{tabular}




\section{NATIONAL WEATHERIZATION ASSISTANCE PROGRAM EVALUATION HOUSEHOLD ELECTRICITY USAGE FORM FREQUENTLY ASKED QUESTIONS}

\section{What is the purpose of the National WAP Evaluation?}

We are evaluating the performance of the U.S. Department of Energy's Weatherization Assistance Program, which is a program that installs energy efficiency measures in the homes of low-income clients. A primary component of the evaluation is to determine the electricity savings achieved by the Program in housing units heated primarily by electricity or natural gas.

\section{What is the purpose of this form?}

These data are being collected to estimate change in electricity use in homes weatherized by the Weatherization Assistance Program. The data you supply will be used in statistical procedures to estimate electricity savings.

\section{How do I know this is a valid U.S. Government survey?}

All U.S. Government surveys are required to be reviewed by the U.S. Office of Management and Budget (OMB). An OMB approved survey will have a valid OMB number and expiration date on the data collection form. You will find the OMB approval number and expiration date at the top righthand corner of this form. In addition, if you wish to contact someone at the Oak Ridge National Laboratory to verify that this is a valid survey, call Bruce Tonn at 865-574-4041 or you can email him at bet@ornl.gov.

\section{What data are to be reported and in what format?}

The monthly billing data should be provided to us in electronic format. At a minimum for each month, the billing information should identify the account number, the customer name, the service address, the date the meter was read, the meter reading or the consumption, any code associated with the reading (e.g., estimated value), and the $\mathrm{kWh}$ charge. See the attached form for an example of how we would like the data formatted. We are interested in the monthly energy consumptions of each housing unit, even if a change of occupancy has occurred.

\section{How do I know that this information request does not violate my customer's privacy?}

We have obtained fuel release forms for all the account numbers shown above. Please contact us if you need to see copies of these signed forms.

In addition, the information that you provide will be protected and will remain confidential. When analysis results are reported, energy use and savings will not be associated with the housing units, account numbers, or the names of the clients in any way. 


\section{Who is conducting the survey?}

The sponsor of this survey, the Energy Efficiency and Renewable Energy Branch of the U.S. Department of Energy, has contracted with Oak Ridge National Laboratory (ORNL) to conduct this evaluation. ORNL has subcontracted with APPRISE Incorporated and their partner the Energy Center of Wisconsin (ECW) to collect the information for this evaluation. You will return your completed forms on $\mathrm{CD}$ to ECW or will upload your data file to the secure website identified by ECW.

\section{How long will it take to complete this form?}

Public reporting burden for this collection of information is estimated to average 24 hours per response, including the time for reviewing instructions, searching existing data sources, gathering and maintaining the data needed, and completing and reviewing the collection of information.

\section{How may I report these data? What format can I use?}

We are furnishing a data file with account number, name, and service address. By merging these data will your records, you will be able to develop an electronic data file with the required information. You should send this data file by mail to ECW on a password protected CD or upload this data file to the secure FTP site furnished by ECW. Under special circumstances, you can furnish data in other formats. Please consult with your case manager at ECW to discuss other options. 
OMB Control Number: XXXX-XXXX

\section{APPENDIX J. DF5B: NATIONAL WEATHERIZATION ASSISTANCE PROGRAM EVALUATION HOUSEHOLD NATURAL GAS USAGE FORM}

This data is being collected to assist in the evaluation of energy savings attributable to the U.S. Department of Energy's Weatherization Assistance Program.

Public reporting burden for this collection of information is estimated to average twenty-four hours per response, including the time for reviewing instructions, searching existing data sources, gathering and maintaining the data needed, and completing and reviewing the collection of information. Send comments regarding this burden estimate or any other aspect of this collection of information, including suggestions for reducing this burden, to Office of the Chief Information Officer, Records Management Division, IM-11, Paperwork Reduction Project (XXXX-XXXX), U.S. Department of Energy, 1000 Independence Ave SW, Washington, DC, 20585-1290; and to the Office of Management and Budget (OMB), OIRA, Paperwork Reduction Project (XXXX-XXXX), Washington, DC 20503.

All of the information obtained from this data form will be protected and will remain confidential. The data will be analyzed in such a way that the information provided cannot be associated back to your utility or the housing units and buildings that your utility served.

\section{STEP 1 - Review List of Customer Accounts}

This form is accompanied by a list of households that have voluntarily participated in the Weatherization Assistance Program (WAP). These program participants have indicated that your company furnishes natural gas services to their household and have signed an Authorization Form that allows you to release data to ORNL for purposes of program evaluation. The list of customer accounts includes the following information:

\begin{tabular}{|c|c|c|}
\hline Field & Purpose & Notes \\
\hline Utility Company ID & Internal reference number & Developed by Evaluation Team \\
\hline WAP Project ID & Internal reference number & Developed by Evaluation Team \\
\hline Customer Account Number & Identifies record to be extracted & $\begin{array}{l}\text { Collected by local agency from client at the time } \\
\text { of service delivery }\end{array}$ \\
\hline Customer Last Name & Last name of program participant & \multirow{2}{*}{$\begin{array}{l}\text { Individual who signed the utility data } \\
\text { Authorization Form }\end{array}$} \\
\hline Customer First Name & First name of program participant & \\
\hline Service Address (Line 1) & Service address & \multirow{5}{*}{$\begin{array}{l}\text { Address at which the weatherization services } \\
\text { were delivered }\end{array}$} \\
\hline Service Address (Line 2) & Supplemental address information & \\
\hline City & City & \\
\hline State & State & \\
\hline ZIP & ZIP & \\
\hline
\end{tabular}

Please review this list of customers and confirm that the listed account numbers are consistent with your records.

\section{STEP 2 - Prepare a Data File with Customer Usage and Charge Information}


Please furnish an electronic data file with monthly natural gas usage and charge information for the period from XXXX through XXXX. The extract should furnish one record for each month for each customer. The required information includes:

\begin{tabular}{|c|c|c|}
\hline Field & Purpose & Notes \\
\hline Utility Company ID & Internal reference number & Developed by Evaluation Team \\
\hline WAP Project ID & Internal reference number & Developed by Evaluation Team \\
\hline Customer Account Number & Identifies record to be extracted & $\begin{array}{l}\text { Collected by local agency from client at the time } \\
\text { of service delivery }\end{array}$ \\
\hline Customer Last Name & Last name of program participant & \multirow{2}{*}{$\begin{array}{l}\text { Individual who signed the utility data } \\
\text { Authorization Form }\end{array}$} \\
\hline Customer First Name & First name of program participant & \\
\hline Service Address (Line 1) & Service address & \multirow{5}{*}{$\begin{array}{l}\text { Address at which the weatherization services } \\
\text { were delivered }\end{array}$} \\
\hline Service Address (Line 2) & Supplemental address information & \\
\hline City & City & \\
\hline State & State & \\
\hline ZIP & ZIP & \\
\hline Meter Read Date & Date of the read & $\mathrm{MM} / \mathrm{DD} / \mathrm{YYYY}$ or MM/DD/YY \\
\hline Days in Billing Period & Allows computation of start date & $\mathrm{XXX}$ \\
\hline Meter Reading Code & Allows assessment of data quality & $\begin{array}{l}\mathrm{A}=\text { Actual } \\
\mathrm{E}=\text { Estimated } \\
\mathrm{P}=\text { Phone } / \text { postcard customer read } \\
\mathrm{C}=\text { Corrected } \\
\mathrm{F}=\text { Final }\end{array}$ \\
\hline Usage Amount & Furnishes consumption amount & Report units in next column \\
\hline Units & Furnishes units & $\begin{array}{l}\mathrm{C}=\mathrm{CCF} \\
\mathrm{M}=\mathrm{MCF} \\
\mathrm{T}=\text { Therms } \\
\mathrm{D}=\text { dTherms } \\
\mathrm{O}=\text { Other }\end{array}$ \\
\hline Usage Charge $(\$ \$$.cc) & Furnishes charge amount & $\begin{array}{l}\text { Report usage charge only (exclude service charge } \\
\text { and charges for other services) }\end{array}$ \\
\hline
\end{tabular}

We are interested in the monthly natural gas consumption of each housing unit, even if a change of occupancy has occurred. We will review the monthly customer name data to identify a change of occupancy

\section{STEP 3 - Return Data File via CD or FTP}

Your case manager will furnish instructions for delivery of the data file. The data can be delivered on a password protected CD or via a secure FTP site. 
NATURAL GAS USAGE DATA FORM EXAMPLE

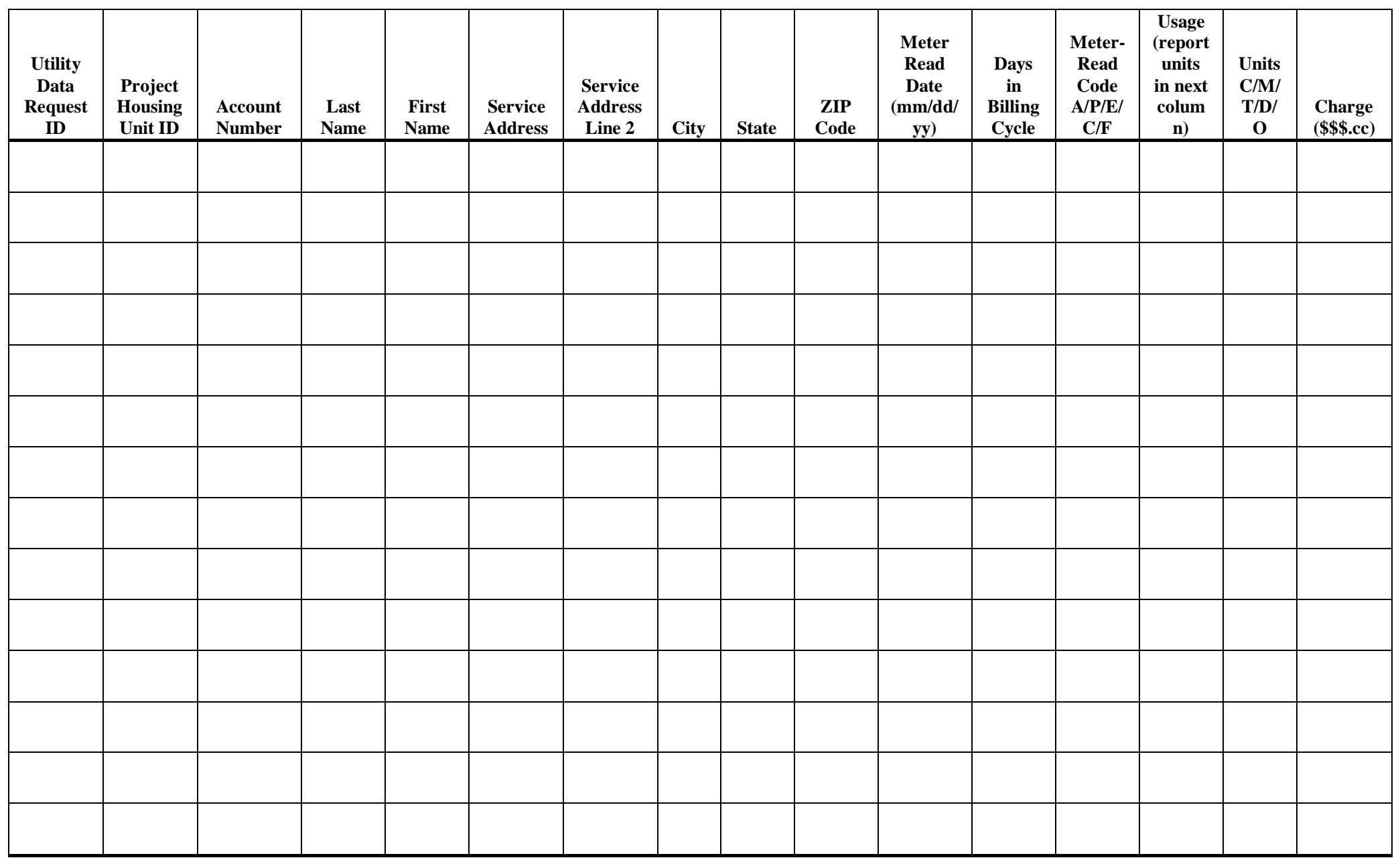




\section{NATIONAL WEATHERIZATION ASSISTANCE PROGRAM EVALUATION HOUSEHOLD NATURAL GAS USAGE FORM FREQUENTLY ASKED QUESTIONS}

\section{What is the purpose of the National WAP Evaluation?}

We are evaluating the performance of the U.S. Department of Energy's Weatherization Assistance Program, which is a program that installs energy efficiency measures in the homes of low-income clients. A primary component of the evaluation is to determine the natural gas savings achieved by the Program in housing units heated primarily by natural gas.

\section{What is the purpose of this form?}

These data are being collected to estimate change in natural gas use in homes weatherized by the Weatherization Assistance Program. The data you supply will be used in statistical procedures to estimate natural gas savings.

\section{How do I know this is a valid U.S. Government survey?}

All U.S. Government surveys are required to be reviewed by the U.S. Office of Management and Budget (OMB). An OMB approved survey will have a valid OMB number and expiration date on the data collection form. You will find the OMB approval number and expiration date at the top right-hand corner of this form. In addition, if you wish to contact someone at the Oak Ridge National Laboratory to verify that this is a valid survey, call Bruce Tonn at 865-574-4041 or you can email him at bet@ ornl.gov.

\section{What data are to be reported and in what format?}

The monthly billing data should be provided to us in electronic format. At a minimum for each month, the billing information should identify the account number, the customer name, the service address, the date the meter was read, the meter reading or the consumption, the consumption units, any code associated with the reading (e.g., estimated value), and the usage charge. See the attached form for an example of how we would like the data formatted. We are interested in the monthly energy consumptions of each housing unit, even if a change of occupancy has occurred.

\section{How do I know that this information request does not violate my customer's privacy?}

We have obtained fuel release forms for all the account numbers shown above. Please contact us if you need to see copies of these signed forms.

In addition, the information that you provide will be protected and will remain confidential. When analysis results are reported, energy use and savings will not be associated with the housing units, account numbers, or the names of the clients in any way.

\section{Who is conducting the survey?}

The sponsor of this survey, the Energy Efficiency and Renewable Energy Branch of the U.S. Department of Energy, has contracted with Oak Ridge National Laboratory (ORNL) to conduct this evaluation. ORNL has subcontracted with APPRISE Incorporated and their partner the Energy Center of Wisconsin (ECW) to collect the information for this evaluation. You will return your completed forms on CD to ECW or will upload your data file to the secure website identified by ECW. 


\section{How long will it take to complete this form?}

Public reporting burden for this collection of information is estimated to average 24 hours per response, including the time for reviewing instructions, searching existing data sources, gathering and maintaining the data needed, and completing and reviewing the collection of information.

\section{How may I report these data? What format can I use?}

We are furnishing a data file with account number, name, and service address. By merging these data will your records, you will be able to develop an electronic data file with the required information. You should send this data file by mail to ECW on a password protected CD or upload this data file to the secure FTP site furnished by ECW. Under special circumstances, you can furnish data in other formats. Please consult with your case manager at ECW to discuss other options. 
OMB Control Number: XXXX-XXXX

\section{APPENDIX K. S4: OCCUPANT SURVEY}

This data is being collected to conduct a survey of occupants about their experiences with the Weatherization Assistance Program and benefits they believe they have received from the program. The data you supply will be used to describe occupant satisfaction with the program as well as changes in energy education and non-energy benefits provided by the program.

Public reporting burden for this collection of information is estimated to average two hours per response, including the time for reviewing instructions, searching existing data sources, gathering and maintaining the data needed, and completing and reviewing the collection of information. Send comments regarding this burden estimate or any other aspect of this collection of information, including suggestions for reducing this burden, to Office of the Chief Information Officer, Records Management Division, IM-11, Paperwork Reduction Project (XXXX-XXXX), U.S. Department of Energy, 1000 Independence Ave SW, Washington, DC, 20585-1290; and to the Office of Management and Budget (OMB), OIRA, Paperwork Reduction Project (XXXX-XXXX), Washington, DC 20503.

Lastly, all of the information obtained from this survey will be protected and will remain confidential. The data will be analyzed in such a way that the information provided cannot be associated back to you or your household. Your answers will not be shared with or reported back to anyone within the agency that served you or your state.

\section{PRE-WEATHERIZATION SURVEY}

\{INTERVIEWER: STATE PRIOR TO PRE-WEATHERIZATION SURVEY ONLY\}I will need to ask these questions of the adult in the household most involved with the weatherization of the home or the head of the household. Am I speaking to the right person?

\section{POST-WEATHERIZATION SURVEY}

\{INTERVIEWER: VERIFY RESPONDENT IS THE SAME RESPONDENT FROM THE PREWEATHERIZATION SURVEY\}Before we begin, I need to verify that this is the same person who completed this survey before your home received weatherization services. Am I speaking to the same person?

\section{PLEASE RECORD RESPONDENT'S NAME, GENDER and AGE}

$$
\text { Name Gender Age }
$$

Main Respondent:

1. How long have you lived in your current home?

\{If less than one year\} Enter: months

Enter: years 
1a. $\{$ IF RESPONDENT HAS LIVED IN THE HOME < ONE YEAR $\}$ Has ANY OTHER ADULT living in the household lived in the home for more than one year?

(1) Yes

(2) No

\{IF YES $\}$ Name \{IF NO: STOP SURVEY\}

PART I. Energy Consumption, Non-Energy Impacts, Health and Demographics

2. Are you currently...?
(1) Married
(2) Divorced
(3) Widowed
(4) Separated
(5) Never married
(6) A member of an unmarried couple
(7) Refused

3. What is the highest degree or level of school you have completed?

(1) No Schooling Completed

(2) Kindergarten to grade 12 (No Diploma)

(3) High school diploma or GED

(4) Some college, no degree

(5) Associate's degree (for example: AA, AS)

(6) Bachelor's degree (for example: BA, BS)

(7) Master's degree (for example: MA, MS, MBA)

(8) Professional degree (for example: MD, JD)

(9) Doctorate degree (for example: $\mathrm{PhD}, \mathrm{EdD}$ )

(10) Refused

4. Do you consider yourself to be of Hispanic or Latino

origin, such as Mexican, Puerto Rican, Cuban, or other Spanish background?
(1) Yes
(2) No
(3) Don't know/Not Sure
(4) Refused

5. Which describes your race? You can select one or more categories.

(1) White

(2) Black or African-American

(3) American Indian or Alaska Native

(4) Asian

(5) Native Hawaiian or Other Pacific Islander

(6) Other (if volunteered)

(7) Hispanic or Latino (if volunteered)

(8) Refused 
5a. \{IF MORE THAN ONE \} Which ONE of these groups best represents your race? You can select one or more categories.

(1) White

(2) Black or African-American

(3) American Indian or Alaska Native

(4) Asian

(5) Native Hawaiian or Other Pacific Islander

(6) Other (if volunteered)

(7) Hispanic or Latino (if volunteered)

(8) Refused

6. Were you born a citizen of the United States or did you become a citizen of the United States through naturalization?

(1) Born

(2) Naturalized

(3) Neither

(4) Refused

In this next section, I will be asking you about your home and your use of energy.

7. Do you rent or own your current residence?

(1) Rent

(2) Own

(3) Neither (Please describe the housing agreement).

8. Which of the following best describes the location of your home? Do you live in a city, a town, the suburbs, or in a rural area?
(1) City
(2) Town
(3) Suburbs
(4) Rural
(5) Don't Know/Not Sure
(6) Refused

9. In the past 12 months has anyone in your household owned or had the regular use of any cars, trucks, vans, sports-utility-vehicles or similar vehicles? DO NOT INCLUDE MOTORCYCLES OR MOPEDS.

(1) Yes

(2) No

(3) Don't Know/Not Sure

(4) Refused

INTERVIEWER: “REGULAR USE” MEANS THE VEHCILE IS KEPT AT HOME AND IS AVAILABLE FOR SOME PERSONAL USE. 
10. Thinking of the area where you live, in the past 12 months, have members of your household had regular access to public transportation? \{PROBE: buses, trolley buses, trains, trams, rapid transit (metro/subway/underground), water taxi/ferries, free transportation offered by community services agencies, Medicaid covered transportation...)
(1) Yes
(2) No
(3) Don't Know/Not Sure
(4) Refused

11. Which of the following do you believe best describes your current home? Is it a ... (INTERVIEWER: DEFINE EACH HOUSING TYPE IF NEEDED)

(1) Single-family detached house

(2) a Single-family attached house,

(3) an Apartment building with 2-4 units,

(4) an Apartment building with 5 or more units, or

(5) a Mobile home?

12. How many bedrooms do you have in your home? [Include bedrooms in finished attics or finished basements.]

13. Now think about other rooms in your home besides bedrooms and bathrooms. Not including unfinished areas, hallways, and closets, how many other rooms are there in your home?

16. Is your home heated during the winter?
(1) Yes (SKIP to Q17)
(2) No
(3) Don't Know/Not Sure
(4) Refused

16a. \{IF NO\}You have just told me that you don't heat your home during the winter. Just to clarify, is it that you have heating equipment but don't use it, or does your home just not have any heating equipment?
(1) Have equipment, but don't use it (SKIP to Q8)
(2) Don't have any heating equipment
(3) Don't Know/Not Sure
(4) Refused

17. Last winter, did you heat all \# (sum from Q12 ad Q13) rooms?
(1) Yes (SKIP to Q18)
(2) No
(3) Don't Know/Not Sure
(4) Refused

17a. How many of those rooms were not heated last winter?

Enter the number

18. Is any air conditioning equipment used in your home?

(5) Yes (SKIP to Q19)

(6) No

(7) Don’t Know/Not Sure

(8) Refused 
18a. (IF NO) Just to clarify, do you have air conditioning equipment but don't use it, or does your home just not have any air conditioning equipment?
(1) Have equipment, but don't use it (SKIP to Q 20)
(2) Don't have any air conditioning equipment
(3) Don't Know/Not Sure
(4) Refused

19. Last summer, did you air condition all \# (sum Q12 and Q13) rooms?
(1) Yes (SKIP to Q20)
(2) No
(3) Don't Know/Not Sure
(4) Refused

19a.How many of those rooms were not cooled last summer?

Enter the number

20. Is any part of your home over a crawl space with exposed dirt as the floor?
(1) Yes
(2) No
(3) Don't Know/Not sure
(4) Refused

21. Is any part of your home over a basement?
(1) Yes
(2) No (SKIP TO 22)
(3) Don't Know/Not Sure
(4) Refused

21a. Do you use your basement for living space? That is, do you use it for work, play or sleep?
(1) Yes
(2) No (SKIP to Q22)
(3) Don't Know/Not Sure
(4) Refused

21b. Is the basement warm enough to be used as a living space in the winter?
(1) Yes
(2) No
(3) Don't Know/Not Sure
(4) Refused

21c. Is the basement cool enough to be used as a living space in the summer?
(1) Yes
(2) No
(3) Don't Know/Not Sure
(4) Refused 
22. An attic is an area directly below the roof, accessible by stairs, with space for you to stand upright and easily move about. Does your home have an attic?
(1) Yes
(2) No (SKIP to Q23)
(3) Don’t Know/Not Sure
(4) Refused

22a. Do you use the attic for living space? That is, do you use it for work, play or sleep?
(1) Yes
(2) No (SKIP to Q23)
(3) Don't Know/Not Sure
(4) Refused

22b. Is the attic warm enough to be used as a living space in the winter?
(1) Yes
(2) No
(3) Don't Know/Not Sure
(4) Refused
(5)

22c. Is the attic cool enough to be used as a living space in the summer?
(1) Yes
(2) No
(3) Don't Know/Not Sure
(4) Refused

23. Does your home have a garage that is attached to or part of your home?
(1) Yes
(2) No (SKIP to 24)
(3) Don't Know/Not Sure
(4) Refused

23a. Do you warm up your vehicle in your garage?
(1) Yes
(2) No
(3) Don't Know/Not Sure
(4) Refused

23b. Have you or anyone else living in your home observed the smell of vehicle exhaust inside your home?
(1) Yes
(2) No
(3) Don't Know/Not Sure
(4) Refused

I have some questions about heating your home. 
24. $\{$ IF NO TO HEAT FROM PREVIOUS SECTION SKIP TO COOLING $\}$ Let's start with the main source of heating in your home. Please tell me which type of heating equipment provides most of the heat for your home. Remember to include portable heaters, fireplaces, heating stoves and cooking stoves.

(1) Heat pump

(2) Central furnace with ducts to individual rooms

(3) Steam/Hot water system with radiators or pipes in each room

(4) Built-in electric units in each room installed in walls, ceilings, baseboards, or floors

(5) Built-in floor/wall pipeless furnace

(6) Built-in room heater burning gas, oil, or kerosene

(7) Heating stove burning wood, coal, or coke

(8) Portable heaters

(9) Fireplace

(10) Cooking stove used to heat your home as well as to cook

(11) Some other equipment (Specify

25. Does the main heating equipment for your home also heat any other apartments, condos, households, businesses, or farm buildings?
(1) Yes
(2) No
(3) Don’t Know/Not Sure
(4) Refused

26. What is the main fuel used for heating your home? That is, which fuel is the one that provides the most heat for your home?
(1) Electricity
(2) Natural gas from underground pipes
(3) Propane (bottled gas)
(4) Fuel oil
(5) Kerosene
(6) Wood
(7) Biomass
(8) Solar or Wind
(9) Geothermal
(10) District steam
(11) Some other fuel (Specify

27. You told me that [EQUIPM] is the main source of heat in your home. In the past 12 months, did you use any other types of heating equipment? Remember to include portable heaters, fireplaces, heating stoves and cooking stoves. CHECK ALL THAT APPLY

(1) No other equipment

(2) Heat pump

(3) Central furnace with ducts to individual rooms

(4) Steam/Hot water system with radiators or pipes in each room

(5) Built-in electric units in each room installed in walls, ceilings, baseboards, or floors

(6) Built-in floor/wall pipeless furnace

(7) Built-in room heater burning gas, oil, or kerosene

(8) Heating stove burning wood, coal, coke, or biomass (such as pellets or corn)

(9) Portable heaters

(10) Fireplace

(11) Cooking stove used to heat your home as well as to cook

(12) Some other equipment (Specify 
28. What fuel does the [FILL: EQUIPAUX] use?

(1) Electricity

(2) Natural gas from underground pipes

(3) Propane (bottled gas)

(4) Fuel oil

(5) Kerosene

(6) Wood

(7) Biomass (wood pellets or corn)

(8) Solar or Wind

(9) Geothermal

(10) District steam

(11) Some other fuel (Specify

29. \{IF YES WIND OR SOLAR FOR EITHER MAIN OR OTHER FUELS USED $\}$

Do you have any on-site system that generates electricity such as a solar system or a small wind turbine?

(1) Yes

(2) No (SKIP to Q30)

(3) Don't Know/Not Sure

(4) Refused

29a. What type of on-site system do you have?

(1) Solar or Photovoltaic system

(2) Small wind turbine

(3) Combined Heat and Power system

(4) Other . Please specify

29b. Is your on-site system connected to the grid?
(1) Yes
(2) No
(3) Don't Know/Not Sure
(4) Refused

30. \{IF YES HEATING STOVE $\}$ Which statement best describes your heating stove?
(1) Manufactured before 1992
(2) Energy Star
(3) Neither
(4) Don't Know/Not Sure
(5) Refused

31. \{IF YES FIREPLACE $\}$ Does this fireplace have a flue to the outside or is it entirely self-contained?

(1) Flue to the outside

(2) Flueless (self-contained)

(3) Don't Know/Not Sure

(4) Refused 
32. \{IF YES HEATING STOVE OR FIREPLACE $\}$ In the past 12 months how often did you have to burn garbage, cardboard, plastics, foam, colored ink, magazines, boxes, or wrappers to keep warm?
(1) Never
(2) Once
(3) Sometimes
(4) Often
(5) Most of the winter
(6) Don't Know/Not Sure
(7) Refused

33. \{IF YES HEATING STOVE OR FIREPLACE $\}$ In the past 12 months how often did you have to burn coated, painted, or pressure-treated wood, driftwood, plywood, particle board, or any wood with glue in it to keep warm?
(1) Never
(2) Once
(3) Sometimes
(4) Often
(5) Most of the winter
(6) Don't Know/Not Sure
(7) Refused

34. $\{$ IF YES HEATING STOVE OR FIREPLACE $\}$ In the past 12 months how often did you have to burn wet, rotted, diseased, or moldy wood

to keep warm?
(1) Never
(2) Once
(3) Sometimes
(4) Often
(5) Most of the winter
(6) Don't Know/Not Sure
(7) Refused

35. What fuel does the cooking stove and/or oven use? CHECK ALL THAT APPLY
(1) Electricity
(2) Natural gas from underground pipes
(3) Propane (bottled gas)
(4) Fuel oil
(5) Kerosene
(6) Wood
(7) Some other fuel (Specify
(8) No working stove or oven in the home

36. Is an exhaust fan that vents to the outside used regularly when cooking in your kitchen?
(1) Yes
(2) No
(3) Don't Know/Not Sure
(4) Refused 
37. In the past 12 months how often have you used your oven to heat your house?
(1) Never
(2) Rarely
(3) Sometimes
(4) Frequently
(5) All the time
(6) Don't Know/Not Sure
(7) Refused

38. Does your household use a microwave oven?
(1) Yes
(2) No (SKIP to 39)
(3) Don't Know/Not Sure
(4) Refused

38a. Which answer best describes how frequently your household uses the microwave to prepare hot meals and snacks in a typical week?

(1) Used to cook or reheat most meals and snacks

(2) Used to cook or reheat about half of meals and snacks

(3) Used to cook or reheat a few meals and snacks

(4) Used very little

(5) Don't Know/Not Sure

(6) Refused

39. Does your heating system have an air filter?
(1) Yes
(2) No (SKIP to 40)
(3) Don't know/Not Sure
(4) Refused

39a. Is the air filter in your heating system a High Efficiency Particulate Arresting (HEPA) filter?
(1) Yes
(2) No
(3) Don't Know/Not Sure
(4) Refused

39b. Approximately, how often does someone in your household change (or clean) the air filter in your heating system?
(1) Monthly
(2) Every three months
(3) Every six months
(4) Once a year
(5) Once every two years
(6) Don't change (or clean) it
(7) Air filter is changed by service company
(8) Don't Know/Not Sure
(9) Refused 
40. \{IF YES FURNACE $\}$ Do you know when was the last time your furnace received maintenance service by a furnace contractor to ensure optimum and safe operation?
(1) Yes
(2) No (SKIP to Q41)
(3) Refused

40a. How many years and months ago did this occur?

41. Do you have a CO (or carbon monoxide) monitor in your house?
(1) Yes
(2) No (SKIP to Q 42)
(3) Don't know/Not Sure
(4) Refused

41a. Is your $\mathrm{CO}$ monitor currently working?
(1) Yes
(2) No
(3) Don't know/Not Sure
(4) Refused

42. Do you have one or more smoke detectors in your house?
(1) Yes
(2) No (SKIP to Q43)
(3) Don't know/Not Sure
(4) Refused

42a. How many smoke detectors are there in your house?

Enter Number

(1) Don't Know/Not Sure

(2) Refused

42b. How many of these smoke detectors are currently working?

Enter Number

(1) Don't Know/Not Sure

(2) Refused

43. In the past 12 months how many times has the fire department been called to put out a fire in your home during the past year?

44. In the past 12 months did any fire start in your home as a result of using an alternate heating source, such as space heaters, electric blankets, your kitchen stove or oven, heating stove, furnace, or your fireplace?
(1) Yes
(2) No
(3) Don't Know/Not Sure
(4) Refused

45. In the past 12 months, how many individuals needed medical attention because of fire?

$$
\text { Enter Number }
$$


Now I have some questions about cooling your home.

46. (IF NO TO AIR CONDITIONING FROM PREVIOUS SECTION SKIP TO CEILING FAN USE

Q47) Central air conditioning requires that the system have ducts to carry the cooled air to the individual rooms. These ducts may also carry warm air for space heating. Does your home have ducts like these?

(1) Yes

(2) No (SKIP to 47)

(3) Don’t Know/Not Sure

(4) Refused

46a. Does the central air conditioning equipment that cools your home also cool any other apartments, condos, households, businesses, or farm buildings?
(1) Yes
(2) No

46b. Which of the statements shown best describes the way your central air conditioning system was used last summer?

(1) Not used at all (if volunteered)

(2) Turned on only a few days or nights when really needed

(3) Turned on quite a bit

(4) Turned on just about all summer

47. Which of the following statements best describes the way your household used the most used window/wall air conditioning unit last summer?

(1) Turned on only a few days or nights when really needed

(2) Turned on quite a bit

(3) Turned on just about all summer

(4) No working window/wall units in home

48. Which of the following statements best describes the way your household used a Swamp or Evaporative Air Cooler last summer?

(1) Turned on only a few days or nights when really needed

(2) Turned on quite a bit

(3) Turned on just about all summer

(4) No swamp/evaporative air cooler in home.

49. How many ceiling fans does your household have?

Enter Number

(1) None (SKIP to Q 50)

(2) Don't Know/Not Sure

(3) Refused

49a. How many ceiling fans does your household use?

Enter Number of ceiling fans

(1) None (SKIP to 50)

(2) Don't Know/Not Sure

(3) Refused 
49b. Thinking about the ceiling fan that you use the most, how often was this fan used last summer? Is it . . .

(1) Used only a few days or nights, when it's really needed,

(2) Used quite a bit, or

(3) Used just about all summer?

(4) Not used at all

(5) Don't Know/Not Sure

(6) Refused

49c. Thinking about the ceiling fan that you use the most, how often was this fan used last winter? Is it . . .

(1) Used only a few days or nights,

(2) Used quite a bit, or

(3) Used just about all winter?

(4) Not used at all

(5) Don't Know/Not Sure

(6) Refused

50. Opening windows on opposite sides of the house to cool the indoor temperature is called natural cross ventilation. In the past 12 months, has your household used window fans to assist with natural cross ventilation in the warmer months?
(1) Yes
(2) No
(3) Don't Know/Not Sure
(4) Refused

51. How often are your windows open in the summer?
(1) Never
(2) Rarely
(3) Sometimes
(4) Frequently
(5) All the time
(6) Don't Know/Not Sure
(7) Refused

52. How often are your windows open in the winter?
(1) Never
(2) Rarely
(3) Sometimes
(4) Frequently
(5) All the time
(6) Don't Know/Not Sure
(7) Refused

53. Do any large trees shade your home from the afternoon summer sun?

(1) Yes

(2) No

(3) Don't Know/Not Sure

(4) Refused 
54. Do you close the drapes, curtains, shades, and/or blinds during the day to block out the sun during the summer?

(1) Never

(2) Rarely

(3) Sometimes

(4) Frequently

(5) All the time

(6) Don’t Know/Not Sure

(7) Refused

INTERVIEWER INSTRUCTION: RECORD ANY INFORMATION HERE ABOUT THE AIRCONDITIONING EQUIPMENT IN THIS HOUSING UNIT AND ITS' USAGE THAT MIGHT PROVIDE CLARIFICATION TO THE RESPONDENT'S ANSWERS.

Now I have some questions on the indoor air temperature of your home.

55. Does your home have a thermostat that controls the heating and/or cooling in your home?
(1) Yes
(2) No (SKIP to Q 64)
(3) Don't Know
(4) Refused

55a. What equipment does your thermostat control?
(1) Central heating only
(2) Central cooling only
(3) Central heating and cooling
(4) Don't know

56. Some thermostats can be programmed so that the temperature changes automatically at different times of the day; for example, the heat can be automatically turned down or lowered at night when you go to bed, then automatically adjusted up again in the morning. Is the thermostat that controls your main [heating and/or cooling] equipment programmable?
(1) Yes
(2) No (SKIP to Q57)
(3) Don't know/Not Sure
(4) Refused

56a. Do you or someone else in your household know how to use the programmable thermostat?
(1) Yes
(2) No (SKIP to Q57)
(3) No, someone who does not live in my home programs the thermostat for use
(4) Don't know/Not Sure
(5) Refused 
56b. Is your thermostat programmed to change the temperature at different times of the day?
(1) Yes
(2) No (SKIP to Q56d)
(3) Don't know/Not Sure
(4) Refused

56c. Please indicate how the programmable thermostat is used. (Select all that apply.)

(1) Thermostat is automatically adjusted to a lower temperature at night during the winter

(2) Thermostat is automatically adjusted to a lower temperature during the day when no one is home during the winter

(3) Thermostat is automatically adjusted to a higher temperature at night during the summer

(4) Thermostat is automatically adjusted to a higher temperature during the day when no one is home during the summer

(5) Other

(6) Don't know/Not Sure

(7) Refused

56d. Which statement best describes your programmable thermostat...

(1) It is very easy to use

(2) It is somewhat easy to use

(3) It is neither easy nor difficult to use

(4) It is somewhat difficult to use

(5) It is very difficult to use

(6) Refused

56e. Typically, how often is your programmable thermostat reprogrammed, that is, the time schedule and desired indoor temperature setting changed permanently?

(1) Daily

(2) Weekly

(3) Monthly

(4) Every three months of so

(5) Once a year

(6) Less than once a year

(7) Never

(8) Don't know/Not Sure

(9) Refused

56f. How often is the current temperature setting "overridden" temporarily and why?

(1) Daily

(2) Weekly

(3) Monthly

(4) Every three months of so

(5) Once a year

(6) Less than once a year

\{IF ANSWERED ANY OF THE ABOVE\} Please explain why

(7) Never

(8) Don't know/Not Sure

(9) Refused 
56g. How often is the "hold" mode used and why?

Daily

(2) Weekly

(3) Monthly

(4) Every three months of so

(5) Once a year

(6) Less than once a year

\{IF ANSWERED ANY OF THE ABOVE\} Please explain why.

(7) Never

(8) Don't know/Not Sure

(9) Refused

56h. Please indicate what features need improvement in your programmable thermostat.

(1) Size of words and numbers?

(2) Ease of programming?

(3) Additional features, such as the energy use in my home?

(4) Being able to change its settings using a cell phone, Internet?

(5) Other features. Please Specify.

(6) Don't Know/Not Sure

(7) Refused

56i. Is there anyone in your home who doesn't operate the programmable thermostat? Why? (select all that apply)

(1) It's too complicated/too difficult

(2) We do not have an instruction manual / Nobody showed us how

(3) We haven't needed to

(4) Other (Specify)

(5) Don't Know/Not Sure

(6) Refused

56j. \{IF NO TO 56b. or ANSWERED (7)NEVERTO 56e $\}$ Why is your programmable thermostat not programmed to automatically change the temperature? (select all that apply)

(1) We change the temperature manually/don't need to program

(2) It takes too much effort to use

(3) Household members cannot agree on what temperatures at which to set the thermostat

(4) It is better to always keep the temperature setting always the same. (Why?)

(5) There is always somebody at home

(6) Other (Specify)

(7) Don't Know/Not Sure

(8) Refused

57. During the winter, what is the temperature when someone is inside your home during the day? [IF NO ANSWER, PROBE 1: THEN AT WHAT TEMPERATURE IS THE THERMOSTAT SET? PROBE 2: CAN I JUST HAVE YOUR BEST ESTIMATE?]

Enter degrees Fahrenheit 
58. During the winter, what is the temperature when no one is inside your home during the day? [IF NO ANSWER, PROBE 1: THEN AT WHAT TEMPERATURE IS THE THERMOSTAT SET? PROBE 2: CAN I JUST HAVE YOUR BEST ESTIMATE?]

Enter degrees Fahrenheit

59. During the winter, what is the temperature inside your home at night? [IF NO ANSWER, PROBE 1: THEN AT WHAT TEMPERATURE IS THE THERMOSTAT SET? PROBE 2: CAN I JUST HAVE YOUR BEST ESTIMATE?]

\section{Enter degrees Fahrenheit}

Now I would like you to think about the temperature inside your home when using your central air conditioning equipment last summer. [If NUMTHERM>1: Earlier you reported having [FILL:

NUMTHERM] thermostats. For the next questions, if the thermostats are set at different temperatures, only report for the thermostat that affects the rooms where most of the people are.]

60. During the summer, what is the temperature when someone is inside your home during the day? IF NO ANSWER, PROBE 1: THEN AT WHAT TEMPERATURE IS THE THERMOSTAT SET? PROBE 2: WHAT'S YOUR BEST ESTIMATE?

\section{Enter degrees Fahrenheit}

Air-conditioner Turned Off

61. During the summer, what is the temperature when no one is inside your home during the day? IF NO ANSWER, PROBE 1: THEN AT WHAT TEMPERATURE IS THE THERMOSTAT SET? PROBE 2: WHAT'S YOUR BEST ESTIMATE?

Enter degrees Fahrenheit Air-conditioner Turned Off

62. During the summer, what is the temperature inside your home at night? IF NO ANSWER, PROBE 1: THEN AT WHAT TEMPERATURE IS THE THERMOSTAT SET? PROBE 2: WHAT'S YOUR BEST ESTIMATE?

Enter degrees Fahrenheit

Air-conditioner Turned Off

63. Answer the following statements -- true or false:

a. If the thermostat is turned up very high in the winter, my home will get warmer faster.

(1) True

(2) False

b. The thermostat controls the temperature of the air coming from the heating/cooling unit into my home.

(1) True

(2) False 
c. The thermostat only senses the temperature in the air in the room where the thermostat is located. It turns the heating unit off when the temperature in the room reaches the temperature on the thermostat setting.
(1) True
(2) False

d. If the thermostat is turned down at night or when no one is home, then more energy is used than saved when your home is heated up again.
(1) True
(2) False

64. In the past 12 months, was your household unable to use any of the following equipment because it was broken? CHECK ALL THAT APPLY
(1) Main Heating Equipment
(2) Central Air Conditioner
(3) Room Air Conditioner
(4) Don't Know/Not Sure
(5) Refused

65. Which of the following statements best describes the indoor temperature of your home during the winter:
(1) Very cold
(2) Cold
(3) Comfortable (SKIP)
(4) Hot
(5) Very hot
(6) Other
(7) Refused

66. Which of the following statements best describes the indoor temperature of your home during the summer:
(1) Very cold
(2) Cold
(3) Comfortable (SKIP TO NEXT Q....)
(4) Hot
(5) Very hot
(6) Other
(7) Refused

67. In the past 12 months, has a landlord controlled the temperature inside your home?
(1) Yes
(2) No
(3) Do not have landlord
(4) Don't Know/Not Sure
(5) Refused 
68. In the past 12 months how often did your household keep your home at a temperature that you felt was unsafe or unhealthy?
(1) Almost every month
(2) Some months
(3) 1 or 2 months
(4) Never
(5) Don't Know/Not Sure
(6) Refused

69. In the past 12 months, has anyone in the household needed medical attention because your home was too cold?
(1) Yes
(2) No
(3) Don't Know/Not Sure
(4) Refused

70. In the past 12 months did anyone in your household need medical attention because your home was too hot?
(1) Yes
(2) No
(3) Don't Know/Not Sure
(4) Refused

71. During the past 12 months, how often have you or other members of your household found your home too drafty? Would you say it is. . .
(1) All the time,
(2) Most of the time,
(3) Some of the time, or
(4) Never
(5) Don't Know/Not Sure
(6) Refused

The next group of questions is about laundry appliances and water use in your home.

72. Is a clothes washing machine used in your home? Do not include community clothes washers that are located in the basement or laundry room of your apartment building.
(1) Yes
(2) No (SKIP to Q73)
(3) Refused

72a. In an average week, how many loads of laundry are washed in your clothes washer?
(1) 1 load or less each week
(2) 2 to 4 loads each week
(3) 5 to 9 loads each week
(4) 10 to 15 loads each week
(5) More than 15 loads each week
(6) Don’t Know/Not Sure
(7) Refused 
72b. Does your household wash only full loads of laundry?
(1) Always
(2) Most of the time
(3) Some of the time
(4) Never
(5) Don't know/Not Sure
(6) Refused

72c. What water temperature setting is usually used for the wash cycle of your clothes washer? Is it hot, warm, or cold water?
(1) Hot
(2) Warm
(3) Cold
(4) Don't Know/Not Sure
(5) Refused

72d. What water temperature setting is usually used for the rinse cycle of your clothes washer? Is it hot, warm, or cold water?
(1) Hot
(2) Warm
(3) Cold
(4) Don't Know/Not Sure
(5) Refused

73. Do you use a clothes dryer in your home? Do not include community clothes dryers that are located in the basement or laundry room of your apartment building.
(1) Yes
(2) No (SKIP TO Q74)
(3) Don't Know/Not Sure
(4) Refused

73a. Does your household dry only full loads of laundry....?
(1) Always
(2) Most of the time
(3) Some of the time
(4) Never
(5) Don't Know/Not Sure
(6) Refused

73b. Does your clothes dryer vent directly to the outdoors?
(1) Yes
(2) No
(3) Dryer is ventless
(4) Don't Know/Not Sure
(5) Refused

73c. Do you clean your clothes dryer's lint filter after every use?
(1) Yes
(2) No
(3) Dryer has not lint filter
(4) Don't Know/Not Sure
(5) Refused 
74. How frequently does your household hang clothes to dry?
(1) Very frequently
(2) Frequently
(3) Infrequently
(4) Very infrequently
(5) Never
(6) Don't Know/Not Sure
(7) Refused

75. In the last 12 months, has the temperature of your hot water heater been adjusted?
(1) Yes, the temperature is much warmer
(2) Yes, the temperature is warmer
(3) No adjustment has been made to the temperature
(4) Yes, the temperature is cooler
(5) Yes, the temperature is much cooler
(6) Hot water heater was not in working order for the last 12 months
(7) No water heater
(8) Don't Know/Not Sure
(9) Refused

76. Over the past 12 months, has the duration of the showers taken by household members changed?
(1) Increased a lot
(2) Increased some
(3) No change
(4) Decreased some
(5) Decreased a lot
(6) No Shower
(7) Don't Know/Not Sure
(8) Refused

77. Does your main bathroom have a ventilation fan in it that works?
(1) Yes
(2) No (SKIP to Q78)
(3) Don't know/Not Sure (SKIP to Q50)
(4) Refused

77a. How often do you or members of your household operate the fan while showering?
(1) Never
(2) Rarely
(3) Sometimes
(4) Frequently
(5) All the time
(6) Don't Know/Not Sure
(7) Refused 
77b. How long after showering do you or members of your household operate the fan?

(1) Don't turn the fan on for showers

(2) The fan is turned off when leaving the shower area

(3) A few minutes

(4) Several minutes

(5) Until the steam in the shower area is gone

(6) Don't know/Not Sure

(7) Refused

78. Electric dehumidifiers remove moisture from the air and are often used in the summer. Is a dehumidifier used in your home?
(1) Yes
(2) No (SKIP to Q79)
(3) Don't Know/Not Sure
(4) Refused

78a. In the past 12 months, how many months was the dehumidifier used?
(1) 1 to 3 months, 4 to 6 months,
(2) 7 to 9 months,
(3) 10 to 11 months, but not all year, or is it
(4) Turned on all year long?
(5) Don't Know/Not Sure
(6) Refused

Now I have some questions about lights inside your home and energy efficiency.

79. How often do you find lights left on in rooms that are not occupied?
(1) Never
(2) Almost never
(3) Sometimes
(4) Most of the time
(5) All the time
(6) Don’t Know/Not Sure
(7) Refused

80. Do members of your household purchase or intentionally seek out and install compact fluorescent bulbs in your home?
(1) Yes
(2) No (SKIP to Q81)
(3) I do not know what compact fluorescent bulbs are (SKIP to Q81)
(4) Don't know/Not Sure
(5) Refused

80a. How do you dispose of compact fluorescent light bulbs that are broken or no longer working?

(1) Directly in household garbage

(2) Doubled bagged in plastic in household garbage

(3) Transport to local recycling center

(4) Other (Please Specify)

(5) Don't Know/Not Sure

(6) Refused 
81. Are you familiar with the Energy Star ${ }^{\circledR}$ label?
(1) Yes
(2) No (SKIP to 82)
(3) Refused

81a. Has your household bought or intentionally installed appliances or consumer electronics that have an Energy Star® label?
(1) Yes
(2) No
(3) Don't know/Not Sure
(4) Refused

82. Do you unplug any appliances like TVs, VCRs, stereos, radios, clocks, or computers to save energy when they are turned off?
(1) Yes
(2) No
(3) Don't know/Not Sure
(4) Refused

In this next set of questions, I will ask you about other conditions of your home.

83. How much outdoor noise do you hear indoors when the windows are closed?
(1) A great deal
(2) Some
(3) Hardly any
(4) None at all
(5) Don't know/Not Sure
(6) Refused

84. Please rate the outside appearance of your home:
(1) Very attractive
(2) Attractive
(3) Neither attractive nor unattractive
(4) Unattractive
(5) Very unattractive
(6) Refused

85. Over the past 12 months, how has the property value of your home changed?
(1) Very much higher
(2) Higher
(3) No change
(4) Lower
(5) Very much lower
(6) Not applicable, don't own the home or live in an apartment
(7) Don't know/Not Sure
(8) Refused 
86. How infested is your home with cockroaches or other insects or spiders?
(1) Extremely infested
(2) Very infested
(3) Somewhat infested
(4) Hardly infested
(5) Not infested at all (SKIP to Q87)
(6) Don't know/Not Sure
(7) Refused

86a. What have you done about the cockroaches, other insects or spiders?
(1) Nothing
(2) Used insecticides, bug sprays, or poison
(3) Hired an exterminator or other professional
(4) Other. Please specify.
(5) Don't Know/Not Sure
(6) Refused

87. How infested is your home with rats or mice?
(1) Extremely infested
(2) Very infested
(3) Somewhat infested
(4) Hardly infested
(5) Not infested at all (SKIP to Q88)
(6) Don't know/Not Sure
(7) Refused

87a. What have you done about the pests?
(1) Nothing
(2) Used bait or poison
(3) Hired an exterminator or other professional
(4) Other. Please specify.
(5) Don’t Know/Not Sure
(6) Refused

88. Does your home frequently have a mildew odor or musty smell?
(1) Yes
(2) No
(3) Don't Know/Not Sure
(4) Refused

89. How often do you observe standing water anywhere in your home?
(1) Never
(2) Rarely
(3) Sometimes
(4) Often
(5) Always
(6) Don't Know/Not Sure
(7) Refused 
90. Have you seen mold in your home in the past 12 months?

(1) Yes

(2) No \{SKIP to Q91\}

(3) Don't know/Not Sure

(4) Refused

90a. \{If YES MOLD \}What have you done about the mold?

(1) Nothing

(2) Cleaned with bleach

(3) Cleaned with other chemical mold remover

(4) Cleaned with natural mold remover (vinegar or natural product)

(5) Air Conditioned

(6) Ventilation (fans)

(7) Used a dehumidifier

(8) Contacted a Professional

(9) Other. Please Specify

(10) Don't know/Not Sure

(11) Refused

Now I would like to ask you a few questions about your energy bills.

Some households may have faced challenges in paying home energy bills. The following questions ask about challenges your household may have had paying home energy bills or maintaining heating and cooling equipment. When thinking about these questions, include all of your experiences in the past 12 months.

91. Some energy utilities and suppliers offer budget payment plans that allow a household to pay the same amount on the home energy bill each month. In the past 12 months, did your household use a budget plan for any home energy bill?

(1) Yes

(2) No

(3) Don't Know/Not Sure

(4) Refused

INTERVIEWER INSTRUCTION: BUDGET PLANS ARE NOT USUALLY RELATED TO LATE OR DISCONNECT NOTICES AND ARE NOT A WAY TO PAY DOWN PAST DUE BALANCES.

92. How well do you understand the information on your energy bill other than the amount owed (e.g., information about how much energy your household used during the billing period compared to the same billing period one year ago)?

(1) Very well

(2) Well

(3) Neither well nor not well

(4) Not well

(5) Not well at all

(6) Don't know/Not Sure

(7) Refused 
93. How hard is it to pay your energy bills?
(1) Very hard
(2) Hard
(3) Neither hard or not hard
(4) Not hard
(5) Not hard at all
(6) Don't know/Not Sure
(7) Refused

94. Has your household ever had to move in the past 5 years because your household could not pay the energy bills?

(1) Yes

(2) No (go to Q20)

(3) Don't know (go to Q 20)

95. Over the past 12 months, how often has your household not paid energy bills in order to pay other utility bills (PROBE: water/sewage/telephone/Secondary energy fuel type)?
(1) Every month
(2) Every other month
(3) Every few months
(4) Every six months
(5) Once in twelve months
(6) Never
(7) Don't Know/Not Sure
(8) Refused

96. Over the past 12 months, how often has your household not paid other utilities in order to pay the primary energy bill (PROBE: water/sewage/telephone/Secondary energy fuel type)?

(1) Every month

(2) Every other month

(3) Every few months

(4) Every six months

(5) Once in twelve months

(6) Never (SKIP to Q97)

(7) Don't Know/Not Sure

(8) Refused

96 a. What utilities were not paid for in order to pay an energy bill? (Check all that apply)
(1) Water
(2) Sewage
(3) Telephone
(4) Secondary energy fuel type
(5) Other
(6) Don't Know/Not Sure
(7) Refused 
97. Over the past 12 months, how often has your household not purchased food in order to pay an energy bill?
(1) Every month
(2) Every other month
(3) Every few months
(4) Every six months
(5) Once in twelve months
(6) Never
(7) Don't Know/Not Sure
(8) Refused

98. Over the past 12 months, how often has your household not paid energy bills in order to purchase food?
(1) Every month
(2) Every other month
(3) Every few months
(4) Every six months
(5) Once in twelve months
(6) Never
(7) Don't Know/Not Sure
(8) Refused

99. In the past four weeks, did you or any household member go a whole day and night without eating anything because there was not enough food?
(1) Yes
(2) No
(3) Don't Know/Not Sure
(4) Refused

100. In the past four weeks, did you worry that your household members would not have nutritious food?
(1) Yes
(2) No
(3) Don't Know/Not Sure
(4) Refused

101. Some households receive additional assistance to help pay for food. In the past 12 months did you or any members of your household receive food stamps or WIC assistance (Women, Infants, and Children nutrition program)? (ASK ONCE/DO NOT REPEAT QUESTION FOR EACH INDIVIDUAL)
(1) Yes
(2) No; Did not apply
(3) No; Applied for, but rejected
(4) Don't Know/Not Sure
(5) Refused 
102. In the past 5 years have you or anyone in the household experienced any of the following as a result of energy bills? (Check all that apply)

(1) Eviction from home

(2) Foreclosure on mortgage

(3) Moved in with friends or family

(4) Moved into a shelter or been homeless

(5) Family Separation

(6) Refused

102a. \{If YES FAMILY SEPARATION\}In what way or ways was the family separated?

(1) Adult partners only separated

(2) One adult partner separated from partner and children

(3) One parent separated from children only

(4) Both parents separated from children

(5) Elder parent or relative separated from family

(6) Refused

103. In the past 12 months how often did your household pay an amount less than what you owed on your home energy bill, because you were unable to afford the whole home energy bill?

(1) Almost every month

(2) Some months

(3) 1 or 2 months

(4) Never

(5) Don't Know/Not Sure

(6) Refused

104. In the past year, have you used any of the following to assist with paying your energy bill?

(1) Payday loan

(2) Tax Refund Anticipation Loan

(3) Car Title loan

(4) Other type of short term, high-interest loan

(5) Pawn shop

(6) Don't Know/Not Sure

(7) Refused

104a. \{If YES to any of the above\}In the past year, in order to pay your home energy bill, how often did you need to use a payday loan, a Tax Refund Anticipation Loan, a car title loan, another type of shortterm, high-interest loan, or pawn shop?

(1) Almost every month

(2) Some months

(3) 1 or 2 months

(4) Never

(5) Don't Know/Not Sure

(6) Refused 
105. When home energy bills are not paid on time, it is common for energy utilities and suppliers to send late notices. If the bill is very late, they will send a disconnect, shut-off, or non-delivery notice. How often did you receive a disconnect, shut-off, or non-delivery notice?

(1) Almost every month

(2) Some months

(3) 1 or 2 months

(4) Never (SKIP to Q106)

(5) Don’t Know/Not Sure

(6) Refused

105a. Did you enter into a payment arrangement with your energy utility or supplier in response to the disconnect shut-off, or non-delivery notice?
(1) Yes
(2) No
(3) Don't Know/Not Sure
(4) Refused

106. In the past 12 months was your electricity or natural gas ever disconnected because you were unable to pay your home energy bill?
(1) Yes
(2) No (SKIP to Q107)
(3) Don't Know/Not Sure
(4) Refused

106a. While your electricity or natural gas was disconnected, was there a time when you wanted to use your main source of heat but were unable to?
(1) Yes
(2) No
(3) Don't Know/Not Sure
(4) Refused

106b. While your electricity was disconnected, was there a time when you wanted to use your air conditioner but were unable to?

(1) Yes

(2) No

(3) Don't Know/Not Sure

(4) Refused

107. In the past 12 months did your fuel oil, kerosene, propane, or wood ever run out because you were unable to pay for a home energy delivery?

(1) Yes

(2) No (SKIP to Q108)

(3) Don't Know/Not Sure

(4) Refused

107a. When you ran out of your fuel oil, kerosene, propane, or wood was there a time when you wanted to use your main source of heat but were unable to?

(1) Yes

(2) No

(3) Don't Know/Not Sure

(4) Refused 
Next, I will be asking about health care and coverage.

108. In the past 12 months have you had any kind of health care coverage, including health insurance, prepaid plans such as HMOs, or government plans such as Medicare?

(1) Yes (SKIP to Q108b)

(2) No

(3) Refused

108a. \{IF NO COVERAGE\} According to the information given, you do NOT have health care coverage of any kind. Do you have health insurance or coverage through a plan I might have missed?

(INTERVIEWER: REVIEW PLANS IF INFORMANT IS UNSURE.)

(1) NO/NOT COVERED BY ANY PLAN (SKIP to Q109)

(2) HEALTH INSURANCE PLAN FROM A

(3) CURRENT OR PAST EMPLOYER/

(4) UNION/SCHOOL

(5) A HEALTH INSURANCE PLAN BOUGHT ON

HIS/HER OWN/PROF. ASSN

(6) A PLAN BOUGHT BY SOMEONE WHO

DOES NOT LIVE IN THIS HOUSEHOLD

(7) MEDICARE

(8) MEDICAID/STATE NAME

(9) CHAMPUS/CHAMP-VA, TRICARE, VA,

(10) OTHER MILITARY

(11) INDIAN HEALTH SERVICE

(12) [FILL STATE PLAN]

(13) OTHER PLAN [SPECIFY]

(14) DON'T KNOW/NOT SURE

(15) REFUSED

108b. \{IF YES COVERAGE $\}$ During the past 12 months was there any time that you did not have any health insurance coverage?

(1) Yes

(2) No

(3) Don't Know/Not Sure

(4) Refused

108c. Does your health plan pay for at least some of the cost of prescription medicines prescribed by a doctor?

(1) Yes

(2) No

(3) Don't Know/Not Sure

(4) Refused

109. During the past 12 months, was there any time your household members needed prescription medicines but didn't get them because you couldn't afford it?

(1) Yes

(2) No

(3) Don't Know/Not Sure

(4) Refused 
110. Over the past 12 months, how often did members of your household not fill a prescription or took less than the full dose of a prescribed medicine in order to pay the utility bill?

(1) Every month

(2) Every other month

(3) Every few months

(4) Every six months

(5) Once in twelve months

(6) Never

(7) Don't Know/Not Sure

(8) Refused

111. Over the past 12 months, how frequently has your household not paid energy bills in order to purchase prescription medicines?

(1) Every month

(2) Every other month

(3) Every few months

(4) Every six months

(5) Once in twelve months

(6) Never

(7) Don't Know/Not Sure

(8) Refused

112. Was there a time in the past 12 months when you needed to see a doctor but could not because of cost?

(1) Yes

(2) No

(3) Don't Know/Not Sure

(4) Refused

113. During the past 12 months, have you or other adults in your household had any problems paying medical bills?

(1) Yes

(2) No

(3) Don't Know/Not Sure

(4) Refused

\{Note: Ask these questions of the adult in the household most involved with all the other members of the household because proxy responses are required.\}

114. Including yourself, how many people normally live in this household? Do not include anyone who is just visiting, those away in the military, or children who are away at college.

Enter Number 
115. Can you please tell me their first names, gender and age, and your relationship to the person?

\section{First Name Gender Age Relationship In $\operatorname{school}(\mathbf{Y} / \mathbf{N})$}

Person 1.

Person 2.

Person 3.

Person 4.

Person 5.

Person 6.

Person 7.

Person 8.

Person 9.

Person 10.

116. On a typical week day is there someone at home most or all of the day?
(1) Yes
(2) No
(3) Don't Know/Not Sure
(4) Refused

For this section, I will be asking health related questions.

117. Now thinking about physical health, which includes physical illness and injury, for how many days during the past 30 days was your physical health not good?
(1) Number of days
(2) None
(3) Don't know / Not sure
(4) Refused

118. Now thinking about your mental health, which includes stress, depression, and problems with emotions, for how many days during the past 30 days was your mental health not good?

(1) Number of days

(2) None

(3) Don't know / Not sure

(4) Refused

119. During the past 30 days, for about how many days have you felt you did not get enough rest or sleep?

(1) Number of days

(2) None

(3) Don't know / Not sure

(4) Refused

120. During the past 30 days, for about how many days have you felt very healthy and full of energy?

(1) Number of days

(2) None

(3) Don't know / Not sure

(4) Refused 
121. During the past 30 days, for about how many days did poor physical or mental health keep you from doing your usual activities, such as self-care, work, or recreation?

(1) Number of days

(2) None

(3) Don't know / Not sure

(4) Refused

Next, I am going to ask you whether you have had some particular health problems in the last 3 months. In the past 3 months, have you had . . .

122. Shortness of breath when lying down, waking up, or with light work or light exercise?

(1) Yes

(2) No

(3) Don't know/Not Sure

(4) Refused

123. Headaches that are either new or more frequent or severe than ones you have had before?

(1) Yes

(2) No

(3) Don't know

(4) Refused

In the past 12 months were you or anyone else in the household ever told by a doctor or health professional that you or they have... (Check all that apply)

124. Lead poisoning

(1) Yes

(2) No

(3) Don't Know/Not Sure

(4) Refused

\{IF YES \}Please list all individuals, including yourself: 
125. Three or more ear infections per year
(1) Yes
(2) No
(3) Don't Know/Not Sure
(4) Refused

\{IF YES $\}$ Please list all individuals, including yourself:

126. Any kind of respiratory allergy
(1) Yes
(2) No
(3) Don't Know/Not Sure
(4) Refused

$\{$ IF YES $\}$ Please list all individuals, including yourself:

127. Flu
(1) Yes
(2) No
(3) Don't Know/Not Sure
(4) Refused

\{IF YES \} Please list all individuals, including yourself:

128. Persistent Cold symptoms lasting more than 14 days (SYMPTOMS INCLUDE COUGHING, SORE THROAT, SNEEZING, SINUS PAIN, CONGESTION, FEVER, FATIGUE, AND HEADACHE)
(1) Yes
(2) No
(3) Don't Know/Not Sure
(4) Refused

$\{$ IF YES $\}$ Please list all individuals, including yourself: 
129. Sinus infection or Sinusitis
(1) Yes
(2) No
(3) Don't Know/Not Sure
(4) Refused

\{IF YES $\}$ Please list all individuals, including yourself:

130. Bronchitis
(1) Yes
(2) No
(3) Don't Know/Not Sure
(4) Refused

\{IF YES $\}$ Please list all individuals, including yourself:

131. Have you ever been told by a doctor or other health professional that you have asthma?
(1) Yes
(2) No (SKIP to Q132)
(3) Don't Know/not sure
(4) Refused

131a. Do you still have asthma?
(1) Yes
(2) No
(3) Don't Know/Not sure
(4) Refused

131b. During the past 12 months, how many times did you see a doctor or health professional for a routine checkup for your asthma?

READ: Symptoms of asthma include coughing, wheezing, shortness of breath, chest tightness or phlegm production when you have a cold or respiratory infection. 
131c. How long has it been since you last had any symptoms of asthma?

(1) Never

(2) Less than one day ago

(3) 1-6 Days ago

(4) 1 week to less than 3 months ago

(5) 3 months to less than 1 year ago

(6) 1 year to less than 3 years ago

(7) 3 years to 5 years ago

(8) More than 5 years ago

(9) Don't Know/Not sure

(10) Refused

131d. During the past 12 months did you have to stay overnight in the hospital because of asthma?

(1) Yes

(2) No

(3) Don’t know/Not Sure

(4) Refused

131e. Not counting hospitalizations, during the past 12 months, did you go to an emergency room because of asthma?
(1) Yes
(2) No
(3) Don't know/Not Sure
(4) Refused

These next questions are about cigarette smoking.

132. Which one of the following statements best describes the rules about smoking in your home...

(1) No one is allowed to smoke anywhere inside your home

(2) Smoking is allowed at some places or at sometimes

(3) Smoking is permitted anywhere

(4) Don't know/Not sure

(5) Refused

133. Have you smoked at least 100 cigarettes in your entire life?

(1) Yes

(2) No

(3) Don't know/Not sure

(4) Refused

134. Do you now smoke cigarettes every day, some days or not at all?

(1) Everyday

(2) Some days

(3) Not at all

(4) Don't Know/Not sure

(5) Refused 
135. In the past 12 months has anyone in the household been food poisoned from eating food inside your home and therefore went to see a medical professional?

(1) Yes

(2) No

(3) Don't Know/Not sure

(4) Refused

136. In the past 12 months, has anyone in the household been poisoned by breathing in carbon monoxide, and therefore went to see a medical professional?
(1) Yes
(2) No
(3) Don't Know/Not sure
(4) Refused

137. In the past 12 months, has anyone in the home been burned from scalding hot water coming out of a faucet or showerhead in your home?
(1) Yes
(2) No (SKIP to Q138)
(3) Don't Know/Not Sure
(4) Refused

137a. \{IF YES BURN\}Did you talk to or see a medical professional about this injury?
(1) Yes
(2) No
(3) Don't Know/Not Sure
(4) Refused

138. I am going to read some statements about health and medical care.

Usually, you go to the doctor as soon as you start to feel bad. Is that:

(1) definitely true,

(2) mostly true,

(3) mostly false, or

(4) definitely false?

(5) Don't Know/Not Sure

(6) Refused

139. You will do just about anything to avoid going to the doctor. Is that ...

(1) definitely true,

(2) mostly true,

(3) mostly false, or

(4) definitely false?

(5) Don't Know/Not Sure

(6) Refused 
In this last section I will be asking employment and school related questions.

140. Are you or primary wage earner in the household currently...?

(1) Employed for wages

(2) Self-employed

(3) Out of work for more than 1 year (SKIP to Q140c)

(4) Out of work for less than 1 year (SKIP to Q140c)

(5) A Homemaker (SKIP to Q141)

(6) A Student

(7) Retired (SKIP to Q141)

(8) Unable to work (SKIP to Q141)

(9) Refused

140a. Are you or the primary wage earner in the household employed full-time or part-time?

(1) Full-time

(2) Part-time

(3) Don't Know/Not Sure

(4) Refused

140b. How many hours per week do you or the primary wage earner usually work at all of your jobs?

Enter hrs

140c. \{IF ANSWERED (3) or (4) to Q140\} Have you/Has the primary wage earner looked for work during the last 4 weeks?
(1) Yes
(2) No
(3) Don't Know/Not Sure
(4) Refused

140d. \{IF ANSWERED (3) or (4) to Q140\} What is the main reason you were/the primary wage earner was not looking for work during the LAST 4 WEEKS? CHECK ALL THAT APPLY (DO NOT READ LIST)

(1) Believes no work available in line of work or area

(2) Couldn't find any work

(3) Lacks necessary schooling, training, skills or experience

(4) Employers think too young or too old

(5) Other types of discrimination

(6) Can't arrange child care

(7) Family responsibilities

(8) In school or other training

(9) Ill health, physical disability

(10) Transportation problems

(11) Other

(12) Don't Know/Not Sure

(13) Refused 
141. Does a physical, mental or emotional problem NOW keep you or the primary wage earner from working at a job or business?
(1) Yes
(2) No
(3) Don't know/Not Sure
(4) Refused

142. In the past 12 months did anyone in the household receive income from any of the following sources? (Check all that apply)

(1) Supplemental Security Income (SSI)

(2) Welfare payments or case assistance

(3) Veteran's payments (VA Benefits)

(4) Unemployment Compensation

(5) Don't Know/Not Sure

(6) Refused

143. During the past 12 months have you or the primary wage earner had more than one job (or business), including part time, evening, or weekend work?

(1) Yes

(2) No

(3) Don't Know/Not Sure

(4) Refused

144. \{IF ANSWERED (1), (2), (4), or (6) to Q140\}Thinking about the last 12 months, is your or the primary wage earner's main job, where you work(ed) the most amount of hours, considered seasonal?

(1) Yes

(2) No (SKIP to Q145)

(3) Don't Know/Not Sure

(4) Refused

144a. In what season do you/does the primary wage earner work the least amount of hours?

(1) Winter

(2) Spring

(3) Summer

(4) Fall

145. \{IF ASWERED (1) or (2) TO Q 140 \}In the past 12 months, about how many days of work did you or the primary wage earer miss work at a job or business because of illness or injury (DO NOT INCLUDE MATERITY LEAVE\}.

Enter Number

(1) None

(2) Don't Know/Not Sure

(3) Refused 
146. \{IF ASWERED (1) or (2) TO Q 140 \}In the past 12 months, about how many days of work did you or the primary wage earner miss because of illness or injury of another household member?

Enter Number
(1) None
(2) Don't Know/Not Sure
(3) Refused

147. In the past 12 months, about how many days of school have you, the primary wage earner, and/or those in the household enrolled in school, missed because of illness or injury? \{IF PRE-SCHOOLER IN HOME\}Please tell us about the preschooler who has missed the most number of days. \{IF SCHOOL AGED CHILD IN HOME ? Please tell us about the school aged child who has missed the most number of days.

Enter Number:

Main Respondent
(1) Not in School
(2) Don't Know/Not Sure
(3) Refused days

Primary Wage Earner

(1) Not in School

(2) Don't Know/Not Sure

(3) Refused

Pres-School Child who has missed the most amount of school days
(1) None
(2) Don't Know/Not sure
(3) Refused

School Aged child who has missed the most amount of school
(1) None
(2) Don't Know/Not sure
(3) Refused

148. \{IF STUDENT $\}$ In the past 12 months, how frequently did you find it hard to study in your home because of excessive heat or cold?
(1) Very frequently
(2) Frequently
(3) Not frequently or infrequently
(4) Infrequently
(5) Very infrequently
(6) Never
(7) Does not study at home
(8) Don't Know/Not sure
(9) Refused 
149. \{IF SCHOOL AGED CHILDREN IN THE HOME \} In the past 12 months, how frequently does any school aged child in the home find it hard to study because of excessive heat or cold?

(1) Very frequently

(2) Frequently

(3) Not frequently or infrequently

(4) Infrequently

(5) Very infrequently

(6) Never

(7) Does not study at home

(8) Don't Know/Not sure

(9) Refused

That is the end of the survey. Thank you for your participation! You will receive your \$25 gift card in the mail to compensate you for your time. Could you please verify your mailing address:

Address:

\{INTERVIEWER: ADMINISTER AS A SEPARATE SURVEY POST-WEATHERIZATION\}

\section{PART II. Client Satisfaction}

\{Note: Ask these questions of the adult in the household most involved with the weatherization of the home or the head of the household

Approximate Date of Weatherization Job:

1. How long have you known about your local weatherization program? ENTER THE RESPONSE IN YEARS

2. How did you find out about your local weatherization program? CHECK ALL THAT APPLY

(1) A call from the weatherization agency

(2) Information received in the mail from the weatherization agency

(3) Local newspaper

(4) Found the program on the Internet

(5) Relative or friend mentioned the weatherization program

(6) Neighbor who had their home weatherized

(7) Agency providing utility assistance such as LIHEAP

(8) Email from an organization with which you are a member

(9) Church

(10) Other (Specify

3. How long ago did you request that your home be weatherized? ENTER THE RESPONSE IN YEARS 
4. How satisfied are you with the length of time between your request to have your home weatherized and when it actually was weatherized?
(1) Very satisfied
(2) Satisfied
(3) Not satisfied or dissatisfied
(4) Dissatisfied

(5) Very dissatisfied

5. How easy was it to request that your house be weatherized?
(1) Very easy
(2) Easy
(3) Not easy or difficult
(4) Difficult
(5) Very difficult

6. How easy was it to schedule the initial audit of your home?
(1) Very easy
(2) Easy
(3) Not easy or difficult
(4) Difficult
(5) Very difficult

7. How timely were those who did the initial audit of your home?
(1) Early or On Time
(2) $<30$ Minutes Late
(3) 30-60 Minutes Late
(4) 1 to 3 Hours Late
(5)More than 4 Hours Late
(6) Did not show up on scheduled day

8. How courteous were those who did the initial audit of your home?
(1) Very Courteous
(2) Courteous
(3) Not Courteous or Rude
(4) Rude
(5) Very Rude

9. How easy was it to schedule the time for the weatherization crew to come to your home?
(1) Very easy
(2) Easy
(3) Not easy or difficult
(4) Difficult
(5) Very difficult

10. How timely was the weatherization crew?
(1) Early or On Time
(2) $<30$ Minutes Late
(3) 30-60 Minutes Late
(4) 1 to 3 Hours Late
(5)More than 4 Hours Late
(6) Did not show up on scheduled day 
11. How courteous was the weatherization crew?

(1) Very Courteous

(2) Courteous

(3) Not Courteous or Rude

(4) Rude

(5) Very Rude

12. How careful of your home and belongings was the weatherization crew?
(1) Very careful
(2) Careful
(3) Neither careful or careless
(4) Careless
(5) Very careless

13. Overall, how clean did the weatherization crew leave the inside of your home?
(1) Very clean
(2) Clean
(3) Neither clean nor dirty
(4) Dirty
(5) Very dirty

13a. Overall, how clean did the weatherization crew leave the outside of your home?
(1) Very clean
(2) Clean
(3) Neither clean nor dirty
(4) Dirty
(5) Very dirty

14. Overall, how satisfied are you with final condition the inside of your home was left in?
(1) Very satisfied
(2) Satisfied
(3) Not satisfied or dissatisfied
(4) Dissatisfied
(5) Very dissatisfied

14a. Overall, how satisfied are you with final condition the outside of your home was left in?

(1) Very satisfied

(2) Satisfied

(3) Not satisfied or dissatisfied

(4) Dissatisfied

(5) Very dissatisfied

15. How easy was it to schedule the final inspection of your home?
(1) Very easy
(2) Easy
(3) Not easy or difficult
(4) Difficult
(5) Very difficult
(6) Final inspection was not done (go to Q18) 
16. How timely were those who did the final inspection of your home?
(1) Early or On Time
(2) $<30$ Minutes Late
(3) 30-60 Minutes Late
(4) 1 to 3 Hours Late
(5)More than 4 Hours Late
(6) Did not show up on scheduled day

17. How courteous were those who did the final inspection of your home?
(1) Very Courteous
(2) Courteous
(3) Not Courteous or Rude
(4) Rude
(5) Very Rude

18. How satisfied are you with the work performed in your home?
(1) Very satisfied
(2) Satisfied
(3) Not satisfied or dissatisfied
(4) Dissatisfied
(5) Very dissatisfied

19. How satisfied are you with any new equipment installed in house?
(1) Very satisfied
(2) Satisfied
(3) Not satisfied or dissatisfied
(4) Dissatisfied
(5) Very dissatisfied

20. Do you feel that other things should have been installed in your home to help you save energy?

(1) Yes

(2) No (go to Q21)

20a. What other things?

21. How satisfied are you with the energy savings achieved after having your home weatherized?

(1) Very satisfied

(2) Satisfied

(3) Not satisfied or dissatisfied

(4) Dissatisfied

(5) Very dissatisfied

(6) Too soon to tell

(7) Don’t know

22. Did the weatherization agency staff check your home for major repairs (e.g., fixing roof)?

(1) Yes

(2) No (go to Q23)

22a. Were major repairs needed in your home?

(1) Yes

(2) No (go to Q23) 
22b. Were major repairs done to your home?
(1) Yes
(2) No
(3) Not yet but expecting repairs to be done

23. Did the weatherization staff ask you about the health of the member(s) of your household?

(1) Yes (go to Q24a)

(2) No

24. Without the weatherization staff asking, did you provide to them any information about the health of the member(s) of your household?
(1) Yes
(2) No (SKIP to Q25)

24a. Were any of the members of your household in need of care that they were not receiving at the time?
(1) Yes
(2) No (go to Q25)

24b. Did the weatherization staff help you to obtain the needed care?
(1) Yes
(2) No

25. Did your weatherization agency refer you to any other housing and/or social service programs?
(1) Yes
(2) No (go to Q26)

25a. What program or programs?

26. Did you file a complaint about the weatherization services provided?
(1) Yes
(2) No (go to Q27)

26a. What was the complaint about?

26b. How satisfied are you with the resolution of the situation you complained about?
(1) Very satisfied
(2) Satisfied
(3) Not satisfied or dissatisfied
(4) Dissatisfied
(5) Very dissatisfied

26c. How might the agency have done a better job of resolving your complaint?

27. Did you get any information on ways to save energy in your home from the people who weatherized your home?

(1) Yes

(2) No (go to Q33) 
28. How much time did the weatherization agency staff talk to you about ways to save energy?

(1) Less than 5 minutes

(2) 5 to 14 minutes

(3) 15 to 29 minutes

(4) 30 to 60 minutes

(5) More than one hour

29. How well did you understand what the weatherization agency staff said to you about saving energy?

(1) Very well (go to Q30)

(2) Well (go to Q30)

(3) Neither well or not well (go to Q30)

(4) Not well

(5) Not well at all

29a. Why did you not understand what the weatherization agency staff said?

CHECK ALL THAT APPLY

(1) The staff person did not speak my primary language

(2) The staff person was confusing

(3) The staff person did not speak well

(4) The staff person was hurried

(5) The staff person was boring

(6) I did not get along with the staff person

(7) Other

30. What materials about saving energy did the weatherization agency staff give you? (Check all that apply)

(1) One or more brochures, booklets, or manuals

(2) One or more compact discs (CDs), videos, or DVDs

(3) Hardware kit of weatherization materials

(4) No materials were provided (go to Q31)

(5) Weatherization staff spent time demonstrating how to save energy (go to Q31)

30a. How much time have you spent reading/reviewing the materials about saving energy that the weatherization agency staff gave you?

(1) No time (go to Q31)

(2) Less than 5 minutes

(3) 5 to 14 minutes

(4) 15 to 29 minutes

(5) 30 to 59 minutes

(6) More than one hour

30b. How well did you understand the energy savings materials that the weatherization agency staff gave you?

(1) Very well

(2)Well

(3)Neither well or not well

(4)Not well

(5)Not well at all 
30c. How useful have the energy savings materials been to you?

(1) Very useful

(2) Useful

(3) Neither useful or not useful

(4) Not useful

(5) Not very useful

30d. What about the materials were particularly useful?

30e. How could the materials have been improved for your use?

31. How satisfied are you with the ways that the weatherization agency provided you with information about saving energy?
(1) Very satisfied
(2) Satisfied
(3) Not satisfied or dissatisfied
(4) Dissatisfied
(5) Very dissatisfied

32. Did you get any information on ways to improve health and safety in your home from the people who weatherized your home?

(1) Yes

(2) No (go to Q38)

33. How much time did the weatherization agency staff talk to you about ways to improve health and safety?

(1) Less than 5 minutes

(2) 5 to 14 minutes

(3) 15 to 29 minutes

(4) 30 to 59 minutes

(5) More than one hour

34. How well did you understand what the weatherization agency staff said to you about improving health and safety?

(1) Very well (go to Q36)

(2) Well (go to Q36)

(3) Neither well or not well (go to Q36)

(4) Not well

(5) Not well at all

34a. Why did you not understand what the weatherization agency staff said? (Check all that apply)

(1) The staff person did not speak my primary language

(2) The staff person was confusing

(3) The staff person did not speak well

(4) The staff person was hurried

(5) The staff person was boring

(6) I did not get along with the staff person

(7) Other 
35. What materials about improving health and safety did the weatherization agency staff give you? (Check all that apply)

(1) One or more brochures, booklets and manuals

(2) One or more compact discs

(3) One or more videos (including DVD's)

(4) No materials were provided (go to Q36)

35a. How much time have you spent reading/reviewing the materials about improving health and safety that the weatherization agency staff gave you?
(1) No time (go to Q36)
(2) Less than 5 minutes
(3) 5 to 14 minutes
(4) 15 to 29 minutes
(5) 30 to 59 minutes
(6) More than one hour

35b. How well did you understand the improving health and safety materials that the weatherization agency staff gave you?
(1) Very well
(2) Well
(3)Neither well or not well
(4)Not well
(5)Not well at all

35c. How useful have the improving health and safety materials been to you?
(1) Very useful
(2) Useful
(3) Neither useful or not useful
(4) Not useful
(5) Not very useful

35d. What about the materials were particularly useful?

35e. How could the materials have been improved for your use?

36. How satisfied are you with the ways that the weatherization agency provided you with information about improving health and safety?
(1) Very satisfied
(2) Satisfied
(3) Not satisfied or dissatisfied
(4) Dissatisfied
(5) Very dissatisfied

37. How could the agency improve the ways that it provides households with information about improving health and safety?

38. What are some of the greatest benefits your household received by participating in the weatherization program?

39. What suggestions do you have for how the weatherization program can be improved? 
40. In the last 12 months, have you informed other people who might be interested in receiving weatherization services of the program?
(1) Yes
(2) No

41. Do you know if these people have had their homes weatherized or are scheduled to have their home weatherized, as a result of your suggestion?
(1) Yes
(2) No

42. Why did you apply for the Weatherization Assistance Program? ${ }^{37}$
(1) Reduce energy bills
(2) Support environmental efforts to conserve energy
(3) Make home more comfortable
(4) Receive free services
(5) Other
(6) Don't know

43. Prior to receiving weatherization services, in what ways did your household attempt to weatherize your home?

Please

Explain

44. Would you say your household is now less likely to move from your current home as a result of weatherization?

(1) Yes

(2) No

(3) Don't Know/Not Sure

(4) Refused

45. Please rate the chances of your household's moving during the next 12 months for any reason or combination of reasons:
(1) Very high
(2) High
(3) Medium
(4) Low
(5) Very low
(6) No chance

46. Were you asked about preexisting health conditions that you or your family members living in the home may have?
a. Yes
b. No

\footnotetext{
${ }^{37}$ Ohio REACH
} 
47. Did the crew take precautions so that those conditions were not made worse?
a. Yes
b. No
c. Don't Know
d. N/A

48. How do you feel as far as the health and safety of your home since weatherization was conducted?

a. Much better

b. Better

c. Neither better or worse

d. Worse

e. Much Worse

49. Finally, please rate your overall satisfaction with the weatherization program.

(1) Very satisfied

(2) Satisfied

(3) Not satisfied or dissatisfied

(4) Dissatisfied

(5) Very dissatisfied

\section{QUESTIONS TO BE ADDED TO CLIENT SATISFACTION PART}

Financial Programs - Household Participants

1. Do you understand the terms of the loan/on-bill payment agreement?

a. Yes

b. No

If not, what do you not understand? Please explain

2. Have you noticed a change in your utility bills since your home was weatherized?

a. Yes, bills have gone down substantially

b. Yes, bills have gone down somewhat

c. No, no change

d. Yes, bills have gone up somewhat

e. Yes, bills have gone up substantially

f. Don't know

3. Have you been able to afford the loan/ on-bill payments?

a. No

b. Yes, but just barely

c. Yes

4. In retrospect, would you make the same decision to participate in this loan/on-bill payment program?

a. Yes

b. No

If No, please explain 
5. How did you hear about this program?

a. Advertisement

b. Directly contacted by program

c. From relatives/friends

d. Browsing the Internet

e. Other

Financial Programs --Multi-family renting residents

1. Do you know that your building owner is participating in a program that subsidizes weatherization of your building?

a. No

b. Yes

2. Did the owner consult with you and other tenants about the program before signing up for it?

a. No

b. Yes

3. Did your building association consult with you about the program?

a. No

b. Yes

c. N/A, there is no building association

4. Has your rent increased since XXXX?

a. Yes, rent has gone down substantially

b. Yes, rent has gone down somewhat

c. No, no change

d. Yes, rent has gone up somewhat

e. Yes, rent has gone up substantially

f. Don't know

5. Have your utility bills changed since XXXX?

a. Yes, bills have gone down substantially

b. Yes, bills have gone down somewhat

c. No, no change

d. Yes, bills have gone up somewhat

e. Yes, bills have gone up substantially

f. Don't know

g. I do not pay utility bills 
6. Over the past XXXX months, please rate the changes in the following in your building and/or your unit:

\begin{tabular}{|l|l|l|l|l|l|l|}
\hline & Much Better & Better & No Change & Worse & Much Worse & $\begin{array}{l}\text { Not } \\
\text { Applicable }\end{array}$ \\
\hline Hallway lighting & & & & & & \\
\hline Stairway lighting & & & & & & \\
\hline $\begin{array}{l}\text { Entrance lighting } \\
\text { unit in winter }\end{array}$ & & & & & & $\begin{array}{l}\text { (If survey is } \\
\text { administered } \\
\text { prior to their } \\
\text { experiencing } \\
\text { a winter since } \\
\text { the retrofit) }\end{array}$ \\
\hline $\begin{array}{l}\text { Comfort of your } \\
\text { unit in the } \\
\text { summer }\end{array}$ & & & & & & $\begin{array}{l}\text { Same as } \\
\text { above. }\end{array}$ \\
\hline
\end{tabular}

7. Have you received any education about how to reduce energy consumption in your unit during the past 12 months?
a. No
b. Yes

To those who received new technology (active):

Are you aware that you received ???? in conjunction with the Weatherization Program you applied for?
a. Yes
b. No

Did you receive ???? at the same time as the organization weatherized your home?
a. Yes
b. No
c. Don't Know

Did the agency mention anything different about ???? as compared to the other improvements they made in your home?
a. Yes
b. No

1. Do you understand how ???? works?

a. No

b. Yes

2. Did you receive any education and/or training about how to operate ?????
a. No
b. Yes
c. N/A 
3. Did you receive any education and/or training about how to maintain ????
a. No
b. Yes
c. N/A

4. Does ???? seem to work?

a. Yes (go Q7)

b. No

c. Don't Know

5. In your opinion, did ???? ever work?

a. No (go to Q7)

b. Yes

6. How long ago do you think that ???? stopped working?

a. 1-2 months

b. 2-4 months

c. 5-6 months

d. 7-8 months

e. more than 8 months ago

7. Have your utility bills changed since ???? was installed?

a. Yes, bills have gone down substantially

b. Yes, bills have gone down somewhat

c. No, no change

d. Yes, bills have gone up somewhat

e. Yes, bills have gone up substantially

f. Don't know

8. Have you experienced any other benefits to yourself or your household since ???? was installed?

a. No

b. Yes

If yes, please explain

9. Do you have any worries about ????

a. No

b. Yes

If yes, please explain

10. Are you glad, in retrospect, to have ????? installed?

a. No

b. Yes

11. Have any of your friends and/or relatives asked you about your new ?????

a. No

b. Yes

12. If so, does it seem as though they would also be interested in having ???? installed in their homes?

a. Yes, most are interested

b. Yes, some are interested

c. No, none seem interested 
In-home monitors in addition

1. Do you understand the information that the in-home monitor provides to you?

a. Yes

b. No

If no, please explain

2. How often do you read the information in the in-home monitor?

a. Several times a day

b. About once a day

c. Once every few days

d. Once a week

e. Once every couple of weeks

f. Once a month

g. Fewer than once a month

h. Never

3. How easy is the in-home monitor to read?

a. Very easy

b. Easy

c. Neither easy or hard

d. Hard

e. Very hard

4. Did you receive education about how to read the in-home monitor?

a. No

b. Yes

5. From your perspective, how could the in-home monitor be improved?

6. Has the in-home monitor influenced how your household uses energy?

a. No

b. Yes

If yes, please explain

7. Do you change thermostat settings in the winter based on information from the in-home monitor?

a. No

b. Sometimes

c. Frequently

8. Do you change thermostat settings in the summer based on information from the in-home monitor?

a. No

b. Sometimes

c. Frequently 
Financial Programs - Household Participants

1. How did you hear about this program?

a. Local weatherization agency

b. From relatives or friends

c. Advertisement on TV, radio or in newspaper

d. Other

e. Don't know

2. Have you noticed a change in your utility bills since your home was weatherized?

a. Yes, bills have gone down substantially

b. Yes, bills have gone down somewhat

c. No, no change

d. Yes, bills have gone up somewhat

e. Yes, bills have gone up substantially

f. Don't know

3. Have you been able to afford the loan/ on-bill payments?

a. No

b. Yes, but just barely

c. Yes

4. Do you understand the terms of the loan/on-bill payment agreement?

a. Yes

b. No

If not, what do you not understand? Please explain

5. In retrospect, would you make the same decision to participate in this loan/on-bill payment program?

a. Yes

b. No

If No, please explain

Financial Programs --Multi-family renting residents

1. Do you know that your building owner is participating in a program that subsidizes weatherization of your building?

a. No

b. Yes

2. Did the owner consult with you and other tenants about the program before signing up for it?

a. No

b. Yes

3. Did your building association consult with you about the program?

a. No

b. Yes

c. N/A, there is no building association 
4. Has your rent increased since XXXX?

a. Yes, rent has gone down substantially

b. Yes, rent has gone down somewhat

c. No, no change

d. Yes, rent has gone up somewhat

e. Yes, rent has gone up substantially

f. Don't know

5. Have your utility bills changed since XXXX?

a. Yes, bills have gone down substantially

b. Yes, bills have gone down somewhat

c. No, no change

d. Yes, bills have gone up somewhat

e. Yes, bills have gone up substantially

f. Don't know

g. I do not pay utility bills

6. Over the past XXXX months, please rate the changes in the following in your building and/or your unit:

\begin{tabular}{|l|l|l|l|l|l|l|}
\hline & Much Better & Better & No Change & Worse & Much Worse & $\begin{array}{l}\text { Not } \\
\text { Applicable }\end{array}$ \\
\hline Hallway lighting & & & & & & \\
\hline Stairway lighting & & & & & & \\
\hline $\begin{array}{l}\text { Entrance lighting } \\
\text { unit in winter }\end{array}$ & & & & & $\begin{array}{l}\text { (If survey is } \\
\text { administered } \\
\text { prior to their } \\
\text { experiencing a } \\
\text { winter since } \\
\text { the retrofit) }\end{array}$ \\
\hline $\begin{array}{l}\text { Comfort of your } \\
\text { unit in the } \\
\text { summer }\end{array}$ & & & & & & $\begin{array}{l}\text { Same as } \\
\text { above. }\end{array}$ \\
\hline
\end{tabular}

7. Have you received any education about how to reduce energy consumption in your unit during the past 12 months?

a. No

b. Yes 
To those who received new technology (active):

1. Are you aware that you received ???? in conjunction with the Weatherization Program you applied for?

c. Yes

d. No

2. Did you receive ???? at the same time as the organization weatherized your home?
d. Yes
e. No
f. Don't Know

3. Did the agency mention anything different about ???? as compared to the other improvements they made in your home?
c. Yes
d. No

4. Do you understand how ???? works?

a. No

b. Yes

5. Did you receive any education and/or training about how to operate ?????

a. No

b. Yes

c. N/A

6. Did you receive any education and/or training about how to maintain ????

a. No

b. Yes

c. N/A

7. Does ???? seem to work?

a. Yes (go Q7)

b. No

c. Don't Know

8. In your opinion, did ???? ever work?

a. No (go to Q7)

b. Yes

9. How long ago do you think that ???? stopped working?

a. 1-2 months

b. 2-4 months

c. 5-6 months

d. 7-8 months

e. more than 8 months ago 
10. Have your utility bills changed since ???? was installed?

a. Yes, bills have gone down substantially

b. Yes, bills have gone down somewhat

c. No, no change

d. Yes, bills have gone up somewhat

e. Yes, bills have gone up substantially

f. Don't know

11. Have you experienced any other benefits to yourself or your household since ???? was installed?

a. No

b. Yes

If yes, please explain

12. Do you have any worries about ????

a. No

b. Yes

If yes, please explain

13. Are you glad, in retrospect, to have ????? installed?

a. No

b. Yes

14. Have any of your friends and/or relatives asked you about your new ?????

a. No

b. Yes

15. If so, does it seem as though they would also be interested in having ???? installed in their homes?

a. Yes, most are interested

b. Yes, some are interested

c. No, none seem interested

In-home monitors installed in homes

1. Do you understand the information that the in-home monitor provides to you?

a. Yes

b. No

If no, please explain

2. How often do you read the information in the in-home monitor?

a. Several times a day

b. About once a day

c. Once every few days

d. Once a week

e. Once every couple of weeks

f. Once a month

g. Fewer than once a month

h. Never 
3. How easy is the in-home monitor to read?

a. Very easy

b. Easy

c. Neither easy or hard

d. Hard

e. Very hard

4. Did you receive education about how to read the in-home monitor?

a. No

b. Yes

5. From your perspective, how could the in-home monitor be improved?

6. Has the in-home monitor influenced how your household uses energy?

a. No

b. Yes

If yes, please explain

7. Do you change thermostat settings in the winter based on information from the in-home monitor?

a. No

b. Sometimes

c. Frequently

8. Do you change thermostat settings in the summer based on information from the in-home monitor?

a. No

b. Sometimes

c. Frequently

That is the end of the survey. Thank you for your participation! You will receive your $\$ 10$ gift card in the mail to compensate you for your time. Could you please verify your mailing address:

Address: 
OMB Control Number: 1910-5151

\section{APPENDIX L - DF9 OCCUPANT SURVEY INFORMATION DATA FORM}

\section{DF9: Contact Information from Agencies for Occupant Survey}

This information is being collected to choose a sample of homes that are expected to receive weatherization in order to administer a survey to the occupants. The information will be used to build a sampling frame to use to randomly select homes for this survey.

Public reporting burden for this collection of information is estimated to average one hour per response, including the time for reviewing instructions, searching existing data sources, gathering and maintaining the data needed, and completing and reviewing the collection of information. Send comments regarding this burden estimate or any other aspect of this collection of information, including suggestions for reducing this burden, to Office of the Chief Information Officer, Records Management Division, IM-11, Paperwork Reduction Project (1910-5151), U.S. Department of Energy, 1000 Independence Ave SW, Washington, DC, 20585-1290; and to the Office of Management and Budget (OMB), OIRA, Paperwork Reduction Project (1910-5151), Washington, DC 20503.

Introduction: As part of the national evaluation of the Weatherization Assistance Program, occupants of housing units weatherized in Program Year 2010 will be surveyed before and after weatherization to obtain information on their health and demographics, determine their energy consumption behavior and knowledge, evaluate non-energy benefits, and establish their satisfaction with the Program. In addition, occupants of households that have received (or will receive) assistance from the Low-Income Home Energy Assistance Program (LIHEAP) but whose houses have not been (or will not be) weatherized will be surveyed to serve as a control group for the occupant survey.

We would like to survey several such occupants served by your agency. In order for us to randomly select several weatherized households, please provide us with the names and contact information for clients currently in the queue (i.e., in line) for receiving audits using the first attached form. Similarly, please use the second attached form to provide us with the names and contact information for clients your agency has provided, or will provide, LIHEAP assistance in Program Year 2010 so we can select several control households (provide a maximum of 20 names). [NOTE: If weatherization services and LIHEAP assistance are provided by two separate organizations, then similar instructions and forms will be used that only request information on weatherization clients or LIHEAP recipients.]

The information that you provide and that we obtain from the occupants will be protected and will remain confidential. When results of the survey are reported, information collected from the occupants will not be associated with their names in any way. In order to maintain the integrity of the survey, we will not be able to tell you which clients have been selected for the survey. We will be paying the occupants a small incentive to participate in the survey, so an undo burden will not be placed on your clients. 


\section{Clients in Queue for Audits}

Agency name:

State:

Date:

Please provide the following information for clients currently in the queue to receive audits by your agency.

\begin{tabular}{|c|c|c|c|c|c|c|c|}
\hline & Name & Address & City & State & Zip Code & $\begin{array}{c}\text { Phone } \\
\text { Number }\end{array}$ & $\begin{array}{c}\text { Expected } \\
\text { Audit } \\
\text { Date }\end{array}$ \\
\hline 1. & & & & & & & \\
\hline 2. & & & & & & & \\
\hline 3. & & & & & & & \\
\hline 4. & & & & & & & \\
\hline 5. & & & & & & & \\
\hline 6. & & & & & & & \\
\hline 7. & & & & & & & \\
\hline 8. & & & & & & & \\
\hline 9. & & & & & & & \\
\hline 10. & & & & & & & \\
\hline 11. & & & & & & & \\
\hline 12. & & & & & & & \\
\hline 13. & & & & & & & \\
\hline 14. & & & & & & & \\
\hline 15. & & & & & & & \\
\hline 16. & & & & & & & \\
\hline 17. & & & & & & & \\
\hline 18. & & & & & & & \\
\hline 19. & & & & & & & \\
\hline 20. & & & & & & & \\
\hline
\end{tabular}


OMB Control Number:

\section{S4 - OCCUPANT SURVEY: MULTI-FAMILY UNIT VERSION}

This data is being collected to conduct a survey of occupants about their experiences with the Weatherization Assistance Program and benefits they believe they have received from the program. The data you supply will be used to describe occupant satisfaction with the program as well as changes in energy education and non-energy benefits provided by the program.

Public reporting burden for this collection of information is estimated to average minutes per response, including the time for reviewing instructions, searching existing data sources, gathering and maintaining the data needed, and completing and reviewing the collection of information. Send comments regarding this burden estimate or any other aspect of this collection of information, including suggestions for reducing this burden, to Office of the Chief Information Officer, Records Management Division, IM-11, Paperwork Reduction Project (XXXX-XXXX), U.S. Department of Energy, 1000 Independence Ave SW, Washington, DC, 20585-1290; and to the Office of Management and Budget (OMB), OIRA, Paperwork Reduction Project (XXXX-XXXX), Washington, DC 20503.

Lastly, all of the information obtained from this survey will be protected and will remain confidential. The data will be analyzed in such a way that the information provided cannot be associated back to you or your household. Your answers will not be shared with or reported back to anyone within the agency that served you or your state.

\section{POST-WEATHERIZATION SURVEY}

\{INTERVIEWER: VERIFY RESPONDENT IS THE TENANT ON THE APARTMENT

LEASE B Before we begin, I need to verify that this is one of the people on the apartment lease. Is this your apartment?

PLEASE RECORD RESPONDENT'S NAME, GENDER and AGE

Name Gender Age

Main Respondent:

1. How long have you lived in your current apartment?

\{If less than one year\} Enter: months

Enter: years

1a. \{IF RESPONDENT HAS LIVED IN THE APARTMENT < ONE YEAR \} Has ANY OTHER ADULT living in the household lived in the apartment for more than one year? 
(3) Yes

(4) No

$\{$ IF YES $\}$ Name

\{IF RESPONDENT DID NOT LIVE IN THE APARTMENT PRIOR TO WEATHEIZATION: STOP SURVEY. IF OTHER ADULT LIVED IN THE APARTMENT PRIOR TO WEATHERIZATION: REQUEST TO INTEVIEW THAT INDIVIDUAL OR CALL BACK IF NOT AVAILABLE\}

1b. Did you know that your building owner participated in a program that subsidized the weatherization of your building?

(1) Yes

(2) No

(3) Don't know/Not Sure

$\{$ IF NOT SURE, IF LIVED IN BUILDING FOR N MONTHS INFORM THEM THAT THE WORK COMPLETED ON THE BUIDLING WAS PART OF A WEATHERIZATION PROGRAM AND THAT YOU WILL BE REFERRING TO THIS WORK AS WEATHERIZATION THROUGHOUT THE SURVEY.\}

\section{PART I. Energy Consumption, Non-Energy Impacts, Health and Demographics}

In this next section, I will be asking you about your apartment and your use of energy.

2. How many bedrooms do you have in your apartment? [Include bedrooms in finished attics or finished basements.]

3. How many bathrooms do you have in your apartment?

4. Now think about other rooms in your apartment besides bedrooms and bathrooms. Not including unfinished areas, hallways, and closets, how many other rooms are there in your apartment?

Number of Rooms

I have some questions about heating your apartment.

5. Before the weatherization of the building, did you use any of the following types of heating equipment in your apartment?

CHECK ALL THAT APPLY

(13) Portable heaters

(14) Fireplace

(15) Cooking stove used to heat your apartment as well as to cook

(16) Some other equipment (Specify

(17) No other equipment

6. During the past N months (SINCE WEATHEIZATION WORK WAS COMPLETED), have you used any of the following types of heating equipment in your apartment in the winter? 


\section{CHECK ALL THAT APPLY}

(1) Portable heaters

(2) Fireplace

(3) Cooking stove used to heat your apartment as well as to cook

(4) Some other equipment (Specify

(5) No other equipment

7. What fuel does your cooking stove and/or oven use? CHECK ALL THAT APPLY

(9) Electricity

(10) Natural gas from underground pipes

(11) Propane (bottled gas)

(12) Fuel oil

(13) Kerosene

(14) Wood

(15) Some other fuel (Specify

(16) No working stove or oven in the apartment

8. Which of the categories shown best describes how often the most used oven is used?

(1) Three or more times a day

(2) Two times a day

(3) Once a day

(4) A few times each week

(5) About once a week

(6) Less than once a week

(7) Not used (if volunteered)

9. During the past $\mathrm{N}$ months, how many times has the fire department been called to put out a fire in your apartment?

10. During the past $\mathrm{N}$ months, has any fire start in your apartment as a result of using an alternate heating source, such as space heaters, electric blankets, your kitchen stove or oven, or your fireplace?

(5) Yes

(6) No

(7) Don’t Know/Not Sure

(8) Refused

Now I have some questions about cooling your apartment.

(IF NO TO AIR CONDITIONING EQUIPMENT SKIP TO CEILING FAN USE Q15)

11. Is any air conditioning equipment used in your apartment?

(9) Yes (SKIP to Q13)

(10) No

(11) Don't Know/Not Sure

(12) Refused 
12. (IF NO) Just to clarify, do you have air conditioning equipment but don't use it, or does your apartment just not have any air conditioning equipment?

(5) Have equipment, but don't use it (SKIP to Q 20)

(6) Don't have any air conditioning equipment

(7) Don't Know/Not Sure

(8) Refused

13. Which of the statements shown best describes the way your central air conditioning system was used last summer?

(5) Not used at all (if volunteered)

(6) Turned on only a few days or nights when really needed

(7) Turned on quite a bit

(8) Turned on just about all summer

14. Which of the following statements best describes the way your household used the most used window/wall air conditioning unit last summer?

(5) Turned on only a few days or nights when really needed

(6) Turned on quite a bit

(7) Turned on just about all summer

(8) No working window/wall units in apartment

15. How many ceiling fans does your apartment have?

Enter Number

(4) None (SKIP to Q 29)

(5) Don't Know/Not Sure

(6) Refused

16. How many ceiling fans does your household use?

Enter Number of ceiling fans

(4) None (SKIP to 50)

(5) Don't Know/Not Sure

(6) Refused

27. Thinking about the ceiling fan that you use the most, how often was this fan used last summer? Is it ...

(7) Used only a few days or nights, when it's really needed,

(8) Used quite a bit, or

(9) Used just about all summer?

(10) Not used at all

(11) Don't Know/Not Sure

(12) Refused

28. Thinking about the ceiling fan that you use the most, how often was this fan used last winter? Is it ...

(7) Used only a few days or nights,

(8) Used quite a bit, or

(9) Used just about all winter? 
(10) Not used at all

(11) Don't Know/Not Sure

(12) Refused

29. How often are your windows open in the summer?
(1) Never
(2) Rarely
(3) Sometimes
(4) Frequently
(5) All the time
(6) Don't Know/Not Sure
(7) Refused

29. How often are your windows open in the winter?
(1) Never
(2) Rarely
(3) Sometimes
(4) Frequently
(5) All the time
(6) Don't Know/Not Sure
(7) Refused

30. Do any large trees shade your apartment from the afternoon summer sun?
(5) Yes
(6) No
(7) Don't Know/Not Sure
(8) Refused

31. Do you close the drapes, curtains, shades, and/or blinds during the day to block out the sun during the summer?
(1) Never
(2) Rarely
(3) Sometimes
(4) Frequently
(5) All the time
(6) Don't Know/Not Sure
(7) Refused

INTERVIEWER INSTRUCTION: RECORD ANY INFORMATION HERE ABOUT THE AIRCONDITIONING EQUIPMENT IN THIS HOUSING UNIT AND ITS' USAGE THAT MIGHT PROVIDE CLARIFICATION TO THE RESPONDENT'S ANSWERS.

Now I have some questions on the indoor air temperature of your apartment. 
32. Does your apartment have a thermostat that controls the heating and/or cooling in your apartment?

(5) Yes

(6) No (SKIP to Q 33)

(7) Don't Know

(8) Refused

32a. What equipment does your thermostat control?

(1) Heating only

(2) Cooling only

(3) Heating and cooling

(4) Don't know

32b. Some thermostats can be programmed so that the temperature changes automatically at different times of the day; for example, the heat can be automatically turned down or lowered at night when you go to bed, then automatically adjusted up again in the morning. Is the thermostat that controls your main [heating and/or cooling] equipment programmable?

(5) Yes

(6) No (SKIP to Q32d)

(7) Don't know/Not Sure

(8) Refused

32c. Do you or someone else in your household know how to use the programmable thermostat?

(6) Yes

(7) $\mathrm{No}$

(8) No, someone who does not live in my apartment programs the thermostat for use

(9) Don't know/Not Sure

(10) Refused

32d. During the winter, what is the temperature when someone is inside your apartment during the day? [IF NO ANSWER, PROBE 1: THEN AT WHAT TEMPERATURE IS THE THERMOSTAT SET? PROBE 2: CAN I JUST HAVE YOUR BEST ESTIMATE?]

Enter degrees Fahrenheit

32e. During the winter, what is the temperature when no one is inside your apartment during the day? [IF NO ANSWER, PROBE 1: THEN AT WHAT TEMPERATURE IS THE

THERMOSTAT SET? PROBE 2: CAN I JUST HAVE YOUR BEST ESTIMATE?]

Enter degrees Fahrenheit

32f. During the winter, what is the temperature inside your apartment at night? [IF NO ANSWER, PROBE 1: THEN AT WHAT TEMPERATURE IS THE THERMOSTAT SET? PROBE 2: CAN I JUST HAVE YOUR BEST ESTIMATE?]

Enter degrees Fahrenheit 
Now I would like you to think about the temperature inside your apartment when using your central air conditioning equipment last summer. [If NUMTHERM>1: Earlier you reported having [FILL: NUMTHERM] thermostats. For the next questions, if the thermostats are set at different temperatures, only report for the thermostat that affects the rooms where most of the people are.]

32g. During the summer, what is the temperature when someone is inside your apartment during the day? IF NO ANSWER, PROBE 1: THEN AT WHAT TEMPERATURE IS THE THERMOSTAT SET? PROBE 2: WHAT'S YOUR BEST ESTIMATE?

Enter degrees Fahrenheit Air-conditioner Turned Off

32h. During the summer, what is the temperature when no one is inside your apartment during the day? IF NO ANSWER, PROBE 1: THEN AT WHAT TEMPERATURE IS THE THERMOSTAT SET? PROBE 2: WHAT'S YOUR BEST ESTIMATE?

Enter degrees Fahrenheit Air-conditioner Turned Off

32i. During the summer, what is the temperature inside your apartment at night? IF NO ANSWER, PROBE 1: THEN AT WHAT TEMPERATURE IS THE THERMOSTAT SET? PROBE 2: WHAT'S YOUR BEST ESTIMATE?

Enter degrees Fahrenheit Air-conditioner Turned Off

We're interested in knowing how tenants in apartment buildings control the temperature inside their apartments especially when they feel too hot or too cold. Remember, your answers are confidential and they will not be collected or reported in a way that ties them back to you.

33. During the past $\mathrm{N}$ months, has your thermostat kept your apartment at a comfortable temperature?

(5) Yes

(6) No

(7) Don't Know/Not Sure

(8) NA: No Thermostat

(9) Refused

33a. (IF NO) What have you done about it?

34. Before the building was weatherized, how would you describe the temperature in your apartment in the winter?

(8) Very cold

(9) Cold 
(10) Comfortable (SKIP)

(11) Hot

(12) Very hot

(13) Other

(14) Refused

35. During that time, other than adjustments to a thermostat, how did you control the indoor temperature of your apartment in the winter?

35a. Do you continue to do those things now that the weatherization work is complete?

(1) Yes

(2) No

(3) Don't Know/Not Sure

(4) Refused

36. Before the building was weatherized, how would you describe the temperature in your apartment in the summer?

(1) Very cold

(2) Cold

(3) Comfortable (SKIP)

(4) Hot

(5) Very hot

(6) Other

(7) Refused

37. During that time other than adjustments to a thermostat, how did you control the indoor temperature of your apartment in the summer?

37a. Do you continue to do those things now that the weatherization work is complete?

(1) Yes

(2) No

(3) Don't Know/Not Sure

(4) Refused

38. During the past $\mathrm{N}$ months, was your household unable to use any of the following equipment because it was broken?

CHECK ALL THAT APPLY

(6) Main Heating Equipment

(7) Central Air Conditioner

(8) Room Air Conditioner

(9) Don't Know/Not Sure

(10)

Refused

39. Thinking about the past $\mathrm{N}$ months, which of the following statements best describes the indoor temperature of your apartment during the winter: 
(1) Very cold

(2) Cold

(3) Comfortable

(4) Hot

(5) Very hot

(6) Other

(7) Refused

40. Thinking about the past $\mathrm{N}$ months, which of the following statements best describes the indoor temperature of your apartment during the summer:

(8) Very cold

(9) Cold

Comfortable (SKIP TO NEXT Q....)

(12)

Hot

(13)

Very hot

(14)

Other

Refused

41. During the past $\mathrm{N}$ months, has a landlord or superintendant controlled the temperature inside your apartment?
(1) Yes
(2) No
(3) Do not have landlord
(4) Don't Know/Not Sure
(5) Refused

42. During the past $\mathrm{N}$ months, how often was your apartment at a temperature that you felt was unsafe or unhealthy?

(7) Almost every month

(8) Some months

(9) 1 or 2 months

(10) Never

(11) Don't Know/Not Sure

(12) Refused

43. During the past $\mathrm{N}$ months, has anyone in the household needed medical attention because your apartment was too cold?

(5) Yes

(6) No

(7) Don't Know/Not Sure

(8) Refused

44. During the past $\mathrm{N}$ months, did anyone in your household need medical attention because your apartment was too hot?

(5) Yes

(6) No 
(7) Don't Know/Not Sure

(8) Refused

The next group of questions is about laundry appliances and water use in your apartment.

45. Is a clothes washing machine used in your apartment? Do not include community clothes washers that are located in the basement or laundry room of your apartment building.
(4) Yes
(5) No
(6) Refused

46. Do you use community clothes washers in the basement or laundry room of your apartment building?
(1) Yes
(2) No
(3) Refused

47. In an average week, how many loads of laundry are washed in your clothes washer?

(8) 1 load or less each week

(9) 2 to 4 loads each week

(10) 5 to 9 loads each week

(11) 10 to 15 loads each week

(12) More than 15 loads each week

(13) Don't Know/Not Sure

(14) Refused

48. What water temperature setting is usually used for the wash cycle of your clothes washer? Is it hot, warm, or cold water?
(6) Hot
(7) Warm
(8) Cold
(9) Don't Know/Not Sure
(10) Refused

49. What water temperature setting is usually used for the rinse cycle of your clothes washer? Is it hot, warm, or cold water?
(6) Hot
(7) Warm
(8) Cold
(9) Don't Know/Not Sure
(10) Refused

50. Do you use a clothes dryer in your apartment? Do not include community clothes dryers that are located in the basement or laundry room of your apartment building.
(5) Yes
(6) No
(7) Don't Know/Not Sure
(8) Refused 
51. Do you use community clothes washers in the basement or laundry room of your apartment building?
(1) Yes
(2) No
(3) Don't Know/Not Sure
(4) Refused

52. How frequently does your household hang clothes to dry?
(1) Very frequently
(2) Frequently
(3) Infrequently
(4) Very infrequently
(5) Never
(6) Don't Know/Not Sure
(7) Refused

53. Does your main bathroom have a ventilation fan in it that works?
(1) Yes
(2) No (SKIP to Q56)
(3) Don't know/Not Sure (SKIP to Q56)
(4) Refused

54. How often do you or members of your household operate the fan while showering?
(1) Never
(2) Rarely
(3) Sometimes
(4) Frequently
(5) All the time
(6) Don't Know/Not Sure
(7) Refused

55. How long after showering do you or members of your household operate the fan?
(1) Don't turn the fan on for showers
(2) The fan is turned off when leaving the shower area
(3) A few minutes
(4) Several minutes
(5) Until the steam in the shower area is gone
(6) Don't know/Not Sure
(7) Refused

56. Do any of your faucets or bath or shower fixtures leak?

57. Electric dehumidifiers remove moisture from the air and are often used in the summer. Is a dehumidifier used in your apartment?

(5) Yes 

(6) No (SKIP to Q59)
(7) Don't Know/Not Sure
(8) Refused

58. Before the building was weatherized, was a dehumidifier used in your apartment?
(1) Yes
(2) No

Now I have a couple of questions about lights inside your apartment and energy efficiency.

59. How often do you find lights left on in rooms that are not occupied?
(1) Never
(2) Almost never
(3) Sometimes
(4) Most of the time
(5) All the time
(6) Don't Know/Not Sure
(7) Refused

60. About how may CFL bulbs are in lighting fixtures in your apartment right now?

Number of bulbs:

Now I have some questions about other appliances used in the apartment.

61. Do you have a computer in your unit?
(1) Yes
(2) No
(3) Don't know/Not Sure
(4) Refused

(IF YES)

61a. How many computers do you have?

62. Do you unplug any appliances like TVs, VCRs, stereos, radios, clocks, or computers to save energy when they are turned off?
(1) Yes
(2) No
(3) Don't know/Not Sure
(4) Refused

63. Do you have an extra refrigerator or freezer in the unit?
(1) Yes
(2) No
(3) Don't know/Not Sure
(4) Refused

64. Does your household use a microwave oven? 
(5) Yes

(6) No (SKIP to 66)

(7) Don't Know/Not Sure

(8) Refused

65. Which answer best describes how frequently your household uses the microwave to prepare hot meals and snacks in a typical week?

(7) Used to cook or reheat most meals and snacks

(8) Used to cook or reheat about half of meals and snacks

(9) Used to cook or reheat a few meals and snacks

(10) Used very little

(11) Don't

Know/Not Sure

(12) Refus ed

Now I would like to ask you a few questions about your energy bills.

Some households may have faced challenges in paying apartment energy bills. The following questions ask about challenges your household may have had paying apartment energy. When thinking about these questions, include all of your experiences since the work on the building was completed.

66. Are your energy bills for your apartment paid by you separate from your rent?
(1) Yes
(2) No \{SKIP to Q69\}
(3) Don't Know/Not Sure
(4) Refused

67. How well do you understand the information on your energy bill other than the amount owed (e.g., information about how much energy your household used during the billing period compared to the same billing period one year ago)?

(1) Very well

(2) Well

(3) Neither well nor not well

(4) Not well

(5) Not well at all

(6) Don't know/Not Sure

(7) Refused

68. How hard is it to pay your energy bills?

(8) Very hard

(9) Hard

(10) Neither hard or not hard

(11) Not hard 
(12) Not hard at all

(13) Don't know/Not Sure

(14) Refused

69. Has your household ever had to move in the past 5 years because your household could not pay the energy bills?
(4) Yes
(5) No
(6) Don't know

70. In the past 5 years have you or anyone in the household experienced any of the following as a result of energy bills? CHECK ALL THAT APPLY.

(7) Eviction from apartment

(8) Foreclosure on mortgage

(9) Moved in with friends or family

(10) Moved into a shelter or been apartment less

(11) Family Separation as a result of moving

(12) Refused

71. Including yourself, how many people normally live in this household? Do not include anyone who is just visiting, those away in the military, or children who are away at college.

Enter Number

72. Can you please tell me their first names, gender and age, and your relationship to the person?

First Name Gender Age Relationship In school (Y/N)

Person 1.

Person 2.

Person 3.

Person 4.

Person 5.

Person 6.

Person 7.

Person 8.

Person 9.

Person 10.

73. On a typical week day is there someone at the apartment most or all of the day?

(5) Yes

(6) No

(7) Don't Know/Not Sure

(8) Refused

For this section, I will be asking health related questions. 
In the past 12 months were you or anyone else in the household ever told by a doctor or health professional that you or they have. CHECK ALL THAT APPLY

74. Lead poisoning

(5) Yes

(6) No

(7) Don't Know/Not Sure

(8) Refused

$\{$ IF YES \}Please list all individuals, including yourself:

75. Any kind of respiratory allergy

(5) Yes

(6) No

(7) Don't Know/Not Sure

(8) Refused

\{IF YES $\}$ Please list all individuals, including yourself:

76. Have you or anyone else in the household ever been told by a doctor or other health professional that you have asthma?

(5) Yes

(6) No (SKIP to Q79)

(7) Don't Know/not sure

(8) Refused

\{IF YES \} Please list all individuals, including yourself:

77. Do you or they still have asthma?

(5) Yes

(6) No

(7) Don't Know/Not sure 
(8) Refused

\{IF YES \} Please list all individuals, including yourself:

READ: Symptoms of asthma include coughing, wheezing, shortness of breath, chest tightness or phlegm production when you have a cold or respiratory infection.

78. How long has it been since you last had any symptoms of asthma?

(11) Never

(12) Less than one day ago

(13) 1-6 Days ago

(14) 1 week to less than 3 months ago

(15) 3 months to less than 1 year ago

(16) 1 year to less than 3 years ago

(17) 3 years to 5 years ago

(18) More than 5 years ago

(19) Don't Know/Not sure

(20) Refused

79. Which one of the following statements best describes the rules about smoking in your apartment...

(6) No one is allowed to smoke anywhere inside your apartment

(7) Smoking is allowed at some places or at sometimes

(8) Smoking is permitted anywhere

(9) Don't know/Not sure

(10)

Refused

80. During the past $\mathrm{N}$ months, has anyone in the household been poisoned by breathing in carbon monoxide, and therefore went to see a medical professional?

(5) Yes

(6) No

(7) Don't Know/Not sure

(8) Refused

81. During the past $\mathrm{N}$ months, has anyone in the apartment been burned from scalding hot water coming out of a faucet or showerhead in your apartment?

(5) Yes

(6) No (SKIP to Q83)

(7) Don't Know/Not Sure

(8) Refused 
82. \{IF YES BURN\}Did you talk to or see a medical professional about this injury?
(5) Yes
(6) No
(7) Don't Know/Not Sure
(8) Refused

In this last section I will be asking employment and school related questions.

83. Does a physical, mental or emotional problem NOW keep you or the primary wage earner from working at a job or business?

(5) Yes

(6) No

(7) Don't know/Not Sure

(8) Refused

84. \{IF STUDENT $\}$ During the past N months, how frequently have you found it hard to study in your apartment because of excessive heat or cold?

$\begin{array}{ll}(10) & \text { Very frequently } \\ (11) & \text { Frequently } \\ (12) & \text { Not frequently or infrequently } \\ (13) & \text { Infrequently } \\ (14) & \text { Very infrequently } \\ (15) & \text { Never } \\ (16) & \text { Does not study at apartment } \\ (17) & \text { Don't Know/Not sure } \\ (18) & \text { Refused }\end{array}$

85. \{IF SCHOOL AGED CHILDREN IN THE APARTMENT \} During the past $\mathrm{N}$ months, how frequently has any school aged child in the apartment found it hard to study because of excessive heat or cold?

(10) Very frequently

(11) Frequently

(12) Not frequently or infrequently

(13) Infrequently

(14) Very infrequently

(15) Never

(16) Does not study at apartment

(17) Don't Know/Not sure

(18) Refused 


\section{PART II. Client Satisfaction}

1. How did you first learn that your building was going to have weatherization work done on it?

(1) Informed during a tenant meeting

(2) By written notice

(3) Phone call from building management

(4) Observation of work when it started

(5) Other tenant(s)

(6) By workers/crew when they introduced themselves inside your apartment

(7) Don't Know/Not Sure

(8) Refused

2. Did the owner consult with you and other tenants about the program before they signed up for it?

(1) Yes

(2) No

(3) Don't know/Not Sure

(4) Refused

3. Did your building association consult with you about the program?

(1) Yes

(2) No

(3) N/A: There is no Building Association

(4) Don't know/Not Sure

(5) Refused

4. Was an energy audit conducted in your apartment?

(1) Yes

(2) No (SKIP to Q6)

(3) Don't Know/Not Sure (SKIP to Q6)

(4) Refused (SKIP to Q6)

5. How courteous were those who did the initial audit of your apartment?

(1) Very Courteous

(2) Courteous

(3) Not Courteous or Rude

(4) Rude

(5) Very Rude

6. Were energy conservation measures installed in your apartment? (GIVE EXAMPLES IF NEEDED)?

(1) Yes

(2) No (SKIP to Q14) 
(3) Don't Know/Not Sure (SKIP to Q14)

(4) Refused (SKIP to Q14)

7. How courteous was the weatherization crew when installing these measures?

(1) Very Courteous

(2) Courteous

(3) Not Courteous or Rude

(4) Rude

(5) Very Rude

8. How careful of your apartment and belongings was the weatherization crew?

(6) Very careful

(7) Careful

(8) Neither careful or careless

(9) Careless

(10) Very careless

9. Overall, how clean did the weatherization crew leave the inside of your apartment?

(6) Very clean

(7) Clean

(8) Neither clean nor dirty

(9) Dirty

(10)

Very dirty

10. Overall, how satisfied are you with final condition the inside of your apartment was left in?

(5) Very satisfied

(6) Satisfied

(7) Not satisfied or dissatisfied

(8) Dissatisfied

(5) Very dissatisfied

11. How courteous were those who did the final inspection of your apartment?
(1) Very Courteous
(2) Courteous
(3) Not Courteous or Rude
(4) Rude
(5) Very Rude

12. How satisfied are you with the work performed in your apartment?

(5) Very satisfied

(6) Satisfied

(7) Not satisfied or dissatisfied

(8) Dissatisfied

(5) Very dissatisfied 
13. How satisfied are you with any new equipment installed in apartment?

(5) Very satisfied

(6) Satisfied

(7) Not satisfied or dissatisfied

(8) Dissatisfied

(5) Very dissatisfied

14. Other than the measures installed in your building and/or apartment, do you feel that other things should have been installed in your apartment to help you save energy?

(3) Yes

(4) No (go to Q15)

14a. What other things?

15. If you pay a utility bill for your apartment how satisfied are you with the energy savings achieved after having your apartment weatherized?

(8) Very satisfied

(9) Satisfied

(10) Not satisfied or dissatisfied

(11) Dissatisfied

(12) Very dissatisfied

(13) Too soon to tell

(14) Don't Know/Not Sure

(15) I do not pay utility bill (SKIP to Q17)

16. Have your utility bills changed since your building was worked on?

a. Yes, bills have gone down substantially

b. Yes, bills have gone down somewhat

c. No, no change

d. Yes, bills have gone up somewhat

e. Yes, bills have gone up substantially

f. Don't know/Not Sure

g. I do not pay utility bills

17. Has your rent changed since your building was worked on?

a. Yes, rent has gone down substantially

b. Yes, rent has gone down somewhat

c. No, no change

d. Yes, rent has gone up somewhat

e. Yes, rent has gone up substantially

f. Don't know

18. Are you worried that your rent will increase within the next 5 years?

(1) Yes

(2) No

(3) Don't know/Not Sure 
(4) Refused

19. Have you received any education about how to reduce energy consumption in your unit as part of actions taken to lower the energy use in the building?

(1) Yes

(2) No (SKIP to Q24)

(3) Don't know/Not Sure

(4) Refused

20. How much time did the weatherization team talk to you about ways to save energy?
(1) Less than 5 minutes
(2) 5 to 14 minutes
(3) 15 to 29 minutes
(4) 30 to 60 minutes
(5) More than one hour

21. How well did you understand what the weatherization team said to you about saving energy?

(1) Very well (go to Q22)

(2) Well (go to Q22)

(3) Neither well or not well (go to Q22)

(4) Not well

(5) Not well at all

21a. Why did you not understand what the weatherization team said?

CHECK ALL THAT APPLY

(1) The team member did not speak my primary language

(2) The team member was confusing

(3) The team member did not speak well

(4) The team member was hurried

(5) The team member was boring

(6) I did not get along with the team member

(7) Other

22. What materials about saving energy did the weatherization team give you? CHECK ALL THAT APPLY

(1) One or more brochures, booklets, or manuals

(2) One or more compact discs (CDs), videos, or DVDs

(3) Hardware kit of weatherization materials

(4) No materials were provided (go to Q23)

(5) Weatherization staff spent time demonstrating how to save energy (go to Q23)

22a. How much time have you spent reading/reviewing the materials about saving energy that the weatherization team gave you?

(1) No time (go to Q31)

(2) Less than 5 minutes

(3) 5 to 14 minutes 
(4) 15 to 29 minutes

(5) 30 to 59 minutes

(6) More than one hour

22b. How well did you understand the energy savings materials that the weatherization team gave you?

(6) Very well

(7) Well

(8) Neither well or not well

(9) Not well

(10) Not well at all

22c. How useful have the energy savings materials been to you?

(1) Very useful

(2) Useful

(3) Neither useful or not useful

(4) Not useful

(5) Not very useful

22d. What about the materials were particularly useful?

22e. How could the materials have been improved for your use?

23. How satisfied are you with the ways that the weatherization team provided you with information about saving energy?

(6) Very satisfied

(7) Satisfied

(8) Not satisfied or dissatisfied

(9) Dissatisfied

(5) Very dissatisfied

24. What is the greatest benefit your household received from the weatherization of your apartment building?

25. Would you say your household is now less likely to move from your current apartment as a result of weatherization?

(5) Yes

(6) No

(7) Don't Know/Not Sure

(8) Refused

26. Since the building improvement please rate the changes in the following in your building and/or your unit: 


\begin{tabular}{|l|l|l|l|l|l|l|}
\hline & Much Better & Better & No Change & Worse & Much Worse & $\begin{array}{l}\text { Not } \\
\text { Applicable }\end{array}$ \\
\hline $\begin{array}{l}\text { Entrance } \\
\text { lighting }\end{array}$ & & & & & & \\
\hline $\begin{array}{l}\text { Stairway } \\
\text { lighting }\end{array}$ & & & & & & \\
\hline $\begin{array}{l}\text { Hallway } \\
\text { lighting }\end{array}$ & & & & & & \\
\hline $\begin{array}{l}\text { Lighting in } \\
\text { your apartment }\end{array}$ & & & & & & \\
\hline $\begin{array}{l}\text { Comfort of } \\
\text { your unit in } \\
\text { winter }\end{array}$ & & & & & & \\
\hline $\begin{array}{l}\text { Comfort of } \\
\text { your unit in the } \\
\text { summer }\end{array}$ & & & & & & \\
\hline
\end{tabular}

27. Please rate your overall satisfaction with the weatherization work completed on your building.

(6) Very satisfied

(7) Satisfied

(8) Not satisfied or dissatisfied

(9) Dissatisfied

(10) Very dissatisfied

\section{Demographics}

1. Are you currently...?

(8) Married

(9) Divorced

(10) Widowed

(11) Separated

(12) Never married

(13) A member of an unmarried couple

(14) Refused

2. What is the highest degree or level of school you have completed?

(11) No Schooling Completed

(12) Kindergarten to grade 12 (No Diploma)

(13) High school diploma or GED

(14) Some college, no degree

(15) Associate's degree (for example: AA, AS)

(16) Bachelor's degree (for example: BA, BS) 
(17) Master's degree (for example: MA, MS, MBA)

(18) Professional degree (for example: MD, JD)

(19) Doctorate degree (for example: $\mathrm{PhD}, \mathrm{EdD}$ )

(20) Refused

3. Do you consider yourself to be of Hispanic or Latino origin, such as Mexican, Puerto Rican, Cuban, or other Spanish background?

(5) Yes

(6) No

(7) Don't know/Not Sure

(8) Refused

4. Which describes your race? You can select one or more categories.

(9) White

(10) Black or African-American

(11) American Indian or Alaska Native

(12) Asian

(13) Native Hawaiian or Other Pacific Islander

(14) Other (if volunteered)

(15) Hispanic or Latino (if volunteered)

(16) Refused

4a. \{IF MORE THAN ONE \} Which ONE of these groups best represents your race? You can select one or more categories.

(9) White

(10) Black or African-American

(11) American Indian or Alaska Native

(12) Asian

(13) Native Hawaiian or Other Pacific Islander

(14) Other (if volunteered)

(15) Hispanic or Latino (if volunteered)

(16) Refused

That is the end of the survey. Thank you for your participation! You will receive your \$----- gift card in the mail to compensate you for your time. Could you please verify your mailing address:

Address: 
OMB Control Number: XXXX-XXXX

\section{APPENDIX M: WEATHERIZATION STAFF SURVEY}

This data is being collected to evaluate weatherization staff training and other workforce issues. Public reporting burden for this collection of information is estimated to average thirty minutes per response, including the time for reviewing instructions, searching existing data sources, gathering and maintaining the data needed, and completing and reviewing the collection of information. Send comments regarding this burden estimate or any other aspect of this collection of information, including suggestions for reducing this burden, to Office of the Chief Information Officer, Records Management Division, IM-11, Paperwork Reduction Project (XXXX-XXXX), U.S. Department of Energy, 1000 Independence Ave SW, Washington, DC, 20585-1290; and to the Office of Management and Budget (OMB), OIRA, Paperwork Reduction Project (XXXX-XXXX), Washington, DC 20503.

\section{Part I. National Weatherization Staff}

Introduction: Thank you for agreeing again to participate in the Weatherization Staff Survey being conducted as part of the national evaluation of the Weatherization Assistance Program. All of the information that we obtain from this survey will remain confidential and will be analyzed in such a way that your answers cannot be associated with your name. Your answers will not be shared with or reported back to anyone within your agency or state.

\section{Part I - For National Weatherization Staff Survey Respondents}

1. The first time we interviewed you, you reported you were working for ??????? Do you still work for ?????
a. Yes
b. No (go to Q13)

2. The first time we interviewed you, you reported your primary weatherization job title as ????? Is this still your primary weatherization job title?

a. Yes (go to Q4)

b. No

3a. What is your primary weatherization job title?
a. Administrator
b. Auditor
c. Inspector
d. Crew leader/foreman
e. Crew member
f. Other
g. I work for the same employer but not in weatherization any more. (go to Q17)

3b. Please indicate your current certifications: 

a. BPI
b. HERS
c. Weatherization Installer
e. Weatherization Crew Chief
f. Weatherization Auditor
g. Weatherization Monitor
h. Other

3c. Do you feel that you would like training that is not currently offered? If yes, what?

4. How satisfactory are these aspects of your job weatherizing low-income homes?

\begin{tabular}{|l|c|c|c|c|c|}
\hline & \multicolumn{1}{|l|}{$\begin{array}{c}\text { Very } \\
\text { Satisfactory }\end{array}$} & Satisfactory & $\begin{array}{c}\text { Satisfactory } \\
\text { nor } \\
\text { unsatisfactory }\end{array}$ & Unsatisfactory & $\begin{array}{c}\text { Very } \\
\text { unsatisfactory }\end{array}$ \\
\hline a. Pay & $\square$ & $\square$ & $\square$ & $\square$ & $\square$ \\
\hline b. Health benefits & $\square$ & $\square$ & $\square$ & $\square$ & $\square$ \\
\hline c. Steady work & $\square$ & $\square$ & $\square$ & $\square$ & $\square$ \\
\hline d. Boss/supervisor(s) & $\square$ & $\square$ & $\square$ & $\square$ & $\square$ \\
\hline e. Co-workers & $\square$ & $\square$ & $\square$ & $\square$ & $\square$ \\
\hline $\begin{array}{l}\text { f. Interactions with } \\
\text { clients }\end{array}$ & $\square$ & $\square$ & $\square$ & $\square$ & $\square$ \\
\hline $\begin{array}{l}\text { g. Flexibility of work } \\
\text { schedule }\end{array}$ & $\square$ & $\square$ & $\square$ & $\square$ & $\square$ \\
\hline h. Dress code & $\square$ & $\square$ & $\square$ & $\square$ & $\square$ \\
\hline i. Paid time off policy & $\square$ & $\square$ & $\square$ & $\square$ & $\square$ \\
\hline j. Retirement benefits & $\square$ & $\square$ & $\square$ & $\square$ & $\square$ \\
\hline k. Job safety & $\square$ & $\square$ & $\square$ & $\square$ & $\square$ \\
\hline
\end{tabular}

5. Including your weatherization employer, how many employers do you have?

$\square \quad$ One (go to Q7)

$\square$ Two

$\square$ More than two

6. Is working for your current weatherization employer your main job?

$\square$ Yes

$\square \quad$ No

7. Considering all your employers, do you work full-time or part-time?

$\square$ Full-time

$\square$ Part-time

$\square$ More than full-time 
8. How many hours per week do you usually work at all of your jobs?

$$
\text { Enter }
$$
hrs

9. Do you have health insurance?

$$
\begin{aligned}
& \square \quad \text { Yes } \\
& \square \quad \text { No (go to Question 11) }
\end{aligned}
$$

10. Who provides your health insurance?
a. Your current weatherization employer
b. A non-weatherization employer
c. Your state
d. You purchase your own insurance
e. You have insurance through a family member
f. Other

11. What is your annual income from your weatherization job?
a. $\$ 0-\$ 10,000$
b. $\$ 10,001-\$ 15,000$
c. $\$ 15,001-\$ 20,000$
d. $\$ 20,001-\$ 25,000$
e. $\$ 25,001-\$ 30,000$
f. $\$ 30,001-\$ 40,000$
g. $\$ 40,001-\$ 50,000$
h. $\$ 50,001-\$ 75,000$
i. $\$ 75,001$ and over

12. How likely would it be that you would be unemployed if you did not have a job with your current weatherization employer?
a. Very likely
b. Likely
c. Neither likely or unlikely
d. Unlikely
e. Very unlikely

\section{END SURVEY}

13. Do you still work in low-income weatherization?

a. Yes

b. No (go to Q15)

14. For whom do you work?

- Local weatherization agency

- Private weatherization contractor

$\circ$ Other

14a. What is your primary weatherization job title? 


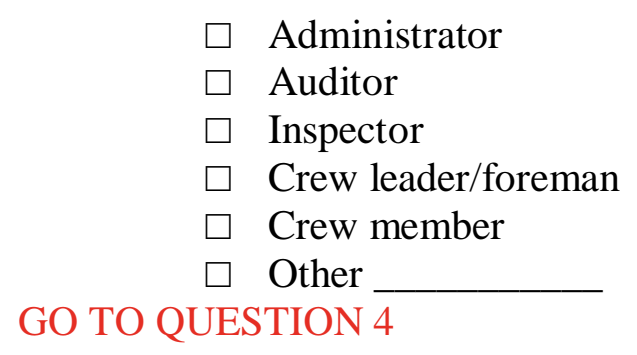

15. Are you currently...?

(1) Employed for wages (go to Q16)

(2) Self-employed (go to Q16a)

(3) Out of work for more than 1 year (SKIP to Q21)

(4) Out of work for less than 1 year (SKIP to Q21)

(5) A Homemaker (END SURVEY)

(6) A Student (SKIP to Q23)

(7) Retired (END SURVEY)

(8) Unable to work (END SURVEY)

(9) Refused (END SURVEY)

16. Please choose the description that best describes your current primary employer:

a. Private sector contractor (Choose if you are self-employed in this field)

b. Local government

c. State government

d. Federal government

e. Non-profit organization

f. Other type of for-profit firm

g. Other

16a. Please choose the description that best describes what industry you work in:

a. home retrofit

b. construction

c. clean energy

d. other

17. Do you have health insurance?

○ Yes

○ No (go to Question 19)

18. Who provides your health insurance?
a. Your current primary employer
b. Your state
c. You purchase your own insurance
d. You have insurance through a family member
e. Other

19. What is your annual income from your primary job? 
$\$ 0-\$ 10,000$

$\$ 10,001-\$ 15,000$

$\$ 15,001-\$ 20,000$

$\$ 20,001-\$ 25,000$

$\$ 25,001-\$ 30,000$

$\$ 30,001-\$ 40,000$

$\$ 40,001-\$ 50,000$

$\$ 50,001-\$ 75,000$

$\$ 75,001$ and over

20. How satisfactory are these aspects of your job primary job?

\begin{tabular}{|l|c|c|c|c|c|}
\hline & $\begin{array}{c}\text { Very } \\
\text { satisfactory }\end{array}$ & Satisfactory & $\begin{array}{c}\text { Neither } \\
\text { satisfactory } \\
\text { nor } \\
\text { unsatisfactory }\end{array}$ & Unsatisfactory & $\begin{array}{c}\text { Very } \\
\text { unsatisfactory }\end{array}$ \\
\hline a. Pay & $\square$ & $\square$ & $\square$ & $\square$ & $\square$ \\
\hline b. Health benefits & $\square$ & $\square$ & $\square$ & $\square$ & $\square$ \\
\hline c. Steady work & $\square$ & $\square$ & $\square$ & $\square$ & $\square$ \\
\hline $\begin{array}{l}\text { d. } \\
\text { Boss/supervisor(s) }\end{array}$ & $\square$ & $\square$ & $\square$ & $\square$ & $\square$ \\
\hline e. Co-workers & $\square$ & $\square$ & $\square$ & $\square$ & $\square$ \\
\hline $\begin{array}{l}\text { f. Interactions with } \\
\text { clients }\end{array}$ & $\square$ & $\square$ & $\square$ & $\square$ & $\square$ \\
\hline $\begin{array}{l}\text { g. Flexibility of } \\
\text { work schedule }\end{array}$ & $\square$ & $\square$ & $\square$ & $\square$ & $\square$ \\
\hline h. Dress code & $\square$ & $\square$ & $\square$ & $\square$ & $\square$ \\
\hline $\begin{array}{l}\text { i. Paid time off } \\
\text { policy }\end{array}$ & $\square$ & $\square$ & $\square$ & $\square$ & $\square$ \\
\hline $\begin{array}{l}\text { j. Retirement } \\
\text { benefits }\end{array}$ & $\square$ & $\square$ & $\square$ & $\square$ & $\square$ \\
\hline k. Job safety & $\square$ & $\square$ & $\square$ & $\square$ & $\square$ \\
\hline
\end{tabular}

\section{END SURVEY}

21. Have you looked for work during the last 4 weeks?

(1) Yes (END SURVEY)

(2) No

$\square$ Don't Know/Not Sure

$\square$ Refused (END SURVEY)

22. What is the main reason you were not looking for work during the LAST 4 WEEKS? CHECK ALL THAT APPLY 
(1) Believes no work available in line of work or area

(2) Couldn't find any work

(3) Lacks necessary schooling, training, skills or experience

(4) Employers think too young or too old

(5) Other types of discrimination

(6) Can't arrange child care

(7) Family responsibilities

(8) In school or other training

(9) Ill health, physical disability

(10) Transportation problems

(11) Other

(12) Don't Know/Not Sure

(13) Refused

\section{END SURVEY}

23. Please choose the best description of your current educational status.

a. Enrolled in high school

b. Enrolled in community college

c. Enrolled in 4-year university or college

d. Enrolled in graduate school

e. Other

\section{END SURVEY}

\section{Part II - For Weatherization Training Center Trainees}

24a. If you are currently employed do you feel that your training has increased your ability to:
a. Perform your current job (Go to Q24c)
b. Get a better job (Go to Q24c)
c. No benefit (Go to Q24c)
d. No currently employed

24b. If you are not currently employed, do you feel that your training has increased your ability to get a job?
a. Yes
b. No
c. Maybe
d. Don't know

(Go to Q15)

24c. Do you currently work for a local agency that conducts low-income weatherization or a private contractor that performs low-income weatherization? 
a. Yes

b. No (Go to Q15)

25. For whom do you work?

○ Local weatherization agency

- Private weatherization contractor

o Other

GO TO Q3 
OMB Control Number: XXXX-XXXX

\section{APPENDIX N: DF11 - WEATHERIZATION STAFF SURVEY DATA FORM}

This information is being collected to help implement the Weatherization Staff Survey. Public reporting burden for this collection of information is estimated to average fifteen minutes per response, including the time for reviewing instructions, searching existing data sources, gathering and maintaining the data needed, and completing and reviewing the collection of information. Send comments regarding this burden estimate or any other aspect of this collection of information, including suggestions for reducing this burden, to Office of the Chief Information Officer, Records Management Division, IM-11,

Paperwork Reduction Project (XXXX-XXXX), U.S. Department of Energy, 1000 Independence Ave SW, Washington, DC, 20585-1290; and to the Office of Management and Budget (OMB), OIRA, Paperwork Reduction Project (XXXX-XXXX), Washington, DC 20503.

Thank you in advance for completing this data form.

1. Please identify your local weatherization agency.

2. Please provide the following information about each individual who has conducted energy audits for you agency so far in XXXX:

\begin{tabular}{|l|l|l|}
\hline NAME & TELEPHONE NUMBER & EMAIL ADDRESS \\
\hline & & \\
\hline & & \\
\hline & & \\
\hline & & \\
\hline & & \\
\hline & & \\
\hline & & \\
\hline & & \\
\hline & & \\
\hline & & \\
\hline & & \\
\hline & & \\
\hline & & \\
\hline & & \\
\hline
\end{tabular}




\section{APPENDIX O. SAMPLE SIZE JUSTIFICATION}

This appendix addresses sample sizes needed for the various WAP evaluation component surveys. Populations to be sampled are discussed in Section O.1. In addition to dependencies on weather, weatherization data tends to be noisy because of complex and frequently changing behavior of occupants. Wide confidence intervals often occur for estimates computed even from relatively large samples. Equivalently, relatively large samples are often required to achieve specified levels of accuracy. The WAP evaluation will require statistical sampling of weatherization agencies is discussed in Section O.2. Statistical sampling associated with the Weatherization Innovation Pilot Project, Sustainable Energy Resources for Consumers, Deferral, and Social Network Studies are found in Sections O.3-O.6, respectively.

The usual approach taken in justifying a survey sample size is to identify a main quantity to be estimated, to justify a sample size necessary for estimating it, and to argue that additional information to be collected in the survey will be obtained at little or no additional burden to either subjects or analysts. The sample size calculation ordinarily requires (1) a preliminary assessment of the variability of the main quantity to be estimated (for example, a preliminary estimate of its coefficient of variation, and (2) a specification of the accuracy required of the main quantity to be estimated - for example "to within $10 \%$ of its true value with $90 \%$ confidence." Also, in cases of complex (multi-stage, stratified, probability-sampled, and control-adjusted) designs, as is proposed for the WAP evaluation, sample size formulas for simpler (e.g., simple random sampling) designs are often used as an approximation. The sample design in preliminary/pilot studies is usually much simpler anyway. These approaches are taken below.

Much of the material in these sections will be used directly for the WAP evaluation OMB Paperwork Reduction Act (PRA) submission and Supporting Statement required for surveys employing statistical methods (www.whitehouse.gov/omb/inforeg/83i-fill.pdf). Some of the discussion is therefore written in that context. Section O.7 contains additional notes about topics such as nonresponse that will also have to be addressed in the OMB PRA submission.

\section{O.1 POPULATIONS SAMPLED}

The WAP evaluation will require statistical sampling of weatherization agencies. Agency weatherization staff and weatherization and control homes/occupants will be subsampled. WAP management will also be interviewed, and $100 \%$ of State weatherization programs will be surveyed. WAP management and State weatherization programs will be sampled completely (i.e., 100\%) rather than statistically, because these populations are small and it is expedient to sample them that way. (For PRA purposes, DOE program management interviews are not considered a "collection of information," because the information acquired is to be used for a specific purpose (i.e., the WAP evaluation) rather than general statistical purposes - "“Collection of information' includes questions posed to...employees of the United States, if the results are to be used for general statistical purposes..." [5CFR1320.3].)

A justification for taking a complete sample rather than a statistical subsample of State agencies, which $i s$ required by OMB, is given by OMB (2006): "When the target population is small and each unit is unique, a census is likely to be preferred over a sample survey. For example, when an agency evaluates a Federal program that is implemented by the states (each one perhaps somewhat differently), a census of state program directors may provide higher quality information with little cost difference from a sample survey of a slightly smaller number of states. In this case, there may also be concerns about missing practices of some states that were not included in the sample if a census were not conducted." 
Several case studies will also be conducted as components of the WAP evaluation. The case studies will not involve statistical sampling or inference, however, or they will be below the PRA threshold of ten or more observations. They do not require OMB approval because either the sample size will be less than ten or they will be conducted by direct observations by social scientists or weatherization experts of homes or workers during the execution of normal weatherization activities, and such information collections are not subject to the PRA: "'Information' does not generally include items in the following categories...Facts or opinions obtained through direct observation by an employee or agent of the sponsoring agency or through nonstandardized oral communication in connection with such direct observations;" [5CFR1320.3]. Sample sizes for the case-studies will be based on judgment rather than formal statistical calculations.

\section{O.2 AGENCY SAMPLING}

\section{O.2.1 Agency sampling for energy benefits (billing data analysis)}

As in the 1990 evaluation (Brown et al, 1993), occupant-level energy consumption and dwelling characteristic data will be obtained by first sampling agencies and then acquiring occupant-level data from the agencies. In the 1990 evaluation, 400 agencies were sampled, 361 agencies responded, and one third of the records for the weatherized units and one third of the records for the control units were subsampled for each agency that responded (ibid.). This rate applied to single-family detached dwellings as well as mobile homes. To properly determine weatherization savings in multifamily buildings, all units in each selected building must be analyzed. Therefore, multifamily buildings were selected at the rate of one third of buildings.

The 1990 evaluation (ibid.) lead to the following mean \pm standard error control-adjusted natural gas and electricity savings estimates per weatherized unit per year:

\begin{tabular}{|c|c|c|c|}
\hline $\begin{array}{c}\text { Primary Heating } \\
\text { Fuel }\end{array}$ & $\begin{array}{c}\text { Average Savings } \\
\text { per Weatherized } \\
\text { Unit }\end{array}$ & $\begin{array}{c}\text { Standard Error of } \\
\text { Average }\end{array}$ & Precision \\
\hline Natural gas & $17.8 \mathrm{MMBtu} /$ year & $1.8 \mathrm{MMBtu} / \mathrm{year}$ & $10 \%$ \\
\hline Electricity & $1,830 \mathrm{kWh} /$ year & $358 \mathrm{kWh} / \mathrm{year}$ & $20 \%$ \\
\hline
\end{tabular}

The precision obtained in the 1990 evaluation was subsequently found to adequate for that evaluation and is assumed adequate for the proposed evaluation as well. Thus the basic objective of the proposed study is to update the 1990 evaluation by repeating it today. However, the proposed evaluation will incorporate several minor refinements and additions.

The 1990 evaluation was stratified by agency size and geographic region. The agency size strata were sampled at the same rate except for the largest-size stratum which was certainty (100\%) sampled. Thus, with the exception of the very largest agencies, large agencies had no greater chance of selection than small ones. Yet, in general, the larger the agency, the greater its contribution to total energy savings. In the proposed evaluation probability proportional to size (PPS) sampling with size measured as agency funding will provide a refinement of the 1990 stratification by agency size by allowing agency size to be continuously reflected in the sampling probabilities, with the effect that all agencies will be statistically represented, but larger agencies will be sampled preferentially. ${ }^{38}$

\footnotetext{
${ }^{38}$ An alternative measure of an agency's size is the number of units it weatherizes. The number of units weatherized is not as good a measure of size, however, because of an accounting feature in the WinSAGA
} 
The geographic stratification in the proposed evaluation will also be a refinement of the 1990 study's. The earlier study employed ten climate subregions, which were approximations of standard climate regions based on state boundaries. For the proposed study, in addition to representing all climate zones, it was considered politically advantageous to guarantee representation of all states. (Furthermore some states may commission add-on survey components of their own.) Therefore stratification for the proposed study will be by state.

Although the sampling for the proposed study is thus a refinement of the 1990 sampling, the two studies will still be substantially similar, and the 1990 study is by far the best available source of prior information for the proposed one. For the purpose of sample size calculations, it is reasonable to regard the proposed evaluation as emulating the 1990 study. Therefore 400 agencies will be sampled in the proposed study, as in the 1990 evaluation.

For each sampled agency, houses (or buildings for multifamily buildings) will be randomly sampled. In general, the rate of sampling within agencies will be fixed for all agencies. That rate will be approximately one-in-three and will thus achieve the same overall sample size and precision achieved in the 1990 evaluation. However, the exact sampling rate for each agency will depend on the following factors that must be determined during the course of the study: (1) The target population of weatherized and control units must be restricted to "DOE" units, that is, units weatherized primarily with DOE funds. Agencies weatherize homes using various funding sources (states and utilities also provide funding), and use different bookkeeping methods for counting weatherized units, and in particular, DOE units. The target population of DOE weatherized and control units has to be determined for each agency on a caseby-case basis. Target population sizes are expected be smaller than in the 1990 evaluation, and sampling proportions will be larger to achieve a comparable sample overall size. (2) In the proposed study, more so than in 1990, some agencies will be able to deliver complete sets of data in electronic formats. However, the extent to which this happens and the ease of compliance of agencies with requests for data in general is unclear. Recent interaction with a few agencies has shown that many agencies still rely on paper record keeping and that delivery by an agency of a complete electronic database is still likely to be more the exception than the rule. Nevertheless, agencies that can just as easily deliver all of their data as sample part of it will be asked to do so. (3) As in the 1990 evaluation, some utilities will not comply with requests for data. Utility nonresponse is considered independent of agency weatherization performance, however, and is thus nonbiasing. Utility nonresponse is also likely to be lower than in the in the 1990 evaluation, because of advances in electronic bookkeeping.

A listing of weatherization agencies along with their planned dollar allocation and units sampled can be obtained from the WinS AGA (Systems Approach to Grants Administration for Windows) data base. ${ }^{39}$ As of 2005, there were 927 agencies. A PPS sample of 400 agencies with the 2005 funding allocation as the measure of PPS size and stratified by state was selected in order to see what the PPS sampling of agencies and one-third subsampling of units would likely translate to in terms of allocation dollars and weatherized units in the actual sample. A ten percent nonresponse rate was assumed. Because of constraints on PPS sampling, the very largest agency had to be sampled with certainty. Thus 361 agencies were actually sampled (as in the 1990 evaluation). Results of the sample are summarized in Table 1.

After deducting the nonresponders, 361 agencies were sampled, which is $39 \%$ of the 927 . Of course the sample of 361 agencies represents all 927 agencies in a statistical sense. Because size is agency funding

database (see following discussion) in which units weatherized with only one dollar of DOE funding can be counted as DOE weatherized units.

${ }^{39}$ WinSAGA data kindly provided by Christine Askew, Office of the Weatherization and Intergovernmental Program, Energy Efficiency and Renewable Energy, U.S. DOE. 
allocation, although the sample accounts for $39 \%$ of agencies, it accounts for $65 \%$ of funding. The sample also accounts for $63 \%$ of weatherized units. (The reason for the differences in the funding percentage $(65 \%)$ and the units percentage $(63 \%)$ may be related to the way units are counted in the WinSAGA database, with only one dollar of DOE funding necessarily required for a unit to be counted as a DOE unit.)

Table 1 also shows the units actually sampled $(17,232)$ in a one-in-three subsample of units, and, assuming (as in the 1990 evaluation) that $60 \%$ of units are gas or electric, the number of units $(10,339)$ potentially available for billing the analyses. Utility nonresponse will depreciate this number. However, the final column in the table shows that if data is obtained for $46 \%$ of the units potentially available for billing the analysis, then the number of units sampled will equal the number sampled in the 1990 evaluation. The $46 \%$ acquisition rate is reasonable and similar to the corresponding rate in the 1990 evaluation (ibid.).

\subsubsection{Agency sampling for program characterization and process assessment}

In addition to energy use and savings data, information about the weatherization process and program, also necessary for the evaluation, will be obtained from the 400 sampled agencies. The justification for collecting this additional information is based on the above for the metered fuel (natural gas and electric) savings studies and that the additional burden in collecting/delivering this information from agencies from which energy use and savings data is already being collected is small.

\section{Table O.1 WAP 2005 National and Approximate PPS Sample Totals Size $=2005$ Dollar Allocation and $10 \%$ Nonresponse}

\begin{tabular}{|c|c|c|c|c|c|c|c|}
\hline $\begin{array}{c}\text { National } \\
\text { Agencies } \\
(2005 \\
\text { Listing) }\end{array}$ & $\begin{array}{l}\text { Agencies } \\
\text { Sampled }\end{array}$ & $\begin{array}{l}\text { Agencies } \\
\text { esponding }\end{array}$ & $\begin{array}{r}\text { Per } \\
\text { Nat } \\
\text { Age } \\
\text { Respo }\end{array}$ & $\begin{array}{l}\text { ent } \\
\text { onal } \\
\text { cies } \\
\text { nding }\end{array}$ & $\begin{array}{r}2005 \\
\text { National } \\
\text { Allocation }\end{array}$ & $\begin{array}{r}\text { Allocation } \\
\text { Represented } \\
\text { by } \\
\text { Responders }\end{array}$ & \begin{tabular}{|} 
Percent \\
Allocation \\
Represented \\
by \\
Responders
\end{tabular} \\
\hline 929 & 400 & 361 & & $39 \%$ & $\$ 258,231,144$ & $\$ 168,535,723$ & $65 \%$ \\
\hline $\begin{array}{c}2005 \\
\text { National } \\
\text { Units } \\
\text { Planned }\end{array}$ & $\begin{array}{c}\text { Units } \\
\text { Represented } \\
\text { by } \\
\text { Responders }\end{array}$ & $\begin{array}{r}\text { Per } \\
\text { of } \mathrm{U} \\
\text { Repre } \\
\mathbf{b} \\
\text { Respo }\end{array}$ & $\begin{array}{l}\text { ent } \\
\text { nits } \\
\text { ented } \\
\text { aders }\end{array}$ & $\begin{array}{r}\mathrm{U} \\
\text { Subs: } \\
(\mathbf{a t}\end{array}$ & $\begin{array}{l}\text { lnits } \\
\text { ampled } \\
33 \% \text { ) }\end{array}$ & $\begin{array}{l}\text { Gas/Elec } \\
\text { Units } \\
\text { bsampled } \\
\% \text { Approx) }\end{array}$ & $\begin{array}{c}\text { Capture Rate } \\
\text { To Achieve } \\
1990 \\
\text { Number } \\
\text { Usable } \\
(4,796)\end{array}$ \\
\hline 82,701 & 51,695 & & $63 \%$ & & 17,232 & 10,339 & $46 \%$ \\
\hline
\end{tabular}

\section{O.2.3 Agency staff subsampling}

A subsample of agency staff members will be taken from a list compiled from the agency staff contact information. To ensure adequate representation, the sample will be stratified by staff functional classification (crew, supervisor, auditor/inspector) with equal-size strata. A computer assisted telephone interviewing (CATI) survey will be conducted of the sampled staff. Several technical questions will be posed to the staff members to characterize current staff understanding and awareness of weatherization methods and technologies. The primary endpoint of interest is the combined proportion of correct 
responses and how it relates to staff training experience. The proportion of correct responses is expected also to serve as a baseline for future studies.

Sampling will be implemented by random sampling from staff lists identified by the sampled agencies. As an approximation in reckoning sample sizes, we ignore the agency sampling weights, though they will be accounted for in the data analysis. The proportions of correct responses in each sampling strata (crew, supervisor, auditor/inspector) will be estimated to within five percentage points with $90 \%$ confidence. The standard error of the combined proportion of correct responses can be no greater than the standard error of an individual (correct/incorrect) response, which cannot exceed $.5 / \mathrm{n}^{1 / 2}$ (maximum standard error of binomial proportion). This will be achieved if $1.645 \times .5 / \mathrm{n}^{1 / 2}=.05$, that is, if $\mathrm{n}=271$, where $\mathrm{n}$ is the sample size in each stratum. Nonresponse in this survey is expected to be negligible, because the survey will be of agency employees whose contact information has been provided by the agencies. The total sample size will be $271 \times 3=813$.

\section{O.3 WEATHERIZATION INNOVATION PILOT PROGRAM SAMPLING}

The WIPP currently comprises sixteen projects, all of which have been selected for evaluation. Various project components will be evaluated, not all of which necessarily require OMB approval or even statistical planning. For example, because each project is unique and there is only one grantee per project, it seems unlikely that substantially the same question will be asked to all sixteen grantees, in which case the PRA would not apply to the grantee evaluation. Similarly, case studies probably also will not involve asking substantially the same question to ten or more individuals. However other WIPP evaluation components will most likely involve asking the same questions to ten or more individuals. These include (1) occupant surveys, (2) home inspections, (3) utility bill analyses, and (4) weatherization staff surveys. These four evaluation components are discussed below. 


\section{Occupant Surveys and Home Inspections}

Table O.2 below lists the sixteen WIPP projects, the numbers of homes slated for weatherization, and the federal requests for the projects.

\section{Table O.2. WIPP Projects, Numbers of Units to be Weatherized, and Federal Funding}

\begin{tabular}{|c|c|c|c|}
\hline WIPP Project & $\begin{array}{l}\text { Number } \\
\text { of Units }\end{array}$ & $\begin{array}{cc}r & \text { Federal } \\
S & \text { Request }(\$)\end{array}$ & $\begin{array}{l}\text { Percent of } \\
\text { Total Request }\end{array}$ \\
\hline Green and Healthy Homes Initiative & 220 & $2,400,000$ & 8.00 \\
\hline In Home Monitoring & 2,500 & $2,400,000$ & 8.00 \\
\hline Performance-based Revolving Loan Pilot... & 450 & 850,000 & 2.83 \\
\hline Energy Pioneer Solutions Weatherization... & 250 & $2,400,000$ & 8.00 \\
\hline SAHF Energy Performance Contracting... & 2,500 & 810,000 & 2.70 \\
\hline Connecticut Green and Healthy Homes... & 2,285 & $3,000,000$ & 10.00 \\
\hline Streamlined Weatherization Improvements... & 800 & $2,000,000$ & 6.67 \\
\hline Leveraging Smart Grid Technology to... & 550 & 720,000 & 2.40 \\
\hline YouthBuild USA Weatherization... & 998 & $1,400,000$ & 4.67 \\
\hline Habitat for Humanity Weatherization... & 1,770 & $3,000,000$ & 10.00 \\
\hline Community Environmental Center... & 1,200 & $3,000,000$ & 10.00 \\
\hline Building Deep Efficiency... & 425 & 600,000 & 2.00 \\
\hline Project with the City matching federal... & 300 & $1,015,746$ & 3.39 \\
\hline Tackling the Problem of Weatherizing... & 1,700 & $1,898,938$ & 6.33 \\
\hline Replicable, Innovative, Sustainable... & 2,240 & $3,000,000$ & 10.00 \\
\hline People Working Cooperatively... & 340 & $1,500,000$ & 5.00 \\
\hline All Proje & 18,528 & $29,994,684$ & 100.00 \\
\hline
\end{tabular}

Although the units in Table O.2 cannot yet be listed in a population frame, they are welldefined. A table such as Table O.3 can be used to suggest a sample size for sampling from all 18,528 of the units. The table gives the sample sizes needed to estimate a proportion (e.g., proportion of customers who say they are satisfied) to within the specified margin of error with the specified statistical confidence. 
Table O.3. Suggested Sample Sizes for Sampling Units (for Occupant Survey/Home Inspections)

\begin{tabular}{|c|c|c|c|}
\hline Confidence & $\begin{array}{l}\text { Margin } \\
\text { of } \\
\text { Error }\end{array}$ & $\begin{array}{l}\text { Infinite } \\
\text { Population } \\
\text { Sample Size }\end{array}$ & $\begin{array}{l}\text { Corrected } \\
\text { Sample Size } \\
\text { (For Finite } \\
\text { Population } \\
\text { of 18,528) }\end{array}$ \\
\hline \multirow[t]{3}{*}{90} & 0.10 & 68 & 68 \\
\hline & 0.05 & 271 & 267 \\
\hline & 0.03 & 752 & 723 \\
\hline \multirow[t]{3}{*}{95} & 0.10 & 97 & 96 \\
\hline & 0.05 & 385 & 377 \\
\hline & 0.03 & 1,068 & 1,009 \\
\hline
\end{tabular}

Occupant surveys will be conducted by telephone interviewing. The 3\% margin of error and 95\% statistical confidence (03-95 criteria, last row of Table O.3) are standard for this kind of telephone survey. For home inspections, because of the much higher expense per subject, a $10 \%$ margin of error and $90 \%$ statistical confidence (10-90 criteria, first row of Table O.3) are more appropriate. For these criteria, sample sizes of 1,009 and 68 are needed for the occupant survey and home inspections respectively. However, Table 2 is for simple random sampling, and we will stratify the sampling by the sixteen WIPP projects. As the stratification is expected to improve the survey's precision, however, the figures in Table 2 are slightly higher than actually necessary.

We use the projects' percentage of the total federal request for the sixteen projects to allocate the sample across the sixteen WIPP projects. As shown in Table O.4, for each project, a sample of the specified size will be sampled from a frame of the corresponding number of units. Because the necessary number in each stratum was rounded up to the next whole number, the numbers in Table O.4 add to slightly more than the targets of 68 units for inspection and 1,009 occupants. 
Table O.4. Housing Unit Sample Sizes Allocated Across the Sixteen WIPP Projects

\begin{tabular}{|c|c|c|c|}
\hline WIPP Project & $\begin{array}{l}\text { Number } \\
\text { of Units }\end{array}$ & $\begin{array}{l}\text { Sample } \\
\text { Size for } \\
10-90\end{array}$ & $\begin{array}{l}\text { Sample } \\
\text { Size for } \\
03-95\end{array}$ \\
\hline Green and Healthy Homes Initiative & 220 & 6 & 81 \\
\hline In Home Monitoring & 2,500 & 6 & 81 \\
\hline Performance-based Revolving Loan Pilot... & 450 & 2 & 29 \\
\hline Energy Pioneer Solutions Weatherization... & 250 & 6 & 81 \\
\hline SAHF Energy Performance Contracting... & 2,500 & 2 & 28 \\
\hline Connecticut Green and Healthy Homes... 2 & 2,285 & 7 & 101 \\
\hline Streamlined Weatherization Improvements... & .. 800 & 5 & 68 \\
\hline Leveraging Smart Grid Technology to... & 550 & 2 & 25 \\
\hline YouthBuild USA Weatherization... & 998 & 4 & 48 \\
\hline Habitat for Humanity Weatherization... & 1,770 & 7 & 101 \\
\hline Community Environmental Center... & 1,200 & 7 & 101 \\
\hline Building Deep Efficiency... & 425 & 2 & 21 \\
\hline Project with the City matching federal... & 300 & 3 & 35 \\
\hline Tackling the Problem of Weatherizing... & 1,700 & 5 & 64 \\
\hline Replicable, Innovative, Sustainable... & 2,240 & 7 & 101 \\
\hline People Working Cooperatively... & 340 & 4 & 51 \\
\hline All Projects & 18,528 & 75 & 1,016 \\
\hline
\end{tabular}

\section{Utility Bill Analysis}

In each of the sixteen WIPP projects, billing data or equivalent or better energy use data will be collected for each weatherized unit. The billing data--for all weatherized units--can be obtained in conjunction with the DF4 surveys (lists of units and buildings weatherized). Comparison data will be collected from an equal or greater number of units from the comparison (i.e., not weatherized) group data collected in the retrospective evaluation. Units will be matched as closely as possible by city, heating and cooing degree days (when not matched on city), size, construction type, and other characteristics. The billing data for all sixteen projects will be analyzed by the evaluation team.

\section{Staff Survey}

A survey of staff members, analogous to the occupant survey, will be conducted for the sixteen WIPP projects. As in the occupant survey, a sampling frame (in this case a list of project staff members) has not yet been compiled but will be compiled for each project, and the overall sample will be allocated to the individual projects in proportion to federal funding. Table O.4, for staff members, is analogous to Table O.2 for weatherized units: 
Table O.5. WIPP Projects, Jobs Created or Retained, and Federal Funding

\begin{tabular}{|c|c|c|c|}
\hline WIPP Project & $\begin{array}{l}\text { Number } \\
\text { of Jobs }\end{array}$ & $\begin{array}{l}\text { Federal } \\
\text { Request (\$) }\end{array}$ & $\begin{array}{l}\text { Percent of } \\
\text { Total Request }\end{array}$ \\
\hline Green and Healthy Homes Initiative & 96 & $2,400,000$ & 12.64 \\
\hline In Home Monitoring & 120 & $2,400,000$ & 12.64 \\
\hline Performance-based Revolving Loan Pilot... & 38 & 850,000 & 4.48 \\
\hline Energy Pioneer Solutions Weatherization... & 25 & $2,400,000$ & 12.64 \\
\hline SAHF Energy Performance Contracting... & 123 & 810,000 & 4.27 \\
\hline Connecticut Green and Healthy Homes... & 593 & $3,000,000$ & 15.81 \\
\hline Streamlined Weatherization Improvements... & 25 & $2,000,000$ & 10.54 \\
\hline Leveraging Smart Grid Technology to... & 16 & 720,000 & 3.79 \\
\hline YouthBuild USA Weatherization... & 74 & $1,400,000$ & 7.38 \\
\hline Habitat for Humanity Weatherization... & 168 & $3,000,000$ & 15.81 \\
\hline Community Environmental Center... & 63 & $3,000,000$ & 10.00 \\
\hline Building Deep Efficiency... & 28 & 600,000 & 2.00 \\
\hline Project with the City matching federal... & 10 & $1,015,746$ & 3.39 \\
\hline Tackling the Problem of Weatherizing... & 85 & $1,898,938$ & 6.33 \\
\hline Replicable, Innovative, Sustainable... & 169 & $3,000,000$ & 10.00 \\
\hline People Working Cooperatively... & 673 & $1,500,000$ & 5.00 \\
\hline $180 \mathrm{~J}$ & & $18,980,000$ & 100.00 \\
\hline
\end{tabular}

A table such as Table O.6 (analogous to Table O.4) can be used to suggest a sample size for sampling from the (approximately) 2,306 staff members. The table gives the sample sizes needed to estimate a proportion (e.g., proportion of customers who say they are satisfied) to within the specified margin of error with the specified statistical confidence.

Table O.6. Suggested Sample Sizes for Sampling Staff Members

\begin{tabular}{|c|c|c|c|}
\hline $\begin{array}{l}\text { Statistical } \\
\text { Confidence }\end{array}$ & $\begin{array}{l}\text { Margin } \\
\text { of } \\
\text { Error }\end{array}$ & $\begin{array}{l}\text { Infinite } \\
\text { Population } \\
\text { Sample Size }\end{array}$ & $\begin{array}{l}\text { Corrected } \\
\text { Sample Size } \\
\text { (For Finite } \\
\text { Population } \\
\text { of } 2,306 \text { ) }\end{array}$ \\
\hline \multirow[t]{3}{*}{90} & 0.10 & 68 & 66 \\
\hline & 0.05 & 271 & 243 \\
\hline & 0.03 & 752 & 567 \\
\hline \multirow[t]{3}{*}{95} & 0.10 & 97 & 93 \\
\hline & 0.05 & 385 & 330 \\
\hline & 0.03 & 1,068 & 730 \\
\hline
\end{tabular}


Staff survey interviews are not as critical to the evaluation as occupant surveys. (Presumably the staff will also be studied in assessing the affects of the ARRA.) Therefore, for the staff survey, we use the 90\% statistical confidence and .05 margin of error criteria, which suggests a sample size of 243. Again the overall sample is allocated across the sixteen WIPP programs in proportion to funding. Table O.7 shows the allocated sample sizes (rounded up to the next whole number) for the individual projects.

Table O.7. Staff Sample Sizes Allocated Across the Sixteen WIPP Projects

\begin{tabular}{lcc} 
& & Sample \\
WIPP Project & $\begin{array}{l}\text { Number } \\
\text { of Jobs }\end{array}$ & $\begin{array}{l}\text { Size for } \\
\mathbf{0 5 - 9 0}\end{array}$ \\
\hline Green and Healthy Homes Initiative & 96 & 20 \\
In Home Monitoring & 120 & 20 \\
Performance-based Revolving Loan Pilot... & 38 & 7 \\
Energy Pioneer Solutions Weatherization... & 25 & 20 \\
SAHF Energy Performance Contracting... & 123 & 7 \\
Connecticut Green and Healthy Homes... & 593 & 25 \\
Streamlined Weatherization Improvements... & 25 & 17 \\
Leveraging Smart Grid Technology to... & 16 & 6 \\
YouthBuild USA Weatherization... & 74 & 12 \\
Habitat for Humanity Weatherization... & 168 & 25 \\
Community Environmental Center... & 63 & 25 \\
Building Deep Efficiency... & 28 & 5 \\
Project with the City matching federal... & 10 & 9 \\
Tackling the Problem of Weatherizing... & 85 & 16 \\
Replicable, Innovative, Sustainable... & 169 & 25 \\
People Working Cooperatively... & 673 & 13 \\
---------------------------------------------------------------------- \\
All Projects & 2,306 & 252
\end{tabular}

\section{O.4 SUSTAINABLE ENERGY RESOURCES FOR CONSUMERS SAMPLING}

As discussed above, all 92 SERC grantees will be included in the sub-sample of 450 subgrantees that will be asked to provide information re weatherized homes and utility account information.

\section{O.5 DEFERRAL STUDY SAMPLING}

Ten states and ten agencies will be sampled for this a deferral study, and the deferral incidence and process (e.g., quality assurance) will be examined for a random sample of weatherized units from each sampled agency. The number of units to be sampled is (at least tentatively) specified in the draft Evaluation Plan as "200 occupants engaged in the deferral process." Deferral rates encountered by some agencies are reckoned by agency staff to be as high as twenty percent. 
Agency selection will be purposive for agencies for which deferrals are understood to be troublesome. Inferences will therefore be restricted to the ten sampled agencies. However the ten sampled agencies will serve collectively as anecdotal evidence about the extent to which deferrals can be a problem, and the overall deferral rate for the ten sampled agencies will thus be a parameter of primary interest in the analysis. Since we'll ask substantially the same question to each of the agencies, we need to develop a formal OMB 83-i submission for this. Note that if (1) we sampled only nine agencies instead of ten, and (2) the information about the deferral could be obtained directly from agency staff, without posing additional questions to home owners, we might be able to circumvent the OMB submission. Whether or not we pursue such an approach, however, we still need to decide about how many of each agency's units to sample for the deferral analysis. That statistical question is considered in the next paragraph.

The specifications can be tweaked, of course, but suppose for the moment that we would like to estimate the overall deferral rate for the ten agencies to within five percentage points with $90 \%$ confidence. Given that deferral rates encountered by some agencies are reckoned by agency staff to be as high as $20 \%$, suppose that the deferral rate for any sampled agency is no higher than $25 \%$. This implies that the variance of the overall deferral rate estimate is maximum when the deferral rate is $25 \%$ for each sampled agency. That is, the worst-case (i.e., maximum) variance of the overall deferral rate estimate is $.25(1-.25) /(10 * n)$, where $n$ is the number of units sampled per agency. Hence, letting $\mathrm{Z}=1.645$ (95th percentile of the standard normal distribution), the worst-case required sample size for the 5-percentage-point-90\%-confidence specification is

$\mathrm{n}=\mathrm{Z} * \mathrm{Z} * .25(1-.25) /(10 *(.05) * * 2)=20.3$ units per agency.

So the sample size of 200 units seems reasonable.

\section{O.6 PERSISTENCE STUDY SAMPLING}

\section{Sample Size for the Persistence Study}

The methodological approach is to base the Persistence Study on a comparison of a treatment group of homes weatherized circa 1995 with a control group of homes selected from recent WAP-applicant homes to match the treatment group on age and other characteristics. The primary comparison measurements will be blower-door test cfm50 values, and we'll base sample size calculations on those measurements. As no circa-1995 blower-door tests were conducted for the controls, the comparison will be based on blower-door tests conducted currently (i.e., circa 2011-2012).

We now have pre and post-weatherization blower-door measurements from the Retrospective Evaluation's IAQ study homes, which can be used as pilot data for the sample size calculations. The IAQ study blower-door data is summarized in the following table:

\begin{tabular}{llll}
\multicolumn{4}{c}{ Table O.8. IAQ Study Pre and Post-Weathe } \\
Variable & N & Mean & Std Dev \\
- & ------- & \\
Pre-Wx cfm50 & 2,324 & $3,466.7$ & $1,829.28$ \\
Post-Wx cfm50 & 2,251 & $2,362.5$ & $1,003.41$
\end{tabular}


Difference $\quad 2,220 \quad-1,093.9 \quad 1,177.64$

The treatment-control group matching for the Persistence Study could be conducted in two ways: (i) The treatment and control homes could be matched on a case-by-case basis, with the data then analyzed with a paired t-test, or (ii) the treatment and control homes could be matched more loosely, with age and other distributions of the two groups kept the same, but without case-by-case matching or even the same sample sizes in the two groups, with the data then analyzed with a two-sample t-test. If case-by-case matching can be done precisely, which will be the initial goal of this study, and with many characteristics, then approach (i) may lead to more precise comparisons. However, the looser approach (ii) is more likely to be reasonable. Furthermore we have pilot study data to support approach (ii) only. Therefore we assume approach (ii) for reckoning sample sizes. If approach (i) is ultimately used instead, the sample size suggested here may be a little bigger than necessary.

The current, residual effect of the 1995 weatherizations will thus be measured as the difference between the averages of the current blower-door measurements for the 1995-weatherized (treatment) homes and the pre-weatherization control homes. Persistence can then be estimated by comparing that difference to the average of either the 1995 post-pre blower-door differences for the treatment homes or the current post-pre blower-door difference for the control homes. The average of the current differences for the control homes today is probably a better reference, however, as blower-door tests conducted in 1995 are considered to be less accurate than those tests conducted today. Presently, in lieu of control home differences, we can us the Retrospective Evaluation's IAQ study for pilot data for calculating sample sizes. IAQ Study blower-door cfm50 flow rates were reduced by $1093.9 \mathrm{cfm}$ on average after weatherizations (Table O.8). Fifteen years after weatherization we'd expect the effect of the weatherization to be reduced from its initial effect. Thus we'd like to detect a mean difference delta between the treatment and control blower-door cfm50 measurements on the order of, say, delta $=250,500$, or $750 \mathrm{cfm}$.

To determine a sample size, we consider a statistical test of the null hypothesis Ho: delta $=0$ vs the alternative hypothesis $\mathrm{H} 1$ : delta $>0$, with the requirements that (1) if delta $=0$, then the probability alpha that the test rejects (i.e., finds a difference) is low, say alpha $=.10$ or .05 , and (2) if delta $=250,500$, or 750 $\mathrm{cfm}$, then the probability beta that the test rejects is high, say .90 or .95 . We use a two-sample z-test as an approximation to the two-sample t-test.

Let $\mathrm{Nw}$ and $\mathrm{Nc}$ denote the numbers of treatment and control homes (possibly but not necessarily the same), and let rho=Nw/Nc. Let $\mathrm{Vw}$ and $\mathrm{Vc}$ denote the variance of the treatment and control cfm50's respectively. Then by straightforward calculation the smallest Nw that satisfies conditions (1) and (2) is

$\mathrm{Nw}=(\mathrm{Vw}+\mathrm{rho} * \mathrm{Vc}) *\left(\left(\mathrm{z} \_\right.\right.$beta $-\mathrm{z} \_$alpha $) /$delta $) * * 2$.

where z_alpha and z_beta are the alpha and beta quantiles of the normal distribution. Substituting the squares of the Pre-Wx cfm50 and Post-Wx cfm50 standard deviations in Table O.8 for Vc and Vw respectively then leads to the approximate necessary and sufficient sample sizes in Table 2 below. The only values of rho considered in the table are $0.5,1$, and 2 , although other values might also be reasonable. The total number of homes, $\mathrm{N}=\mathrm{Nw}+\mathrm{Nc}$, is also shown, in the last column of the table.

The WAP ARRA-Period Evaluation Plan calls for a Persistence Study treatment group of approximately $\mathrm{Nw}=125$ single family and mobile homes, and a corresponding control group. A total sample size of 250 corresponds to about the middle of the table: delta $=500 \mathrm{cfm}$, alpha $=.10$, and beta $=.90$. For this delta, alpha, and beta, the required total (for both treatment and control) sample sizes are $211(\mathrm{Nw}=70$, $\mathrm{Nc}=141), 228(\mathrm{Nw}=114, \mathrm{Nc}=114)$, and $303(\mathrm{Nw}=202, \mathrm{Nc}=101)$ for $\mathrm{rho}=0.5,1$, and 2, respectively. For 
delta $=500 \mathrm{cfm}$ and alpha and beta either .05 and .90 or .10 and .95 , a sample size of approximately 276 $(\mathrm{Nw}=92, \mathrm{Nc}=184)$ would be needed for $\mathrm{rho}=0.5$.

Table 0.9. Approximate Necessary and Sufficient Sample Sizes for Persistence Study delta

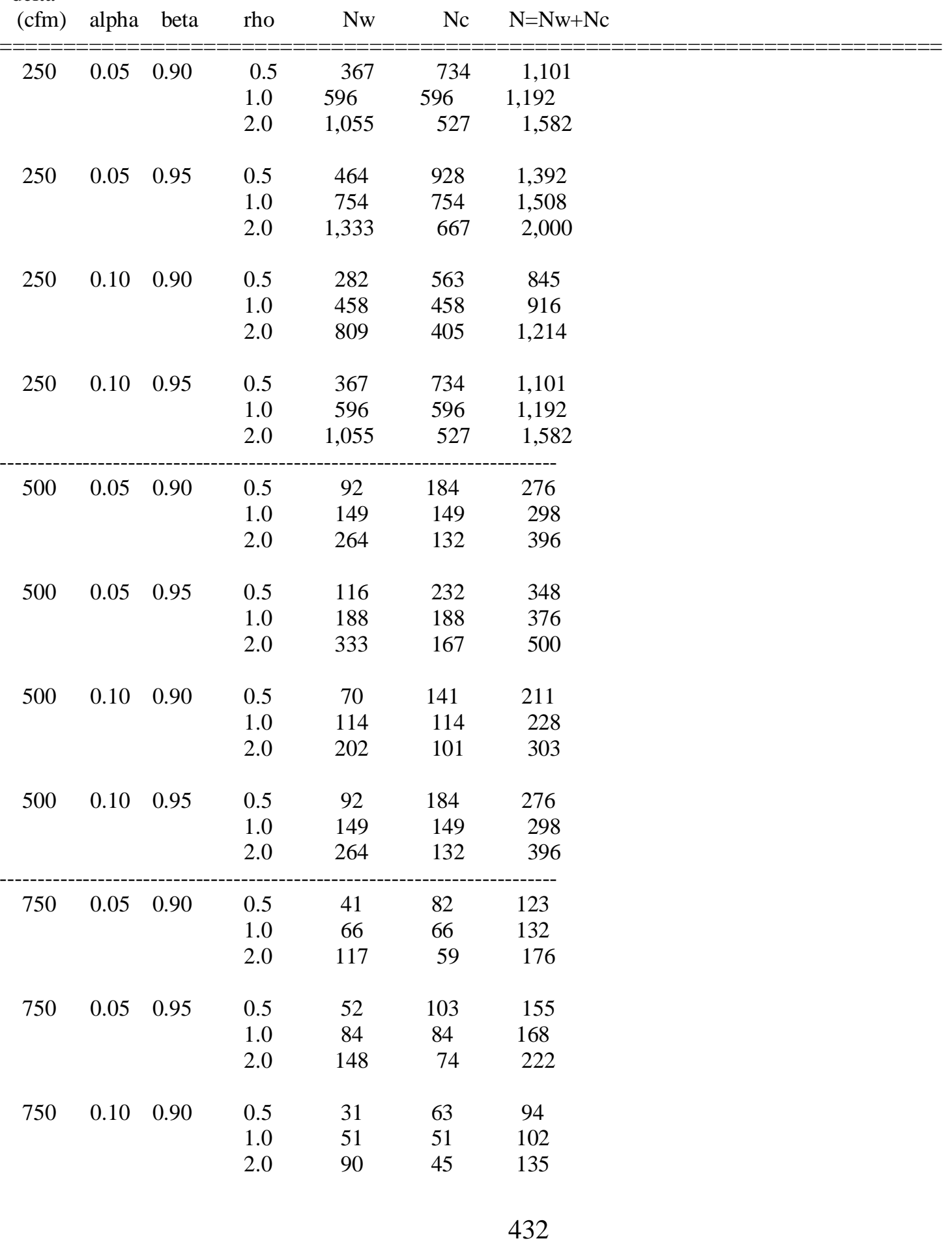




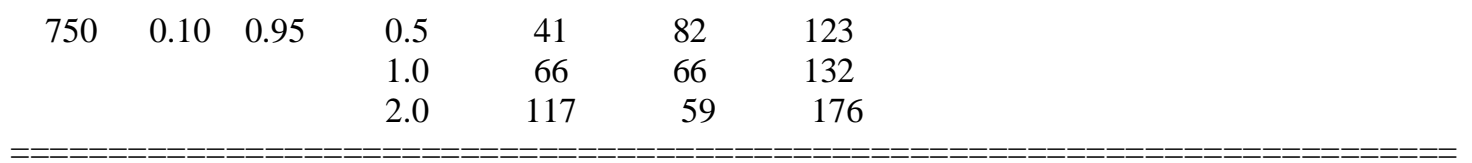

\section{O.7 ADDITIONAL NOTES}

The following notes taken from OMB guidance (OMB 2006) identify several additional issues of key importance in developing the evaluation plan.

\section{O.7.1 Pretest/Pilot Studies}

According to OMB (2006), "Agencies should always consider conducting pretests (small trials of the measurement process) or pilot studies (larger trials yielding statistical information) when planning for a new information collection or changing methods and procedures for an ongoing survey. These kinds of tests may provide critical information necessary to ensure the quality of the data and smoothness of operations needed in the full-scale information collection. They can provide essential information to the agency and result in higher data quality than would have been achieved without them and may be the only vehicle for measuring the effects of different changes an agency is considering implementing. Thus, agencies will need to weigh the importance and use of pretests against the time and resources needed to conduct them."

The proposed evaluation uses the 1990 evaluation, which it is intended to emulate, and several other studies (Blasnik, 2006; Cavallo and Mapp, 2000; Levins and Ternes, 1994; Ternes and Levins, 1992) as a pilot studies.

The OMB (2006) guidance continues, "It is important that agencies test their survey questionnaires in all modes that they plan to use to collect information for the full-scale survey (see section on Questionnaire Design). Usability testing of computer survey instruments should also be included as part of questionnaire pretesting to identify problems either interviewers or respondents may have with the instrument...."

The survey instruments for the proposed evaluation are being pre-tested with internal and (fewer than ten) external personnel. They are also being peer-reviewed by subject matter experts.

\section{O.7.2 Influential information}

According to OMB (2006, Question 18), information is considered "influential" if "an agency can reasonably determine that dissemination of the information will have or does have a clear and substantial impact on important public policies or important private sector decisions," and agencies should "hold the information they designate as 'influential' to a higher standard of reproducibility and transparency than information that is not defined as influential."

The information collected for the proposed WAP evaluation is thus "influential."

\section{O.7.3 Response rates}


According to OMB (2006), “An agency's justification for a survey response rate should reflect, at least in part, the intended use of the data. For example, surveys collecting influential information or information that will otherwise have a substantial impact on an agency's programs or policies should be designed to minimize all sources of survey error (see question \#20), including nonresponse bias...Agencies need to document in their ICRs the importance and use of the information and the methods they will use to achieve acceptable response rates for their collections... ICRs for surveys with expected response rates of 80 percent or higher need complete descriptions of the basis of the estimated response rate and a detailed description of steps that will be taken to achieve the expected response rate..."

In general, response rates in the proposed evaluation are expected to be high (much higher than 80\%), because weatherization recipient contact information will be provided by weatherization agencies, and because recipients have received weatherization services. For various reasons including legal issues, utilities in the past have not always provided customer billing data requested by agencies. Although this is a form nonresponse, because it is independent of performance by the agencies in weatherizations, it is reasonable to treat it as nonbiasing and therefore not requiring adjustment in the analysis. In general, nonresponse is not expected to be a problem in the analysis of the weatherization data.

The OMB 83-i (www.whitehouse.gov/omb/inforeg/83i-fill.pdf) form requires a description of "methods to maximize response rates and to deal with issues of non-response." Methods that will be employed to accomplish this include

- contacting an appropriate person at each utility to identify and smooth out the data collection process

- planning the billing data requests so that data for multiple housing units and buildings are requested from each utility at the same time

- requesting billing data at regular intervals to reduce the chance that the utilities will not be able to provide data because it has been archived and no longer readily accessible, but limit the number of such requests so that utilities have to provide data just several times during the course of the evaluation

- soliciting assistance from utility regulatory commissions and similar organizations as needed.

\section{O.8 REFERENCES}

Brown, Marilyn A., Berry, Linda G., Balzer, Richard A., and Faby, Ellen (1993), "National Impacts of the Weatherization Assistance Program in Single-Family Dwellings," ORNL/CON-326, Oak Ridge National Laboratory, Oak Ridge, Tennessee, May, 1993 (http://weatherization.ornl.gov/pdf/ORNL_CON326.pdf).

OMB (2006) "Questions and Answers When Designing Surveys for Information Collections," Office of Information and Regulatory Affairs, Office of Management and Budget, http://www.whitehouse.gov/omb/inforeg/pmc_survey_guidance_2006.pdf, January 2006.

Iowa Bureau of Weatherization (2005), "Statistics," Innovative Outstanding Weatherization Assistance News, Volume 3, Issue 2. (http://www.dcaa.iowa.gov/bureau_weath/April2005.pdf) 
Levins, William. P., and Ternes, Mark P. (1994). "Impacts of the Weatherization Assistance Program in Fuel-Oil Heated Houses," ORNL/CON-327, October 1994

(http://weatherization.ornl.gov/pdf/ORNL_CON_327.pdf).

Sharp, T. (1994), "The North Carolina Field Test: Field Performance of the Preliminary Version of an Advanced Weatherization Audit for the Department of Energy's Weatherization Assistance Program.," ORNL/CON-362, June 1994 (http://weatherization.ornl.gov/pdf/ORNL_CON-362.pdf). 


\section{APPENDIX P. BUILDING TYPE DEFINITIONS}

The energy analyses methods are dependent on the building/housing type. Throughout the evaluation, housing units will be categorized into four building types as defined below:

- Single-family - A single-family housing unit, detached or attached, provides living space for one family or household and is contained within walls extending from the basement (or the ground floor, if there is no basement) to the roof. An attached house, such as a townhouse, row house, and duplex, is considered a single-family housing unit as long as it (a) is not divided into more than one housing unit, (b) there is no household living above another one within the walls extending from the basement to the roof to separate the units, and (c) it has an independent outside entrance.

- Mobile home - A mobile home is built on a movable chassis, moved to the site, and typically placed on a permanent or temporary foundation. If rooms are added to the structure, it is considered a mobile home if the added floor area is less than the mobile home's original floor area; otherwise, it is a single-family housing unit. A manufactured house assembled on site is a single-family housing unit, not a mobile home.

- Small multifamily - A small multifamily housing unit is in a building with two to four housing units (i.e., in a building structure that is divided into living quarters for two, three, or four families or households in which one household lives above or beside another). This category includes houses originally intended for occupancy by one family (or for some other use) that have since been converted to separate dwellings for two to four families. Typical arrangements in these types of living quarters are separate apartments downstairs and upstairs or one apartment on each of three or four floors.

- $\quad$ Large multifamily - A large multifamily housing unit is in a building with five or more housing units (i.e., in a building structure that contains living quarters for five or more families or households and in which one household lives above or beside another).

These definitions are consistent with those used in the Residential Energy Consumption Survey conducted by the DOE Energy Information Agency with one exception. Mobile homes with rooms added to the structure are considered to be single-family housing units in RECS in all cases. Mobile homes weatherized by the Program often have small rooms added to them (e.g., small rooms added to the front or back doors, rooms that connect to and extend the living room). Mobile homes with room additions will still be classified as mobile homes in this evaluation as long as the floor area of the additions is less than the floor area of the original mobile home for two reasons. First, these mobile homes are still treated in the Program using the diagnostic approaches, weatherization measures, and installation techniques unique to mobile homes. Second, the majority of Program expenditures are typically directed at improvements to the mobile home structure rather than the room additions. If room additions exceed the floor area of the original mobile home, then the house should be classified as a single-family housing unit.

These definitions are also generally consistent with those used in the 1990 National evaluation. The one uncertainty is with mobile homes because it is not known how mobile homes were defined in the 1990 National evaluation. However, it is believed that the categorization of mobile homes by weatherization agencies is more consistent with the definition developed for this evaluation than the RECS definition. Also, the 1990 National evaluation made a distinction between attached and detached single-family housing units that will not be made in this evaluation. 
The Program uses three rather than four categories of housing unit types in its quarterly reporting and other functions. Mobile homes and large multifamily categories are conceptually the same as those defined above for this evaluation. However, the single-family category as defined by the Program includes the small multifamily category as defined for this evaluation. It is important to have a clear definition of small multifamily housing units and a separate category for these units for two reasons:

1. Small multifamily housing units were often mistakenly identified as belonging to the large multifamily housing category by agencies in the 1990 National evaluation. This led to considerable sampling and analysis problems. Providing a separate category for small multifamily housing units should help avoid this identification problem.

2. The energy analysis methods and approaches to be employed to study single family homes are different and/or will be applied differently than those for large multifamily units. The analyses methods and approaches for small multifamily housing units may also be unique because they have characteristics of both of these other two groups of houses. 


\section{APPENDIX Q. UNIT/BUILDING LEVEL ENERGY ANALYSIS}

\section{Q.1 SINGLE-FAMILY HOUSES AND MOBILE HOMES}

Natural gas billing data will be collected on homes heated by natural gas as part of the comprehensive billing data sample. These data will be analyzed using the Princeton Scorekeeping Method (PRISM, Fels et al., 1995) to calculate annual, weather-normalized pre- and post-weatherization energy consumptions and energy savings for each individual home. Since natural gas can be used in these homes for water heating, cooking, and possibly clothes drying in addition to space heating, these energy consumptions and savings represent both space heating and baseload uses combined (i.e., natural gas consumption and savings for space heating will not be calculated separately from baseload).

The Network Planning Committee felt that the energy consumption and savings of houses heated by fuel oil and propane are critical to the evaluation and need to be measured. Billing/delivery data are usually insufficient for a PRISM type analysis because fuel oil and propane are typically delivered just several times a year to a house at infrequent intervals, and because household storage tanks are not always filled at each delivery (so that the amount of fuel delivered is not necessarily equal to consumption). Therefore, energy use in these homes must be specially monitored by submetering the space heating system or collecting more accurate and frequent delivery data. If submetered fuel oil and propane use along with indoor and outdoor temperatures are collected on houses heated by these fuels in the fuel-oil and propane monitored sample, then an energy use model will be developed for each house by regressing weekly or daily consumptions (the dependent variable) vs. the temperature difference between the indoors and outdoors (the independent variables) for each consumption period. Annual, weather-normalized pre- and post-weatherization energy consumptions and energy savings will be calculated using the regression models, historical weather for each home location, and a standard indoor temperature (e.g., 68 or $70^{\circ} \mathrm{F}$ ) or the actual indoor temperature for each house. Uncertainty statistics and indicators of model reliability comparable to those calculated by PRISM will also be calculated. Since fuel oil and propane are not typically used in single-family or mobile homes for water heating or cooling, the annual energy consumptions and savings based on the analysis of submetered fuel oil and propane use typically represent just space-heating use. If more accurate and frequent delivery data are collected, then these data will be analyzed using PRISM or a simply calculating the ratio of energy use to heating degree days for the monitoring period.

Electricity billing data will be collected on all the homes sampled (not just those heated by electricity) as part of the billing data sample, fuel-oil and propane monitored sample, and hot climate submetered sample. These data will be analyzed using PRISM to calculate annual pre- and post-weatherization electricity consumptions and energy savings for each individual home. PRISM's model selection feature will be used to select the best PRISM model for each house (i.e., heating-only, cooling-only, or heating and cooling model). In homes heated by electricity, these electricity consumptions and savings include both space heating and baseload uses in addition to space cooling if employed. In non-electrically heated homes, these energy consumptions and savings include baseload uses, space cooling if employed, and any supplemental space heating that is done using electricity. Electricity consumptions and savings will not be broken down into their separate heating, cooling, and baseload components.

Although the Network Planning Committee felt that submetering and subsequent analysis of a sample of natural gas and electrically heated houses could improve accuracy and add context to the PRISM billing data analysis results, such sampling and analysis is not currently planned because of the costs that would be required. 


\section{Q.2 LARGE MULTIFAMILY BUILDINGS}

The calculation of energy use and savings is complicated in large multifamily buildings for many reasons, including:

- some buildings have central building heating and/or hot water systems while in others each unit has its own heating (central apartment system or in-space heaters) and/or hot water system,

- the whole building is weatherized in some cases while in others only individual units are weatherized,

- $\quad$ some buildings have significant common areas (including recreation rooms, offices, and kitchens) while others have little or none,

- $\quad$ operating ventilation systems are present in some buildings and not in others,

- $\quad$ there are many billing meters in the building (especially those with individual heating systems) so rarely is there a complete and consistent set of data for all the meters (i.e., there is usually some gap in data for at least a few meters),

- $\quad$ occupancy turnover and vacancies can be prevalent, and

- many buildings use fuel oil which has the same problems with the delivery data as with single-family homes (i.e., fuel is delivered at infrequent and/or random intervals and the building storage tanks are not always filled at each delivery).

These complications can manifest themselves at different times during the analysis process, such as in estimating annual consumption, normalizing consumption to a per unit level, and/or aggregating the consumptions of various buildings or units together.

For the reasons outlined above, the process of calculating the energy use and savings in each multifamily building and determining how to include these values in the totals or averages with other multifamily buildings must be developed individually for each building. Although some basic analysis approaches are outlined below for the two primary building types that will be commonly encountered, experienced analysts will need to follow and analyze the data collected on each building individually since cookiecutter approaches will not work.

\section{Q.2.1 Buildings with central building heating systems}

In buildings with central building heating systems, a whole building energy analysis is usually required because the weatherization activity in such buildings usually focuses on the central heating system rather than just selected apartment units. A whole building energy analysis will be performed as follows:

1. Depending on which fuel is used by the central building heating system, natural gas billing data for the building's master meter or fuel-oil delivery data will be collected as part of the large multifamily billing data sample. These data will be analyzed using PRISM to calculate annual pre- and post-weatherization energy consumptions and energy savings for the building. These energy consumptions and savings represent either just space heating, space heating and hot water, or space heating and baseload (e.g., hot water, cooking) depending on the fuel and what other 
systems are connected to the master meter or fuel tank (e.g., central building hot water system, apartment stoves).

Although fuel-oil delivery data are usually insufficient for a PRISM type analysis in single family homes, there is a greater chance that such data can be analyzed for multifamily buildings, especially if several years of data can be collected, because deliveries may be more frequent (ratio of consumption to tank size may be greater) and/or fills may be more common.

As part of the monitored sample, fuel oil consumption will be specially monitored in some buildings either through submetering or collecting more accurate and frequent delivery data. Annual pre- and post-weatherization energy consumptions and energy savings for the building will be calculated using these data and PRISM if possible (if data during some non-heating periods can be collected) or using regression models and historical weather for each building (models developed by regressing weekly or daily consumptions vs. outdoor temperature or heating degree days).

2. Electricity billing data will be collected from all electric meters (building and apartment level) installed in the sampled buildings (not just those heated by electricity) as part of the billing data sample or fuel-oil and propane monitored sample. Apartment level data will be aggregated for each billing period and then analyzed using PRISM to calculate annual pre- and post-

weatherization electricity consumptions and energy savings for each building. Some refinements will be needed to account for missing data and/or apartments for which no billing data can be collected. The building electricity data will be analyzed similarly either separately or by aggregating it with the apartment level data. PRISM's model selection feature will be used to select the best PRISM model for each building (i.e., heating-only, cooling-only, or heating and cooling model). In buildings with central building heating systems, these electricity consumptions and savings include apartment-level baseload uses (possibly including hot water if the building has individual hot water systems in each apartment fueled by electricity), common area electricity consumption, space cooling if employed, and any supplemental space heating that is done using electricity. The electricity consumptions and savings will not be broken down into their separate heating, cooling, and baseload components.

3. Natural gas billing data will be collected from any other building and apartment level natural gas meters installed in the sampled buildings (other than the master meter supplying the central building heating system) as part of the billing data sample or fuel-oil and propane monitored sample. These data will be analyzed using PRISM in a manner similar to that for electric billing data. In buildings with central building heating systems, these natural gas consumptions and savings include apartment-level baseload uses (cooking and possibly hot water if the building has individual hot water systems in each apartment fueled by natural gas) and any common area consumption.

4. Building-level energy consumptions and savings calculated above will be divided by the number of units in the building to calculate unit-level values which will facilitate comparison and aggregation with other buildings. In addition, natural gas and fuel oil consumptions and savings will be added into one value.

The Inverse Modeling Toolkit (IMT) is a software program available from the American Society of Heating, Refrigerating, and Air Conditioning Engineers (ASHRAE) for calculating linear, changepoint linear, variable-based degree-day, multilinear, and combined regression models (Kissock, Haberl, and Claridge, 2004). As such, it offers an alternative approach to PRISM in the analysis presented above. The use of IMT in this evaluation will be investigated. Depending on analytical difficulties encountered 
with PRISM in the above analyses and the results of the IMT investigation, IMT will be used to supplement and/or supersede the PRISM analyses as warranted.

\section{Q.2.2 Buildings with apartment-level heating systems}

In buildings with apartment-level heating systems (e.g., central systems in the apartment, baseboard electric heaters), a whole building energy analysis will be performed if the whole building was weatherized. If just individual units in a multifamily building were weatherized, then the energy analysis will be performed on an apartment or unit basis. These two approaches are described below:

1. In buildings in which the whole building was weatherized, billing data will be collected as part of the large multifamily billing data sample for all building-level and apartment-level electricity meters and natural gas (if present) installed in the building (fuel oil is not usually used in such buildings). For each building, apartment-level and building-level electricity data will be aggregated for each billing period and then analyzed using PRISM to calculate annual buildinglevel pre- and post-weatherization electricity consumptions and energy savings. PRISM's model selection feature will be used to select the best PRISM model for each building (i.e., heating-only, cooling-only, or heating and cooling model). If natural gas is used in the building, the same procedure as used for electricity will be followed to calculate annual building level pre- and postweatherization natural gas consumptions and energy savings. Some refinements will be needed to account for missing data and/or apartments for which no billing data can be collected.

The electricity consumptions and savings calculated above represent space heating, space cooling, and baseload use (for the apartments and common areas combined) depending on the specific end uses that electricity is used for. Likewise, the natural gas consumptions and savings calculated above can represent space heating and/or baseload use. The energy consumptions and savings will not be broken down into their separate heating, cooling, and baseload components.

Building-level energy consumptions and savings calculated above will be divided by the number of units in the building to calculate unit-level values which will facilitate comparison and aggregation with other buildings. The use of IMT may be used to supplement and/or supersede the PRISM analyses as warranted.

2. In buildings in which just individual units were weatherized, annual energy consumptions and savings will be calculated as if they were single-family dwelling units (see Sect.3.2.1). Electricity billing data and natural gas billing data (if present) will be collected on such units as part of the large multifamily billing sample. These data will be analyzed using PRISM to calculate annual pre- and post-weatherization energy consumptions and energy savings for the individual dwelling (apartment) units. PRISM's model selection feature will be used to select the best PRISM model for each house when analyzing the electricity data (i.e., heating-only, cooling-only, or heating and cooling model).

Since natural gas (if present) can be used in these homes for water heating, cooking, and possibly clothes drying in addition to space heating, the natural gas consumptions and savings represent both space heating and baseload uses combined. In units heated by electricity, the electricity consumptions and savings include both space heating and baseload uses in addition to space cooling if employed. In non-electrically heated units, these energy consumptions and savings include baseload uses, space cooling if employed, and any supplemental space heating that is done using electricity. The electricity and natural gas consumptions and savings will not be broken down into their separate heating, cooling, and baseload components. 


\section{Q.3 SMALL MULTIFAMILY BUILDINGS}

Energy consumptions and savings in small multifamily buildings will be analyzed in a manner similar to that for large multifamily buildings (see Section D.2):

- Small multifamily buildings with central building heating systems or with apartment-level heating systems that were weatherized as a building - A whole building analysis will be performed because weatherization costs will likely be known at the building rather than unit level. Building level consumptions and savings will then be normalized to a per unit basis by dividing by the number of units in the building.

- Buildings in which just individual apartments are weatherized-A unit-level analysis will be performed.

This analysis approach will be applied primarily to electricity and natural gas billing data collected from the comprehensive billing sample. If fuel-oil consumption data are collected on small multifamily buildings as part of the monitored sample, then these data will be analyzed as described for single-family homes (see Sect. 3.2.1). 


\section{APPENDIX R. ORNL AGGREGATE MODEL}

ORNL's aggregate model applies the basic logic of the PRISM approach to billing and weather databases aggregated over many houses to determine an overall program effect. It was developed and will be used in the national evaluation to support and supplement the PRISM analysis when needed.

Many factors that often occur in the low-income homes that the Program serves can mask weather-related correlations with fuel usage. These include:

- $\quad$ periods of zero or below normal consumption because of service shutoff due to nonpayment, household vacancies, and equipment breakdowns;

- $\quad$ erratic use of heating and/or cooling equipment by occupants;

- $\quad$ undersized heating and/or cooling equipment that runs at full capacity after a threshold outdoor temperature is reached;

- $\quad$ behavioral and occupancy changes; and

- availability of just few months of data for a house before and/or after weatherization

Use of PRISM, which relies on a linear model of the relationship between weather and energy consumption, can lead to high model failure rates at the individual household level (e.g., low $\mathrm{R}^{2}$, high coefficient of variance on the normalized annual consumption estimate, unrealistic balance point temperature) because of these factors. Excluding large numbers of homes from the statistical analysis due to model failures likely introduces potential sample bias, making the measurement of representative Program impacts difficult because so many homes are eliminated. Although every effort will be made to reduce model failures (e.g., use of PRISM's flatness index, data collection design to ensure a year's worth of data before and after weatherization), an alternative approach is still needed.

The ORNL aggregate model examines and performs weather-normalizations on a group of houses to smooth out the confounding effects that occur at the individual house level. It is a simpler method than PRISM in that it does not assume that a linear model has to fit every house and does not attempt to produce house-specific savings estimates. Its advantages are that it can use "noisy" data and analyze data for a more complete and representative sample of houses. As a result, the ORNL aggregate model focuses on the overall Program (i.e., group) effect, rather than individual household savings, and reduces sample bias due to excessive exclusion of households from the analysis. 
PRISM and the ORNL aggregate model can be compared and contrasted as follows:

\section{PRISM}

- Assumes a linear model of the relationship between energy consumption and heating degree days for each individual house.

- $\quad$ For each house, energy consumption and heating degree days for multiple billing periods are used to determine the model coefficients for the house (i.e., $\forall$ and $\exists$ ).

- Regression performed for "all possible" reference temperatures, and reference temperature and subsequent model coefficients chosen that gives the highest model $\mathrm{R}^{2}$.

- $\quad$ For group of houses, total or average consumption or savings calculating by adding or average values for individual houses.

\section{ORNL Aggregate Model}

- $\quad$ Assumes a linear model of the relationship between energy consumption and heating degree days for a group of houses.

- $\quad$ For the group of houses, energy consumption and heating degree days over one time period for each house are used to determine the model coefficients for the group of houses (i.e., $\forall$ and $\exists$ ).

- $\quad$ A fixed reference temperature (e.g., $65^{\circ} \mathrm{F}$ ) is used for all houses to calculate heating degree days.

- $\quad$ For group of houses, total or average consumption or savings calculated directly from model. 


\section{R.1 PRISM}

The PRISM model can be written as:

$\mathrm{e}_{\mathrm{i}}=\forall+\exists \mathrm{X} \operatorname{hdd}_{\mathrm{i}}(\mathrm{t})$

Where:

$$
\begin{aligned}
& \mathrm{e}_{\mathrm{i}}=\text { average daily energy use (e.g., Btu/day) for billing period } \mathrm{i}, \\
& \forall=\text { average daily baseload (non-heating) energy use (e.g., Btu/day), } \\
& \exists=\text { heating slope (e.g., Btu/HDD), and } \\
& \text { hdd }_{\mathrm{i}}(\mathrm{t})=\text { heating degree days per day for billing period i calculated at balance point } \\
& \text { temperature } \mathrm{t}\left({ }^{\circ} \mathrm{F}\right) \text {. }
\end{aligned}
$$

Typically, energy consumption data and daily outdoor temperatures corresponding to each billing period are obtained for a house (preferably about 12 monthly billing periods over a year). Knowing the number of days in each billing period, PRISM converts these data into an average daily energy use $\left(\mathrm{e}_{\mathrm{i}}\right)$ and average daily heating degree days $\left[\mathrm{hdd}_{\mathrm{i}}(\mathrm{t})\right]$ for each billing period and then uses these average daily values to estimate three parameters for the house using linear least-squared regression techniques: the average daily baseload energy use $(\forall)$, heating slope $(\exists)$, and balance point temperature (t) that produces the highest correlation coefficient $\left(\mathrm{R}^{2}\right)$. The normalized annual energy consumption (NAC) for the house can then be calculated using these estimated parameters as follows:

$\mathrm{NAC}=(\forall \mathrm{X} 365.25)+\left(\exists X \operatorname{HDD}_{\mathrm{o}}\left(\mathrm{t}_{\mathrm{o}}\right)\right)$

Where:

$$
\begin{aligned}
& \text { NAC }=\text { normalized annual energy consumption }(\text { e.g., Btu }) \text {, and } \\
& \operatorname{HDD}_{\mathrm{o}}\left(\mathrm{t}_{\mathrm{o}}\right)=\text { annual heating degree days calculated at the optimum balance point } \\
& \text { temperature } \mathrm{t}_{\mathrm{o}}\left({ }^{\circ} \mathrm{F}\right) \text { estimated by PRISM. }
\end{aligned}
$$

When data are available before and after a house is weatherized, the NAC before weatherization (NAC $\left.\mathrm{pre}_{\text {p }}\right)$ and after weatherization $\left(\mathrm{NAC}_{\text {post }}\right)$ can be calculated, and the normalized annual energy savings (NAS) for the house can be determined by:

$$
\mathrm{NAS}=\mathrm{NAC}_{\text {pre }} ! \mathrm{NAC}_{\text {post }}
$$

Where:

NAS $=$ normalized annual energy savings,

$\mathrm{NAC}_{\text {pre }}=$ normalized annual energy consumption before weatherization, and

$\mathrm{NAC}_{\text {post }}=$ normalized annual energy consumption after weatherization . 
The average per household savings for a group of houses can be estimated using the NAS calculated for each house individually by:

$$
\mathrm{AGS}=\left(3 \mathrm{NAS}_{\mathrm{i}}\right) / \mathrm{n}
$$

Where:

$$
\begin{aligned}
& \text { AGS = average group savings, } \\
& \text { NAS }_{\mathrm{i}}=\text { normalized annual energy savings for house } \mathrm{i} \text {, and } \\
& \mathrm{n}=\text { number of houses used in the summation. }
\end{aligned}
$$

If data are available for a group of control homes, the net savings of a weatherized group can be calculated by:

$$
\text { Net savings }=\mathrm{AGS}_{\text {weatherized }} ! \mathrm{AGS}_{\text {control }}
$$

Where:

$$
\begin{aligned}
& \mathrm{AGS}_{\text {weatherized }}=\text { average group savings of the weatherized houses, and } \\
& \mathrm{AGS}_{\text {control }}=\text { average group savings of the control houses. }
\end{aligned}
$$

In Eqs. 1-5, statistical uncertainties associated with estimated parameters and calculated values can be determined using normal statistical procedures.

\section{R.2 AGGREGATE PRISM}

An aggregate version of PRISM exists in which a linear model of energy use vs. heating degree days is fit to a group of houses rather than to houses individually. In this case, each house must have the same number of billing periods and the billing periods must coincide for each house (e.g., bills were read on the 15th of each month for 12 months for each house), and all the houses must be in the same geographic area so that the heating degree days for the houses are the same. The energy consumption data for each billing period are averaged and used with Eq. 1 so that the $\forall$ and $\exists$ that are estimated represent an average house in the group. The NAC and the NAS for an average house can be calculated using Eqs. 2 and 3; in this case, the NAS is equivalent to the average group savings calculated using Eq. 4 for houses that were analyzed individually.

\section{R.3 ORNL AGGREGATE MODEL}

The PRISM model described by Eq. 1 above could be rewritten slightly as:

$$
\mathrm{E}_{\mathrm{i}}=\forall \mathrm{X} \mathrm{D}_{\mathrm{i}}+\exists \mathrm{X} \operatorname{HDD}_{\mathrm{i}}(\mathrm{t})
$$

Where:

\footnotetext{
$\mathrm{E}_{\mathrm{i}}=$ energy use (e.g., Btu) for billing period $\mathrm{i}$,

$\forall=$ average daily baseload (non-heating) energy use (e.g., Btu/day),

$\mathrm{D}_{\mathrm{i}}=$ number of days in billing period $\mathrm{i}$,

$\exists=$ heating slope (e.g., Btu/HDD), and

$\mathrm{HDD}_{\mathrm{i}}(\mathrm{t})=$ heating degree days for billing period $\mathrm{i}$ calculated at balance point temperature $\mathrm{t}\left({ }^{\circ} \mathrm{F}\right)$.
} 
Note that $E_{i}$ and $\operatorname{HDD}_{i}(t)$ are energy use and heating degree days for billing period $i$, whereas $e_{i}$ and hdd in Eq. 1 are average daily values for billing period $i\left(e_{i}=E_{i} / D_{i}\right.$ and $\left.h d d_{i}(t)=H_{D D}(t) / D_{i}\right)$.

Data for an individual house could be applied to this model as before.

The ORNL aggregate model modifies Eq. 6 so that it can be applied to a group of houses simultaneously rather than to houses individually. The model is:

$$
\mathrm{E}_{\mathrm{i}}=\forall \mathrm{X} \mathrm{D}_{\mathrm{i}}+\exists \mathrm{X} \mathrm{HDD}_{\mathrm{i}}(65)
$$

Where:

$$
\begin{aligned}
& \mathrm{E}_{\mathrm{i}}=\text { energy use (e.g., Btu) for house i over some time period, } \\
& \forall=\text { average daily baseload (non-heating) energy use (e.g., Btu/day), } \\
& \mathrm{D}_{\mathrm{i}}=\text { number of days in the time period for house i, } \\
& \exists=\text { heating slope (e.g., Btu/HDD), and } \\
& \mathrm{HDD}_{\mathrm{i}}(65)=\text { heating degree days over the time period for house i calculated at a balance } \\
& \text { point temperature of } 65^{\circ} \mathrm{F} .
\end{aligned}
$$

Note that the subscript $i$ in Eq. 7 identifies different houses, whereas the subscript $i$ in Eq. 6 identifies different billing periods for the same house. Also note that the ORNL aggregate model uses heating degree days calculated at a fixed balance point temperature of $65^{\circ} \mathrm{F}$ for all houses, whereas PRISM calculates a house-specific balance point temperature.

To apply the ORNL model, the following three values must be known for each house: the energy use over a given time period, the number of days in the time period, and the number of heating degree days in the time period (calculated at the same balance point temperature of $65^{\circ} \mathrm{F}$ for each house). Typically, monthly billing data for each house are aggregated to obtain a single set of values for the house (e.g., 11 monthly bills for a house are combined so that the energy use, the number of days, and the number of heating degree days in the 11-month period are known for that house). The time periods and the length of the time periods do not need to be the same for each house. Houses do not need to be geographically constrained; houses from one area can be combined with houses from another area as long as the location appropriate heating degree days are calculated for the time period associated with each house and at the same base temperature.

These three values for many houses are used to estimate the average daily baseload energy use $(\forall)$ and heating slope $(\exists)$ for an average house in the group using least-squared regression techniques. A NAC for an average house in the group at a selected geographical location can then be calculated by:

$$
\mathrm{NAC}=\forall \mathrm{X} 365.25+\exists \mathrm{X} \mathrm{HDD}_{\mathrm{o}}(65)
$$

Where:

$\mathrm{NAC}=$ normalized annual energy consumption (e.g., Btu), and

$\mathrm{HDD}_{\mathrm{o}}(65)=$ annual heating degree days for the chosen location calculated at a balance point temperature of $65^{\circ} \mathrm{F}$.

By aggregating/totaling billing data for each house over time, some of the variability in the energy data is smoothed out and the influence of weather variations on consumption can be modeled more easily. By 
analyzing a group of houses in an aggregate manner, unexplained variability seen at the individual house level is removed and a model of an average house that represents the group of houses is produced.

If data are available for the group of houses before and after each one is weatherized, the $\mathrm{NAC}_{\text {pre }}$ and $\mathrm{NAC}_{\text {post }}$ for an average house in the group at a selected geographical location can be calculated, and the NAS for such a house can be determine using Eq. 3.

If an average NAC and/or NAS were desired that was representative of all the houses weatherized, covering multiple locations, weighted annual heating degree days could be calculated and used in Eq. 8, or the annual heating degree days for each house could be used in Eq. 8 and the subsequent NACs averaged.

The ORNL aggregate model was presented in simplistic form above. In reality, pre- and postweatherization differences in energy use can be modeled to avoid the need to model pre- and postweatherization consumption separately and then subtracting to obtain savings. Energy savings can be modeled as follows:

$$
) \mathrm{E}_{\mathrm{i}}=\mathrm{E}_{\mathrm{i}, \text { pre }} ! \mathrm{E}_{\mathrm{i}, \text { post }}=\left[\forall_{\text {pre }} X \mathrm{D}_{\mathrm{i}, \text { pre }}+\exists_{\text {pre }} \mathrm{X} \operatorname{HDD}_{\mathrm{i}, \text { pre }}(65)\right] !\left[\forall_{\text {post }} X \mathrm{D}_{\mathrm{i}, \text { post }}+\exists_{\text {post }} \mathrm{X} \operatorname{HDD}_{\mathrm{i}, \text { post }}(65)\right]
$$

Where:

$$
\begin{aligned}
& ) \mathrm{E}_{\mathrm{i}}=\text { energy use difference (e.g., Btu) between pre and post periods for house } \mathrm{i}, \\
& \mathrm{E}_{\mathrm{i}, \text { pre }}=\text { energy use (e.g., Btu) for house i for pre-weatherization period, } \\
& \mathrm{E}_{\mathrm{i} \text {, post }}=\text { energy use (e.g., Btu) for house } \mathrm{i} \text { for post-weatherization period, } \\
& \forall_{\text {pre }}=\text { average daily baseload energy use (e.g., Btu/day) for pre period, } \\
& \forall_{\text {post }}=\text { average daily baseload energy use (e.g., Btu/day) for post period, } \\
& \mathrm{D}_{\mathrm{i}, \text { pre }}=\text { number of days for house i in pre period, } \\
& \mathrm{D}_{\mathrm{i}, \text { post }}=\text { number of days for house i in post period, } \\
& \exists_{\text {pre }}=\text { heating slope (e.g., Btu/HDD) for pre period, } \\
& \exists_{\text {post }}=\text { heating slope (e.g., Btu/HDD) for post period, } \\
& \mathrm{HDD}_{\mathrm{i}, \text { pre }}(65)=\text { heating degree days for house i calculated at a balance point temperature } \\
& \quad \text { of } 65^{\circ} \mathrm{F} \text { for pre period, and } \\
& \operatorname{HDD}_{\mathrm{i}, \text { post }}(65)=\text { heating degree days for house i calculated at a balance point temperature } \\
& \quad \text { of } 65^{\circ} \mathrm{F} \text { for post period. }
\end{aligned}
$$

By modeling the difference in energy use, the correlation between pre- and post-weatherization consumption for the same household is dealt with much like in a paired t-test.

The model can be simplified and the statistical variability of the remaining parameters reduced if there is reason to assume that $\forall_{\text {pre }}$ and $\forall_{\text {post }}$ are equal to each other (because weatherization primarily impacts the degree-day parameters) and/or if the bias in making the parameters equal to each other is acceptable. The model can also be expanded to include control adjustments directly and, like PRISM, can include weather adjustment for cooling energy consumption using cooling degree days simultaneously with adjustment for heating energy consumption using heating degree days (although there is no provision for automatically selecting the model as in PRISM). Furthermore, additional terms can be added to the model (e.g., for climate region), with fitting occurring in one stage.

As with PRISM, the statistical uncertainties associated with estimated parameters and calculated values in Eqs. 7-9 can be determined using normal statistical procedures. 


\section{APPENDIX S. ASSESSMENT OF A POTENTIAL SPLIT-WINTER RCT CONFIRMATORY PROJECT}

Despite the barriers to a classical RCT approach to WAP evaluation, we also consider here a hypothetical "split-winter" RCT that could be conducted in conjunction with the QE WAP evaluation study. By "splitwinter," we mean that weatherization would be performed during one particular winter, and the total duration of the study would generally be less than in a full evaluation. Sample size calculations for the split-winter RCT suggest that, even if the legislative and cultural barriers could be circumvented, this alternative RCT approach would still not be a good idea because of very large (and therefore expensive) sample size requirements. This further supports the assumption that an RCT is not feasible in the WAPARRA context and that a carefully conducted QE study is a better approach.

Section S.I of this section presents additional background and some notation, and suggests another, control-only, validation study design, as a potential alternative to a split-winter RCT approach. Sample sizes calculations for the split-winter study are presented in Section S.II. Sample size calculations for the alternative control-only validation study are in Section S.III. Concluding remarks are in Section S.IV.

S.I Background. One objective (among many) of the WAP evaluation study will be to estimate the normalized annual savings (NAS) due to weatherization performed during a target time period, for example, a program year. In the QE approach, treated subjects are selected randomly from the population of subjects who received weatherization during the target time period. Control subjects are selected randomly from (i) WAP-eligible subjects who applied during the target time period but did not receive weatherization during that period, and (ii) eligible subjects who applied during a subsequent time period (and may or may have yet received weatherization). In either cases (i) or (ii), only pre-weatherization control-group consumption data is used to characterize the controls; post-weatherization control-group data is inadmissible.

Treated subjects in the QE approach are selected as they would be in a hypothetical RCT in which a random subset of subjects initially selected for treatment (per all priority constraints) are shunted off to serve as controls. However, control subjects in this RCT would differ statistically from the controls in the QE study. In the QE approach, the overall time periods (both beginning and ending dates) for the controls are shifted toward times later than the target time period for subjects who receive weatherization. In the RCT, by definition of RCT, the overall time periods must have exactly the same distribution for both the treatment and control groups. Therefore, either (1) the weatherization eventually performed for the controls must be delayed fairly long, or (2) the post-weatherization periods for the weatherized subjects and must be fairly short.

In both the QE and RCT approaches, pseudo-weatherization dates are assigned to control subjects so that the distribution of pseudo-weatherization dates for the controls is the same as the distribution of actual weatherization dates for the treated subjects. The pseudo-weatherization dates are used in the analysis of the control energy consumption data in the same way that the actual weatherization dates are used in the analysis of the weatherized subject data.

However, in the QE approach, unlike the RCT approach, if the WAP applicant population changes during the overall time-period (either for subjects who receive weatherization or controls), then the QE NAS estimates could be biased. Therefore it is reasonable to consider (at least hypothetically) an RCT-based check on potential bias in the QE NAS estimates. Although an across-the-board RCT approach would not be feasible, it might be feasible to implement a confirmatory RCT on a much smaller scale.

The following notation will be needed in discussing NAS estimates. We are trying to estimate the control-adjusted NAS (CNAS): 
CNAS $=$ NASW - NASC

where

NASW $=$ Normalized Annual Savings, Weatherized $=\mathrm{Cwb}-\mathrm{Cwa}$

NASC $=$ Normalized Annual Savings, Controls NASC $=$ Ccb - Cca

where in turn

$\mathrm{Cwb}=$ weather-adjusted average annual consumption before weatherization for subjects who receive weatherization

Cwa = weather-adjusted average annual consumption after weatherization for subjects who receive weatherization

$\mathrm{Ccb}=$ weather-adjusted average annual consumption before pseudo-weatherization for controls

Cwa $=$ weather-adjusted average annual consumption after pseudo-weatherization for controls

Note that the QE weatherized group sample is actually selected the same way as the weatherized group sample would be selected in an RCT in which selected subjects are randomly assigned to either the treatment or control groups. For this reason, in theory, a full RCT (e.g., a split-winter study) would not actually be needed to validate the QE CNAS estimate. Instead, a validation check on the QE estimate could be performed by (1) selecting an independent sample of controls (as in the RCT approach) from the same population (i.e., target time period) that the weatherized group is selected from, and then (2) estimating the NASC for the independent sample and comparing it to the NASC estimate from the QE study. A conclusion of no-difference between the two estimates supports the QE approach. This validation check would require only supplemental control subjects, not an entire supplemental RCT. However, as with the split-winter approach, either the control subjects would have to be denied treatment for a long time (and compensated accordingly), or the post-pseudo-weatherization study periods would have to be relatively short.

The longer weatherization is delayed, the less feasible a study becomes. Therefore, a control-only validation study with a randomly selected control group that matches the study period of the main QE study weatherization group may not be feasible. On the other hand, if the study period is shorter than the study period for the main study, then this kind of validation would be compromised. In view of this tradeoff, we will consider two studies supplemental to a main WAP QE evaluation study: (1) a splitwinter RCT with post-weatherization periods shorter than the post-weatherization periods in the main QE study, and (2) a comparison study of the main QE control group with a set of controls randomly selected from subjects initially selected for weatherization in the QE study, and with weatherization delayed as needed for consistent comparisons with the main study weatherization group. In case (1) the main study CNAS estimate would be compared with the split-winter validation study CNAS. Agreement supports the main study CNAS estimates. In case (2) the main study control group would be compared with the validation study control reference group. Agreement supports the use of the main study control group and thus the main study CNAS estimates. Sample sizes for a split-winter RCT are considered in Section S.II. Sample sizes for the alternative control-only validation are discussed in Section S.III.

S.II Sample Size Requirements for a Split-Winter RCT Study To implement a split winter study requires installing submeters in homes to directly measure energy use. These studies are more expensive than billing history studies because of the cost of the submeters and staff to install and retrieve the submeters. To reckon sample sizes necessary for the split-winter study, we estimate the variability of both the RCT 
and QE studies using estimates from the 1990 WAP evaluation. ${ }^{40}$ We use the approximation that the RCT and QE designs with the same number of subgrantees and housing units (and assuming the same subsampling of housing units for both studies) have the same precision. This approximation may actually lead to underestimates of necessary sample size, because, in fact, the split-winter studies control estimates, although more accurate, are likely to be more variable than corresponding QE estimates. This is true for the reason discussed above, that for the RCT study, the control data period ends at the end of the split winter study, whereas the control data period is much longer for the QE study. This potential variability underestimation is discussed further below.

Consider the CNAS for the main national QE study and corresponding CNAS' for the RCT study, where because of differences in the study time periods, CNAS and CNAS' are not necessarily equal. As a check, we will test the hypothesis that they are. Let $\Delta=$ CNAS - CNAS'. We will test the null hypothesis Ho: $\Delta=0$ with a hypothesis test constructed so that:

(1) the level of the test (i.e., probability of rejecting under the null hypothesis) is $\alpha$ (e.g., .05 or 0.1 )

(2) for specified $\delta$, a hypothetical difference between the main CNAS and the RCT CNAS, the power (i.e., probability of rejecting Ho) when $\Delta=\delta$ is at least a specified probability (e.g., .8 or .9)

Property (1) is to control the probability of false rejection, and property (2) is to control the probability of false acceptance, in particular at $\Delta=\delta$. (The probability of false acceptance is 1 minus the power.)

Given various values for $\alpha, \delta$, and the power, we can compute sample sizes for various validation RCTs. Here we compute the RCT sample size as a percentage of the main-study sample of 400 subgrantees. Appropriate values for $\delta$ are suggested by the 1990 study results: Tables 5.1 and 5.3 in the 1990 study report list the following CNAS estimates and standard errors:

\begin{tabular}{llll} 
Fuel & $\begin{array}{l}\text { CNAS } \\
\text { Estimate }\end{array}$ & Units & $\begin{array}{l}\text { Standard } \\
\text { Error }\end{array}$ \\
\hline Electricity & 1830 & kwh/year & 358 \\
Natural Gas & 173 & ccf/year & 18
\end{tabular}

\footnotetext{
${ }^{40}$ Brown, M., Berry, L., Balzer, R., Faby, E., National Impacts of the Weatherization Assistance Program in SingleFamily Dwellings, ORNL/CON-326, Oak Ridge National Laboratory, Oak Ridge, Tennessee, May, 1993. Available at http://weatherization.ornl.gov/pdf/ORNL_CON-326.pdf.
} 
We take $\delta$ to be either $.5,1$, or 2 times the CNAS estimate from the 1990 evaluation. For $\alpha$ either .05 or .1 , and for power of either .8 or .9 , we then get the following tables of values for the necessary sample size for the corresponding RCT validation study, expressed as percentage of the main (1990 or 2010) study:

\section{Fuel=Electricity, CNAS Estimate=1,830, CNAS Estimate StdErr=358, Units=kwh/year}

\begin{tabular}{|c|c|c|c|c|}
\hline$\delta$ & Factor & $\begin{array}{l}\text { Test } \\
\text { Level } \\
(\alpha)\end{array}$ & $\begin{array}{c}\text { Power of } \\
\text { Test at } \\
\Delta=\delta\end{array}$ & $\begin{array}{c}\text { Percentage } \\
\text { of Main } \\
\text { Study } \\
\text { Needed }\end{array}$ \\
\hline 915 & 0.5 & $\begin{array}{l}.05 \\
.10\end{array}$ & $\begin{array}{l}.8 \\
.9 \\
.8 \\
.9\end{array}$ & $\begin{array}{l}240.3 \\
321.7 \\
189.3 \\
262.2\end{array}$ \\
\hline 1,830 & 1.0 & $\begin{array}{l}.05 \\
.10\end{array}$ & $\begin{array}{l}.8 \\
.9 \\
.8 \\
.9\end{array}$ & $\begin{array}{l}60.1 \\
80.4 \\
47.3 \\
65.5\end{array}$ \\
\hline 3,660 & 2.0 & $\begin{array}{l}.05 \\
.10\end{array}$ & $\begin{array}{l}.8 \\
.9 \\
.8 \\
.9\end{array}$ & $\begin{array}{l}15.0 \\
20.1 \\
11.8 \\
16.4\end{array}$ \\
\hline
\end{tabular}

Fuel=Natural Gas, CNAS Estimate=173, CNAS Estimate StdErr=18, Units=ccf/year

\begin{tabular}{|c|c|c|c|c|}
\hline$\delta$ & Factor & $\begin{array}{l}\text { Test } \\
\text { Level } \\
(\alpha)\end{array}$ & $\begin{array}{c}\text { Power of } \\
\text { Test at } \\
\Delta=\delta\end{array}$ & $\begin{array}{c}\text { Percentage } \\
\text { of Main } \\
\text { Study } \\
\text { Needed }\end{array}$ \\
\hline 87 & 0.5 & $\begin{array}{l}.05 \\
.10\end{array}$ & $\begin{array}{l}.8 \\
.9 \\
.8 \\
.9\end{array}$ & $\begin{array}{l}68.0 \\
91.0 \\
53.5 \\
74.2\end{array}$ \\
\hline 173 & 1.0 & $\begin{array}{l}.05 \\
.10\end{array}$ & $\begin{array}{l}.8 \\
.9 \\
.8 \\
.9\end{array}$ & $\begin{array}{l}17.0 \\
22.7 \\
13.4 \\
18.5\end{array}$ \\
\hline 346 & 2.0 & $\begin{array}{l}.05 \\
.10\end{array}$ & $\begin{array}{l}.8 \\
.9 \\
.8 \\
.9\end{array}$ & $\begin{array}{l}4.2 \\
5.7 \\
3.3 \\
4.6\end{array}$ \\
\hline
\end{tabular}

So, roughly speaking, to detect in the main national CNAS and the validation RCT CNAS' a difference the size of $100 \%$ of the main national CNAS (Factor $=1.0$ in the tables) would require the supplemental validation RCT to be about $60-80 \%$ of the size of the national evaluation for electricity, and about $15-$ $20 \%$ of the size of the national evaluation for natural gas. These percentages for even this limited RCT study are high enough to suggest skipping the split-winter RCT study completely. Note too that the value 1 (and .5 and 2) considered here for $\delta$ is rather large. Smaller values of $\delta$ entail even larger sample sizes. As discussed above, the use here of the approximation that the RCT and QE designs have the same precision may also lead to understated sampled sizes. 
The large (e.g., 100\% of CNAS) values for $\delta$ and the large necessary sample sizes (expressed as percentages of the national evaluation) reflect the high variability inherent in weatherization billing data and, ultimately, in the national CNAS estimates. The coefficients of variation (CV) of the 1990-study CNAS estimates are

$\mathrm{CV}=100 \times 358 / 1,830=19.6 \%$ for Electricity

$\mathrm{CV}=100 \times 18 / 173=10.4 \%$ for Natural Gas

which are quite high for overall estimates for a national study of that size. High variability seems to be a fact of life for domestic energy consumption and billing data. The estimated sample sizes, and the difference between the split-wither RCT and the QE study's time spans suggests that the RCT approach may not be worth pursuing at all in the context of WAP evaluation.

S.III Sample Size Requirements for an Alternative, Control-Only Validation Study Next consider the RCT validation study, with validation-study controls only, where a supplemental validation control group is selected for which weatherization is delayed for as long as the main-study weatherized group is observed. Except for the weatherization, such a validation control group would be statistically the same as the weatherized group from the main QE study. Only supplemental control subjects (no supplemental weatherized subjects) would be needed with this approach, and so the approach would require substantially less resources than the split-winter RCT. On the other hand, it would require longer delays in the weatherizations for the control subjects.

The hypothesis of interest in the validation is that the control group NASC from the main study and the validation control group NASC' are the same. Redefining $\Delta$ above so that $\Delta=$ NASC - NASC', we are again interested in testing the null hypothesis Ho: $\Delta=0$, and in the power of the test when $\Delta$ assumes a particular value $\delta$. For this control-only validation approach, however, the appropriate values for $\delta$ are still relative to the CNAS estimate, which is the ultimate objective of the study. Again from Tables 5.1 and 5.3 in the 1990 study:

\begin{tabular}{lllll} 
Fuel & $\begin{array}{l}\text { NASC } \\
\text { Estimate }\end{array}$ & $\begin{array}{l}\text { CNAS } \\
\text { Estimate }\end{array}$ & Units & $\begin{array}{l}\text { NASC Estimate } \\
\text { Standard Error }\end{array}$ \\
\hline Electricity & -963 & 1830 & kwh/year & 238 \\
Natural Gas & -37 & 173 & ccf/year & 14
\end{tabular}


So again taking $\delta$ to be either $.5,1$, or 2 times the CNAS estimate from the 1990 evaluation, $\alpha$ either .05 or .1 , and the power to be either .8 or .9 , we get the following tables of values for the necessary sample size for the alternative control-only validation study, again expressed as a percentage of the control group from the 1990 (or 2010) evaluation

\section{Fuel=Electricity, CNAS Estimate=1,830, NASC Estimate StdErr=238, Units=kwh/year}

\begin{tabular}{|c|c|c|c|c|}
\hline$\delta$ & Factor & $\begin{array}{l}\text { Test } \\
\text { Level } \\
(\alpha)\end{array}$ & $\begin{array}{c}\text { Power of } \\
\text { Test at } \\
\Delta=\delta\end{array}$ & $\begin{array}{l}\text { Percentage } \\
\text { of Main } \\
\text { Control } \\
\text { Group } \\
\text { Needed }\end{array}$ \\
\hline 915 & 0.5 & .05 & $\begin{array}{l}.8 \\
.9\end{array}$ & $\begin{array}{l}106.2 \\
142.2\end{array}$ \\
\hline & & .10 & .8 & $\begin{array}{r}83.7 \\
115.9\end{array}$ \\
\hline 1,830 & 1.0 & .05 & $\begin{array}{l}.8 \\
.9\end{array}$ & $\begin{array}{l}26.6 \\
35.5\end{array}$ \\
\hline & & .10 & $\begin{array}{l}.8 \\
.9\end{array}$ & $\begin{array}{l}20.9 \\
29.0\end{array}$ \\
\hline 3,660 & 2.0 & $\begin{array}{l}.05 \\
.10\end{array}$ & $\begin{array}{l}.8 \\
.9 \\
.8 \\
.9\end{array}$ & $\begin{array}{l}6.6 \\
8.9 \\
5.2 \\
7.2\end{array}$ \\
\hline
\end{tabular}

\section{Fuel=Natural Gas, CNAS Estimate=173, NASC Estimate StdErr=14, Units=ccf/year}

\begin{tabular}{|c|c|c|c|c|}
\hline$\delta$ & Factor & $\begin{array}{l}\text { Test } \\
\text { Level } \\
(\alpha)\end{array}$ & $\begin{array}{c}\text { Power of } \\
\text { Test at } \\
\Delta=\delta\end{array}$ & $\begin{array}{l}\text { Percentage } \\
\text { of Main } \\
\text { Control } \\
\text { Group } \\
\text { Needed }\end{array}$ \\
\hline 87 & 0.5 & $\begin{array}{r}.05 \\
.10\end{array}$ & $\begin{array}{l}.8 \\
.9 \\
.8 \\
.9\end{array}$ & $\begin{array}{l}41.1 \\
55.0 \\
32.4 \\
44.9\end{array}$ \\
\hline 173 & 1.0 & $\begin{array}{l}.05 \\
.10\end{array}$ & $\begin{array}{l}.8 \\
.9 \\
.8 \\
.9\end{array}$ & $\begin{array}{r}10.3 \\
13.8 \\
8.1 \\
11.2\end{array}$ \\
\hline 346 & 2.0 & $\begin{array}{l}.05 \\
.10\end{array}$ & $\begin{array}{l}.8 \\
.9 \\
.8 \\
.9\end{array}$ & $\begin{array}{l}2.6 \\
3.4 \\
2.0 \\
2.8\end{array}$ \\
\hline
\end{tabular}

So, roughly speaking, to detect in the main national NASC and validation NASC' a difference the size of $100 \%$ of the national CNAS (Factor $=1.0$ in the tables) would require the supplemental validation control group to be about $20-30 \%$ of the size of main control group for electricity and 10-12\% of the size of the main control group for natural gas. Although these sample sizes are much smaller than what is required for the split-winter study, they are still substantially, particularly in the context of (1) the 100\% (or 50\% or $200 \%$ ) of the national CNAS that the study would be designed to detect, and (2) the procedural difficulty of extended delays in weatherization of the supplemental control group. 


\section{S.IV Observations}

The sample-size requirements for a split-winter RCT are so substantial they suggest that RCTs are not feasible for a WAP evaluation. The sample-size requirements for an alternative validation approach involving only control subjects are more reasonable, but they are still substantial, particularly in view of the large differences they are designed to detect and the procedural constraints that would have to be circumvented with that approach. The sample sizes that would be needed for either of the split-winter RCT or control-only approaches suggest that these approaches are not be worth pursuing even as supplemental validation or partial-validation studies, and the RCT approach certainly does not seem worth pursuing as a design for a main WAP evaluation.

\section{S.V. Conclusions}

If a classical RCT approach is inappropriate, the encouragement design is limited in its scope, and a splitwinter design is infeasible, the QE approach becomes a natural contender to consider as an alternative. The weatherization group in the QE approach is selected as it would be in an RCT. The issue in the QE approach, then, is whether because of application/weatherization time differences between the weatherized and comparison groups, differences between the comparison group and the ideal control group that would be selected in an RCT might be substantial enough to render the comparison group so flawed that the QE approach (and in that case most likely any other approach) should not be pursued at all.

The comparison group in the QE approach is an approximation. However, in a QE study, the comparison and weatherization groups are generally compared with respect to potentially influential characteristics (e.g., dwelling size, primary fuel, participant income), and if necessary the analysis can be stratified according to those characteristics. Of course, in weatherization studies, weather-adjustments are made for both weatherized and comparison dwellings. Thus the comparison group is examined and controlled in every feasible way to ensure its adequacy as an approximation. Analysts know if the approximation is inadequate.

The QE approach cannot be justified to the absolute standard that an RCT (were it feasible) might be justified to. As the GAO report points out, however, insistence on an absolute standard will "exclude many potentially effective and worthwhile practices." Thus the QE approach provides a viable alternative to an RTC as the design basis for a WAP evaluation. 
OMB Control Number: XXXX-XXXX

\section{APPENDIX T. S6: ALL STATES POST-ARRA SURVEY}

The U.S. Department of Energy's (DOE) Weatherization Assistance Program received an unprecedented level of support from the American Recovery and Reinvestment Act (ARRA). The Program's grantees and subgrantees have successfully ramped up their efforts to meet the weatherization goals created for the ARRA-period. The next challenge facing the Program and its grantees and subgrantees is to transition to post-ARRA world. This survey is being administered to all of the Program's ARRA-period grantees. The data will assist the Program and its grantees and subgrantees to better manage this transition.

Public reporting burden for this collection of information is estimated to average one hour per response, including the time for reviewing instructions, searching existing data sources, gathering and maintaining the data needed, and completing and reviewing the collection of information. Send comments regarding this burden estimate or any other aspect of this collection of information, including suggestions for reducing this burden, to Office of the Chief Information Officer, Records Management Division, IM-11, Paperwork Reduction Project (XXXX-XXXX), U.S. Department of Energy, 1000 Independence Ave SW, Washington, DC, 20585-1290; and to the Office of Management and Budget (OMB), OIRA, Paperwork Reduction Project (XXXX-XXXX), Washington, DC 20503.

All of the information obtained from this survey will be protected and will remain confidential. The data will be analyzed in such a way that the information provided cannot be associated back to your state, your agencies, or the housing units and clients that your state served. 
1. Please indicate how leveraged funding changed from PY 2008 to PY2010 and you expect leveraged funding to change from PY2010 to PY2012.

Provide the amount of leveraged funding received in PY 2010 by source. Please forecast leveraging relationship for the post-ARRA period (i.e., during PY 2012).

\begin{tabular}{|c|c|c|}
\hline $\begin{array}{l}\text { Source of Leveraged } \\
\text { Weatherization Funding } \\
\text { Administered by State }\end{array}$ & 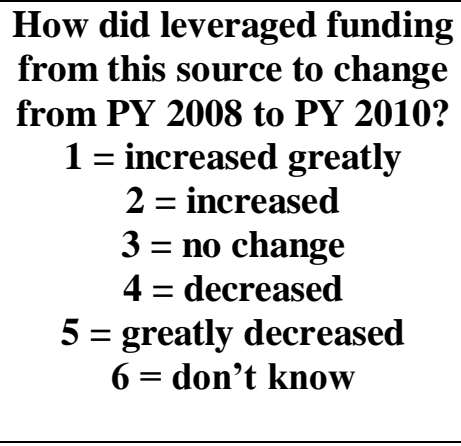 & $\begin{array}{l}\text { How do you expect leveraged funding } \\
\text { from this source to change from PY } 2010 \\
\text { to the post-ARRA period in PY } 2012 ? \\
1=\text { increase greatly } \\
2=\text { increase } \\
3=\text { no change } \\
4=\text { decrease } \\
5=\text { greatly decrease } \\
\text { q = uncertainty is too great to answer this } \\
\text { question }\end{array}$ \\
\hline \multicolumn{3}{|r|}{ 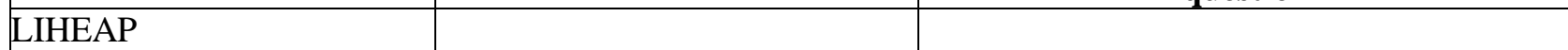 } \\
\hline \multicolumn{3}{|l|}{$\begin{array}{l}\text { Petroleum Violation Escrow } \\
\text { (PVE) }\end{array}$} \\
\hline \multicolumn{3}{|l|}{ Other Federal Programs } \\
\hline \multicolumn{3}{|l|}{ State Public Benefit Funds } \\
\hline \multicolumn{3}{|l|}{ Other State } \\
\hline \multicolumn{3}{|l|}{ Utilities } \\
\hline \multicolumn{3}{|l|}{ Program Income } \\
\hline \multicolumn{3}{|l|}{ In-Kind } \\
\hline \multicolumn{3}{|l|}{ Non-Profits } \\
\hline Other & & \\
\hline
\end{tabular}

2. Under ARRA, the allowable average amount of investment was increased from $\$ 2500$ to $\$ 6500$. Moving forward, what level of average investment in homes does your state prefer?
a. $\$ 2500$
b. $\$ 6500$
c. Other
d. No preference

3. Under ARRA, the eligibility threshold was increased from $150 \%$ of the poverty level to $200 \%$. Moving forward, what income eligibility threshold does your state prefer?
a. $150 \%$ of poverty threshold
b. $200 \%$ of poverty threshold
c. Other
d. No preference

4. Should the policy on re-weatherization of homes to those weatherized before 1994 be re-considered in light of program changes and new technology 'bumps'?

a. No

b. Yes

If yes, how should the policy be changed? 
5. Should WAP endeavor to go 'deeper' into homes?

a. No

b. Yes

If yes, please explain

6. Should WAP formally incorporate water conservation into its program?

a. No

b. Yes

7. Does your state plan on increasing large multi-family weatherization post-ARRA?

a. Yes, increase substantially

b. Yes, increase somewhat

c. No Change

d. No, decrease somewhat

e. No, decrease substantially

8. Should DOE set goals for MF weatherization (i.e., to equal the percentage of multi-family units in the state)?

a. No

b. Yes

If yes, what should the goals be?

9. Does your state expect a pre-mature degradation in production as the ARRA period draws to a close in March, 2012?

a. No

b. Yes

If yes, please explain

10a. What specific types of training assistance can DOE provide to support post-ARRA ramp down? (check all that apply)

a. Multi-family

b. Health and Safety

c. Other

10b. What other types of assistance can DOE provide to support post-ARRA ramp down? (check all that apply)

a. Up-dating and expanding the national curriculum

b. Up-dating and expanding other national training resources

c. Support and expand a certification scheme for the weatherization workforce

d. Other

11. Will your state act to consolidate subgrantees post-ARRA?

a. No

b. Yes, limited consolidation

c. Yes, substantial consolidation

12. How many new staff have been added to your state weatherization office during the ARRA period?

13. How many staff from your state weatherization office will be laid-off post-ARRA? 
14. What strategies are being used to retain new, young weatherization staff hired during ARRA by your state office? Please describe

15. Is the training capacity created by your state's program and agencies, community colleges, etc. sustainable after ARRA?

a. Yes

b. No

c. No new training capacity was added

16a. Does your state training plan include utilizing weatherization training centers for worker training?

a. Yes (go to 16c)

b. No

16b. If no, how does your state intend to provide worker training?

a. Staff resources- i.e. State monitors to provide worker training

b. Private, consultant trainers- i.e, Saturn, BMI, ECM etc.

c. Other

d. No future training is planned.

16c. Does your state training plan include funding a weatherization training center either existing or new?

a. Yes

b. No

16d. Will your state require that training resources be accredited weatherization training providers?

a. Yes

b. No

16e. In the future, will your state require weatherization workers to be certified in their job category (assuming that a national Weatherization certification is available)?

a. Yes

b. No

17. Is your state doing anything to transition workers to other jobs post-ARRA?

a. No

b. Yes

If yes, what?

18. Does your state have plans to use alternative workforces for weatherization (e.g., volunteer labor)?

a. No

b. Yes

19. How many weatherization jobs created during ARRA may be lost after ARRA in your state?

20. How substantial will be the costs that are associated with workforce reductions (e.g., workers compensation) to local weatherization agencies in your state?

a. very substantial

b. substantial

c. not very substantial

d. no additional costs 
21. Does your state see health and safety audits as a growing business for your subgrantees over the next five years?

a. No

b. Yes, somewhat

c. Yes, substantially

22. Which alternative financing mechanisms to support weatherization post-ARRA might your state pursue post-ARRA? (check all that apply)

a. revolving loan funds

b. on-bill payments

c. PACE programs

d. ESCO financing

e. carbon offsets

f. none of the above

23a. How can DOE provide support for expansion of the use of alternative third party financing mechanisms (e.g., interest in WAP funding in the form of a (e.g. revolving loans, loan loss reserves, rather than a grant? One target property type for a revolving loan product are Low-Income Housing Tax Credit Properties)?

23b. What discussions have you had with third parties regarding financing? What has the response been?

23c. Do you have any existing relationships with lenders?

a. Yes

b. No, but working on developing relationships

c. No

24. Over the next five years, what percentage of your state's subgrantees' service areas may become saturated with respect to low-income weatherization?
a. 0
b. $1-10 \%$
c. $11-20 \%$
d. $21-30 \%$
e. $30+\%$

25. Where do you see the market for non-low income home retrofit in your state over the next five years?
a. greatly increasing
b. increasing
c. no change
d. decreasing
e. greatly decreasing

26. Have you heard of the Home Energy Score system?
a. No
b. Yes 
27. If so, how might this initiative impact low-income weatherization in your state?

a. no impact

b. might lead to some funding increases

c. might lead to moderate funding increases

d. might lead to substantial funding increases

28. Post-ARRA, compared to pre-ARRA funding levels, how do you foresee the size of your state's weatherization assistance program?

a. Greatly expanded

b. Expanded

c. About the same

d. Reduced

e. Greatly reduced

29. On balance, how beneficial do you think that the ARRA funding will eventually be to the longer-term prospects for your state's WAP-program?

a. Extremely beneficial

b. Beneficial

c. No long-term impact

d. Unbeneficial

e. Extremely unbeneficial 
OMB Control Number: XXXX-XXXX

\section{APPENDIX U: S7: ALL AGENCIES POST-ARRA SURVEY}

The U.S. Department of Energy's (DOE) Weatherization Assistance Program received an unprecedented level of support from the American Recovery and Reinvestment Act (ARRA). The Program's grantees and subgrantees have successfully ramped up their efforts to meet the weatherization goals created for the ARRA-period. The next challenge facing the Program and its grantees and subgrantees is to transition to post-ARRA world. This survey is being administered to all of the Program's ARRA-period subgrantees. The data will assist the Program and its grantees and subgrantees to better manage this transition.

Public reporting burden for this collection of information is estimated to average one hour per response, including the time for reviewing instructions, searching existing data sources, gathering and maintaining the data needed, and completing and reviewing the collection of information. Send comments regarding this burden estimate or any other aspect of this collection of information, including suggestions for reducing this burden, to Office of the Chief Information Officer, Records Management Division, IM-11, Paperwork Reduction Project (XXXX-XXXX), U.S. Department of Energy, 1000 Independence Ave SW, Washington, DC, 20585-1290; and to the Office of Management and Budget (OMB), OIRA, Paperwork Reduction Project (XXXX-XXXX), Washington, DC 20503.

All of the information obtained from this survey will be protected and will remain confidential. The data will be analyzed in such a way that the information provided cannot be associated back to your state, your agencies, or the housing units and clients that your state served. 
1. Please provide the amount of leveraged funding received in PY 2010 by source. Please forecast leveraging relationship for the post-ARRA period (i.e., during PY 2012).

\begin{tabular}{|c|c|c|}
\hline $\begin{array}{l}\text { Source of PY } 2010 \text { Leveraged } \\
\text { Weatherization Funding } \\
\text { Administered by Agency }\end{array}$ & $\begin{array}{c}\text { How did leveraged } \\
\text { funding from this } \\
\text { source to change from } \\
\text { PY } 2008 \text { to PY } 2010 ? \\
1 \text { = increased greatly } \\
2=\text { increased } \\
3=\text { no change } \\
4=\text { decreased } \\
5=\text { greatly decreased } \\
6=\text { don't know }\end{array}$ & $\begin{array}{c}\text { How do you expect leveraged funding from } \\
\text { this source to change from PY } 2010 \text { to the } \\
\text { post-ARRA period in PY 2012? } \\
1=\text { increase greatly } \\
2=\text { increase } \\
3=\text { no change } \\
4=\text { decrease } \\
5=\text { greatly decrease } \\
6 \text { = uncertainty is too great to answer this } \\
\text { question }\end{array}$ \\
\hline \multicolumn{3}{|l|}{ LIHEAP } \\
\hline \multicolumn{3}{|l|}{$\begin{array}{l}\text { Petroleum Violation Escrow } \\
(\mathrm{PVE})\end{array}$} \\
\hline \multicolumn{3}{|l|}{ Other Federal Programs } \\
\hline \multicolumn{3}{|l|}{ State Public Benefit Funds } \\
\hline \multicolumn{3}{|l|}{ Other State } \\
\hline \multicolumn{3}{|l|}{ Utilities } \\
\hline \multicolumn{3}{|l|}{ Program Income } \\
\hline \multicolumn{3}{|l|}{ In-Kind } \\
\hline \multicolumn{3}{|l|}{ Non-Profits } \\
\hline Other & & \\
\hline
\end{tabular}

2. Under ARRA, the allowable average amount of investment was increased from $\$ 2500$ to $\$ 6500$. Moving forward, what level of average investment in homes does your agency prefer?
a. $\$ 2500$
b. $\$ 6500$
c. Other
d. No preference

3. Under ARRA, the eligibility threshold was increased from $150 \%$ of the poverty level to $200 \%$. Moving forward, what income eligibility threshold does your agency prefer?
a. $150 \%$ of poverty threshold
b. $200 \%$ of poverty threshold
c. Other
d. No preference

4. Should the policy on re-weatherization of homes to those weatherized before 1994 be re-considered in light of program changes and new technology 'bumps'?

a. No

b. Yes

If yes, how should the policy be changed? 
5. Should WAP endeavor to go 'deeper' into homes?

a. No

b. Yes

If yes, please explain

6. Should WAP formally incorporate water conservation into its program?

a. No

b. Yes

7. Does your agency plan on increasing large multi-family weatherization post-ARRA?

a. Yes, increase substantially

b. Yes, increase somewhat

c. No Change

d. No, decrease somewhat

e. No, decrease substantially

8. Should DOE set goals for multi-family weatherization (i.e., to equal the percentage of multi-family units in the state)?

a. No

b. Yes

If yes, what should the goals be?

9. Does your agency expect a pre-mature degradation in production as the ARRA period draws to a close in March, 2012?

a. No

b. Yes

If yes, please explain

10. What assistance can DOE provide to support post-ARRA ramp down?

a. Health and safety audit training

b Support and expansion of a national weatherization certification scheme

c. Training assistance to prepare workers for certification

d. Other

11. How many new staff have been added to your agency's weatherization program during the ARRA period?

12. How many staff from your agency's weatherization program might be laid-off post-ARRA?

13. What strategies are being used to retain new, young weatherization or trained staff hired during ARRA by your agency? Please describe

14. Are expenses for new equipment, software, etc. purchased by your agency during ARRA sustainable after ARRA?

a. Yes

b. No

c. No new equipment, software, etc. was purchased 
15. Is the training capacity created by your agency sustainable after ARRA?

a. Yes

b. No

c. No new training capacity was added

16. Is your agency doing anything to transition workers to other jobs post-ARRA?

a. No

b. Yes

If yes, what?

17. Does your agency have plans to dispose of extra trucks post-ARRA?

a. No, we do not have extra trucks

b. No, we may have extra trucks but we do not have a disposal plan yet

c. Yes, we have extra trucks and we have a disposal plan

If yes, please describe the disposal plan

18. Does your agency have plans to dispose of extra blower doors post-ARRA?

a. No, we do not have extra blower doors

b. No, we may have extra blower doors but we do not have a disposal plan yet

c. Yes, we have extra blower doors and we have a disposal plan

If yes, please describe the disposal plan

19. Does your agency have plans to dispose of extra infra-red and/or cameras post-ARRA?

a. No, we do not have extra cameras

b. No, we may have extra cameras but we do not have a disposal plan yet

c. Yes, we have extra cameras and we have a disposal plan

If yes, please describe the disposal plan

20. How will your agency cost-out unused equipment post-ARRA?

21. Does your agency have plans to use alternative workforces for weatherization (e.g., volunteer labor) post-ARRA?

a. No

b. Yes

If yes, please explain

22. How many weatherization jobs created during ARRA may be lost post-ARRA in your agency's jurisdiction?

23. If your agency uses contractors to perform weatherization, how much will your contractor pool decrease post-ARRA?
a. $0 \%$
b. $1-10 \%$
c. $11-20 \%$
d. $21-30 \%$
e. $31-40 \%$
f. more than $40 \%$ 
24. Will some of your agency's contractors go out of business?

a. No

b. Yes

If yes, how many?

25. How substantial be will the costs that are associated with workforce reductions (e.g., workers compensation) to your agency?

a. very substantial

b. substantial

c. not very substantial

d. no additional costs

26. Will your agency abandon Davis-Bacon wages post-ARRA?

a. No

b. Yes

27. Does your agency see its weatherization clientele changing demographically over the next five years?

a. No

b. Yes

If yes, please explain

28. Does your agency see the types of homes in your weatherization program changing over the next five years?

a. No

b. Yes

If yes, please explain

29. As of the end of PY 2010, what is the demand for low-income weatherization services in your agency's jurisdiction?

a. extremely high

b. very high

c. high

d. moderate

e. low

f. very low

30. Does your agency see the demand for weatherization services changing over the next five years?

a. No

b. Yes

If yes, please explain

31. Will your agency explore fee for service projects post-ARRA?

a. No

b. Yes

32. Does your agency see health and safety audits as a growing business for your subgrantees over the next five years?

a. No

b. Yes, somewhat

c. Yes, substantially 
33. Which new measures would your agency encourage DOE approving to be installed in homes over the next five years?

34. Which alternative financing mechanisms to support weatherization post-ARRA might your agency pursue post-ARRA? (Check all that apply)

a. revolving loan funds

b. on-bill payments

c. PACE programs

d. ESCO financing

e. carbon offsets

f. none of the above

35. What help can DOE provide to support expansion of the use of alternative third-party financing mechanisms?

36. Does your agency see the demographics of its weatherization workforce changing over the next five years?

a. No

b. Yes

If yes, please explain

37. What are your agency's major weatherization workforce challenges over following five years?

38. Where do you see the market for non-low income home retrofit in your agency's jurisdiction over the next five years?

a. greatly increasing

b. increasing

c. no change

d. decreasing

e. greatly decreasing

39. Have you heard of the Home Energy Score system?

a. No (go to Q41)

b. Yes

40. If so, how might this initiative impact low-income weatherization conducted by your agency?
a. no impact
b. might lead to some funding increases
c. might lead to moderate funding increases
d. might lead to substantial funding increases

41. Post-ARRA, compared to pre-ARRA funding levels, how do you foresee the size of your agency's weatherization assistance program?
a. Greatly expanded
b. Expanded
c. About the same
d. Reduced
e. Greatly reduced 
42. Is your agency resigned to going back to business as usual post-ARRA?

a. No

b. Yes

43. On balance, how beneficial do you think that the ARRA funding will eventually be to the longer-term prospects for your agency's WAP-program?

a. Extremely beneficial

b. Beneficial

c. No long-term impact

d. Unbeneficial

e. Extremely unbeneficial 


\title{
APPENDIX V. S8: WEATHERIZATION TRAINING CENTERS POST-ARRA SURVEY
}

\author{
OMB Control Number:
}

\section{S8 - WEATHERIZATION TRAINING CENTERS POST-ARRA SURVEY}

This data is being collected to conduct a survey of the directors of DOE funded Weatherization Training Centers to gain insights into weatherization training strategies and needs anticipated post-ARRA. The ARRA period is defined to run from April 2009 to March 2012.

Public reporting burden for this collection of information is estimated to average 60 minutes per response, including the time for reviewing instructions, searching existing data sources, gathering and maintaining the data needed, and completing and reviewing the collection of information. Send comments regarding this burden estimate or any other aspect of this collection of information, including suggestions for reducing this burden, to Office of the Chief Information Officer, Records Management Division, IM-11, Paperwork Reduction Project (XXXX-XXXX), U.S. Department of Energy, 1000 Independence Ave SW, Washington, DC, 20585-1290; and to the Office of Management and Budget (OMB), OIRA, Paperwork Reduction Project (XXXX-XXXX), Washington, DC 20503.

Lastly, all of the information obtained from this survey will be protected and will remain confidential. The data will be analyzed in such a way that the information provided cannot be associated back to you or your training center.

1. What is the name of your weatherization training center?

2. Please describe the weatherization training offered by your Center? \{Inquire about training topics, certifications given and supported

3. What percentage of your weatherization training program was supported by DOE funds preARRA, during the ARRA period, and expected to be post-ARRA?

4. What was your Center's budget pre-ARRA, during ARRA, and expected to be post-ARRA?

5. How many staff did your Center employ pre-ARRA, during ARRA, and expected to employ post-ARRA?

6. How did your Center ramp up its weatherization training program during the ARRA period? \{Inquire about increases in number of courses, hiring of staff, non-traditional/innovative training, marketing techniques, and equipment/technology purchases. 
7. Did you find the support for your Center from DOE useful in implementing your ARRA period training and planning? What worked well? What didn't?

8. Is DOE providing adequate support for post-ARRA planning? What is working? What else do you need?

9. What assistance ought DOE provide to assist in your center's post-ARRA transition?

10. How is or will your center ramp down its weatherization training program post-ARRA? \{Inquire about laying off staff, transitioning into non-low income programs, finding new leveraging partners, selling equipment, changing fee structures for classes, dropping weatherization classes.

11. Is there a risk that your Center may have to close down post-ARRA? If so, what would be required to prevent that?

12. At the peak during the ARRA period, how many weatherization trainees were served by your center per year and how many do you expect to serve post-ARRA?

13. How will weatherization training offered by your center change post-ARRA? \{e.g., less hands-on

14. Will your relationship with the grantee(s) continue post-ARRA?

15. Please describe your thoughts about the demand for weatherization training in your area and nationally over the next five years.

16. What types of trainees will be attracted to this field over the next five years and what types of jobs will they be able to land? \{Inquire about potential problems in attracting new trainees \} 